DAGMA CIBELE EID

\title{
Miguel Llobet: Canciones Catalanas para violão (1899-1927)
}

\begin{abstract}
Dissertação apresentada ao Programa de Pós-Graduação em Música, Área de Concentração Processos de Criação Musical, Linha de Pesquisa Técnicas Composicionais e Questões Interpretativas, da Escola de Comunicações e Artes da Universidade de São Paulo, como exigência parcial para obtenção do Título de Mestre em Artes, sob a orientação do Prof. Dr. Edelton Gloeden.
\end{abstract}

São Paulo

2008 
DAGMA CIBELE EID

\title{
Miguel Llobet: Canciones Catalanas para violão (1899-1927)
}

\begin{abstract}
Dissertação apresentada ao Programa de Pós-Graduação em Música, Área de Concentração Processos de Criação Musical, Linha de Pesquisa Técnicas Composicionais e Questões Interpretativas, da Escola de Comunicações e Artes da Universidade de São Paulo, como exigência parcial para obtenção do Título de Mestre em Artes, sob a orientação do Prof. Dr. Edelton Gloeden.
\end{abstract}

São Paulo

2008 


\section{AGRADECIMENTOS}

À minha mãe Elisa Eid por ter me encaminhado aos estudos de música na minha tenra idade e ao meu pai, Jorge Eid, por ter proporcionado boas condições para me dedicar aos meus estudos.

Aos meus professores de violão Márcia Braga, Edson Lopes, Paulo Porto Alegre e Giácomo Bartoloni pela confiança no meu trabalho e incentivo.

À alaudista e professora Carin Zilling por sua orientação e incentivo nos meus estudos de alaúde.

Ao violonista e Dr.Robert Phillips por compartilhar sua pesquisa a respeito do compositor abordado aqui.

Ao violonista italiano Stefano Grondona, cujo contato proporcionou dados valiosos que me motivaram a prosseguir a pesquisa.

À violonista e amiga Ana Maria de Souza pela efetiva ajuda na formatação e realização deste trabalho.

Ao colega Gedson Bravim pela troca de informações valiosas que resultaram na idéia deste projeto.

Ao colega coordenador da área de violões do Conservatório Dramático e Musical de Tatuí Adriano Paes por seu apoio.

À professora Maria Tereza Bryg por sua orientação na língua inglesa e ao catalão Jose Portoles por sua preciosa ajuda na aquisição de materiais essenciais para a pesquisa e na revisão dos textos em catalão.

Ao meu orientador Edelton Gloeden pela paciência e atenção dedicada a este projeto. 
O, Llobet, lleno de sol, amor de Espana! Artista lleno de púrpura y de oros! Guitarra que da el clavel, la flor extraña Regada por la sangre de los toros! Flor de gitanos, flor que amor recela! Amor de sangre y luz, pasiones locas! Flor que transciende a clavo y a canela, Roja cual las heridas y las bocas! (Rubén Darío) 


\section{RESUMO}

As Canciones Catalanas para violão de Miguel Llobet pertencem ao campo do folclore musical catalão, cuja tradição é milenar. Portanto, buscamos na história da música e na etnomusicologia catalã as informações a respeito da origem de tais melodias usadas na obra do compositor catalão. Ao penetrarmos neste universo localizamos os textos inseridos nas melodias que ajudam a reconhecer o significado delas, estabelecendo assim novos elementos de interpretação para esta coleção de versões de canções tradicionais catalãs para violão. Consultamos o cancioneiro tradicional catalão e encontramos as melodias em sua forma primitiva, junto com seus textos em catalão, que foram transcritos e traduzidos para o português.

A pesquisa das Canciones Catalanas enfatiza que tais transcrições representam um marco para a literatura do violão do século XX. Os procedimentos técnicos e expressivos usados nestas transcrições contribuíram para o instrumento entrar numa nova fase idiomática e influenciou outros compositores a escreverem para violão. Analisar o papel das canções tradicionais catalãs no início do século XIX possibilitou traçar a personalidade artística multifacetada de Llobet cuja biografia final ainda não se encontra publicada. Os resultados que encontramos ajudam a posicioná-lo como uma figura extremamente importante para história do violão. No entanto, sua produção foi sufocada por uma série de tragédias ocasionadas pela guerra civil espanhola e algumas obras foram esquecidas.

O reconhecimento progressivo do legado deixado pelas atividades de Llobet tem gradativamente fomentado uma pesquisa que vem resgatando tais obras. Portanto, esta dissertação pretende dar sua contribuição neste processo a fim de completar um capítulo essencial na história do violão. 


\section{ABSTRACT}

The Canciones Catalanas for the guitar by Miguel Llobet belong to the Catalan folklore music area, whose tradition is millennial. However we search in the history of music and Catalan etnomusicology the information about the origin of such melodies used in the works of the Catalan composer. When we enter this universe, we find the texts which are inserted in the melodies that help recognise the meaning of them and establish new elements of interpretation for the collection of Catalan traditional songs for the guitar. We have consulted the Catalan traditional Cancioneros and we have found the melodies in their primitive forms with their texts in the Catalan language transcribed and translated into the Portuguese language.

The research about Canciones Catalanas emphasizes the statement that they are a mark in the literature of the guitar from the twenthieth century. The technical and expressive procedures used in these transcriptions contributed towards the entrance of the instrument into a new idiomatic phase and influenced other composers to write for the guitar. To analyse the function of the traditional melodies in the beginning of the nineteenth century, propitiates the possibility to trace Llobet's manifold artistic personality, whose final biography has not been published yet. The results helped to give him a position as an extremely important figure for the history of the guitar. However, his production was stifled by several tragedies brought about by the Spanish Civil War and some of the works fell into oblivion.

The progressive recognition of the legacy left by Llobet's activities has been gradually promoting a research and thus rescuing his works. However, the present dissertation intends to give a contribution to this process so as to complete an essential chapter in the history of the guitar. 


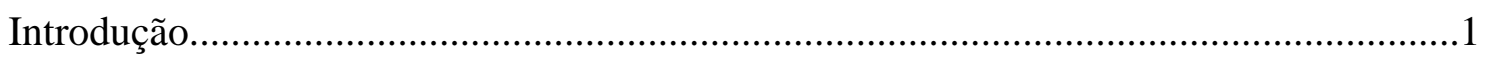

1- REFERÊNCIAS HISTÓRICAS DA CANÇÃO TRADICIONAL CATALÃ ......6 2-MIGUEL LLOBET: SEUS PREDECESSORES E CONTEMPORÂNEOS ......26

3-MIGUEL LLOBET Y SOLÉS (1878-1938) ………………………………….....42

4 - MIGUEL LLOBET E A TOTALIDADE DE SUA OBRA....................................65

5- CANCIONES CATALANAS - ASPECTOS HISTÓRICOS, SOCIAIS E

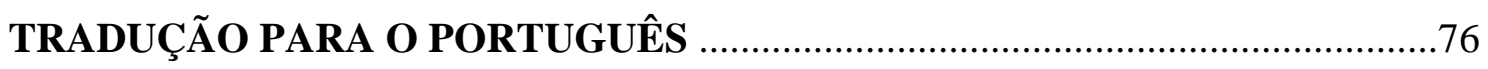

5.1 - MIGUEL LLOBET: CANCIONES CATALANAS …………………………….........

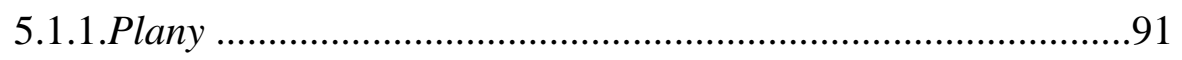

5.1.2. La filla del marxant (1899) .......................................................93

5.1.3. El testament d'Amelia (1900) .....................................................98

5.1.4. Cançó del Lladre (1900) .........................................................107

5.1.5. El Rossinyol (1900) ………………………………………...115

5.1.6. El fill del rei (1900) ...........................................................120

5.1.7. L'hereu Riera (1900) ...............................................................125

5.1.8. El mestre $(1910)$...................................................................133

5.1.9. La nit de nadal (1918) ........................................................146

5.1.10. La filadora (1918) ………………………………………...153

5.1.11. La pastoreta (1918) ............................................................157

5.1.12. La Presó de Lleida (1920).....................................................163

5.1.13. El Noi de la Mare (s.d.) ...................................................169

5.2 - CANCIONES CATALANAS RECÉM-DESCOBERTAS ......................................174

5.2.1. L’Anunciació …………………………………………….....180

5.2.2. L'hostal de la Peira ...............................................................183 
5.3.2. El cant dells ocells ................................................................199

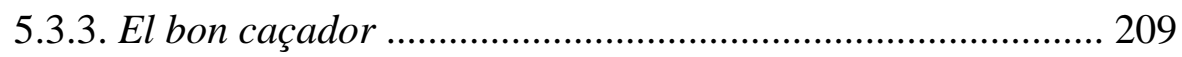

5.3.4. La ploma de perdiu ........................................................... 215

5.3.5. Els Estudiants de Tolosa ................................................... 219

5.3.6. Muntanyes del Canigó .....................................................222

5.3.7. Catarina d'Alió ..................................................................... 227

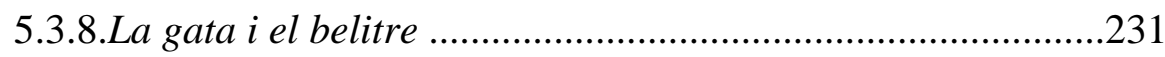

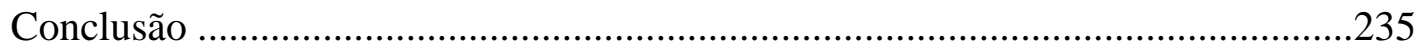

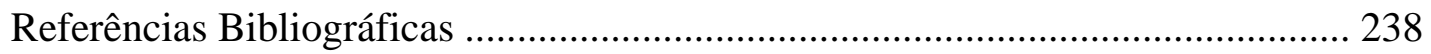

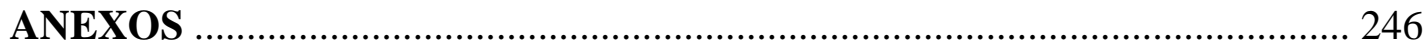

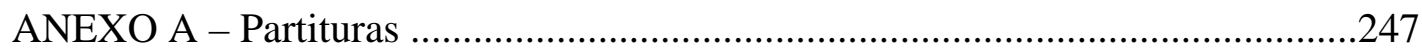

ANEXO B - Entrevista com Stefano Grondona ...................................................2270

ANEXO C - Programas de Recital realizados no II Encontro Internacional de

Violonistas de Tatuí 


\section{INTRODUÇÃO}

A pesquisa acerca das Canciones Catalanas harmonizadas por Miguel Llobet (1878-1938) teve início quando entramos em contato com a música da Idade Média e do Renascimento através dos estudos de alaúde, da experiência adquirida na participação de conjuntos de música antiga e na atuação no ensino e execução de violão.

O trabalho com a música dos Cancioneiros Ibéricos levou-nos a temas antigos, que remontam há séculos, e por fim, ao Cancioneiro Catalão, cuja tradição é milenar.

Outra forte influência que nos aproximou da memória catalã foi a audição do grupo catalão La Capella Reial de Catalunya da gravação intitulada Cançons de la Catalunya Mil-lenária, Planys \& Llegendes (Astrée, 1977), que nos conduziu a uma outra visão da interpretação da música tradicional catalã. O repertório nos chamou a atenção, pois incluía temas utilizados pelo compositor e violonista catalão Miguel Llobet (1878-1938) em suas Canciones Catalanas, estudadas durante a nossa formação musical como violonistas, tanto na execução como no ensino delas. Isso nos remeteu a um interesse em desvendar este passado histórico e a procurar respostas para a interpretação deste repertório, tanto para prática num conjunto de música antiga quanto na execução destas versões românticas para violão.

As Canciones Catalanas de Llobet tornaram-se obras consagradas no repertório violonístico, tanto para a execução em recitais quanto para a formação dos violonistas. Tal coleção elaborada no início do século $\mathrm{XX}$, época decisiva para a afirmação do violão, que ainda não ocupava seu espaço no cenário musical, chegou a ser gravada tanto de maneira fragmentada quanto integralmente por importantes músicos como Andrés Segovia, Julian Bream, John Williams, David Russel e Stefano 
Grondona, entre outros. Em nenhuma destas gravações há a citação das letras nem mesmo seus significados. Conhecer seu texto contribui, no mínimo, para a definição de novos elementos de interpretação.

Um dos fatores que nos chamou a atenção foi justamente o rico conteúdo do texto das canções que estão ausentes nas publicações e nos registros que envolvem o repertório violonístico e, em particular, os arranjos de Llobet.

Dividimos nosso trabalho em cinco capítulos:

No capítulo 1 trataremos de um breve histórico da canção, onde delinearemos alguns elementos que vieram, mais tarde, a influenciar as canções utilizadas na obra de Llobet. Quando estudamos a música antiga, reconhecemos alguns temas nos Cancioneiros do século XVI, no trovadorismo, e até mesmo no canto litúrgico. Incluímos neste capítulo, o movimento de música nacional espanhola no século XIX que marcou presença no renascimento da cultura do país, através dos trabalhos de intelectuais catalães, onde o emprego da canção popular é bastante valorizado. O violão ressurge, da mesma maneira, pelas mãos de violonistas catalães, que reunidos com violonistas de outras regiões da Espanha, criaram um movimento semelhante, utilizando canções populares.

No capítulo 2, comentaremos a geração de violonistas catalães que precedeu Llobet e que ajudaram a construir a importante escola de violão moderna, bem como seus contemporâneos. Acreditamos que o conjunto da obra de Llobet foi decisivo para a evolução da técnica violonística, mas esta figura tão importante ainda não teve seu destaque merecido dentro do cenário musical. Portanto, reservamos um capítulo, o número 3, para comentar a personalidade marcante e a importância da obra de Llobet, especialmente as Canciones Catalanas, bem como as possíveis causas da perda de algumas obras. 
O capítulo 4 abordará a questão da totalidade da obra de Llobet. Os catálogos realizados precisam ser revistos, pois recentemente, foi descoberto um arquivo com obras inéditas. Entre elas, novas transcrições de canções tradicionais catalãs, aumentando assim o número das treze canções já editadas. O responsável pela pesquisa inédita é o violonista italiano Stefano Grondona (1958), que registrou estas e outras obras inéditas em recentes gravações.

O material explorado por Llobet nesta coleção pertence ao terreno da tradição folclórica catalã, de origem bastante antiga. As canções originaram-se de maneira espontânea e anônima, e foram transmitidas através da tradição oral. Graças ao poder que a música exerce sobre a memória coletiva, as melodias das canções tradicionais puderam ser conservadas no decorrer dos séculos. O pesquisador que se ocupa em registrar o texto de uma canção ajuda a preservar, portanto, a música tradicional, pois foi exatamente graças ao fato da música estar intimamente ligada à poesia que as canções populares sobreviveram. De fato, a música ajuda-nos a lembrar uma poesia na íntegra quando cantarolamos a melodia inserida em seu texto e somos remetidos a ele.

Apresentar o texto das canções torna-se indispensável para formar o corpo musical que estamos propondo, de texto e melodia indissociáveis, para incorporar o significado que tem o folclore para a cultura nacional de qualquer povo. Assim, no capítulo 5, comentaremos alguns aspectos históricos e sociais ligados ao folclore catalão - suas lendas, histórias, costumes, bem como a tradução das letras das melodias para o português. Ao abordar as letras das melodias, incluímos a transcrição monofônica das canções na sua forma original.

Apesar do folclore catalão não ser difundido entre outras culturas, incluindo a nossa, e de não termos, a priori, um compromisso de conhecê-lo a fundo, quando 
lidamos com estes temas em quase toda a nossa vida profissional, sentimos a necessidade de penetrar neste universo.

Temos o nosso próprio folclore musical para ilustrar o quanto tais melodias folclóricas estão presentes na alfabetização infantil, no cotidiano de pessoas de diversas classes sociais e inseridas, inclusive, na obra de compositores eruditos brasileiros consagrados.

Examinando o material bibliográfico para este trabalho, podemos estabelecer certo paralelo com o que vimos em Heitor Villa-Lobos (1887-1959), que utilizou as músicas do folclore brasileiro nos seus cantos orfeônicos, cuja finalidade também era social, e para compor suas grandes obras. Procuraremos analisar, no caso de Llobet, a finalidade de usar melodias folclóricas em sua obra para violão.

O repertório de canções folclóricas presentes na obra de Villa-Lobos exemplifica o quanto a letra está associada à sua melodia e presente na memória coletiva de um povo que valoriza sua identidade. De fato, quando ouvimos a obra instrumental das Cirandas $^{1}$ de Villa-Lobos, das quais a canções populares Terezinha de Jesus, O Cravo Brigou com a Rosa, Fui no Itororó, Nesta Rua e A Canoa Virou (1926) fazem parte, é inevitável não cantarolarmos, mesmo que mentalmente, as letras de suas melodias.

A partir de uma reflexão sobre a importância de pesquisar as letras das melodias catalãs, e reuni-las num trabalho para posterior consulta, foi o que nos motivou a procurar as canções que Llobet escolheu para suas versões em coletâneas de música folclórica espanhola, especialmente a catalã. O trabalho de Joan Amades ${ }^{2}$, musicólogo catalão, serviu de base para a pesquisa, pois constitui o trabalho mais

\footnotetext{
${ }^{1}$ VILLA-LOBOS, H. Coleção de 16 peças para piano sobre temas. Rio de Janeiro: Editora Arthur Napoleão Ltda, 1968 (partitura).

2 AMADES, J. Folk-lore de Catalunya, cançoner. Barcelona: Editorial Selecta, 1951.
} 
importante e completo sobre o assunto, citado em diversas publicações de música tradicional catalã.

Llobet explorou temas populares antigos de forma inusitada, modernizandoos e tornando-os extremamente importantes para o instrumento entrar numa nova fase idiomática. Portanto, esta pequena coleção de treze peças tem uma grande importância dentro do repertório violonístico, sendo muito executadas e gravadas pelos mais importantes violonistas e fazendo parte da formação dos estudantes de violão de toda a parte.

Citaremos, ainda, outros compositores e violonistas importantes para o posicionamento do violão, que também exploraram temas tradicionais catalães, seguindo o modelo deixado por Llobet.

A música que recorre a tais temas ficou registrada na história do violão. No entanto, os violonistas em geral não identificam a sua origem e não conhecem o texto original das canções catalãs encontradas na música antiga. Portanto, a pesquisa das letras e sua tradução visam oferecer elementos para uma melhor compreensão dos temas explorados por Miguel Llobet. 


\section{REFERÊNCIAS HISTÓRICAS DA CANÇÃO TRADICIONAL}

\section{CATALÃ}

A Espanha é um país de diversas culturas, com características diferentes em cada região. A variedade de estilos musicais resulta em diferentes aspectos da canção popular espanhola, sendo necessário delimitar tais diferenças regionais, em função dos diversos grupos étnicos que se estabeleceram na Península Ibérica ao longo da história.

Muitos adotam o modelo musical da região andaluza - o flamenco - para exemplificar a canção popular espanhola, esquecendo-se e relegando a um segundo plano outras modalidades cancionísticas como a galega, a asturiana, a vasca, a salmantina, a burgalesa, e finalmente, a catalã, objeto do nosso estudo.

A música tradicional da Catalunha se distingue da música tradicional da região andaluza, por sua distinta colonização ${ }^{3}$, não tendo tanta influência dos cantos carregados de lamentos vindos da cultura árabe, embora alguns elementos contidos na tradição musical espanhola às vezes se confundam. Notamos isso ao considerar os primeiros documentos musicais da Espanha, encontrados dentro da igreja.

A Catalunha, liberada do julgo mulçumano, adotou o rito romano em seu repertório litúrgico, mas alguns códices monásticos catalães do século XI conservam traços da cultura árabe, indicando assim possíveis ocorrências de elementos árabes na música litúrgica desta região (LIVERMORE, 1974, p. 69).

Os elementos populares, por sua vez, muitas vezes se confundem com os elementos religiosos. A música de caráter popular se associava em algumas ocasiões a certos atos relacionados com o culto religioso. Podia influenciar a confecção das missas,

\footnotetext{
${ }^{3}$ Sobre o tipo distinto de colonização que a Catalunha sofreu, vale citar que durante meados do século XII, os catalães foram chamados de los francos, no poema de El Cid, devido à influência francesa na região (DUFOURCQ, p. 175).
} 
e muitas vezes letra e música eram tiradas de fontes populares que tinham relação direta com a dança. A dança era praticada tanto nos átrios das igrejas, quanto em seu interior (SUBIRÁ, 1953, p. 88).

A tradição oral estava fortemente arraigada à implantação do canto litúrgico. Os monges sabiam de memória a estrutura dos ofícios religiosos, de maneira que, assim como as melodias populares, eram de extensão pequena e de fácil memorização. A difusão dos cantos litúrgicos acontecia durante as peregrinações religiosas feitas pelos fiéis, onde o povo tinha a oportunidade de cantar e dançar, dando origem às canções de traços manifestadamente populares.

A influência do canto gregoriano se manifesta de maneira muito forte na canção catalã (ANGLÉS, 1954, p. 421), e pouco em outras regiões da Espanha. Em contrapartida, o uso dos sistemas modais dentro do sistema diatônico, que foram gradualmente cromatizados pela intervenção das escalas orientais pouco influenciou a canção tradicional catalã.

Segundo a afirmação de vários especialistas, a canção popular é uma das manifestações mais antigas da cultura popular. O musicólogo Francesc Baldelló (18871977) comenta a influência da música litúrgica na canção popular, como veremos efetivamente no capítulo que descreve as canções. O povo, que assistia às funções religiosas dos grandes monastérios - onde era executado o canto gregoriano - assimilava suas melodias e as transformava numa nova manifestação artística. A única influência que a população recebia vinha da música ouvida na igreja (BALDELLÓ, 1926, vol. 2, p. 357).

Os monastérios tiveram participação definitiva na difusão da música na Catalunha, e suas relações com os grandes centros litúrgicos franceses levam alguns 
teóricos a afirmar que a história da música na Catalunha pertence mais à história da Europa que à da Espanha (DUFOURCQ, 1965, vol. 1, p. 176).

Santa Maria de Ripoll, um monastério beneditino fundado em 888 é uma referência para a história da cultura musical catalã. Trata-se de um grande centro musical onde se desenvolveram as transformações da canção caracterizada por alguns elementos populares. Suas relações culturais com outros monastérios, especialmente os da França, foi uma das causas do florescimento artístico da música na Catalunha. No que se refere à produção musical, identificam-se nos seus códices, a influência dos monastérios franceses de Fleury, de Saint Germain des Pres, de Cluny, Moissac e Saint Martial de Limoges (ANGLÈS, 1954, vol. 2, p. 1888). Os monges beneditinos no monastério de Ripoll inventaram, no século X, uma notação musical neumática típica conhecida como notação catalã, cujos traços recordam os neumas mozárabes (figura 1). Este sistema de notação propagou-se por várias regiões da Catalunha, chegando a ultrapassar os Pirineus, penetrando até na França, tal a força da cultura musical da escola de Ripoll (DE LA CUESTA, 1983, p. 225).

A partir do século XIII, surgem outros monastérios, e com isso, a possibilidade de criar e conservar mais códices.

O monastério de Las Huelgas (Burgos), fundado por Alfonso VIII de Castilla entre os anos 1180-1187, foi um centro musical de primeira ordem, como podemos ver pelo célebre códice musical com polifonia religiosa do século XIII - o Códex Musical de las Huelgas, uma das antologias mais ricas da música medieval européia. Trata-se de uma coleção de 186 obras: 28 organa para missa, 31 benedictamus, 31 prosas, 59 motetes, 32 conductus e 1 credo (o mais antigo de seu gênero). 


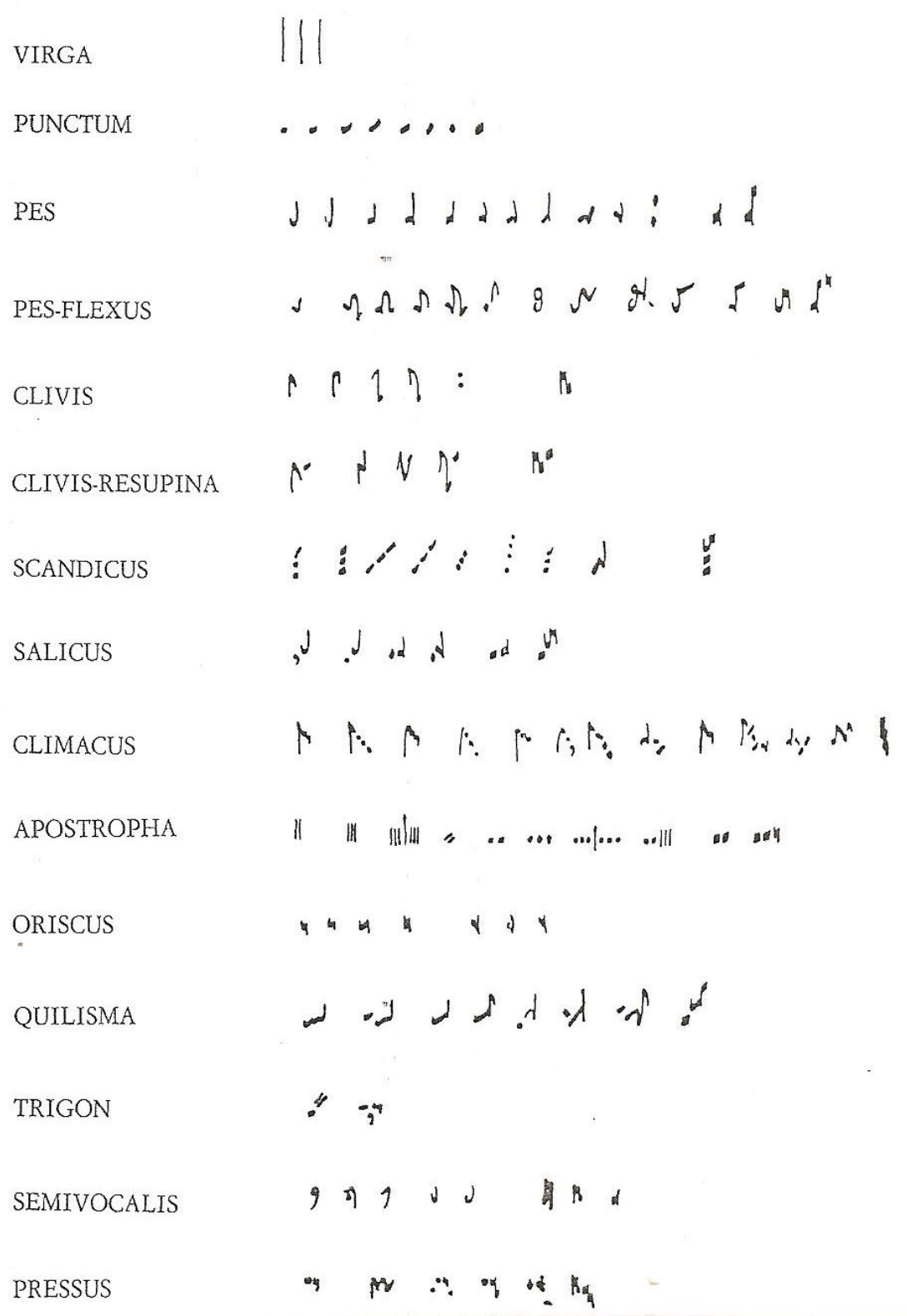

Figura 1. Notação catalã criada no século X

Como veremos adiante, uma das canções usadas nas adaptações para violão de Miguel Llobet, possui uma melodia que se assemelha com uma das melodias que figura neste códice de Burgos (LIVERMORE, 1974, p. 81). Portanto, podemos supor um intercâmbio também entre as escolas monásticas de Burgos e Ripoll em relação à cultura musical. 
Ainda comentando a importância dos monastérios na cultura musical catalã, inserimos o monastério de Montserrat situado na montanha que lhe dá o nome, a $35 \mathrm{~km}$ da capital Barcelona. Exerce profunda atração no povo, que por séculos tem subido à montanha em peregrinação. Também representa a primeira escola de música de toda a Europa, de onde saiu um bom número de maestros que ocuparam importantes posições na Península Ibérica. Seu antigo e valioso arquivo musical desapareceram no século XIX por ocasião da invasão das tropas napoleônicas (1811). O documento musical mais antigo conservado no monastério é o Libre Vermell de Montserrat, chamado assim devido à cor da capa que recebeu ao ser recuperado e encadernado com uma capa vermelha.

Trata-se de uma coleção de cantos e danças religiosos dos séculos XIII e XIV em homenagem à santa padroeira da Catalunha - a virgem de Montserrat. Suas melodias foram concebidas com a finalidade de edificar os peregrinos que tinham que subir 2.910 degraus para ver a virgem negra - a "moreneta" - encontrada milagrosamente nas montanhas. Tal circunstância faz das canções contidas no Libre Vermell um conjunto de melodias populares, pois foram cultivadas em ambiente doméstico, fora da igreja, apesar de seu tema religioso.

São dez melodias - oito com texto em latim (O Virgo Splenders, Stella Splenders, Laudemus Virginem, Cuncti Simus, Polorum Regina, Maria Matrem, Splenders Ceptigera e Ad Mortem Festinatus) e duas com texto catalão (Los Set Goyts e Imperaytrix de la Ciutat Joiosa).

Los Set Goyts ${ }^{4}$ é uma dança em círculo, que possivelmente deu origem à popular sardana ${ }^{5}$ e consequentemente influenciou as canções populares posteriores,

\footnotetext{
${ }^{4}$ Goyts ou "goigs” (gozos) são manifestações típicas catalãs e pertencem ao terreno da música popular. Possuem uma sucessão de estrofes (cobles) e um estribilho (refrany) que se repete ao final de cada uma delas. Sua finalidade é louvar divindades religiosas, ocasião intimamente ligada à dança. Esta melodia representa a mais antiga do gênero, que foi usado por diversos compositores durante os séculos seguintes.
} 
inclusive algumas que estudaremos na pesquisa. Outro aspecto peculiar nesta coleção, é que o mesmo povo que dançava durante a noite no monastério de Montserrat diante do santuário da virgem, dançava durante o dia em praça pública. Tal fato comprova como os elementos populares podiam conviver no ambiente religioso. Desta maneira, entre os variados textos musicais encontramos uma dança com um título em seu cabeçalho: Ballada dels goigs de Nostra Dona en vulgar cathalan, a ball rodon (Baile dos gozos de Nossa Senhora em catalão vulgar, em baile de roda) (SUBIRÁ, 1953, p. 88).

\section{Los Set Goyts}

Ballada dels set goys de Nostra Donaen vulgar cathalan

Refranys

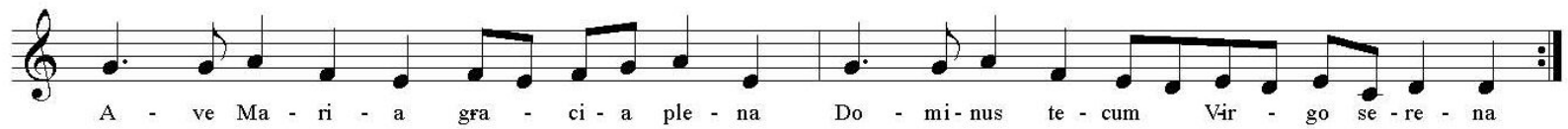

Cobles
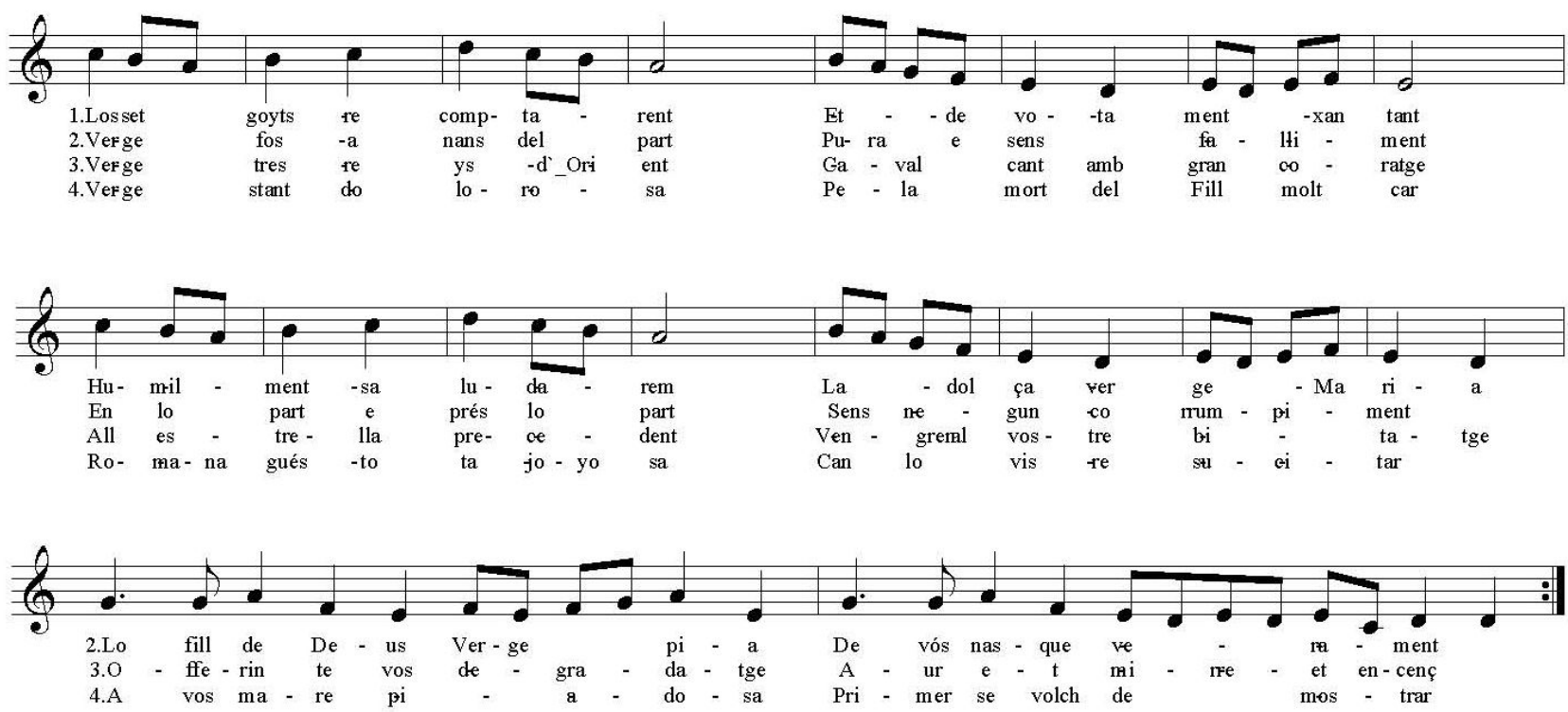

\footnotetext{
${ }^{5}$ Dança típica da Catalunha na qual um grupo reúne-se ao ar livre, formando uma roda. As pessoas entram livremente no círculo de bailarinos e são integradas pelos outros sardanistas. Participam todos que têm interesse nesta espécie de baile social (BUADES, 2006, p.269). A sardana pode se apresentar como sardana llarga com grande quantidade de bailarinos e sardana corta, sem grande acúmulo de pessoas. A banda que tradicionalmente acompanha a sardana é chamada de cobla.
} 
Imperaytrix de la Ciutat Joiosa é um canto de contemplação à virgem que significava, para os peregrinos, o reconforto e a absolvição para executarem a última melodia Ad Mortem Festinatus, que constitui uma dança de traços profanos - a dança da morte (LIVERMORE, 1974, p. 82). Algumas melodias inseridas no Libre Vermell já indicam o processo de desvinculação da igreja, trazendo elementos populares em seu texto e melodia, uma vez que algumas delas eram destinadas à dança.

Esta coleção de melodias populares, com tema religioso, marca o aparecimento da canção popular, como percebemos no comentário de D. Gregório Estrada: “O Livre Vermell de Montserrat constitui uma das amostras mais antigas e impressionantes do folclore medieval europeu”.(RUBIO, 1983, p. 109)

As Cantigas de Santa Maria são uma coleção de canções monódicas em homenagem à Maria, escritas pelo rei espanhol Alfonso X, o Sábio (1252-1284) e seus trovadores, copiadas entre 1275 e 1280 . Evoca uma antiga tradição espanhola - a de entoar temas com acompanhamento de instrumentos a fim de contar uma história que recitavam - os chamados romances ${ }^{6}$. As 417 canções possuem melodias de vários tipos: trovadorescas, romances velhos, e aires religiosos cantados por peregrinos em suas procissões (LIVERMORE, 1974, p. 73). É mais uma amostra de que elementos religiosos e populares se confundiam, pois possui uma lírica religiosa com texto vulgar.

A maior parte das cantigas se baseia em fatos do tempo do rei Afonso X e sua família, em lendas locais e principalmente anedotas milagrosas. Outras narram histórias lendárias de caráter universal, então muito em voga na Europa. Não encontramos nenhuma cantiga com texto catalão, mas como veremos adiante, encontramos elementos que vieram a influenciar, mais tarde, a canção tradicional catalã.

\footnotetext{
${ }^{6}$ Forma tradicional na Espanha, influenciada pelo canto gregoriano e pela lírica trovadoresca, que usava canções para narrar estórias criadas pelo povo e continuadas pelos músicos profissionais no século XIV (BARGALLÓ, 1983, p. 38).
} 
Imperaytrix de la Ciutat Joiosa
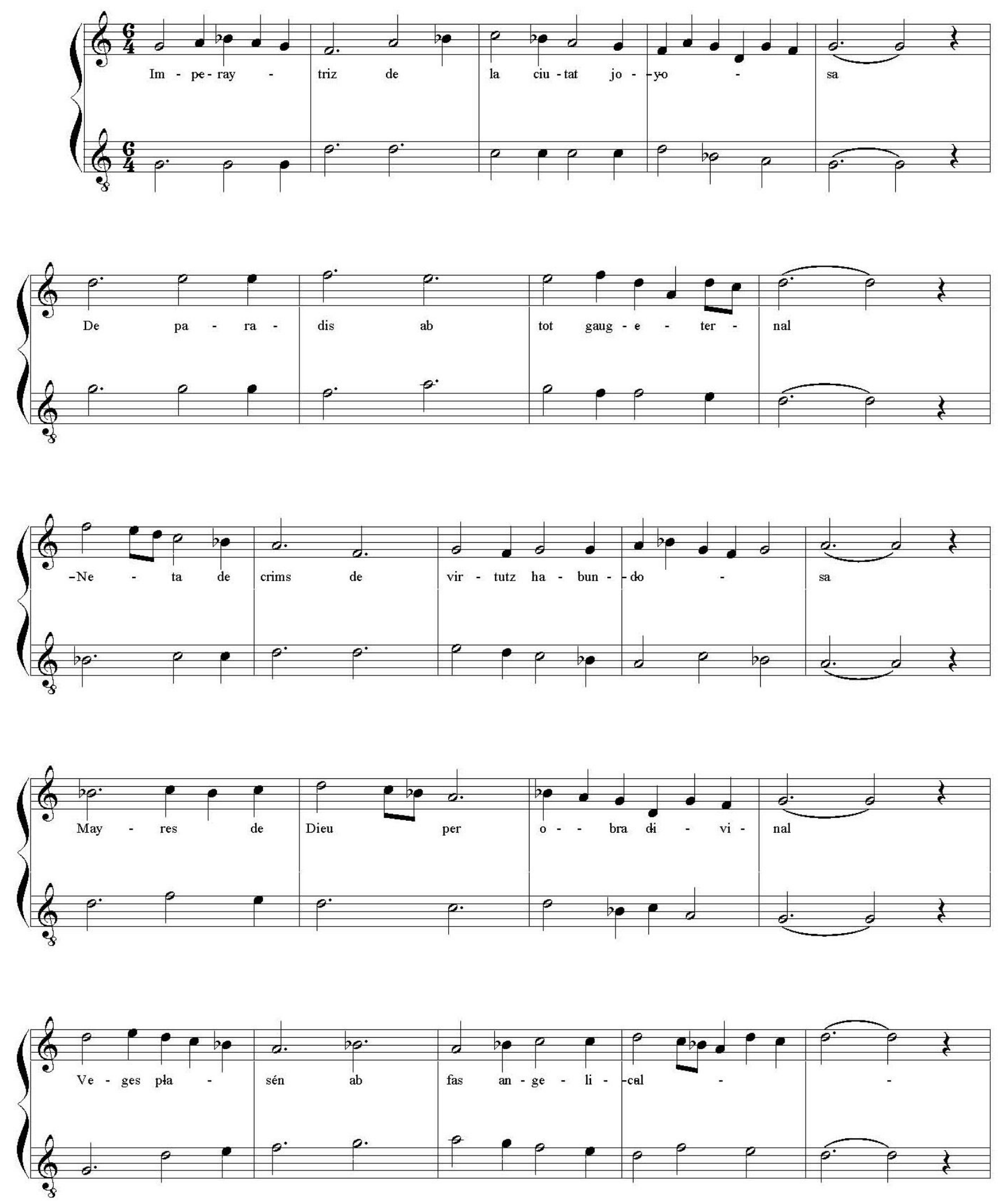
O El Cant de la Sibil-la era muito praticado na Catalunha, sobretudo no monastério de Ripoll. Primeiramente era cantado em latim e com melodia gregoriana, no século X, e depois, no século XII, se cantava com texto vulgar. Esta coleção de música, cujo repertório tradicional era usado para certas festividades, é metade litúrgica, metade popular (DUFOURCQ, 1965, vol. 1, p. 175). Tal prática ilustra bem como o profano e o religioso conviviam bem dentro do contexto histórico, uma vez que o canto gregoriano e outros elementos autônomos se fundiram para formar linhas melódicas medievais.

Ainda na Idade Média, encontramos algumas melodias de caráter popular que surgiram a partir de um movimento realizado por músicos ambulantes, que difundiam sua arte por diversas regiões da Europa.

Na primeira metade do século XII surgem no sul da França os trovadores, poetas-músicos, que cantam seus versos em língua d’oc (dialeto com o qual a Catalunha manteve importantes relações lingüísticas) com importantes ramificações na Catalunha - lugar preferido de muitos trovadores, em cujas cortes encontraram ajuda efetiva - o que favoreceu a criação de canções por parte de seus próprios habitantes ${ }^{7}$ (DE LA CUESTA, 1983, p. 291). Os trovadores se ocupavam de cantar os chamados romances, gênero incorporado pela canção e recorrente em diversas melodias catalãs. Encontramos uma melodia trovadoresca muito semelhante a uma canção tradicional catalã, como veremos adiante.

As fontes que temos das obras dos trovadores, a maioria de autoria anônima, são os Cancioneiros.

\footnotetext{
${ }^{7}$ Algumas músicas que sobreviveram são de trovadores catalães como Ponç de la Guardia (1154-1188), Guillem de Berguedá (1138-1192), Guillem de Cabestany (1212), Guillem de Cervera (1259-1285), Huguet de Mataplana (1185-1213), Formit de Perpiná, Guillem Ramón de Gironella, Pere Salvatge, Berenguer de Palou (1164) e Ponç d’Orfatá (1184-1246).
} 
Os cancioneiros ibéricos mais conhecidos são: Cancionero Musical de Montecassino (1480-1500), Cancionero Musical de la Colombina (1490), Cancionero Musical de Barcelona (1500-32), Cancionero Musical de Palácio (1505-1520), Cancionero Musical d'Elvas (1550), Cancionero de Upsala (1556), Cancioneiro Musical de Medinacelli (1569), Romances y letras a tres voces (1600), Cancionero Musical de Casanatense (1620), Cancioneiro de Segovia, Cancionero Musical de Sablonara (1625), Cancionero de Valladolid (1650).

São coletâneas de música polifônica na forma de villancicos ${ }^{8}$, o que denota o desenvolvimento da polifonia de maneira contundente, já no século XVI. Os temas contidos nestes cancioneiros são em sua maioria profano, mas encontramos também temas religiosos.

Rafael Mitjana (1869-1921) descobriu o Cancioneiro de Upsala conservado na Biblioteca da Universidade de Upsala, na Suécia editado no México em 1944 - uma coleção de 54 villancicos, na maioria com temas profanos, e poucos religiosos, intitulada Villancicos de diversos autores a dos y a tres y a quatro y a cinco bozes agora nuevamente corregidos (Venice, 1556), mais conhecida com o nome Cancioneiro de Upsala (Cancionero del Duque de Calabria). Neste cancioneiro figuram quatro canções com texto catalão - no. 23, no. 24, no. 35 e no. 45 . A primeira, no. 23 utiliza em seu texto a poesia de Ausias March e foi usada posteriormente pelo mestre catalão Felipe Pedrell (cuja importância destacaremos a seguir) em sua obra de teatro lírico espanhol Los Pirineus (MITJANA, 1944, p. 67).

\footnotetext{
${ }^{8}$ Forma poética e musical espanhola derivado do poema lírico medieval que era musicado para dança e ligado a temas rústicos e populares, extensivamente cultivado na música secular polifônica nos séculos XV e XVI, aparecendo anteriormente nas Cantigas de Santa Maria. Possui características semelhantes à canção popular, como a forma ABBA, o refrão e a base em temas poéticos do cotidiano. O villancico é semelhante ao romance e à canção, possuindo cada um apenas tamanhos diferentes de refrão. No século XVII, o villancico religioso tornou-se mais difundido e a forma popular foi deslocada para o romance. A partir do século XIX, villancico significa simplesmente "canção de natal”.
} 

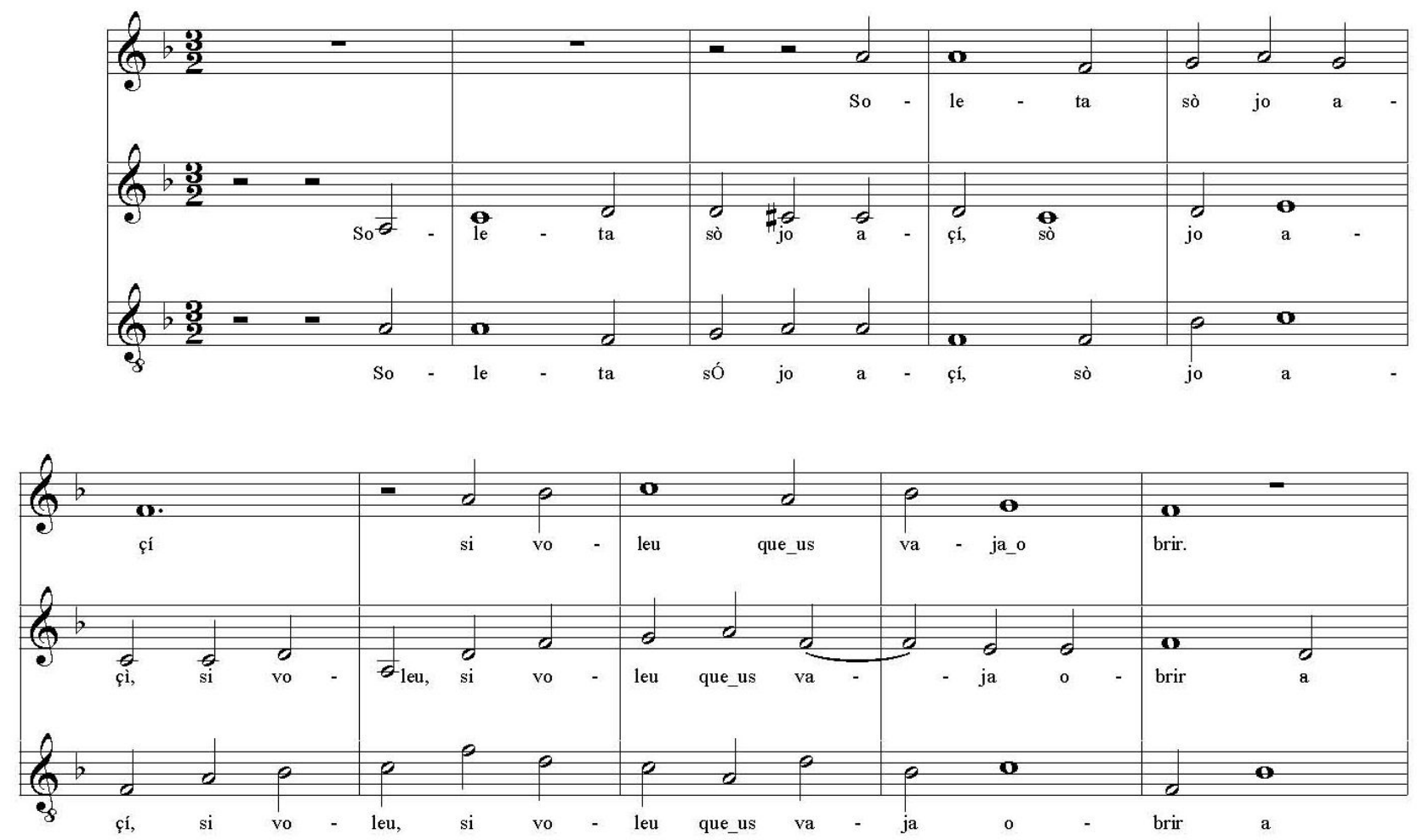

Outro villancico com texto catalão é o de no. 24:
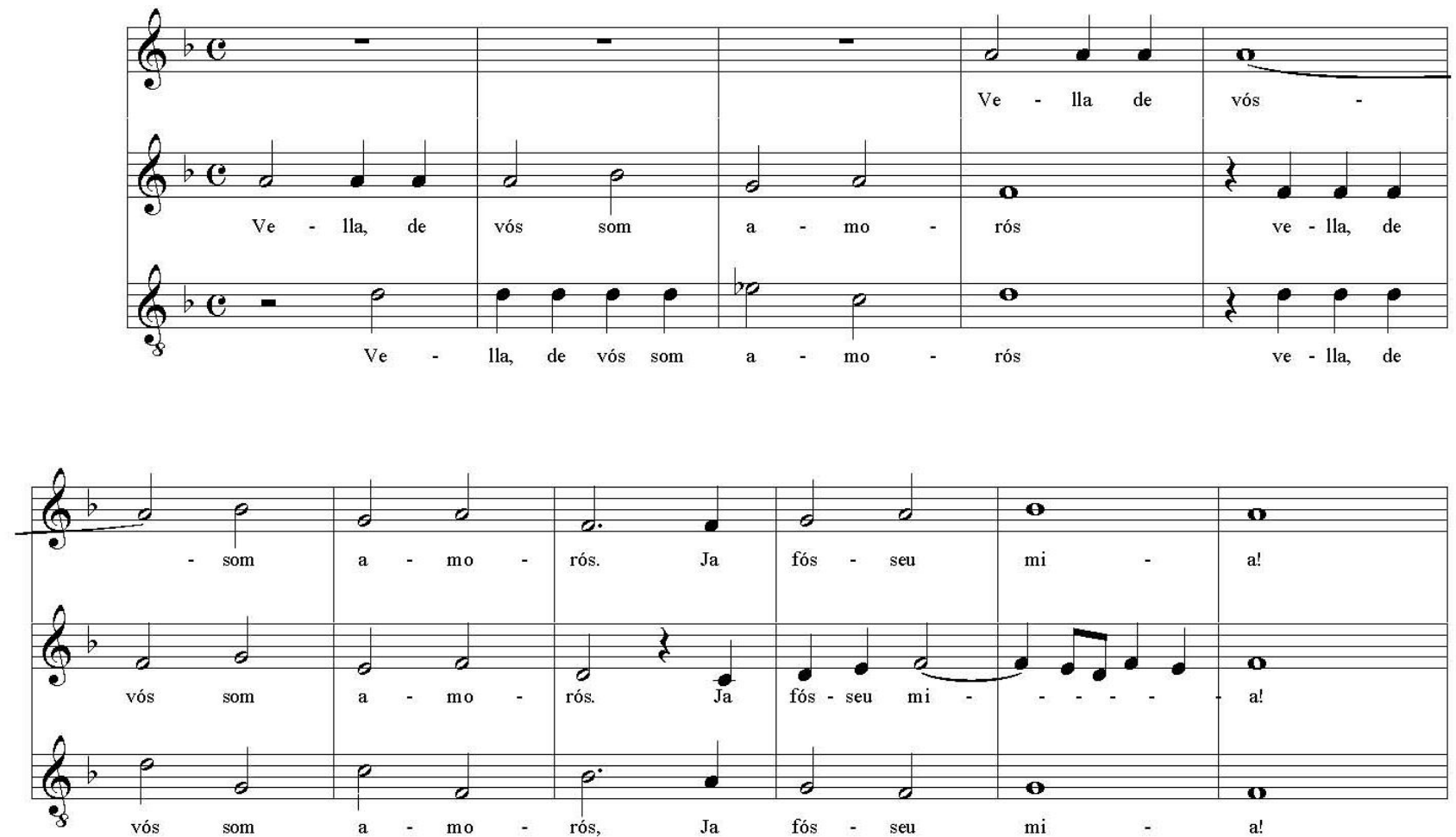
No villancico de no. 45 encontramos um tema religioso:
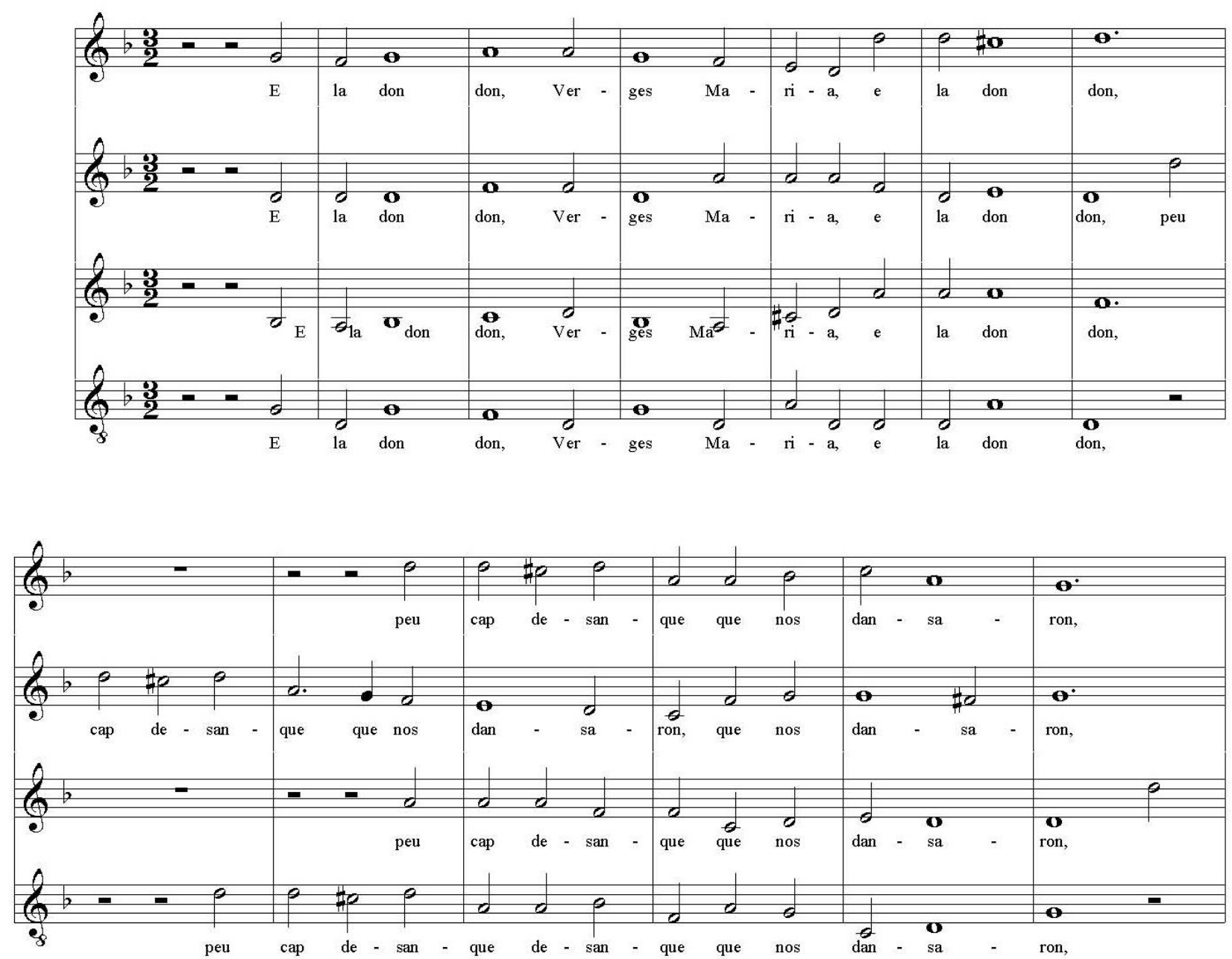

A polifonia profana sobressai tanto quanto a música religiosa na Catalunha, terreno em que os nomes de Joan Brudieu (1520-1591) e Mateo Flecha, o Velho (14831553) figuram entre os primeiros compositores catalães a escrever madrigais ${ }^{9}$ de caráter popular.

Joan Brudieu foi maestro de capela e publicou uma coleção de dezesseis madrigais profanos no De Los Madrigales del muy reverendo Joan Brudieu maestro de capilla dela sancta yglesia de La Seo de Urgel a quatro bozes (Barcelona, 1585). Seus

\footnotetext{
${ }^{9}$ Partituras dos séculos XVI e XVII sobre versos seculares.
} 
temas, na maioria, são populares e os textos de dois deles são baseados na poesia do poeta catalão Auzias March, citado acima.

Mateo Flecha, o Velho tem uma produção religiosa que se perdeu, mas sua Ensaladas - espécies de "poutpourris" de madrigais integrados com diferentes elementos - foram publicadas em Praga (1581) pelo seu sobrinho e homônimo Mateo Flecha, o Jovem (1520-1604), as quais foram adaptadas por alguns vihuelistas.

Uma das melodias do Cancionero de Upsala - a no. 35 - é atribuída a Mateo Flecha no livro Orphenica Lyra (Lira de Orfeu-1554) do vihuelista Miguel de Fuenllana (RUBIO, 1983, p. 91).
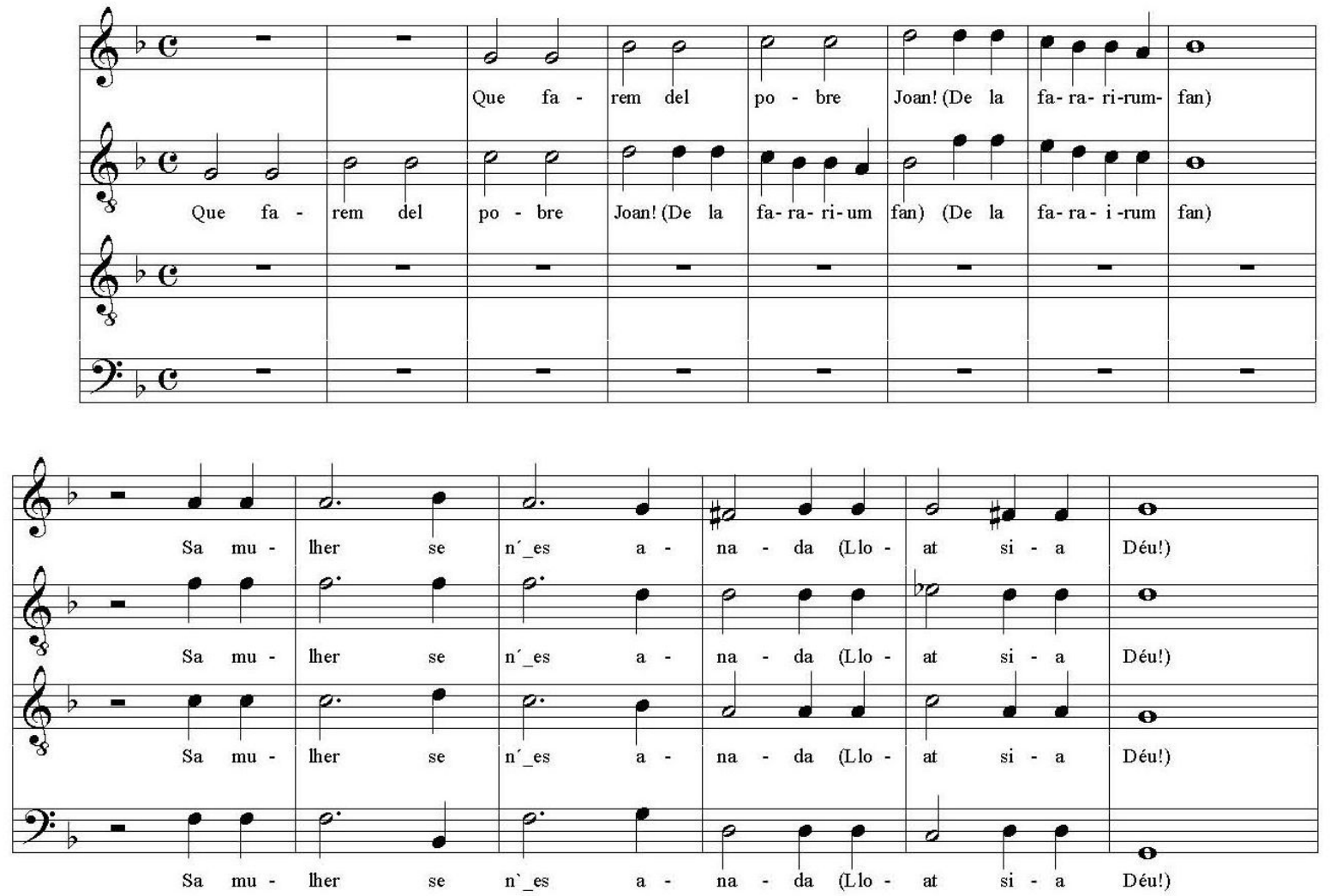

O trabalho dos vihuelistas na Espanha é digno de nota, pois se trata de um dos fenômenos musicais mais importantes para a música instrumental polifônica do século XVI de toda a Europa e foi publicado na forma de livros e tratados. Tais publicações incluíam obras de outros músicos espanhóis, e nelas era evidente o hábito e 
arranjar e entabular as obras vocais. Tal repertório polifônico, que teve sua fase áurea no século XVI, foi fortemente explorado e estavam presentes nos livros de vihuela ${ }^{10}$ - um dos instrumentos responsáveis por sua difusão. Os principais tratados de vihuela e as composições destinadas a este instrumento contêm uma infinidade de motivos tradicionais - villancicos, romances e canções populares da época são tratadas magistralmente por Luys Milán (Valencia, 1535-36), Luys de Narváez (Granada, 1538), Alonso de Mudarra (Sevilla, 1546), Enríquez de Valderrábano, (Valladolid, 1547) Miguel de Fuenllana (Sevilla, 1554) e Diego Pisador (Salamanca, 1552). Poderíamos citar muitíssimos autores que se abasteceram das fontes de música tradicional.

No século XVII a vihuela cedeu lugar à guitarra ${ }^{11}$, que passou a ser usada para acompanhar canções e danças populares (PUJOL, 1960, p. 240).

O primeiro tratado sobre guitarra espanhola foi publicado em 1586, em Barcelona, pelo médico e músico catalão Joan Carles Amat: Guitarra española y vandola em dos maneras de guitarra castellana y cathalana de cinco órdenes ${ }^{12}$. Este breve método, em catalão, trata de modo especial de melodias populares e nele encontramos instruções bastante precisas para afinar a guitarra e para realizar acompanhamentos (figura 2).

\footnotetext{
${ }^{10} \mathrm{O}$ termo vihuela designa um instrumento musical de 6 cordas, das quais 5 são duplas, em forma de oito (o alaúde tem a forma de pêra) que pode ser de arco, ou de mano, afinada como o alaúde. Na Idade Média a vihuela de mano era dedilhada e a vihuela de pua com plectro. A tablatura era o meio de notação gráfica da música para instrumentos de cordas dedilhadas do século XVI. Existem basicamente três tipos de tablaturas: a italiana, a francesa e o sistema alfabeto. A maior parte da música publicada na Espanha usava o sistema italiano, que consistia em um pentagrama com cada linha representando cada ordem do instrumento e o traste a ser usado era indicado com números sobrepostos nas linhas. A vihuela pode ser $\mathrm{o}$ instrumento mais antigo que pode ser relacionado com violão. Modo de execução ponteado.

${ }^{11}$ Semelhante no formato com a vihuela, um pouco menor e com afinação diferente, mais próxima ao violão e com um par de cordas a menos do que a vihuela de seis cordas. Modo de execução rasgueado e ponteado. Era o instrumento preferido, junto com a vihuela, para acompanhar o gênero romance (BARGALLÓ, 1983, p. 137).

${ }^{12}$ Ordenes em espanhol, ordem em português, course em inglês são os termo usados para designar os pares de cordas dos instrumentos antigos de cordas dedilhadas, com literatura escrita a partir de 1508 até o final do século XVIII. São eles: alaúdes, guitarras renascentistas, guitarras barrocas e vihuelas. As tablaturas foram utilizadas aproximadamente até o final do século XVIII.
} 


\section{TRACTAT BREU, \\ Y EXPLICACIO DELS PUNTS \\ de la Guitarra, en Ydioma $\mathrm{Ca}-$ \\ thalì, ajuftat en efta ultima \\ impreffio de la prefent \\ obra.}

PERAQUE LOS NATURALS QUE gultaran de apendrer, $y$ no entendràn la explicacio Caftellana pugan fatif-

fer fon gult ab eft breu, y compendiós eftil.

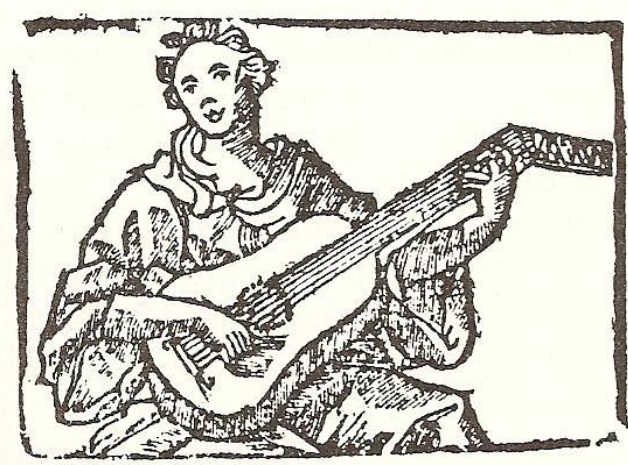

Geroma: Per Jofeph Bró, Eitamper.

Figura 2. Tratado catalão de guitarra do século XVI

Os polifonistas espanhóis representam a melhor fase musical da Espanha, nos séculos XVI e XVII. Seus trabalhos alcançaram um grande desenvolvimento na música em relação a outros países da Europa, mas depois desta fase, houve uma decadência na música espanhola ${ }^{13}$.

A decadência da música espanhola ocorreu nos séculos seguintes. Enquanto a arte musical se desenvolvia em outros países europeus, a Espanha estacionou até ocorrer o renascimento da música nacional no século XIX, fenômeno chamado de "Renaixença” na Catalunha. O impulso intelectual criado com este movimento consiste, sobretudo, numa difusão progressiva da consciência autônoma política e cultural entre

13 “(...) Desde la invasión napoleónica, las luchas políticas que con frecuencia turbaban el orden nacional adormecieran la música autóctona, y sólo canciones ligeras o de carácter patriótico aparecían como tímida expresión lírica de um pueblo que había enriquecido otrora la música universal (...)” (PUJOL, 1960, p. 45). 
os catalães. A valorização da língua nativa, uma nova economia e a formação de correntes políticas próprias impulsionam tal revolução onde figuram importantes nomes de intelectuais resultando no aumento da produção cultural catalã.

No campo da música, com a liderança de Felipe Pedrell (1841-1922), o pioneiro da musicologia espanhola, iniciou-se o movimento nacionalista, que buscava na música antiga um dos elementos da renovação da cultura musical.

A atuação de Pedrell teve reflexos decisivos na Catalunha. O movimento musical ocorrido no período de Pedrell favoreceu a criação de uma escola nacional - a escola catalã. Foi a mais importante da Espanha, pois o interesse por música não pertencia somente a uma minoria, mas sim a quase toda a população. A música coral baseava-se na tradição folclórica e junto com a sardana inspirou a autonomia cultural catalã. As sociedades coral envolviam todas as classes sociais, que se dirigiam às instituições criadas com a finalidade de divulgar o repertório regional. Os orfeões cumpriram seu papel social, pois eram “uma grande família”. Do ponto de vista musical, contribuiu de maneira decisiva para a renovação musical espanhola. Foram criadas novas salas de concerto, escolas de música, o que possibilitou o surgimento de novos cantores (SOPENA, 1958, p. 62).

As primeiras corporações orfeônicas surgiram na Catalunha, onde a música vocal florescia, abrindo terreno para ser praticada por toda a Espanha. O iniciador do movimento coral catalão foi José Anselmo Clavé (1824-1874). Em 1845, dirigiu a sociedade "La Aurora” - núcleo inicial que serviu de base para a criação de outras sociedades musicais, sobretudo, de música coral. Lluís Millet (1867-1941), aluno de Pedrell, fundou em 1891 o Orfeu Catalá junto com os compositores Amadeo Vives (1871-1932) e Enrique Morera (1865-1942) que também fundou o coral Catalunya Nova (DUFOURCQ, 1965, vol. 2, p. 211). 
Algumas destas instituições perduram até hoje e se ocupam ainda em divulgar a música folclórica, como por exemplo, o coral Orfeo Catalá, cuja atuação foi decisiva para o movimento nacionalista e fomentou a produção de uma literatura musical baseada fundamentalmente em elementos folclóricos:

This choral society became the heart and the state of a genuine artistic tradition. Whilst encouraging the performance of folksong it also revived the great works of the Golden Age and commissioned new choral works. The importance of vocal music to the Catalan nationalists can be explained by their concern to preserve their own language. It was response to the literaly renaixença (PAINE, 1989, p. 21).

Paralelamente a atividade coral, com a mesma finalidade de valorizar a música folclórica espanhola, foram criados grupos de violões aliados a outros instrumentos da família de cordas dedilhadas e pinçadas. Um exemplo disso foi o movimento das Estudiantinas, como ficou conhecido, que unia diversos estudantes de diversas especialidades e classes sociais. Tais agrupações surgiram no início do século XIX ligadas à música popular e com o tempo, sua presença nas festas populares era habitual $^{14}$. Na sociedade formada por Clavé, foi organizada uma estudiantina que associava guitarras (violões), mandolinas ${ }^{15}$, bandurrias $^{16}$ e outros instrumentos populares (SUBIRÁ, 1953, p. 651). A Estudiantina Española era uma destas agrupações dirigida por Eugenio Arredondo. Em 1878, a Estudiantina Fígaro, dirigida por Domingo Granados, tocou nos principais teatros da Europa (NAVARRO, 1993, p. 139). Em 1897, foi criada a Estudiantina Universitária, composta por bandurrias, alaúdes, violinos, violões e instrumentos de percussão, dirigida por Juan Antonio Pujol

\footnotetext{
${ }^{14}$ Tais agrupações já existiam em 1808, conforme um dado histórico encontrado durante manifestações cívicas do dia 2 de Maio, onde homens, mulheres e crianças participavam num coral acompanhado por guitarras e bandurrias. Junto com a guitarra tradicional se usavam outros instrumentos (...) Em 20 de Outubro de 1892, o tenor Gayarre foi acompanhado com a mesma formação e em 1894, um coral de Clavé se reuniu a trezentos instrumentos que formavam uma estudiantina (NAVARRO, 1993, p. 80).

${ }^{15}$ Instrumento da família do alaúde, caixa de ressonância em forma de pêra e de tessitura aguda. Esteve muito em voga no século XVIII, e suas quatro ordens são afinadas iguais ao violino. Tem geralmente 16 trastes e se toca com pua.

${ }^{16}$ Instrumento de cinco ou seis cordas duplas que se toca com plectro com caixa de ressonância em forma de pêra com seis ou sete trastes.
} 
(RIERA, 1974, p. 20). Em outra região da Península, na Universidade de Coimbra (Portugal), onde a prática de música tradicional efervescia, temos o registro de que foi criado um movimento semelhante ${ }^{17}$ (figura 3).

O repertório destas estudiantinas era formado basicamente por músicas populares, e incluía canções tradicionais catalãs estudadas nesta pesquisa. No mesmo formato, se insere o Lira Orfeu - importante grupo musical do qual Llobet foi cofundador - que tem papel importante em suas adaptações de canções catalãs, como veremos adiante.

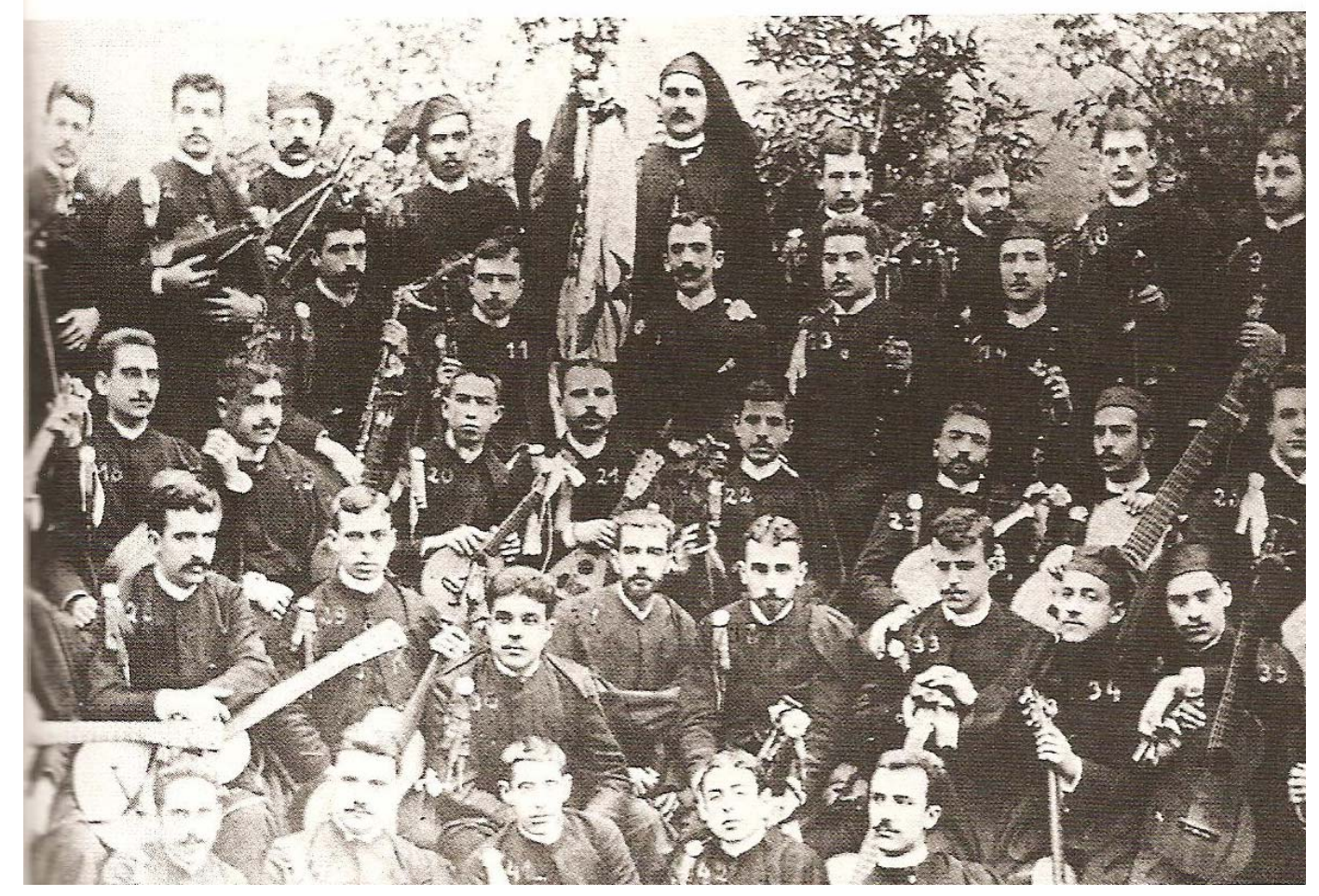

Figura 3. Estudiantina da Universidade de Coimbra

Alguns nomes que pertenceram à geração de músicos nacionalistas como Albeniz e Granados, exploraram abundantemente temas folclóricos. Outros nomes usaram inclusive os mesmos que Llobet, em seus arranjos e transcrições indicando assim e que mostram o ambiente folclórico que alimentava as produções desta geração.

\footnotetext{
${ }^{17}$ NERY, R.V. Para uma História do Fado. Lisboa: Edição Público, 2004, p. 113.
} 
Isaac Albéniz (1860-1909) e Enrique Granados (1867-1916), discípulos de Felipe Pedrell e filhos da Catalunha, mas apesar disso, escreveram pouca música catalã.

A obra de Albéniz foi escrita principalmente para piano. O contato com cancioneiros ibéricos (sobretudo o Cancioneiro do Palácio) e com Pedrell resultou em trabalhos baseados cada vez mais no folclore espanhol (GROVE, vol. 1, p. 203), principalmente o andaluz. Inserido neste repertório estão algumas peças que fazem referência à Catalunha: para piano solo, a Suíte espanhola op. 47 (1886) - $2^{\circ}$. movimento denominado Cataluña ${ }^{18}$ - e Capricho Catalán $^{19}$; além da produção para orquestra a Suíte Popular Catalonia (1899), Escenas Sinfônicas Catalanas (1889) e a obra originalmente escrita para orquestra Cataluña que junto com outras obras de música típica andaluza, ajudaram a dar corpo e vida para a escola nacional.

Granados dedicou sua obra ao piano e à música vocal. Estava fortemente atraído à tonadilla, à arte espanhola do período clássico e aos compositores românticos como Grieg, Schumann e Liszt, os quais influenciaram sua produção, como vemos em suas Escenas Românticas (sem data) e a ópera Goyescas (1911) baseada em impressões dramáticas de seu pintor favorito Francisco Goya (1746-1828).

Llobet manteve contato com esses dois importantes compositores, como veremos mais adiante.

Albeniz e Granados exploraram, sobretudo, o folclore andaluz, considerado, naquele momento, a arte mais nacional da Espanha. A música popular andaluza, com seus acentos característicos, se tornou uma grande escola musical através da sensibilidade de compositores catalães. A música catalã, por outro lado, possui outras

\footnotetext{
${ }^{18}$ ALBENIZ. I. Suíte Española op. 47. Transcribed and Fingered for Guitar by Manuel Barrueco. Bewin- Mills Publisher Corp., 1981; ALBENIZ, I. Suíte Española no. 2, Cataluña für 2 Gitarren bearbeitet von Hans-Gerhard Fey. Berlin: Edition Margaux, 1989 (partituras).

${ }^{19}$ ALBENIZ, I. Capricho Catalán. Trasncribed by Balaguer. Shawnee Press, s.d. Transcrição para violão (partitura).
} 
características que procuraremos comentar nesta pesquisa, através da investigação da canção tradicional.

Quando observamos o transcurso histórico da canção, percebemos que alguns elementos se perpetuaram. O costume de narrar fatos históricos, lendas e a religiosidade caminham juntos. De fato, perceberemos tais elementos nas canções tradicionais catalãs comentadas nesta pesquisa. Também levantaremos as possíveis origens dos temas usados na obra para violão de Llobet, à medida que traçamos o histórico das canções. 


\section{MIGUEL LLOBET: SEUS PREDECESSORES E}

\section{CONTEMPORÂNEOS}

Quando falamos do ressurgimento da escola nacional espanhola, notamos que foram músicos catalães que iniciaram o movimento que elevou o nível da música de seu país.

Da mesma maneira, o violão ressurgiu pelas mãos de violonistas catalães. Podemos dizer que existe um capítulo essencial no século XIX e XX na história do violão que passa obrigatoriamente por nomes importantes independentemente das correntes estéticas às quais estavam inseridos. Numa linha cronológica temos: Fernando Sor (1778-1839), e os discípulos de Francisco Tárrega (1852-1909) - Miguel Llobet, Domingo Prat (1886-1944), também aluno de Llobet, Daniel Fortea (1882-1953), e Emilio Pujol (1886-1980) ${ }^{20}$.

Fernando Sor estudou no monastério de Montsserrat, onde adquiriu uma base teórica sólida para se dedicar de forma autodidata ao violão, pois foi o primeiro grande compositor a escrever de maneira especial para o instrumento, pois vinha de uma fase de transição dos instrumentos de cordas duplas para os instrumentos de cordas simples, criando novas concepções técnicas. Suas obras constituem uma referência obrigatória para os violonistas ${ }^{21}$. Sor foi o primeiro violonista a valorizar temas populares catalães. Sua obra coral Crits del Carrer $^{22}$, que faz alusão aos gritos dos

\footnotetext{
${ }^{20}$ Embora Tárrega e Fortea sejam valencianos, ambos se estabeleceram em Barcelona e se integraram ao círculo musical deste grande centro artístico da Catalunha. Além disso, a delimitação política, geográfica e lingüística desta região em relação à Catalunha, é assunto de intermináveis debates políticos e movimentos separatistas.

${ }^{21}$ Um estudo mais específico sobre o violão deste período e do pensamento de Fernando Sor está contido no seu Méthode pour la Guitare, de 1830. Há uma tradução em português realizada por Guilherme de Camargo (CAMARGO, 2005).

${ }^{22}$ Esta obra é citada por Brian Jeffery com o título Draps i Ferro Vell (1861), e se encontra em quatro versões: duas versões para 4 vozes e piano, uma versão para 3 vozes e pequena orquestra e outra versão para 4 vozes e quarteto de cordas (JEFFERY, 1977, p. 9).
} 
vendedores ambulantes, foi cantada diversas vezes pelo coral Orfeo Catalá. Durante o período que passou em Paris escreveu um ballet sobre o tema catalão de Ventafocs (AMADES, 1951, p. 17). As obras Fantasia op. 54 bis, para dois violões, e Folias de Espagne op.15 (a), para violão solo, também citam temas populares ${ }^{23}$.

Domingo Prat estudou com Llobet de 1898 a 1904, passando a receber a orientação de Tárrega regularmente após a ida de Llobet a Paris. Em 1907, se estabelece definitivamente em Buenos Aires. Funda uma academia de violão onde se formam os concertistas mais destacados da época, entre eles, Maria Luisa Anido (1907-1996). Prat foi um dos responsáveis pela vinda de Llobet à América do Sul. No campo da investigação histórica, nos deixou uma obra de grande valor - o Diccionario de Guitarras, Guitarristas e Guitarreros (...), editado em 1934 e reeditado em 1986, nos Estados Unidos e no Japão ${ }^{24}$.

Daniel Fortea (1882-1953) era valenciano, mas passou boa parte de sua vida artística em Barcelona. Fundou a Biblioteca Fortea (figura 1) pela qual publicou suas obras originais e transcrições. Os violonistas espanhóis devem a esta biblioteca a condição favorável de terem suas obras editadas. Possui publicações de obras de concerto e composições para violão de caráter didático, poético e folclórico (PUJOL, 1960, p. 167).

Emilio Pujol iniciou seus estudos em sua terra natal - Granadella, província de Lérida - e estudou com Tárrega. Em 1898 já realizava apresentações junto com a Estudiantina Universitária, onde tocava bandurria, seu primeiro instrumento. Atuou como musicólogo, concertista, compositor e pedagogo.

\footnotetext{
${ }^{23}$ JEFFERY, B. Fernando Sor. Composer and Guitarrist. Londres: Tecla Editions, 1977, p. 155 et. seq. ${ }^{24}$ PRAT, D. Diccionario de Guitarristas. Columbus, Ohio: Editions Orphée, 1986.
} 


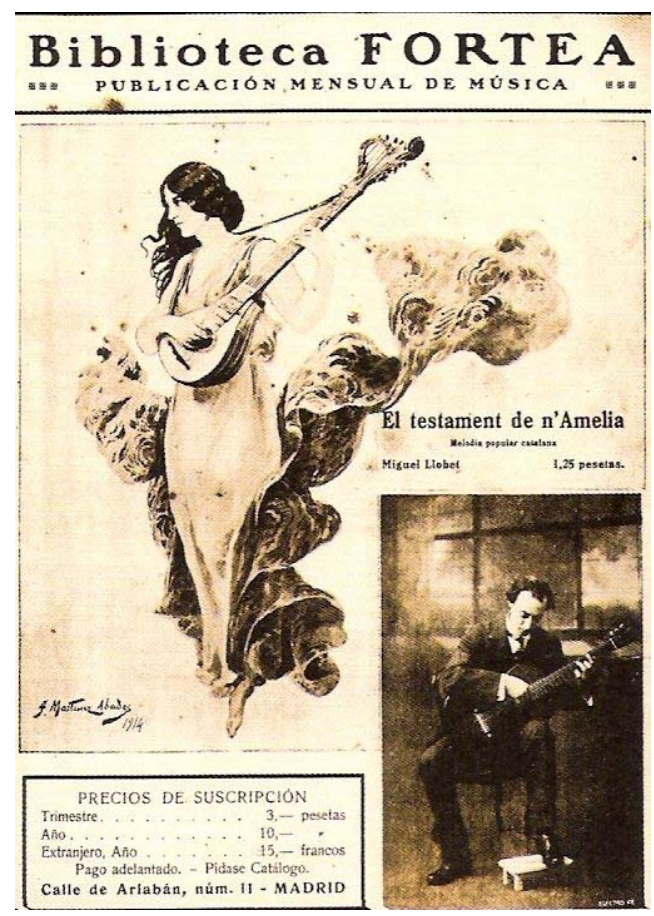

Figura 1. Edição de uma canção tradicional catalã de Llobet pela Biblioteca Fortea

No campo da musicologia, teve influência direta de Felipe Pedrell. Seu interesse pelo passado histórico ficou evidente em suas pesquisas do repertório do século XVI para instrumentos de cordas dedilhadas - guitarra, alaúde e principalmente, vihuela. Foi o primeiro violonista do século XX a realizar um concerto de vihuela, numa cópia deste instrumento realizada pelo luthier espanhol Francisco Simplicio (1874-1933). Como compositor Pujol seguiu o modelo deixado por Tárrega e como transcritor, seguiu os passos de Llobet, como veremos mais adiante nas adaptações de canções tradicionais catalãs que também realizou. Como pedagogo, escreveu Escuela Razonada de la Guitarra - uma obra que contém orientações inéditas para professor e aluno - baseado em suas experiências nas áreas em que atuava. Miguel Llobet foi um grande incentivador para a realização desta obra, dividida em quatro volumes (RIERA, 1974, p. 98).

Após a morte de Sor, o violão se encontrava decadente em toda a Europa, incluindo a Espanha. Como observou Emilio Pujol: 
La guitarra, entonces, era tenida por instrumento de limitados recursos. Desacreditada y manoseada por gentes incultas y de baja condición, sólo se la consideraba adecuada para rasguear en ella simples aires vulgares, acompañar toscamente canciones callejeras, o para unirla a otros instrumentos congéneres en rondas y serenatas de pintoresco tipismo. Como si fuese un instrumento al margen de la música, excluído del concepto general del arte, no podía ofrecer al artista un medio idóneo para el desarollo de sus faculdades, ni la utilidad práctica que brindaba la más humilde profesión. (PUJOL, 1960, p. 39)

Francisco Tárrega veio a ser um ponto de partida para melhorar a imagem do instrumento. Curiosamente, foi incentivado pelos seus professores do Conservatório de Madri a estudar piano - instrumento que gozava de grande popularidade na época - pois não existia curso de violão. Sua formação pianística o levou a realizar diversas transcrições para o violão, a fim de mostrar as possibilidades de tocar no instrumento os grandes clássicos dentre as obras de concerto para piano, quartetos, trechos orquestrais e trechos de ópera. Podemos atribuir suas renovações ao pensamento musical que adquiriu através de seus estudos de piano.

A única referência de seu tempo era a obra de Julian $\operatorname{Arcas}^{25}$ (1832-1882), de quem sofreu influência. Portanto, teve que forjar sua própria técnica, influenciada pelo ambiente musical que o cercava (piano e instrumentos de cordas), criando assim o que chamamos de "Escola de Tárrega” ${ }^{26}$. Apesar de não ter deixado escrito a definição de sua escola, passou seus conhecimentos de forma oral a seus discípulos já citados, e a ele são atribuídas mudanças na técnica de execução que foram seguidas por mais de um

\footnotetext{
${ }^{25}$ Arcas é o principal representante do violão que sucedeu Sor e Aguado. Sua atividade como concertista abrangeu toda a Espanha e parte da Europa, principalmente no período de 1860-70. Como compositor, deixou 30 obras originais, a maioria de caráter folclórico. Arcas teve uma influência decisiva nos trabalhos do luthier Antonio Torres e nas alterações que o violão sofreu neste período, em seu tamanho e estrutura. Pode ser considerado pioneiro na realização de adaptações de obras de piano para violão, e muitos gêneros musicais que integravam seu repertório foram adotados mais tarde pelos violonistas. Arcas pode ser considerado o introdutor do nacionalismo no violão ao explorar temas regionais. Estava atento aos acontecimentos políticos de sua época e tinha afinidades com o movimento de independência cubano que teve repercussão no governo espanhol e influenciou sua obra para violão ao utilizar temas populares cubanos (GRONDONA, 2004, encarte de Cd).

${ }^{26}$ Não se sabe em que período Tárrega recebeu conselhos ou orientação de Arcas, mas ambos utilizavam uma técnica de mão direita semelhante conforme narra Pujol na biografia de seu mestre (PUJOL, 1960, p. 224) O conceito da existência de uma escola sistematizada por Tárrega vem sendo discutido por diversos violonistas. Falaremos a respeito da polêmica difusão deste conceito mais adiante.
} 
século. Suas inovações, do ponto de vista instrumental, especificavam claramente suas intenções musicais e exploravam as possibilidades timbrísticas do violão.

Tárrega deixou obras de valor permanente na literatura para violão: predominando a peça de caráter nas formas de dança de salão, estudos, transcrições, trêmolos e os admiráveis Prelúdios, onde encontramos a influência de Schumann e Chopin. No Preludio no. 2 podemos notar o uso de timbres e harmonias pouco convencionais na obra de Tárrega, em homenagem à seu querido discípulo Miguel Llobet, que tinha uma concepção diferenciada de seu mestre ao compor suas obras, como veremos adiante. O interesse de Tárrega pelos clássicos o levou a realizar excelentes transcrições de obras de Bach, Mendelssohn, Albeniz, Granados, entre outros, linha seguida depois por Llobet, que levou adiante as técnicas de composição e transcrição vindas de Tárrega.

Fernando Sor, Francisco Tárrega e Miguel Llobet são citados por Jaime Pahissa (1955, p. 117) por serem os principais responsáveis em elevar o prestígio do violão. No entanto, existe um período em que outros nomes figuraram no cenário violonístico, mesmo que timidamente.

Pouco se sabe a respeito deste período, por isso reservamos um espaço para falar dos violonistas catalães pouco conhecidos que marcaram presença no século XIX. Segundo Mangado (1998, p. 19-24), esta fase pode ser dividida em dois períodos: Primeiro Período (1814-1840) e Segundo Período (1840-1939): 

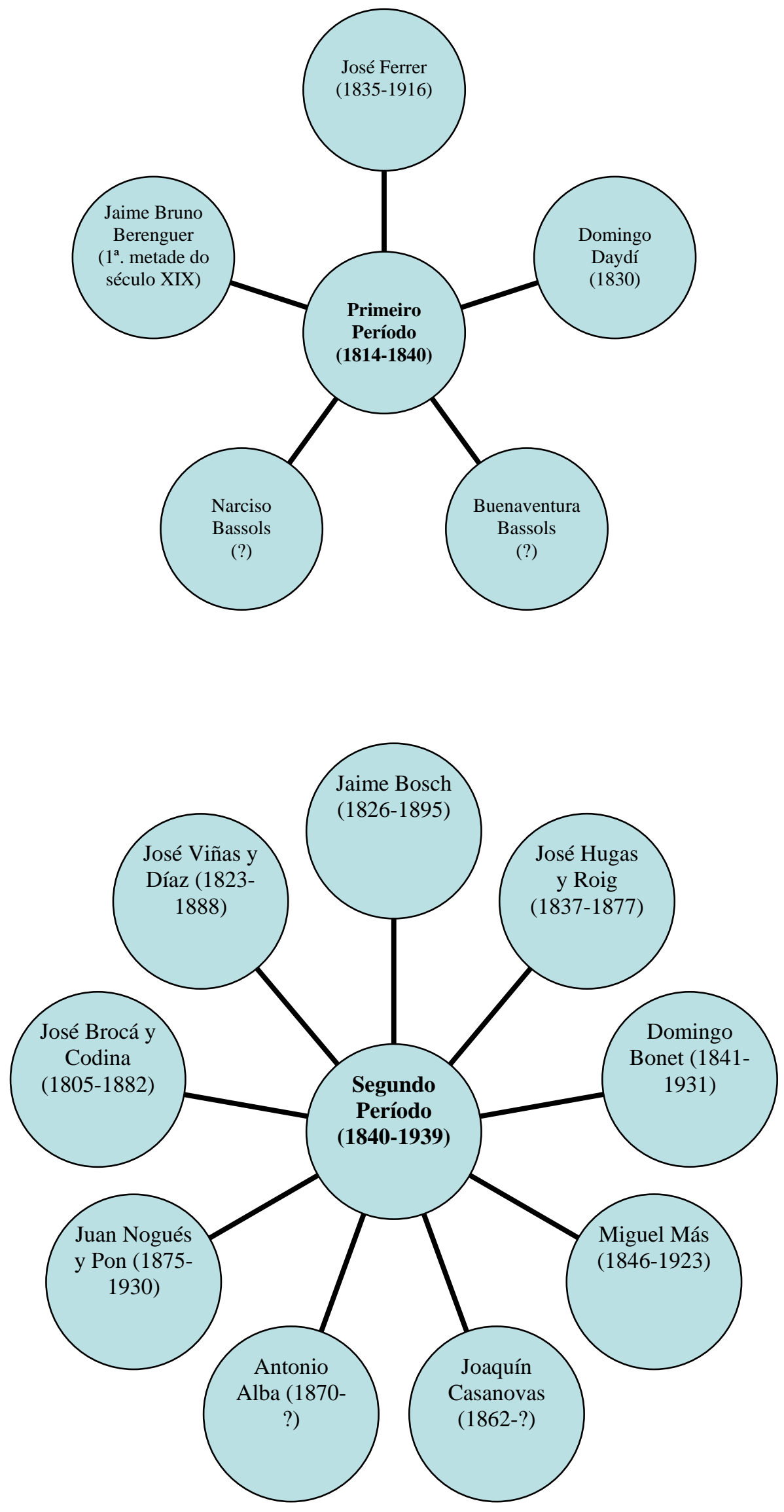
Alguns nomes desta geração ainda pouco conhecida participaram da sociedade musical Lira Orfeo (figura 2). Esta sociedade foi criada em $1^{\circ}$. de Outubro de 1898 pelo violonista catalão Pedro Lloret Blanch (1874-?) com a ajuda de outros sócios fundadores, entre eles, Miguel Llobet. Integravam o corpo docente desta sociedade: Pedro Lloret, Domingo Prat e o próprio Llobet - que exerciam a atividade de professores de violão - além de outros nomes como Baldomero Caldera (1856-1929), Domingo Bonet e Juan Bas - professores de instrumentos de plectro - e Manuel Burgés, José Barberá, José Aznar e Salvador Bártoli - como professores teóricos.

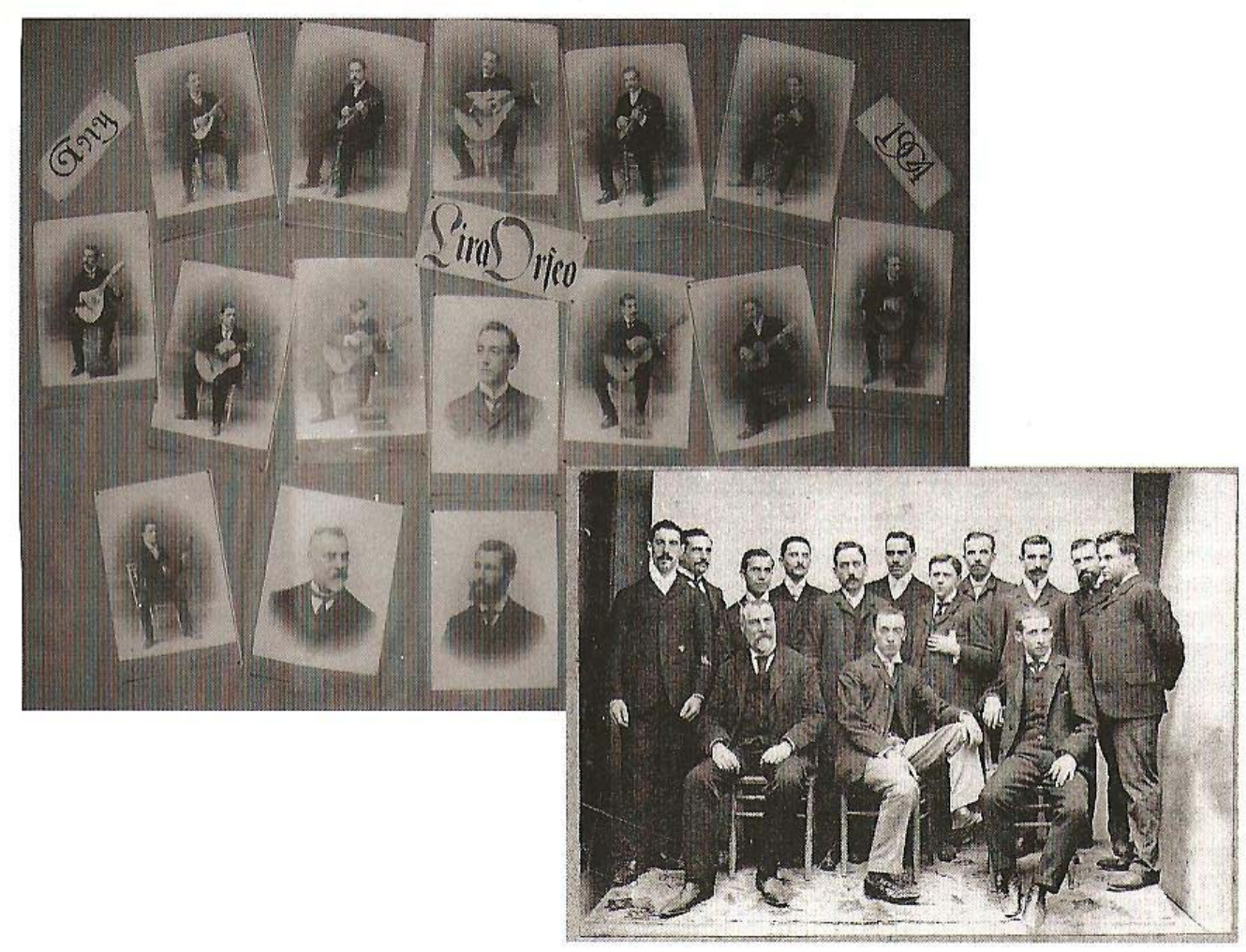

Figura 2. Sociedade Lira Orfeo

Os alunos tinham aulas de solfejo, harmonia, história do instrumento e recebiam orientações que lhes proporcionavam uma técnica depurada de execução clássica. A sólida formação musical que os alunos desta sociedade recebiam fica evidente no comentário da violonista Rosa Lloret (1909-?), filha de Lloret e discípula de Llobet: 
Todos ellos, com verdadero altruismo, daban las lecciones por las noches, de 9 a 1 hasta las dos de madrugada, individualmente e en grupos de 15, 20 y hasta 25 alumnos dos y tres veces a la semana, y además uma classe de conjunto cada 4 días. También se preocupaban de la cultura teórico-artística de los alumnos, mediante uma numerosa serie de conferencias relacionadas con el de la música en particular, se obsequiaba a los socios protectores con selectos y variados conciertos íntimos en los que tomaban parte como solistas los maestros de la escuela (MANGADO, 1998, p. 91).

Lira Orfeo, também conhecida como Els Lirons, teve uma curta duração devido a diversos problemas entre os sócios fundadores e ao estabelecimento de Llobet em Paris em 1905. Tal importante iniciativa para o violão em Barcelona acabou em 2 de Dezembro de 1907, nove anos depois de sua fundação. Por ela devem ter passado mais de 500 alunos.

As atividades da Lira Orfeo foram determinantes para o ensino do instrumento de forma mais sistematizada, uma vez que o violão durante o século XIX não encontrava espaço para ser divulgado e ensinado nas escolas de música. Antes da sociedade Lira Orfeo, encontramos algumas classes de violão e instrumentos de plectro embora não estivessem oficialmente integradas nas instituições.

Toda la actividad de la enseñanza de la guitarra durante el siglo XIX, se impartía en dos ámbitos de la vida barcelonesa, las academias privadas de música y las classes particulares que algunos maestros de dicho instrumento proporcionaban. Hasta que en la ultima década del siglo XIX las instituciones de la ciudad decidieron instaurar este servicio en sus centros (MANGADO, 1998, p. 89).

O centro mais antigo de ensino musical em Barcelona era o Conservatório Superior de Música del Liceo, fundado em 1837 com o nome de Liceo Dramático de los Aficionados, conhecido popularmente como Liceo. Outro centro importante era o Conservatório Superior de Música de Barcelona, fundado em 1886 com o nome de Escola Municipal de Música. Os primeiros professores de violão nestes dois principais centros de música foram os discípulos de José Brocá. Miguel Más foi o primeiro a exercer a função de professor de violão e instrumentos de plectro, seguido por Juan 
Nogués y Pon, na Escola Municipal. Domingo Bonet (de 1897 a 1898) e José Ferrer (de 1898 a 1901) foram os primeiros professores do Liceo, seguidos por Joaquin Casanovas que ocupou o cargo até ser substituído por Graciano Tarragó ${ }^{27}$ (1892-1973), em 1933.

Vale citar também algumas casas que serviam para reunir os diletantes, onde se tocava e discutia violão.

A Ca'ls Guitarrers (Casa dos Violonistas) existia em 1892 e oferecia o ambiente ideal para os aficionados pelo violão, pois reunia os professores e violonistas mais importantes da época (PUJOL, 1960, p. 119).

A Casa Llibre em Barcelona, por sua situação estratégica, reunia vários artistas (RIERA, 1974, p. 47). Nestas ocasiões era muito comum ocorrer o costume que é muito popular até hoje entre os espanhóis - a tertúlia ${ }^{28}$.

Neste contexto, o violão se estabelecia gradualmente na sociedade como instrumento de concerto e conquistava seu espaço nas cadeiras das escolas de música da Catalunha.

As contribuições de Antonio Torres (1817-1892) marcaram grandes transformações na arte de lutheria do violão ${ }^{29}$ estabelecendo novos padrões estéticos. A construção de um novo violão, com mais sonoridade, um timbre de maior qualidade e contornos mais harmoniosos, ofereceram condições para sua evolução e este modelo foi adotado pelos construtores que o sucederam, na Espanha e no resto do mundo. Torres

\footnotetext{
${ }^{27}$ Tarragó foi aluno de Casanovas antes de ocupar o cargo de professor do Liceo e possuía algumas deficiências em sua formação como violonista (MANGADO, 1998, p. 90). Não tendo suas necessidades musicais atendidas por seu professor, foi procurar a orientação dos discípulos de Tárrega e teve de escolher entre Pujol e Llobet. A respeito de sua decisão, comentaremos mais adiante, para tentarmos delinear a personalidade e a concepção musical de Llobet.

${ }^{28}$ A tertúlia consiste em que outros escutem mesmo que o locutor não tenha a mínima idéia do que está falando. O importante é saber falar alto numa espécie de torneio para decidir quem tem o pulmão mais forte ou quem fala a maior besteira. Os assuntos podem ser os mais variados: arte, política, esportes, história, ciência, etc (BUADES, 2006, p. 32). Llobet pode ser reconhecido como um verdadeiro tertuliano, como veremos adiante, para delinear sua personalidade engajada em acontecimentos políticos e sociais que pode tê-lo motivado a escrever as canções tradicionais catalãs.

${ }^{29}$ Para mais informações sobre lutheria histórica realizada na Espanha recomendamos o trabalho de GRONDONA, S.; WALDNER, L. La Guitarra di Liuteria. Master Pieces of Guitar Making. L'officina del libro, 2001.
} 
era andaluz, mas enviava a maioria de seus violões, para a região da Catalunha, que representava o grande centro de música culta para violão. Julián Arcas foi o primeiro a utilizar um violão Torres e tornou-o conhecido através de suas atuações. Na ocasião em que Tárrega ouviu Arcas pela primeira vez, ele usava um modelo que ficou conhecido como “La Leona”30, por ser considerada a melhor de todas existentes (PUJOL, 1960, p. 35). O “novo violão” surgiu principalmente pelas mãos de Torres, e em breve o monopólio que era mantido pelos catalães gradualmente deixou de existir, tendo seus modelos espalhados pela Europa, através das atividades de concertista de Tárrega, Llobet e Pujol. O violão de Torres era o preferido de Llobet (figura 3), que o apresentou mais tarde para o luthier alemão Hermann Hauser I (1882-1952), talvez o primeiro construtor fora da Espanha a adotar o modelo Torres.

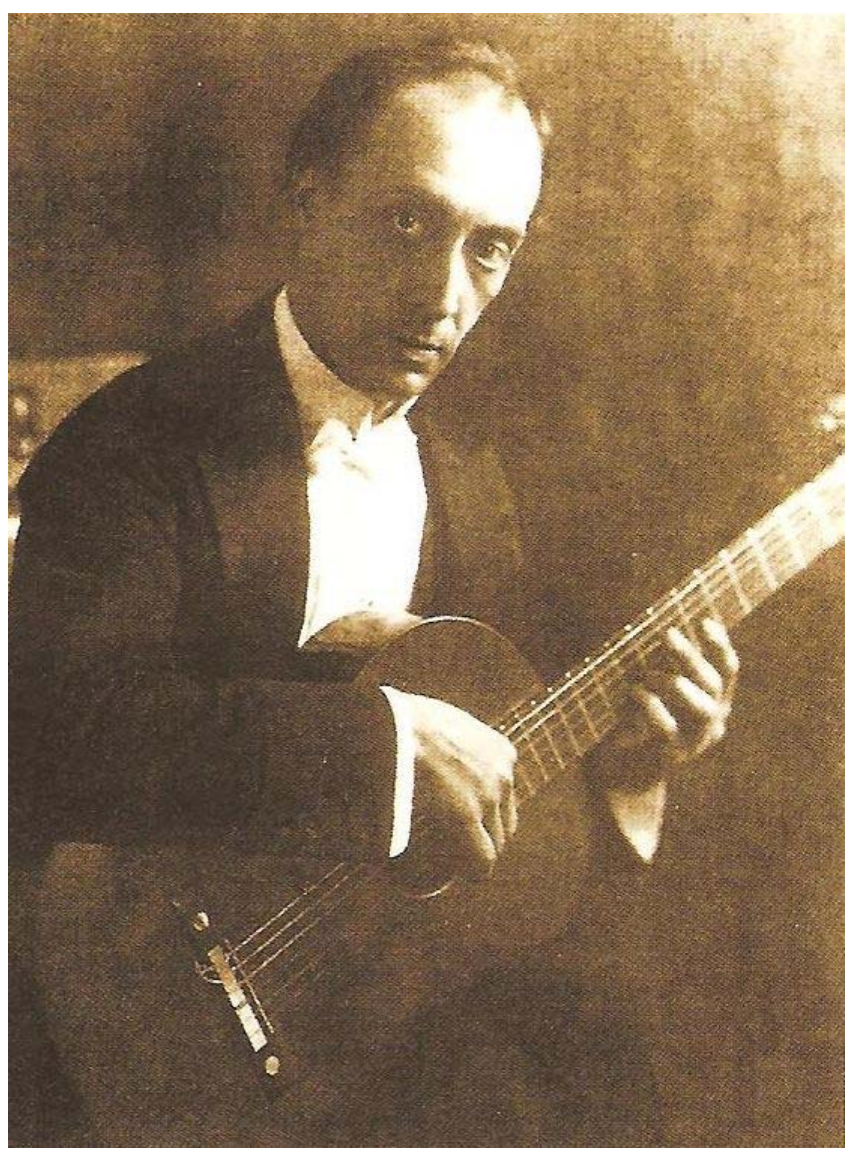

Figura 3. Miguel Llobet com um violão Torres de 1859

\footnotetext{
${ }^{30}$ Cf. STEFANO GRONDONA. La Guitarra de Torres. Appassionato, 2000 (Cd). O violonista Stefano Grondona usou este violão histórico nas gravações deste Cd.
} 
Não podemos deixar de mencionar o violonista andaluz Andrés Segovia (1893-1987), que com sua carreira de quase oitenta anos continua a fascinar estudantes, profissionais e amadores. Segovia ainda é considerado como a personificação do violonista-intéprete por várias gerações de violonistas e teve um papel decisivo no desenvolvimento do violão. Além de transformá-lo num instrumento de prestígio através de seus concertos nas salas mais importantes do mundo, ajudou a ampliar o repertório com obras por ele comissionadas a outros compositores como: Federico Moreno Torroba (1891-1982), Joaquin Rodrigo (1902-1999), Alexander Tansman (1897-1986), Mario Castelnuovo-Tedesco (1895-1968), Manuel Ponce (1882-1948) e Heitor Villa-Lobos (1887-1959). O conjunto deste repertório foi dedicado a Segovia, por isso é conhecido hoje como repertório segoviano. O próprio Segovia teve uma pequena incursão como compositor e algumas de suas obras também utilizaram canções tradicionais catalãs, como veremos adiante.

Segovia divulgou o violão, levando-o às melhores salas de concerto do mundo, após Llobet refinar a arte do violão tanto nos aspectos da composição, da transcrição e da execução.

As informações que encontramos sobre a formação de Segovia não oferecem dados precisos. Afirmava ser autodidata, embora reconhecesse ter sido um discípulo indireto de Tárrega. Em sua biografia, fala de seus encontros com Llobet, com quem mantinha uma relação de amizade. Destes encontros, espécies de classes de violão, podemos concluir que Llobet teve influência sobre a formação de Segovia.

Llobet causou uma forte impressão em Segovia, quando se conheceram em 1914. Segovia narra esta ocasião em sua autobiografia:

No other guitarist I had heard, I told him, had made me forget the limitations of the guitar or revealed the scope of its potencial (...) I assured him I agreed implicitly with his technique and would follow it relentlessly, no matter in how difficult the path ahead for me (...) In spite of the difference in our ages, Llobet and I became good friends 
and, in time, the results o four relationship were happy ones for me. My attitude towards him was one of admiration for the artist and affection for the friend. Once he had tested my technique and capacity of expression, his esteem for me was probably increased by my profound determination to broaden the guitar's repertoire and raise the instrument's prestige. I was in every sense a friend! (SEGOVIA, 1976, p.100 e 102).

O impacto resultou em diversas sessões de concerto particulares e uma relação de amizade entre os violonistas. Embora Segovia não admita, Llobet pode ter representado para ele a figura de orientador.

Purcell publicou uma foto (figura 4) onde Llobet está tocando num círculo de amigos. Entre eles, outro discípulo de Tárrega, Abade Corelle, Juan Parras (aluno de Segovia), o luthier Enrique Garcia, Alfred Cottin, Francisco Rizo (filho de Tárrega) e finalmente, Segovia, sentado à sua direita e não só estava atento à sua execução, como levou um de seus alunos para o concerto íntimo (PURCELL, 1989, vol. 1, p. viii).

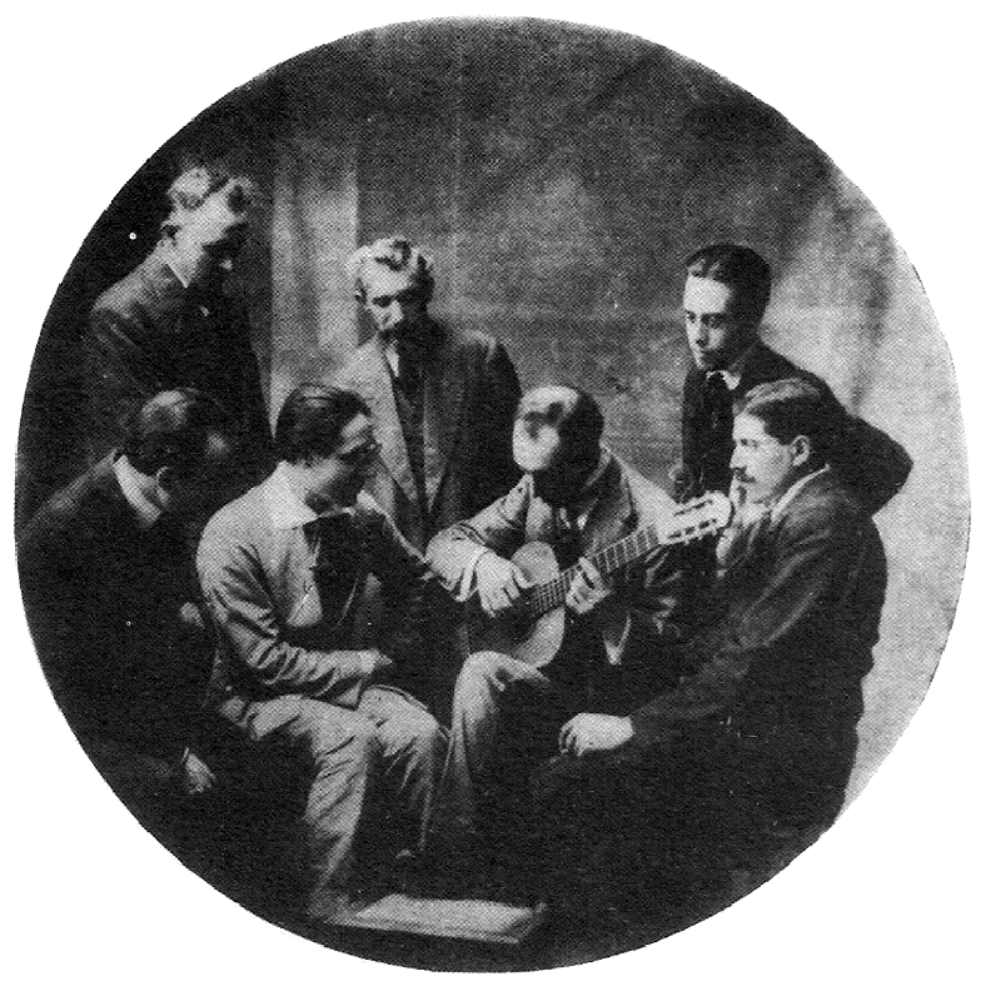

Figura 4. Llobet rodeado pelo "grupo de admiradores”

Phillips afirma que Llobet teve uma influência direta na formação de Segovia: “The Llobet was mentor to María Luisa Anido, José Rey de la Torre and 
Andrés Segovia, three of the most important guitarrists of the first half of twentieth century, must be considered relevant.” (PHILLIPS, 2002b, p. 4) Podemos concluir a evidência disso ao analisarmos as gravações realizadas por Llobet ${ }^{31}$ e Segovia $^{32}$, onde percebemos a influência do estilo de Tárrega em ambos os violonistas (PURCELL, 1989, vol.1, ii). Segovia, obviamente, teve contato com a técnica de Tárrega através dos discípulos de Tárrega, principalmente de Llobet (figura 5).

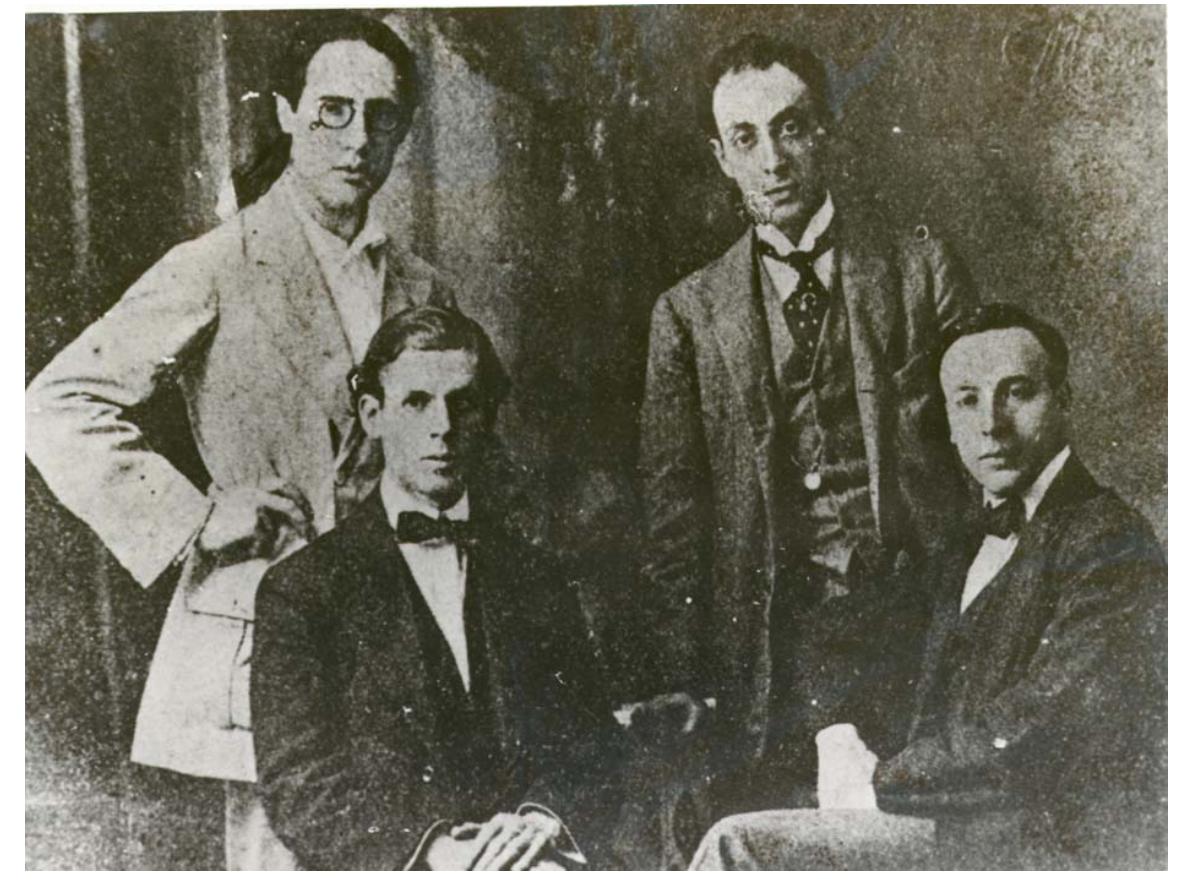

Figura 5. Fotografia histórica (c. 1918): Segovia, Fortea, Llobet e Pujol

O próprio Segovia, numa passagem em sua autobiografia, narra que Llobet o convidou para ir a sua casa a fim de orientá-lo na execução de algumas composições suas (SEGOVIA, 1976, p. 106). Com as informações encontradas na autobiografia de Segovia, podemos posicionar a figura de Llobet na formação de Segovia e atribuir o devido crédito ao violonista catalão ao influenciar gerações de violonistas importantes. Uma fotografia (c. 1924) publicada por Purcell nos faz acreditar que Segovia estava muito interessado na carreira de Llobet como concertista. Nesta foto ele aparece ao lado

\footnotetext{
${ }^{31}$ MIGUEL LLOBET. The Guitar Recordings 1925-1929. Chanterelle Historical Recordings (Cd).

${ }^{32}$ Andrés Segovia 1927-1939 Recordings, volume 1 e 2.
} 
do violonista catalão em meio a outras personalidades como Alfred Rondorf, Heinrich Albert, Hermann Hauser I e os membros da Munich Guitar Society (figura 6).

A polêmica relação entre Segovia e Llobet é um capítulo importante da história do violão. Emilio Pujol numa nota biográfica a respeito de Llobet no prefácio de primeira edição da obra Le Tombeau de Claude Debussy, que falaremos mais adiante, comenta que Segovia estava entre seus estudantes. Hector Garcia, detentor de parte do arquivo com obras e documentos de Pujol, responde esta questão numa carta para Robert Phillips:

De acuerdo con anécdotas contadas a mí por el maestro Emilio Pujol, Andrés Segovia le pidió tomar lecciones de él. El Maestro Pujol declino de la petición y recomendó a Segovia que tomará lecciones de Miguel Llobet quien aparte de la ayuda musico-instrumental, podría ayudarlo a darse conocer a través de los contactos que Llobet, por ser el guitarrista-concertista más conocido, tenía en toda Europa (...) Pujol le prometió que hablaria con Llobet y que estaba seguro que debido a la amistad entre ellos, este accederia a la petición. Asi fué, y Segovia comenzó a recibir lecciones de Miguel Llobet, unas cuatro o cinco. Al cabo de las mismas Llobet le informo a Pujol que él havia accedido a tomar a Segovia como estudiante, pero dada la rebeldia de Segovia a seguir las indicaciones de Llobet, este se verá obligado a terminar las clases con Segovia. (GARCIA, 2002 apud PHILLPS, 2002b, p. 85)

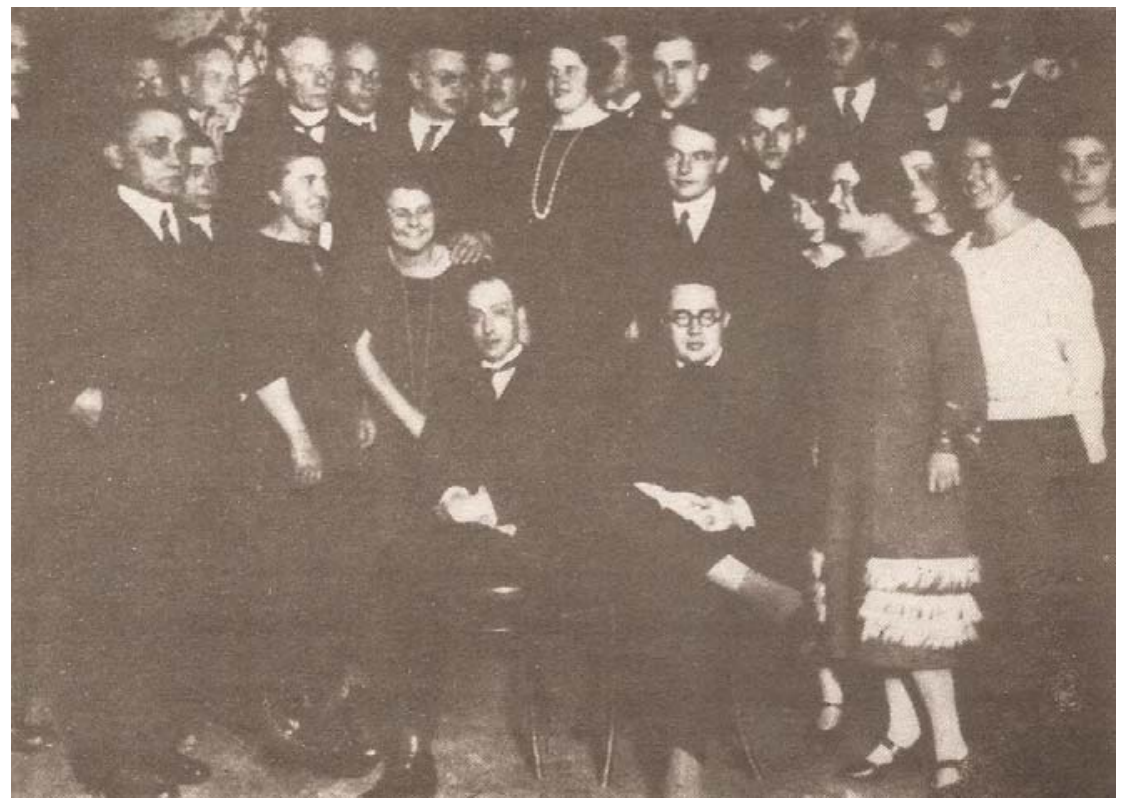

Figura 6. Llobet com a Munich Guitar Society após um concerto 
Não sabemos até que ponto Llobet influenciou Segovia. Mas examinando depoimentos de seus contemporâneos e alguns episódios relatados pelo próprio Segovia, somos cada vez mais levados a crer que tal influência é um fato.

Trataremos agora de comentar a geração de discípulos de Llobet, representados na figura dos irmãos Regino (1896-1981) e Eduardo Sainz de la Maza (1903-1982), Maria Luisa Anido (1907-1996), Luise Walker (1910-1998) e José Rey de la Torre (1917-1994).

Os irmãos Sainz de la Maza iniciaram seus estudos com Daniel Fortea em Madri, mudando-se em seguida para Barcelona a fim de continuar seus estudos com Llobet. Regino tornou-se mais conhecido por sua carreira de concertista internacional, enquanto que Eduardo tornou-se um respeitado professor de violão.

Maria Luisa Anido foi uma prodigiosa violonista argentina. Seu primeiro concerto se deu em 1918, quando tinha apenas 11 anos de idade.

Transcreveremos aqui um comentário de Llobet feito em 1919:

Maria Luisa Anido fué para mi una revelación. La impressión que me produjo no se borrará jamás de mi mente, pues en realidade es algo que sobrepasa todo lo imaginable. Ver uma nina de once años venciendo y dominando las más grandes dificultades sin el menor esfuerzo, cual podría hacerlo el más consumado de los concertistas, es cosa que causa assombro, y lo más admirable en ella, quizá, y que sen duda alguna constituye el más preciado de los dotes, es la rica intuición musical que revelan sus interpretaciones, la mayoría de ellas altamente artísticas. A pesar de las sensacionales noticias que de elle tenía por la prensa de Buenos Aires, a raiz de sus primeras audiciones y muy especialmente por su eminente maestro Domingo Prat, tuve, al oírla, la sensación de lo increíble. Desconcierta el pensar qué es lo que podrá hacer esa maravilhosa criatura cuando esté en plena madurez. (PRAT, 1986, p. 30)

Podemos encontrar dados importantes sobre Llobet nos depoimentos desta célebre violonista em forma de entrevistas. Sobre estes dados falaremos adiante. 
Luise Walker, violonista austríaca que recebeu orientação de Llobet durante suas idas à Viena. Realizou intensas atividades como concertista na Europa, Rússia e Estada Unidos e como compositora.

José Rey de la Torre, violonista cubano, também foi um menino prodígio do violão. Mudou-se para Barcelona em 1932 com a finalidade de estudar com Llobet, com quem estudou durante dois anos e meio. Sua carreira de concertista teve grande sucesso nos Estados Unidos, onde se estabeleceu em 1939. Várias obras de compositores importantes foram escritas para ele. Entre estes, Julian Orbón, José Ardevol e Joaquín Nin-Cumell. Podemos tirar algumas conclusões sobre a concepção técnica e musical de Llobet dos relatos de Rey de la Torres a respeito da orientação que recebeu de seu mestre e discutiremos isso mais adiante.

No Brasil temos um violonista que estudou com Llobet - o uruguaio Isaías Sávio (1900-1977) (PHILLIPS, 2002b, p. 9; DUDEQUE, 1994, p. 103) - que colaborou na difusão da escola de violão espanhola quando se estabeleceu no país em 1931.

As atividades dos discípulos de Llobet tiveram destaque no cenário musical e ajudaram a difundir a importância de seu mestre para a história do violão e sua nova linguagem estética, temas que discutiremos adiante. 


\section{MIGUEL LLOBET Y SOLÉS (1878-1938)}

Neste capítulo vamos procurar analisar a personalidade de Miguel Llobet como compositor, transcritor, professor, artista plástico, concertista e intelectual bem como comentar a sua importância na história do violão e sua contribuição para posicionar o violão dentro de uma nova linguagem estética com a adaptação das Canciones Catalanas, entre outras obras.

Falaremos sobre a vida de Llobet a fim de contextualizar sua obra no tempo, considerar as influências que recebeu a partir de suas relações com outros compositores e violonistas e delinear algumas facetas de sua personalidade com base em algumas informações biográficas encontradas ${ }^{33}$.

Miguel Llobet y Solés nasceu em 18 de Outubro de 1878 em Barcelona, capital da Catalunha. Filho de pai escultor, Llobet mostrou disposição para a pintura, mas foi pela música seu maior interesse. Além do violão estudou violino e piano na Escola Municipal de Música de Barcelona e sua paixão pelo violão começou quando ganhou o instrumento de um tio. Ao contrário de Tárrega, Llobet em sua juventude teve condições mais favoráveis. Em 1889, Llobet assiste um concerto de Antonio Manjón $(1866-1919)^{34}$ e impressionado com o instrumento, decide dedicar-se completamente,

\footnotetext{
${ }^{33}$ Para mais dados biográficos a respeito de Miguel Llobet, recomendamos a leitura de autores como: PRAT, D. Diccionario de Guitarristas. Columbus, Ohio: Editions Orphée, 1986; PURCELL, R. Miguel Llobet Guitar Works, 5 volumes (partitura); TONAZZI, B. Miguel Llobet, Chitarrista dell'Impressionismo. Ancona: Bérben, 1966 e STEFANO GRONDONA (encarte de Cds).

${ }^{34}$ Antonio Manjón é uma figura ainda pouco estudada que ainda precisa ser desvendada. Estudou com um discípulo de Aguado em sua terra natal, Jaén, embora seja possível afirmar que era considerado um autodidata. Devemos a ele o método mais completo de instrumentos com mais de seis cordas. Os primeiros anos de sua carreira foram muito difíceis, devido à falta de apoio e a perda da visão, aos 13 anos. Seus programas de concerto revelam uma personalidade nada comum para o mundo violonístico de sua época, pois incluía obras dos grandes compositores como Beethoven e Schumann. Este fato o coloca numa posição curiosa em relação à Tárrega, que apenas um pouco mais tarde realizou as transcrições destes compositores. A impressão que deixava em seu público era inesquecível e as críticas de seus concertos eram sempre as melhores. A este importante e pouco conhecido violonista é atribuído o fato de Llobet ter abandonado sua carreira promissora de artista plástico para se dedicar aos estudos de violão, após ter assistido um de seus concertos. Cf. RAPHAËLLA SMITH. Antonio Jimenez Manjón 18661919 (Cd); MANJÓN, A. Collected Works. Chanterelle, 1996 (partitura).
} 
estudando com Magín Alegre (?-?) ${ }^{35}$, um nome com poucas referências, e depois, com Francisco Tárrega ${ }^{36}$.

Miguel Llobet é uma figura extremamente importante na história do violão, mas ainda não teve seu merecido destaque. Apesar das informações citadas acima, Llobet ficou um tanto esquecido e sufocado entre as notoriedades de Tárrega e Segovia. Procuramos identificar, portanto, os fatores que contribuíram para o esquecimento da totalidade da obra de Llobet, o atraso das edições de suas obras e arquivos perdidos.

A guerra civil espanhola ${ }^{37}$ (1936-39) colocou uma espécie de cortina na produção musical e intelectual desta etapa em toda a Espanha e Llobet foi um dos autores que ficou neste ostracismo latente. A maioria de suas obras começou a ser editadas somente a partir da década de 60. Além disso, a bibliografia que temos não é suficiente para classificar esta figura tão importante para o violão.

Esta insuficiência nas publicações a respeito de Llobet traz a necessidade de analisarmos sua posição na história do violão de maneira contextualizada, a partir de suas relações com outros nomes importantes do cenário violonístico de sua época.

No capítulo 2 citamos alguns nomes pouco conhecidos dos violonistas que sucederam a Sor. Os dois períodos onde figuram tais nomes foram pouco investigados. A partir de Tárrega temos mais informações sobre os acontecimentos na Catalunha. Temos os ensaios biográficos tanto de Tárrega como de Pujol. No entanto, falta um

\footnotetext{
${ }^{35}$ Prat revela que Magín Alegre era compositor e guitarrista modesto que se viu obrigado a se dividir em duas profissões, visto pertencer a uma época em que o violão era pouco difundido. Era comerciante e professor de violão. Seus discípulos foram Pedro Lloret, o próprio Llobet, José Tey, Tomás Prat e outros. Realizava reuniões animadas em sua casa onde recebia seus alunos para tocar obras dos violonistas da época como Brocá, Viñas, Arcas e outros. Julián Arcas dedicou a ele a célebre “Jota Aragonesa”. No ano de 1892 foi organizada uma sociedade de violão de efêmera existência cujo conselheiro era o Senhor Magi, como era conhecido. Apesar de sua modéstia, foi decisiva a sua participação na formação de uma geração de violonistas.

${ }^{36}$ Seu primeiro contato com Tárrega se deu na Casa dos Violonistas (Cáls Gitarrers) citada no capítulo 2 (RIERA, 1974, p. 119).

37 A guerra civil pode ser interpretada como o episódio mais cruel e sangrento do processo de modernização espanhol. Entre as causas diagnosticadas desta guerra encontra-se um complexo conjunto de sentimentos nacionais (BUADES, 2006, p. 171). Os catalães possuem um forte sentimento nacionalista que os levou a lutar por sua autonomia lingüística, literária e musical, além de sua autonomia econômica, social e política através de uma forte campanha anarquista (figura 1).
} 
livro biográfico mais completo sobre Miguel Llobet, o que dificulta comentarmos sua vida artística e social de maneira definida. Mas podemos ter certeza que sua influência desencadeou perspectivas de um futuro para o violão que Andrés Segovia soube aproveitar e aumentar.

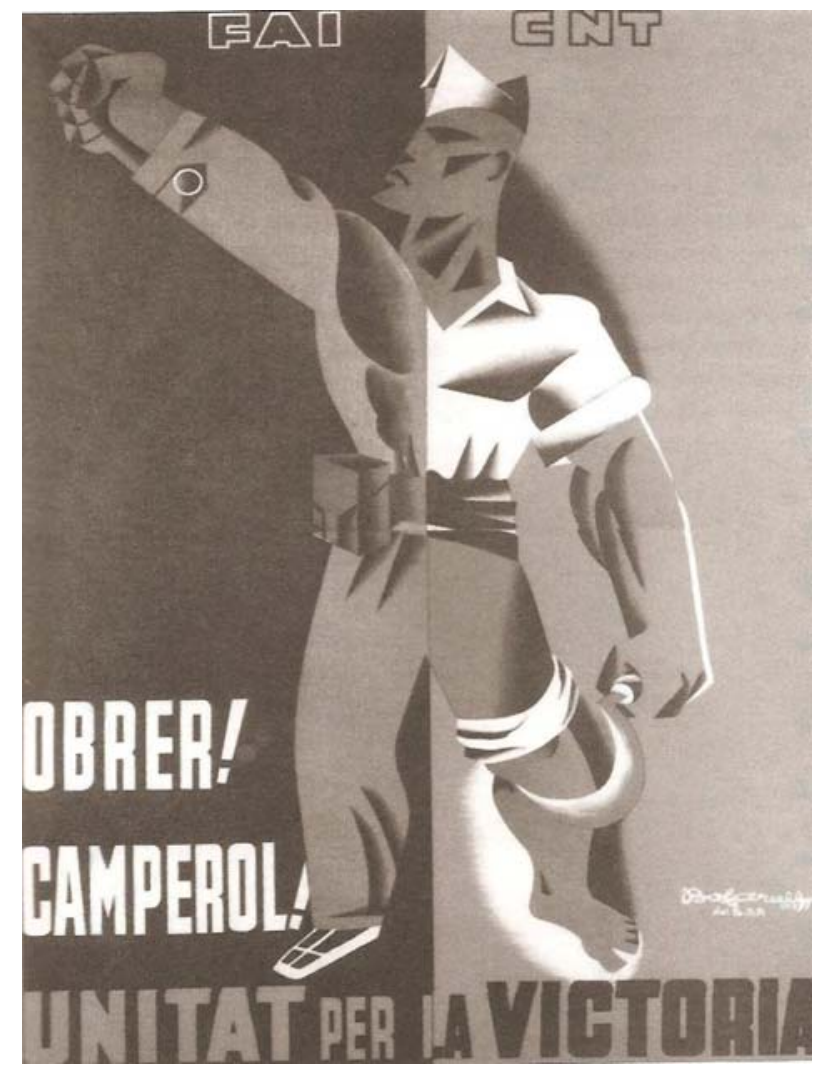

Figura 1. Cartaz anarquista que fomentou a propaganda política durante a Guerra Civil Espanhola

Examinando o escasso material bibliográfico que tivemos acesso, nos sentimos cada vez mais atraídos pela obra deste extraordinário violonista, bem como por sua personalidade. Segundo Pahissa (1947, p. 121) Llobet era amável e bom. Anido comenta a respeito da personalidade contraditória de Llobet, seu virtuosismo, embora um pouco acomodado:

(...) una persona que era más camarada que otra cosa. Como guitarrista era de una facilidade natural y un virtuosismo que pocas veces he visto en mi vida. Llobet no estudiaba casi nada, no pasaba de una hora, pero siempre estaba pensando en música (...) Llobet era un hombre muy libre en sus cosas aunque era metódico en su forma de vida, en sus horas de comida y todo; pero no sé, tenía esa facilidade natural que lo hacía estudiar poco o casi nada. Es decir: entre concierto y concierto 
(diez dias, por ejemplo) él se limaba las uñas para no estudiar, aunque siempre estaba pensando en la guitarra (...). (HELGUERA, 2001, p. 12)

Grondona comenta que as três facetas de Llobet como intelectual, concertista e compositor também eram um tanto contraditórias (informação verbal) ${ }^{38}$. Este conjunto de informações ajuda a identificar os problemas que dificultam uma definição da obra e da personalidade de Llobet.

Sabemos que Llobet manteve relações com figuras importantes do cenário musical, dentro e fora da Espanha. Seu contato com Albéniz, Granados e Falla o levou a transcrever obras destes grandes compositores, o que fez com que aprimorasse ainda mais no campo da exploração timbrística tendo Tárrega como referência.

Vimos que Llobet começou a carreira muito jovem, encontrando condições mais favoráveis do que seu mestre Tárrega. Seu primeiro concerto público foi em 1901, no Conservatório de Valencia, e neste mesmo ano em outros conservatórios importantes da Espanha. Seu contato com Ricardo Viñes (1885-1943) ${ }^{39}$ o levou a Paris (1904), onde realizou seu primeiro concerto fora da Espanha. Este contato foi muito importante, pois foi Viñes que o introduziu neste novo mundo e possibilitou o convívio com a elite musical francesa. Este ambiente musical na França certamente o influenciou na concepção de algumas de suas obras. Suas turnês pela Europa o colocaram em centros musicais onde manteve relações com compositores célebres como Debussy, Ravel, Fauré, Dukas e Stravinsky.

Devido ao pouco espaço que o violão encontrava em Barcelona ${ }^{40}$, Llobet se viu motivado a mudar-se para Paris (1904). Na Espanha, seus concertos limitavam-se às sociedades particulares, e muitas vezes não recebia nada além de um agradecimento.

\footnotetext{
${ }^{38}$ Entrevista realizada durante o II Encontro Internacional de Violonistas de Tatuí, SP, no dia 22 de Abril de 2007 (Anexo B).

${ }^{39}$ Pianista espanhol divulgador das obras de Albeniz e Granados e da música moderna francesa. Era amigo de Debussy, Ravel e Falla.

${ }^{40}$ Domingo Prat afirma que "Barcelona tinha aversão ao violão (...)”. (PRAT, 1986, p. 184) Antes de se mudar para Paris, Llobet conhece Concepción Jacoby, que passa a ser sua protetora. Com o auxílio desta senhora, consegue certa notoriedade tocando em várias partes da Espanha.
} 
Existe uma contradição em sua biografia a respeito do período em que permaneceu na França. Purcell afirma que Llobet residiu em Paris até 1910 (PURCELL, 1989, vol. 1, p. iii, partitura), enquanto que Tonazzi relata seu retorno a Paris em 1910 (TONAZZI, 1966, p. 12). Existem alguns detalhes biográficos confusos a respeito de Llobet, como sua residência durante a Primeira Guerra Mundial $^{41}$ e as datas de algumas Canciones Catalanas, como veremos adiante. Tais contradições em dados cronológicos também dificultam definir a vida e a obra de Llobet.

O catálogo de suas obras realizado pelo autor já citado Bruno Tonazzi, junto com a publicação mais recente de Ronald Purcell e a integral que vem sendo realizada por Stefano Grondona (em vários Cds) nos dão apenas uma idéia da obra do violonista catalão. As dificuldades ocasionadas pela guerra civil espanhola e o fato de Llobet não se mostrar muito preocupado com o registro e a difusão de sua produção levaram à perda de algumas obras ${ }^{42}$. Algumas obras que não foram publicadas se encontram em poder do violonista Fernando Alonso. Sobre este valioso arquivo falaremos adiante.

Llobet tem mais transcrições do que obras originais, a exemplo de seu mestre Tárrega, basicamente situadas na música clássica (Mozart, Beethoven da $1^{\mathrm{a}}$. fase), na música romântica (Mendelssonh, Schumann, Chopin, Tchaikovski) e na música espanhola de seus contemporâneos (Villar, Valverde, Albeniz, Granados, Falla, Lopez Chavarri, Mitjana). Llobet usa em suas obras procedimentos usados anteriormente por Tárrega, mas com a influência francesa absorvida pelo convívio com Viñes, procurou novas possibilidades timbrísticas para o violão. Pujol comenta que enquanto Tárrega pensava no quarteto de cordas, Llobet procurava dar um sentido de

\footnotetext{
${ }^{41}$ Mangado afirma que Llobet viveu nove anos em Paris (MANGADO, 1998, p. 94); Purcell afirma que neste período Llobet se estabeleceu na Argentina (PURCELL, 1989, vol. 1, p. iv), e tanto Purcell (1989, vol. 1, p.iii, partitura) como Gladstone (GLADSTONE, 1957 apud YATES, 1999, p. 7) afirmam que em 1910 Llobet realizou sua turnê pela América do Sul passando pelo norte do Brasil.

${ }^{42}$ Maria Luisa Anido fala a respeito de mais uma faceta de Llobet - a de improvisador. En algunas reuniones en mi casa preguntaba "qué quieren oír? Denme tres notas". Se las dábamos y decía: "qué quiéren escuchar, una romanza, un tema variado o una mazurka?" Con esas tres notas pensaba un poco e improvisaba maravilhas. Nunca escribía nada. (HELGUERA, 2001, p. 12)
} 
orquestração para suas obras, como veremos adiante. Suas Canciones Catalanas denotam tal sentido de orquestração, utilizando efeitos de timbres bastante sofisticados. Portanto, a transcrição ocupava um lugar importante na obra de Llobet e foi com as Canciones Catalanas realizadas entre 1899 e 1927, que ele consagrou-se nesta arte, explorando novos timbres e utilizando harmonias sofisticadas.

A importância do trabalho de Tárrega deu-lhe o título de "pai do violão moderno”, por ter sido o responsável pela criação de uma nova escola. ${ }^{43}$ No entanto, a obra de Llobet deixou um legado vital para posicionar o instrumento dentro de uma nova linguagem. O sentido musical que Llobet confere ao som do violão supera as dimensões formais das obras para o instrumento solista de seu tempo. Isso justifica o fato de Llobet ser chamado de "pai do violão moderno" por alguns pesquisadores e violonistas como Robert Phillips (2002a, p. 31) e Stefano Grondona (informação

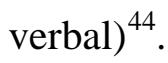

De fato, Llobet seguiu os passos de seu mestre Francisco Tárrega, a quem é atribuída criação de uma escola violonística, mas como discípulo, Llobet elevou os ensinamentos que recebeu principalmente no que diz respeito à concepção sonora e experimentação de timbres. Tárrega não costumava especificar indicações de mão

\footnotetext{
${ }^{43}$ Segundo Ophee, o responsável pela difusão deste conceito foi Emilio Pujol quando intitulou sua Escuela Razonada de la Guitarra basada en los princípios de la técnica de Tárrega, onde pela primeira vez aparece o nome de Tárrega ligado a uma escola violonística (OPHEE, apud PHILLIPS, 2002b, p. 32). Há muita contradição do que se chama de "escola de Tárrega". Em seu Dicionário, Prat discute a "pretendida escola de Tárrega”. Cita Miguel Llobet e outros discípulos, cada um com a sua maneira particular de execução de mão direita e maneira diferente de segurar o instrumento. Com tanta diversidade entre os discípulos de Tárrega, Prat questiona a denominação "escola". Pascual Roch foi o primeiro a escrever uma obra didática inspirada na técnica de Tárrega. Em seu método se refere ao violonista como "el maestro de regras fijas". Portanto, Prat novamente rebate e defende que não existe uma técnica precisa e definida. Vale lembrar que Tárrega não registrou sua escola e técnica violonística, passando seus ensinos de forma oral. (PRAT, 1986, p. 317) Pujol lamenta as críticas de Prat a respeito de seu mestre e chama suas afirmações de "gratuitas, tendenciosas e carentes de fundamento". (PUJOL, 1960, p. 220) No Brasil temos os métodos no de Atílio Bernardini, Osvaldo Soares e Sodré que ajudaram a difundir o conceito sobre a escola de Tárrega entre nós.

${ }^{44}$ Entrevista realizada durante o II Encontro Internacional de Violonistas de Tatuí, SP, no dia 22 de Abril de 2007.
} 
direita em suas edições ${ }^{45}$, enquanto que Llobet indicava com detalhes a maneira de execução de ambas as mãos, bem como a terminologia que orientava o posicionamento da mão direita. Seu estilo de escrita era mais elaborado, e isso fica evidente quando revisou algumas adaptações realizadas anteriormente por Tárrega. Ronald Purcell comenta brevemente como isto se deu: "Harmonic beauty in his transcriptions. He follows the procedure set by Tárrega but with more vigour.” (PURCELL, 1989, v. 1, p. iv)

Não há dúvida de que Llobet avançou alguns passos na harmonização previamente utilizada pelos compositores anteriores. O crédito por composições originais e o emprego de dissonâncias é atribuído a ele. "He had a more modern and advanced conception of the guitar than Tárrega (...) (sic) Thus his arrangements are more artistically satisfying to the discerning ear, though they are more difficult to play.” (APPLEBY, 1962 apud PHILLIPS, 2002b, p. 18)

Segundo Juan Riera, “foi Llobet quem rompeu com o classicismo romântico tradicional da escrita violonística utilizada desde Tárrega” (RIERA, 1974, p. 160).

Tonazzi refere-se a Tárrega como responsável pela conclusão de um período na história do violão, enquanto que a Llobet o início de uma nova fase para o instrumento (TONAZZI, 1966, p. 30).

No entanto, Tonazzzi vai além quando afirma reconhecer em Llobet um violonista-compositor impressionista: [...] nella letteratura della chitarra costituisce il primo esempio impressionistico” (TONAZZI, 1966, p. 33). No entanto, tal afirmação vem sendo alvo de objeções por parte de alguns pesquisadores. Phillips ao comentar aspectos da música impressionista, quanto ao emprego de dissonâncias, afirma: "[...]This is not far removed from Llobet's use of voice leading, in which the harmonic

\footnotetext{
${ }^{45}$ Cf. TÁRREGA, F. The Collected Guitar Works. Espanha: Chanterelle Verlag, 1992. 2 vol (partitura).
} 
function is superseded by step and half-step movements of the voices, and may well contribute to the confusion (PHILLIS, 2002b, p. 23). Grondona também não concorda com tal afirmação (informação verbal) ${ }^{46}$.

O fato de Llobet se relacionar com nomes importantes ligados às novas correntes estéticas de sua época pode ter influenciado sua obra. No entanto, é necessário colocar tais influências de maneira mais cuidadosa, como o comentário de Purcell:

(...) his arrangements of the Catalan folksong tunes (acting as linear vehicles) gave him the opportunity for harmonic experimentation, and, by listening to the works of the impressionists and expressionists, to explore on the guitar, colour effects, such as harmonics, pizzicato, placement of right-hand (sul tasto or sul puente) and left-hand fingering, without destroying the original intent of the composer. His application of these techniques is diligently notated in his own compositions and arrangements. Through the performance of these works on concert tours Llobet shed new ligth on the guitar as a viable musical instrument demanding to be a part of the mainstream of the contemporary music. (PURCELL, 1989, vol. 1, p. iv)

As experimentações harmônicas realizadas por Llobet após seu contato com os impressionistas não o posicionam como compositor desta corrente estética, pois os procedimentos utilizados não o distanciaram de sua concepção inicial como compositor. Com essa “nova luz” Llobet indicou o caminho para o violão tomar parte a música uma linguagem diferenciada.

Trataremos agora de comentar o tratamento violonístico que Llobet deu às suas peças. Sua escrita explorava efeitos de orquestração pela forma que explorava os timbres, ao tratar cada corda do violão de maneira distinta, como se cada corda fosse um instrumento diferente. Como comentamos acima, tal concepção o diferenciava de seu mestre.

Pero apesar de su profunda admiración por Tárrega, su maestro, el sentido estético de Llobet no era el mismo; difería por razones de natural concepción, diferencias de edad y circunstancias de ambiente. Y

\footnotetext{
${ }^{46}$ Informação concedida em entrevista realizada em 22 de Abril, em Tatuí. Como exemplo de harmonia baseada no impressionismo, podemos citar o Preludio en Mi Maior, segundo Phillips (2002b, p. 23) e Grondona.
} 
mientras Tárrega, enamorado de la pureza del cuarteto clásico en su homogênea variedad, hubiera hecho de las seis cuerdas de su instrumento una sola unidad, Llobet, atraído por la diversidad de timbres de la orquestra, hubiera hecho de cada cuerda uma guitarra. (PUJOL, 1960, p. 140)

Os efeitos coloridos usados por Llobet através da combinação de pizzicatos, o uso de harmônicos e sua técnica de mão direita, proveram uma nova gama de sons que aumentaram as possibilidades técnicas e artísticas do instrumento, consideradas hoje como elementos naturais das escolas de composição e interpretação.

Tais elementos estão evidentes em suas Canciones Catalanas, como veremos adiante.

O interesse pela obra de um autor tão importante como Llobet é recente ${ }^{47}$, tanto em relação a textos quanto a gravações. O texto mais importante, enquanto Llobet ainda estava vivo, se encontra na publicação de Domingo Prat, seguido das primeiras publicações pós-morte nos anos 60, pela União Musical Espanhola, pelo pequeno livro de Bruno Tonazzi, e mais recentemente, a primeira edição integral feita pela editora Chanterelle, com textos de Ronald Purcell (1989, 5 volumes) ${ }^{48}$. Os registros sonoros devem ser citados, especialmente o realizado pelo próprio Llobet ${ }^{49}$, um dos violonistas pioneiros no processo de gravação elétrica e de seus registros de algumas de suas versões das canções catalãs - El Testamento d'Amelia, Cançó del Lladre, La Filla del marxant e Plany - que posteriormente tomaram parte em gravações e programas de violonistas de renome como Andrés Segovia, Narciso Yepes, Alirio Dias, John Williams, Julian Bream e outros.

Vemos que a partir da primeira compilação da integral das gravações pela Chanterelle, como vimos acima, iniciaram-se somente nos anos 90 as gravações

\footnotetext{
${ }^{47}$ Na publicação do Dicionário de Prat, o autor comenta a necessidade de mais publicações, considerando apenas a Romanza (1896), de influência chopiniana, que havia sido publicada pela Biblioteca Fortea. Prat desconsidera a importância das Canciones Catalanas, por não serem consideradas obras originais. Sobre tal concepção falaremos adiante.

${ }^{48}$ Esta publicação contém ricas informações não encontradas em nenhuma outra.

${ }^{49}$ LLOBET, M. The Guitar Recordings 1925-1929. Chanterelle Historical Recordings (Cd).
} 
integrais da obra de Llobet, e que a cada nova edição fonográfica vão sendo reveladas novas obras e novas transcrições.

Mencionamos assim, por ordem cronológica, as gravações de: Michael Tröester, Lorenzo Michelli e Stefano Grondona ${ }^{50}$.

Notamos neste percurso o interesse por uma obra que vem sendo paulatinamente revelada como uma das referências mais importantes da história do violão.

A produção de peças e adaptações de Llobet ajudou a aumentar o repertório, numa época em que as obras originais eram escassas. Portanto, Llobet pode ser apontado como um dos responsáveis por alterar a condição geral do violão, como intérprete-compositor dentro de uma tradição secular e por incentivar compositores não violonistas a escreverem para violão, como veremos adiante.

Como vimos acima, a atuação de Llobet como compositor e arranjador indicam algumas diferenças com a atuação de seu mestre Tárrega. Com sua atuação como professor ocorre o mesmo. Tárrega não registrou sua “escola”, nem possuía uma metodologia concreta e descrita ao passar seus ensinamentos aos seus alunos. O próprio Llobet conta que seus estudos se baseavam em observar como Tárrega tocava e depois experimentar a técnica em sua casa: "Cosi, più que impararla, io sperimentavo la mia técnica sull chitarra”. (TONAZZI, 1966, p. 12). Emilio Pujol, outro discípulo de Tárrega, descreve assim a metodologia de seu mestre: "La técnica la aprendían sus alumnos trabajando frente a él, copiando sus procedimientos y empezando por los ejercicios fáciles (...)”. (PUJOL, 1960, p. 239)

Llobet se preocupava mais em estabelecer uma metodologia. Notamos este fato no relato do virtuoso cubano José Rey de la Torre (1917-1994), que foi aluno de

\footnotetext{
${ }^{50}$ MICHAEL TRÖESTER. Tröster plays Miguel Llobet. Thorofon Classics Digital, 1998; LORENZO MICHELLI. Miguel Llobet Guitar Music. Naxos, 2004; STEFANO GRONDONA. RESPUESTA. Stefano Grondona Plays the Guitar Works of Miguel Llobet. Stradivarius, 2006b (Cds).
} 
Llobet. Seu primeiro procedimento foi orientar seu aluno a parar de tocar as peças que faziam parte de seu repertório desde seus dez anos de idade e se dedicar exclusivamente às obras didáticas (PHILLIPS, 2002b, p. 21).

Anido nos conta que Llobet se preocupava com a didática ao tratar seus alunos de maneira individual e sua disposição em resolver problemas técnicos: "Un maestro extraordinário, de uma maravilhosa bonhomía, muy humano y alegre, hacía muy amenas las clases, estudiaba el alumno y si tenía algún problema con los trinos, le escribía un ejercicio para trinos.”(HELGUERA, 2001, p. 12)

A concepção musical de Llobet denota uma preocupação com a sonoridade e a musicalidade. Notamos isso quando encontramos um dado sobre um episódio interessante que aconteceu envolvendo Tarragó, Pujol e Llobet. Tarragó sentiu a necessidade de procurar a orientação dos discípulos de Tárrega a fim de solucionar alguns problemas técnicos. Para encontrar tal solução, decidiu interpretar uma transcrição de J. S. Bach e se apresentou primeiramente a Pujol, depois para Llobet:

De buena mañana, Tarragó se presentó en casa de Pujol, interpretando dicha obra, Pujol ao ver esta digitación, que se repetia varias veces le dijo con buenas palabras: que era incorrecta, aconsejánole que la mejor manera de solucionar este problema técnico era realizar uma nueva transcripción en outro tono, teniendo muy en cuenta que no se volviese a producir esta situación. Tarragó salió de su casa poco convencido de su respuesta.

Ao cabo de unos dias fue a casa de Miguel Llobet, interpretándole la misma obra, éste ni se inmuto al ver la digitación que realizaba, y le dijo que había tocado la obra musicalmente muy bien. Tarragó al ver que no decía nada sobre la digitación que hacia servir em varios pasajes de la obra, le pregunto a Llobet que opinaba sobre esta cuéstion, y Llobet le respondió, suena bien y con naturalidad, si usted lo encuentra factible y correcto, pues adelante. Tiene que tener en cuenta Tarragó que, siempre que uma digitación no afecte al desarollo musical de la obra, y se produzca con toda naturalidad, por muy intrincada que pueda parecer a simple vista, no debemos rechazarla, sino ao contrario. Con la guitarra, debemos intentar siempre explorar y encontrar nuevas soluciones a los problemas técnicos que el futuro nos depare. Como estamos suponiendo, Tarragó escogió para ampliar sus estudios de guitarra a Miguel Llobet (MANGADO, 1998, p. 90). 
Como veremos adiante, Llobet manifestava a mesma preocupação com a sonoridade em sua obra, e isso se evidencia, inclusive, em suas Canciones Catalanas.

Embora no relato de Rey de la Torre possamos notar certa preocupação de Llobet com obras didáticas em seu ensino, no relato de Tarragó, ao contrário, Llobet não menciona técnica nem didática. Isso confirma a personalidade contraditória de Llobet, citada anteriormente. Sua única contribuição no campo pedagógico foi a revisão dos Estudos op. 60 de Matteo Carcassi ${ }^{51}$.

A carreira de Llobet como compositor e intérprete ficou voltada para o violão, mas sabemos que em sua juventude, estudou violino e piano na Escola de Musica de Barcelona. Sua formação pianística certamente influenciou suas concepções renovadoras em sua obra para violão. Llobet também tinha uma forte vocação para artes plásticas e revelou suas ecléticas capacidades expressivas através de seus desenhos e pinturas $^{52}$. Podemos encontrar alguns de seus desenhos, que mostram sua preferência por caricaturas. Destacaremos os rostos de Tárrega (figura 2) e Maria Luisa Anido (figura 3).

No perfil multifacetado de Llobet encontramos outra faceta - a de intelectual. Miguel Llobet era freqüentador da Casa Llibre, citada anteriormente, e pode ser chamado de um verdadeiro tertuliano. Reunia-se periodicamente junto com Emilio Pujol, o violinista Mariano Perelló, o compositor Agustín Grau, o diretor de orquestra José Sabater, Matilde Cuervas e outros para discutir os assuntos mais diversos. Às vezes o francês Carol Berard, de passagem em Barcelona, se reunia ao grupo, pois gostava de envolver-se nas polêmicas sobre arte com o objetivo de apenas “tertuliar”:

\footnotetext{
${ }^{51}$ CARCASSI, M. Estudos op. 60. Editorial Lemoine, Paris, s.d (partitura).

${ }^{52}$ Sobre sua disposição natural para a pintura, temos o relato de um curioso episódio que confirma isso. Em Paris, durante um almoço de Llobet com o editor J. Rowies e em meio a conversas sobre violão e violonistas, Rowies lhe pergunta como seria a figura de Tárrega, já que ele não o conhecia pessoalmente. Então, Llobet pede um pedaço de papel e tira um lápis do bolso para desenhar a fisionomia de seu mestre em questão de minutos (PUJOL, 1960, p. 140). No arquivo de pertences de Llobet que se encontra em poder de Fernando Alonso, constam algumas pinturas a óleo (PHILIPS, 2002b, p. 10).
} 


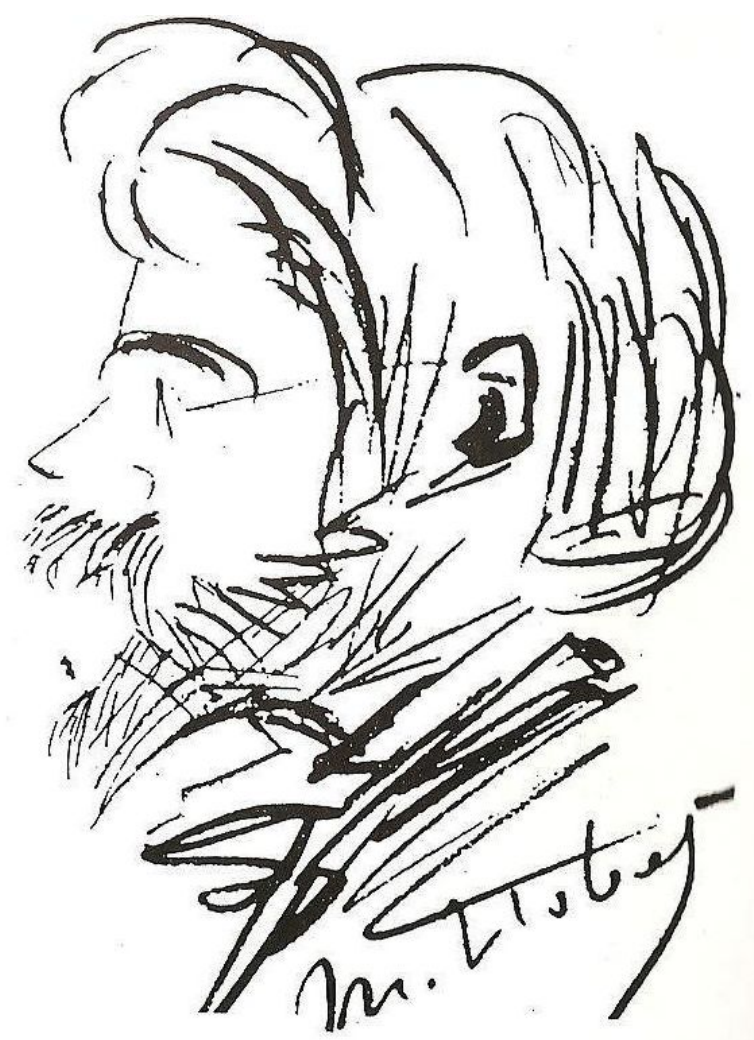

Figura 2. Caricatura de Francisco Tárrega feita por Llobet

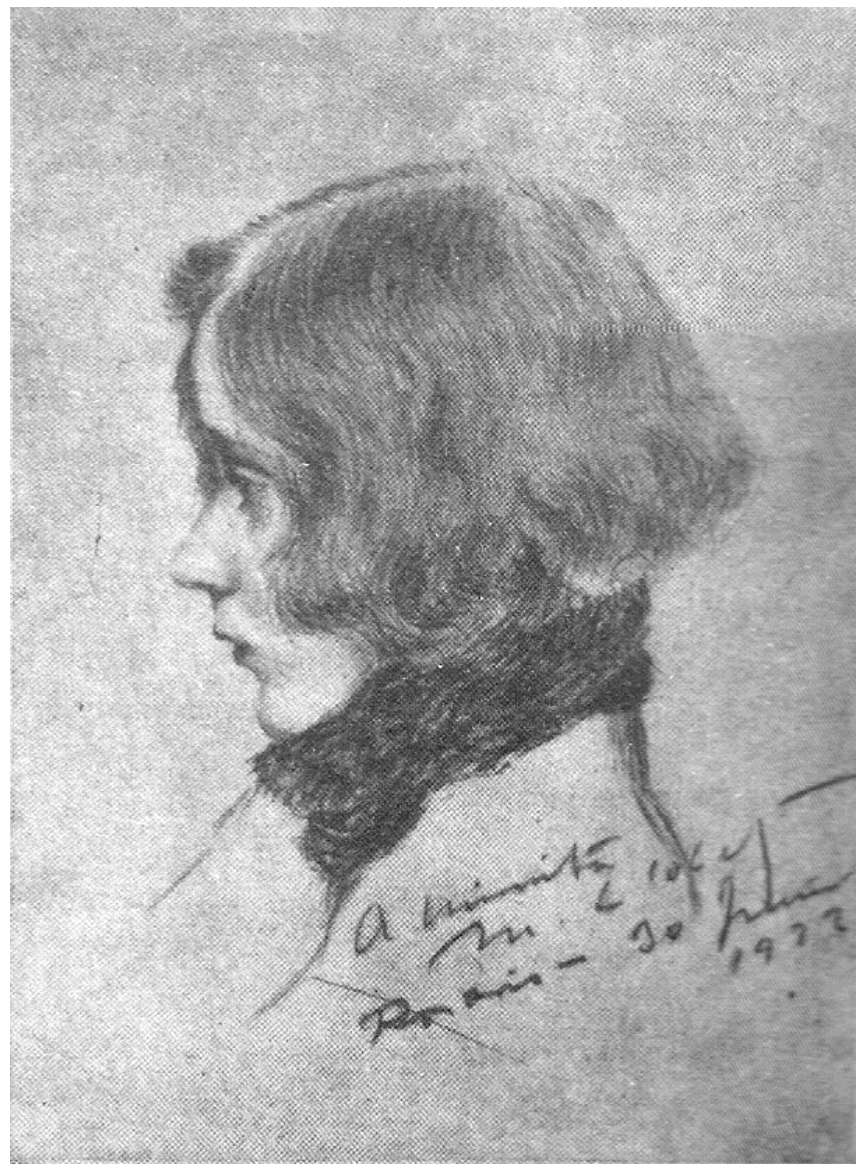

Figura 3. Caricatura de Maria Luisa Anido feita por Llobet 
Lo más gracioso era que tanto Berard como Llobet, dos habladores incorrigibles, acaparaban la atención de los contertulios y los que estaban en el secreto, observaban con maligno deleite como se desarrollaban en cada reunión los lances de un torneo que, por tratarse de quienes se trataba, chisporroteaba de vivo ingenio. (RIERA, 1974, p. 47)

A tertúlia, como vimos anteriormente, estava ligada a diversos assuntos. Não podemos desconsiderar que os catalães são conhecidos como um povo que sempre lutou pelos seus ideais e autonomia dentro da Espanha. Os acontecimentos políticos e sociais na Catalunha no período em que Llobet viveu foram marcantes na história desta região. Esta passagem contribui para notarmos que Llobet não estava alienado aos acontecimentos políticos e sociais de sua época. Percebemos isso ao analisar as melodias das Canciones Catalanas que escolheu para compor suas transcrições. Notaremos mais adiante o quanto tais melodias estavam ligadas ao movimento nacionalista e algumas delas relacionadas ao sentimento patriótico da Catalunha. O fato de estas canções estarem ligadas ao movimento nacionalista no início do século XIX de maneira contundente nos leva a crer que Llobet não desapercebeu a importância de tais melodias no contexto social da Catalunha. O efeito que elas exerciam nas multidões, atraindo a massa para as agrupações orfeônicas citadas no capítulo 1, pode ter levado Llobet a usá-las em sua obra para violão com a finalidade de elevar o prestígio do instrumento atraindo mais público a seus concertos.

Uma outra faceta que podemos notar em Llobet é a de musicólogo, resgatando o passado histórico da Catalunha uma vez que usou melodias tradicionais antigas nas suas adaptações das Canciones Catalanas. Discutiremos a origem de tais melodias no capítulo 5.

Pode-se considerar que Llobet foi um grande concertista, pioneiro ao realizar extensivas turnês internacionais resultando nas melhores críticas publicadas nos meios de comunicação mais importantes dos países em que atuava: 
Paris: "Pureness of taste which is never sacrificed to sheer virtuosity"; Alemanha: "Music, today, tends to be getting noisy like the machines and steam engines. Llobet contrasted thi with his beauty of sound and intimacy of performance.”; Barcelona: “The Casals of the guitar”; Buenos Aires: "Temperament is vigorous and quality of interpretation unchallenged”, "Greatest figure on the guitar today." (PURCELL, 1989, v.1, p. iv, partitura)

A notoriedade da carreira de Segovia sufocou a importância de Llobet como concertista internacional, pois realizou extensivas apresentações antes até de Segovia. Tocou por toda Europa, EUA e América do Sul. Devemos atentar para este fato, pois a importância dos concertos que Llobet realizou não pode ser desconsiderada, além de contribuir com novas obras para o repertório:

To Miguel Llobet Soles to given the credit for bringing the classic guitar into the modern musical world of international concert tours, for contributing new works to the repertoire, both original as well as transcribed; for the presenting to the public in performance the new works of such composers as the Falla, Villa-Lobos, Ponce and others; for teaching the pedagogical principles of Tárrega; and, of utmost importance, for have made the first eletric recordings of the classic guitar. (PURCELL, 1989, vol. 1, p. v, partitura)

Apesar da repercussão de seus concertos, notamos certa comodidade em seus programas (figura 4 e 5), pois alguns deles eram realizados em parceria com outros músicos. Este fato se harmoniza com as conclusões que tiramos dos relatos de Anido, sobre a acomodação de Llobet em comparação à ousadia de Segovia: “(...) Segovia siempre siguió una línea de trabajo intensa, muy metódica, en ese aspecto Llobet era...(sic) se puede decir silvestre?”. (HELGUERA, 2001, p. 12) 


\section{租togrammte}

$\begin{aligned} & \text { La statue - } \\ & \text { Romance }\end{aligned}$
$\begin{aligned} & \text { Fuyez l'amour } \\ & \text { Plus ne suis ce que j'ai été }\end{aligned}$ -
$\begin{aligned} & \text { Allegretto } \\ & \text { Sérénade }\end{aligned}$

Figura 4. Programa de concerto de Llobet e a soprano Nina Varésa

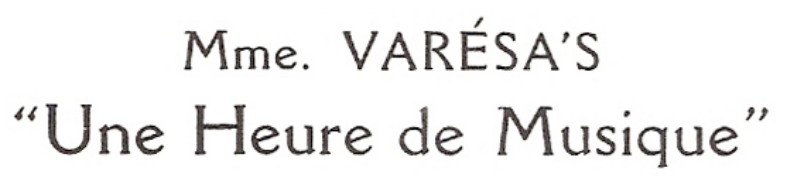

担rograntme

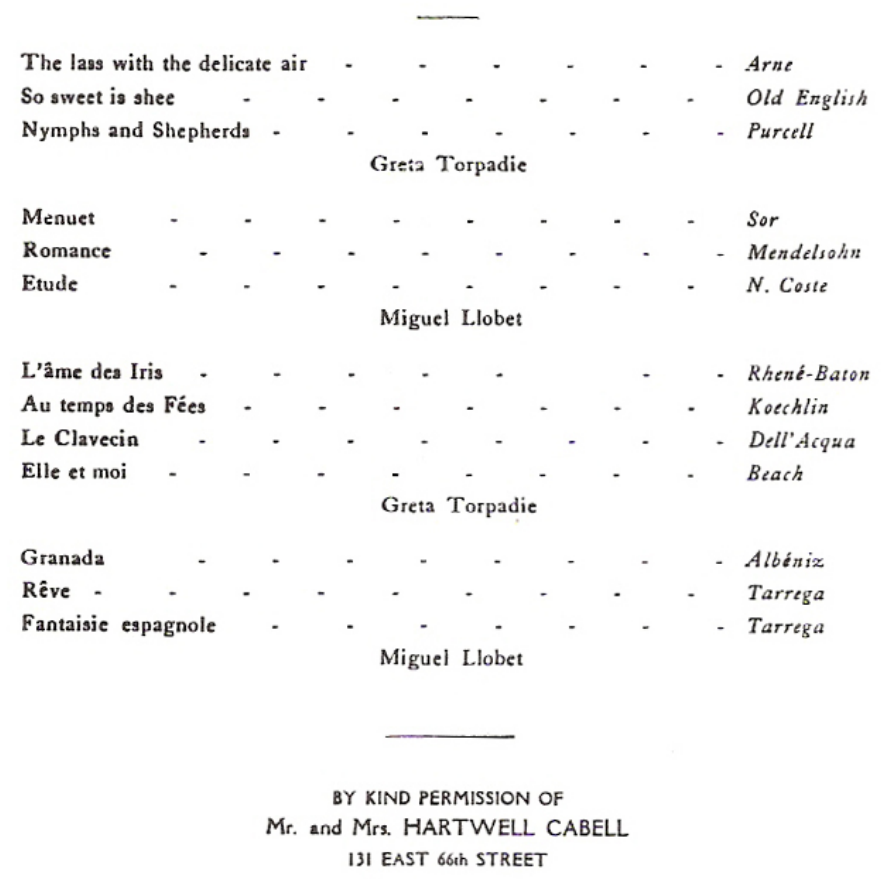

Figura 5. Programa de concerto de Llobet e a soprano Greta Torpadie 
Na América do Sul, passou grande período na Argentina, onde formou o duo com Maria Luisa Anido, cujo repertório consistia inteiramente em arranjos do próprio Llobet $^{53}$. Este duo, ativo até meados de 1930, veio a ser parte da história dos grandes duos de violão, que temos como referência principal desde Sor-Aguado, Llobet-Anido (figura 6), Pujol-Mathilde Cuervas, Presti-Lagoya, Sergio e Eduardo Abreu e Sérgio e Odair Assad.

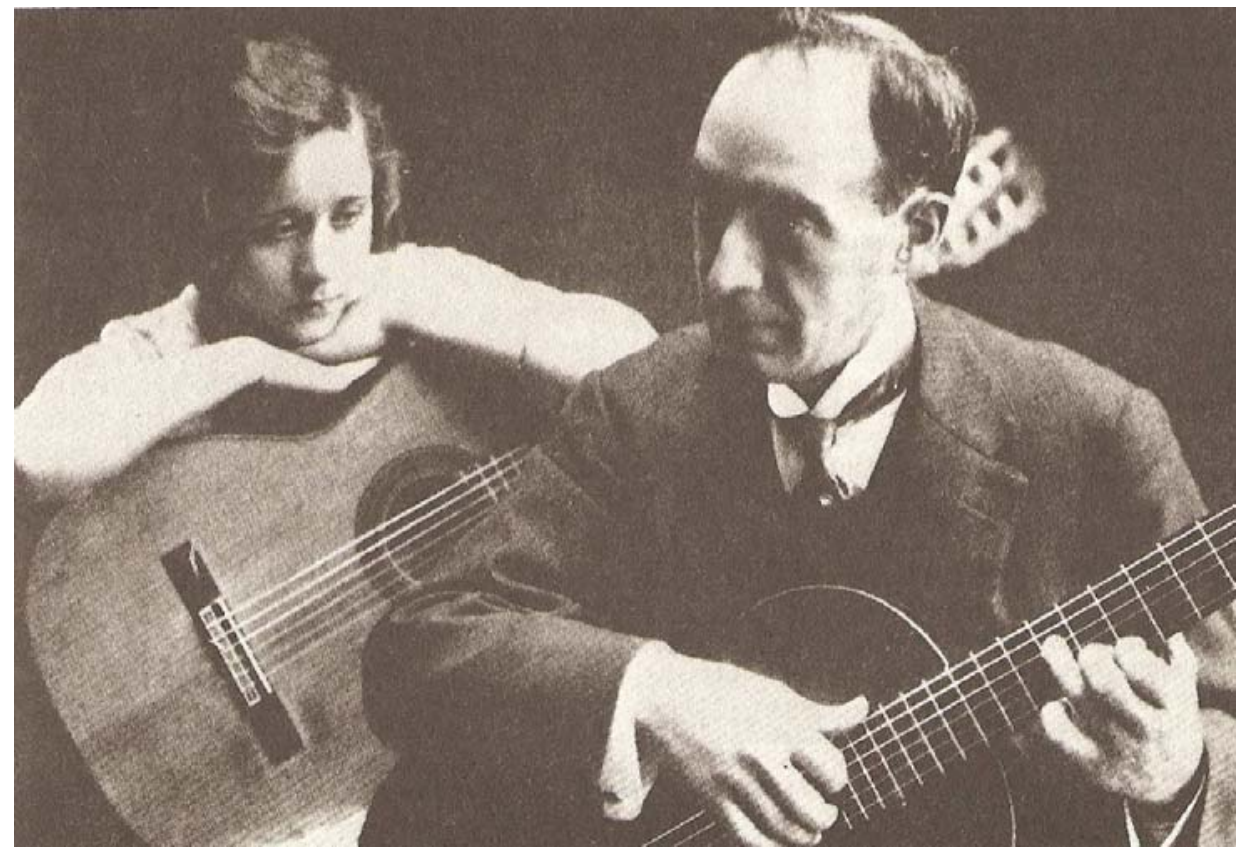

Figura 6. Duo Llobet-Anido

Os contatos de Llobet no período em que passou em Paris incluíram o importante compositor espanhol Manuel de Falla (1876-1946), que resultou em mais benefícios para a literatura de violão (figura 7).

Llobet, com sua insistência junto a Manuel de Falla, contribuiu para o início de uma nova produção de um repertório para o violão. A Homenaje pour le Tombeau de Claude Debussy $^{54}$ foi uma das primeiras obras escritas originalmente para violão, por um compositor não-violonista. Foi publicada pela primeira vez na Revue Musicale de 01

\footnotetext{
${ }^{53}$ MIGUEL LLOBET. The Guitar Recordings 1925-1929. Chanterelle Historical Recordings (Cd). Inclui três faixas gravadas pelo duo Llobet-Anido.

${ }^{54}$ PURCELL, R. Manuel de Falla. Homenaje pour le Tombeau de Claude Debussy. Londres: Chanterelle Verlag, 1989. Vol. 5 (partitura). Revisão e digitação de Miguel Llobet. Com este fato, Purcell justifica na introdução o motivo desta obra de Falla ter sido incluída na série devotada à obra de Llobet.
} 
De Dezembro de $1920^{55}$, junto com outras obras de importantes compositores como Dukas, Roussel, Malipiero, Goosens, Bartok, Fl. Schmitt, Stravinski, Ravel, e Erik Satie, todas dedicadas a Debussy. Pahissa narra como se deu a concepção desta importante obra:

(...) Debussy had died. One day, at a concert, Falla bumped into Henri Prunières, who told him he was going to devote na issue of his Revue Musicale to Debussy an asked Falla towrite na article. Falla would have preferred to make a musical contribution. (...) In the end he wrote the article and the composition (...) which would satisfy both the Revue Musicale and Llobet (...)”. (SPAIN, 1996, p. 133)

Esta importante obra, que foi um marco na literatura para violão, teve sua estréia em 24 de Janeiro de 1921, executada numa harpa-alaúde por Marie-Louise Casadessus, e finalmente executada por um violonista em 2 de Dezembro de 1922 Emilio Pujol ${ }^{56}$.

Suzanne Demarquez faz uma análise desta obra que se tornou célebre entre os violonistas:

La pieza de Falla es un canto fúnebre, un trenó simbólico, tan frecuente en la poesia española, influído por el espíritu musical del amigo perdido. Su armonía se basa esencialmente en la cuarta fundamental del acorde típico - tan bello! - de la guitarra, mi, la, re, sol, si (...) En esa cuarta, el autor sitúa una corta frase rítmica, suerte de lamentación sorda y amarga que resuena como um toque de animas a lo largo de la obra (...). Los recursos especiales del instumento son hábilmente explotados en fora de arpegios, de acordes ampliamente abiertos, de gamas em glissandi, de trazos en punteado y de armónicas a la octava.(DEMARQUEZ, 1968, p. 122)

Depois de inaugurada a nova fase de compositores não violonistas, com a obra de Falla, Segovia continuou a comissionar peças para o violão de maneira intensa.

\footnotetext{
55 Ibid. p. 4.

56 DEMARQUEZ, S. Manuel de Falla. Barcelona: Nueva Colección Labor, 1968, p. 123. Uma informação apontada pelo violonista Stefano Grondona discorda destes dados, pois indica que Llobet estreou esta obra em 13 de fevereiro de 1921, em Burgos e se encarregou de sua publicação. Grondona não deixa de comentar a importância desta obra - a única escrita pelo célebre compositor espanhol graças à influência da figura artística de Llobet. Nem Segovia, posteriormente, conseguiu atrair Falla para escrever outra obra para violão (GRONDONA, 2006a, encarte de Cd).
} 


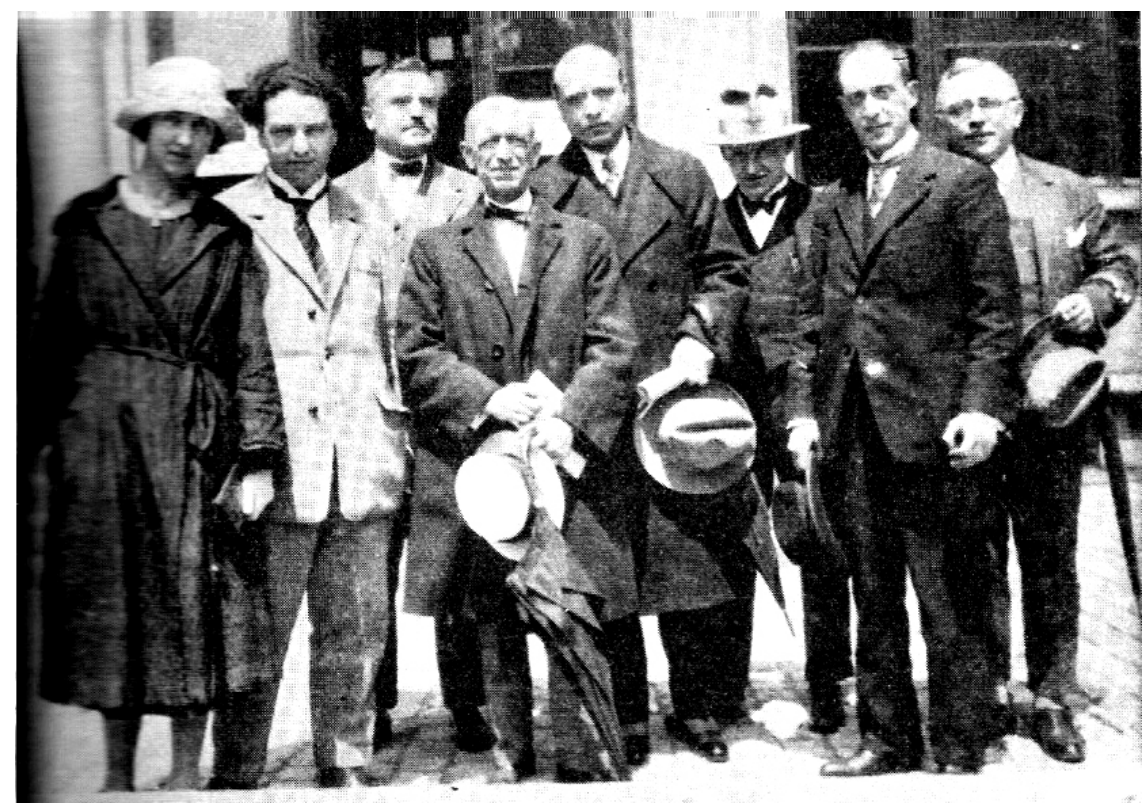

Figura 7. Foto em Paris onde aparecem Falla (ao centro) e Llobet (à direita) entre outros

As obras comissionadas ou dedicadas a Llobet não se destacam pela quantidade, mas sim por sua qualidade. Esta peça é indicada como sendo "a mais significativa composição para violão do século XX (...) uma obra emblematicamente rompedora da evolução do repertório para violão, já que até aquele momento não se acreditava que um compositor pudesse escrever com tanto êxito para um instrumento sem saber tocá-lo”. (GRONDONA, 2006b, encarte de Cd)

Outro compositor que travou contato com Llobet e escreveu para violão foi Paul Hindemith (1895-1963). Compôs um Rondó para trio de violões (1925), mas não sabemos se essa obra tem ligação direta com o violonista catalão.

Esteve no repertório de Llobet (figura 8) uma misteriosa Danse brésilienne de Heitor Villa-Lobos (PURCELL, 1989, p. xi). Esta peça pode ser a Valsa Concerto no. 2 (Valsa Brilhante - 1904) citada num relato de um encontro entre Villa-Lobos e Segovia, que teria sido dedicada a Llobet. (CARVALHO, 1988, p. 170). Trata-se de uma obra inacabada de 122 compassos e 3 páginas catalogada pelo museu Villa-Lobos, no Rio de Janeiro. 
IX. Musikfest der Deutschen Gitarren- u. Lautenspieler vom 11. bis 14. Oktober 1928 in Berlin.

III. Tag.

Sonnabend, den 13. Oktober, 8 Uhr, Meistersaal

Gitarrensoli

\section{Prof. Miguel Llobet}

(Barcelona)

I.

-Allegretto

-Etude

-Andante

-Prélude

Etude

II.

"Prélude

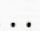

- Sarabande

- Danza...

- Serenade

Torre Bermeja

- Danse espagnole

- Pause -

Ferd. Sor

Dionysio Aguado

W. A. Mozart

Fr. Tariega

Ferd. Sor

\section{.}

III.

- Danse airs argentins

111.

- Danse brésilienne

"Fragment de „L'Amour Soreier"

-Ingenuité

Yota

Joh. Seb. Bach Joh. Seb. Bach M. Torroba M. Torroba

J. Albeniz Granados

.

A. Broqua Villa Lobos M. de Falla Grau M. Llobet

Die mit ' bezeichneten Werke sind Neuigkeiten für Berlin.

\section{Gitarren und Lauten}

in bester tonlicher Qualität und einwandfreier Spielweise für die gesteigerten Bedürfnisse der ernsten Liebhaber und Solisten erhalten Sie in den

$$
\text { Die Gitarre }
$$

J. Rovies, Paris

(die echten Gelasinstrumente)

Berlin-Charlottenburg, Kantstraße
Fr. Simplicio, Barcelona (die Simpliciogitarre)

52 (Steinplatz 2393).

Figura 8. Programa de concerto realizado em Berlim em 1928 onde aparece uma obra de Villa-Lobos 
A passagem de Llobet pelo Brasil é um tanto incerta, mas alguns acreditam que foi nesta ocasião que Villa-Lobos conheceu Llobet (1910). Sobre as relações de Llobet e Villa-Lobos precisamos analisar o arquivo que está nas mãos de Fernando Alonso, cuja descoberta falaremos adiante. Alguns acreditam que esta valsa teria sido corrigida de maneira drástica pelo próprio Llobet, colocando assim em dúvida a autoria de Villa-Lobos (informação verbal) ${ }^{57}$.

Como veremos adiante, Llobet sentiu-se atraído pela obra de Villa-Lobos ao realizar suas adaptações para duo de violões. Da mesma maneira, podemos levantar a hipótese que Villa-Lobos estava atento à escrita violonística de Llobet. Os exemplos mais contundentes são o Preludio Original (1912) e a Respuesta (1922) que podemos relacionar com o Estudo no. 6 (1929) e o Estudo no 11 (1929), respectivamente.

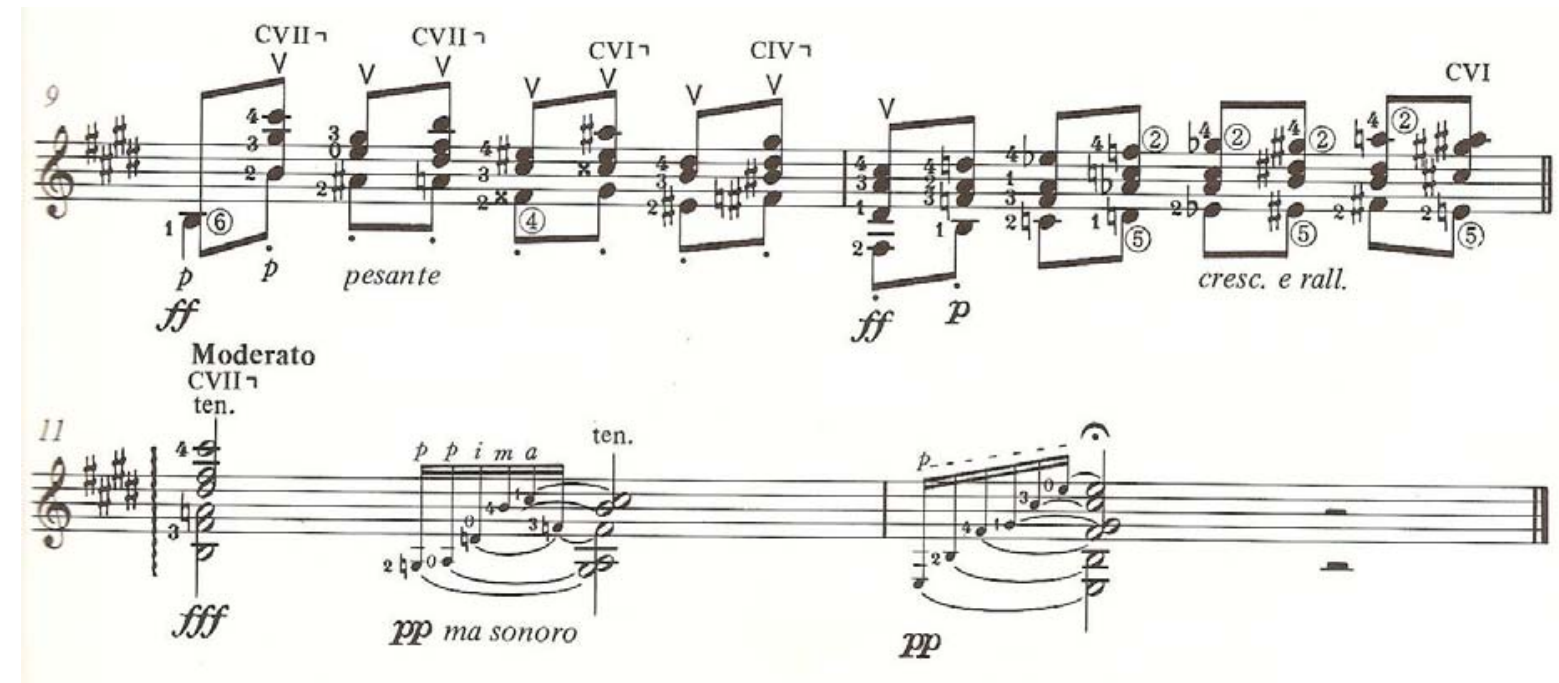

Trecho do Preludio-Original de Llobet

\footnotetext{
${ }^{57}$ Entrevista com Stefano Grondona realizada no II Encontro Internacional de Violonistas, em 22 de Abril de 2007, em Tatuí.
} 

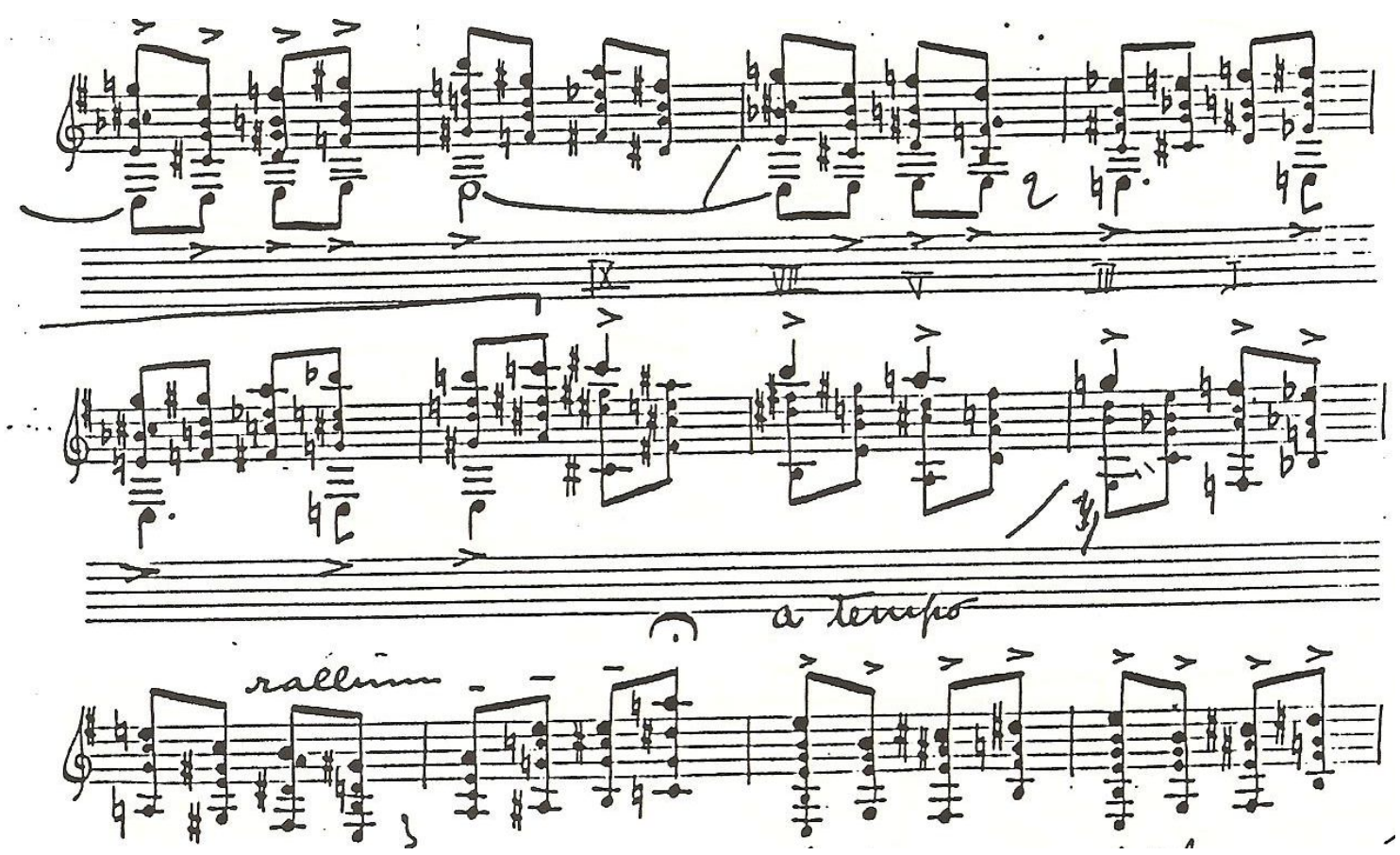

Trecho do Estudo no. 6 de Villa-Lobos
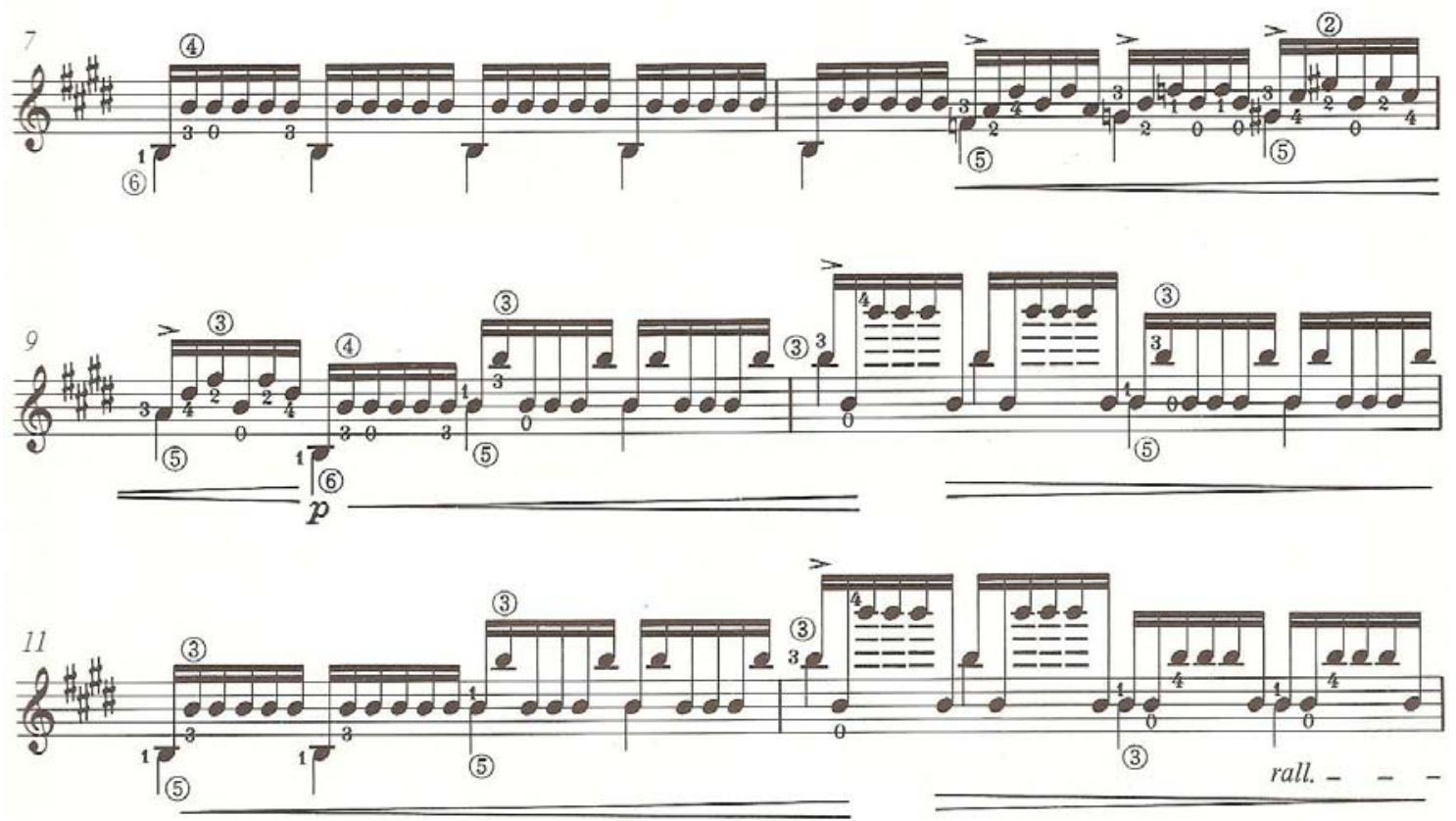

Trecho da Respuesta de Llobet 

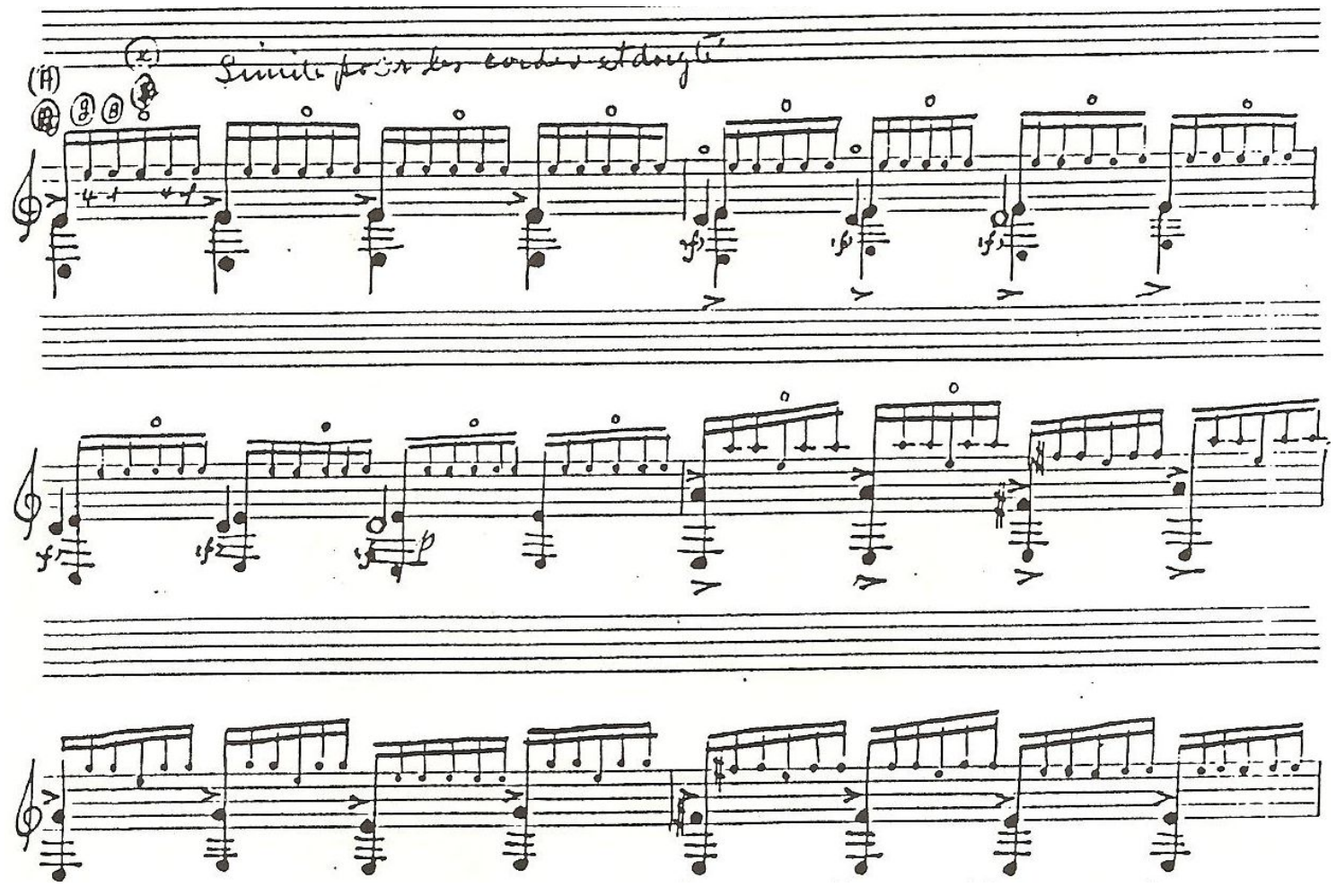

Trecho do Estudo no. 11 de Villa-Lobos

Llobet se dispôs a abandonar a vida agitada de suas turnês para retirar em sua cidade natal, Barcelona. A Espanha encontrava-se em guerra e Llobet se encontrou numa situação econômica difícil. Mangado comenta que Llobet morreu em conseqüência da tristeza que a guerra civil espanhola lhe causava e de uma miocardite (MANGADO, 1998, p. 97). Pahissa narra sua impressão nos seus últimos encontros com Llobet: "Yo le encontre algunas veces durante el primer año de la guerra, 1936-37, caminando por las calles de Barcelona, desorientado, anonadado, vencido, sin ánimo para nada. El 22 de febrero, del año seguinte, 1938, Miguel Llobet murió.” (PAHISSA, 1947, p. 121). 


\section{MIGUEL LLOBET E A TOTALIDADE DE SUA OBRA}

Como vimos no capítulo anterior, a importância da obra de Miguel Llobet na história do violão vem sendo paulatinamente revelada através de pesquisas realizadas a partir da década de 60 . No entanto, existem algumas lacunas com respeito à totalidade da obra de Miguel Llobet comparando o levantamento realizado por Bruno Tonazzi (1966), Ronald Purcell (1989), e mais recentemente, Stefano Grondona (2006).

Tonazzi catalogou um total de 95 produções (algumas não publicadas) entre composições originais, transcrições para violão solo, transcrições para duo de violões, transcrições para canto e violão e revisões (TONAZZI, 1966, p. 44).

Purcell publicou nos cinco volumes Nueva Collección Llobet: 11 composições originais para violão solo, 16 temas folclóricos (entre estes as 13 canções tradicionais catalãs), 10 transcrições para violão solo, 12 transcrições para duo de violões e 2 composições originais para violão solo. Segundo Purcell, a produção de Llobet foi catalogada em 25 composições originais, e suas adaptações cerca de 75 títulos (PURCELL, 1989, vol. 1, p. iv, partitura), totalizando um número de 100 produções.

Antes do contato com o trabalho do violonista Stefano Grondona, nos chamou a atenção um artigo da revista Soundboard que trazia a citação de um arquivo inédito de obras de Llobet redescobertas, nas mãos de Fernando Alonso, mas o acesso a elas ainda não havia sido possível. A expectativa era que este arquivo revelasse mais obras e que estas causariam o renascimento do violão no século $\mathrm{XX}$ e talvez posicionasse Llobet como o pai do violão moderno (PHILLIPS, 2002a, p. 31).

A descoberta deste arquivo ocorreu diante de uma série de casualidades, abrindo possibilidades de surgir ainda mais obras perdidas. Trataremos de narrar como 
se deu o ressurgimento deste arquivo com base nas informações encontradas em Mangado (1998) e Grondona (2006a, encarte de Cd):

A última filha de Llobet, Miguelina, faleceu em 1987, em Barcelona. Vivia no apartamento onde seu pai viveu nos últimos dez anos de sua vida, no quarto andar de num edifício da Rua Layetana. O apartamento foi completamente limpo, com todos os pertences de Llobet, incluindo livros e partituras, que estranhamente, não foram encaminhados a alguma biblioteca por Miguelina, antes de falecer. Os violões de Llobet haviam sido doados anteriormente para o Museu da Música de Barcelona, mas seu arquivo musical havia sido esquecido.

Os parentes próximos recolheram apenas os bens que julgaram ter mais valor, entregando vários pertences de Llobet a um cigano. Tais pertences incluíam algumas partituras, fotos, postais, desenhos e pinturas feitos pelas aos de Llobet e uma maleta que era usada em suas turnês. O cigano ofereceu esses objetos numa casa de música de Barcelona, provavelmente a Casa Sor, cujo proprietário é o violonista Fernando Alonso. A aquisição do arquivo se deu através de uma intuição de Alonso de que poderiam ser importantes. Na década de 70, Alonso e Anido realizam um concerto em homenagem ao histórico violonista, e a partir deste evento, Alonso passa a se interessar por seu trabalho. Tal interresse o levou a pesquisar sobre a vida de Llobet, finalmente chegando ao arquivo musical esquecido, que estava aos cuidados de uma antiga amiga da família - Anita Aguila - cuja professora de piano era a esposa de Llobet. Após alguma insistência, a senhora concorda que as obras estariam em melhores mãos se ficassem com Alonso. Estavam num depósito protegidos apenas por um plástico, preciosos manuscritos que descreveremos adiante.

Com a descoberta e a revelação do arquivo de Alonso, o catálogo final da totalidade da obra de Llobet deve ser revisto. Grondona, com a colaboração do detentor 
do arquivo tem revelado tais obras inéditas através de gravações realizadas a partir de 2006, e ainda podemos aguardar novas pesquisas.

Grondona narra como teve acesso a esse arquivo que resultou na gravação deste patrimônio musical:

La preciosa colaboración de los últimos diez años con Fernando há favorecido mis insistentes anhelos hacia tales descubrimientos, para ir hacia las potencialidades musicales que estaban en este legado. Y no solo para hacer uma simple y justa apología de um personaje que merece respeto, reconocimiento y gratitud, por tan largo tiempo negadas por sensibilidades enfocadas en otras direciones, sino también para que el contenido de tanta energia pudiera desembocar en un acontecimiento musical de nuestro tiempo que provea lo que hoy dia demasiadas veces falta en las experiências: la emoción (...) El entendimiento entre Fernando y yo, ha hecho possible realizar estas interpretaciones, ofrecidas ao público precisamente en el momento en el cual se está procediendo al traspaso de este fondo al Museu de la Música de Barcelona. Además, este material se conservará en la ciudad, tan amada por el Maestro, la cual se está progresivamente sensibilizando, predisponiéndose finalmente a compreender la importancia de um compositor, cuya personalidad, a través de la guitarra, la representa en una fuerte imagen y em su mejor perfil musical modernista. (GRONDONA, 2006a, encarte de Cd)

Ainda não é possível realizar um catálogo definitivo da obra de Llobet, uma vez que mais obras vêm sendo descobertas. Para mais informações devemos aguardar a publicação deste arquivo. O número de obras citadas por Purcell e o catálogo de Tonazzi fornecem apenas uma parte do patrimônio musical deixado por Llobet, pois a recente pesquisa de Grondona vem revelando gradualmente a existência de mais obras.

Abordaremos agora os trabalhos dos três pesquisadores, para uma comparação dos levantamentos realizados até a formatação desta pesquisa.

Catálogo realizado por Tonazzi:

\begin{tabular}{|l|}
\hline \multicolumn{1}{|c|}{ Composições publicadas } \\
\hline Romanza (1896) \\
\hline Estudio (1899) \\
\hline Estudio Capricho (1899) \\
\hline Mazurka (1901) \\
\hline Variaciones sobre un tema de Sor (1908) \\
\hline Scherzo-Vals (1909) \\
\hline Respuesta (1922) \\
\hline
\end{tabular}




\begin{tabular}{|c|c|}
\hline \multicolumn{2}{|c|}{ Prélude original (sem data) } \\
\hline \multicolumn{2}{|c|}{ Preludio em ré maior (1935) } \\
\hline \multicolumn{2}{|c|}{ Preludio em lá maior (1935) } \\
\hline \multicolumn{2}{|c|}{ Preludio em mi maior (1935) } \\
\hline \multicolumn{2}{|c|}{ Estilo popular criollo (sem data) } \\
\hline \multicolumn{2}{|c|}{ La filla del marxant (1899) } \\
\hline \multicolumn{2}{|l|}{ Plany (1899) } \\
\hline \multicolumn{2}{|l|}{ Lo Rossinyol (1900) } \\
\hline \multicolumn{2}{|c|}{ El Testament d'Amelia (1900) } \\
\hline \multicolumn{2}{|l|}{ Lo fill del rei (1900) } \\
\hline \multicolumn{2}{|l|}{ L’Hereu Riera (1900) } \\
\hline \multicolumn{2}{|c|}{ Cançó del lladre (sem data) } \\
\hline \multicolumn{2}{|l|}{ El Mestre (1910) } \\
\hline \multicolumn{2}{|l|}{ La filadora (1918) } \\
\hline \multicolumn{2}{|l|}{ La nit de Nadal (1918) } \\
\hline \multicolumn{2}{|c|}{ Composições Inéditas } \\
\hline \multicolumn{2}{|l|}{ Jota } \\
\hline \multicolumn{2}{|c|}{ Triste (sobre um tema popular argentino em mi maior) } \\
\hline \multicolumn{2}{|c|}{ La Pastorela (melodia popular catalã) } \\
\hline \multicolumn{2}{|c|}{ L'Emigrant (melodia popular catalã) } \\
\hline \multicolumn{2}{|c|}{ Transcrições publicadas para violão } \\
\hline \multirow[t]{4}{*}{ Isaac Albeniz } & Cadiz (serenata) \\
\hline & Granada \\
\hline & $\begin{array}{l}\text { Sevilla (revisão de uma transcrição de } \\
\text { Tárrega) }\end{array}$ \\
\hline & Torre Bermeja \\
\hline \multirow[t]{3}{*}{ Joh. Sebastian Bach } & Preludio (da suíte IV para cello) \\
\hline & Sarabanda (da Partita I para violino) \\
\hline & Bourrée \\
\hline \multirow[t]{5}{*}{ Ludwig van Beethoven } & Largo (da sonata no. 4) \\
\hline & Andante (da sonata no. 10) \\
\hline & Allegretto (da sonata no. 14) \\
\hline & Andante (da sonata no. 23) \\
\hline & Sonata \\
\hline Georges Bizet & Fragmento de L'Alesiana \\
\hline Federigo Bufaletti & Mazurka \\
\hline \multirow{3}{*}{ Fréderic Chopin } & Preludio n. 8 \\
\hline & Preludio n. 9 \\
\hline & Noturno no. 2 \\
\hline Enrique Granados & Danza española no. 5 \\
\hline & Danza española no. 10 \\
\hline & Dedicatória \\
\hline & La Maja de Goya \\
\hline Edward Grieg & Melodia norvegese (da Ballata no. 24) \\
\hline Felix Mendelssohn & Romanza senza parole \\
\hline W. A. Mozart & Andante (Don Giovanni) \\
\hline Anton Rubinstein & Romanza \\
\hline Robert Schumann & Picollo pezzo \\
\hline
\end{tabular}




\begin{tabular}{|c|c|}
\hline & Revérie \\
\hline & Il primo dolore \\
\hline & Coral \\
\hline & Marcha militar \\
\hline & Preghiera del bambino \\
\hline Joaquin Valverde & Clavelitos \\
\hline Rogelio Villar & Danza española \\
\hline Richard Wagner & Fragmento de Parsifal \\
\hline \multicolumn{2}{|c|}{ Transcrições inéditas para violão } \\
\hline \multirow[t]{2}{*}{ Isaac Albeniz } & Córdoba \\
\hline & Oriental \\
\hline Cécile Chaminade & Air de ballet \\
\hline \multirow[t]{2}{*}{ Manuel de Falla } & Romanza del pescador (El Amor brujo) \\
\hline & Canción del fuego fatuo (El Amor brujo) \\
\hline Enrique Granados & Danza española no. 7 \\
\hline W. A. Mozart & Ária \\
\hline \multirow[t]{2}{*}{ Rogelio Villar } & Canción Leonesa \\
\hline & Danza Castellana \\
\hline \multicolumn{2}{|c|}{ Transcrições publicadas para duo de violões } \\
\hline \multirow[t]{4}{*}{ Isaac Albeniz } & Bajo de la Palmera \\
\hline & Evocación \\
\hline & Castilla \\
\hline & Rumores de la caleta \\
\hline Louis Claude D’Aquin & Lê Cou-Cou \\
\hline \multirow[t]{2}{*}{ Enrique Granados } & Danza española no. 6 \\
\hline & Danza española no. 11 \\
\hline Eduardo Lopez Chavarri & Leyenda del castillo moro \\
\hline P. I. Tchaikovsky & Humoreska \\
\hline \multirow[t]{2}{*}{ Felix Mendelssohn } & Romanza senza parole no. 20 \\
\hline & Romanza senza parole no. 25 \\
\hline W. A. Mozart & Minuetto (da sinfonia no. 39) \\
\hline \multicolumn{2}{|c|}{ Transcrições inéditas para duo de violões } \\
\hline Julián Aguirre & Huella \\
\hline Johannes Brahms & Danza ungherese no. 5 \\
\hline \multirow[t]{4}{*}{ Manuel de Falla } & $\begin{array}{l}\text { Danza del molinero (El sombrero de tres } \\
\text { picos) }\end{array}$ \\
\hline & Pantomina \\
\hline & Danza ritual del fuego (El Amor brujo) \\
\hline & Cubana \\
\hline Pascual de Rogatis & Chacarera \\
\hline \multicolumn{2}{|c|}{ Transcrição para canto e violão } \\
\hline Manuel de Falla & Siete canciones populares españolas \\
\hline \multicolumn{2}{|c|}{ Revisões e digitações } \\
\hline Alfonso Broqua & $\begin{array}{l}\text { Milongueos e Ritmos camperos } \\
\text { (Evocaciones Criollas) }\end{array}$ \\
\hline Matteo Carcassi & 25 Estudos Op. 60 \\
\hline Manuel de Falla & Homenaje le Tombeau de Debussy \\
\hline Agustin Grau & Corranda \\
\hline Carlos Pedrell & Betsabé \\
\hline
\end{tabular}


Adolfo Salazar

Romancillo

As obras para violão solo publicadas citadas no catálogo de Tonazzi estão publicadas pela Unión Musical Española (U.M.E). La Pastoreta, o título correto, ainda não havia sido publicada. Foi publicada somente em 1969 pela U.M.E. A coleção das Diez Canciones Catalanas foi publicada em 1964 pela U.M.E. El Noi de la Mare foi publicada em 1975.

Grondona gravou uma das obras inéditas para violão solo que figuram no catálogo de Tonazzi - Canción del pescador (Romanza del pescador ${ }^{58}$.

Obras publicadas por Ronald Purcell:

\begin{tabular}{|l|}
\hline \multicolumn{1}{|c|}{ Composições originais para violão } \\
\hline Romanza (1896) \\
\hline Estudio en mi mayor (1899) \\
\hline Estudio Capricho (1899) \\
\hline Mazurka (1901) \\
\hline Variaciones sobre un tema de Sor, Op. 15 (1908) \\
\hline Scherzo-Vals (1909) \\
\hline Prelude-Original (c. 1912) \\
\hline Preludio em mi mayor (1916) \\
\hline Respuesta (1922) \\
\hline Preludio em la mayor (1935) \\
\hline Preludio em mi mayor (1935) \\
\hline Estilo \\
\hline Preludio \\
\hline \\
\hline Plany (1899) \\
\hline La filla del marxant (1899) \\
\hline El Testament d'Amelia (1900) \\
\hline Canço del lladre (c. 1900) \\
\hline Lo Rossinyol (1900) \\
\hline Lo fill del rei (1900) \\
\hline L’Hereu Riera (1900) \\
\hline El Mestre (1910) \\
\hline La Nit de Nadal (1918) \\
\hline La Filadora (1918) \\
\hline La Pastoreta (c. 1918) \\
\hline La Preçó de Lleida (c. 1920) \\
\hline El noi de la mare \\
\hline Leonesa (c. 1910) \\
\hline
\end{tabular}

\footnotetext{
${ }^{58}$ STEFANO GRONDONA. HOMENAJE. Stradivarius, 2006a (Cd).
} 


\begin{tabular}{|c|c|}
\hline \multicolumn{2}{|c|}{ Estilo popular argentino no. 1 (c. 1910) } \\
\hline Estilo popular argentino $\mathrm{n}$ & \\
\hline \multicolumn{2}{|c|}{ Transcrições para violão } \\
\hline \multirow[t]{4}{*}{ Isaac Albéniz } & Cadiz (Serenata no. 4 da suíte Espanhola \\
\hline & $\begin{array}{l}\text { Oriental (Cantos de Espanha, Op. 232, no } \\
\text { 2) }\end{array}$ \\
\hline & Sevilla (Sevillanas da suíte espanhola) \\
\hline & Torre Bermeja (Serenata, Op. 92, no. 12) \\
\hline \multirow[t]{5}{*}{ Enrique Granados } & Danza Española no. 5 (Andaluza, Op. 37) \\
\hline & Danza española no. 7 (Valencia, Op. 37) \\
\hline & Danza española no. 10 (Triste, Op. 37) \\
\hline & $\begin{array}{l}\text { Dedicatória (Cuentos de la Juventud, Op. } \\
\text { no. 1) }\end{array}$ \\
\hline & La Maja de Goya (Tonadilla) \\
\hline Joaquin Valverde & Clavelitos (Zambra Gitana) \\
\hline \multicolumn{2}{|c|}{ Transcrições para duo de violões } \\
\hline Louis Claude Daquin & Le Cou-Cou \\
\hline \multirow[t]{4}{*}{ Isaac Albéniz } & Rumores de la Caleta (Malagueña, no. 6) \\
\hline & Castilla (Seguidillas, no. 7, Suíte Española) \\
\hline & $\begin{array}{l}\text { Bajo de la Palmera (Canciones de España, } \\
\text { Op. 232) }\end{array}$ \\
\hline & Evocación (Suíte Iberia) \\
\hline \multirow[t]{2}{*}{ Enrique Granados } & $\begin{array}{l}\text { Danza Española no. } 6 \text { (Rondalla } \\
\text { Aragonesa) }\end{array}$ \\
\hline & Danza Española no. 11 (Zambra) \\
\hline Eduardo Lopez-Chavarri & $\begin{array}{l}\text { Leyenda del Castillo Moro (Cuentos y } \\
\text { Fantasias) }\end{array}$ \\
\hline \multirow[t]{2}{*}{ Felix Mendelssohn } & Romanza sin palabras, no. 20, Op. 53 \\
\hline & Romanza sin palabras no. 25, Op. 53 \\
\hline W. A. Mozart & Minuetto (Sinfonia no. 39) \\
\hline Peter Tchaikovsky & Humoresque, Op. 10, no. 2 \\
\hline
\end{tabular}

As composições originais para violão estão publicadas na Nueva Colección Llobet (PURCELL, 1989, vol. 1, partitura), com exceção das peças Preludio e Estilo, que estão publicadas separadamente (PURCELL, 1992, partitura). Os 16 temas folclóricos se encontram publicados no volume 2, as transcrições para violão solo no volume 3 e as transcrições para duo de violões no volume 4 (PURCELL, 1989, partitura).

A canção popular Leonesa figura no catálogo de Tonazzi debaixo da autoria de Rogerio Villar (1875-1937), não de Llobet e foi gravada por Grondona debaixo da 
autoria do mesmo. Portanto, Purcell pode ter publicado equivocadamente esta canção popular debaixo da autoria de Llobet.

Grondona gravou o Estilo no. 1 e 2 citados no catálogo de Tonazzi debaixo da autoria de P. M. Quijano, além de Estilo (PURCELL, 1992, partitura) debaixo do título Estilo Popular Argentino no. 3, autoria também atribuída a Quijano. Gravou também as obras Mazurka de Severina de E. Bufaletti (1862-1936) Danza Española de Rogerio Villar que pode se referir à mesma Danza Castellana citada no catálogo de Tonazzi ${ }^{59}$.

Purcell inclui mais três canções catalãs em sua edição das Treze Canciones Catalanas, aumentando assim o número de canções catalãs editadas anteriormente como Diez Canciones Catalanas catalogadas por Tonazzi - La Pastoreta, La Presó de Lleida e El Noi de la Mare.

No entanto, uma nova pesquisa revela que o número das canções tradicionais catalãs utilizadas na obra de Llobet pode aumentar ainda mais. Trata-se da pesquisa realizada pelo violonista italiano Stefano Grondona ${ }^{60}$.

No capítulo 2, falamos da importante sociedade de instrumentos de cordas dedilhadas e de plectro - a sociedade Lira Orfeo - da qual Llobet fez parte. Entre as disciplinas oferecidas aos estudantes estavam as aulas de grupo de instrumentos. Llobet foi o fundador e diretor artístico de um grupo que reunia tais instrumentos, seguindo o modelo das estudiantinas citadas no capítulo 1. Tal grupo levava o mesmo nome da sociedade catalã.

As atividades do grupo catalão Lira Orfeo estão emergindo graças à pesquisa de Grondona à frente do quinteto de violões Nova Lira Orfeo. Este grupo faz referência

\footnotetext{
${ }^{59}$ STEFANO GRONDONA. RESPUESTA. Stradivarius, 2006b (Cd). Neste registro sonoro o violonista intitula a obra publicada por Purcell (1992, partitura) Estilo como Estilo Popular Argentino no.1, e o Estilo Popular Argentino no. 3 (PURCELL, 1989, vol. 2, p. 19, partitura) como Estilo Popular Argentino no. 1. Portanto, notamos uma variação nos títulos das canções populares argentinas.

${ }^{60}$ STEFANO GRONDONA. HOMENAJE Stradivarius, 2006a (Cd).
} 
ao grupo catalão que se reunia na sociedade catalã. Foi formado em 2002 a fim de difundir a coleção inédita das obras de Llobet para esta formação que ressurgiu apenas recentemente. O grupo Lira Orfeo original reunia mandolinas espanholas, violões, alaúdes, e um arquialaúde. A formação do grupo Nova Lira Orfeo inclui apenas violões.

Além das treze canções editadas (PURCELL, 1989, v. 2, partitura), existem mais três adaptações de canções populares realizadas para este grupo - La Filla del marxant (usada anteriormente na adaptação para violão solo), L'Anunciació (na Catalunha mais conhecida como La Mare de Deu) e L’hostal de la Peira, entre outras adaptações.

Obras inéditas encontradas na pesquisa realizada pelo violonista Stefano Grondona:

\begin{tabular}{|l|l|}
\hline \multicolumn{2}{|c|}{ Transcrições para Lira Orfeo } \\
\hline Rafael Mitjana & Seguidillas \\
\hline W. A. Mozart & Menuet de D. Joan \\
\hline & Serenata de D. Joan \\
\hline L. van Beethoven & Menuet \\
\hline F. Chopin & Preludi \\
\hline F. Mendelssohn & Romança \\
\hline & Romança \\
\hline R. Schumann & Coral \\
\hline & Romança sense paraules \\
\hline Canção tradicional catalã & La Filla del marxant \\
\hline & L'Anunciació \\
\hline & L'hostal de la Peira \\
\hline Isaac Albéniz & Granada \\
\hline
\end{tabular}

Uma obra de Manuel de Falla não citada nos catálogos de Tonazzi e Purcell aparece entre as demais na pesquisa de Grondona. Trata-se de Medianoche - uma transcrição para duo de violões. Dentre as obras inéditas não editadas, existe ainda uma 
outra transcrição para duo de violões - a canção popular brasileira Therezinha de Jesus (1918), baseado na versão pianística de Heitor Villa-Lobos (informação verbal) ${ }^{61}$.

O conjunto das peças que vem sendo reveladas denota o mesmo sentido de orquestração citado no capítulo anterior. A sofisticação da obra de Llobet revela o domínio que este grande artista possuía do instrumento:

Las intuiciones de Llobet, los artifícios colorísticos más próprios de lo instrumental, nos ofrecen acceso al profundo conocimiento que él tenia de la guitarra. Y era este de deslumbrante magnitud, abierta imaginación y entusiática creatividad; cada digitación está rigurosamente indicada, y comunica una conciencia expresiva y meticulosa al preferirla a otras que pudieran ser tambien interesantes soluciones alternativas. Estas obras nos permiten ahora revelar uma nueva luz de la imagen moderna de tal personaje. Su brillantez artística e intelectual había quedado demasiado reprimida por los melancólicos colores de su última decada de vida y su desaparición, que habian desvirtuado su auténtico perfil. (GRONDONA, 2006a, encarte de Cd)

Algumas obras publicadas de Llobet merecem ser destacadas pelo uso de elementos inovadores do ponto de vista harmônico. Sua Romanza (1896) está numa tonalidade pouco usual até então - dó menor; a Mazurka (1901) utiliza acordes de sexta napolitana; o Scherzo-Vals (1909) utiliza harmonias muito próximas da influência francesa; observamos em sua Respuesta (1922) o uso de tons inteiros; e o Preludio em Mi Maior (1935) pode ser considerado sua obra impressionista pelo emprego de dissonâncias mais marcadas, como acordes aumentados.

Poderíamos destacar diversas particularidades na obra de Llobet que posicionam o violão dentro da linguagem do século XX. No entanto, iremos enfocar a nossa pesquisa em suas Canciones Catalanas, onde notamos que Llobet estava preocupado em valorizar a cultura de sua terra natal. Curiosamente, notamos a ausência de elementos hispânicos de caráter andaluz em suas obras originais, enquanto que nas

\footnotetext{
${ }^{61}$ Informação obtida no II Encontro Internacional de violonistas de Tatuí realizado em 19 a 22 de Abril de 2007. Para a nossa surpresa, no dia 22 de Abril, o recital do duo Grondona-Mondiello revelou a existência desta obra inédita (há um registro em DVD).
} 
obras de outros catalães como Albeniz, Granados, Malats e Pujol, eram comuns (GLOEDEN, 1996, p. 56).

O fato de existirem obras desconhecidas nos permite analisar a personalidade artística de Llobet sob uma visão mais modernista.

Aguardamos a publicação e difusão das obras inéditas recém-descobertas de Llobet, pois este patrimônio musical é valioso e precisa ser difundido. 


\section{AS CANÇÕES TRADICIONAIS CATALÃS - ASPECTOS HISTÓRICOS, SOCIAIS E TRADUÇÃO PARA O PORTUGUÊS}

O conjunto da obra de Miguel Llobet foi essencial para a história do violão. Com suas Canciones Catalanas tornou-se mestre na arte da transcrição e ajudou a posicionar o violão no século XX. No entanto, ao observar que o material usado na concepção destas célebres adaptações pertence ao terreno do folclore catalão, cuja tradição é milenar, nos sentimos motivados a buscar as informações a respeito destas melodias.

O contato com as gravações realizadas pelo grupo catalão La Capella Reial de Catalunya foi o ponto de partida para o início da pesquisa, pois citavam algumas canções usadas por Llobet como El fill del rei, La Filadora, Cançó del Lladre, El Mestre, e El Testament d'Amelia. Tal realização fonográfica incluiu as letras das canções, gravadas numa concepção coerente com a origem das melodias. A pesquisa contida nesta gravação nos motivou a encontrar as outras melodias usadas na obra para violão de Miguel Llobet e percebemos que outros compositores, talvez influenciados pelo próprio Llobet, também exploraram temas tradicionais catalães em sua obra. Incluiremos as canções usadas na obra de tais compositores na pesquisa, junto com outras canções tradicionais inéditas que vêm sendo gradativamente reveladas à medida que o interesse pela totalidade da obra de Llobet aumenta.

A tradição musical catalã é permeada por uma série de fatos históricos e lendas que ajudam a criar o contexto onde tais melodias foram concebidas, de forma anônima pelo povo e transmitidas oralmente. Procuramos incluir as narrações de tais fatos na pesquisa para ajudar a desvendar o significado das melodias adaptadas para violão e sua origem. 
A pesquisa sobre a origem e a tradução dos textos das canções escolhidas se baseará na compilação realizada pelo musicólogo Joan Amades, citado em diversas publicações sobre folclore catalão.

A publicação de Purcell trazia uma versão monofônica da canção El Mestre (PURCELL, 1989, vol. 2, p. iv)), com parte da letra original em catalão traduzida para o inglês. Isso também nos motivou a transcrever outras melodias tradicionais catalãs e traduzi-las para o português.

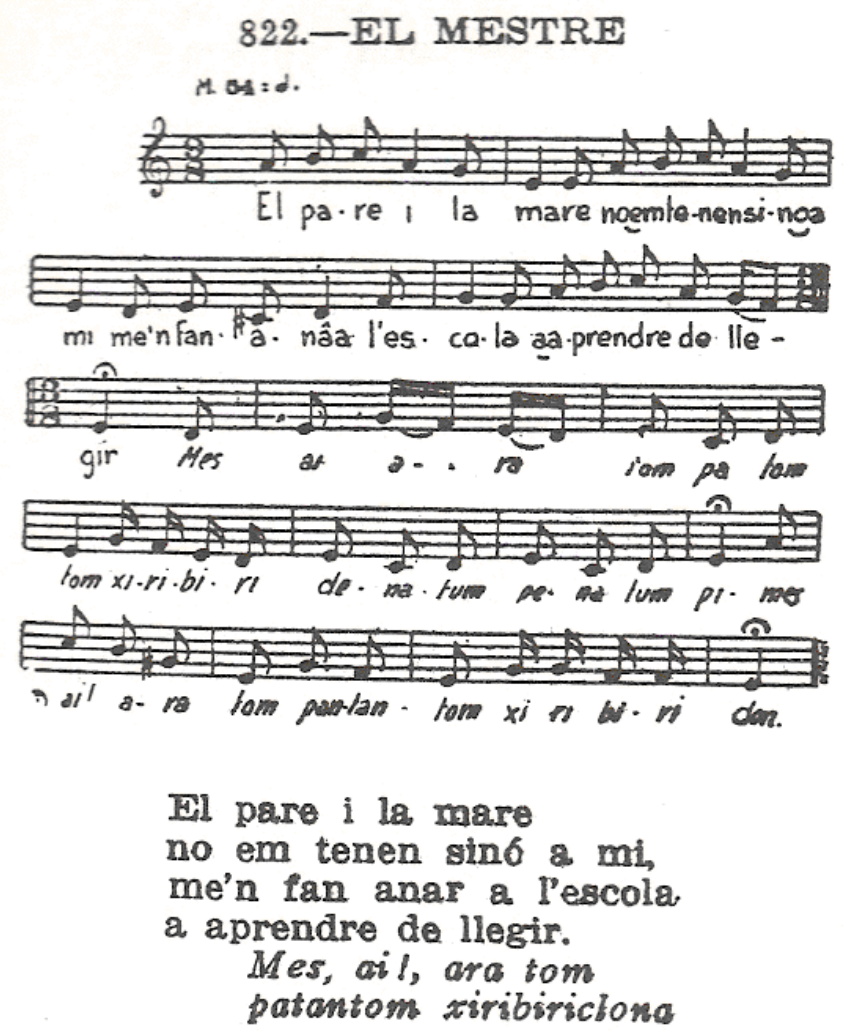

Decidimos partir para uma tradução livre para entendermos o conteúdo destes textos ou para ver se há uma relação entre os arranjos de Llobet e os textos ou se são meramente arranjos engenhosos para violão.

As Canciones Catalanas são produto da tradição oral. Portanto, pequenas variações nos títulos, nas letras e nas melodias podem ocorrer como aponta os trabalhos musicológicos contidos na obra Observaciones, apendix i notes al "romancerillo catalán” de Manuel Mila i Fontanals (PUJOL, 1926). Trata-se de uma pesquisa de 
campo realizada em 1923 nas diversas comarcas da Catalunha que mostra a grande variedade de versões que podem resultar de uma mesma melodia tradicional.

As canções comentadas nesta pesquisa são:

Plany (1899); La filla del marxant (1899); El Testament d'Amelia (1900); Cançó del Lladre (1900); Lo Rossinyol (1900); Lo fill del Rei (1900); L’hereu Riera (1900); El Mestre (1910); La Nit de Nadal (1918); La Filadora (1918); La Pastoreta (1918); La presó de Lleida (1920); El noi de la Mare (s.d.); L'Anunciacó; L’hostal de la Peira; Els tres Tambors; El Cant dels ocells; El bon caçador; La ploma de perdiu; Els Estudiants de Tolosa; Muntanyes del Canigó; Catarina d'Alió; La gata i el belitre.

A Catalunha, como nação mediterrânea, incorporou a cultura da Europa Central durante suas relações comerciais e políticas que acontecia desde o período medieval. Desenvolveu uma identidade política muito forte devida a suas lutas por independência dentro do império espanhol, passando de província a uma nação independente graças à personalidade do povo catalão. Tal personalidade resultou no cancioneiro tradicional catalão, com suas canções de características muito próprias, fugindo um pouco do domínio árabe das melodias andaluzas.

Percebemos traços de uma personalidade guerreira em algumas das canções que estudaremos. O uso de tonalidades menores confere um ar melancólico a quase todas as melodias, uma tristeza que alguns atribuem à série de calamidades cívicas e militares que acometeram o povo catalão nos séculos XVII e XVIII, depois de sucessivas derrotas. O tema de morte e o ambiente de crueldade é recorrente nas canções La Presó de Lleida, El Testament d'Amelia e La Filla del Marxant. Na El Mestre encontramos conotações bélicas, como veremos adiante.

Os catalães, graças ao trabalho dos folcloristas, e à sua identidade de nação lutadora, conservaram suas raízes musicais e cantam as canções tradicionais de sua terra 
desde sua infância. Muitas das canções que comentaremos são familiares a toda criança que nasce em território catalão.

As canções tradicionais catalãs geralmente servem a um objetivo ligado a um trabalho ou a uma ação. As canções que estudaremos estão classificadas por Amades da seguinte maneira:

Cançó de bressol (canção de ninar); cançó de dansa (canção de dança); cançó d’aplec (canção de celebração); cançó de filadora (canção de fiadora); cançó de puntaire (canção de bordar); cançó de tasca (canção de trabalho ou designação); cançó d'espellonar (canção da colheita); cançó de traginers i de cami (canção de viajante e marcha); cançó de Nadal (canção de Natal); cançó de caçador (canção de caçador); cançó de pescador (canção de pescador); cançó de messes (canção de plantio); e cançó de cosidora (canção de costureira).

As canções de ninar são numerosas. Trata-se de um tipo de repertório tradicional pelo qual todos passam, desde a infância, embalados por pais e avós. O embalo do berço fazia os bebês dormirem junto com as melodias que adotavam o ritmo da ação de balançar o berço. Suas melodias são curtas e se repetem até fazer a criança dormir. Deste bloco pertencem a canção El noi de la Mare, e L'Anunciació (La Mare de Deu) e El Cant dels ocells. Estas canções tinham um valor prático de espantar maus espíritos do lado dos bebês que eram embalados ao som desta canção que se destinava a fazê-los dormir. O ritmo era embalado pelo movimento do corpo da mãe ao balançar o berço ou ao segurar o bebê no colo. O musicólogo e compositor Felipe Pedrell afirma lembrar-se da canção que sua mãe costumava cantar para ele e seus irmãos dormirem Comte l’Arnau (AMADES, 1951, p.66).

Muitas canções estão ligadas a costumes tradicionais. Dançar, por exemplo, além de um costume constitui uma necessidade. "O baile constituía um ambiente 
favorável para a criação de canções que correspondiam ao sentimento coletivo do povo”. (AMADES, 1951, p. 180)

A melodia era mais uma vez assimilada e adaptava-se plenamente às necessidades da massa, e passava a fazer parte do corpo de costumes da comunidade, transformando-se em tradição.

As canções adaptadas por Llobet que representam as canções de dança são:

La Filla del Marxant, L’hereu Riera e El Rossyniol.

Algumas danças têm relação com o texto das melodias através dos movimentos de sua coreografia. L’hereu Riera é um exemplo disso. A lenda narrada pelos seus versos faz alusão a um jovem enamorado que, enquanto reza pelo restabelecimento da saúde de sua amada, em seu leito de morte, dança em torno de bastões posicionados no chão em forma de cruz. A dança típica feita com bastões é tradicional até hoje na Catalunha, conhecia como ball de bastó (baile de bastões).

O costume de dançar reunia o povo num tipo de festa que os catalães chamam de "aplecs” (figura 1). A maioria dos “aplecs” é realizado ao ar livre, perto da natureza, ao redor de santuários ou capelas situados em lugares despovoados no alto da montanha. Tal costume está ligado aos rituais de origem litúrgica, pois os cumes das montanhas são santificados, segundo as crenças religiosas (AMADES, 1951, p. 176). Atualmente os “aplecs” são uma reunião para dançar a popular sardana, dança típica da Catalunha. A sardana é uma dança de roda, de caráter social. Como vimos no capítulo 1, os peregrinos que cantavam e dançavam as canções do Libre Vermell de Montserrat, nos séculos XIII e XIV, já praticavam uma dança deste tipo - o ball rodó (RUBIO, 1983, p.109). As canções que representam esta categoria de entretenimento são: El Mestre e La Pastoreta. 


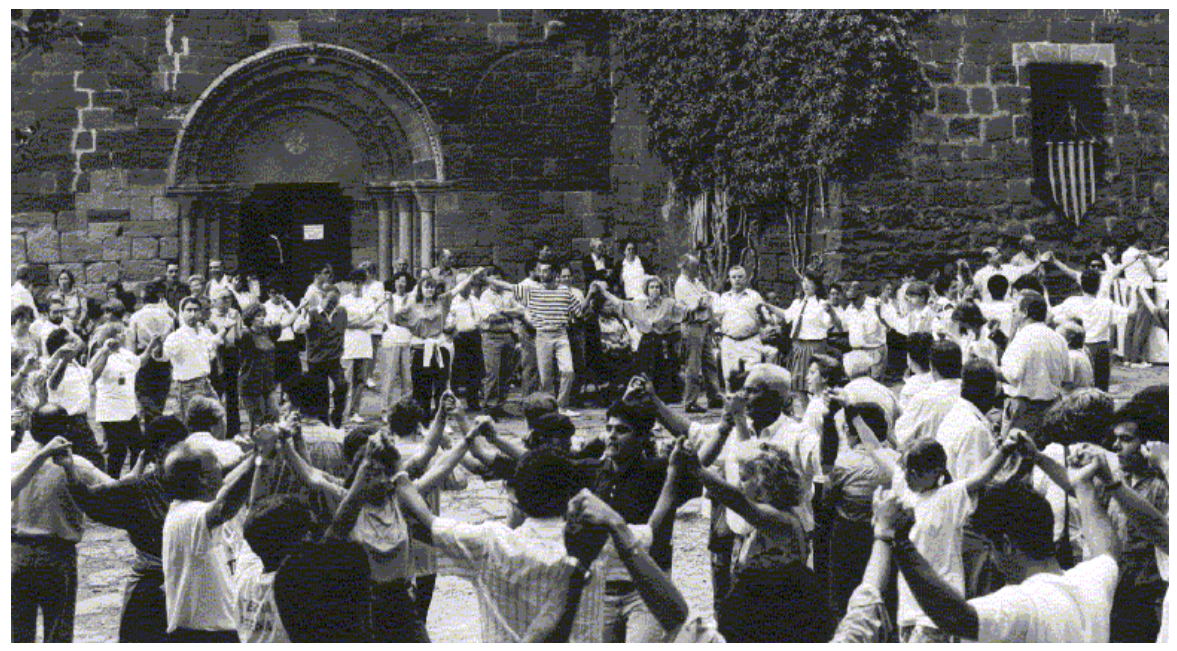

Figura 1. Aplecs

O costume de cantarolar alia-se à necessidade de trabalhar para tornar o trabalho menos monótono e cansativo. Assim, comentaremos as canções que são usadas para trabalhos artesanais e trabalhos agrícolas.

Os povos da Europa tinham canções especiais para realizar o trabalho de fiar. La Filadora é uma das canções mais cantadas com esta finalidade, para acabar com a monotonia do trabalho repetitivo. A ação de pisar na roca de fiar era cadenciada pelo ritmo da canção, o que ajudava a estabelecer o movimento dos fiadores e tornava o trabalho mais interessante (AMADES, 1951, p. 705).

La Ploma de Perdiu se insere no repertório de canções para acompanhar o trabalho artesanal de bordar. Diferentes do trabalho de fiar, os movimentos ao bordar são variados e não se requer cantar as melodias com métrica, pois a ação de bordar é arrítmica. A tradição de bordar reunia muita gente, especialmente as mulheres, por isso a preferência por temas galantes e amorosos era maior enquanto o trabalho era realizado (AMADES, 1951, p. 745).

As canções de trabalho se originaram a partir da necessidade de estabelecer uma harmonia nos movimentos ao trabalhar, como vimos acima, para acabar com a monotonia da repetição da ação e tendem a regular o movimento do corpo de acordo 
com o ritmo do trabalho que se realiza. A canção mesura o tempo, ajuda na ação do corpo e contribui para a perfeição do trabalho. As canções desta categoria se aplicam aos mais variados tipos de profissão: ferreiro, carpinteiro, alfaiate, padeiro, pintor, marinheiro, ceramista, sapateiro, tecedor, etc. São aplicadas também a trabalhos domésticos: amassar, cozinhar, lavar, etc. Para cada tipo de designação, encontramos diversas melodias tradicionais que estão reunidas no trabalho de Amades, e El Fill de Rei representa uma canção que descreve o movimento de remar. Catarina d'Alió representa outra canção de trabalho - o de lavar roupas.

Os trabalhos realizados no campo são os mais típicos dos que se movem ao som de canções características e bem apropriadas. O tipo de trabalho possui ações que adotam um ritmo mais lento ou mais acelerado, dependendo do caso.

As canções de colheita se inserem nesta categoria e para exemplificá-la temos as canções Cançó del Lladre, La Presò de Lleida e El Testament d'Amelia. O trabalho reunia homens e mulheres e o costume de narrar contos e cantar melodias era comum. No fim do dia, o dono da colheita servia seus trabalhadores com frutas secas com vinho e se dançava ao som das mesmas melodias. Tal costume deu origem à festa “La Revellosa” e “La Vinotxa”. As mulheres tinham preferência pelos temas amorosos, e os homens preferiam os temas de caráter histórico (AMADES, 1951, p. 585). De fato, como veremos adiante, as três melodias que se inserem nesta categoria narram alguns fatos históricos incrementados pelas lendas criadas pelo povo.

As canções de marcha eram cantadas pelos viajantes e contrabandistas com a finalidade de se ocuparem enquanto percorriam os bosques e montanhas. Assim, não sentiriam o passar das intermináveis horas de viagem. Els tres Tambors é uma canção de marcha (AMADES, 1951, p. 638). 
Algumas canções citadas servem para dois objetivos quando entramos no universo de canções natalinas. El Desembre Congelat representa a canção de Natal, que todo o povo tem o dom de cantar, por isso dentro do cancioneiro tradicional as canções de natalinas são bastante numerosas (AMADES, 1951, p. 261).

El Bon Caçador evoca a mais antiga tradição - a do homem caçador e está diretamente ligada com o ato de caçar. As canções desta categoria, semelhantes às canções de ninar, caracterizam-se por frase musicais curtas que se repetem até o caçador atingir seu objetivo - capturar a caça (AMADES, 1951, p. 396).

A arte de pescar se insere na mesma categoria da tradição de caçar, pois se baseia no mesmo princípio - o de capturar animais. Portanto, diferencia-se por seu procedimento mecânico, exigindo mais tempo e preparação das ferramentas usadas na pesca. Portanto, as canções de pescar podem ser mais longas (AMADES, 1951, p. 402). Estas são representadas por Els Estudiants de Tolosa e Muntanyes del Carnigó.

Os povos da Europa mediterrânea consideram o trabalho agrícola, pois é vital para alimentar suas famílias. Os rituais envolvidos na cultura catalã vêm de civilizações muito antigas, e muitas crenças e práticas foram herdadas dos povos de cultura clássica, uma boa parte relacionada a canções associadas, por sua vez, à dança (AMADES, 1951, p. 486). As canções de plantio são representadas pela canção L’Hostal de la peira.

As canções de costureira servem para o mesmo objetivo das canções de fiadora - dar movimento ao trabalho. As costureiras tinham preferência pelas melodias longas e tranqüilas (AMADES, 1951, p. 721). La Gata i el belitre representa esta categoria de canções.

Ao pesquisarmos os aspectos históricos e sociais das canções, localizamos suas letras e consideramos importante transcrevê-las junto com a melodia para facilitar 
sua leitura dentro do contexto folclórico, onde melodia e poesia seguiram juntas. A principal fonte destas melodias com texto é o cancioneiro folclórico de Joan Amades, mas procuramos localizar também outras fontes.

Quanto às origens das canções encontramos certa nebulosidade, visto que foram concebidas em circunstâncias que dificultam identificar com precisão sua origem. Seus autores são anônimos, e sua difusão era realizada através da transmissão oral. Um fato que contribui para a conclusão de que as canções são muito antigas são os elementos do canto gregoriano presentes em sua estrutura. O sistema modal antigo maior e menor, sem grande uso de cromatismo, indica que as melodias conservaram sua forma antiga. De fato, uma das características da canção popular catalã são as antigas modalidades gregas.

As referências históricas da canção popular citadas no capítulo 1 possibilitarão levantar algumas hipóteses sobre a origem dos temas harmonizados por Llobet no início do século XX.

À medida que constatamos os livros e os códices é possível identificar a origem de alguns temas usados por Llobet e por outros compositores violonistas e nãoviolonistas. Encontramos no canto gregoriano algumas melodias que serviram de base para a concepção de alguns temas que caíram no gosto popular. O canto litúrgico e a canção popular têm algumas coisas em comum: ambos possuem melodias simples e são de estrutura diatônica; suas melodias não passam de uma oitava (BALDELLÓ, 1926, p. 359).

Os trovadores criavam melodias que se difundiam por toda a parte com sua arte ambulante e apesar de poucas melodias terem sobrevivido, podemos identificar duas delas no cancioneiro catalão que foram utilizadas na obra de Llobet, como veremos adiante. 
É curioso comentar o folclore de outro povo, que não o nosso.

Ao traduzir as letras das canções, nos ativemos ao cancioneiro compilado por Amades, visto que as canções sofrem variações devido à sua natureza popular e ao sistema de transmissão oral durante séculos. Algumas delas possuem mais variações do que outras, sendo possível encontrar algumas diferenças de uma versão para outra, principalmente literárias (PUJOL, 1926, 3 vol.). Durante a pesquisa, foram encontradas algumas destas variações que não foram incluídas. Priorizamos, portanto, a forma mais difundida e mais recente. Para isso, nos baseamos no trabalho de Amades e algumas referências fonográficas, uma vez que o folclore catalão não é familiar para nós, brasileiros. Portanto, simplificaremos a escolha das estrofes para realizar a tradução, citando apenas as estrofes mais cantadas pela população. Algumas canções possuem uns textos mais extensos, que narram cenas do cotidiano. De fato, muitas canções estão ligadas a lendas, e algumas vezes, a fatos históricos ocorridos durante a Idade Média.

A tradução é livre e se deteve na idéia principal do texto. Separamos as estrofes mais conhecidas visto que algumas letras são demasiadamente longas, e por isso difíceis de serem memorizadas pelo povo. Como citamos anteriormente, nosso objetivo não é fazer uma tradução literária, mas uma tradução que dê aos violonistas o entendimento destes textos para que isso possa dar mais subsídios para uma interpretação.

A pesquisa destaca o trabalho de Miguel Llobet, mas incluiu outros compositores que, seguindo a linha de Llobet, realizaram suas adaptações para violão de canções tradicionais catalãs. Alguns seguiram diretamente, outros indiretamente, como veremos adiante.

Decidimos incluir as canções tradicionais catalãs usadas na obra de outros compositores, pois acreditamos que a importante coleção das Canciones Catalanas de 
Miguel Llobet motivou outros violonistas a usarem temas tradicionais na realização de versões criativas para violão, procedimento iniciado por Llobet.

As canções descritas nesta pesquisa são:

\begin{tabular}{|c|c|c|}
\hline Compositores & Canção & Publicação \\
\hline \multirow[t]{17}{*}{ Miguel Llobet } & Plany & Chanterelle \\
\hline & La filla del marxant & Chanterelle \\
\hline & El Testament d'Amelia & Chanterelle \\
\hline & Cançó del Lladre & Chanterelle \\
\hline & El Rossinyol & Chanterelle \\
\hline & El fill del Rei & Chanterelle \\
\hline & L'hereu Riera & Chanterelle \\
\hline & El Mestre & Chanterelle \\
\hline & La Nit de Nadal & Chanterelle \\
\hline & La Filadora & Chanterelle \\
\hline & La Pastoreta & Chanterelle \\
\hline & La Preço de Lleida & Chanterelle \\
\hline & El noi de la Mare & Chanterelle \\
\hline & L'hostal de la peira & não publicada \\
\hline & L’Anunciació & não publicada \\
\hline & L’Emigrant & não publicada \\
\hline & La filla del marxant & não publicada \\
\hline \multirow[t]{3}{*}{ Emilio Pujol } & Els tres tambors & Ricordi Americana \\
\hline & La ploma de perdiu & Max Eschig \\
\hline & El cant dels ocells & Ricordi Americana \\
\hline \multirow[t]{4}{*}{ Andrés Segovia } & La ploma de perdiu & Bérben \\
\hline & Els Estudiantes de Tolosa & Bérben \\
\hline & El noi de la mare & Bérben \\
\hline & El Desembre Congelat & Bérben \\
\hline \multirow[t]{2}{*}{ Narciso Yepes } & Catarina d'Alió & Schott \\
\hline & Muntanyes del Carnigó & Schott \\
\hline \multirow[t]{2}{*}{ Federico Mompou } & El bon caçador & EMEC \\
\hline & El cant dels ocells & EMEC \\
\hline Francisco Casanovas & La gata i el belitre & Schott \\
\hline
\end{tabular}




\subsection{Miguel Llobet: Canciones Catalanas}

A coleção das Canciones Catalanas de Llobet representa a espinha dorsal, criando uma das mais monumentais obras para violão de sua época (informação verbal $^{62}$. As Canciones Catalanas são “o ponto de partida” de um novo futuro para o violão (GILARDINO, 1972 apud PHILLIPS, 2002b, p. 29).

No capítulo 3, falamos sobre a superioridade de Llobet em relação à Tárrega, evidentes em suas versões das Canciones Catalanas, principalmente no estilo de escrita usada da canção tradicional El Mestre, como veremos adiante. El Testamento d'Amelia também é citada como uma das mais originais adaptações realizadas por Llobet, por sua ousadia em usar uma melodia tão simples de maneira tão apurada (RIERA, 1974, p. 14).

Reconhecidas num processo criativo até então não exploradas no repertório para violão, procuraremos discutir aqui tal processo juntamente com a importância de se conhecer o texto das melodias que serviram de material para Llobet elaborar esta coleção de arranjos. Através do conhecimento dos textos e uma breve análise de técnicas de elaboração, procuraremos definir se Llobet conservou a idéia da letra, tonalidade, o tipo de harmonia que utilizou, bem como levantar hipóteses a respeito de sua intenção em atrair mais público para seus concertos de violão. Notamos em capítulos anteriores o quanto a sociedade catalã estava engajada em valorizar sua cultura autônoma, e isso se manifestou na difusão de um repertório de melodias populares que interessava a todas as classes sociais. Portanto, como veremos adiante, algumas melodias usadas por Llobet estavam inseridas neste contexto político-social.

As Canciones Catalanas adaptadas para violão por Miguel Llobet são:

\footnotetext{
${ }^{62}$ Entrevista concedida por Stefano Grondona em 22 de Abril de 2007, em Tatuí.
} 
Plany (1899); La filla del marxant (1899); Cançó del lladre (c.1900); El Testamento d’Amélia (1900); El Rossinyol (1900); El fill del Rei (1900); El Mestre (1910); L’hereu Riera (1900); La nit de natal (1918); La Filadora (c. 1918); La Presó de Lleida (c. 1920); El Noi de la Mare.

Todas elas estão publicadas pela Chanterelle Verlag $(1989)^{63}$.

Primeiramente foram editada as Diez Canciones Populares Catalanas pela Union Musical Española (UME) em 1964. La Pastoreta foi publicada pela UME em 1969 e El Noi de la Mare em 1975. La Presó de Lleida foi publicada somente em 1989 junto com as outras.

As canções que Miguel Llobet usou em suas versões estão entre as mais populares do folclore, segundo citações de diversos folcloristas catalães, como por exemplo, Joan Amades e Milá y Fontanal. De fato, encontramos diversas referências fonográficas destas melodias que também estão incluídas na coletânea das Les Cent Millors Cançons Populars (AMADES, 1948) ${ }^{64}$.

Seus arranjos destas canções folclóricas são de uma maestria incomparável, explorando a capacidade tímbrica do violão ao máximo, utilizando harmonias influenciadas pelos compositores impressionistas (DUDEQUE, 1994, p. 82). A escrita idiomática usada por Llobet não é inédita, mas seu trabalho oferece algo de novo. A maneira que ele explora o timbre é o seu diferencial: “Altro aspetto assolutamente nuovo della sua scrittura è la continua ricerca di timbre diversi.” (TRASI, 1994, p. 25 apud PHILLIPS, 2002b, p. 35)

Phillips destaca o elemento timbre principalmente nas canções El Mestre e Cançó del Lladre:

\footnotetext{
${ }^{63}$ PURCELL, R. Miguel Llobet Guitar Works. 16 Folksongs Settings. Chanterelle Verlag, 1989. Nueva Colección Llobet, vol. 2.

${ }^{64}$ Não foi possível encontrar nenhuma referência bibliográfica das canções publicadas no período das atividades de Llobet como compositor. Portanto, não sabemos quais as fontes que Llobet usou para as suas versões, mas a maioria delas conserva a mesma tonalidade usada na compilação de Amades.
} 
He describes the shifting of melody lines to inner voices or to other strings, wich on the guitar criates new timbral effects, the combined use of harmonics and natural sounding notes, the subtle altering of figurations of the accompaniment, and the changes in harmony as techniques as that Llobet uses. (PHILLIPS, 2002b, p. 35)

Seu estilo de escrita comentado no capítulo 3 mostra que Llobet se sentia atraído pelos diversos timbres da orquestra, ao explorar efeitos contrastantes em cada corda. El Testament d'Amelia é um exemplo disso, como veremos adiante.

A relevância desta coleção de obras nos motivou a questionar as afirmações de alguns especialistas a respeito da originalidade das Canciones Catalanas. Prat desconsidera as canções tradicionais por considerar relevante apenas as obras originais para o instrumento. Em seu Diccionario cita apenas a Romanza como única obra editada, desconsiderando assim os arranjos das Canciones Catalanas, por talvez não fazer idéia do que elas representavam em sua época. Prat critica inclusive o repertório do duo Llobet-Anido, por conter apenas arranjos e não conter obras originais (PRAT, 1986, p. 185).

Se os procedimentos técnicos e musicais utilizados por Llobet nesta coleção podem ser considerados inovadores, acreditamos que podemos considerá-las como obras autorais. Llobet se apropriou de temas populares, de autorias anônimas, originárias do povo, mas atribuiu sofisticação através de sua escrita e não usou apenas os elementos folclóricos, mas também de sua criatividade e da prática musical de sua época, a exemplo de Mompou e Villa-Lobos. Tais compositores tiveram sua autoria reconhecida, assim como outros compositores que usaram temas folclóricos de seu país - Ponce, Falla, Albéniz, Stravinsky, Grieg, Bartók, Dvorak, entre outros.

As Canciones Catalanas foram concebidas em épocas e momentos criativos diferentes, o que nos leva a crer que podem ser o resultado do contato com diversos compositores. Destacaremos as canções El Testamento d'Amelia, El Mestre, Cançó del 
Lladre, El noi de la Mare como bons exemplos de obras autorais, por seu nível de sofisticação e criatividade.

Como cometamos, música e poesia são indissociáveis. Quando combinadas, numa obra instrumental como os arranjos de Llobet, criam um novo tipo de sensibilidade no ouvinte e no executante. O acompanhamento musical de uma canção baseia-se nas palavras, e imprimem assim, o sentimento atrelado à melodia. Iremos analisar assim, como Llobet concebeu suas versões para violão, se conservou o sentido das letras das canções, que procuraremos traduzir. As informações contidas na pesquisa a respeito da origem destas canções irão recuperar os textos originais das canções, além de estabelecer elementos importantes para uma nova interpretação desta representativa obra. 


\subsubsection{Plany ${ }^{65}$}

Plany é um gênero da poesia trovadoresca usado para lamentações fúnebres. Pode ser cantada para lamentar a morte de um amigo ou lamentar a destruição de uma cidade pela guerra. Nesta versão, o tema é a destruição da Catalunha como nação, e a tristeza do povo catalão, subjugado por domínios estrangeiros é descrita em seu texto transcrito em parte abaixo, junto com a tradução para o português. As lutas por sua autonomia política e pela conquista de sua língua ficam evidentes mais uma vez.

Catalunya, en altre temps, Ella sola es governava i en feien les seves lleis en sa llengua i no cap altra. Plora, plora, Catalunya, que já no et governes ara!

Des de ja fa massa temps estrangers són que la manen, i en llengua estranya es fa lleis que a la nació són contraries. Plora, plora, Catalunya, ja que et doblegues encara.

\author{
Catalunha, em outros tempos \\ Sozinha governava-se \\ e fazia suas próprias leis \\ em sua língua e não em outra. \\ Chora, chora Catalunha, \\ que já não te governas agora! \\ Desde há muito tempo \\ estrangeiros são os que mandam \\ e em língua estranha se fazem as leis \\ que são contrárias à nação. \\ Chora, chora, Catalunha, \\ ainda te ajoelhas.
}

\footnotetext{
${ }^{65}$ Não foi possível localizar e transcrever a parte monofônica desta melodia. Consultamos o violonista Stefano Grondona, que declarou também não encontrar nenhuma informação sobre Plany. Parte da letra desta canção foi encontrada na internet, única fonte disponível. (RC, Relats em Català . Disponível em: http://www.relatsencatala.com/rec/Controller?rp_action=view_relat\&rp_relat_id=367934. Acesso em: 6 Janeiro 2008).
} 


\section{PLANY}

(1899)
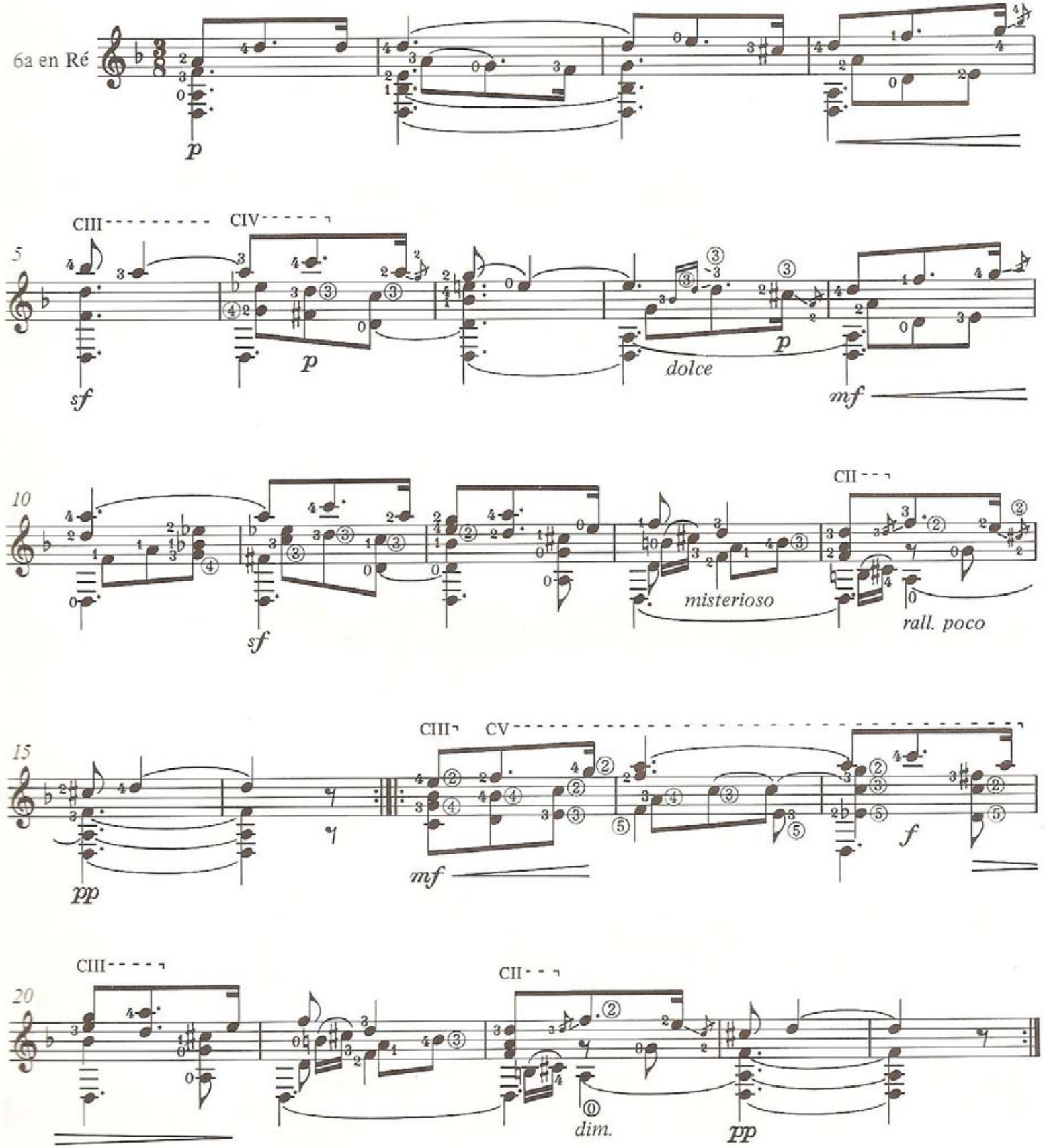


\subsubsection{La filla del marxant}

Llobet escreveu duas versões para esta canção, ambas realizadas em 1899 ano pleno de atividades para Llobet, com numerosas atuações como solista e diretor musical. A versão para violão solo está incluída no Miguel Llobet Guitar Works (PURCELL, 1989, vol. 2, partitura), mas existe uma versão para grupo de instrumentos de cordas dedilhadas, feita especialmente para o Lira Orfeu, sociedade musical que Llobet ajudou a fundar um ano antes. Esta versão, ainda não editada, encontra-se no Cd Homenaje, uma gravação realizada por Stefano Grondona e violonistas convidados ${ }^{66}$.

Domingo Prat incluía esta canção em seus programas de concerto (MANGADO, 1998, p. 114).

A adaptação realizada por Llobet usou a mesma tonalidade que aparece no cancioneiro popular catalão, bem como em arranjos-coral - Mi Maior - o que mostra sua popularidade dentro da tradição musical catalã, sofrendo poucas variações, tanto melódicas como literárias.

O tratamento timbrístico que comentamos no capítulo 3 evidencia-se nesta adaptação, onde Llobet combina harmônicos e notas naturais atribuindo o sentido de orquestração que tanto utilizou na coleção das Canciones Catalanas.

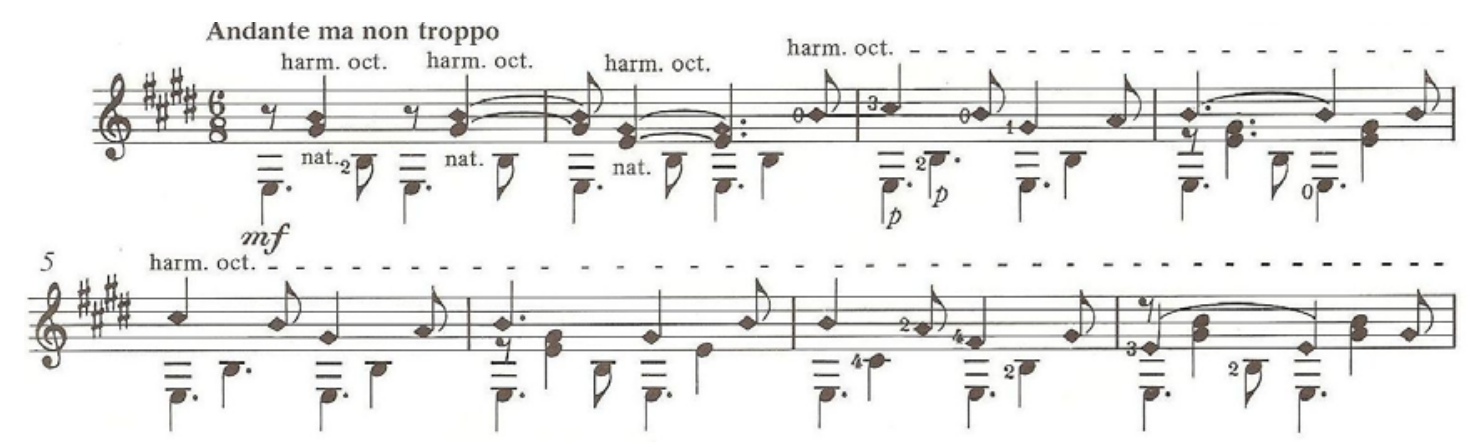

\footnotetext{
${ }^{66}$ STEFANO GRONDONA. HOMENAJE Manuel de Falla, Miguel Llobet and their world. Stefano Grondona, Maria José Montiel, Laura Mondiello, Nova Lira Orfeo. Stradivarius, 2006a (Cd).
} 
Quanto ao texto, possui uma carga bastante dramática. Podemos afirmar que Llobet, ao usar o recurso do baixo ostinato, usado normalmente para sustentar um sentimento, ajudou a criar a tensão necessária para esta melodia de textura linear. O andamento sugerido por Llobet - Andante ma non troppo - apóia o sentido da letra, bem como o andamento sugerido por Amades - semínima pontuada $=52$. A tonalidade usada na versão de Llobet é a mesma que encontramos na transcrição do cancioneiro tradicional (AMADES, 1951, p. 358). Outra referência sugere o andamento semínima pontuada $=56$ em 6/8 (PUJOL, 1926, vol. 2, p. 127).

Para uma maior compreensão do sentido dramático desta canção, recomendamos a audição do registro sonoro da soprano Victoria de Los Angeles ${ }^{67}$.

La filla del marxant
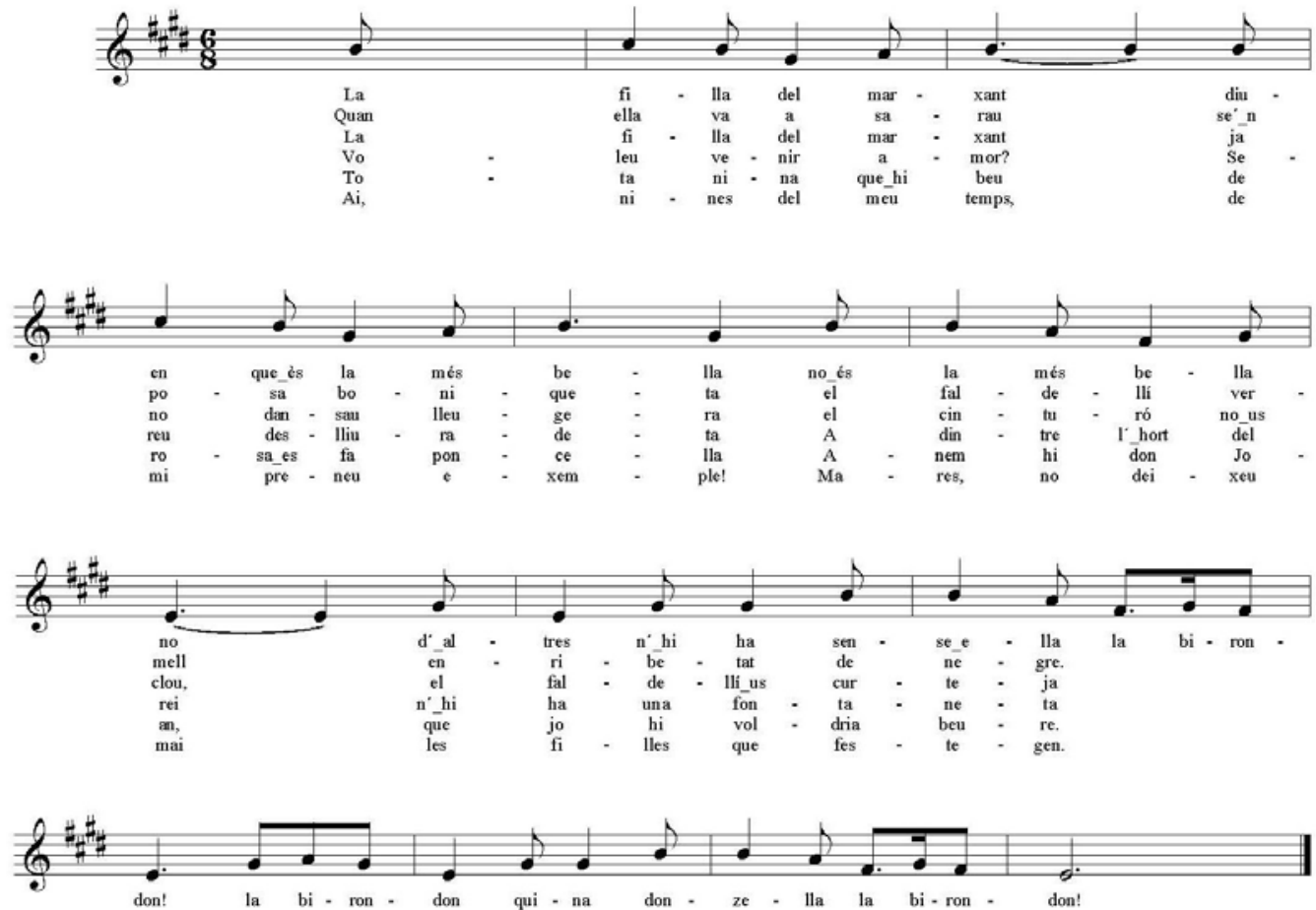

Copyright 1951 by Amades

\footnotetext{
${ }^{67}$ Cançons Tradicionals Catalanes. Collins Classic, 1992 (Cd).
} 
Existem fortes sentimentos por trás do sentido que esta canção adquiriu através das gerações. A letra se refere ao papel das mães em educar bem suas filhas. Era muito cantada pelas mães que tinham a intenção de proteger suas filhas de coisas ruins.

O musicólogo Amades (AMADES, 1951, p. 360), em sua compilação de melodias populares catalãs, constatou que esta canção era cantada, em sua maioria, por mulheres. Quando acabavam, quase sempre, colocavam a culpa de seus problemas em suas mães, e é desta aflição que a letra da canção fala. As mães, por sua vez, se defendiam dizendo que não eram responsáveis pelo que acontecia com suas filhas, sentindo tristeza pela culpa que lhes eram imputadas. As mulheres que a cantam sentem cumplicidade à protagonista da canção.

A letra original é bastante extensa. Narra o enforcamento da mulher do marxant, por ter arruinado a vida de sua filha. A tradição que permeia esta canção faz referência à epidemia da peste, e o período de fome que assolou a Catalunha ${ }^{68}$, indicando que pode ter tido sua origem no século XVII.

Embora o povo catalão tenha uma preferência por temas trágicos, existem mulheres que não conseguem cantar esta canção sem lacrimejar e associar o seu sentimento à dor tanto da mãe como da filha.

Encontramos uma referência, além de Amades, no arranjo para coro de Jaime Pahissa, realizado em 1941, com texto em espanhol (PAHISSA, 194-, p. 2, partitura) e no arranjo de Ribó (s.d., partitura) ${ }^{69}$.

Incluímos neste capítulo parte da extensa letra da canção de dança La Filla del Marxant (A Filha do Comerciante) junto com a tradução livre para o português:

\footnotetext{
${ }^{68}$ Tal época de desolação durou um período de 20 anos dentro do reinado de Felipe IV, de 1621 a 1625.

${ }^{69}$ Cf. ANEXO A, p. 247 e 248.
} 
La filla del marxant

diuen que és la més bella

no és la més bella no

d'altres n’hi há sense ella.

La birondón!

La birondón, quina donzella!

La birondón!

Quan ella va a sarau

se'n posa boniqueta

el faldellí vermell

enribetat de negre.

La filla del marxant

já no dansau lleugera

el cinturó no us clou,

el faldellí us curteja.

Voleu venir amor?

sereu deslliuradeta

A dintre l'hort del rei

n’hi ha una fontaneta.

Tota nina que hi beu de rosa es fa poncella anem hi Don Joan que jo hi voldria beure.

Ai, nines del meu temps de mi preneu exemple! Mares, no deixeu mai les filles festegen.

(AMADES, 1951, p. 359)
A filha do comerciante dizem que é a mais bela não é mais bela não as outras são bonitas como ela.

La birondón!

La birondón, que donzela!

La birondón!

Quando ela vai ao sarau se enfeita com o saiote vermelho de ornamentos negros.

A filha do comerciante já não dança ligeira o cinto não fecha, e a saia se encurta.

Queres vir amor? serena sem medo dentro da horta do rei tem um pequenina fonte.

Toda menina que dela bebe pode ser desabrochada Vamos Don Juan que eu queria beber dela.

Ai, mocinhas da minha idade vejam meu exemplo! Mães, não deixem nunca suas filhas namorarem. 


\section{LA FILLA DEL MARXANT}

(1899)

MIGUEL LLOBET

Andante ma non troppo

(g)
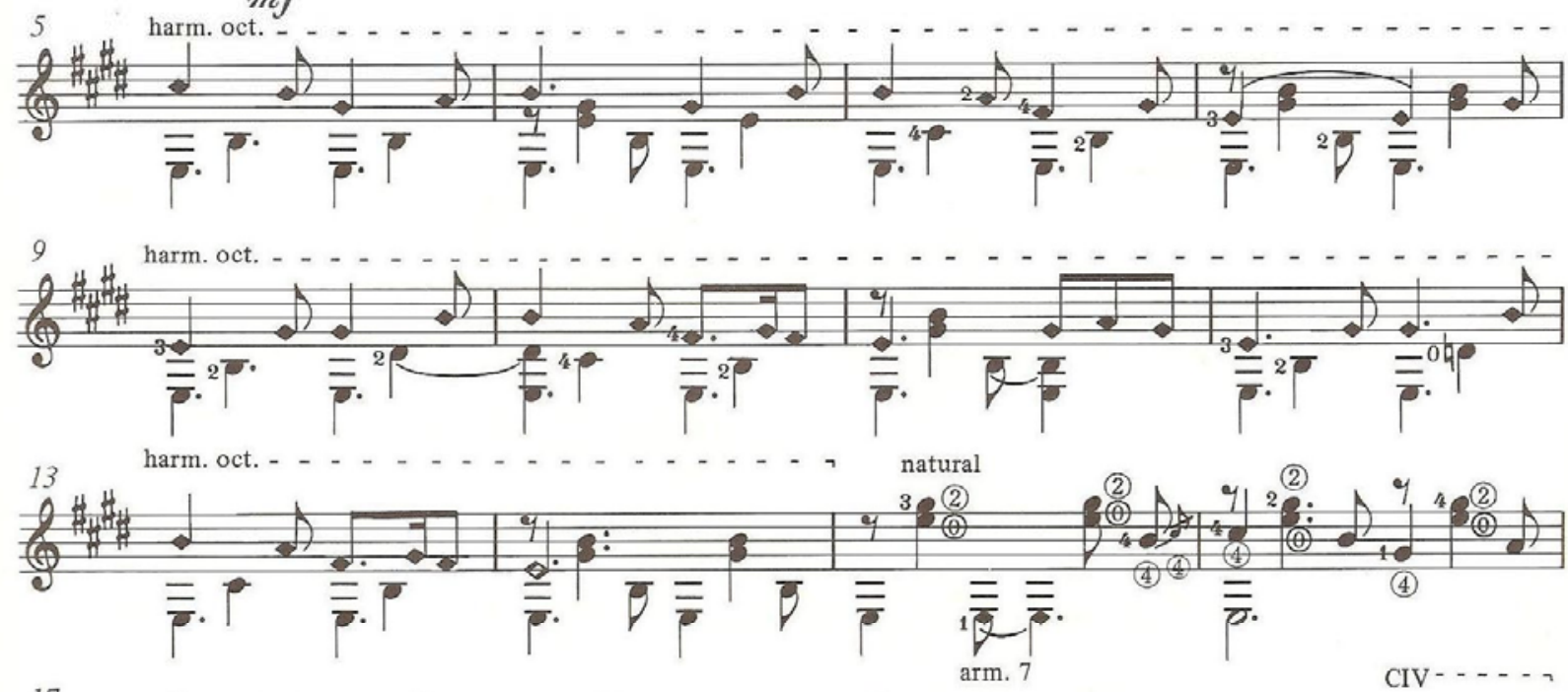

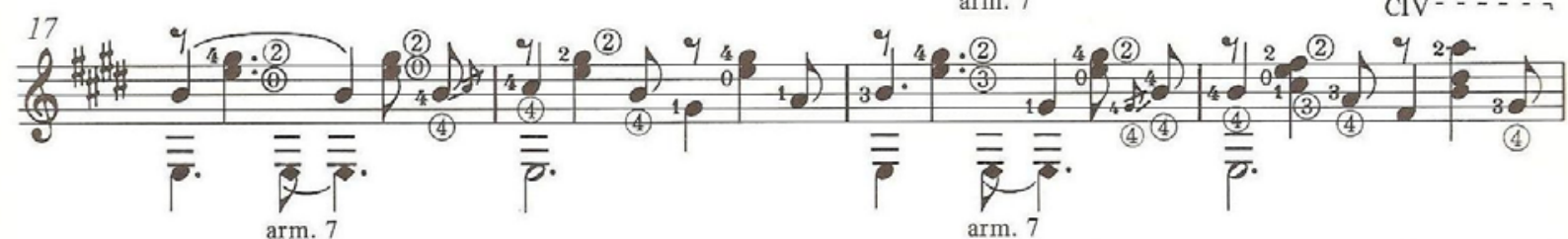
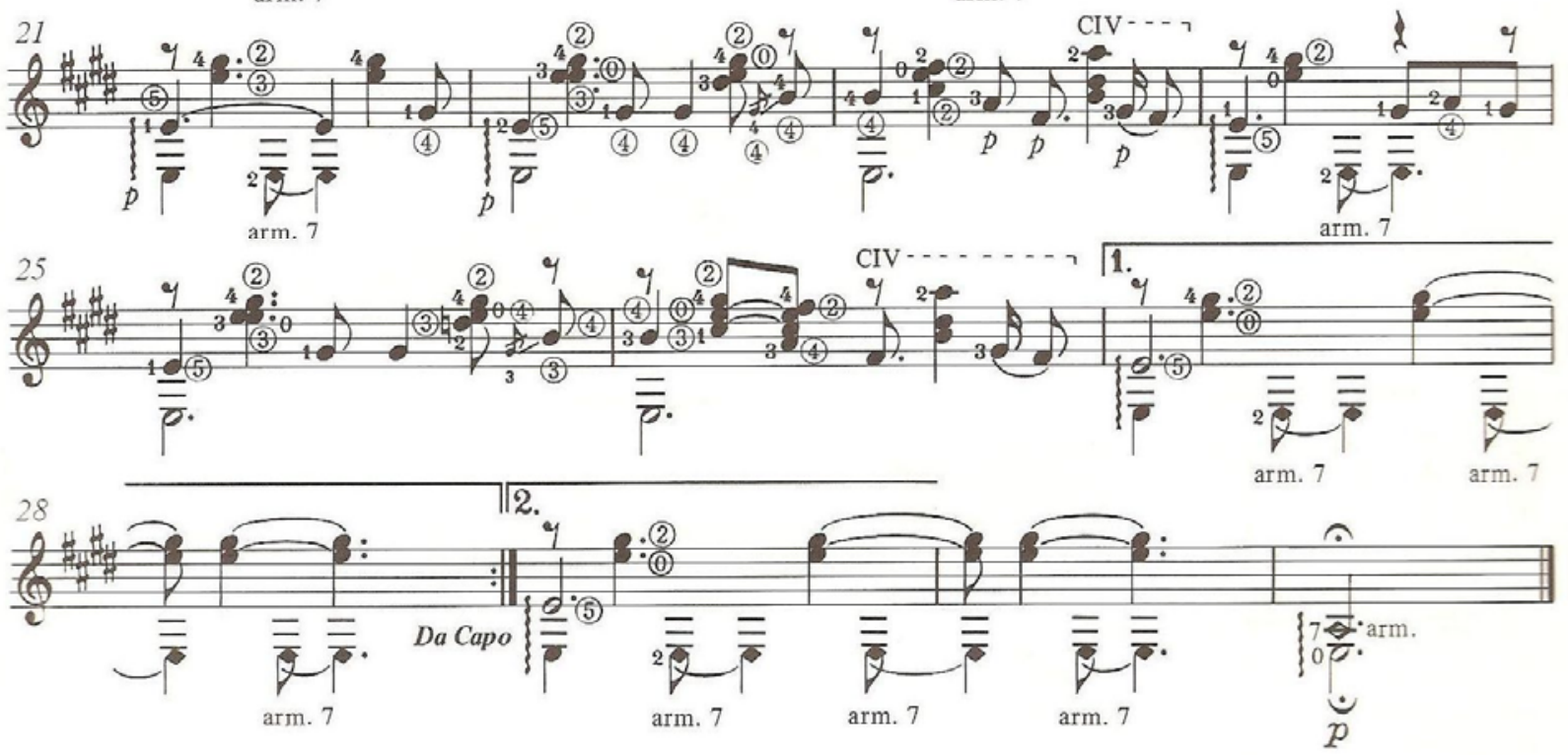


\subsubsection{El Testament d'Amelia}

Este tema está entre os mais tocados pelos violonistas. Explora de forma ampla a tessitura do instrumento, mostrando suas possibilidades tímbricas à maneira de Tárrega.

Uma das técnicas herdadas de Tárrega é a melodia apresentada em naipes diferentes - o tema principal surge ora no soprano, ora no baixo. Para exemplificar, temos um trecho de sua mazurka Marieta:
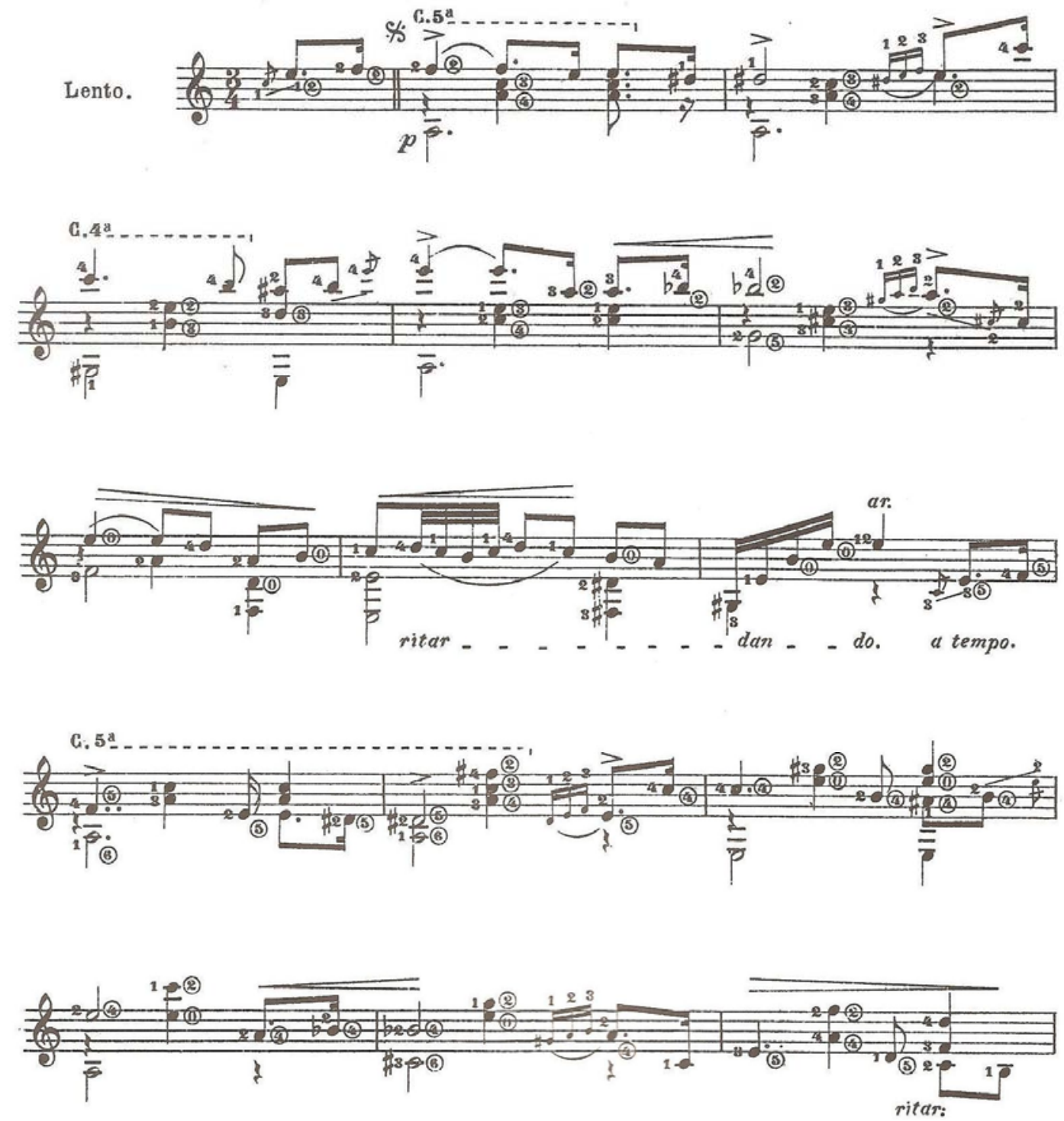

Trecho de Marieta de Francisco Tárrega. 
Nessa adaptação Llobet segue os passos de Tárrega ao explorar a tessitura do violão. No entanto, Llobet vai mais além na exploração de timbres, o que coloca esta versão dentro do status de obra autoral.

Llobet utiliza este procedimento à maneira de Tárrega, mas não fica restrito a ela, explorando timbres de maneira mais sofisticada, embora harmonicamente seja uma obra simples.

No capítulo 3, discutimos as inovações que Llobet realizou no campo timbrístico do violão ao explorar diferentes timbres em cada corda para dar um sentido de orquestração às suas peças. El Testament d'Amélia é um bom exemplo de como Llobet explorou isso, pois combina harmônicos naturais e artificiais com notas naturais que ocorrem primeiramente entre os compassos 17 a 24:

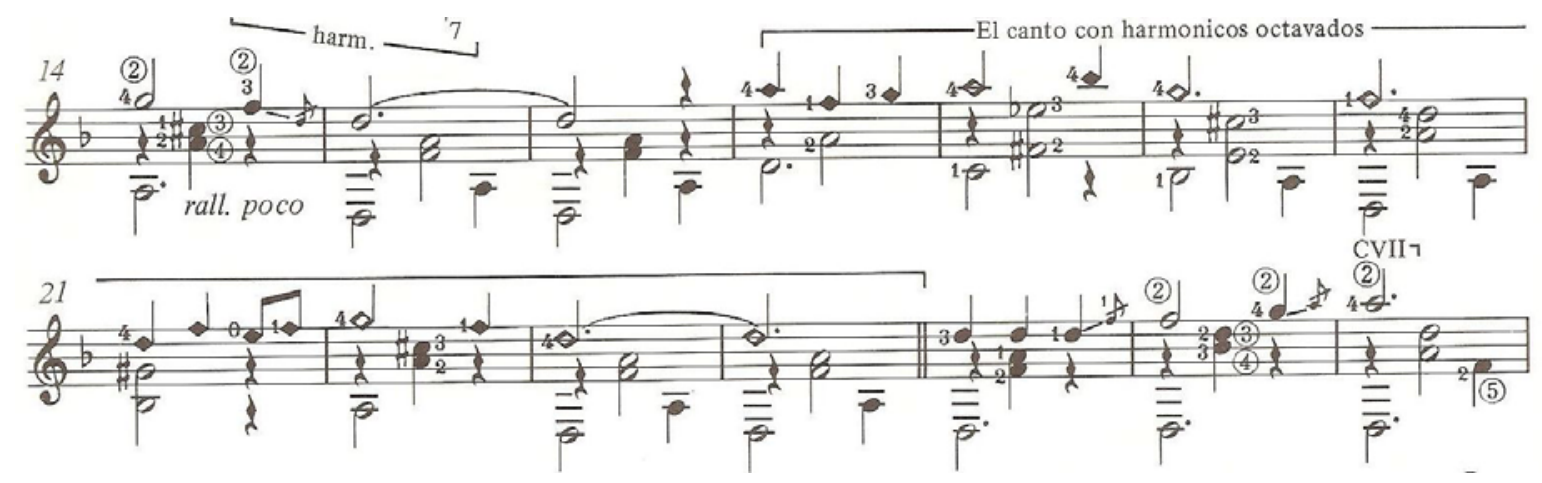

Por aplicar tais procedimentos inovadores no refrão e descrever uma melodia folclórica de forma tão expressiva, acreditamos que El Testament d'Amelia deve ter o status de obra autoral. Embora seja uma das mais tocadas, o que os violonistas não sabem é o clima de tragédia que permeia a narrativa desta canção, uma das mais tristes da coleção. 
Para uma compreensão de seu sentido dramático, recomendamos a audição do registro sonoro da soprano Visctoria de Los Angeles ${ }^{70}$ do coral Orfeo Catalá ${ }^{11}$ e do grupo catalão La Capella Reial de Catalunya ${ }^{72}$.

Esta canção também figura entre as mais conhecidas e difundidas por todo o domínio da língua catalã - Valencia, Maiorca e Catalunha. Sua origem, portanto, é sueca, onde seu sentido é um pouco diferente: as donzelas cantam seu infortúnio de serem abandonadas por seus amantes por causa da guerra. Mas na Catalunha, seu sentido é mais cruel: a amargura de uma filha contra a mãe que rouba seu marido.

Sua melodia de textura linear é muito triste e possui um duro ar de melancolia descrito na tonalidade de ré menor. O refrão exala um profundo lamento quando diz “ $A i$, que el meu cor sém nua” (Ai, meu coração está se despedaçando), enfatizando a dor da protagonista.

O andamento proposto por Llobet é Andante expressivo. Portanto, cabe ao violonista usar de especial expressividade para descrever tamanha dor. Amades sugere o andamento semínima = 73 (AMADES, 1951, p. 594).

Referências geográficas concretas “Set castells tinc a França” (Tenho sete castelos na França) e nomes de pessoas ligadas à nobreza “Don Carles, germà meu” (Don Carles, meu irmão) dão certo realismo à canção.

Muitas versões começam sem citar o nome da protagonista, Amélia, e sim com “malalta”. Acredita-se que o adjetivo “malalta”, neste caso, origina-se de Mahalta, nome feminino muito comum durante a Idade Média, que resultou nas variações catalãs de

\footnotetext{
${ }^{70}$ CANÇONS TRADICIONALS CATALANES. Victoria de Los Angeles with Geoffrey Parsons. Collins Classic, 1992 (Cd).

${ }^{71}$ ORFEO CATALÁ. Chansons Traditionnelles de Catalogne. Harmonia Mundi, 1992 (Cd).

${ }^{72}$ LA CAPELLA REIAL DE CATALUNYA. Cançons de la Catalunya mil-lenària. Planys e Llegendes. Astrée, 1977 (Cd).
} 
Mafalda, Malta i Matha, nome que possuíam algumas princesas da dinastia catalã, como a condessa Mafalda de Calábria, esposa do conde Ramon Berenger. Também se chamava Mafalda a terceira filha de Ramon Berenger III e de Dolça de Provença, que ficou conhecida por ser uma mãe malvada.

A história tem um elevado conceito desta dama, mas a lenda não tem tanta estima por ela. É possível, inclusive, que tal maldade lendária tenha originado esta canção, pois alguns supõem que Amélia podia ser filha de um rei catalão (e não de um rei francês, como diz a letra da canção).

Embora seja muito conhecida não oferece muitas variações quanto ao seu texto. No entanto, é cantada com uma grande variedade de melodias, geralmente cheias de melancolia (PUJOL, 1926, vol. 3, p. 63, 174 e 354).

Uma marca registrada desta melodia é despertar um senso de justiça a favor da protagonista com frases de compaixão pela filha que teve o marido roubado pela sua própria mãe. A mãe, como não poderia deixar de ser, é maldita por seu ato cruel (AMADES, 1951, p.595).

Encontramos uma referência desta tradicional canção no arranjo para coral (MARRACO, 19--, p. 33, partitura) ${ }^{73}$.

Uma outra fonte de pesquisa mostra que é possível reconhecer em alguns fragmentos melódicos desta canção, elementos do canto gregoriano - no $1^{\text {o }}$. Modo (Protus auténtic). - tônica: ré, dominante: lá - o que confirma o que comentamos no capítulo 1 sobre a influência do canto litúrgico na canção tradicional catalã (PUJOL, 1926, vol. 2, p. 368):

\footnotetext{
${ }^{73}$ Cf. ANEXO A, p. 249.
} 
melodia popular

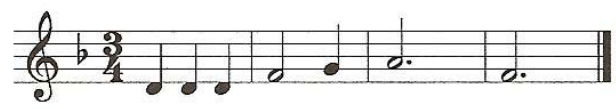

melodia popular

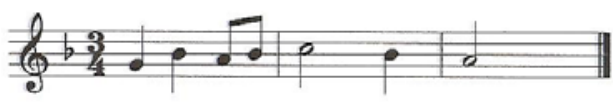

melodia popular

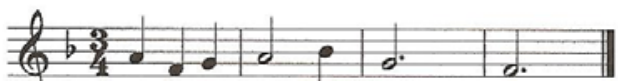

melodia popular

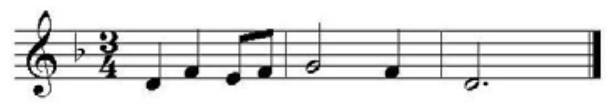

Alleluia de Commune Doctorum

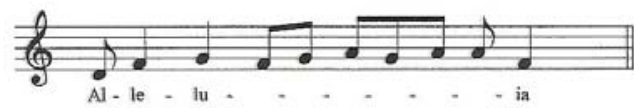

Alleluia de la Dominica IV després de Pasqua

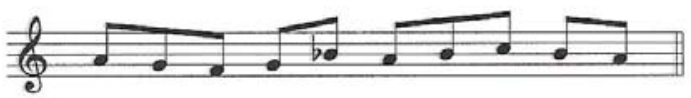

Alleluia de Commune unius Martyris non Pontificis

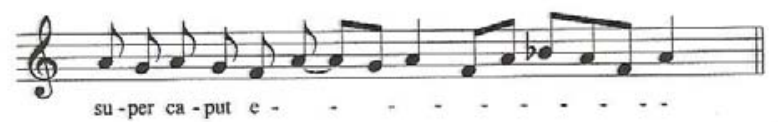

Antífona del Magnificat de Commune Confessoris Pontificis

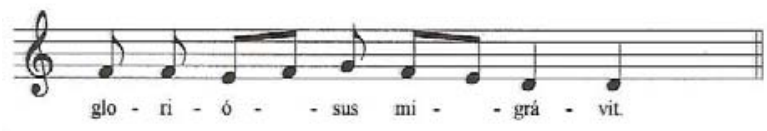




\section{El Testament d'Amèlia}
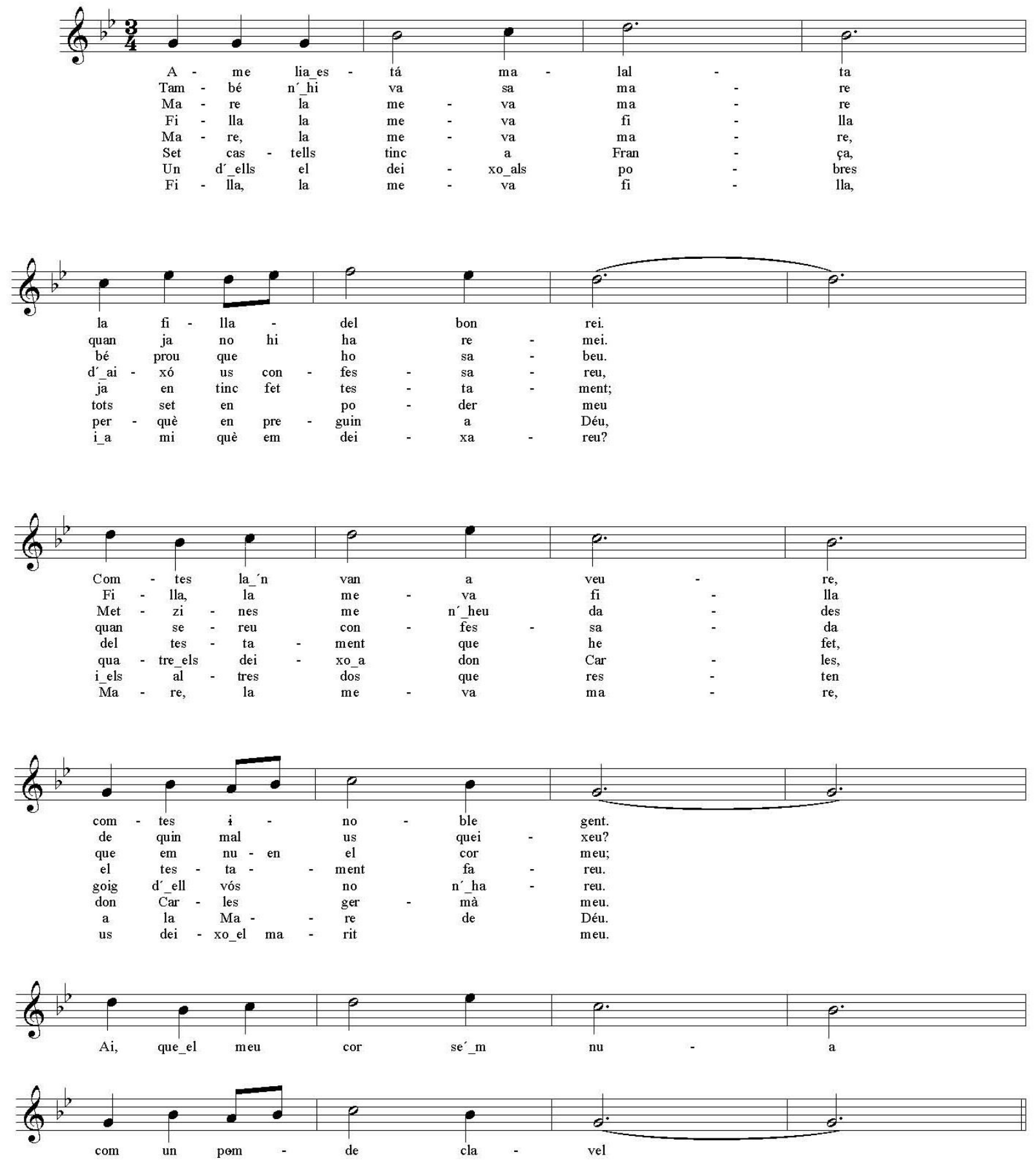

Copyright 1951 by Amades 
Para uma melhor compreensão do contexto em que se insere, segue a tradução

livre da letra da melodia El Testament d'Amelia (O Testamento de Amélia). Amélia, que

morreu de tristeza.

Amelia està malalta, la filla del bon rei, comtes la'n van a veure, comtes i noble gent.

Ai, que el meu cor sém nua com um pom de clavells.

També n’hi va sa mare quan já no hi há remei.

- Filla, la meva filla, de quin mal us queixeu?

- Mare, la meva mare, bé prou que ho sabeu. Metzines me n'heu dades que em nuen el cor meu;

- Filla, la meva filla, d'això us confessareu, quan sereu confessada el testament fareu.

- Mare, la meva mare ja em tinc fet testament; del testament que he fet, goig d'ell vós no n’hareu.

Set castells tinc a França tots set en poder meu, quatre els deixo a don Carles, don Carles, germà meu.

Um d'ells el deixo als pobres perquè en preguin a Déu, $i$ els altres dos que resten a la mare de Déu.

Totes les meves joies, les d'or i les d'argent, quan jo en sigui morta, als argenters dureu.
Amélia está doente, a filha do bom rei, condes vão vê-la, condes e a nobreza.

Ai, meu coração está se despedaçando como um ramo de cravos.

Sua mãe também vai quando já não há mais remédio.

- Filha, minha filha, de que mal se queixa?

- Mãe, minha mãe, a senhora bem sabe. Pois tem me dado remédios que acabam com meu coração;

- Filha, minha filha, disto tereis de confessar-vos, depois de confessar deve fazer o testamento.

- Mãe, minha mãe já fiz o testamento; o testamento que fiz, não lhe trará nenhum benefício.

Sete castelos tenho na França todos em meu poder, quatro deixo a don Carles, don Carles, meu irmão.

Um deles deixo aos pobres para que rezem por mim a Deus, e os outros dois restantes à mãe de Deus.

Todas as minhas jóias, as de ouro e as de prata, quando eu já estiver morta, aos ourives levareis. 
De les joies petites

a l'encant les vendreu, dels diners que us en donin sant oli en comprareu.

Per fer cremar les llànties Nit i dia fareu, que la gent quan les vegin per mi preguin a Déu.

- Filla, la meva filla, i a mi què em deixareu?

- Mare, la meva mare, us deixo el marit meu.

Perquè el tingueu en cambra bem tancat com já feu, perquè tendres carícies a la cara li feu. (AMADES, 1951, p.594)
As jóias pequenas a senhora as venderá, do dinheiro que vos derem óleo santo comprará.

Para queimar as lamparinas, noite e dia, que as pessoas quando as virem orem por mim a Deus.

- Filha, minha filha e para mim, o que deixará?

- Mãe, minha mãe, à senhora meu marido lhe deixo.

Para que o tenha no quarto bem trancado como já fez, porque suave carícias em sua face lhe fez. 


\section{EL TESTAMENT D'AMELIA (1900)}

MIGUEL LLOBET

Andante expressivo

20 Ré

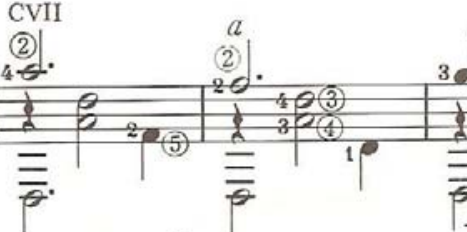

(6)

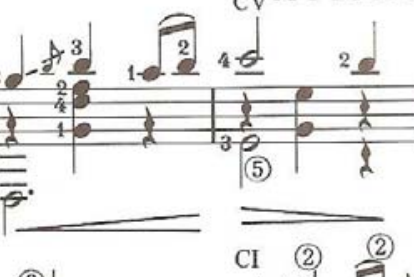

rall. poco $\frac{\bar{\beta}}{\rho}$

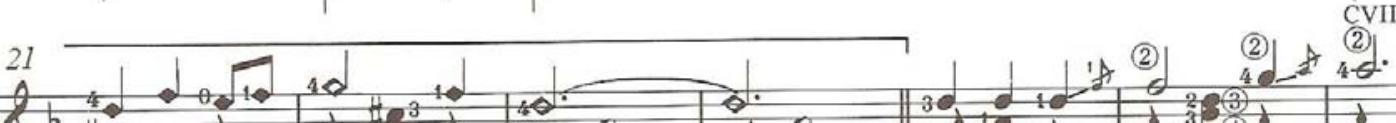

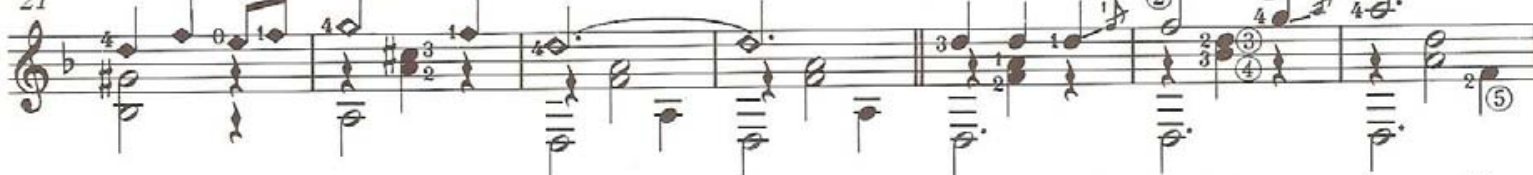

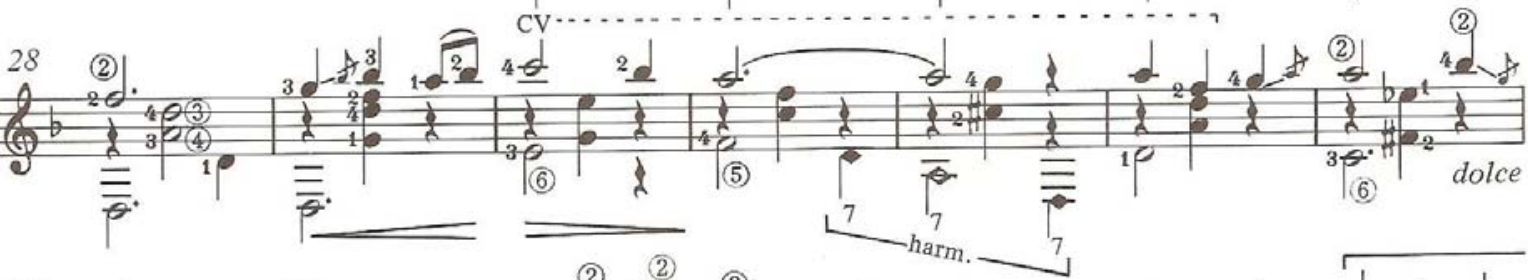

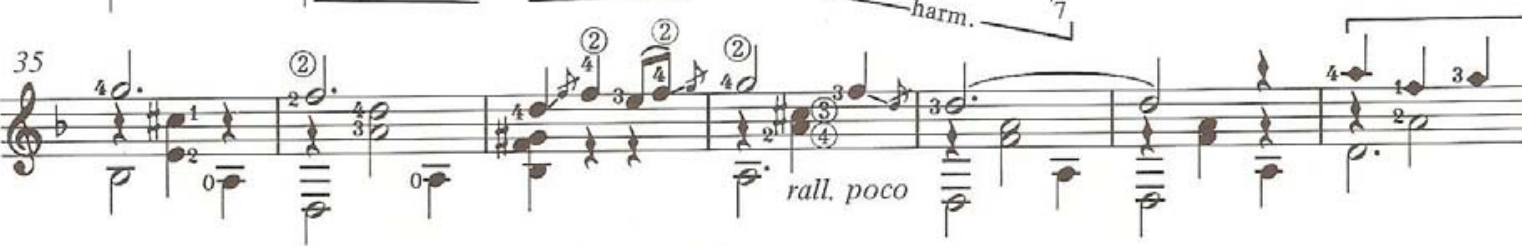

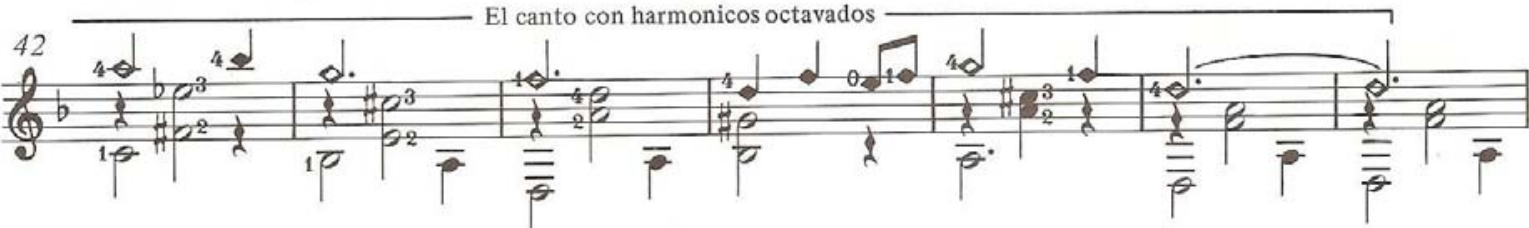

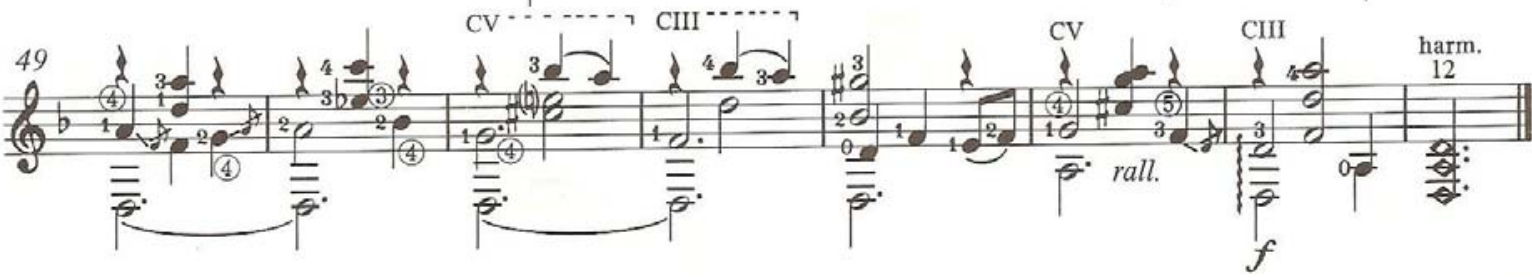




\subsubsection{Cançó del Lladre}

Cançó del Lladre é outra das canções mais tocadas nos programas de violão e gravadas por diversos violonistas importantes. O próprio Llobet a incluía em seus programas de concerto a partir de 1927. Grondona discute a data de sua concepção. Aparentemente pertence ao período em que Llobet produziu poucas obras, devido às suas intensas atividades como concertista:

De hecho, desde el período comprendido entre el año 1922 [...] y el año 1935 [...] (con la excepción de los doce compasses del Preludio em mi mayor y de la Cançó del Lladre, cujas fechas están todavia en discusión), no nos han llegado actualmente otras composiciones del Maestro. Lástima! (GRONDONA, 2006b, encarte de Cd)

Llobet combina harmônicos naturais e artificiais na estrutura de textura contrapontística nos compassos 24-27:
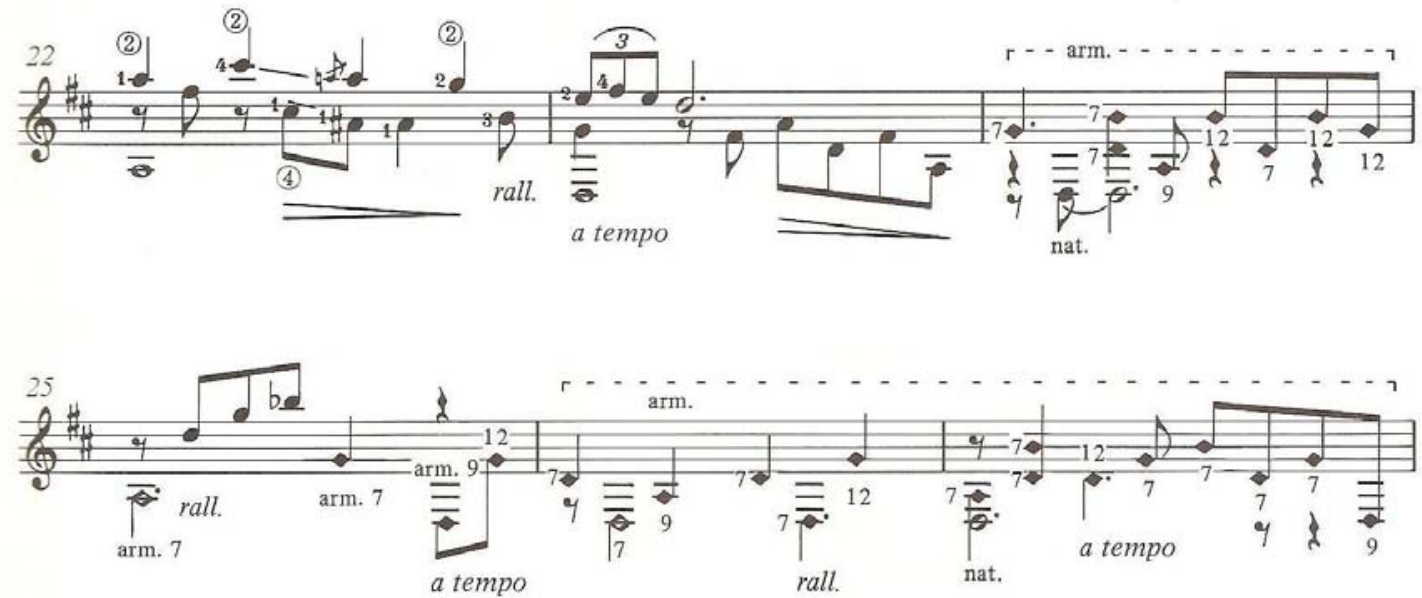

Desta maneira, mostra seu domínio técnico e seu amplo conhecimento do instrumento, como comentamos anteriormente. Notamos que nesta versão Llobet usa a mesma tonalidade encontrada no cancioneiro tradicional catalão. 
Para uma compreensão de seu texto e significado, recomendamos a audição do grupo catalão La Capella Reial de Catalunya (1977, Cd) e da soprano Victoria de Los Angeles ${ }^{74}$.

Como comentamos no capítulo 1, existe uma relação entre as Cantigas de Santa Maria de Alfonso X (figura 2) e as Canciones Catalanas. Alguns musicólogos ${ }^{75}$ afirmam reconhecer esta melodia na Cantiga no. 419 - Des quando Deus sa madre (AMADES, 1951, p. 49).

\section{Cantigas da Santa Maria}

(no. 419)

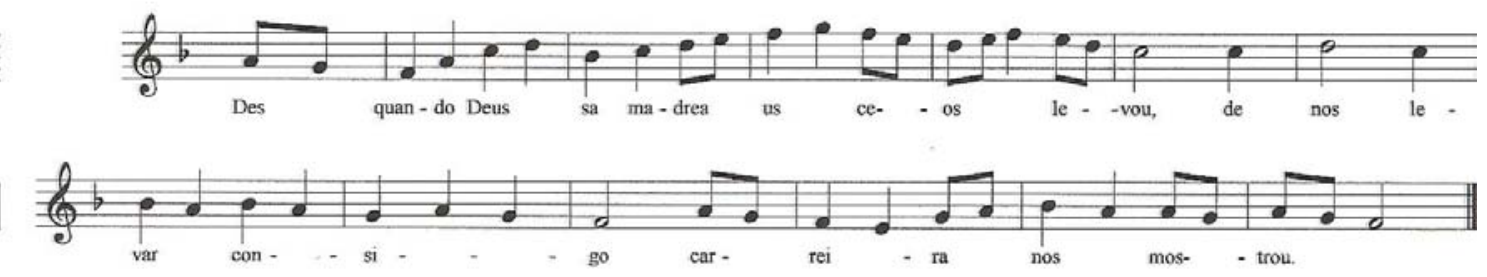

Segundo a lenda popular, muitos ladrões famosos ao se encontrarem presos e a caminho da forca para pagar sua culpa, sentiam-se arrependidos de sua conduta e improvisavam uma canção que descrevia sua vida, uma espécie de autobiografia musical. A lenda também conta que o cantarolar das melodias era um costume ou entretenimento dos presos. Algumas canções que se tornaram populares tiveram sua origem dentro das celas.

As canções de ladrão baseadas em fatos históricos e incrementadas pela fantasia popular são muito freqüentes no cancioneiro catalão.

\footnotetext{
${ }^{74}$ LA CAPELLA REIAL DE CATALUNYA. Cançons de la Catalunya mil-lenària. Planys e Llegendes. Astrée, 1977. CANÇONS TRADICIONALS CATALANES. Victoria de Los Angeles with Geoffrey Parsons. Collins Classic, 1992 (Cds).

${ }^{75}$ Uma transcrição do musicólogo Higino Anglés indica a mesma relação entre as duas melodias. Apesar do ritmo diferente, podemos constatar a semelhança esquemática entre ambas (PUJOL, 1926, vol.1, p. 294).
} 
Os fatos históricos indicam que sua origem pode remontar ao feudalismo. Durante o século XV ocorrem lutas entre bandos em conseqüência das guerras entre as facções dos Nyerros e Cadells ${ }^{76}$. Como comentamos anteriormente, o povo catalão é conhecido por sua personalidade guerreira. As lutas políticas fomentadas por grupos são recorrentes nesta canção: Algunos han remido por cosa política fomentar sus parcialidades por hallarse poderosos en los acontecimientos civilles: con este motivo han conservado siempre entre si los dos famosos bandos de Narros (sic) e Cadells (...) (MELO, 1904, p. 71).

As lendas contêm alguns personagens míticos. Na região de Olot, o bandido conhecido por Tiro cantava uma melodia triste que era ouvida por toda a comunidade enquanto aguardava o dia de seu julgamento. Com o seu canto ele esperava comover o povo, que se convenceu e que ele não merecia ser enforcado. Assim, graças à melodia, ele é perdoado de seu crime.

No século XVII, o mítico bandido Joan de Serralonga é assunto de versos e canções populares (LA CAPELLA REIAL DE CATALUNYA, 1977, encarte de Cd).

Cançó del Lladre pode datar do século XVII e representa uma apologia aos feitos dos ladrões de época, convertidos em lenda popular.

\footnotetext{
${ }^{76}$ Nyerros eram os membros de um dos bandos em que estava dividida a nobreza catalã no final do século XVI. O bando rival eram os cadells, com quem travavam luta frequentemente. Os nyerros defendiam os direitos dos senhores feudais, enquanto que os cadells defendiam os cidadãos. Amades compilou os versos de uma canção popular dedicada a bandos, que recorda as lutas comandadas pelo senhor de Nyer e Cadell - ambos senhores de castelos de Cerdanya: "Els cadells deixo hereus/ que sabran de governar,/ de moia i de l'Estany,/ de tona i de Motmany,/ de Vic e Sant Julià/ Santa Eugènia i de Seva,/ Centelles i Tradell.” (AMADES, 1951, p. 631)
} 
Afreto don patana -..eque out ca x pran.-

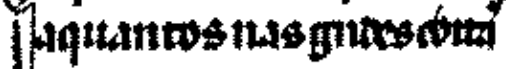
A chanamt chamatan

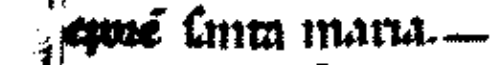
os prowes ha an.antraus pr anogapa cpos ctmpalt ftr. -.. ostexas quem.

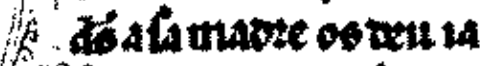
fllepano aftes wos....

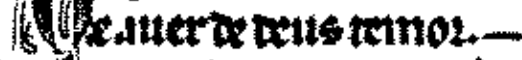
Aquetoun a grotola. peo fempe an amot ipraquetto fot cla. mabse a nio fonnos ihit tip auts i one.ตque pi fempre ugnata Os far wies qute tuts do ath intose os att ta Ontw praquefes fere.ries lle attemos alp. Illanes far wogarlle. - que nos fapa urobar:a fat fillo os pratos. fquenos guatde atme xpguta qino fat tegne itumos wel ala.-... os fere wes que ou.

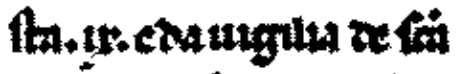
Ganábagofo omodap. The atre munto t forlens D. 10 geo.

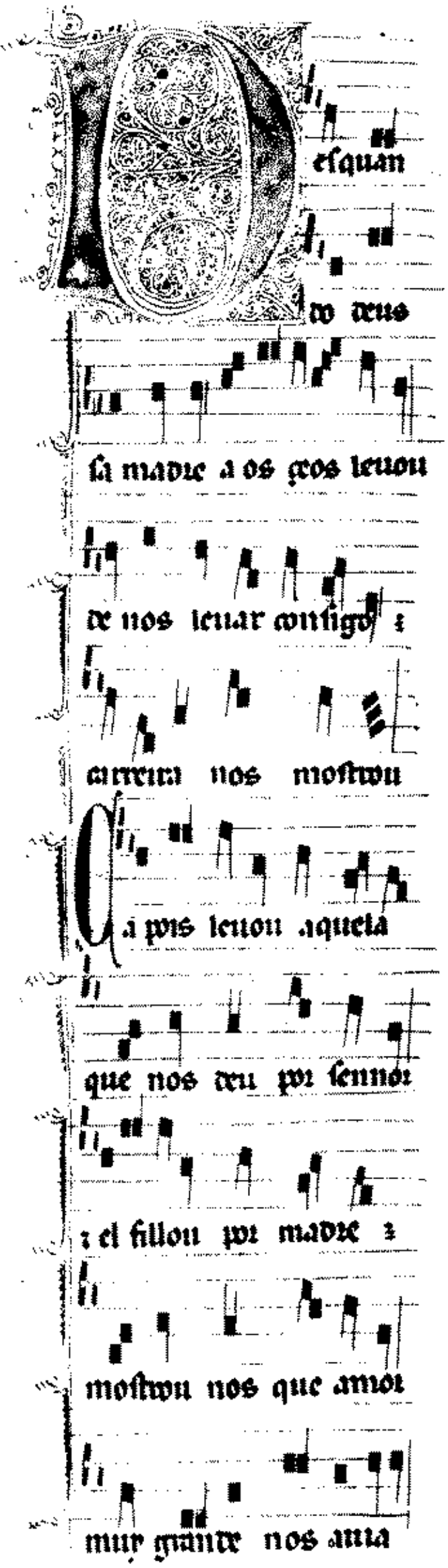

Figura 2. Fac-símile da Cantiga de Santa Maria no. 419 de Alfonso X. 


\section{Cançó del Lladre}

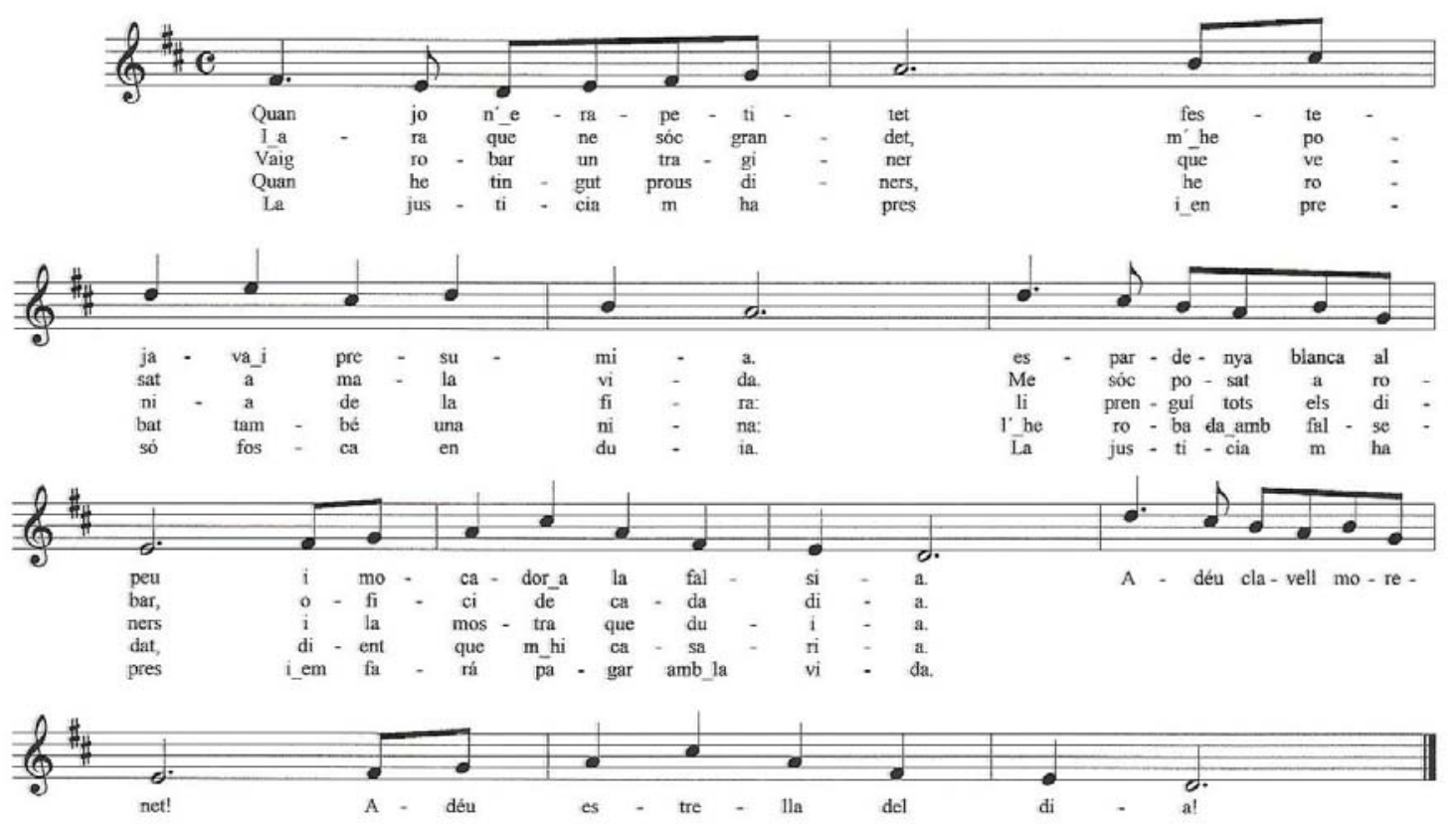

Copyright 1951 by Amades

Para uma melhor compreensão do significado desta canção tradicional, segue

a letra e sua tradução livre para o português:

Quam jo n'era petitet festejaba i presumia, espeardenyablanca al peu i mocador a la falsia. Adèu, clavell morenet! Adèu, estrella del dia!

I ara, que ne sóc grander, m'he posat a mala vida, Me só posat a robar, ofici de cada dia.

Vaig robar un traginer que venia de la fira, li prenguí tots els diners i la mostra que duia.
Quando eu era jovem cortejava e presumia, spardenya ${ }^{77}$ branca no pé e lencinho na cintura. Adeus, cravo escurinho Adeus, estrela do dia.

Agora que eu cresci, ingressei na má vida, comecei a roubar, ofício de cada dia.

Roubei um viajante que vinha da feira, peguei todo o seu dinheiro e a amostra que carregava.

\footnotetext{
${ }^{77}$ Tipo de calçado com sola de cânhamo.
} 
Quan he tingut prou diners, he robat també una nina, l'he robada amb falsedat, dient que m'hi casaria.

La justicia m'ha pres i en presó fosca en duia. La justicia m'ha pres i em farà pagar amb la vida. (AMADES, 1951, p.631)
Quando tive dinheiro suficiente roubei também uma donzela roubei-a com falsidade dizendo-lhe que com ela me casaria.

A justiça me pegou e me levou para a cela escura.

A justiça me prendeu E me fará pagar com a vida. 


\section{CANÇO DEL LLADRE}

MIGUEL LLOBET
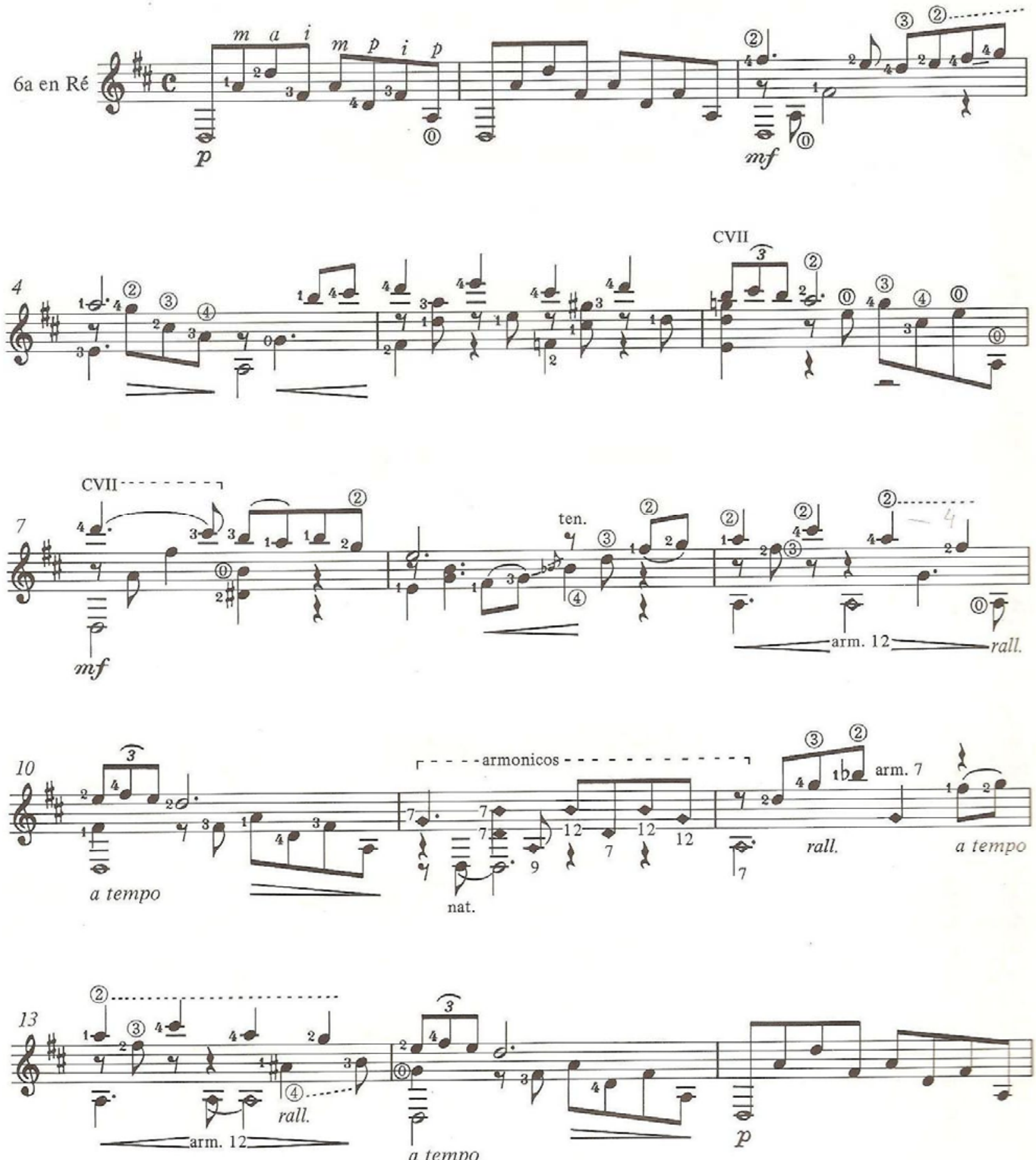

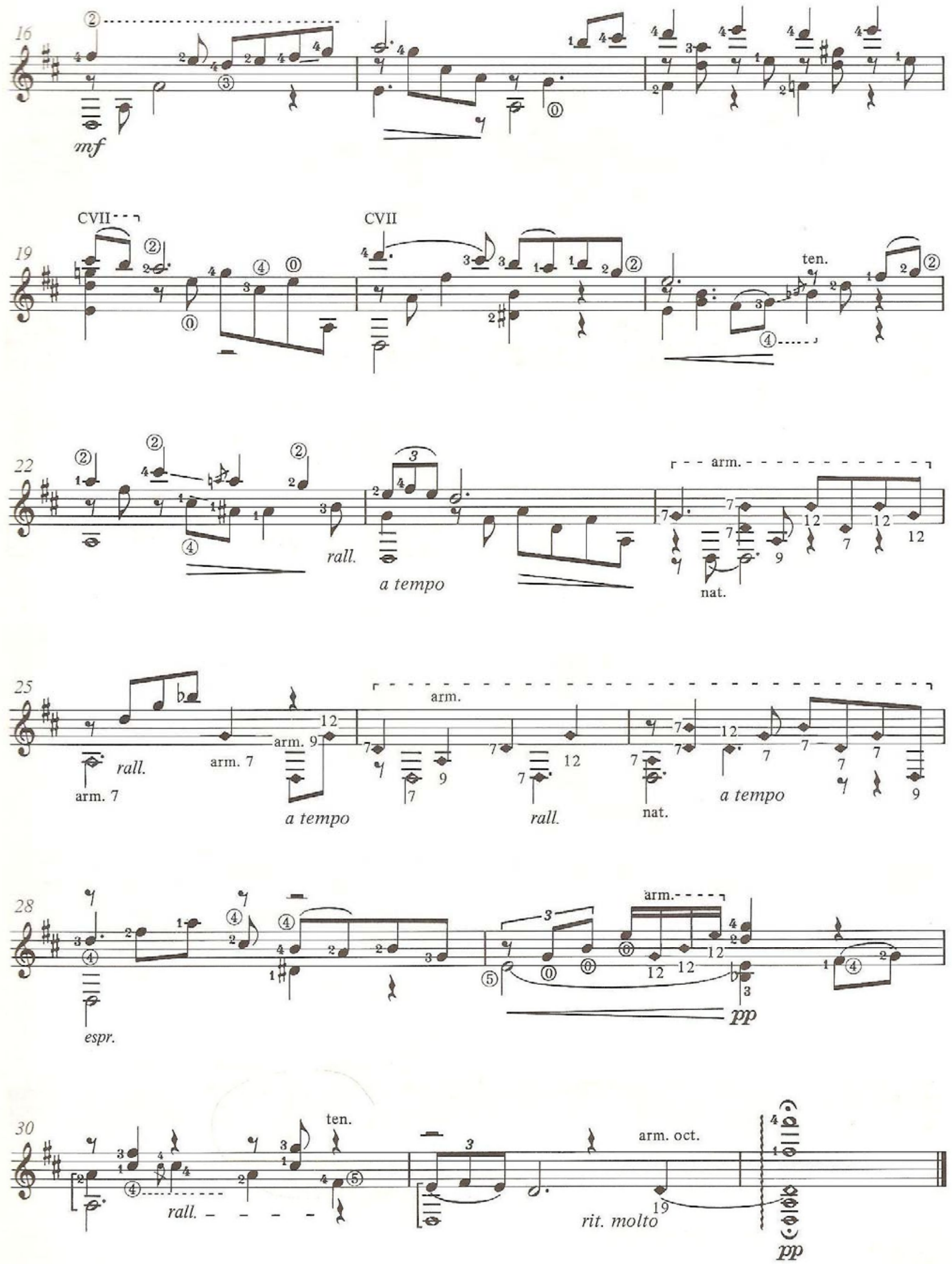


\subsubsection{Lo Rossinyol}

O artigo definido masculino na língua catalão é El. Llobet preferiu usar o artigo Lo nesta, e em outras canções, como veremos adiante. Considerando a origem das canções tradicionais catalãs, produto da tradição oral, discrepâncias nos títulos, letras e melodias podem ocorrer.

O tema de El Rossinyol é recorrente em outras canções populares. A mais conhecida é encontrada em diversas discografias catalãs (AMADES, 1951, p. 450):

\section{El Rossinyol}
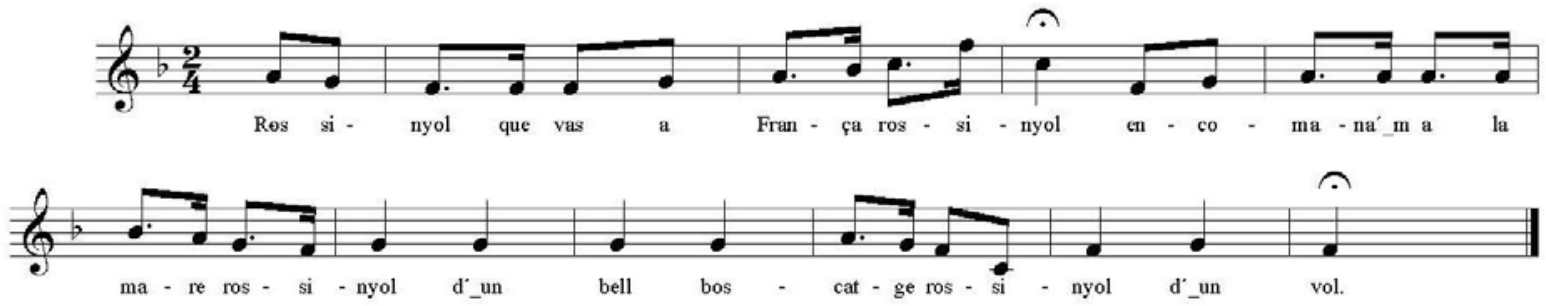

Copyright 1951 by Amades

No entanto, o tema que Llobet utilizou em sua adaptação, realizada em 1900, é outro. Na compilação de Joan Amades, encontramos esta melodia com o nome de $L a$ Cançó del Rossinyol (AMADES, 1951, p. 361). 


\section{La Cançó del Rossinyol}
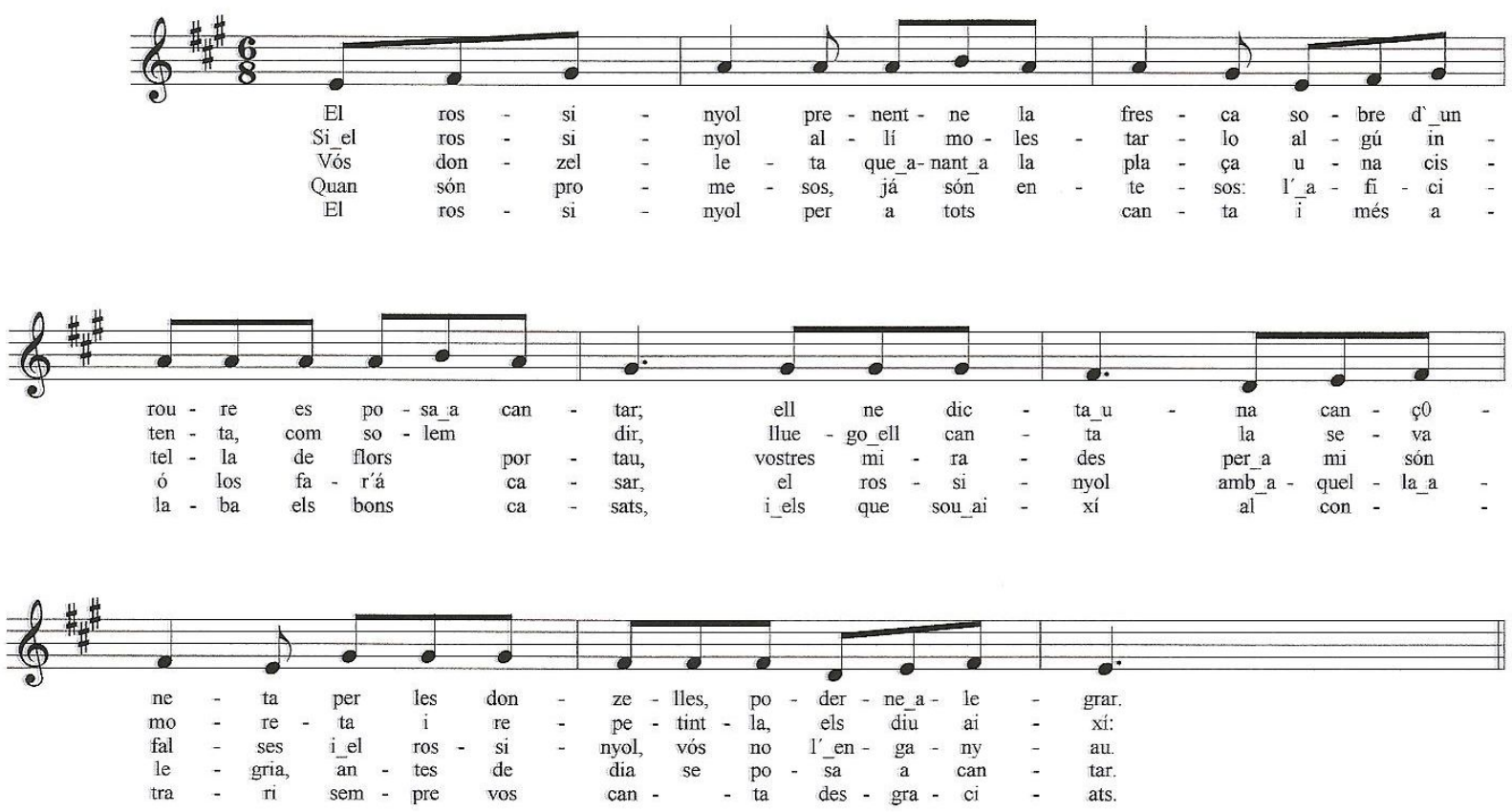

Copyright 1951 by Amades

O arranjo de Llobet imprime uma textura contrapontística, transformando uma melodia tão singela numa peça de considerável dificuldade de execução em andamento usado para caracterizar o movimento de dança - Allegretto. Ao executá-la, é possível cantar quatro das cinco estrofes que traduzimos. Na segunda e quarta estrofe, Llobet brinca com a tessitura, levando a melodia principal a trocar de naipes. Muda a tessitura para uma oitava mais grave que dura quatro compassos (compassos 8 a 11), volta para a tessitura inicial por mais um compasso e meio (compassos 12 e 13), na metade deste compasso retorna novamente para a tessitura mais grave (compassos 13 e 14) para na metade do próximo retomar a tessitura inicial (compasso 14 e 15). 

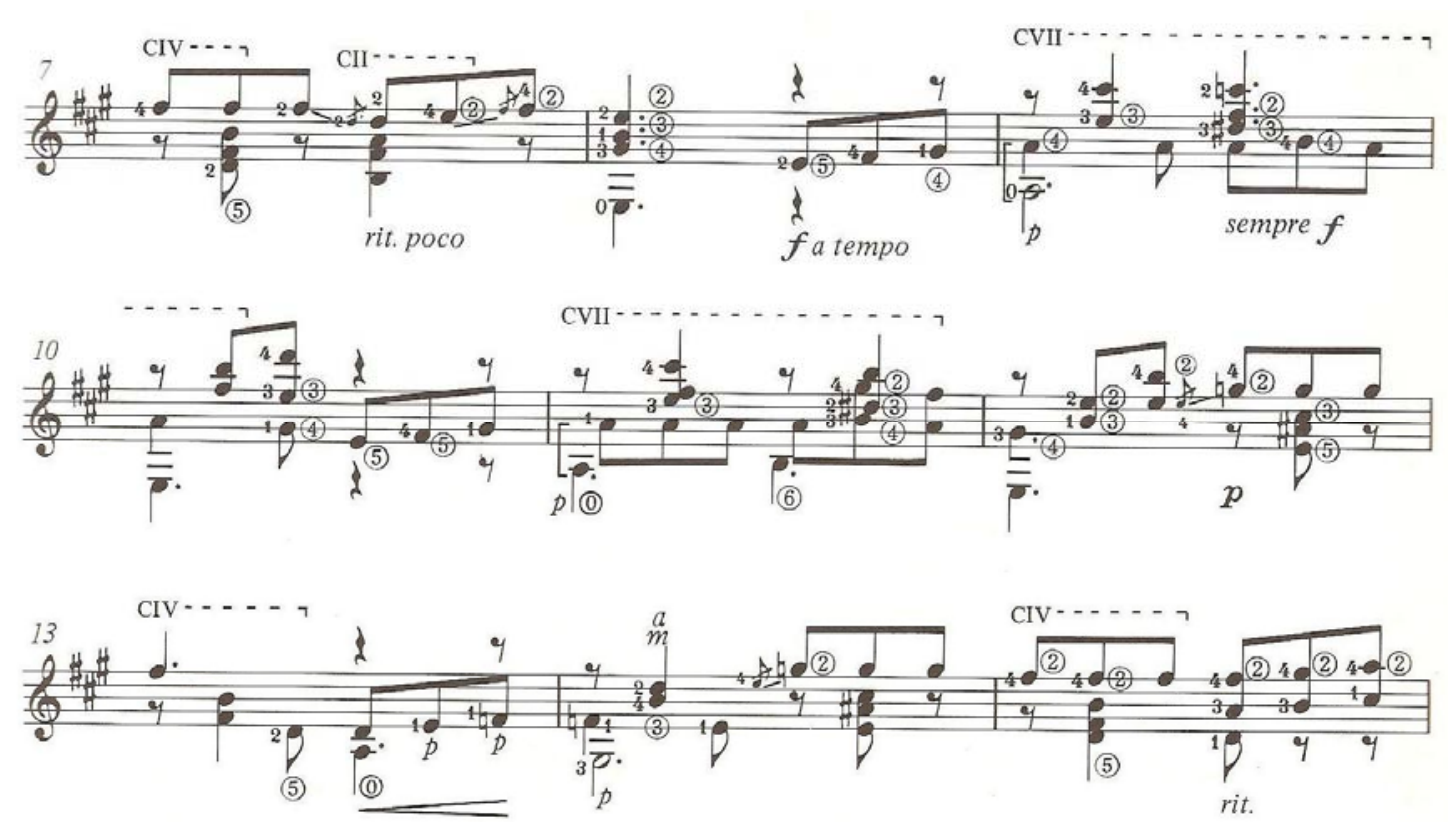

O andamento sugerido por Amades é semínima = 96, que afirma que esta pode ser a mais moderna canção do cancioneiro catalão, e embora jovem, é cantada com diversas melodias de dança, sobretudo no ball pla $^{2}$. Tanto é assim que, uma variante pallaresca (de Pallars - comarca da Catalunha) desta dança de praça é chamada de ball pla del rossinyol.

Na festa de Santa Coloma de Farners se usa esta canção para um baile ao meio-dia no qual escolhiam quem seria o diretor da festa. As pessoas solteiras se reuniam numa taverna para beber vinho enquanto um dançarino praticava a dança diante da garrafa ao som da canção. Se a dança acabasse sem derrubar a garrafa, o dançarino bebia um trago de vinho e começava outra dança. Ao fim da diversão, quem dançava mais vezes sem derrubar a garrafa era eleito o vencedor do jogo.

Encontramos publicações sobre esta dança ilustrada com pequenos rouxinóis sobre uma árvore.

\footnotetext{
${ }^{2}$ Baile de duas duplas que passeiam no salão e vão realizando movimentos graciosos enquanto dançam.
} 
O mais antigo cancioneiro conservado, o Cancioneiro de Cambridge, contém uma canção trovadoresca atribuída a Fulberto de Chartres (1028) de nome Au Rossignol (DUFOURCQ, p. 93, vol. 1)

A tradução livre de La Cançó del Rossyniol (A Canção do Rouxinol) segue abaixo:

El rossinyol, prenent-me la fresca, sobre d'um roure se posa a cantar; ell ne dicta uma cançoneta per les donzelles poder-ne alegrar.

Si el rossinyol allí molestar-lo algú intenta, com solem dir, luego ell canta la seva amoreta i, repetint-la, els diu així:

- Vós, donzelleta que anant a la plaçauma Cistella de flors ne portau, Vostres mirades per a mi són falses, I, el rossinyol, vós no l’enganyau.

Quan són promesos, já són entesos;

L'afició los fará casar, El rossinyol amb aquella alegria, Antes de dia se posa a cantar.

El rossinyol per a tots canta i més alaba els bons casats, i els que sou així al contrari sempre vos canta dasgraciats. (AMADES, 1951, p.361)
O rouxinol, tomando um ar fresco, Sobre um carvalho começa a cantar; ele canta uma pequena canção para alegrar as donzelas.

Se alguém lá tentar incomodá-lo, como costumamos dizer, logo ele canta sua canção de amor e repetindo-a, ele diz assim:

- Donzela que vai a praça Uma cestinha de flores leva, vossos olhares para mim são falsos pois ao rouxinol não podes enganar.

Quando estão prometidos, já estão de acordo;

O empenho os farão casar, O rouxinol com aquela alegria, Antes do dia começa a cantar.

O rouxinol canta para todos e louva mais os bem casados, e aos que são assim ao contrário sempre vos canta desgraças. 


\section{LO ROSSINYOL}

(1900)

Allegretto
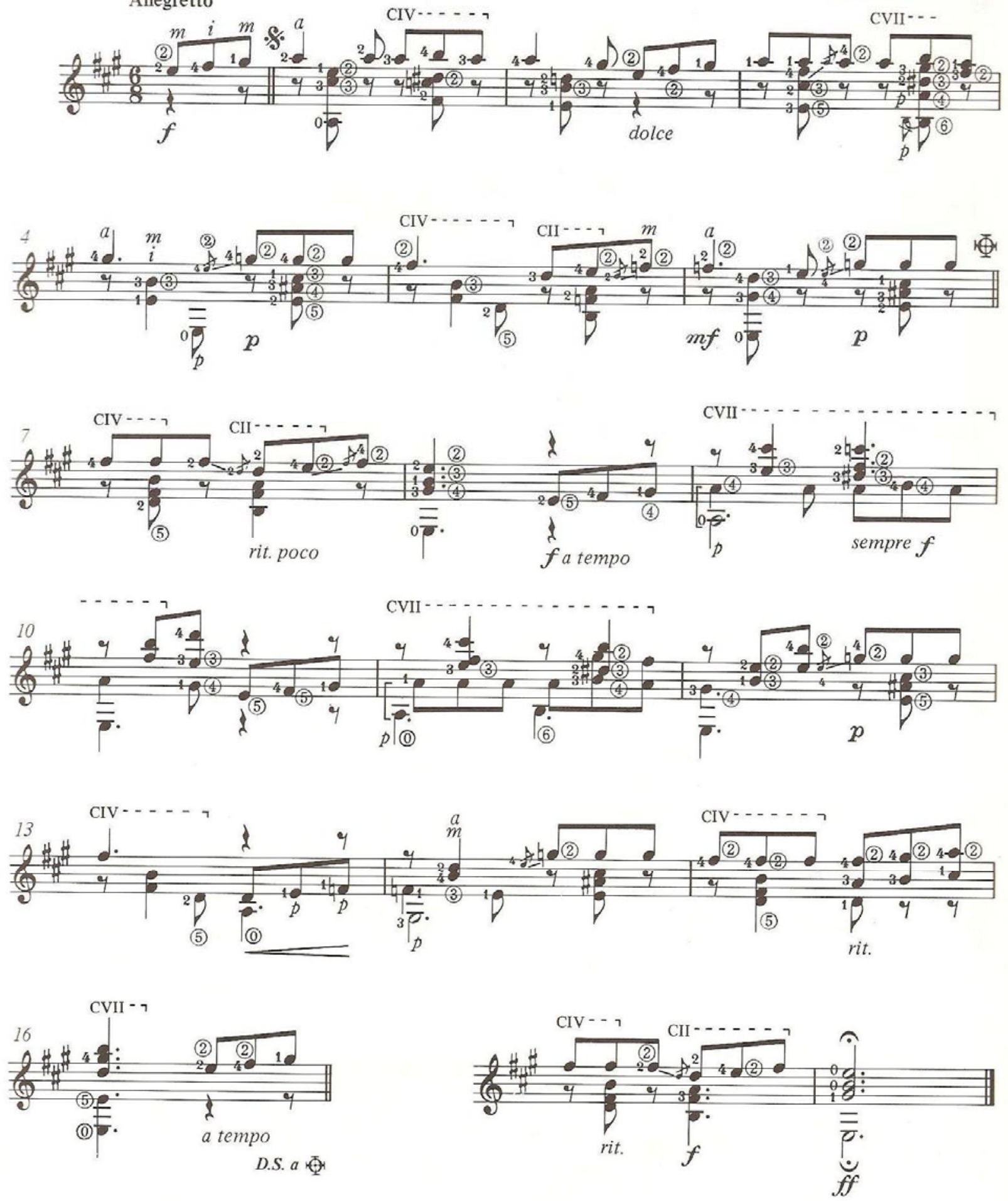


\subsubsection{Lo fill del Rei}

Uma das canções populares mais conhecidas do cancioneiro catalão. O título desta canção foi também alterado por Llobet que usa o artigo $L o$, da mesma forma na canção mencionada anteriormente.

Apesar de sua grande difusão, oferece poucas alterações, tanto literárias quanto musicais. Sua origem pode remeter ao século XV.

Joan Amades a classifica entre as canções de trabalho, especialmente o de transporte comercial pela água. Os navegadores, enquanto cumpriam seu curso, cantavam esta canção com um ritmo lento e cadencioso adequado ao movimento de seu trabalho (AMADES, p. 685).

Tipo de canção nostálgica, muito característica das terras catalãs. A melodia revela um ar de lástima, saturado de melancolia como demonstra o refrão mes ai! (recorrente também em El Testament d'Amelia e El Mestre).

Manifesta similaridades com a canção francesa El petit castell (O pequeno castelo), de origem remota, uma vez que foi utilizada por Adrian Willaert em 1536. (LA CAPELLA REIAL DE CATALUNYA, 1977, encarte de cd).

O arranjo de Llobet atribui maior movimento à melodia. Através de um acompanhamento na voz intermediária baseado em semicolcheias que começa na forma de ostinato e caminha para uma textura contrapontística, ele cria um efeito especial. O andamento indicado é Andante, o que não deixa de nos remeter ao ritmo cadenciado dos navegadores da tradição catalã. 

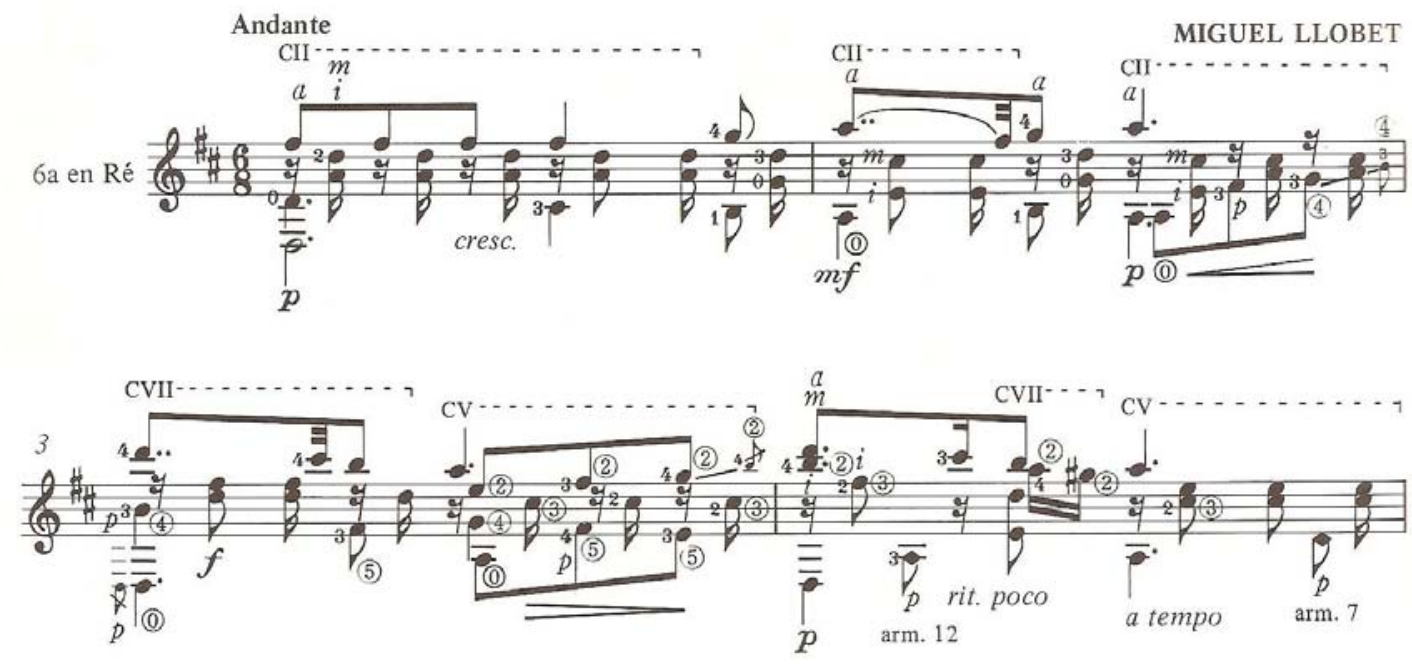

A melodia repete duas vezes, o que indica que Llobet imaginou apenas duas estrofes da poesia inserida nesta melodia antiga.

Amades sugere o andamento semínima pontuada $=48$.

\section{El fill del Rei}
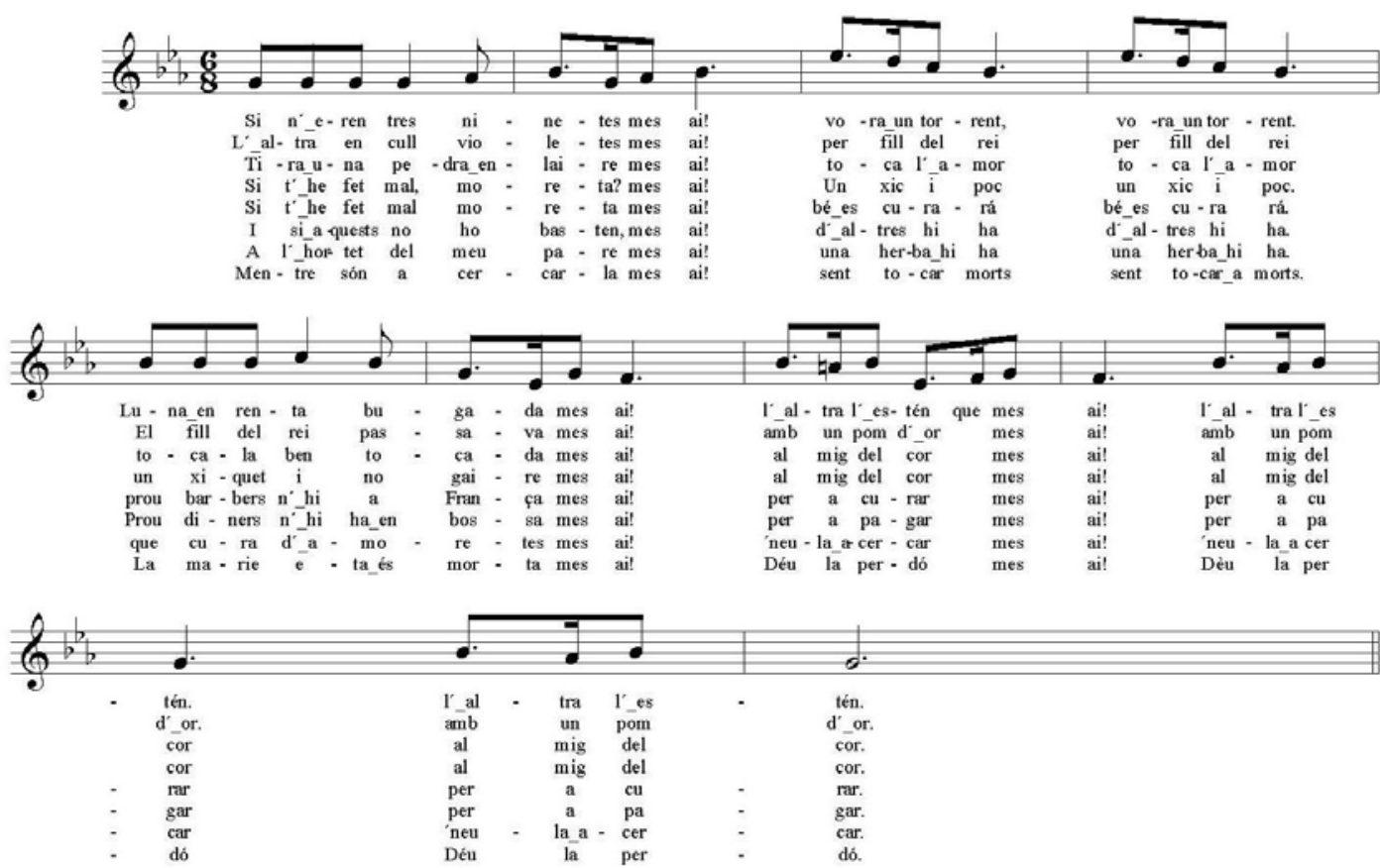

Copyright 1951 by Amades 
O desventurado galã é personificado pelo filho do rei da França. Esta alusão histórica é freqüente nas canções e lendas encontradas por toda a Catalunha.

Recomendamos a audição do grupo catalão La Capella Reial de Catalunya que inclui o texto da canção ${ }^{78}$.

Segue a tradução livre da canção El fill del Rei (O filho do Rei) para o português:

Si n'eren tres ninetes mes ai!

Vora um torrent.

L'uma em treina bugada, mes ai!

l'altra l'estén, que mes ai!

L'altra em cull violetes per fill del rei, El fill del rei passava amb um pom d'or;

Tira uma pedra enlaire, toca l'amor; toca-la ben tocada al mig del cor.

- Si t'he fet mal, moreta?

- Un xic i poc, um xiquet i no gaire al mig del cor.

Si t'he fet mal, moreta, bé es curará:

prou barbers n’hi ha a França per a curar.

I si aquests no ho basten, d'altres hi há

Prou diners n’hi há em bossa per a pagar.
Eram três mocinhas mes ai!

Perto de uma torrente

Uma delas lava roupas sujas mes ai!

a outra as estende, que mes ai!

A outra colhe malvas para o filho do rei, O filho do rei passava com um ramalhete de flores dourado;

Atira uma pedra no ar, acerta 0 amor; acerta direitinho no meio do coração.

- Se te fez mal, mourinha?

- Um pouquinho sim, um pouquinho e não muito no meio do coração.

- Se te fez mal, mourinha, vai se curar bem:

tem muitos barbeiros na França para curar.

E se estes não bastarem, existem outros Tem dinheiro suficiente na bolsa para pagar.

\footnotetext{
${ }^{78}$ La Capella Reial de Catalunya. Cançons de la Catalunya mil-lenària. Planys e Llegendes. Astrée, 1977 (Cd).
} 
A l'hortelet del meu pare una herba hi há que cura d'amoretes: 'neu-la a cercar.

Mentre són a cercar-la sent tocar a morts. La Marieta é morta. Deu la perdó.

(AMADES, 1951, p. 684)
Na hortinha do meu pai

tem uma erva

que cura de amor:

é só ir buscar.

Enquanto está a buscá-las escuta o sino da igreja tocar.

Marieta está morta.

Deus a perdoe. 


\section{LO FILL DEL REI (1900)}
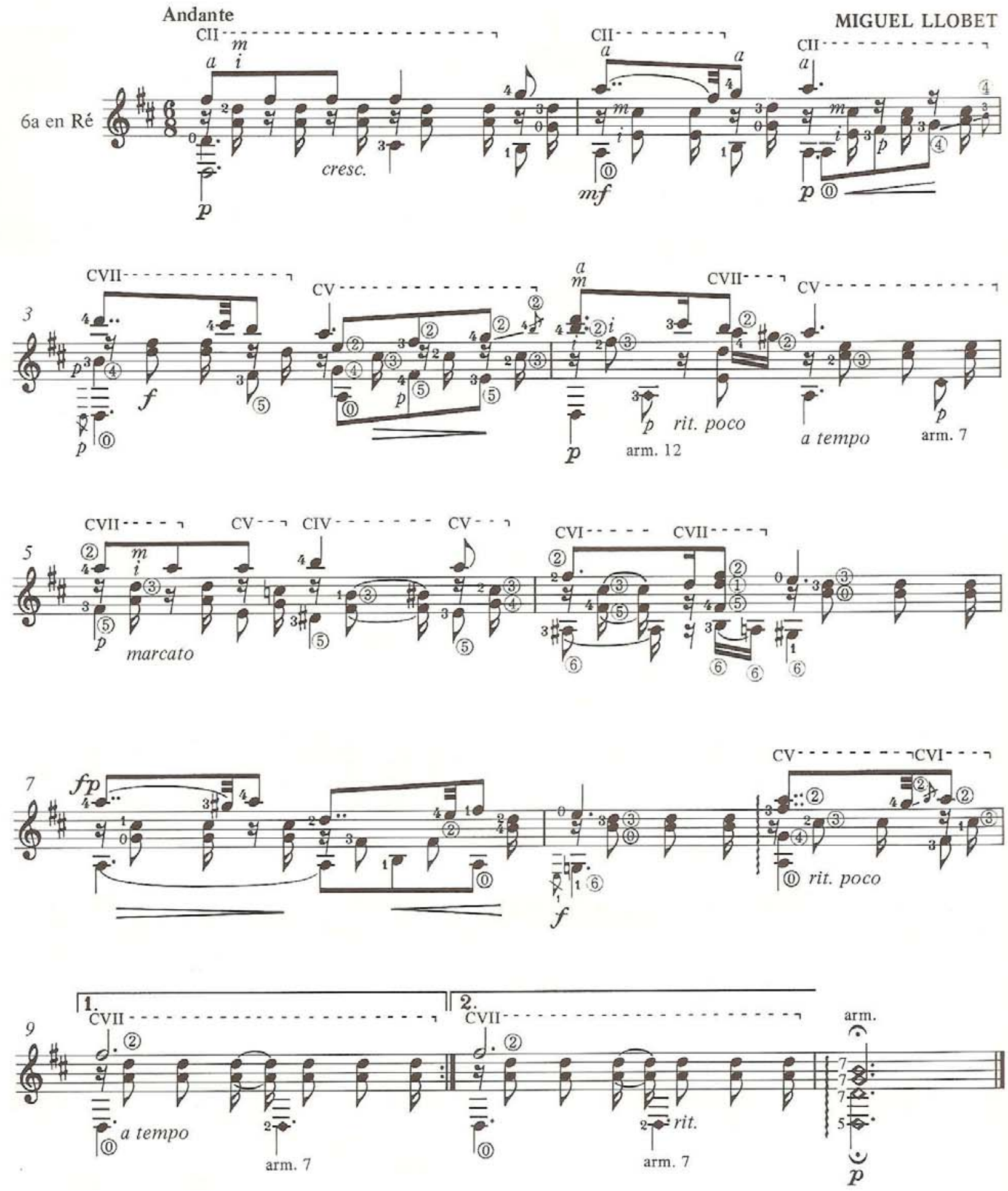


\subsubsection{L’hereu Riera}

O arranjo de Llobet usa a mesma tonalidade da melodia que encontramos no cancioneiro tradicional catalão de Amades - Lá Maior, enquanto que os arranjos corais de Pahissa, Jordá e Morera usam a tonalidade de Sol Maior. Llobet também trabalha aqui com troca de naipes. Podemos, desta maneira, imaginar o diálogo que ocorre entre o galante e sua amada durante as mudanças de tessituras.

Trata-se de uma melodia muito viva, descrita em andamento Allegro Vivo na adaptação de Llobet, em compasso 3/4. No cancioneiro de Amades (1951, p. 362) a melodia encontra-se em compasso 6/8 e o andamento sugerido é semínima pontuada $=$ 60. Uma outra referência traz outra letra e melodia recolhida na década de 20 nas comarcas da Catalunha de andamento semínima =108, escrita em 4/4 (PUJOL, 1926, vol. 2, p. 116).

Outra diferença se encontra no refrão Tra-la-ra-la. Llobet usa outra articulação para o violão - de três semínimas (em compasso 3/4), ao invés de duas colcheias e duas semicolcheias (em compasso 6/8).

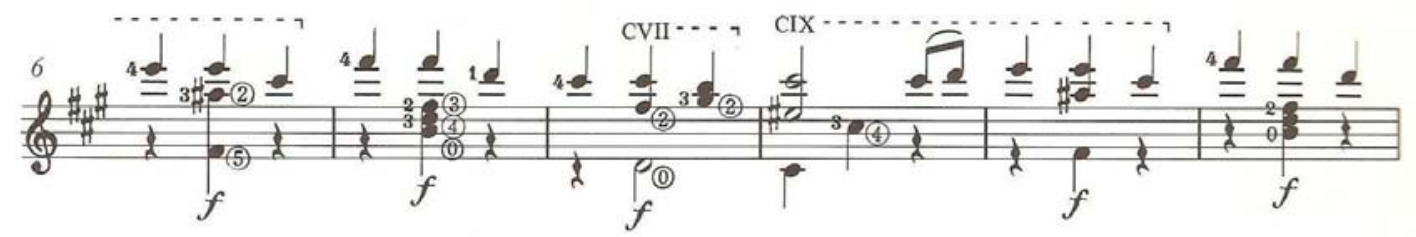

O texto desta canção é extenso, mas a adaptação de Llobet para violão explora o tema de maneira breve. Cita apenas duas estrofes usando textura contrapontística e repete o refrão duas vezes cada vez que é apresentado. A primeira estrofe (compassos 1 a 21) está numa tessitura mais aguda, a segunda mais grave (compassos 22 a 42). Outro recurso usado por Llobet é o glissando: 
No compasso 1:

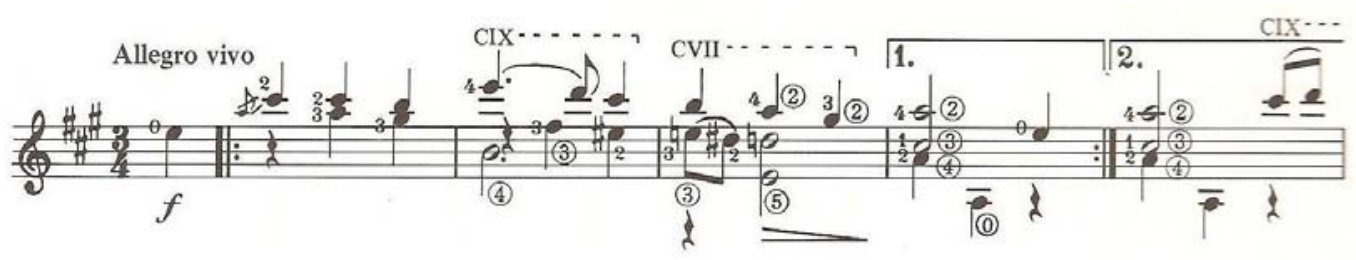

E nos compassos 32 e 35:

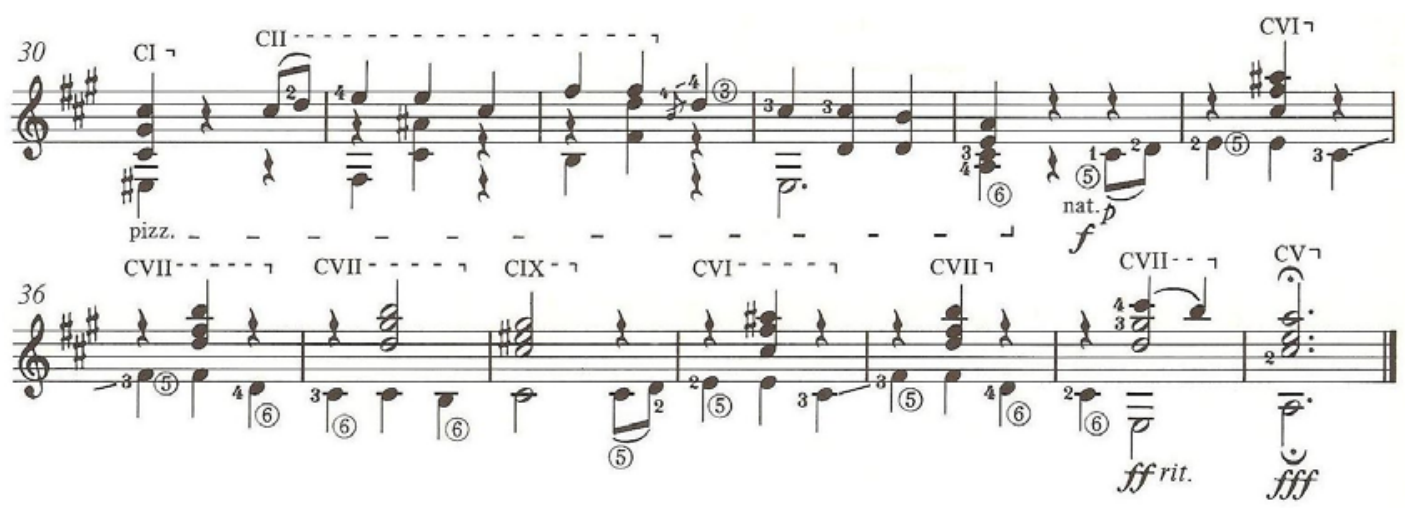

A lenda que permeia esta canção resultou numa narração consideravelmente longa, que descreve o baile, os bailarinos, a figura do galante Riera, sua amada e seu sofrimento diante de sua moléstia. O arranjo de Llobet possui apenas duas das inúmeras estrofes que podemos encontrar nesta canção. Portanto, é uma peça muito mais breve do que a tradição catalã sugere.

Seu tema tem relação com uma dança muito popular na Catalunha - o ball de bastons (baile de bastões). Trata-se da dança tradicional catalã mais antiga e ainda é dançada até hoje nas festas de tradição popular, onde o uso de instrumentos rústicos é muito comum (PAHISSA, 1945, p. 152). As primeiras referências datam do século XII, no reinado de Berenger IV, que realizava banquetes e durante a festa fazia o baile de bastões (figura 3). 


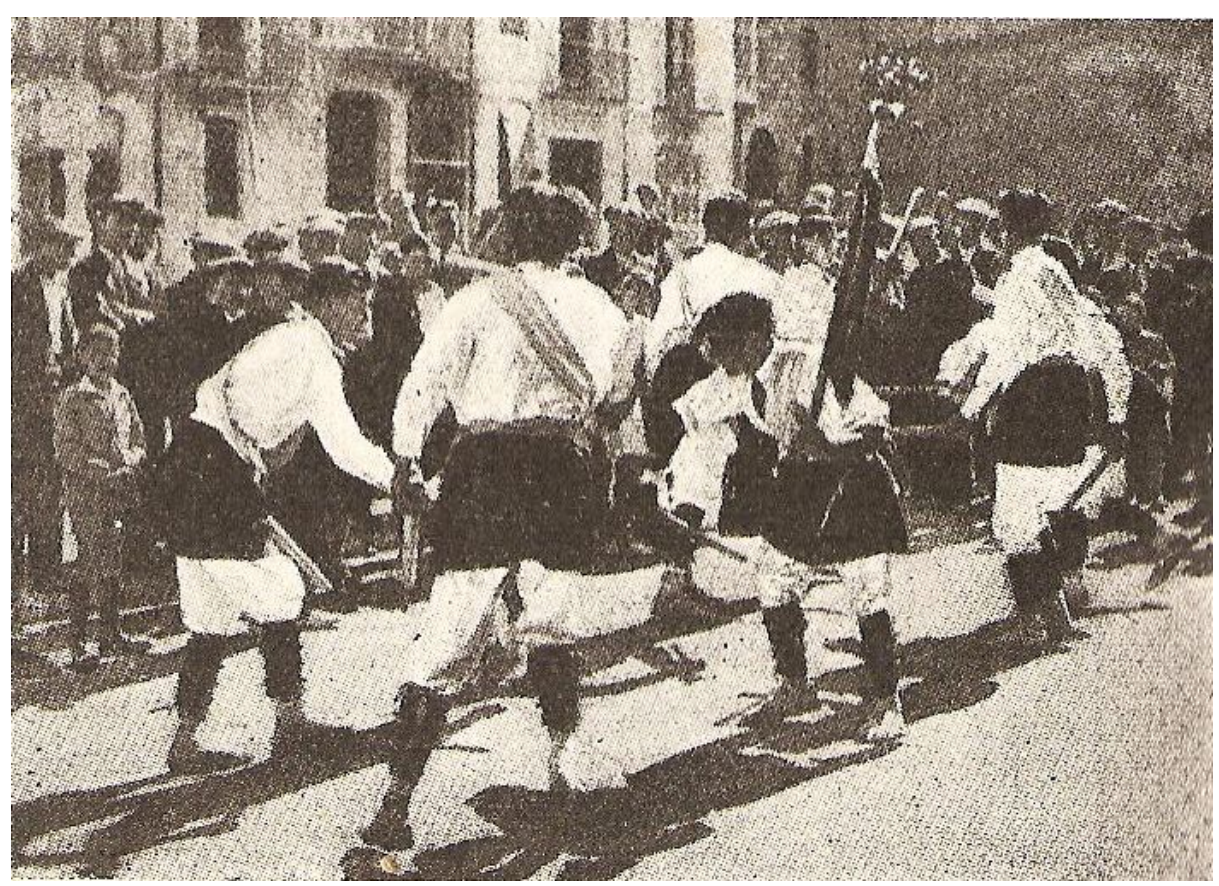

Figura 3. Baile de bastões (ball de bastons)

Originalmente, é um baile dançado apenas por homens, no entanto, a partir dos anos 60, a figura da mulher tornou-se presente, e atualmente participa ativamente. Apenas em algumas regiões se conserva a exclusividade masculina no baile.

Historicamente, sempre se bailava acompanhado por instrumentos musicais como a gralla (figura 4), flaviol (sopro), timbal (percussão), e atualmente, violinos, acordeons e flauta doce.

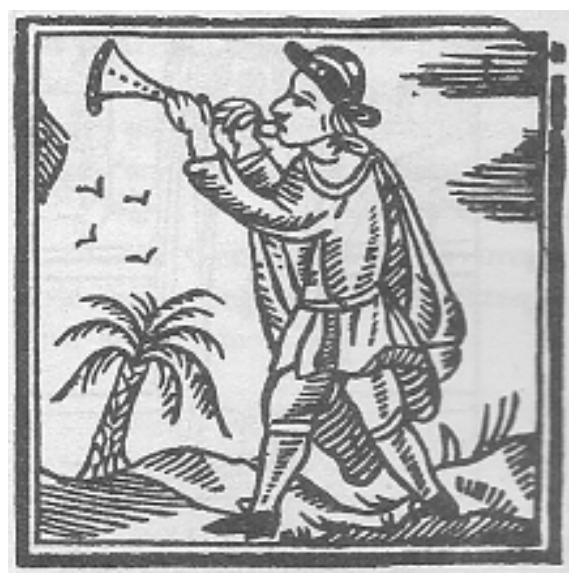

Figura 4. Gralla. 
O baile de $L$ `hereu Riera constitui um dos documentos mais interessantes da cultura popular catalã. O protagonista chama-se Paulo Riera e na maioria das versões a moça chama-se Cecília.

Segundo a lenda, Riera era um solteiro que se ajoelhava ao pé de uma imagem de Cristo perto da cama de sua estimada Cecília, que se encontrava doente, pedindo com muito fervor que ela fosse curada.

Seu pedido é atendido, e ele, atira-se ao pé da imagem e com muita alegria faz uma cruz no chão e dança em volta dela. Deste gesto espontâneo e cheio de gratidão deriva-se a dança que é coreografada diante de dois bastões colocados no chão, em forma de cruz.

O baile chegou até a geração atual sofrendo algumas alterações. Inicialmente era dançado por apenas um bailarino, no máximo dois. Com exercícios engenhosos, o bailarino tinha que dançar sobre a cruz, feita de dois bastões, de preferência bem entrelaçados, para dificultar os movimentos. Colocavam-se os bastões diante de um vaso de vinho no chão, propenso a tombar. O desafio era não derrubar o vaso, nem os bastões, nem gota de vinho alguma. Se o bailarino fosse virtuoso, aumentava a dificuldade com mais vasos de vinho, no máximo quatro, que eram colocados em cada extremidade da cruz. Aquele que causava o tombamento do vaso ou de alguma gota de vinho estava fora do concurso.

Também servia para os viajantes e pastores que visitavam as tavernas não pagarem o vinho que bebiam, em troca de se dançar com seus próprios cajados ou instrumento de trabalho. Se não derrubasse o vaso, podia comemorar o feito bebendo o resto do vinho, mas se tocasse no vaso ou nos bastões, o prêmio era cancelado debaixo de muitas risadas. 
Esta canção é uma das encenadas no teatro rústico durante o carnaval, protagonizada por um folião que dança diante de uma cruz que lembra a imagem de Cristo e, fazendo analogia à lenda, invoca sua ajuda para ser atendido.

É interessante notar que as variações desta canção fazem referência à antiga lenda de Riera: "El ball dels baston/Qui el ballarà/Que el balli Riera/Que el sap ben ballar.”(AMADES, 1951, p. 362)

Este baile se encontra em outras regiões da Europa, sobretudo no norte da Escócia, onde participam tanto homens como mulheres, mas sempre de maneira individual.

A dança também é difundida entre os soldados, por isso, pode ter sua origem cavaleiresca durante o feudalismo. Quando um senhor feudal vencia seu inimigo numa luta, retornava à sua casa e fazia um baile diante dos vassalos como sinal de seu triunfo e humilhação de seu inimigo. No entanto, no lugar de usar bastões, dançava sobre duas espadas (AMADES, p. 362).

O tema de L'hereu Riera foi explorado pelo compositor valenciano Vicent Martin i Soler no início do segundo ato de sua ópera Uma Cosa Rara (1786) e é mencionada na ópera Don Giovanni de W. A. Mozart.

Encontramos três referências além de Amades, no arranjo de Jaime Pahissa para coro a duas vozes (PAHISSA, 1941, p. 12, partitura), no arranjo para coro a quatro vozes de Lluís Jordá (JORDÁ, 19--, p. 8, partitura) e no arranjo para coral a quatro vozes (MORERA, 190-, partitura) $)^{79}$.

Como referência fonográfica recomendamos a soprano Victoria de los Angeles $^{80}$ e o coral Orfeo Catalá ${ }^{81}$ que gravaram esta canção.

\footnotetext{
${ }^{79}$ Cf. ANEXO A, p. 250, 251 e 252.

${ }^{80}$ CANÇONS TRADICIONALS CATALANES. Victoria de Los Angeles with Geoffrey Parsons. Collins Classic, 1992 (Cd).

${ }^{81}$ ORFEO CATALÁ. Chansons Traditionnelles de Catalogne. Harmonia Mundi, 1992 (Cd).
} 


\section{L'hereu Riera}

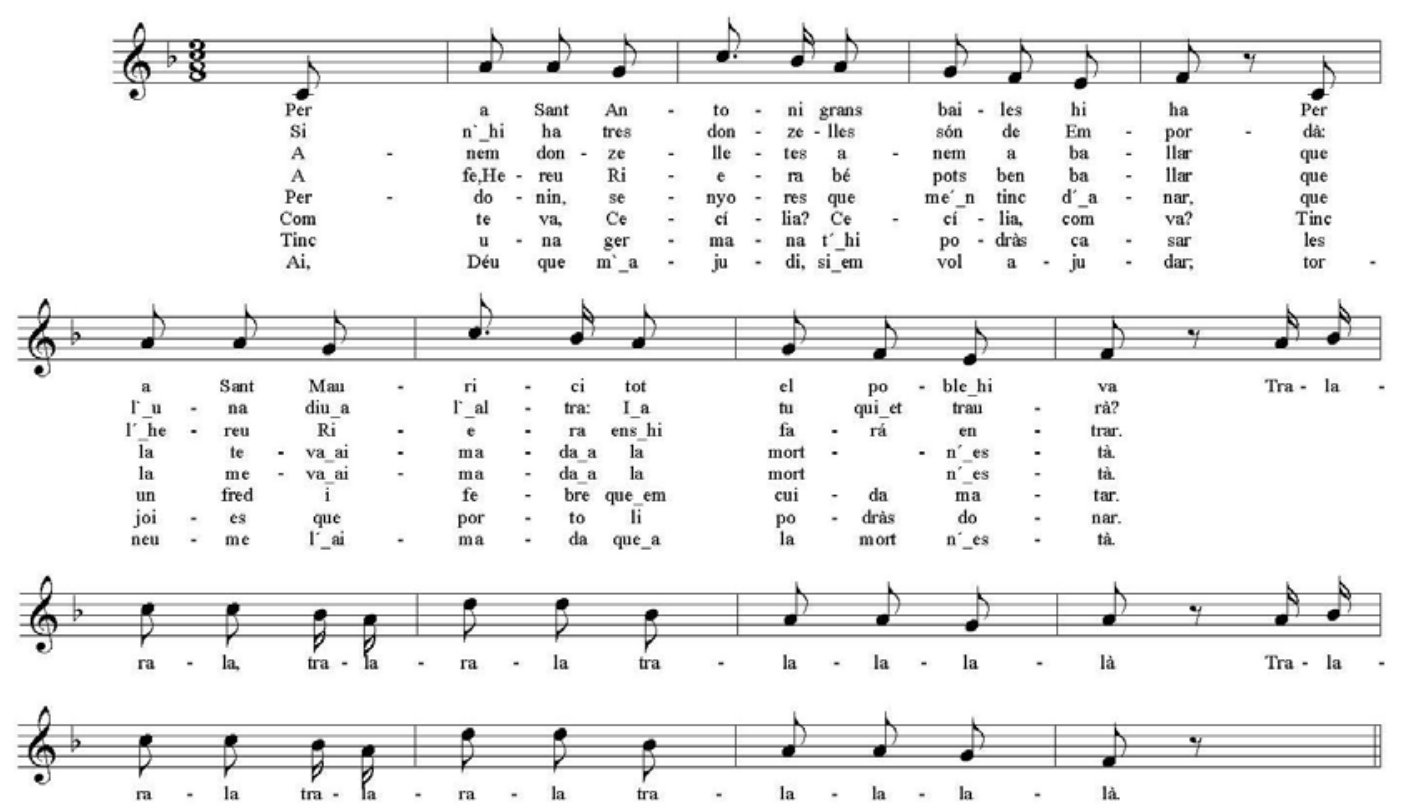

Copyright 1951 by Amades

Riera):

A letra e a tradução livre para o português de L'hereu Riera (O herdeiro

Per a Sant Antoni grans balles hi há

Per a Sant Maurici tot el poble hi va

Tralarala, tralarala, traralala-lalá

Tralarala, tralarala, traralala-lalá

Si n’hi há tres donzelles són de l’Empordá;

l'uma diu a l'altra:

- I a tu, qui et traurá?

Anem, donzelletes, anem a ballar, que l’hereu Riera ens hi fará entrar.

A fe h'ereu Riera, bé pots ben ballar, que la teva aimada a la mort n'está.
No dia de Santo Antônio

há grandes bailes

No dia de São Maurício todo mundo vai dançar.

Tralarala, tralarala, traralala-lalá

Tralarala, tralarala, traralala-lalá

Vão três donzelas que são de Empordá uma diz a outra:

- Quem a tirará para dançar?

Vamos donzelas, vamos dançar que o herdeiro Riera nos fará entrar.

Com certeza o herdeiro Riera pode bem dançar, pois a sua amada à beira da morte está. 
- Perdonim, senyores que me'n tinc d'anar, que la meva aimada a la mort n'está.

- Com te va, Cecília?

Cecília, com va?

- tinc um fred i febre que em cuida matar.

Tinc uma germana t'hi podràs casar les joies que porto li podràs donar.

Já en diu al Sant Crist que a la cambra hi ha: Ai Déu, que mªjudi, si em vol ajudar;

Torneu-me l'aimada, que a la mort n'está.

I a les set setmanes já se'n van casar. (AMADES, 1951, p. 362)
- Perdão, senhores tenho que me retirar porque minha noiva está a beira da morte.

- Como está, Cecília?

Cecília, como está?

- sinto frio e tenho febre que quer me matar.

Tenho uma irmã com quem poderá se casar as jóias que tenho poderá dar-lhes.

Já pedi a Santo Cristo que está no quarto $\mathrm{Ai}$, Deus me ajude, se quiser me ajudar.

Traga de volta minha amada Que está à beira da morte E há sete semanas Já se casaram. 


\section{L'HEREU RIERA}

(1900)

MIGUEL LLOBET

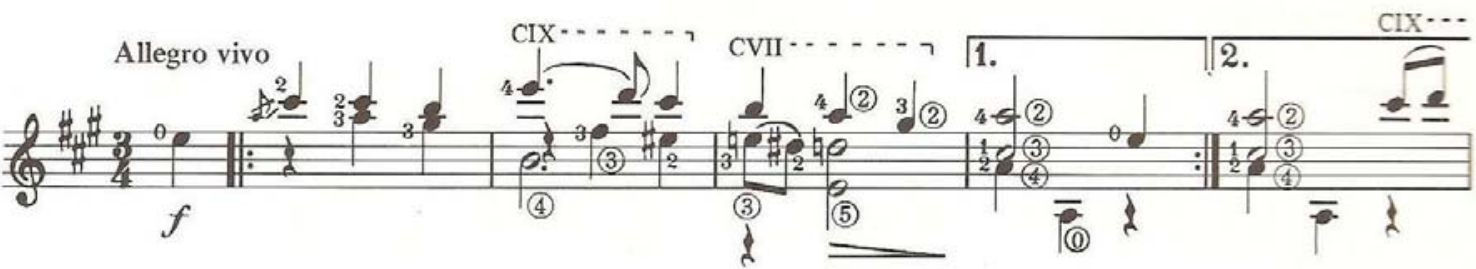

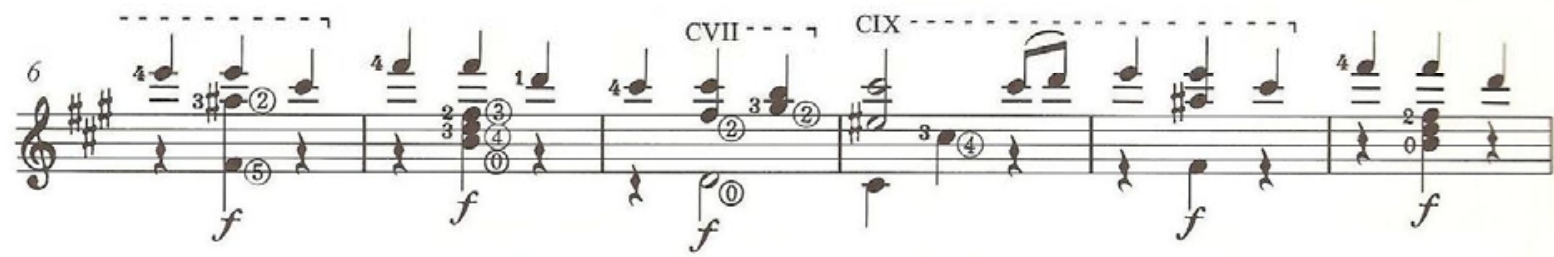

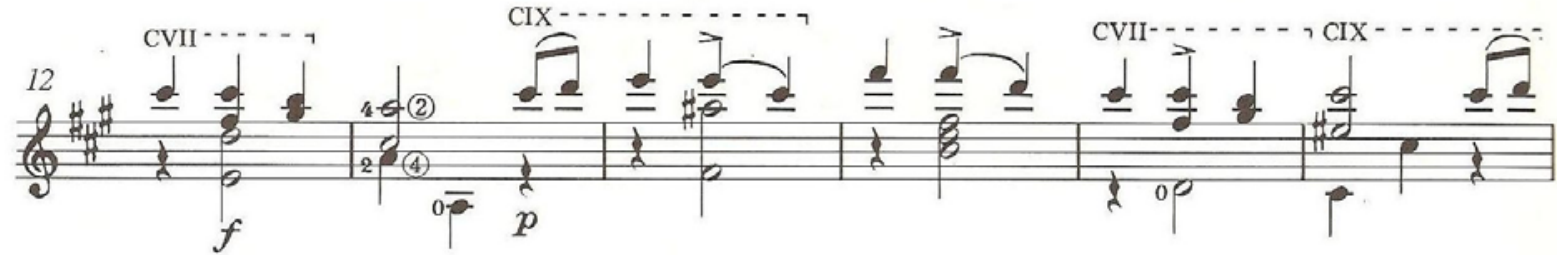

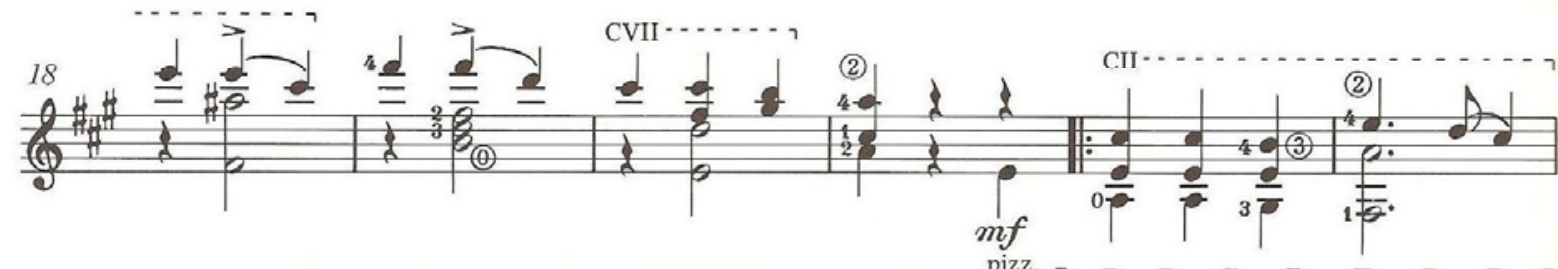

1.

2.

(9)

(6)

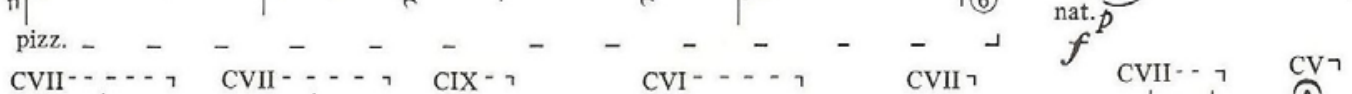

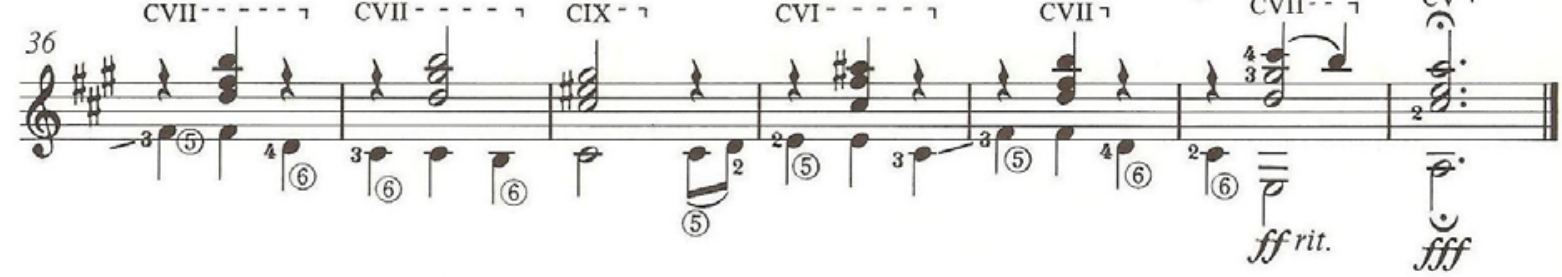




\subsubsection{El Mestre}

Discutimos no início deste capítulo sobre o reconhecimento das Canciones Catalanas como uma coleção de obras autorais, por sua sofisticação e importância na literatura escrita para violão no início do século XX. Um bom exemplo disto é esta canção intitulada El Mestre que destacamos entre as versões que merecem ter seu status de obra autoral reconhecido.

Trata-se da adaptação mais elaborada de Llobet, e a preferida de figuras como Emilio Pujol: "Harmonically, one of the most advanced works of its time for the guitar” (PURCELL, 1989, vol. 2, p. iv, partitura); e Andrés Segovia, em sua autobiografia, comenta sua impressão ao ouvir esta canção interpretada pelo próprio Llobet anos antes: "The effective orchestration of its tone colour and its delicious dissonances play on the plaintive character of that folk theme”. (SEGOVIA, 1976, p. 100). De fato, uma breve análise desta canção tradicional indica como Llobet expandiu as possibilidades técnicas do violão. Segundo a opinião de Pujol, El mestre "marks the point of departure towards new territories containing within itself the seeds of later coloristic effect on the instrument. Thanks to Llobet the guitar displayed a new aesthetic term it awoke to colour and polyphony.” (JONES, 1998, p. 24)

El Mestre foi escrita em 1910, fase de maturidade musical do compositor. Os elementos usados por ele nesta canção marcam uma nova fase para a sua escrita violonística, como o uso de timbres e harmonias mais ousadas, que começam a se distanciar do estilo chopiniano de suas primeiras obras.

A maneira que Llobet explora o uso de harmônicos artificiais inseridos numa textura contrapontística nos faz concluir que ele expandiu a técnica usada anteriormente por seus antecessores. 


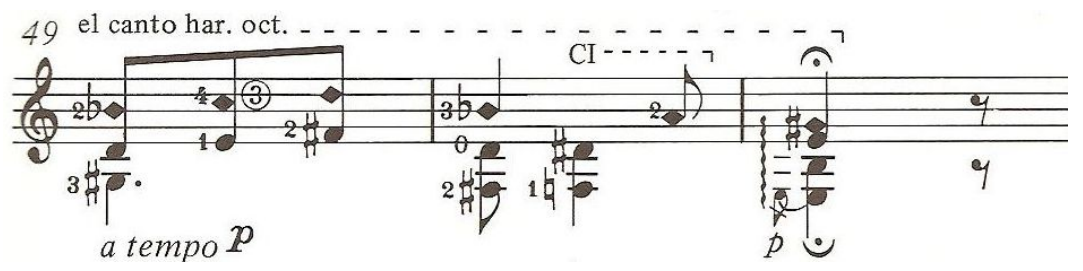

As canções tradicionais usam invariavelmente se desenvolvem dentro de modalidades sem o uso de cromatismo, como constatamos em comentários de musicólogos especialistas em folclore catalão:

“Es opinió correntement admesa, que les nostres cançons populars es desenrotllen dintre modalitats completament diatóniques, amb exclusió de tot cromatisme, i que aquest, el cromatisme, quan apareix em alguma cançó, denota o bé la influencia exótica d'alguna modalitat oriental, o de la música artística (...)”82 (PUJOL, 1926, vol. 2, p. 171)

Acreditamos que a esta canção poderíamos atribuir o status de obra original pelo emprego de cromatismos em diversos trechos, que na versão tradicional não encontramos.

Na Introdução de seus volumes Nueva Colección Llobet Purcell discute a importância das Canciones Catalanas, principalmente El Mestre. Como vimos, providenciou uma transcrição monofônica da melodia original e a letra junto com a tradução para o inglês e foi esta citação que nos motivou a pesquisar as demais canções utilizadas nesta coleção de adaptações ${ }^{83}$.

Apesar de não indicar a mudança de caráter no refrão, pode ser interpretado de forma mais rápida e enérgica, como notamos nas versões para coral, na versão da soprano catalã Victoria de los Angeles e algumas gravações de violonistas.

\footnotetext{
${ }^{82}$ É fato que as nossas canções populares desenvolvem-se dentro de modalidades totalmente diatônicas, com a exclusão de todo cromatismo, e que, quando este aparece em alguma canção, denota bem a influência exótica de alguma modalidade oriental ou da música artística (tradução da autora).

${ }^{83}$ Purcell cita o trabalho de Joan Amades como referência para a pesquisa de outras melodias catalãs.
} 


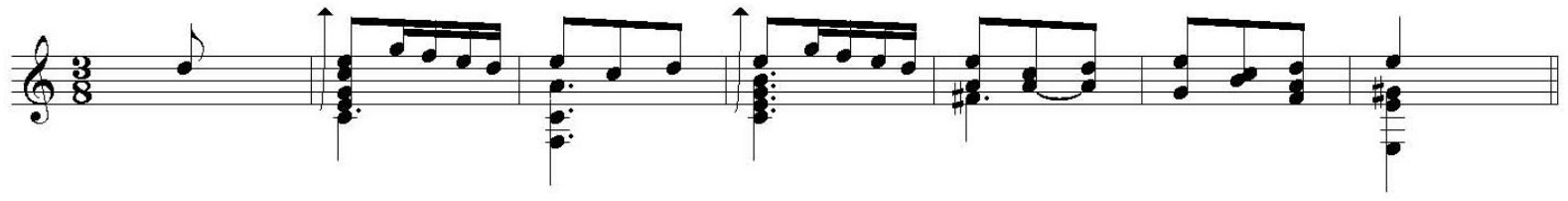

A balada é cantada com um refrão expressivo que usa palavras sem significado que soam como instrumentos de percussão. Segundo Purcell (1989, vol. 2, p. iv), o refrão faz referência aos lamentos medievais mouriscos, que vieram mais tarde, a influenciar a música flamenca, cuja técnica violonística é baseada no uso de rasgueados. Neste trecho notamos o uso do único rasgueado na obra original de Llobet que marca a figura do amante no diálogo entre ele e a donzela, sugerindo assim o mesmo efeito percussivo que a versão original propõe. Na cadência deste trecho (compasso 18), Llobet anota um ritenuto para anunciar a expressão mes ai!, (compasso 19 e 20) usada em outras canções para denotar profundo lamento, como vimos anteriormente.

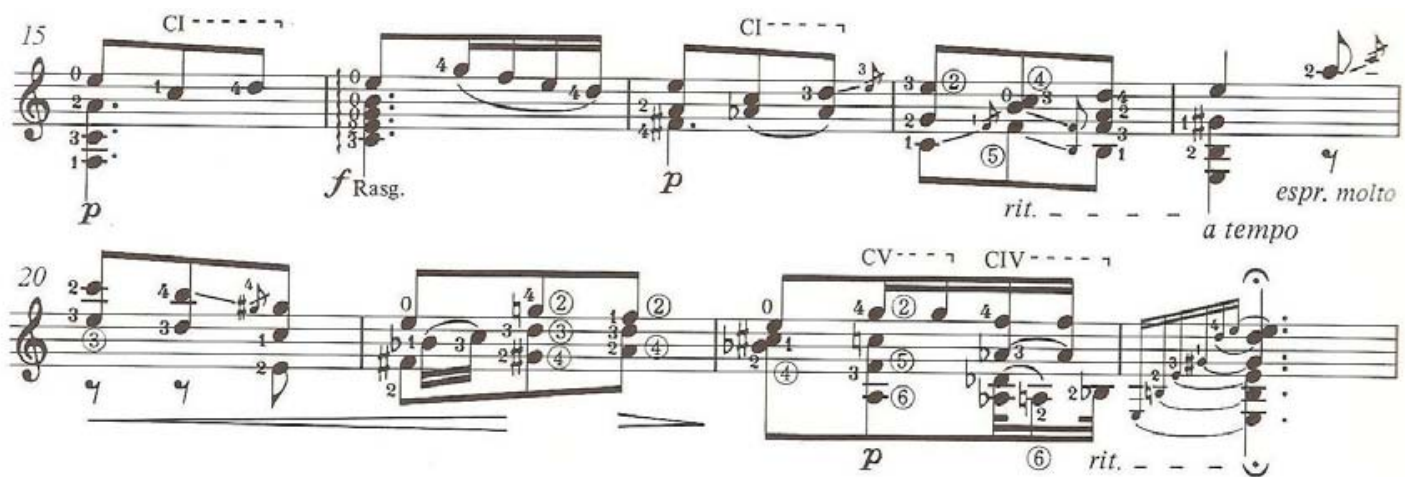

Depois, Llobet modifica o refrão, transpondo sua tonalidade através de harmônicos, fazendo uso de cromatismos e do elemento surpresa, modulando sem preparação (compasso 36):

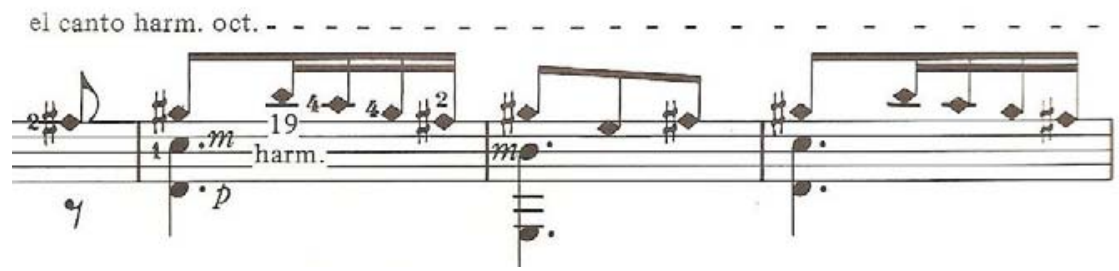


Outro procedimento usado por Llobet que denota sua concepção orquestral é a melodia explorada de maneira expressiva na $4^{\mathrm{a}}$. corda (compasso 24 ) criando um efeito dramático de tenor solo e, logo em seguida, aplica um contraste para responder ao tenor em pizzicatos (compassos 30 a 32).

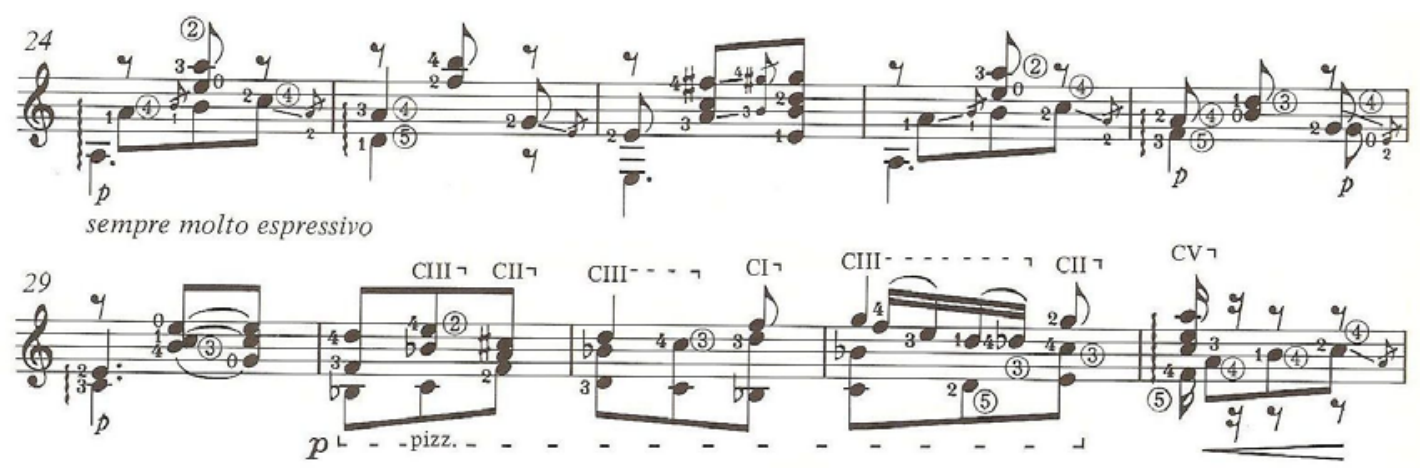

El Mestre tornou-se a canção catalã preferida na Europa, através das performances de Llobet. Pode ser uma da preferidas de Llobet também, pois incluiu entra as canções catalãs que gravou no registro pioneiro que citamos anteriormente.

Quanto ao título, uma correção de Rey de la Torre na partitura (figura 5) a partir da observação do manuscrito de seu professor, nos faz crer que Llobet preferia usar Lo, em vez do artigo definido masculino El da língua catalã, assim como vimos anteriormente nas canções Lo Rossyniol e Lo fill del Rei.

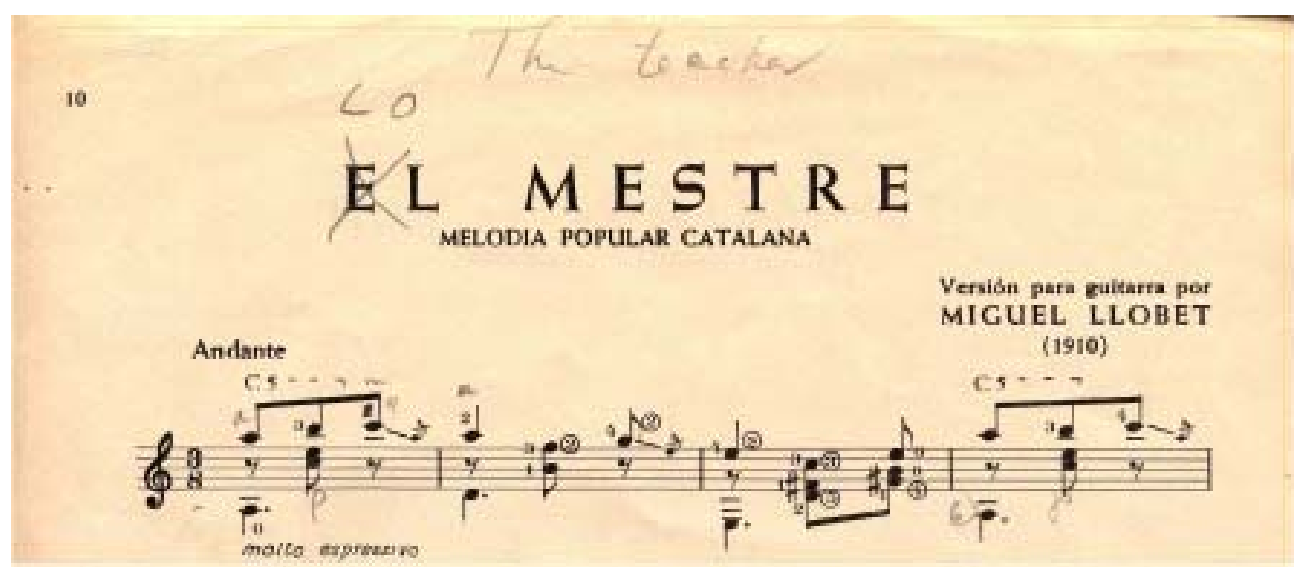

Figura 5. Página com o título da canção El Mestre com anotações de Rey de la Torre

Bruno Tonazzi (1966, p. 33) afirma reconhecer traços impressionistas na obra de Llobet. Se existe alguma relação de Llobet com o impressionismo, é nesta 
expressiva adaptação, realizada em 1910, período em que se estabeleceu em Paris, reduto dos maiores impressionistas de sua época.

Comentaremos agora os aspectos sociais e as lendas que permeiam esta canção. Esta é uma das canções de romaria e festa mais típicas, divulgadas e permanentes devido às peregrinações religiosas por toda a Catalunha, a partir do século XVIII. Possui uma diversidade de melodias com sentido diferentes, por isso é cantada tanto de uma forma alegre como de uma forma triste.

Entre a escassa documentação de música trovadoresca, duas delas são parecidas com outras duas que se encontram no cancioneiro catalão e foram usadas por Llobet $^{84}$. Joan Amades (1951, p. 49) notifica que esta canção é interpretada e dançada com melodias alegres e reconhece sua melodia numa das raras melodias trovadorescas que chegaram até nós, do trovador Pèire Cardenal (1180-1278).

Higino Anglès afirma que o trovador Giraut de Borneill (1775-1220) também cantava uma melodia semelhante - No puesc sofrir qu'a la dolor - usada anteriormente na canção de Cardenal - Ar tal puesc yeu lauzar d'amor (1210-1230) - e declara: "Esta melodia é um exemplo de como o folclore musical pode perdurar durante séculos.” (PUJOL, 1926, vol. 1, p. 293)

Variantes originárias de terras piemontesas e valencianas mesclam-se com outras procedentes da França, Alemanha, Portugal e Dinamarca. Na Catalunha são cerca de dez variantes, todas elas procedentes de várias regiões.

\footnotetext{
${ }^{84}$ A outra canção é a Cançó del Lladre, como vimos anteriormente.
} 
Ar tal puesc yeu lauzar d'amor

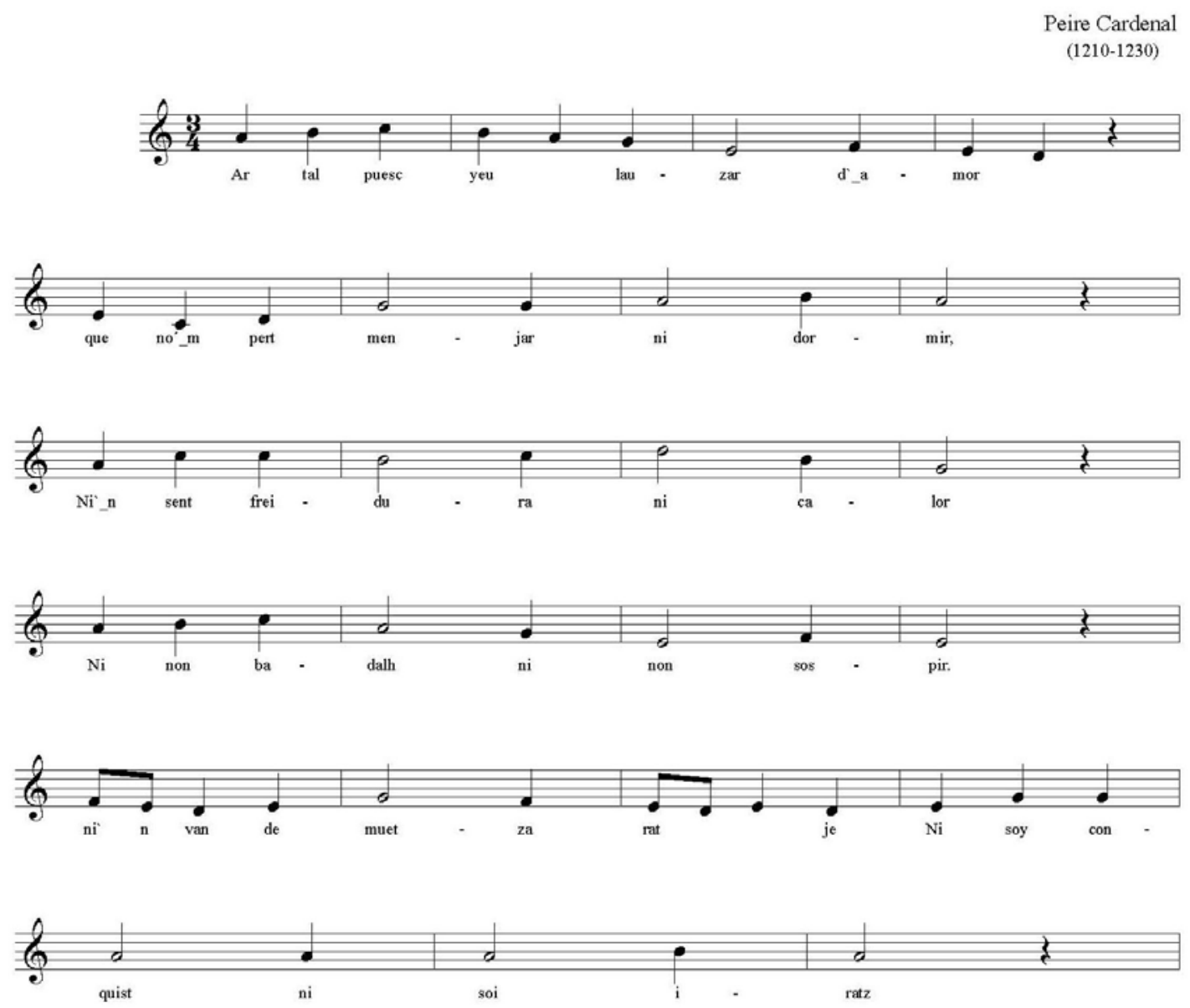

Encontramos uma interessante conotação bélica e histórica nesta canção. Ela mantém uma relação poética com Mambrú ${ }^{85}$, uma versão catalã de uma canção de origem francesa que exalta as vitórias do general francês Malborough no princípio do

\footnotetext{
${ }^{85}$ A canção de origem francesa é popular por toda a Europa. Faz referência ao general inglês Mambrú, ou Marlborough, ascendente de Winston Churchill. Na guerra entre a Inglaterra e a França, na primeira metade do século XVIII, o general Mambrú obteve muitas vitórias que lhe renderam grande fama e popularidade, passando a ser respeitado por uma parte da Europa e hostilizado por outra.

Quando Mambrú morreu, a Inglaterra dedicou-lhe honras fúnebres muito solenes. Os franceses, sofrendo os grandes estragos da guerra, sendo feridos e perdendo suas tropas, cheios de desprezo pela Inglaterra fizeram a canção em tom de paródia. As circunstâncias tornaram-na muito popular durante o século XVIII. Era uma das canções preferidas de Mme. Poitrine, dama de leite de um dos filhos da rainha Maria Antonieta (1755-1793) e de Luis XVI (1754-1793), que a cantava para fazer o bebê dormir. A canção caiu nas graças de todo o reino, que passou a aprender a cantá-la. Devido ao aspecto servil existente na realeza, as damas da corte seguiam os costumes da rainha, e a partir delas, o costume se espalhou por toda a nobreza, e através da burguesia, chegou até o povo. O nome de Marlborough tornou-se amplamente conhecido e divulgado. Fernando Sor também explorou este tema na sua obra op. 28 Variations sur Malbrough se'n va-t-en guerre (Cf. ANEXO A, p. 267).
} 
século XVIII. O texto da canção Mambrú foi recolhido por Amades, e consta no seu cancioneiro (AMADES, 1951, p. 481):

\section{Mambrú}
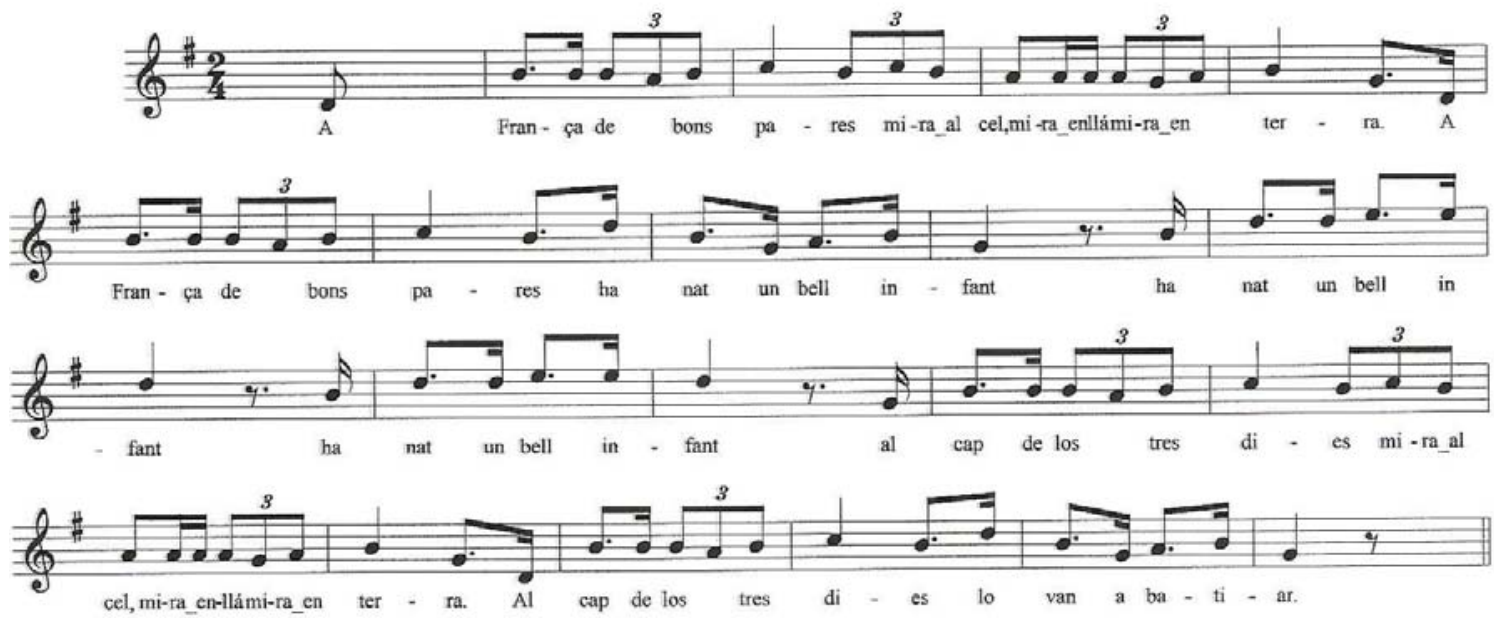

Copyright 1951 by Amades

A França de bons pares

mira al cel,

mira enllà,

mira em terra,

Ha nat um bell infant.

Al cap de los tres dies

lo van a batiar.

El rector ja en demana:

- Com s'ha d'anomenar?

- Mambrú - los padrins diuen.

- Manbrú, doncs, se dirá.

Als cinc anys a l'escola

l'en fan estudiar.

Quan els quinze anys complia

un mestre n'era já.

Llavors totes les armes

va aprendre de jugar,

i, per valent, tan jove, cavaller el van armar.

Quan els vint anys complia

li parlen de casar

amb uma hermosa dama

de grans habilitats.
Na França de bons pais

olha o céu,

olha lá,

olha a terra,

nasceu um belo menino.

No fim de três dias

levam-no para batizar.

O padre pergunta:

- Como ele se chamará?

- Mambrú - dizem os padrinhos.

- Mambru, então, se chamará.

Aos cinco anos o fazem ir a escola

para estudar.

Quando completava quinze anos

já era um mestre.

Então todo tipo de armas

aprendeu a usar,

e por ser valente e tão jovem

cavaleiro se tornou.

Quando completou vinte anos

lhe falaram para casar

com uma formosa dama

de grandes habilidades. 
El dia de les bodes

una carta arribà:

el Rei, amb esta carta,

l'envia a demanar.

Mambrú sén va a la guerra;

no sé quan tornará,

si tornarà per Pasqua

o per la Trinitat ${ }^{1}$.

Les festes són passades:

Mambrú no ha pas tornat.

La dama es fa en finestra

per veure se vindrá.

Ja en veu venir dos patges:

vestits de dol ne van.

- $\quad$ Ai, patges, los meus patges,

quina nova em portau?

- Dama, la triste nova

massa us farà plorar:

Mambrú n'és mort en guerra,

n'és mort i soterrat.

Malmés d'un cop de llança

el vérem expirar.

(AMADES, 1951, p. 183)
No dia do casamento

uma carta chegou a ele:

o Rei, com esta carta,

manda-lhe se apresentar.

Mambrú foi para a guerra;

não sei quando voltará,

se voltará na Pácoa

ou para a Trinitat.

As festas já passaram:

Mambrú não voltou.

A dama está esperando na janela

para ver se ele voltará.

Chegaram dois emissários:

enlutados.

- Ai, emissários, meus emissários, que notícias me trazem?

- Dama, a triste notícia

lhe fará chorar.

Mambrú morreu na guerra

está morto e enterrado.

Atingido por um golpe de lança

o vimos expirar.

A relação entre El mestre e Mambrú é literária. Seu tema é “O retorno do amante” e narra uma donzela enamorada de seu professor, aleijado por causa da guerra. No jardim de seu pai, ela sonha com o retorno de seu amado.

Expressa profunda tristeza e angústia lembrando o estilo dos mouros no período medieval. Desta maneira, o refrão dramatiza o sofrimento dos amantes separados pela guerra, embora em algumas versões ela seja interpretada de maneira alegre. O amante retorna depois de vários anos e duvida da fidelidade de sua amada. Na lenda, o soldado amante retorna irreconhecível por estar gravemente machucado em conseqüência das batalhas. No texto, a donzela ouve a voz de um pássaro e reconhece seu amado quando o pássaro diz: “farina blanca per vós e per mi”. A partir disso, eles começam um diálogo que pode ser notado na adaptação de Llobet. Ao apresentar o tema em tessituras diferentes, é possível imaginar a conversa entre a donzela (que tem início no compasso 1) e o pássaro (início no compasso 24), que faz a voz do suposto amante.

\footnotetext{
${ }^{1}$ Festa litúrgica que se celebra no domingo, 50 dias depois da Páscoa.
} 
Voz da donzela:

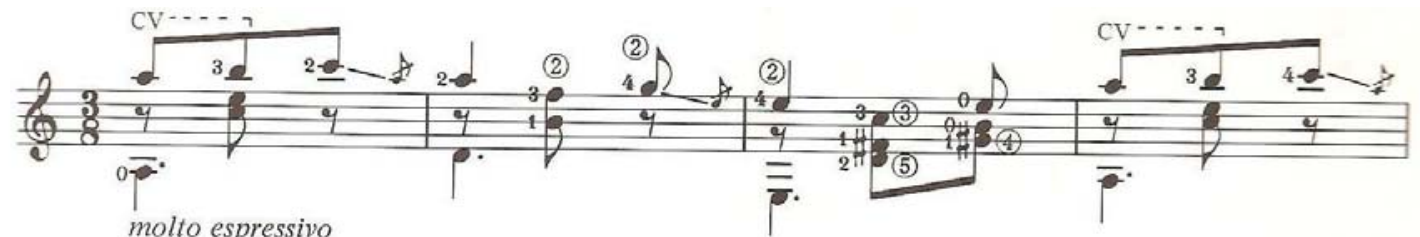

Voz do pássaro:

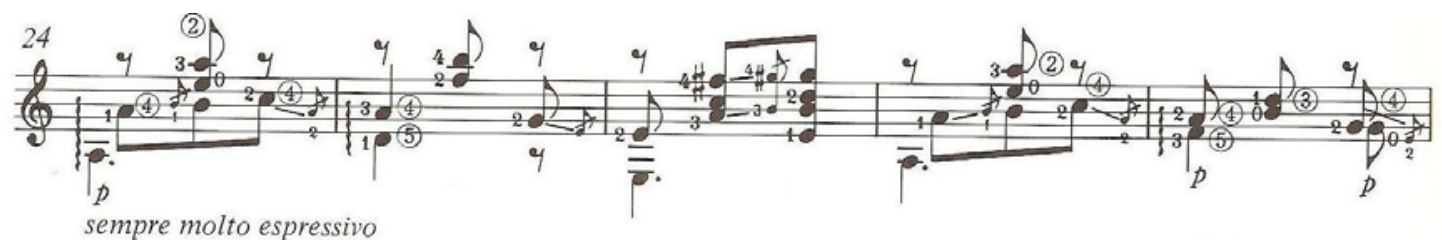

El Mestre
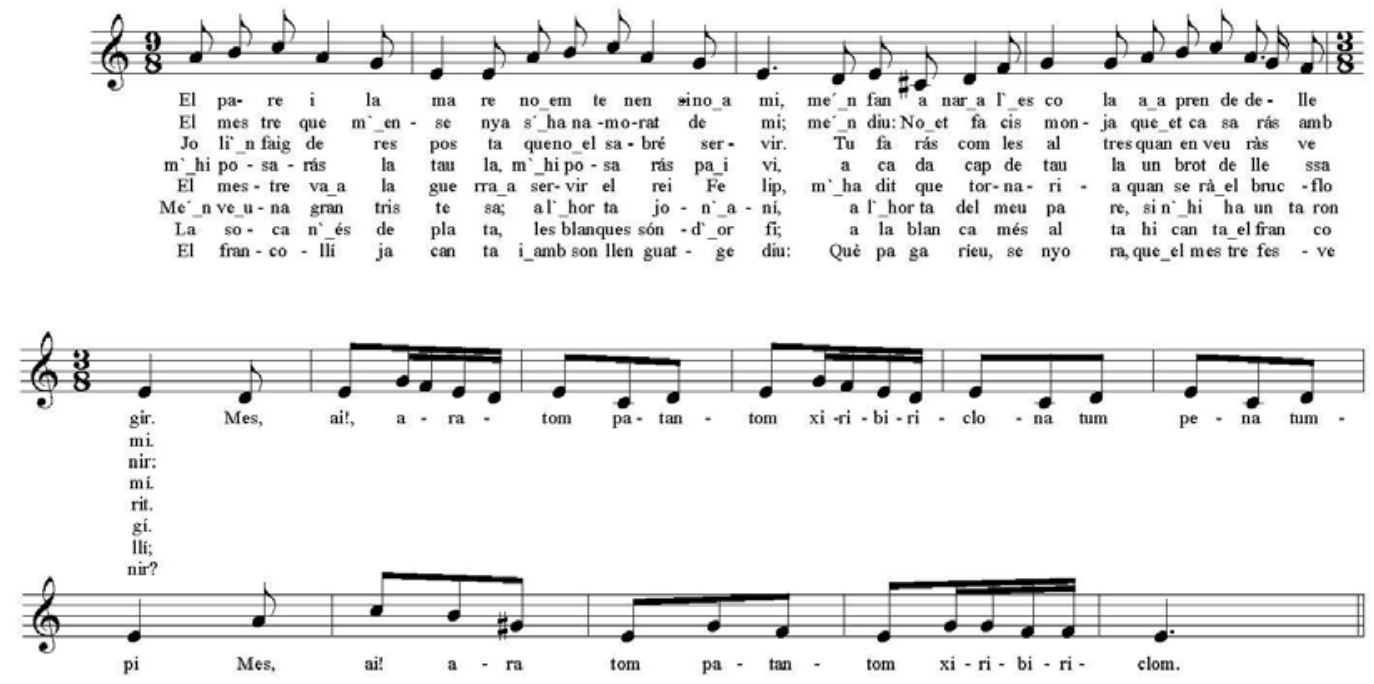

Copyright 1951 by Amades

A conclusão do texto não fornece nenhum detalhe de como acaba a história e deixa no ar se o final é feliz ou não, o que pode ter levado Llobet a concluir sua versão na dominante: 


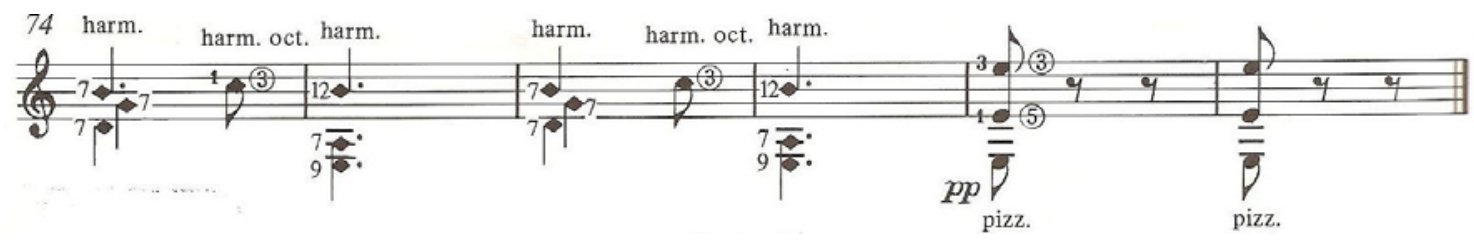

Llobet preferiu captar o sentimento de incerteza em seu arranjo, que soa

melancólico (PURCELL, 1989, vol. 2, p. iv).

A tradução livre da letra de El Mestre (O Mestre):

El pare i la mare

no em tenem sino a mi mén fan anar a l'escola

A aprendre de llegir.

Mês, ai!, ara tom

Patantom, xiribiriclona

Tumpena, tumpí.

Mes, ai!,ara tom

Patantom xiribiriclom.

El mestre que m'ensenya

s'ha enamorat de mi;

me'n diu: - No et facis monja

que et casaràs amb mi.

Jo li'n faig de resposta

que no el sabre servir.

- Tu faràs com les altres,

quan em veurás venir:

M’hi posarás la taula,

M’hi posarás pa i vi,

a cada cap de taula

um brot de llessamí.

El mestre va a la guerra

A servir el rei Felip,

$\mathrm{m}^{\prime}$ ha dit que tornaria

Quan será el bruc florit.

Mén ve una gran tristesa;

a l'horta jo n'aní,

a l'horta del meu pare,

Si n’hi ha un tarongí.

La soca n'és de plata, les branques són d'or fi; a la branca més alta, hi canta el francolí ${ }^{2}$;
Meu pai e minha mãe

têm somente a mim

me colocaram na escola

para aprender a ler.

Mês, ai!, ara tom

Patantom, xiribiriclona

Tumpena, tumpí.

Mes, ai!,ara tom

Patantom xiribiriclom.

O professor que me ensina

apaixonou- se por mim

me disse: - Não vá para o convento

pois você se casará comigo.

Eu respondi

que não saberia servi-lo bem

- Tu farás como as outras fazem

quando me ver retornar.

Você colocará a mesa para mim, me servirá pão e vinho, e em cada ponta da mesa um ramalhete de jasmin.

O professor vai à guerra servir o rei Felipe,

ele me disse que retornará

quando as flores se abrirem.

Uma grande tristeza me tomou

eu fui para o jardim

e no jardim de meu pai

existe uma laranjeira.

Sua base é de prata

seus galhos de ouro fino

lá no galho mais alto

está cantando um francolí;

\footnotetext{
${ }^{2}$ Pequeno pássaro colorido.
} 
El francolí já canta

I amb son llenguatge diu: - Què pagaríeu, senyora, que el mestre fes venir

- En pagaria Tolosa

La meitat de París

- Tolosa no n'és vostra

I París no és per mi.

$T^{\prime}$ en daria uma fonteta que en fa anar tres molins, l'un mol pebre i canyella, l'altre um sucre fi, l'altre farina blanca Per vós e per a mi. (AMADES, 1951, p. 183)
O francolí canta

E com sua linguagem diz:

- O que pagaria, senhora,

para seu amado voltar?

Eu pagaria Toulouse

e metade de Paris.

- Toulouse não é sua

E Paris não é para mim.

Eu te daria uma pequena fonte que faz funcionar três moinhos, um pouco de pimenta e canela, outro de açúcar fino outro de farinha branca para você e para mim. 


\section{EL MESTRE}

(1910)

Andante

MIGUEL LLOBET
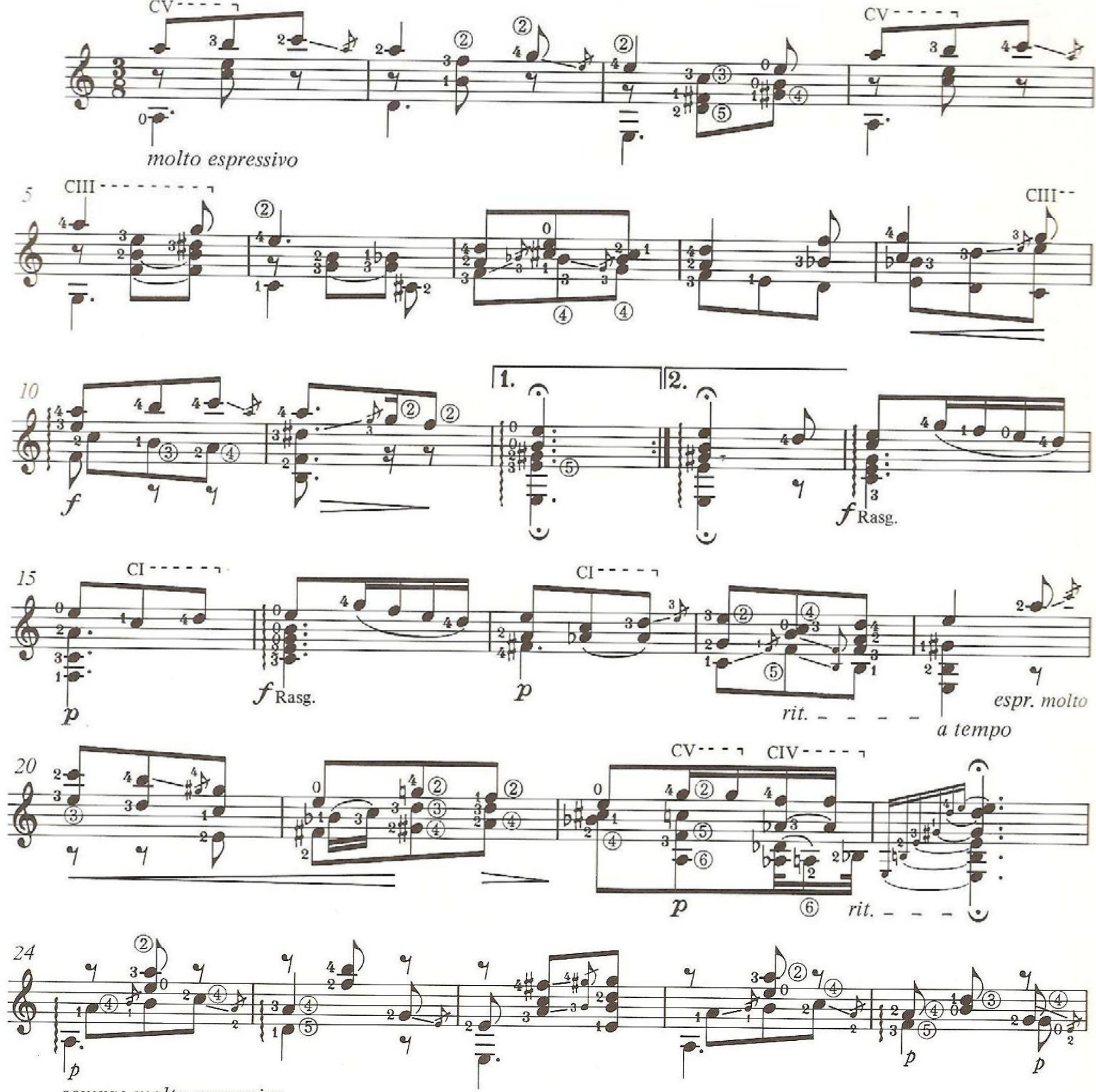

sempre molto espressivo

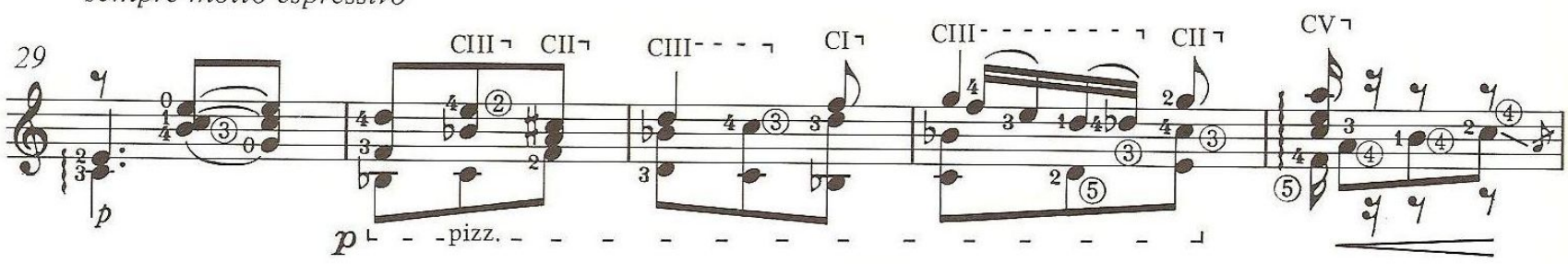



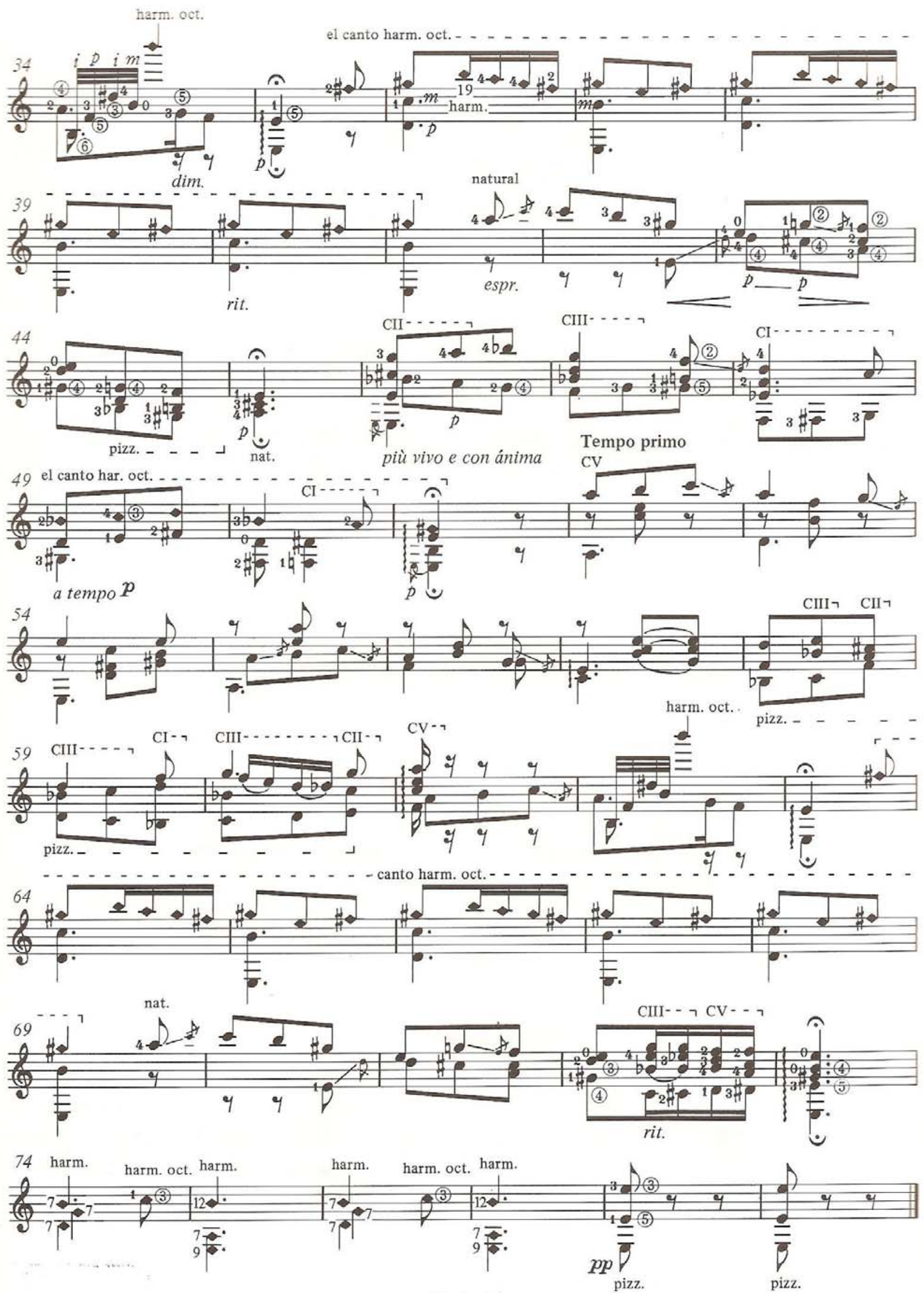


\subsubsection{La Nit de Nadal (El Desembre Congelat)}

Llobet usa como título principal para esta adaptação La Nit de Nadal. No entanto, ela surge no cancioneiro tradicional com o seu título secundário El Desembre Congelat, e é mais conhecida por esse título.

La Nit de Nadal possui uma outra melodia, como podemos notar (AMADES, 1951, p. 227):

\section{La Nit de Nadal}
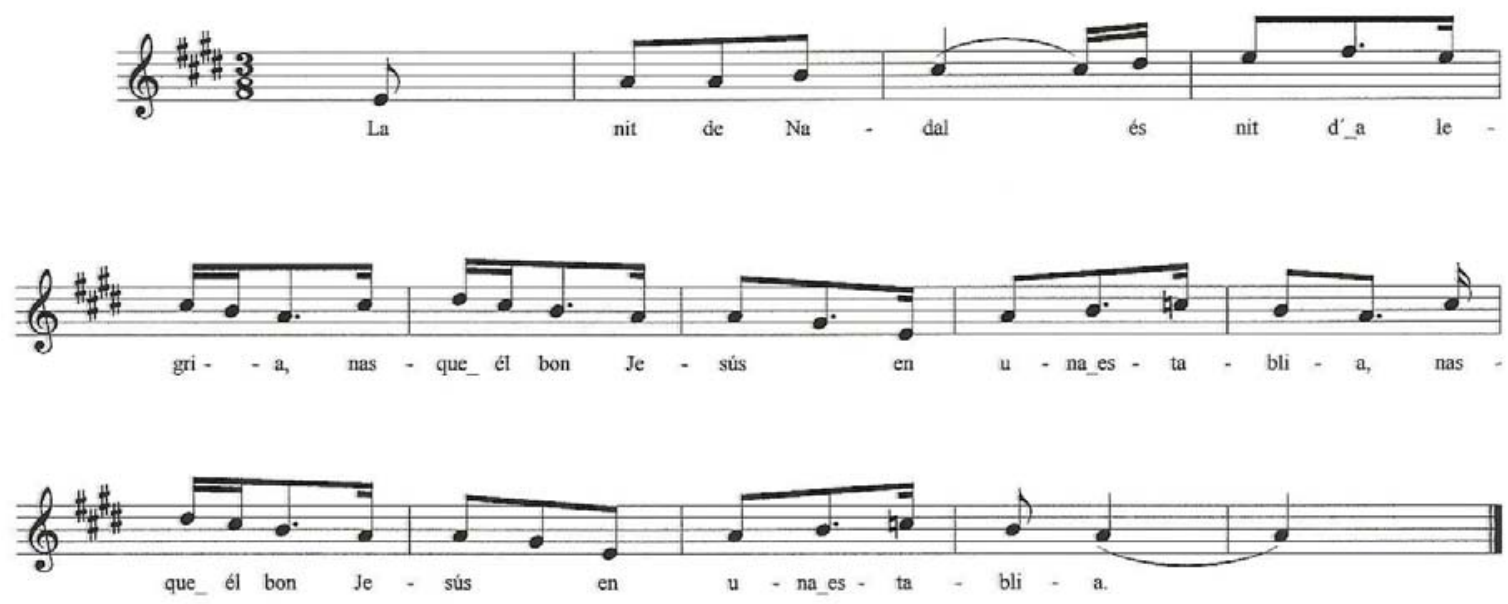

Copyright 1951 by Amades

El Desembre Congelat é uma das canções de Natal mais difundidas e apresenta um grande número de variações, tanto literários como melódicos. Encontra-se nos libretos de canções natalinas sem indicação de autor (AMADES, 1951, p. 223).

Foram encontradas diversas informações sobre esta canção. 
Sua melodia já era cantada na França do século XVI, aplicada a uma canção de taverna que celebra o vinho - Quan la mer Rouge apparut. É muito provável que a adaptação tenha sido feita durante o século XVIII, época em que prevalecia a moda francesa na Catalunha (AMADES, 1951, p.223).

Também no século XVIII, aparece pela primeira vez na coleção Nouveau livre de Noels pour l'orgue (1745), do compositor e organista Louis Claude Daquin ${ }^{86}$ (16941772) (ANGLÈS, 1954, p. 87).

O tema foi usado pelo compositor e diretor de orquestra catalão Joan Lamote de Grignon (1872-1949) em seu oratório La Nit de Nadal (1906) para vozes e orquestra (SUBIRÁ, 1953, p. 809).

El Desembre Congelat foi arranjada por Jordá (19--, partitura) para voz e piano $^{87}$, e gravada pela soprano Victoria de los Angeles junto com seu texto ${ }^{88}$.

A música litúrgica influenciou a melodia popular, como vimos anteriormente. O musicólogo Baldelló, ainda, afirma encontrar fragmentos desta melodia no canto gregoriano - Kyries e Sanctus no 5o. modo gregoriano - Tritus Auténtic. (BALDELLÓ, 1926, vol. 2, p. 386).

melodia popular

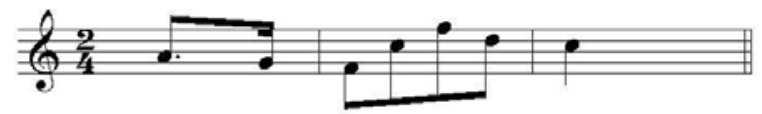

Sanctus de la missa IX del Kyriale

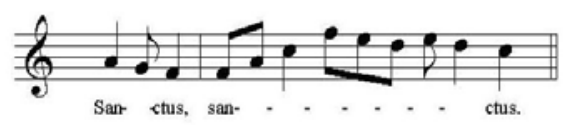

${ }^{86}$ Llobet fez um arranjo para duo de violões de uma obra de Daquin - Le Cou-Cou (PURCELL, 1989, vol. 4, p. 2).

${ }^{87}$ Cf. ANEXO A, p. 253.

${ }^{88}$ CANÇONS TRADICIONALS CATALANES. Victoria de Los Angeles with Geoffrey Parsons. Collins Classic, 1992 (Cd). 
melodia popular

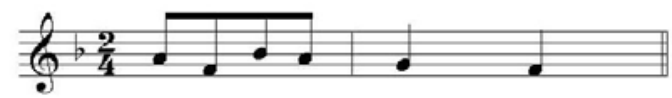

melodia popular

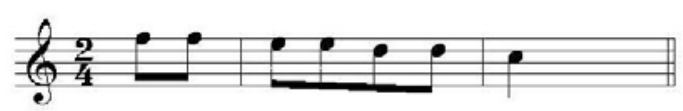

melodia popular

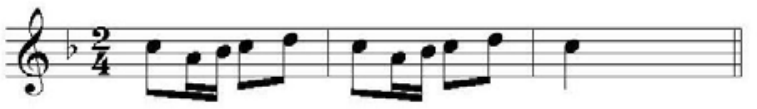

Sanctus de la Missa IX del Kyrie

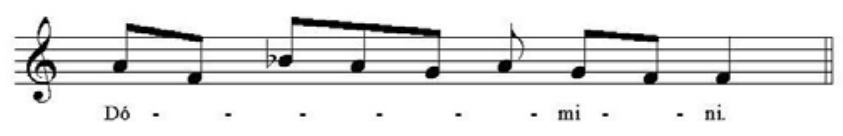

Kyrie de la Missa VIII del Kyriale

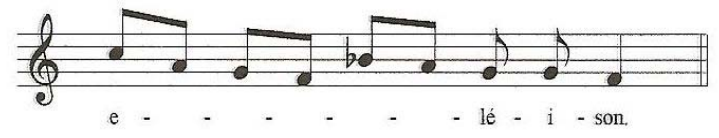

Kyrie de la Missa VIII del Kyriale

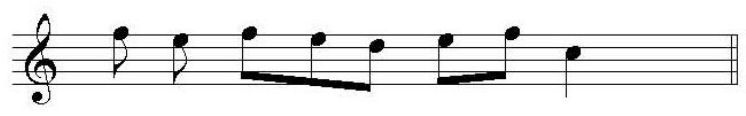

Kyrie de la Missa VIII del Kyriale

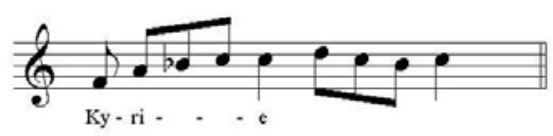

Llobet usou uma textura linear ao adaptar esta canção para violão e insere uma coda em formato de um côro no final da peça. 

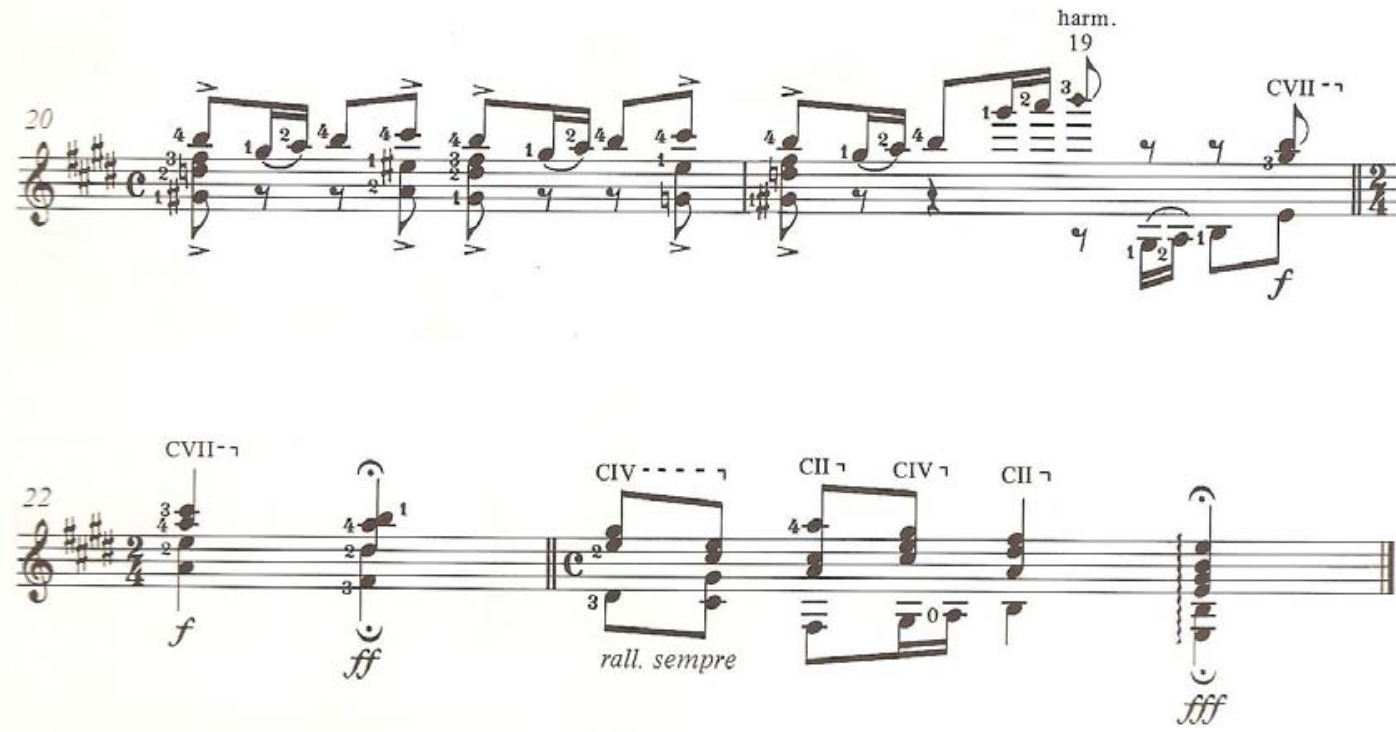

\section{El Desembre Congelat}

(La Nit de Nadal)
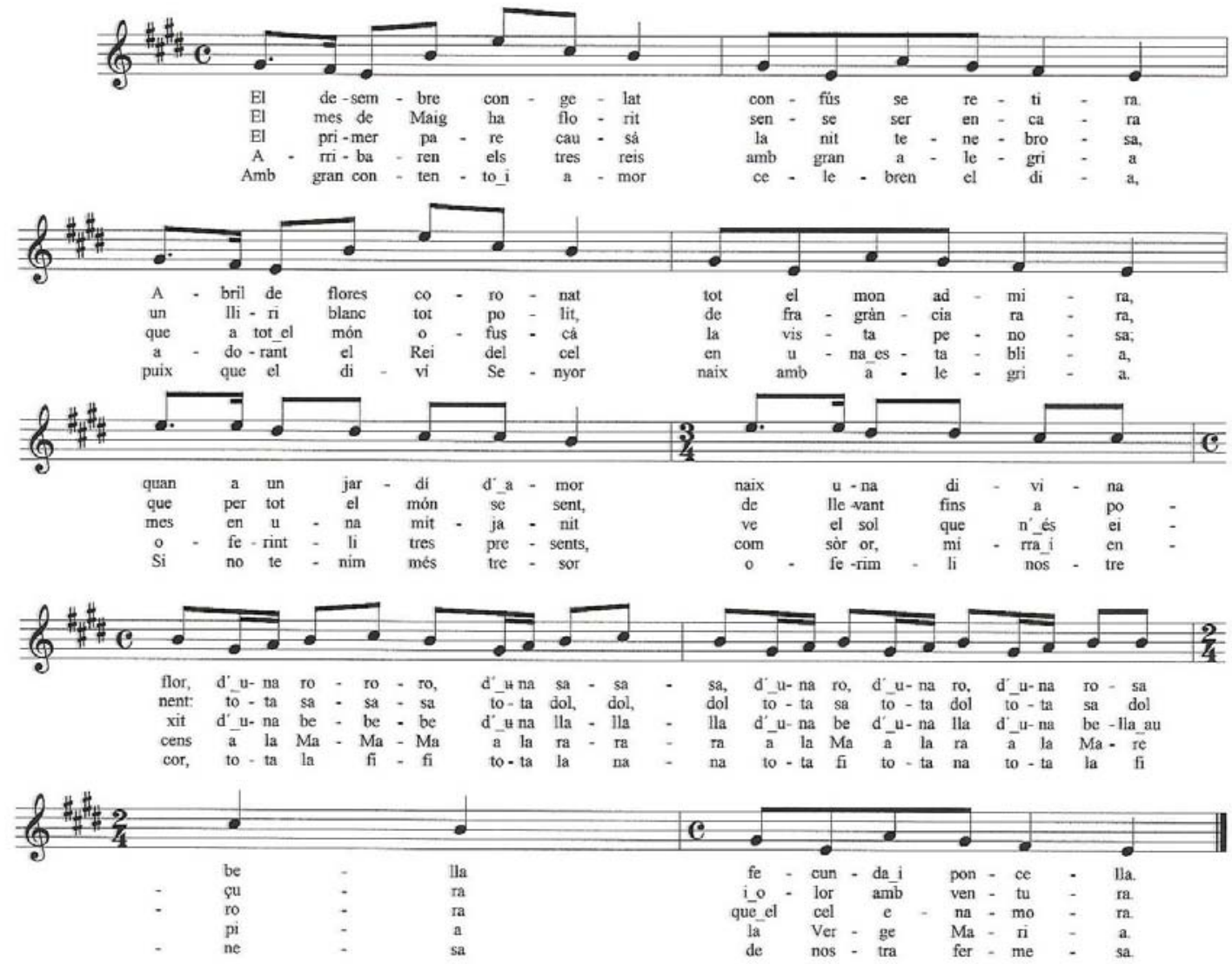


\section{A tradução livre de El Desembre Congelat (O Dezembro congelado):}

El desembre congelat Confós se retira.

Abril, de flors coronat, tot el món admira.

Quan en un jardí d'amor naix una divina flor.

d'una rosa bella

fecunda i poncella.

El mes de maig ha florit, sense ser encara, un lliri blanc y polit de fragrància rara, que per tot el món se sent, de llevant fins a ponent,

Tota sa dolçura

I olor, amb ventura.

Arribaren els tres Reis amb gran alegria. adorant el Rei del cel en una establia, oferint-li tres presents, que són: or, mirra i encens, a la Mare pia, la Verge Maria.

Amb contentament i amor celebren el dia, puix que el diví Senyor naix amb alegria.

Si no tenin més tresor, oferím-lhe el nostre cor, tota la finesa de nostra fermesa.

(AMADES, 1951, p. 223)
O frio Dezembro despede-se confuso. Abril coroado de flores, admirado por todo o mundo Quando em um jardim de amor nasce uma divina flor.

de uma rosa bela

de botão fecundo.

O mês de Maio floresceu, não completamente ainda, um lírio branco todo formoso de rara fragrância, que pode ser sentida por todos, do oriente ao ocidente, toda sua doçura e odor com ventura.

Chegaram os três Reis com grande alegria. adorando o Rei do céu num estábulo, oferecendo-lhe três presentes, que são: ouro, mirra e incenso, à piedosa mãe, a Virgem Maria.

Com contentamento e amor celebram o dia, pois o divino Senhor nasce com alegria.

Se não temos mais nenhum tesouro, ofereçamos-lhe nosso coração, todo o valor de nossa fé. 


\section{LA NIT DE NADAL}

(EL DESEMBRE CONGELAT)

(1918)
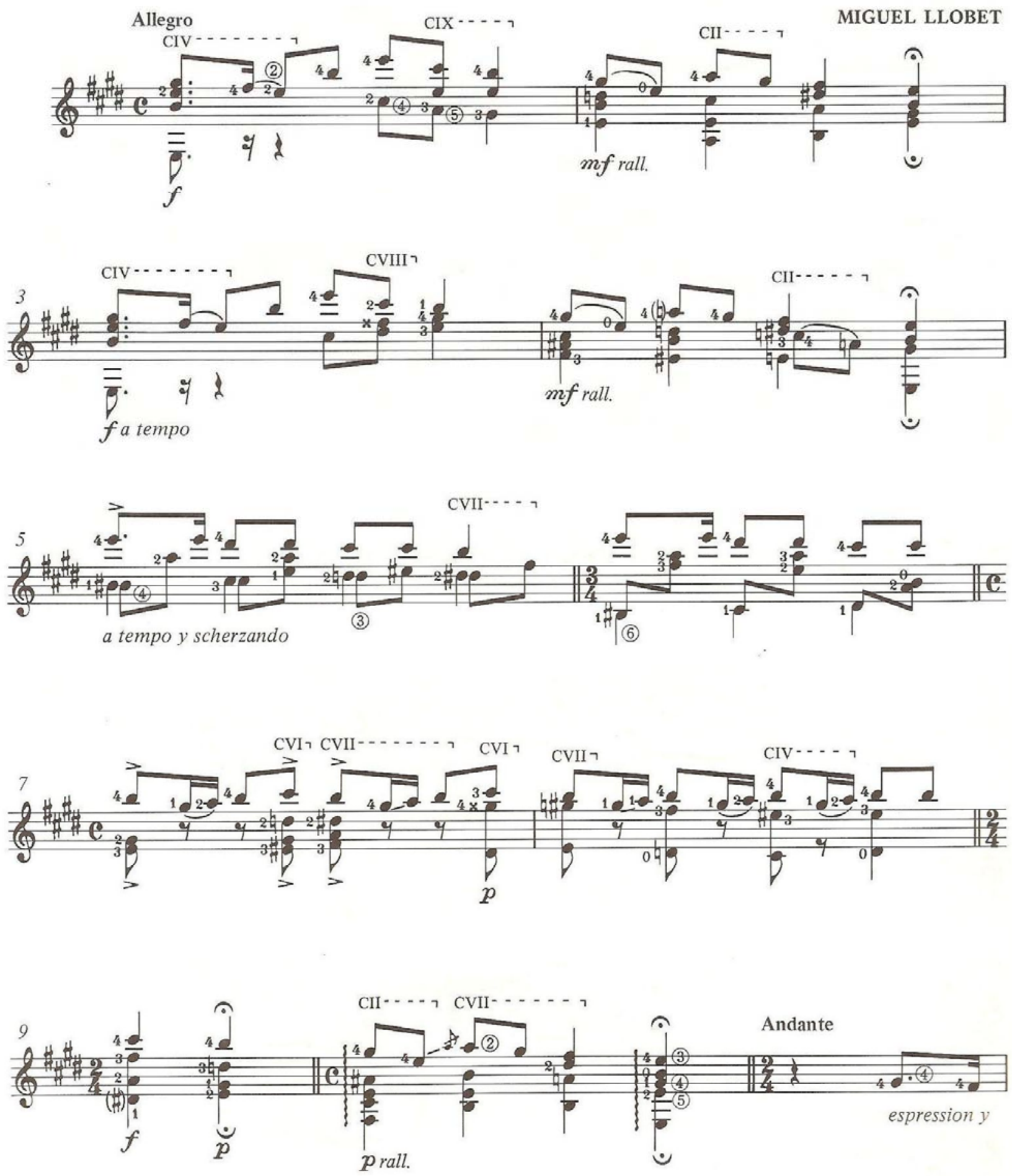

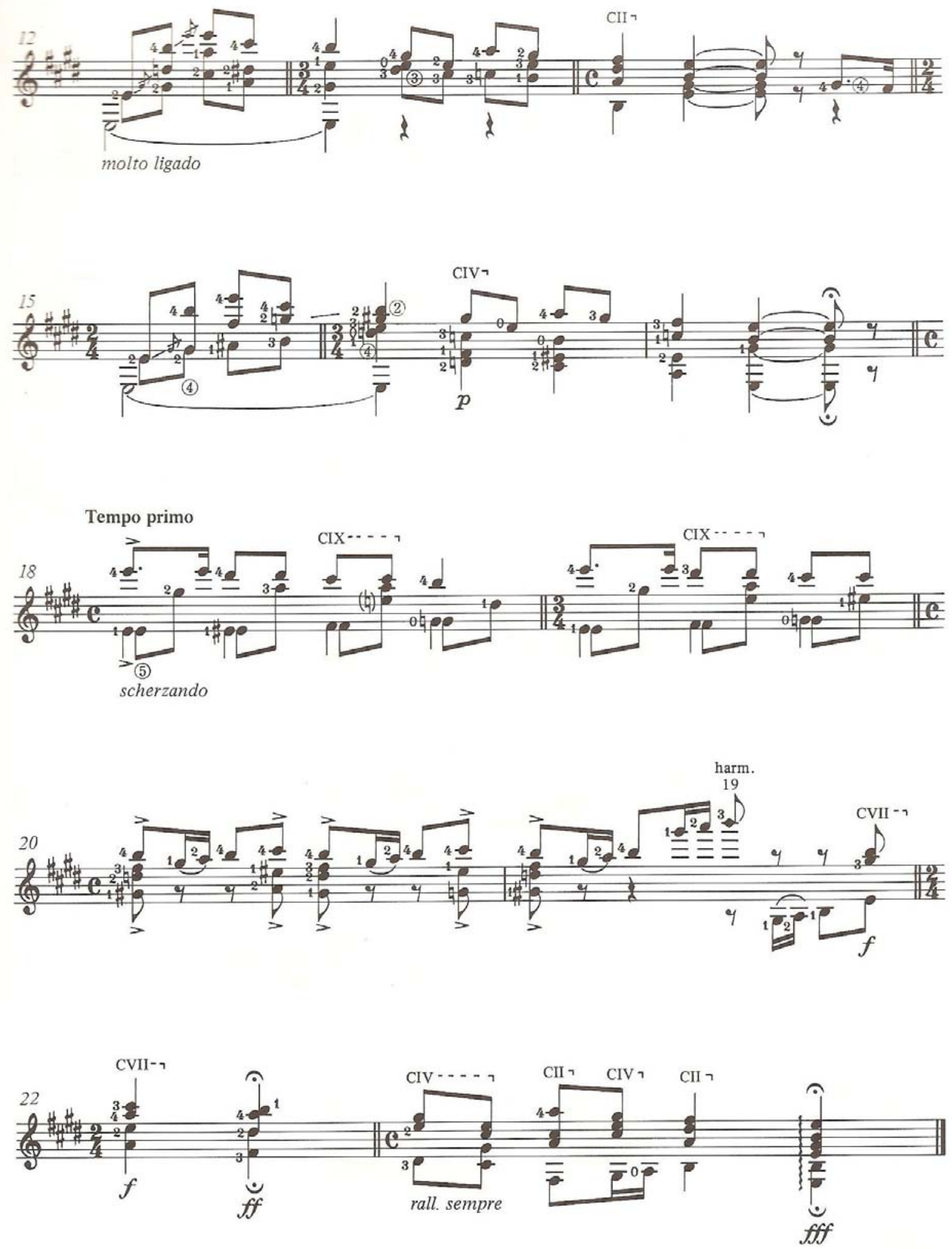


\subsubsection{La filadora}

Classificada como uma canção usada para conferir ritmo ao trabalho de fiar, pode ser encontrada também como canção infantil, muito utilizada nas escolas como música para brincar e alfabetizar. Seu texto é simples e já na primeira estrofe faz alusão à tradição têxtil catalã, muito popular no país. As canções infantis também participam das condições em volta do trabalho, servindo assim, para os dois objetivos.

Conhecida popularmente por "La gandula" (A preguiçosa) conta a estória de Maria, a filha do tecedor que não gostava de fiar. Na noite de Natal, enquanto todos faziam festa, ela fazia mal o trabalho que era levado com muita qualidade o ano inteiro. Nesta noite, Maria encontra seu galante pretendente e "tece" seu futuro amoroso.

O tecido que resultava do trabalho de fiar doméstico tinha qualidade superior ao industrial, apesar de ser chamado de "trapo de casa".

O costume de fiar era comum na Europa, e o povo tinha o hábito de cantarolar melodias para espantar a monotonia deste trabalho. As canções giravam em torno do movimento que se fazia com os pés ao pisarem no pedal, imprimindo assim o ritmo e, para não parar, trocava-se constantemente o fio.

A dança que se originou deste costume também levou o nome de "La Gandula" e fazia parte, junto com a canção, do programa de teatro rústico que se fazia durante o carnaval. Enquanto um par girava, um personagem que simulava ser o tecedor observava Maria tecer da sua maneira e com movimentos exagerados, satirizava a cena que arrancava risos da platéia. A música da gandula passou a ser associada à comédia e, mais uma vez, o cotidiano é transformado em arte (AMADES, 1951, p. 705). 
Llobet realizou esta adaptação em 1918 usando a tonalidade de Mi Maior e andamento Allegro scherzando. No cancioneiro tradicional ela aparece na tonalidade de Fá Maior escrita em 3/4 e com andamento sugerido semínima pontuada = 63.

\section{La filadora}

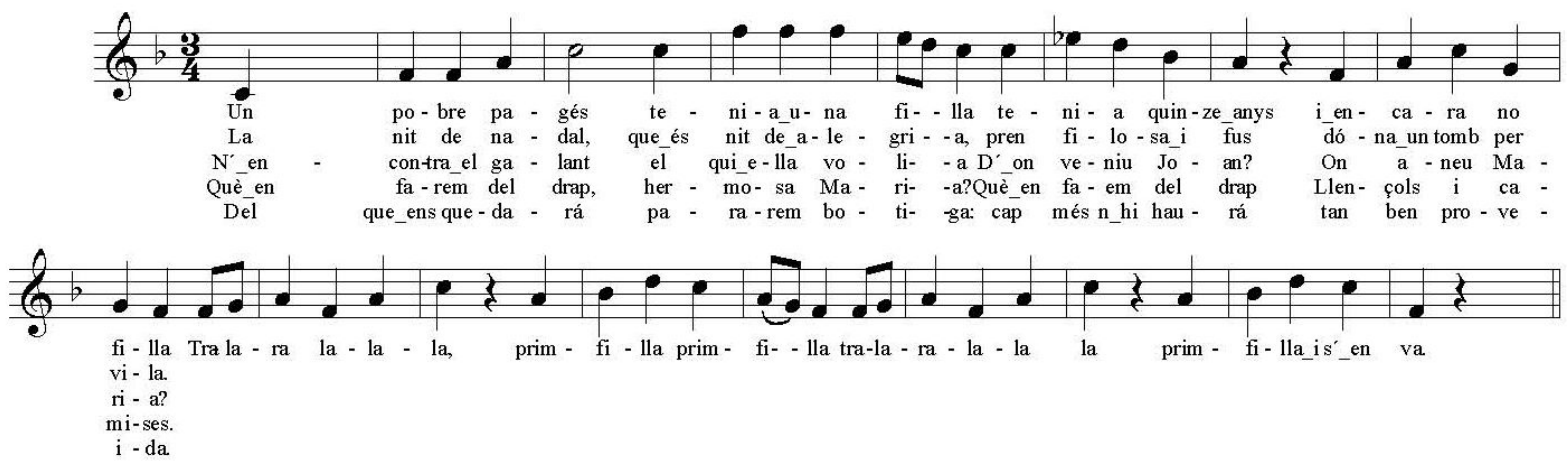

Copyright 1951 by Amades

O caráter de dança é bem descrito nesta adaptação de Llobet. O ritmo constante do acompanhamento reforça a idéia do sentido do texto e da dança.

Uma outra referência que encontramos desta canção está no arranjo para coro a quatro vozes de Lluís Jordá (19--, p. 10, partitura) e no arranjo de Marraco (19--, p. 9, partitura) ${ }^{89}$.

Como referência fonográfica recomendamos a soprano Victoria de los Angeles $^{90}$.

Seguimos com a tradução livre de La Filadora (A fiadora):

\footnotetext{
${ }^{89}$ Cf. ANEXO A, p. 254 e 255.

${ }^{90}$ CANÇONS TRADICIONALS CATALANES. Victoria de Los Angeles with Geoffrey Parsons. Collins Classic, 1992 (Cd).
} 
Um pobre pagés tenia uma filla, tenia quinze anys I encara no fila. Traralá, la, la, la primfila, primfila Traralá, la, la, la primfila i sén va.

La Nit de Nadal, que és nit d'alegria, pren filosa i fus, dóna un tomb per vila.

N'encontra el galant El qui ella volia:

- D’on veniu, Joan?

Traralá...

- On aneu, Maria?

Què em farem, del drap, formosa Maria?

Què em farem, del drap,

- Llençols i camises

- Traralá...

Del que ens quedará pararem botiga:

cap més no n’hi haurá tan bem proveida

Traralá...

(AMADES, 1951, p. 705)
Um pobre camponês

tinha uma filha, tinha quinze anos

E ainda não sabia fiar

Traralá, la, la, la

Fia fininho, fia fininho

Traralá, la, la, la

Fia fininho e pode ir embora.

A noite de Natal, é noite de alegria, pega a roca e fia, dá uma volta na vila.

Ela encontra o rapaz

o que ela queria

- De onde vem, João?

- Onde vai, Maria?

Traralá...

Que faremos do retalho?

Formosa Maria?

Que faremos do retalho?

- Lençóis e camisas.

Traralá...

Do que sobrar abriremos uma loja

não haverá outra tão bem provida.

Traralá... 


\section{LA FILADORA}

(1918)

MIGUEL LLOBET
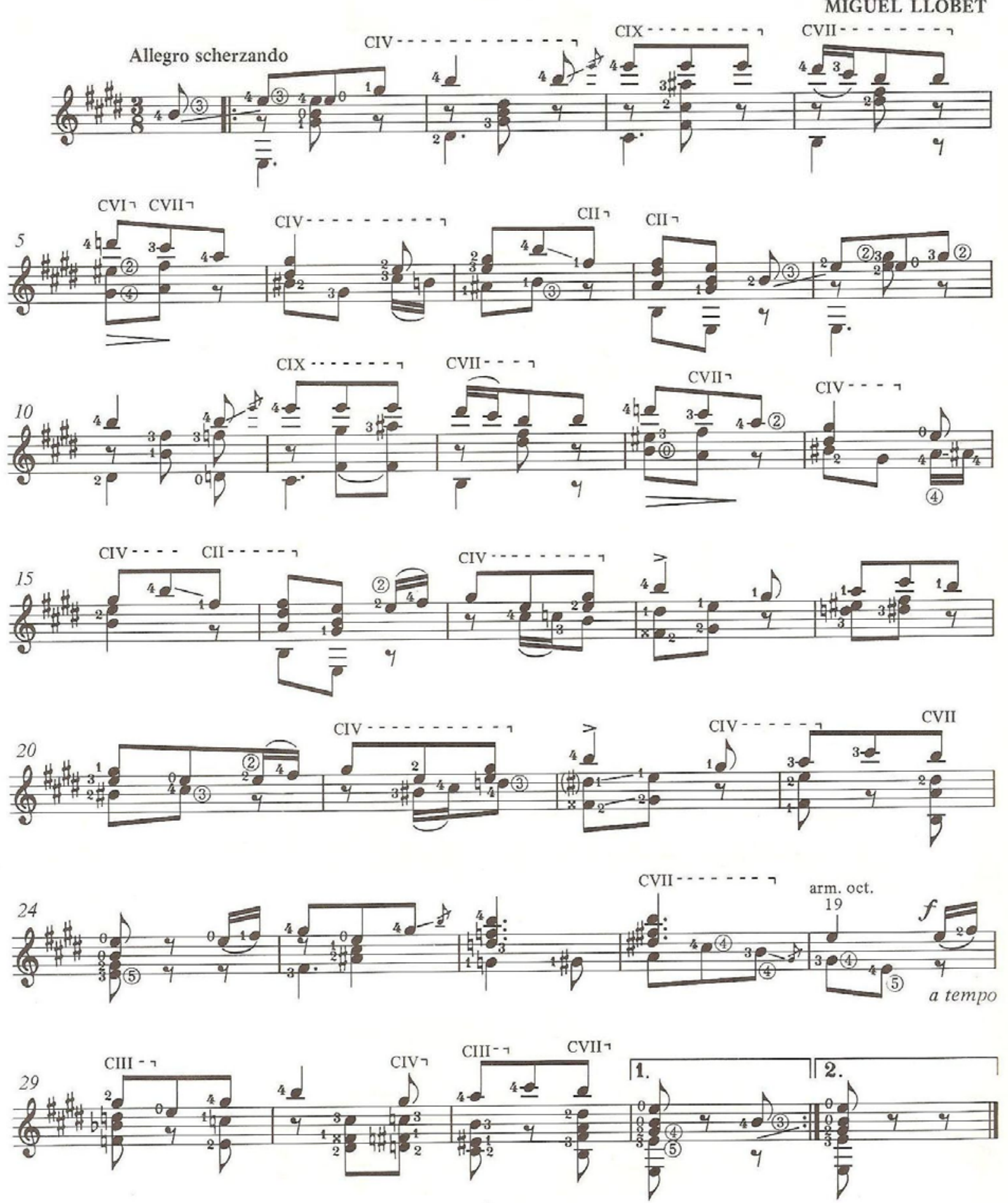


\subsubsection{La Pastoreta}

A adaptação desta melodia foi realizada durante o último ano da Primeira Guerra Mundial (1918) ${ }^{91}$, período em que realiza turnês na América do Sul: Uruguai, Chile, Bolívia e Argentina.

Llobet explora algumas possibilidades técnicas neste arranjo. Grondona afirma:

“La Pastoreta é um verdadeiro tratado de como movimentar a mão esquerda.”(informação verbal) $)^{92}$

Popularíssima, muito dançada e cantada, inclusive no repertório infantil. Apesar de sua grande difusão, não oferece variação de texto e melodia.

Como vimos anteriormente, esta melodia se classifica na categoria de canções de celebração, onde o povo se reúne para festejar e dançar a sardana. Nestes bailes, é comum a presença de uma banda formada de instrumentos típicos - a cobla. A cobla é formada pelos seguintes instrumentos: flaviol (caramillo), tamboril, tiples (xirimias) de tessitura aguda, tenoras de tessituras centrais e graves, cornets, fiscornos (flugelhorns), trombones e mais recentemente baixo. Outra fonte de pesquisa cita a gralla (dulzaina), gaita, flaviol e tamboril usados na sardana mais antiga. O mesmo músico toca o flaviol e o tamboril. O flaviol é um instrumento agudo tocado apenas com três dedos da mão esquerda, enquanto tocava o pequeno e sonoro tamboril com a mão direita (figura 5). A gralla entoava o tema principal da dança e o flaviol ornamentava a melodia (PAHISSA, 1945, p. 148).

La Pastoreta é dançada com a sardana curta, sem acumulação de bailarinos que a dança original tipicamente possui. A estrutura melódica da sardana curta combina

\footnotetext{
${ }^{91}$ Grondona afirma que a data de sua concepção foi 1905, em duas ocasiões diferentes - uma em Paris (Abril) e outra em Barcelona (Agosto) (GRONDONA, 2006a, encarte de Cd).

${ }^{92}$ Entrevista concedida em 22 de Abril de 2007, em Tatuí.
} 
colcheias e semínimas marcadas pelo tamboril em 2/4. O flaviol anuncia o começo da dança com uma breve melodia em 6/8 (PAINE, 1989, p. 59).

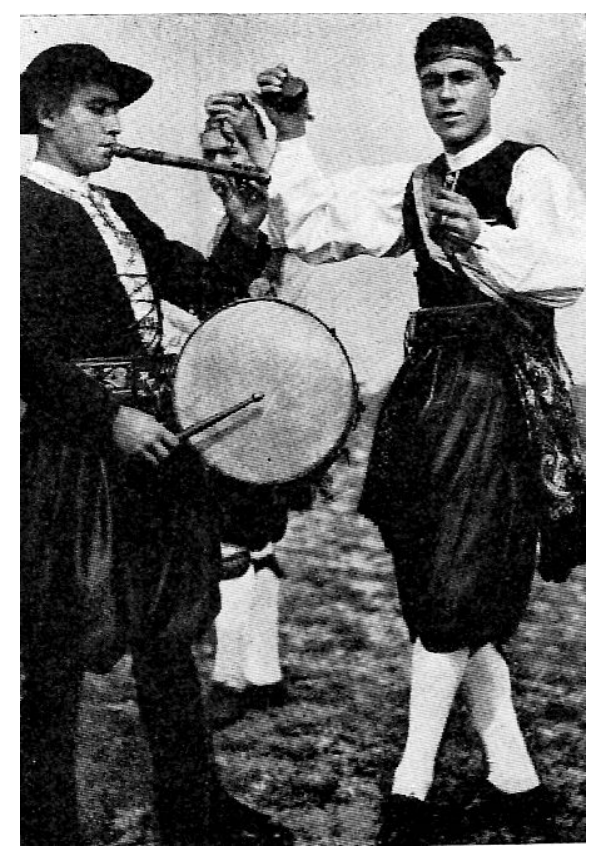

Figura 6. Músico tocando o flaviol e o tamboril

No arranjo de Llobet é possível marcar os baixos com a função de tamboril, uma vez que seguem marcando o ritmo em 2/4 enquanto a melodia se desenvolve.

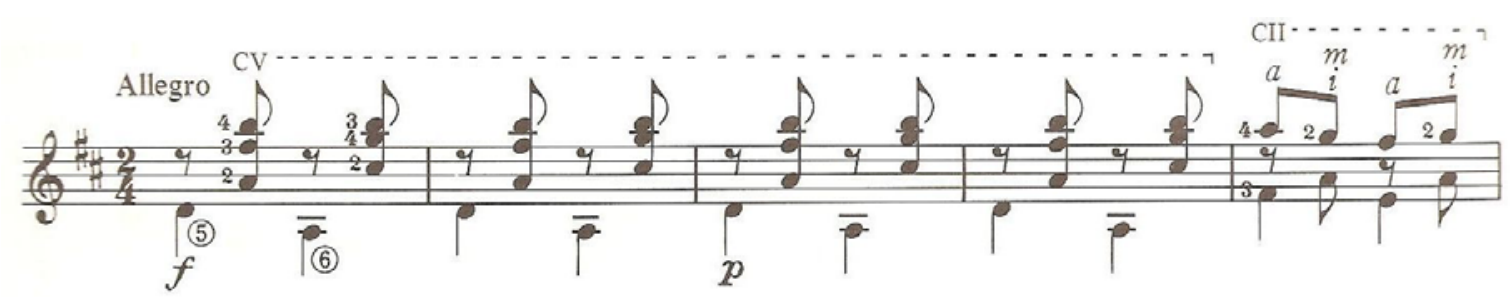

Como vimos no capítulo 1, a música religiosa influenciou a melodia popular. O musicólogo Francesc Baldelló (PUJOL, vol. 2, p. 385), reconhece esta melodia no canto gregoriano, 5º Modo (Tritus Auténtic) - tônica: fa, dominante: do. 
melodia popular

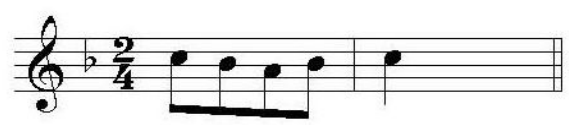

melodia popular

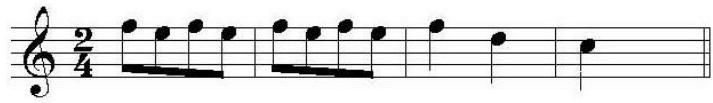

Sanctus de la Missa XVII del Kyriale

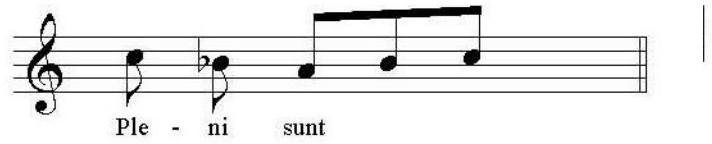

Kyrie de la Missa VIII del Kyriale

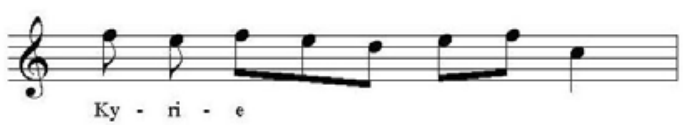

Uma outra referência que encontramos está no arranjo para voz e piano de Lluís

Jordá (JORDÁ, 19-- p. 5, partitura) ${ }^{93}$.

${ }^{93}$ Cf. ANEXO A, p. 256. 


\section{La Pastoreta}
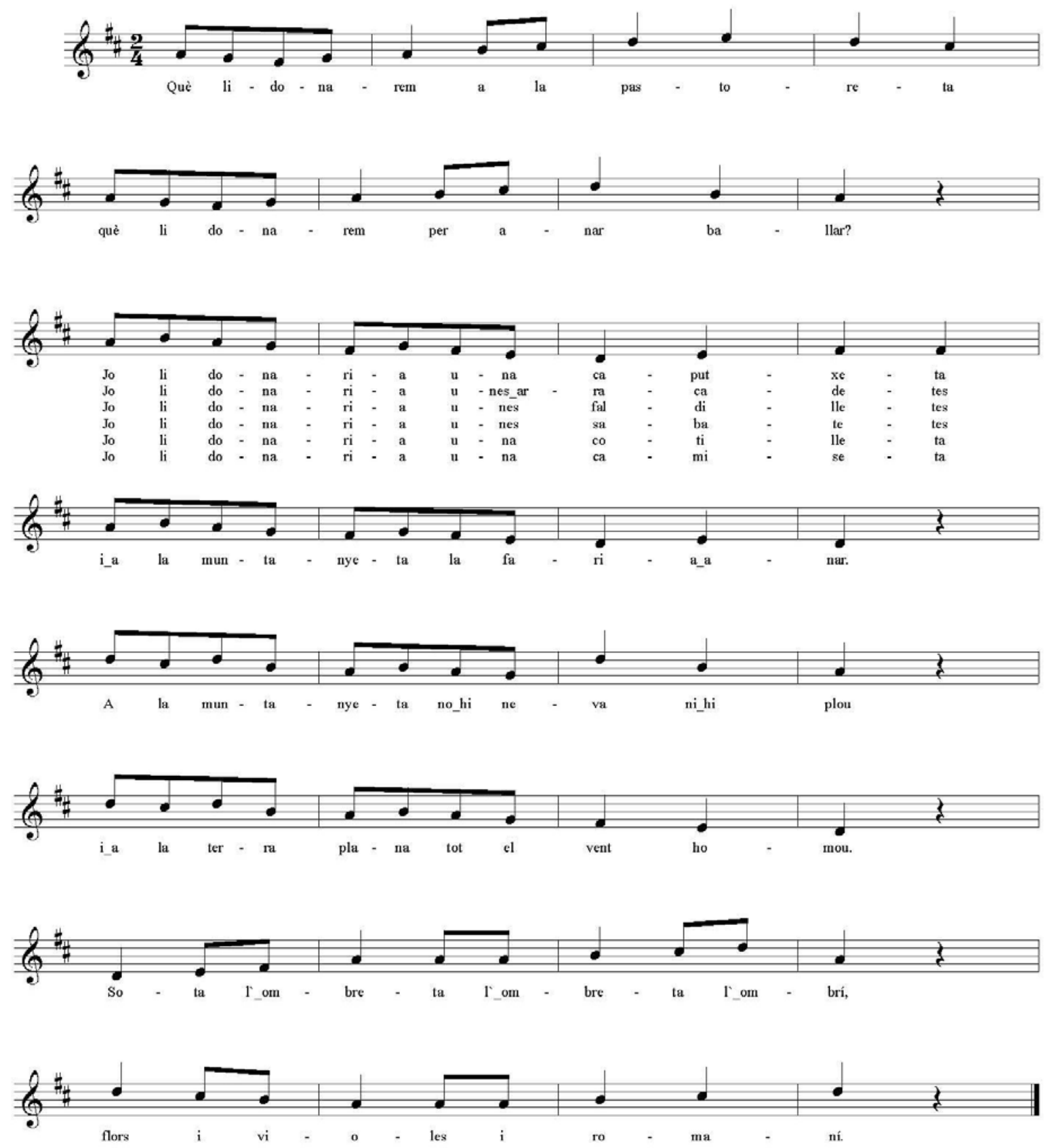

Copyright 1951 by Amades 


\section{A tradução livre da letra de La Pastoreta (A Pastorinha):}

Que li donarem,

a la pastoreta

Que li donarem

per anar a baillar?

- Jo li donaria uma caputxeta

i a la muntanyeta la faria anar.

A la muntanyeta no hi neva

i no plou

i a la terra plana tot el vent ho mou.

Sota l'ombreta, l'ombreta, l'ombrí, flors i violes i romaní.

- Què li donarem,

a la pastoreta?

Què li donarem

por anar a ballar?

- Jo li donaria unes arracadetes.

- Jo li donaria unes faldilletes.

- Jo li donaria unes sabatetes.

- Jo li donaria una cotilleta.

- Jo li donaria una camiseta.

(AMADES, 1951, p. 189)

(AMADES, 1951, p. )
Que daremos

à pastorzinha

- Que daremos

para ela dançar?

- Eu lhe daria um chapeuzinho e à pequena montanha a levaria.

Na pequena montanha não neva nem chove

e na terra plana o vento tudo movimenta.

Debaixo da a sombra,

Flores, malvas e alecrim.

- Que daremos

à pastorinha?

Que daremos

para ela dançar?

- $\quad$ Eu lhe daria um par de brincos.

- Eu lhe daria umas saias.

- Eu lhe daria uns sapatos.

- $\quad$ Eu lhe daria um espartilho.

- Eu lhe daria uma camiseta. 


\section{LA PASTORETA}

(c. 1918)

MIGUEL LLOBET
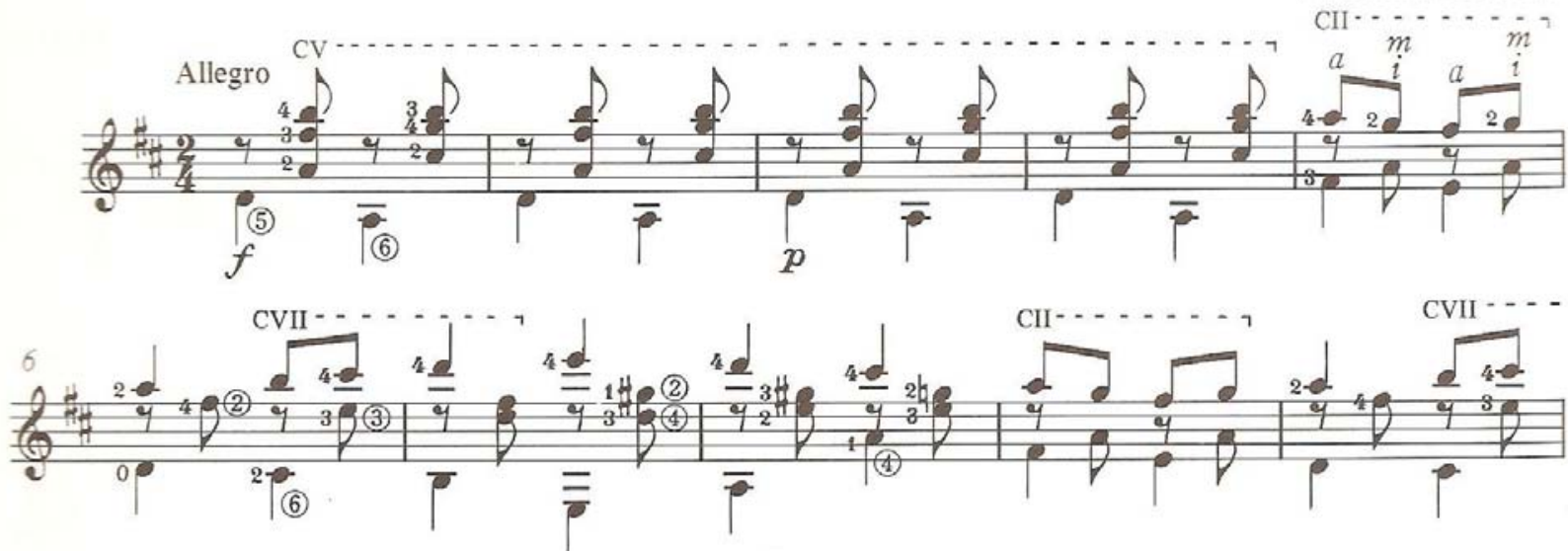

(2)

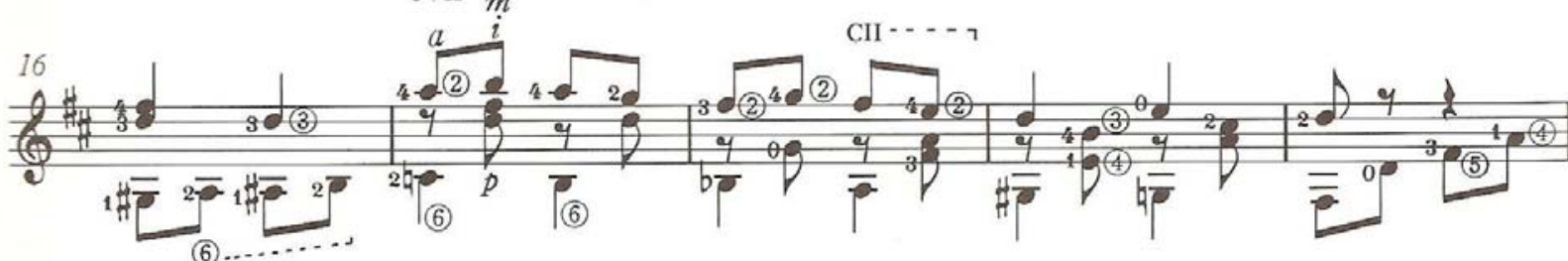

(6)..........

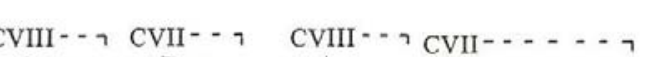
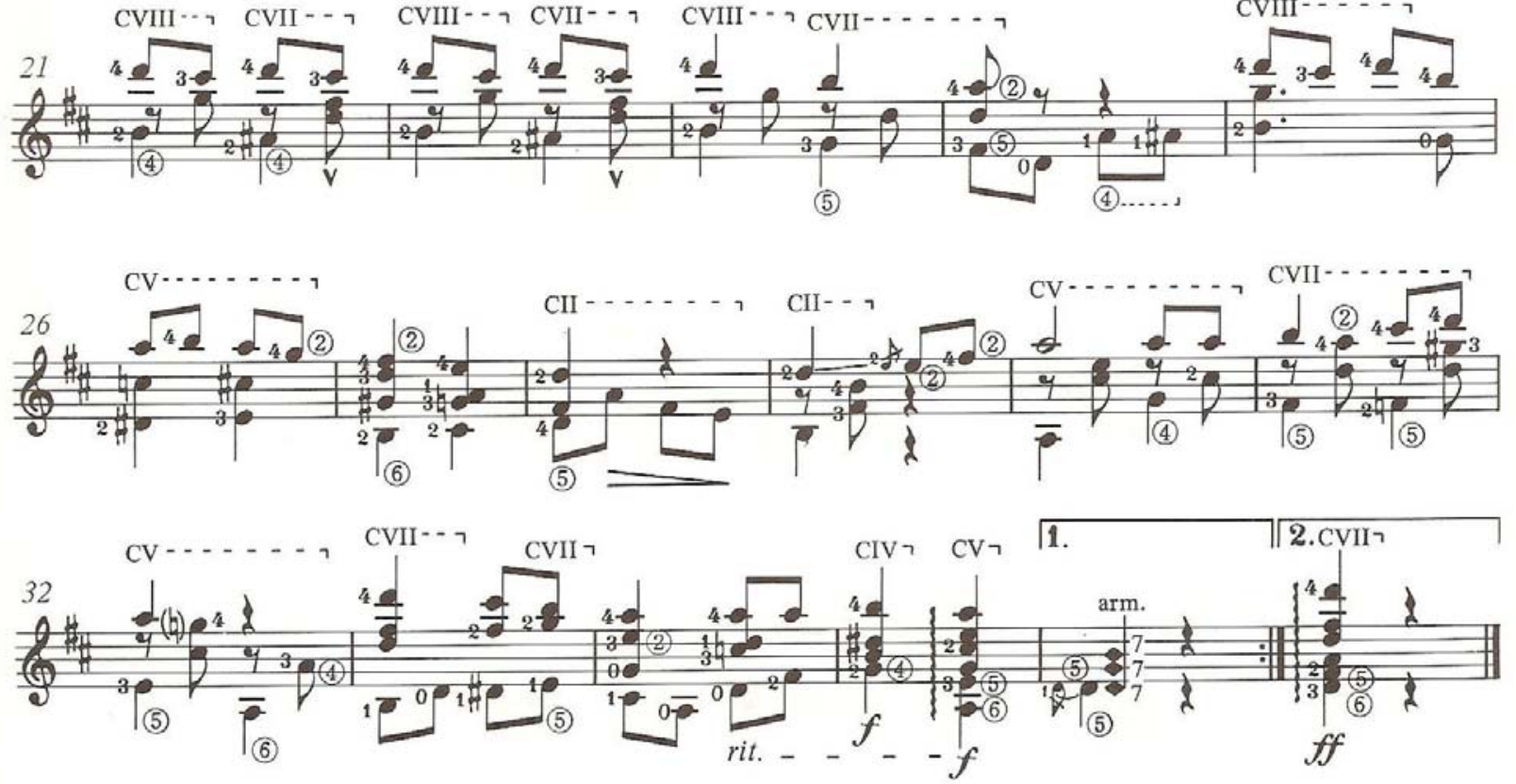


\subsubsection{La Presó de Lleida}

Adaptada em 1920, Llobet mais uma vez explora o timbre e a troca de naipes. O tema inicia no baixo em harmônicos e acompanhamento em acordes de textura linear.

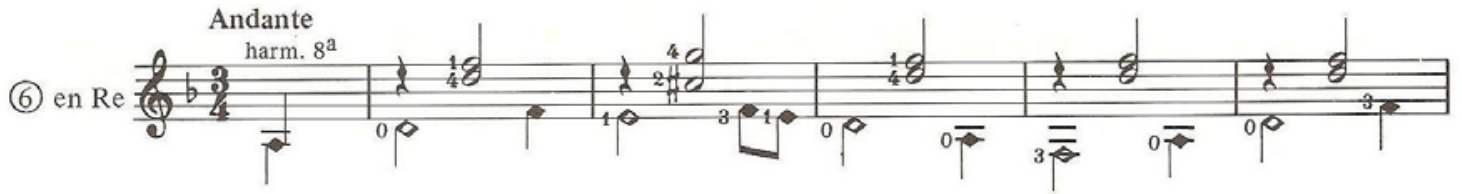

Depois de expor o tema repete mudando a textura, usando acordes na região da tonalidade principal - ré menor - para descrever a melodia (compasso 19).
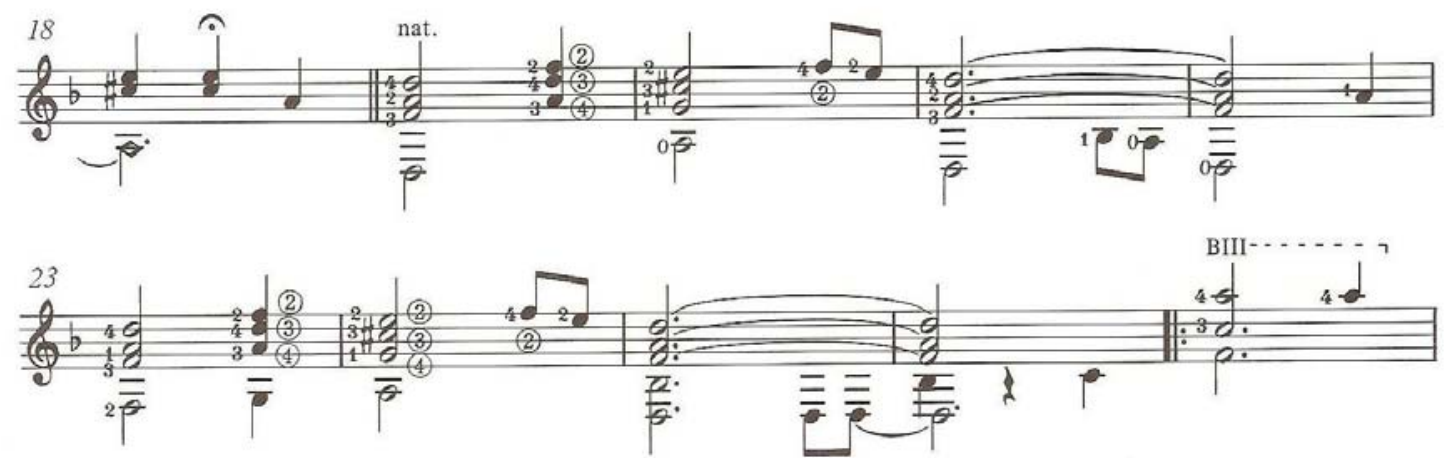

O procedimento dos baixos em harmônicos também foi utilizado por Agustin Barrios (1885-1944). Não sabemos até que ponto Llobet estabeleceu contato com Barrios, mas notamos uma forma de escrita semelhante na El Sueño de la Muñequita ${ }^{94}$.

Segundo Amades (1951, p. 598), esta melodia é uma das preferidas e mais difundidas do cancioneiro catalão. Portanto, sua grande difusão faz com que o texto ofereça uma grande diversidade de variações nos detalhes sem alterar o argumento. Sua melodia pode ser interpretada de modo melancólico, mas adapta-se muito bem à dança.

\footnotetext{
${ }^{94}$ Cf. STOVER, R. (org). The Complete Works of Agustin Marrios Magoré, vol. 1 e 2. Pacific: Mel Bay, 2003. vol. 1, p. 134 e 135. Vol. 2, p. 211 a 213 (partitura).
} 
Outra fonte de pesquisa indica variações de texto, melódicas e de andamento (PUJOL, 1926, vol. 2, p. 128 e p. 141).

Seu texto descreve uma lenda que ocorre na cidade de Lleida (Lérida), cidade natal de violonistas representativos como Domingo Bonet e Emilio Pujol.

Na maioria das versões a protagonista encontra-se na prisão de Lleida, mas outras apresentam regiões da Catalunha como Toledo e Tortosa, e nas versões maiorquinas, Nápoles. Nenhuma das versões especifica o tipo de delito cometido pelos criminosos, mas há uma referência de incêndio em Garriga (região de vegetação típica “garric”), Conflent e Roselló - comarcas da Catalunha perto dos Pirineus - no verso: “Ai, filla, Margarida/Aixó no pot ser/Han cremat la Garriga/Conflent i Roselló//.”95 (La Presó de Lleida, AMADES, 1951, p. 597)

Como vimos anteriormente, os criminosos que se encontrava encarcerados tinham o costume de cantar melodias para espantar a melancolia, e possivelmente, para encantar alguns ouvintes com a finalidade de serem absolvidos.

Nesta canção, a filha do barão pede que um dos criminosos seja poupado da punição, cativada pelo encanto de uma canção que os incendiários cantavam na prisão de seu pai: “Canteu, canteu, els presos/ canteu-ne la cançó/ canteu, canteu, els presos/ que mén captiva el so/.”96 (La Presó de Lleida, AMADES, 1951, p. 597)

Sabendo que morreria pendurado numa forca, pede que seja pendurada junto com ele. Já que não pode salvar aquele que a conquistou com a bela canção, prefere a morte do que deixá-lo: “Ai, pare, lo meu pare/ no em mateu l'aimador/ Ai, pare, lo meu pare/ Pengeu-me'n a mi i tot”. 97 (La Preso de Lleida, AMADES, 1951, p. 597)

No entanto, o barão não se comove e, ao se aproximar o Santo Domingo, todos seriam enforcados. Antigamente, por respeito à Páscoa, não se realizavam

\footnotetext{
${ }^{95} \mathrm{Ai}$, filha, Margarida/Assim não pode ser/Queimaram a Garriga/Conflent e Roselló.

${ }^{96}$ Cantem, cantem, presos/Cantem a canção/Cantem, cantem, presos/que o som me cativa.

${ }^{97} \mathrm{Ai}$, pai, meu pai/não mate o amado/Ai, pare, meu pai/Pendure-me junto com eles.
} 
enforcamentos até que se passassem os dias santos - a Quaresma. Assim, o barão avisa que o dia propício para a punição aproximava-se e a justiça não poderia esperar mais: “Dels presos que allá canten/ digau, què em fareu vós?/S’acosta el sant diumenge/ els penjaram a tots”. ${ }^{98}$ Muito curioso é o pai da donzela fazer cordas muito resistentes para serem utilizadas no enforcamento dos presos. Este detalhe mostra que ele se certificou de que não se fizessem cordas fracas: “Ai, filla, Margarida/ Será el primer de tots/ les cordes són filades/ que ens costen a pes d’or.”99 (AMADES, 1951, p. 597)

Alguns encarregados de confeccionarem cordas, naquele tempo, faziam cordas que não eram suficientemente fortes para agüentar o peso de um corpo. No momento em que se pendurava o corpo do criminoso, a corda arrebentava, salvando o indivíduo da morte. Acreditava-se que os inocentes eram salvos assim, com o rompimento da corda por providência divina. A pena era encarada como um erro da justiça e o criminoso era absolvido e restituído à sociedade. Quando era da vontade do povo que o preso fosse poupado, era usada uma corda falsa, para satisfaze a vontade da opinião pública. Os familiares ofereciam cordas falsas a fim de salvar os seus.

Tudo isso deu origem ao refrão Amargar la corda a casa del penjat (Esconder a corda na casa do pendurado), equivalente a esconder o delito na própria casa do criminoso.

Portanto, para que os presos não fossem salvos, o barão da canção vigiou pessoalmente a confecção da corda que enforcaria os incendiários de sua prisão - a Prisão de Lérida.

A letra original desta canção é extensa. Portanto, com base em fontes fonográficas, selecionamos uma parte de suas estrofes para a tradução livre para o português:

\footnotetext{
${ }^{98}$ Dos presos que lá cantam/diga, que vos fará?/Se aproxima o Domingo/serão todos enforcados.

${ }^{99} \mathrm{Ai}$, filha Margarida/Será o primeiro de todos/as cordas estão prontas/que custaram peso de ouro.
} 
A la ciutat de Lleida

n’hi ha una presó,

de presos mai ni manquen

petita, bonica,

prou n’hi há porta el baró, lireta, liró.

Cent i cinquanta presos

canten una cançó,

la nina se'ls escolta,

petita, bonica,

de dalt del mirador,

lireta, liró.

Canteu, canteu, bons presos, d'aqui us en trauré jo, aniré a veure el meu pare, Petita, bonica,

recaptaré el perdó,

lireta, liró.

Ai, pare, lo meu pare, jo vos demano un do.

Ai, pare, lo meu pare, petita, bonica,

les claus de la preso,

lireta, liró.

Ai, filla Margarida, demá els penjaré a tots, Ai, pare, lo meu pare, petita, bonica, pengeu-me m’hi a mi i tot, lireta, liró.

I a cada cap de forca poseu-hi un ram de flors, perqué la gent quan passi, petita, bonica, sentin la bona olor, lireta, liró.

(AMADES, 1951, p. 597)
Na cidade de Lérida

existe uma prisão,

lá nunca faltam presos

pequena, bonita,

muitos são levados pelo barão,

lireta, liró.

Cento e cinqüenta presos

cantam uma canção,

a menina os escuta,

pequena, bonita,

do alto do mirante,

lireta, liró.

Cantem, cantem, bons presos,

que vou tirá-los daqui,

irei falar com eu pai,

pequena, bonita,

conseguirão o perdão,

lireta, liró.

Ai, pai, meu pai, vou pedir-lhe um favor.

Ai, pai, meu pai, pequena, bonita, as chaves da prisão

lireta, liró.

Ai, filha, Margarida, amanhã serão todos enforcados,

Ai, pai, meu pai

pequena, bonita

enforca também a mim,

lireta, liró.

E no alto de cada forca ponhamos um ramo de flores, para que as pessoas ao passarem, pequena, bonita, sintam bem o seu perfume, lireta, liró. 


\section{La Presó de Lleida}

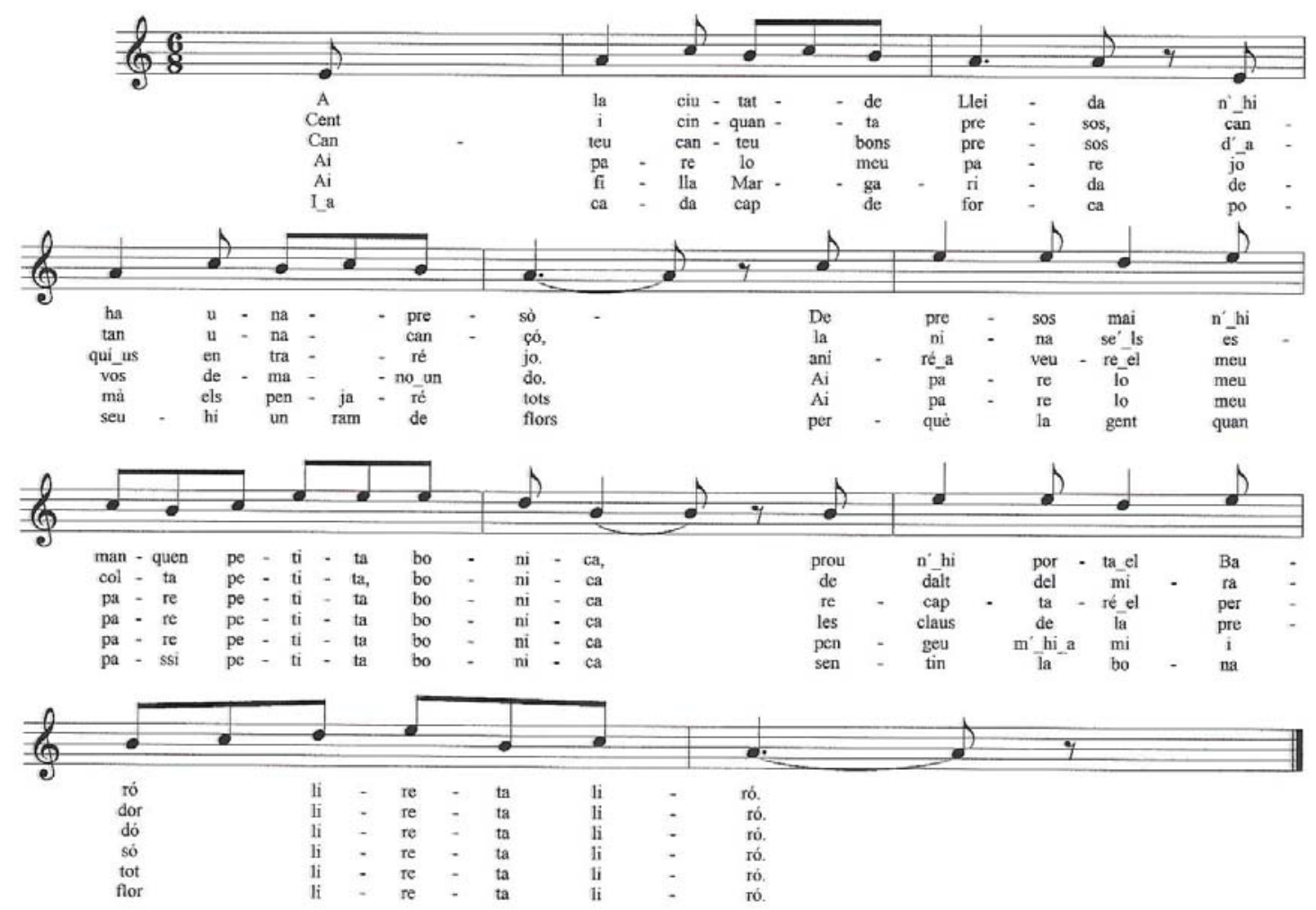

Copyright 1951 by Amades

Encontramos uma outra referência desta melodia no arranjo de Ribó, para coro a quatro vozes (s.d., partitura) ${ }^{100}$.

${ }^{100}$ Cf. ANEXO A, p. 257. 


\section{LA PREÇÓ DE LLEIDA \\ (c. 1920)}

MIGUEL LLOBET

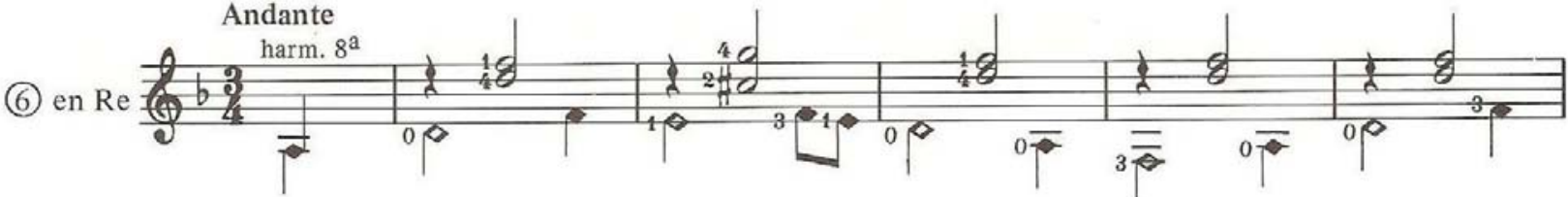
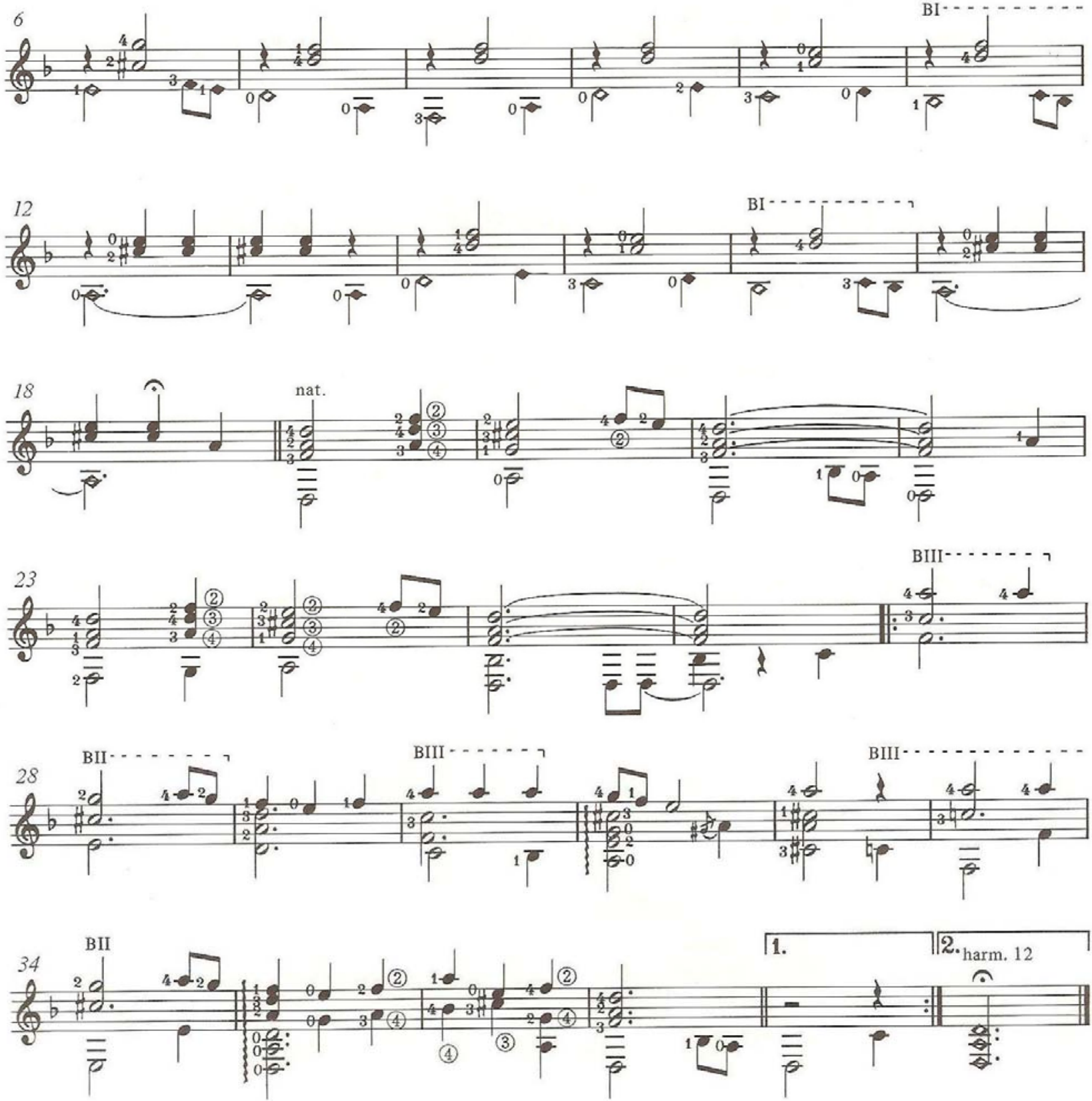


\subsubsection{El noi de la mare}

El Noi de la Mare é uma das canções mais executadas pelos violonistas.

Trata-se de uma melodia simples e curta de estrutura diferente das demais encontradas nos cancioneiros. Possui versos sem estribilho.

Encontramos muitos exemplos fonográficos desta canção, e de diversas versões para violão, devido à sua grande popularidade, como veremos adiante. Apesar de ser classificada como canção de ninar, pode ser encontrada em coletâneas de canções de Natal.

Llobet ao adaptar esta canção para violão, sentiu a necessidade de inserir uma segunda parte (compassos 9 a 18), possivelmente para estabelecer um contraste. Diferente de outras adaptações preferiu conservar a simplicidade da harmonia das melodias folclóricas, usando acordes sem dissonâncias.
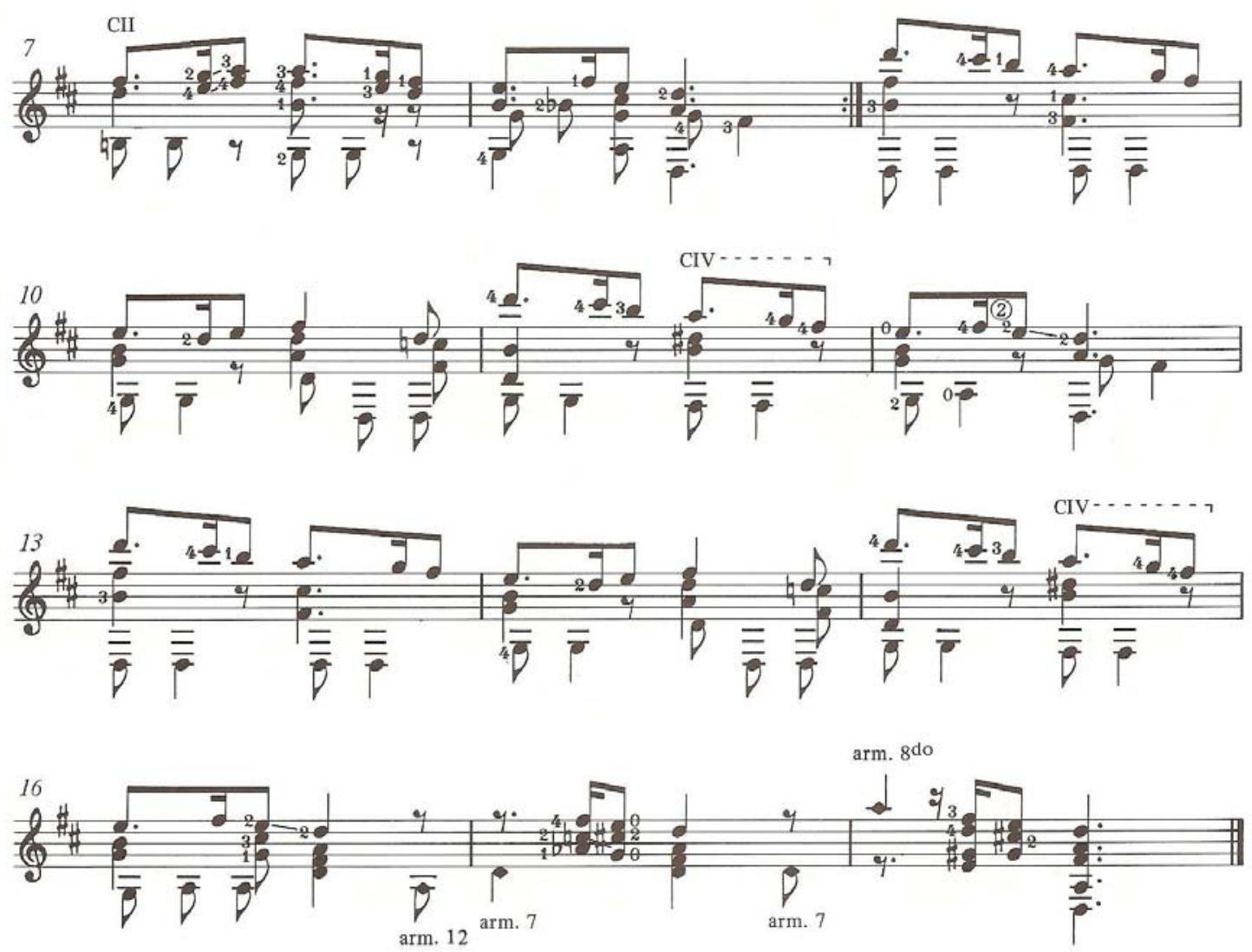
Tal intervenção na melodia tradicional coloca El Noi de La Mare entre as versões que merecem ter seu destaque como obras autorais, e não apenas meros arranjos para violão.

A edição de Purcell (1989, vol. 2, p. 17) não especifica o ano de sua produção, mas parece ter sido concebida em meados de $1918^{101}$.

Uma das canções de ninar mais conhecidas e difundidas pode-se dizer que tem feito dormir muitas gerações de crianças. Conhecida também como “Tam-pa-tamtam”, ou ainda "Que li darem”, oferece algumas variações na letra sem alterar o sentido.

O título “Tam-pa-tam-tam”, ocorrente na terceira estrofe da canção é devido a este som descrever o movimento do balançar do berço enquanto o bebê é embalado pelas mãos da mãe ${ }^{102}$. Tal movimento sugere um andamento cadenciado e calmo, no ritmo do acalanto do bebê, mas se alterarmos o andamento temos uma melodia de dança, usada para outra finalidade.

O título "Que li darem” surge do fato de possuir semelhança com uma Ave Maria de três partes do Codex de las Huelgas - manuscrito medieval copiado no início do século XIV, no monastério de Santa Maria la Real de las Huelgas (LIVERMORE, 1974, p. 80), citado anteriormente como referência histórica da canção tradicional catalã. Catalunha adotou esta melodia como tema de Natal, devido à sua ligação com tema religioso. A letra desta canção, como veremos, destaca a mãe de Jesus e o seu filho, bem como as oferendas que os fiéis desejam levar até o menino por ocasião de seu nascimento.

\footnotetext{
${ }^{101}$ STEFANO GRONDONA. RESPUESTA. Stefano Grondona Plays the Guitar Works of Miguel Llobet. Stradivarius, 2006b (encarte de Cd).

${ }^{102}$ Palavras assim, sem sentido, são característica das canções de ninar. Uma espécie de onomatopéia. Palavras monossilábicas aparecem em outras canções de ninar. Os "non-nons", por exemplo, fazem referência à hora apropriada para crianças irem dormir - a "nona" hora.
} 
Possivelmente foi uma das canções natalinas que servia para fazer uma dança em círculo nas igrejas nas madrugadas de Natal, durante a fervorosa alegria do ofertório, no qual os devotos se expressavam livremente, dançavam abundantemente, umas vezes "al cancell” (dentro) e outras vezes "al presbiteri” (fora). O libreto das canções, publicado pelo construtor de imagens Joan Llorens, leva uma nota ao pé da página dizendo que, ao cantar do coro, seria necessário erguer os braços e dar voltas em torno de si mesmo, indicando o costume de se dançar. Provavelmente ao difundir-se, tornou-se tradicional o costume de o povo dançar ao cantá-la na frente do menino Jesus no presépio (AMADES, 1951, p. 10).

Para comprovar que as melodias tradicionais catalãs ajudaram a impulsionar o movimento nacionalista no século XIX, na Espanha, citaremos o nome do maestro Antonio Nicolau (1858-1933) que está vinculado à arte coral que comentamos no capítulo 1, e seu poema coral El Noi de la Mare (SUBIRÁ, 1953, p. 807) e o de Lluís Millet, que também usou esta melodia em sua obra (LIVERMORE, 1974, p. 335).

Encontramos referências adicionais desta canção no arranjo para coro a quatro vozes (JORDÁ, 19--, p. 3, partitura) e no arranjo para voz e piano de Pahissa (PAHISSA, 19--, p. 14, partitura) ${ }^{103}$.

Como referência fonográfica recomendamos a soprano Victoria de Los Angeles ${ }^{104}$ e o coral Orfeo Catalá ${ }^{105}$.

\footnotetext{
${ }^{103}$ Cf. ANEXO A, p. 258 e 259.

${ }^{104}$ CANÇONS TRADICIONALS CATALANES. Victoria de Los Angeles with Geoffrey Parsons. Collins Classic, 199 (Cd).

${ }^{105}$ ORFEO CATALÁ. Chansons Traditionnelles de Catalogne. Harmonia Mundi, 1992 (Cd).
} 


\section{El Noi de la Mare}
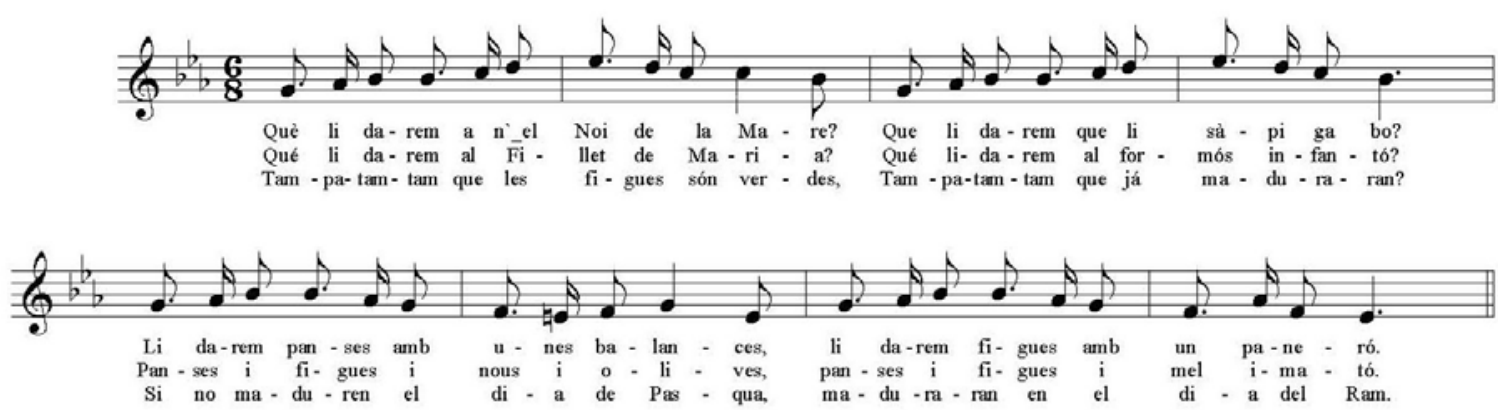

Copyright 1951 by Amades

A tradução livre da letra de El Noi de la Mare (O filho da virgem) segue

Que li darem

a n`el noi de la mare?

Que li darem que li sapiga bó?

Li darem panses amb unes balances

Li darem figues amb un paneró.

Que li darem ao fillet de Maria?

Que li darem ao formós infantó?

Panses i figues i nous i olives

Panses i figues i mel imató.

Tam, patantam que les figues són verdes

Tam, patamtam que já maduraran?

Si no maduren el dia de Pasqua,

Maduraran en el Dia del Ram.

(AMADES, 1951, p. 9)
Que daremos

ao filho da Virgem?

Que lhe daremos, que ele goste?

Lhe daremos uvas passas com balances

Lhe daremos uvas e figos num cestinho.

Que daremos ao filhinho de Maria?

Que daremos ao formoso menino?

Passas, figos e nozes e azeitonas

Passas e figos e coalhada com mel.

Tam, patantam os figos estão verdes

Tam, patantam já amadureceram?

Se não amadurecerem no dia da Páscoa, Amadurecerão no Dia de Ramos. 


\section{EL NOI DE LA MARE}

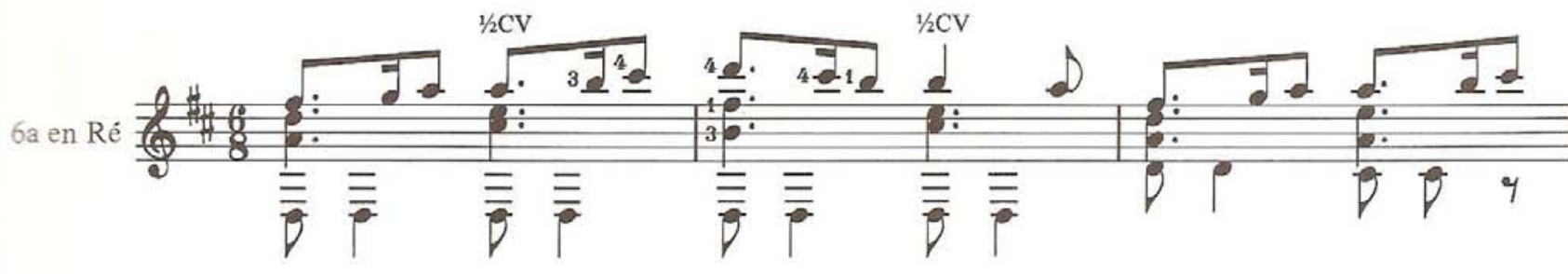
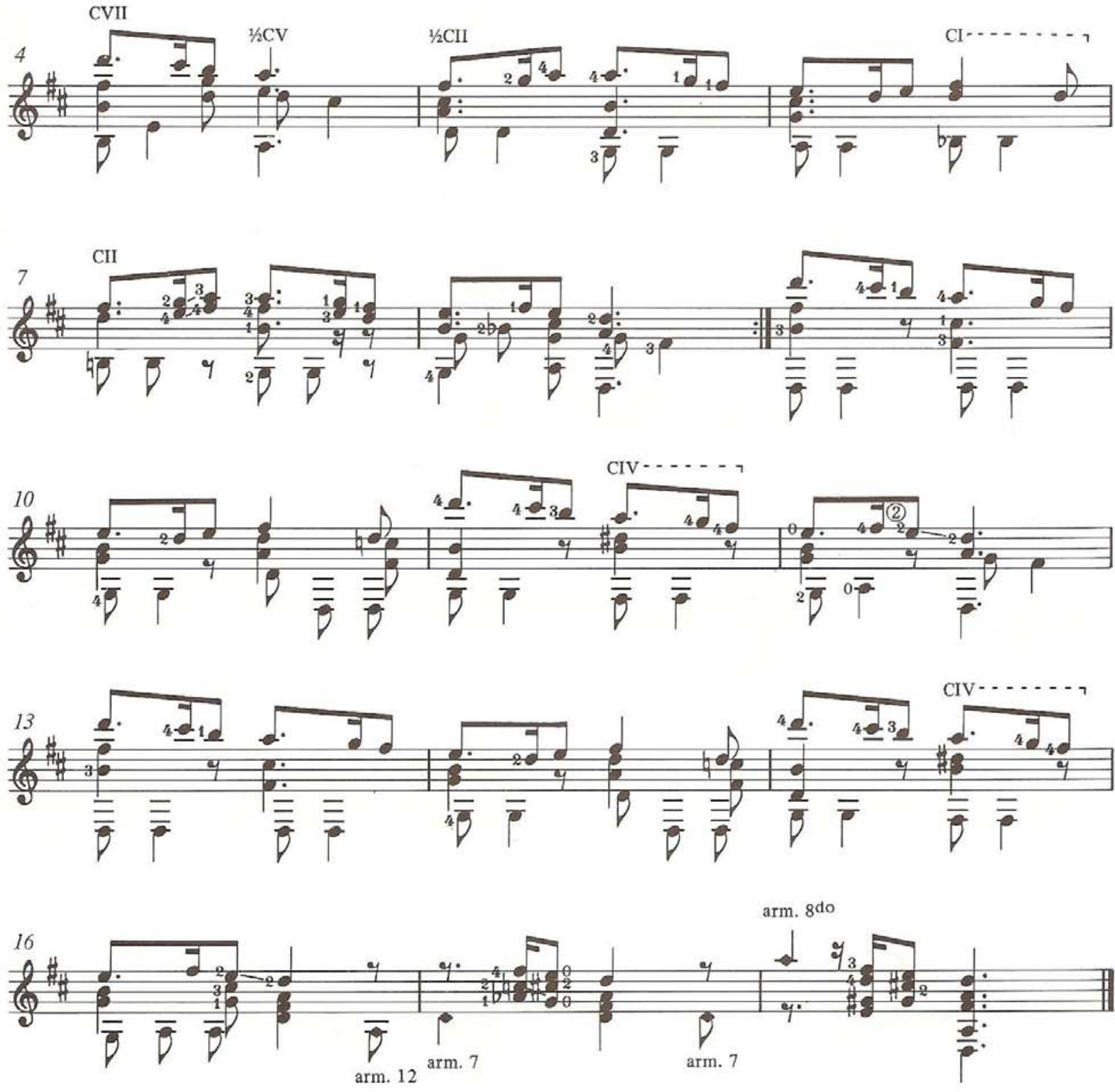


\subsection{Canciones Catalanas recém-descobertas}

No capítulo anterior falamos do arquivo que contém obras inéditas de Miguel Llobet. Entre tais obras, encontramos as adaptações das canções catalãs não incluídas na edição das treze Canciones Catalanas para violão solo (PURCELL, vol. 2, 1989, partitura). São as canções L'Anunciació (mais conhecida como La Mare de Deu), L’hostal de la Peira e uma outra versão de La Filla del Marxant para conjunto de cordas dedilhadas e plectro.

Foram concebidas para um grupo catalão formado em 1898 e pelo qual Llobet era responsável. Lira Orfeu era uma sociedade de música criada para a formação de um grupo de instrumentos de cordas dedilhadas - violões, mandolinas espanholas, alaúdes e um arquialaúde.

Tais obras, ainda não editadas, encontram-se registradas no Cd Homenaje gravado em 2006 por Stefano Grondona e o grupo Nova Lira Orfeu, composto por seis violões, como mencionamos anteriormente. A formação usada na realização destas três peças indica que ela foi escrita para seis vozes, pois Grondona procurou respeitar as partes escritas pelo autor, dentro das possibilidades do violão ${ }^{106}$.

Para las versiones aquí presentadas he respectado básicamente las partes que Llobet había escrito, sin multiplicar los instrumentistas, que se han mantido al mínimo efectivo. He querido respetar aquel espíritu coral en nombre del cual este repertorio había nacido, además evitando rigurosamente reducir el número de instrumentos, aun donde hubiera sido posible concentar en uno las partes de dos o más. (STEFANO GRONDONA, 2006a, encarte de Cd)

A pesquisa de Grondona indica que podem ser encontradas ainda mais duas canções tradicionais catalãs na obra de Miguel Llobet: Els Segadors e L'Imigrant. Numa nota explicativa, sugere a possibilidade de mais obras serem reveladas:

\footnotetext{
${ }^{106}$ As partes graves do arquialaúde e as partes agudas realizadas originalmente por alaúdes e mandolinas tiveram de ser adaptadas à tessitura do violão de seis cordas.
} 
El material sobre Llobet que, en tiempos más recientes, está poco a poco emergiendo, consignándonos nuevos detalhes sobre a vida del Maestro, podría todavia reservar muchas sorpresas, con consecuentes revisiones del cuadro histórico en el cual enfocar su figura. En particular, las fechas de composición de las canciones catalanas podrían sufrir unos cambios. Por el momento, no tenemos a cuanto está ya tradicionalmente asumido, únicamente corregido en unos puntos com las nuevas, pero parciales, informaciones de las que disponemoss. Un más rico cuadro interpretativo de la obra musical de Llobet, y um perfil más completo de un tan importante personaje, será posible cuando todas las fuentes estén a nuestra disposición. Aún sería más bienvenido el descubrimiento de otras composiciones y arreglos de Llobet, de los cuales se supone la existencia por su inclusión em los programas de los conciertos del Maestro. En cuanto al tema de las canciones catalanas, sobretudo nos referimos a dos títulos que esperamos puedan emerger: Els Segadors y L'Emigrant. (STEFANO GRONDONA, 2006b, encarte de Cd)

Diante da possibilidade de surgir mais duas canções catalãs inéditas, decidimos incluir a tradução das letras de suas melodias. Não sabemos ainda as datas de concepção destas versões para violão, mas sabemos que pertencem a um período de grandes manifestações políticas na Catalunha. As duas canções mencionadas possuem forte apelo político, mostrando o engajamento de Llobet em tais assuntos, da mesma forma que o violoncelista Pablo Casals (1876-1973), como veremos adiante.

Els Segadors converteu-se no Hino Nacional da Catalunha, e foi oficializado em $1993^{107}$. Sua origem data da Guerra dos Segadores ${ }^{108}$, que ocorreu no século XVII. A história de luta pela autonomia como nação, bem como de sua própria língua, fez dos catalães um povo conhecido por sua força e personalidade. Tal fato contribuiu para a formação de uma personalidade única que resultou no folclore típico destas terras e um hino próprio.

\footnotetext{
${ }^{107}$ Durante o período de ditadura, o hino Els Segadors ficou proibido de ser cantado na Catalunha. Com a proclamação da República em 14 de Abril de 1931, diversas personalidades políticas desejavam um hino nacional menos belicoso. Por ocasião de uma comemoração civil, o coral Orfeo Catalá cantou a canção $E l$ Cant del Poble, composta por Amadeo Vives e baseada na canção de Clavé, El Xiquet de Valls. O público presente pediu calorosamente por Els Segadors, que se converteu no hino oficial da Catalunha. (XTEC, http://www.xtec.es/serveis/crp/a8903084/docs/himne1.pdf. Acesso em: 18 Novembro 2007).

${ }^{108}$ A Guerra dos Segadores ocorreu durante o reinado de Felipe IV (1605-1665). A luta começou em 7 de Junho de 1640 com a entrada dos segadores em Barcelona, que todos os anos costumavam entrar na cidade para a contratação de "la siega". A partir de 1641, Catalunha instaurou a república catalã debaixo da proteção do rei da França e, a partir desta data, entrou num período de lutas contínuas até o Tratado dos Pirineus firmado entre Espanha e França (MANGADO, 1998, p. 126).
} 
Este hino se baseia numa canção tradicional antiga. Sua letra atual é de 1899 e foi escrita pelo poeta Emilio Guanyavents que utiliza elementos de tradição oral presentes numa pesquisa musicológica realizada anteriormente por Milá y Fontanals $(1818-1874)^{109}$. Francisco Alió (1862-1908) compôs o hino em 1892 baseando-se na versão tradicional. Foi harmonizada por diversos compositores como Enric Morera, Amadeo Vives, Lluís Millet e outros. Não sabemos qual versão Llobet usou em sua obra para violão, a versão tradicional ou a versão atualizada de seu tempo. Inserimos aqui a versão atual do hino da Catalunha.
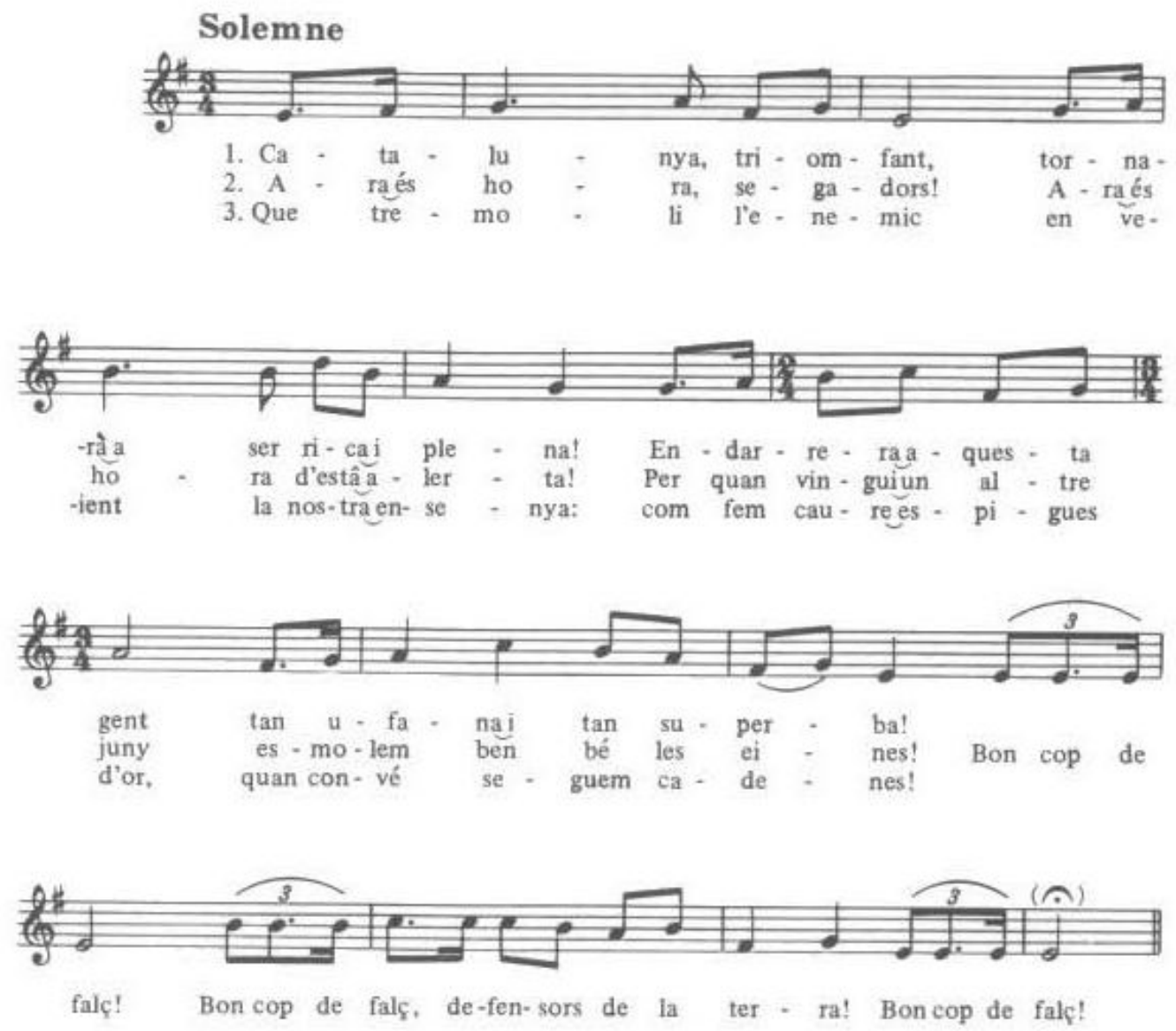

\footnotetext{
${ }^{109}$ A obra que tivemos acesso (PUJOL, 1926, 3 vol.) baseia-se nesta pesquisa musicológica Romancerillo Catalán (1882) de Milá y Fontanals.
} 
Recomendamos a gravação da soprano Victoria de los Angeles ${ }^{110}$ que cita a versão atual de Els Segadors.

Para ver a versão tradicional, recomendamos a consulta da obra de Francisco Pujol (1926, 3 vol.) e a audição do grupo catalão La Capella Reial de Catalunyaa ${ }^{111}$.

Seguimos com a tradução livre da letra do hino nacional da Catalunha Els Segadors para o português:

Catalunha, triomfant, tornará a ser rica i plena! Endarrera aquesta gent tan ufana i tan superba!

Bon cap de falç! Bon cap de falç, défensors de la terra! Bon cap de falç!

Ara és hora, segadors! Ara és hora d'estar alerta! Per quan vingui un altre juny esmolem ben bé les eines!

Bon cap de falç!...

Que tremoli l'enemic en veient la nostra ensenya: com fem caure espigues d'or, quan convé seguem cadenes!

Bon cap de falç!...
Catalunha, triunfante, Tornará a ser rica e plena! Por detrás desta gente Tão ufana e tão soberba!

Bom golpe de foice! Bom golpe de foice! defensores da terra! Bom golpe de foice!

Agora é hora segadores! Agora é hora de estar alerta! Para quando chegar o outro junho Amolem bem as ferramentas!

Bom golpe de foice!...

Que trema o inimigo Mostraremos a nossa bandeira: Como fazemos cair as espigas de ouro Quando convém ceifamos as correntes!

Bom golpe de foice!...

\footnotetext{
${ }^{110}$ CANÇONS TRADICIONALS CATALANES. Victoria de Los Angeles with Geoffrey Parsons. Collins Classic, 1992 (Cd).

${ }^{111}$ CAPELLA REIAL DE CATALUNYA. Cançons de la Catalunya mil-lenària. Planys e Llegendes.
} Astrée, 1977 (Cd). 
L’Emigrant fez parte do repertório folclórico dos corais do início do século

XIX. Amadeo Vives, nome ligado ao coral Orfeo Catalá usou esta melodia em sua obra e afirmou que “el orfeó contiene e resume toda la entraña romántica de la ciudad de Barcelona.” (FERNANDES-CID, 1973, p. 94) Durante o período de ditadura na Catalunha, L’Emigrant substituiu Els Segadors nos eventos cívicos.

Segue a tradução livre de L'Emigrant (O Emigrante) para o português:

Dolça Catalunya, pàtria del meu cor, quan de tu s'allunya d'enyorança es mor.

Hermosa vall, bressol de ma infantesa, blanc Pirineu, marges i rius, ermita al cel suspesa, per sempre adéu!

Arpes del bosc, pinsans i caderneres ${ }^{112}$, cantau, cantau, jo dic plorant a boscos i riberes: adéu-siau!

¿On trobaré tos sanitosos climes, ton cel daurat?

Mes ai, mes ai! ¿on trobaré tes cimes, bell Montserrat?

Enlloc veuré, ciutat de Barcelona, ta hermosa Seu, ni eixos turons, joiells de la corona que et posà Déu.

Adéu, germans: adéu-siau, mon pare, no us veuré més!

Oh! si al fossar on jau ma dolça mare, jo el llit tingués!

Oh mariners, lo vent que me'n desterra que em fa sofrir!

Estic malalt, mes ai! tornau-me a terra, que hi vull morir!
Doce Catalunha, pátria do meu coração, quando de tu se afasta de saudades se morre.

Formoso vale, berço da minha infância branco Pirineu, Margens e rios, santuários suspensos Para sempre, adeus!

Harpas do bosque, pinsans e caderneres, Cantem, cantem

Eu digo chorando a bosques e florestas Adeus!

Onde encontrarei os climas tão saudáveis, teu céu dourado?

Mes ai! onde encontrarei teus cumes, belo Montserrat?

El lugar algum, cidade de Barcelona, tão formosa, nem estas colinas, jóias da coroa que Deus te coloca.

Adeus, irmãos: adeus, meu pai, não os verei mais!

Oh!se no túmulo onde jaz minha doce mãe, eu tivesse o meu leito!

Oh marinheiros, o vento que me desterra que me faz sofrer!

Estou doente, mes ai!levai-me de volta, que quero morrer!

\footnotetext{
112 Espécies de pássaros.
} 
A letra desta canção descreve o profundo sentimento dos catalães que se viram obrigados a deixar sua terra natal devido ao período de entraves políticos no século XIX. Llobet deixou seu país para viver um período em Paris e sabemos também que passou algum tempo na Argentina, justamente durante o período de grandes dificuldades na Catalunha que o impossibilitaram de exercer suas atividades artísticas.

Embora não tenhamos acesso a nenhuma publicação que descreva alguma declaração de Llobet sobre o assunto, acreditamos que ele estava atento aos acontecimentos políticos de sua época, e sofreu os efeitos deste período em sua vida artística. Os fatos políticos e sociais que envolvem estas duas canções não escaparam à sensibilidade deste importante compositor e intelectual, pois utilizou as melodias inseridas neste contexto em suas Canciones Catalanas.

Tais obras ainda não foram publicadas. Portanto, precisamos aguardar a disponibilidade deste arquivo inédito para mais informações a respeito da totalidade da obra de Llobet. 


\subsubsection{L’Anunciació (La Mare de Deu)}

Grondona afirma que esta melodia tradicional catalã foi usada na obra de Llobet e está entre os arquivos ainda não desvendados. Ainda não temos acesso a esta partitura. Portanto, é necessário aguardar a publicação do arquivo inédito de Llobet para analisarmos o sentido musical desta obra e sua amplitude orquestral. Sabemos que ela foi escrita em seis partes e está registrada no Cd Homenaje ${ }^{113}$, executada pelo sexteto de violões Nova Lira Orfeo.

Entre as canções de ninar, é uma das mais cantadas quando pesquisamos o cancioneiro infantil. A primeira estrofe é comum em todas as versões, mas depois, pode variar bastante.

Sua popularidade ajudou a impulsionar o movimento do renascimento espanhol "La Renaixença”, citado no capítulo 1. Lluis Millet usou o tema em sua obra, junto com outras melodias tradicionais catalãs (LIVERMORE, 1974, p. 335).

\section{L'Anunciació}

(La Mare de Déu)
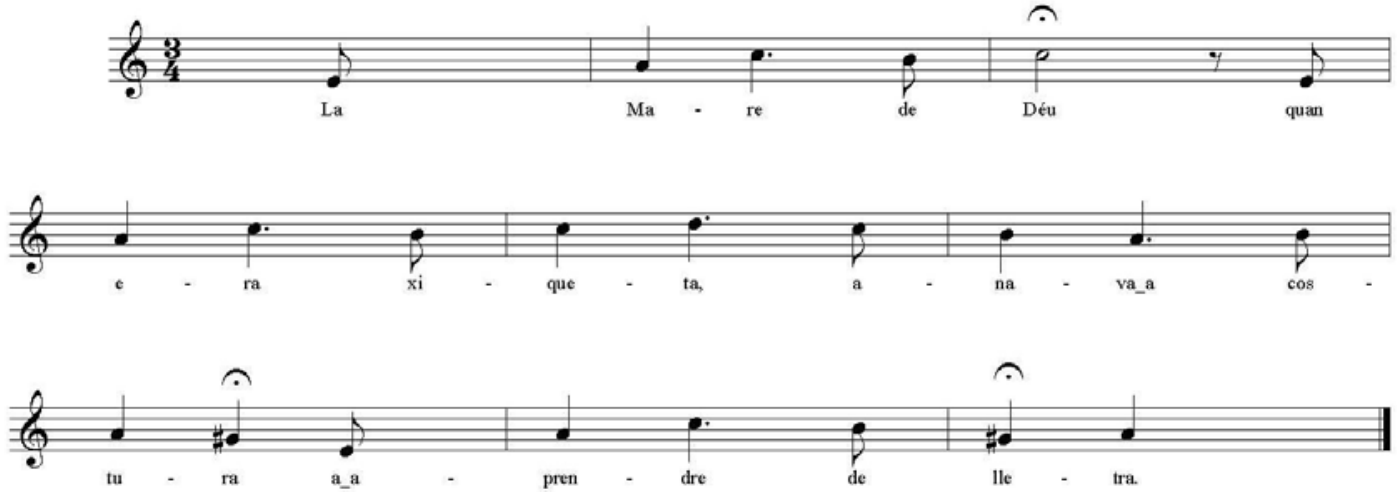

\footnotetext{
${ }^{113}$ STEFANO GRONDONA. HOMENAJE Manuel de Falla, Miguel Llobet and their world. Stefano
} Grondona, Maria José Montiel, Laura Mondiello, Nova Lira Orfeo. Stradivarius, 2006a (Cd). 
Um manuscrito incompleto encontrado na paróquia de Santa Maria de Betlem comprova mais uma vez a influência do canto litúrgico na canção tradicional. Este manuscrito data do século XIX, escrito em 3/8 e de tonalidade moderna (PUJOL, 1926, vol. 2, p. 403).

\section{Kyrial}
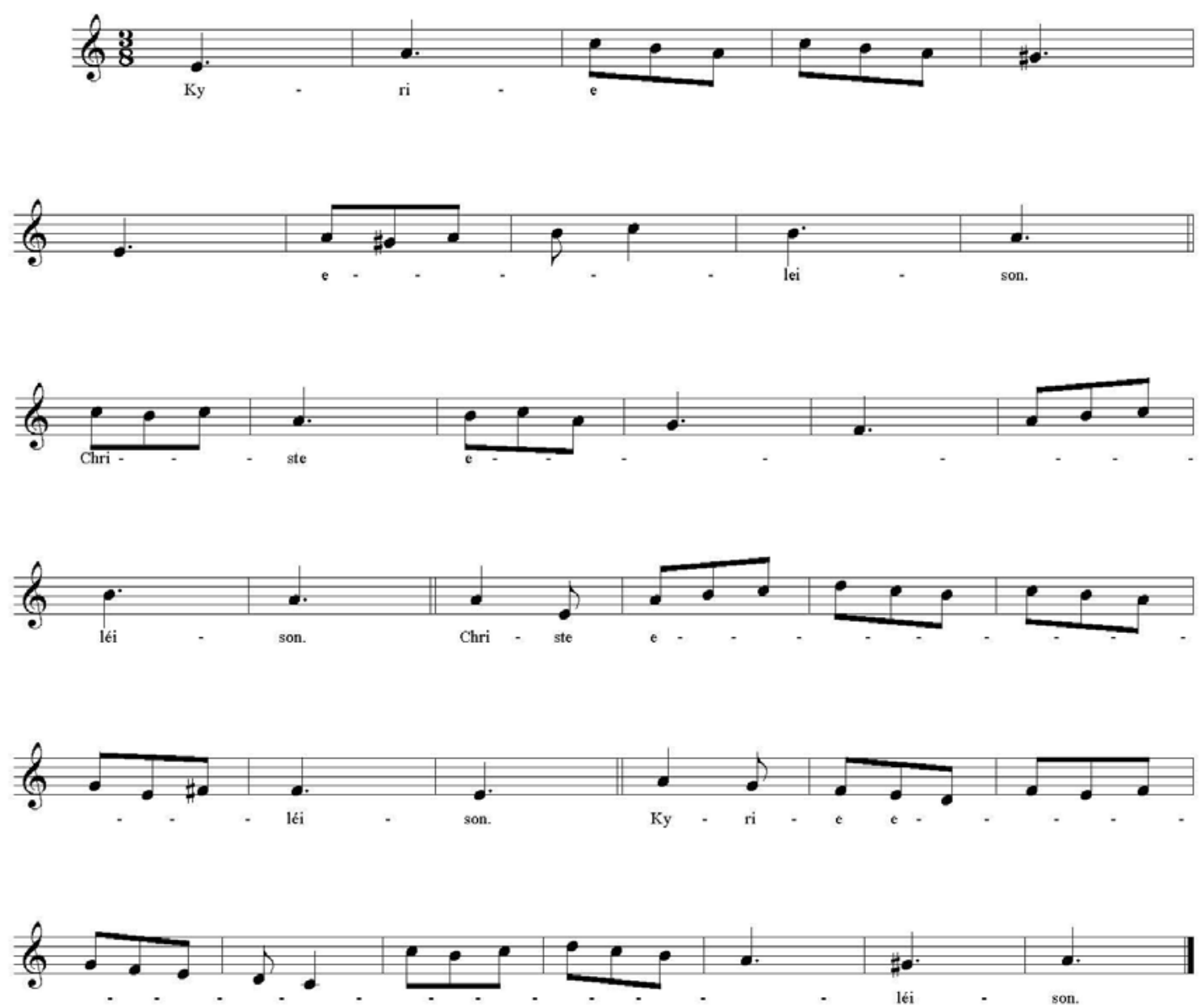

Destacaremos os poemas corais La Mare de Deu (SUBIRÁ, 1953, p. 807) de Antonio Nicolau (? -?), o que denota mais uma vez a popularidade das melodias tradicionais catalãs usadas na obra de Llobet. 
Encontramos no arranjo de Jordá (19--, p. 2, partitura) para piano e voz ${ }^{114}$ uma referência para conhecer melhor seu texto com andamento Andante. Amades sugere o andamento semínima =58 (1951, p. 8).

Encontramos outra referência na tonalidade de fá menor, com variação melódica e literária (PUJOL, 1926, vol. 2, p. 113).

Como referência fonográfica recomendamos a soprano Victoria de Los Angeles ${ }^{115}$.

La maré de Déu quan era xiqueta anava a costura a aprendre de lletra, amb son coixinet i la cistelleta.

Em um libret d'or Aprenia lletra; Els àngels cantaven:

"Garindó dindeta".

Filava finet i teixía beta, cosia vestits per'nà endreçadeta. (AMADES, 1951, p. 8)
A mãe de Deus quando era criança costumava costurar aprender a escrever, com seu travesseiro e a cestinha de costura.
Num libreto dourado Aprendia as letras; Os anjos cantavam "Garindó dindeta"
Fiava fininho e tecia fitas, costurava vestidos para ir bem vestida.

\footnotetext{
${ }^{114}$ Cf. ANEXO A, p. 260.

${ }^{115}$ CANÇONS TRADICIONALS CATALANES. Victoria de Los Angeles with Geoffrey Parsons. Collins Classic, 1992 (Cd).
} 


\subsubsection{L'Hostal de la Peira}

Llobet adaptou esta canção para o grupo Lira Orfeo anteriormente citado. Trata-se de um arranjo que se encontra no arquivo de Alonso, que em parceria com Stefano Grondona, $\mathrm{t}$ 
em revelado gradualmente as obras inéditas de Llobet. O Lira Orfeo era formado por violões, mandolinas, alaúdes e arquialaúdes. Como vimos anteriormente, a pesquisa de Grondona foi realizada com um grupo de seis violões o que mostra que este arranjo foi concebido para seis partes, uma vez que Grondona afirma ter respeitado o arranjo original, apenas adaptando-o para as possibilidades do violão de seis cordas.

Encontramos uma referência desta canção no arranjo para coral de Morera (190-, partitura) ${ }^{116}$ e uma transcrição monofônica em tonalidade diferente (fá menor) e com pequenas variações no texto literário. Texto musical descrito em 3/2 com a sugestão de andamento mínima =54 (PUJOL, vol. 2 , p. 110).

Esta melodia também pode ser reconhecida no canto gregoriano (PUJOL, 1926, vol. 2, p. 366):

melodia popular

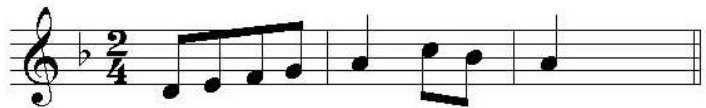

melodia popular

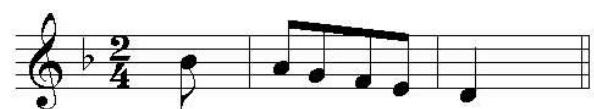

Gradual de Commune plurimorum Martyrum

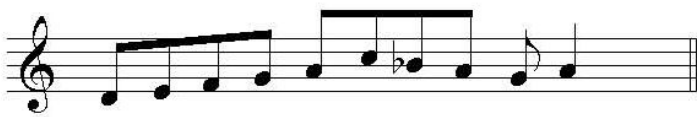

Final solemne del Salm de primer to.

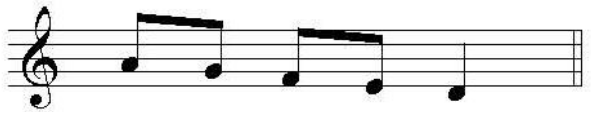

${ }^{116}$ Cf. ANEXO A, p. 261. 
Juntando a primeira frase com a última, temos uma melodia gregoriana bem característica:

Primer Kyrie de la Missa VII del Kyriale

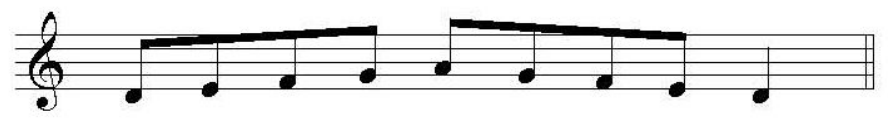

No cancioneiro de Amades (1951, p. 515) ela surge junto com a sugestão de andamento semínima $=100$.

\section{L'hostal de la Peira}
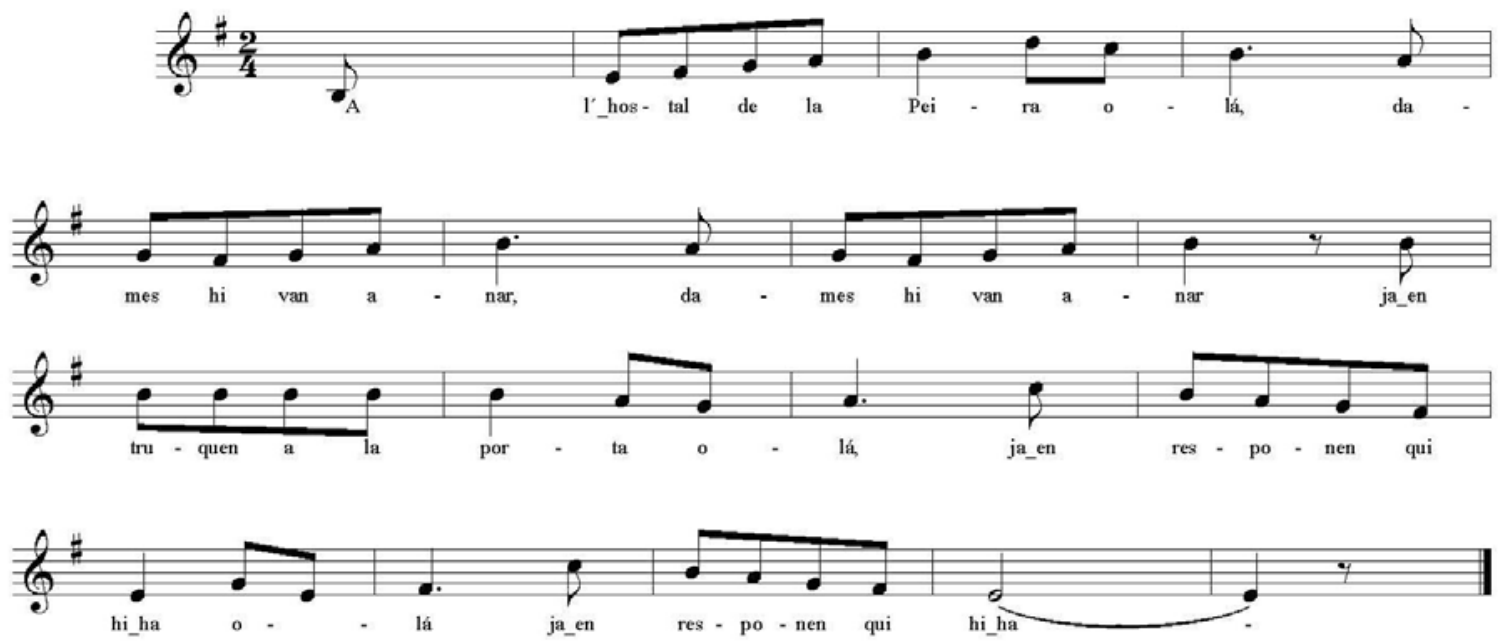

Copyright 1951 by Amades

Peira):

Segue a tradução livre para o português de L'hostal de la Peira (A Pensão da 
A l'hostal de la Peira

olá,

Dames hi van anar,

dames hi van anar.

Já em truquen a la porta,

olá,

Já em responen: - Qui hi há?

Som unes pobres dames;

Si ens voleu allotjar?

- Obre la porta, noia,

I deixa-les entrar.

Diuen a la mestressa:

- Que hi há para sopar?

- Hi há cargols amb ceba, Samfaína i bacallá.

(AMADES, 1951, p. 515
Na pensão da Peira

olá,

Damas foram,

damas foram.

Já chamam na minha porta,

olá,

Já respondem: - Quem é?

Somos pobres damas,

Pode nos alojar?

- Abre a porta, menina

E deixe-as entrar.

Dizem à dona de casa:

- Que tem para jantar?

- Tem caracóis com cebola,

Refogado de verduras e bacalhau. 


\subsection{Outros compositores e suas abordagens}

Como citamos anteriormente, temos exemplos de outros compositores violonistas e não violonistas que usaram melodias tradicionais catalãs para compor suas obras. Entre os violonistas, Emilio Pujol, Andrés Segovia, Narciso Yepes (19271997), e entre compositores não-violonistas, Federico Mompou (1893-1987), Lleonard Ballada Ibáñez (1933), Franscisco Casanovas (1899-?) ${ }^{117}$, e o já citado compositor mexicano Manuel Ponce.

As outras canções tradicionais da Catalunha que foram usadas por compositores que seguiram a mesma linha de Llobet, são:

Els tres Tambors , El bon Caçador, El Cant dels Ocells,La Ploma de Perdiu, Els Estudiants de Tolosa, Muntanyes del Carnigó, Catarina d'Alió, La Gata i el Belitre e Canción Galega.

Sobre as atividades do violonista catalão Emilio Pujol, comentamos brevemente no capítulo 2. Falamos sobre os campos em que ele atuava, inclusive como compositor e concertista. Uma observação dos cinco programas característicos de Pujol mostra que ele incluía as canções de Llobet em seus concertos, e ele próprio também realizou transcrições de outras canções populares (RIERA, 1974, p. 81). Possui uma obra Cançò de Bressol (Canción de Cuna) ${ }^{118}$ considerada a obra “mais espontânea, correta, delicada e violonística” como aponta o Diccionario de Domingo

\footnotetext{
117 Outros compositores da escola modernista basearam suas obras em temas tradicionais catalães: John W. Duarte (1919), Toru Takemitsu (1930), e Leo Brouwer (1939) são compositores conhecidos que também usaram temas catalãs em suas obras. J. W. Duarte em sua Variations on a Catalan folksong utiliza a canção Cançó de Lladre. Takemitsu em sua obra para oboé d'amore, violão e orquestra Vers, l'arc-em-ciel, Palma cita a canção tradicional catalã La Filadora .Brouwer selecionou as melodias El Noi de la Mare e El Mestre em sua obra Retrats Catalans. Cf. TAKEMITSU. To the edge of dream. Takemitsu played by John Willians. Esa-Pekka Salonen London Sinfonieta. Sony Classical, 1989; JOHN W. DUARTE. Variations on a Catalan folk-song, Sonatinette, English Suíte, Musikones. Guitar Music, Antigoni Goni. Naxos, 2001; EDUARDO FERNÁNDEZ. English Chamber Orchestra. Arnold, Chappell, Brouwer. London, 1990 (Cds).

${ }^{118}$ PUJOL, E. Canción de Cuna. Paris: Max Eschig (partitura).
} 
Prat (PRAT, 1934, p. 253). Sua Festívola ${ }^{119}$ é baseada na dança popular catalã - a sardana.

Andrés Segovia, como vimos no capítulo 2, teve grande importância na história do violão. A influência de sua personalidade como intérprete atraiu diversos compositores a escrever para violão, resultando na formação de um repertório moderno. Como compositor, deixou algumas obras e se apropriou de alguns temas populares catalães em algumas adaptações ${ }^{120}$.

Além de Pujol, Segovia também utilizou a melodia popular La Ploma de Perdiu, uma canção usada em ocasiões que reuniam pessoas para o trabalho de bordar, como descrevemos anteriormente. Segovia também adaptou a canção Els Estudiants de Tolosa, e seguindo o exemplo de Llobet, realizou outras adaptações sobre El noi de la Mare e El Desembre Congelat ${ }^{121}$.

Narciso Yepes, violonista espanhol, criou em 1964 um violão de dez cordas na intenção de ampliar o repertorio antigo e moderno e explorar novas possibilidades de tessitura e textura. Realizou versões das canções tradicionais catalãs Catarina d'Alió e Muntanyes del Carnigó gravadas pelo próprio compositor $^{122}$.

O compositor catalão Federico Mompou faz parte dos "Grupo dos Quatro” - Mompou, Adolfo Salazar, Oscar Esplá e Roberto Gerhard (PAINE, 1989, p. 66) - compositores modernistas espanhóis e teve como seus principais mentores os compositores franceses do “Grupo dos Seis”. Sua obra está repleta de elementos folclóricos de sua terra natal. Seu amor pela cultura popular catalã é evidente no ciclo

\footnotetext{
${ }^{119}$ PUJOL, E. Festívola. Paris: Max Eschig (partitura).

120 SEGOVIA, A. 23 Canciones Populares de distintos países. Ancona: Bèrben Edizioni Musicali, s.d. (partitura).

${ }^{121}$ Cf. ANEXO A, p. 268 e 269 e ELIOT FISK. World Première Recording. Segovia Canciones Populares. Music Masters Classics, 1996 (Cd).

${ }^{122}$ Musique Catalane Narcyso Yepes, guitare. Deutsche Gramophon (Lp).
} 
de Canções e Danças $^{123}$ para piano. São 15 obras, uma para órgão (no. 15) e uma para violão (no. 13), dedicada a Narciso Yepes. Nesta obra ele usou o tema tradicional catalão El cant dels ocells (Canção), usado também por Pujol, e El Bon Caçador (Dança).

Explorou duas das Cantigas de Santa Maria, de Alfonso X, na Canción y Danza no. 10 sobre dos Cantigas de Alfonso X El Sabio ${ }^{124}$, e na Suíte Compostellana original para violão (1962).

Mompou usou os temas catalães em sua obra para piano com padrão estético muito próximo aos utilizados por Llobet. Alguns temas coincidem, inclusive $^{125}$. Criou uma nova linguagem baseada, no entanto, em temas antigos submergidos da tradição da Europa Central.

Lleonard Ballada Ibáñez, compositor catalão, tem uma extensa produção musical interpretada por orquestras européias e americanas. Suas obras têm sido estreadas e gravadas por Narciso Yepes, Eliot Fisk, Angel Romero e John Willians. Sua obra para violão está catalogada em treze peças, entre elas, Four Catalan Melodies (1978): La Pastoreta, Els Tres Tambors, El Noi de la Mare e La Mare de $\mathrm{Deu}^{126}$.

Francisco Casanovas (1899-?), flautista catalão, também se tornou conhecido por suas atividades pedagógicas. Realizou uma adaptação de uma canção catalã para violão - La gata i el belitre - gravada pelo violonista Narciso Yepes ${ }^{127}$.

\footnotetext{
${ }^{123}$ Cf. JORDI MASÓ. Frederic Mompou. Piano Music Volume 1. Cançons i Danses. Charmes Scènes d'enfants. NAXOS, 1997 (Cd). d'enfants. NAXOS, 1997; STEPHEN HOUGH. Piano music by Federico Mompou. Hypérion, 1997 (Cds). MOMPOU, F. Cancion y Danza. Madrid: Union Musical Española, 1924, 1926, 1928 (partitura).

${ }_{124}^{124}$ Adaptada para violão pelo próprio compositor.

${ }^{125}$ El Noi de la Mare (Canção no. 3), L'hereu Riera (Dança no. 7), El Testament d'Amelia (Canção no. 8), La Filadora (Dança no. 8), Cançó del Lladre (Canção no. 14).

${ }^{126}$ Não foi possível ter acesso às partituras.

${ }^{127}$ Musique Catalane Narciso Yepes guitare. Deutsche Gramophon (Lp).
} 
Manuel Ponce, compositor mexicano faz parte do grupo de compositores que escreveram obras comissionadas por Segovia, citados no capítulo 2. Usou uma canção tradicional catalã em sua Canción Gallega y Alborada ${ }^{128}$. Sobre este título temos duas hipóteses: o título pode ser um equívoco ou pode existir uma versão galega de El Noi de la Mare (que não conhecemos). Possivelmente Ponce escreveu esta canção por sugestão do Segovia que já tocava uma versão própria muito próxima da versão de Llobet.

A repercussão das Canciones Catalanas de Llobet levou outros compositores a realizarem adaptações para violão, seguindo a mesma linha de Llobet. Percebemos isso claramente em Pujol, Segovia e Yepes. Não sabemos se Mompou teve contato com Llobet, mas notamos um padrão estético muito semelhante entre suas obras Cancion y Danza no. 3, 7, 83 e 14 e Canciones Catalanas.

Decidimos incluir na pesquisa a transcrição monofônica das demais canções tradicionais encontradas no cancioneiro catalão, junto com a letra e a tradução para o português, salientando a importância da obra de Llobet ao influenciar outros compositores violonistas e não-violonistas.

${ }^{128}$ OTERO, C. Manuel Ponce Y la Guitarra. México: Fondo Nacional para Actividades Sociales, 1981. 


\subsubsection{Els tres tambors}

Esta canção foi utilizada na obra de Emilio Pujol e foi dedicada a Miguel

Llobet.

Sua primeira audição foi realizada em 21 de fevereiro de 1934, em Barcelona, pelo próprio autor, Emilio Pujol. Apesar de ser mais conservador que Llobet, como vimos no capítulo 3 no episódio relatado por Tarragó, realizou uma adaptação de uma canção tradicional catalã, onde transcendeu a linguagem moderna usada por Llobet. Trata-se de uma canção catalã escrita pela primeira vez com duas tonalidades sobrepostas - Ré e Mi bemol. Riera estabelece uma comparação desta adaptação com a adaptação de El Mestre realizada por Llobet, considerando-a "mais atrevida [...], e um marco no desenvolvimento histórico do violão” onde se insere a coleção de adaptações de Llobet. Pode ser considerada como peça "sinfônica, pois cada tambor está representado em forma tonal e polifônica distintas.” (RIERA, 1974, p. 160)

Dentro da tradição catalã é uma das canções mais populares e, segundo Joan Amades, "uma das mais bonitas e vibrantes do cancioneiro catalão”. Narra a história de uma donzela que se enamora de um soldado, personificado por um tambor. Este tema já era recorrente no século XII, o que mostra que sua origem é bastante antiga (AMADES, 1951, p. 49). Não oferece muitas variações textuais. Na maioria das versões a donzela é qualificada de filha de Ruan, que pode se referir ao duque de Ruan, capitão das forças protestantes que lutaram contra os católicos durante a Reforma. O rei da Inglaterra ajudou os huguenotes ${ }^{129}$, e em seu exército

\footnotetext{
${ }^{129}$ Membros da Igreja Protestante Reformada da França, durante os séculos XVI e XVII.
} 
existia um tambor histórico e lendário que rejeitava a filha do capitão porque esta não servia para um filho do rei.

A Reforma ganhou terreno entre o povo justamente com a ajuda das canções introduzidas nas cerimônias. Lutero, líder da Reforma Protestante, era poeta e músico e teve uma genial intuição ao musicar os textos cerimoniais de maneira a ser de fácil memorização, como uma canção popular. Os corais luteranos constituíam um veículo eficiente, pois contava com a participação ativa da comunidade. Seu texto e melodia eram indissociáveis (MASSIN, 1997, p.290).

Como referência fonográfica recomendamos a audição da soprano Victoria de Los Angeles ${ }^{130}$.

Outra referência que encontramos desta canção marcial está no trabalho de José Subirá, que comenta a grande popularidade deste romance cheio de onomatopéias que imitam o som bélico de um tambor. É cantado por toda a Catalunha, tanto em sua forma primitiva, como em harmonizações corais ${ }^{131}$. Surge também nos cancioneiros da Bélgica (SUBIRÁ, 1953, p. 692).

A canção é cantada em outras línguas e dialetos e também aparece no cancioneiro francês e italiano. Sua melodia é cantada de modo vibrante, com ar de marcha que convida a caminhar com ânimo. Pujol sugere o mesmo caráter com a anotação Tempo di Marcia.

Os pastores a usavam para conduzir o rebanho. O líder ia à frente e cantarolava o primeiro verso e os acompanhantes respondiam os versos seguintes enquanto o líder usava o som de um chicote para conduzir o rebanho à marcha. $\mathrm{Na}$ compilação que consta no cancioneiro catalão encontramos o andamento semínima = 100 (AMADES, 1951, p. 641).

${ }^{130}$ CANÇONS TRADICIONALS CATALANES. Victoria de Los Angeles with Geoffrey Parsons. Collins Classic, 1992 (Cd).

${ }^{131}$ Cf. ANEXO A, p. 262. 


\section{Els Tres Tambors}

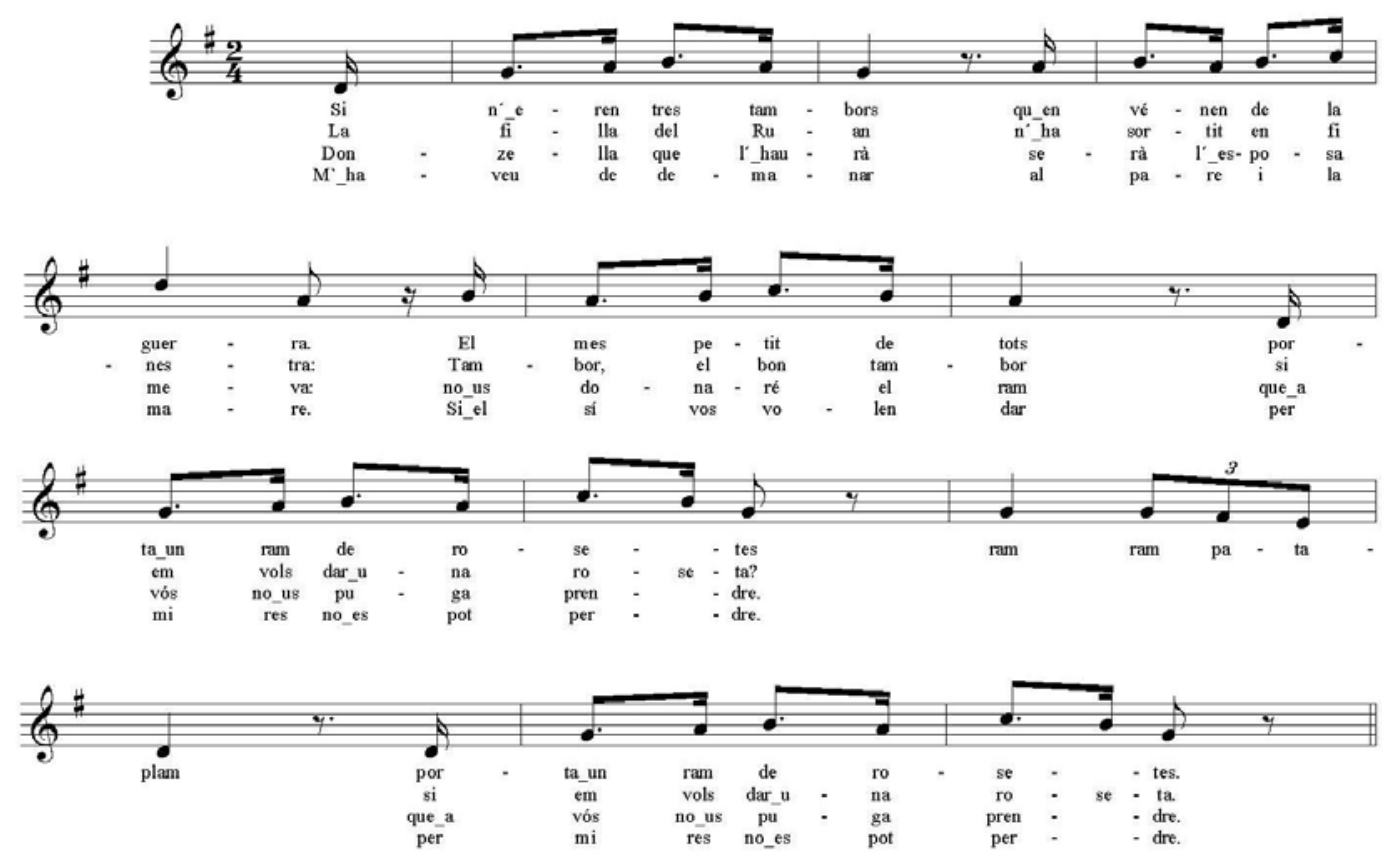

Copyright 1951 by Amades

Segue a tradução livre de Els Tres Tambors (Os Três Tambores):

Si n'eren tres tambors, venien de la guerra, i el més petit de tots porta un ram de rosetes. Ram, ram, pataplam!, porta un ram de rosetes.

La filla del Ruan

n'ha sortit a la finestra:

-Tambor, el bon tambor, si em vols dar una roseta? Ram, ram, pataplam!, si em vols dar una roseta?

- Donzella que l'haurà serà l'esposa meva; no us donaré jo el ram que a vós no us pugui prendre. Ram, ram, pataplam!, que a vós no us pugui prendre.
Haviam três tambores,

vindos da guerra e o menor de todos carregava um ramo de rosas Ram, ram, pataplam!, Carregava um ramo de rosas.

A filha de Ruan saiu na janela:

- Tambor, bom tambor, quer me dar uma rosa? Ram, ram, pataplan!, quer me dar uma rosa?

A donzela que ganhar será a minha esposa não posso te dar o buquê a menos que eu possa tê-la Ram, ram, pataplan!, a menos que eu possa tê-la. 
M'haveu de demanar

al pare i a la mare; si el sí vos volen dar, per mi, res no es pot perdre. Ram, ram, pataplam!, per mi, res no es pot perdre.

- Vine, vine, tambor ma filla será teva.

- No en sento grat por vós tampoc ne sento d'ella, Ram, ram, pataplan!, tampoc ne sento d'ella.

Que allá em meu país n’hi há que són més belles: més hermosa i gentil n'és la meva promesa. Ram, ram, pataplan!, n'és la meva promesa. (AMADES, 1951, p. 641)
- Você deve pedir ao meu pai minha mãe; se eles consentirem, nada posso perder. Ram, ram, pataplan! Nada posso perder.

Venha, venha, tambor minha filha será tua - Não sinto afeição por vós nem sinto por ela, Ram, ram, pataplan!, nem sinto por ela.

Lá no meu país há moças mais belas: a mais bonita e gentil é minha prometida. Ram, ram, pataplan!, É minha prometida. 
A MIGUEL LLOBET

\section{ELS TRES TAMBORS}

(Los tres tambores)

C. IV

QRHLIO PUJOL

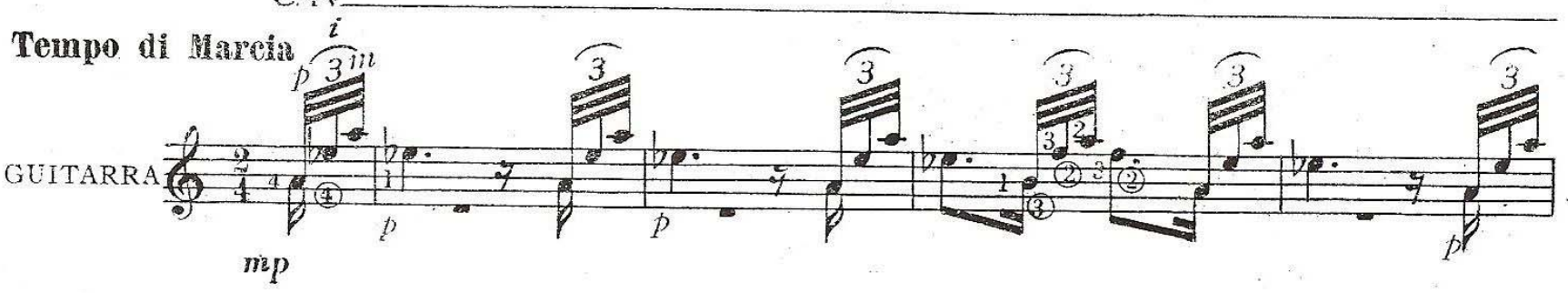

C. IV
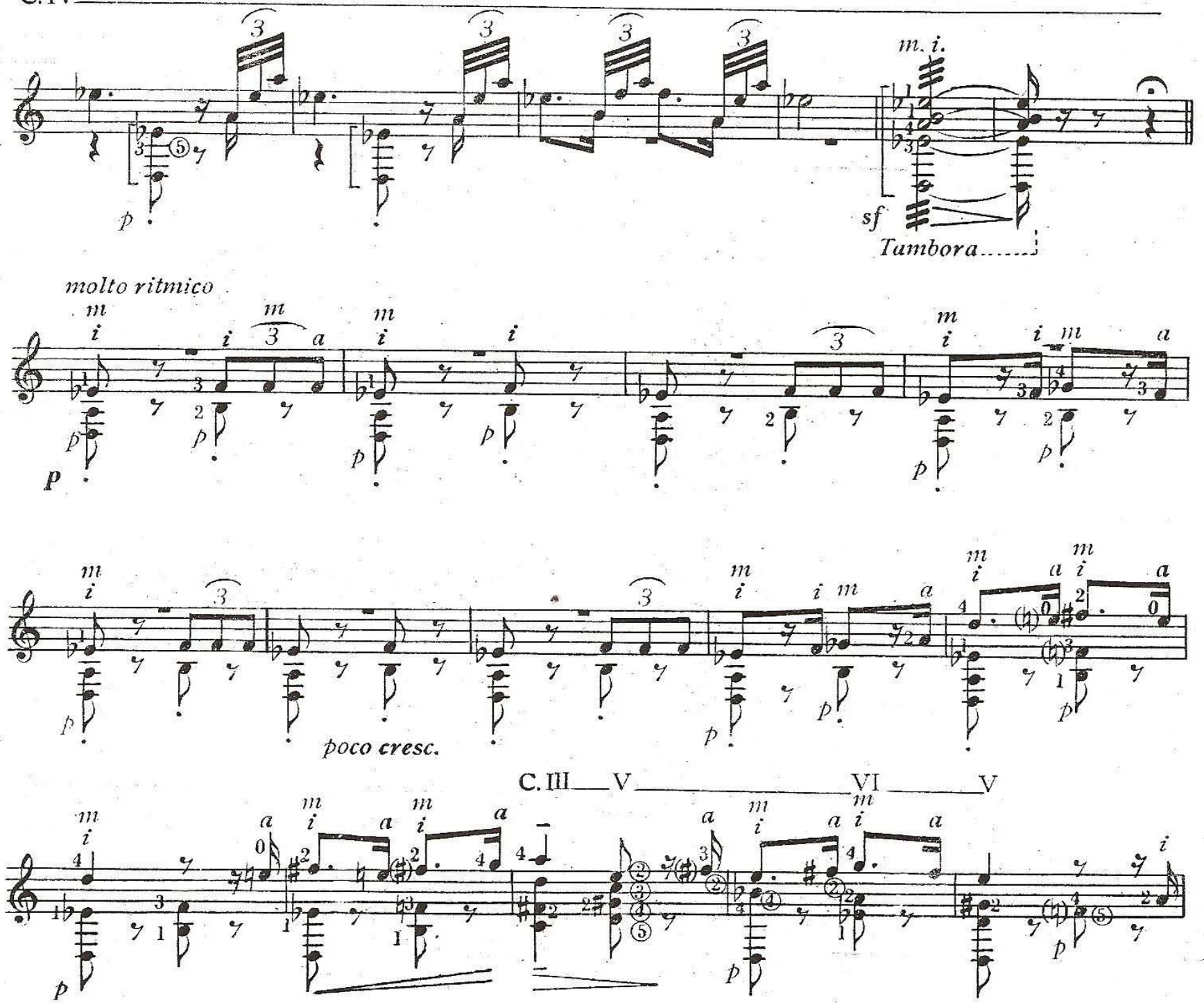

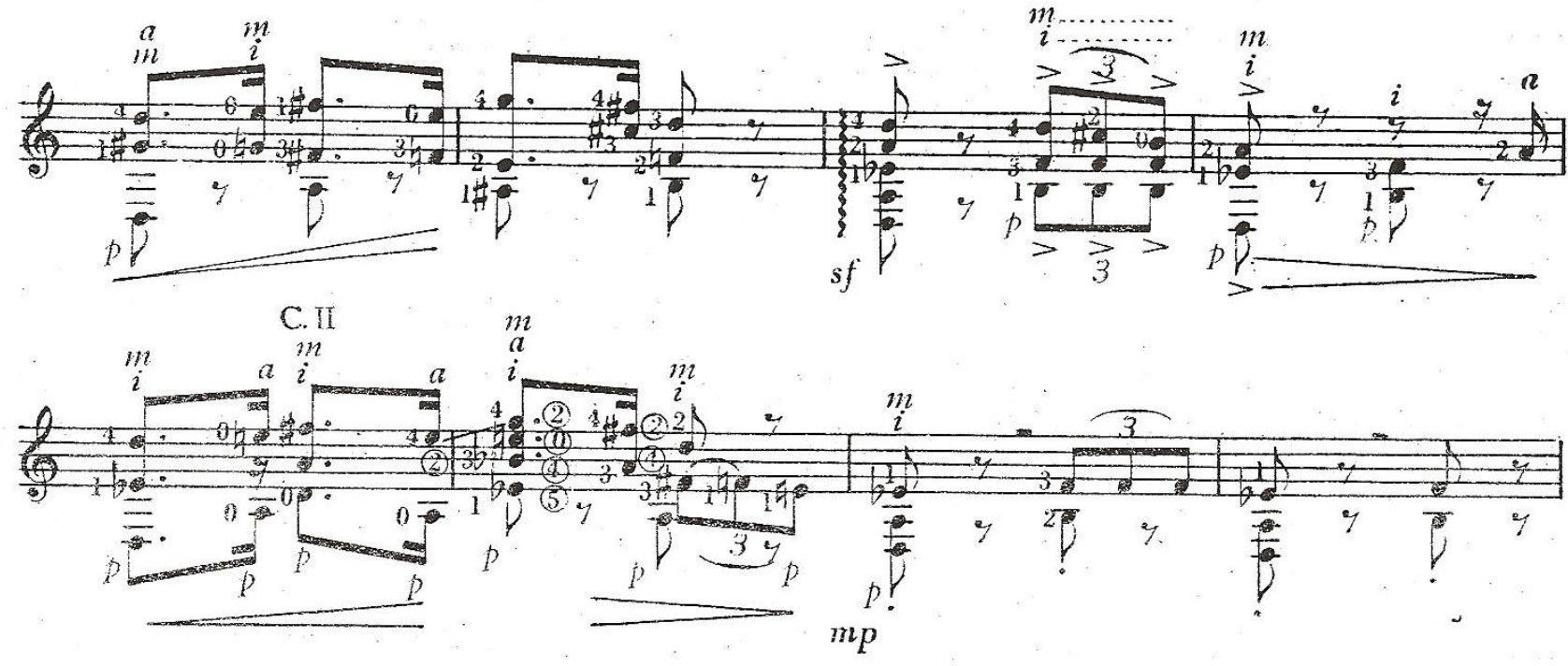

C. III
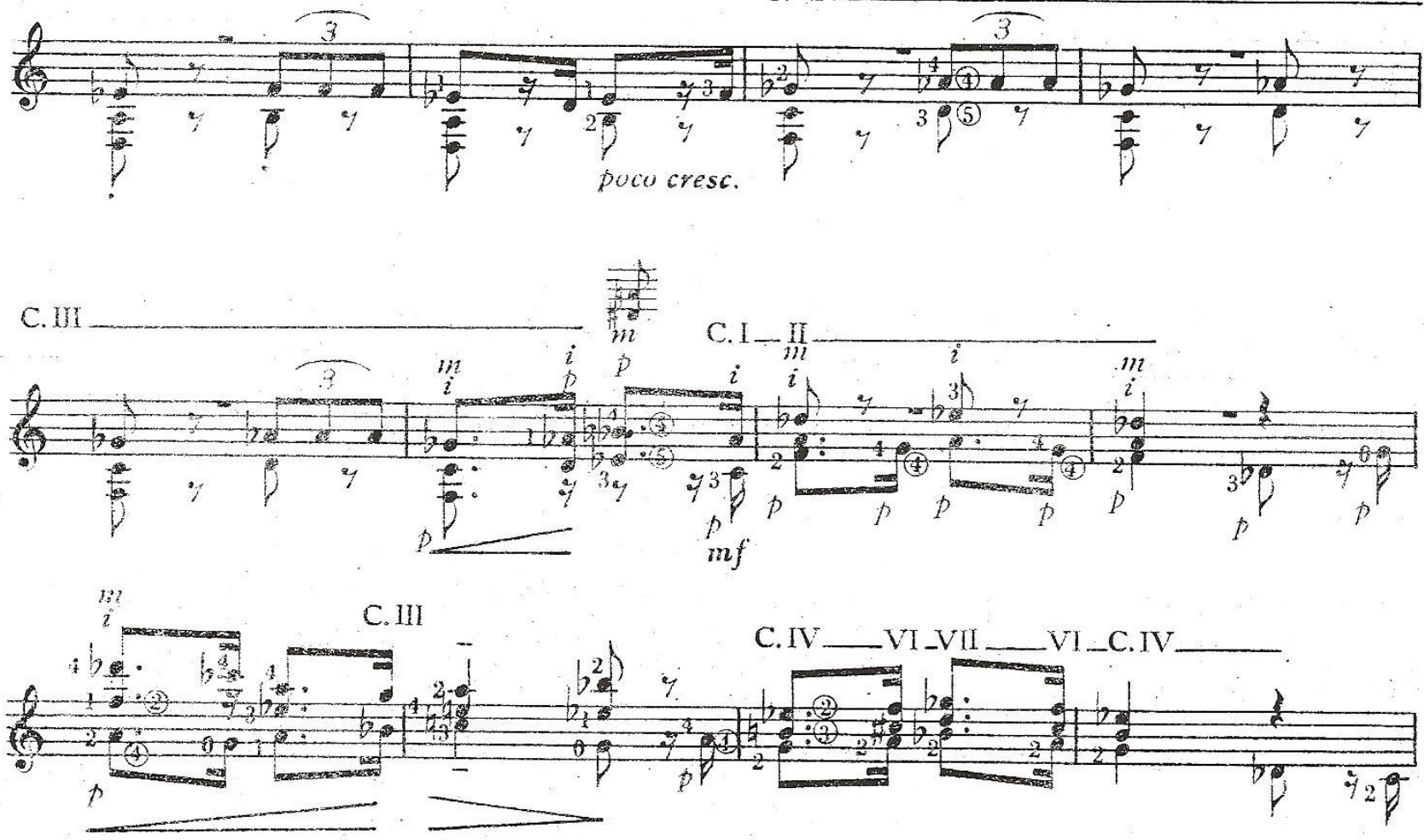

C.II

C. II - C.III

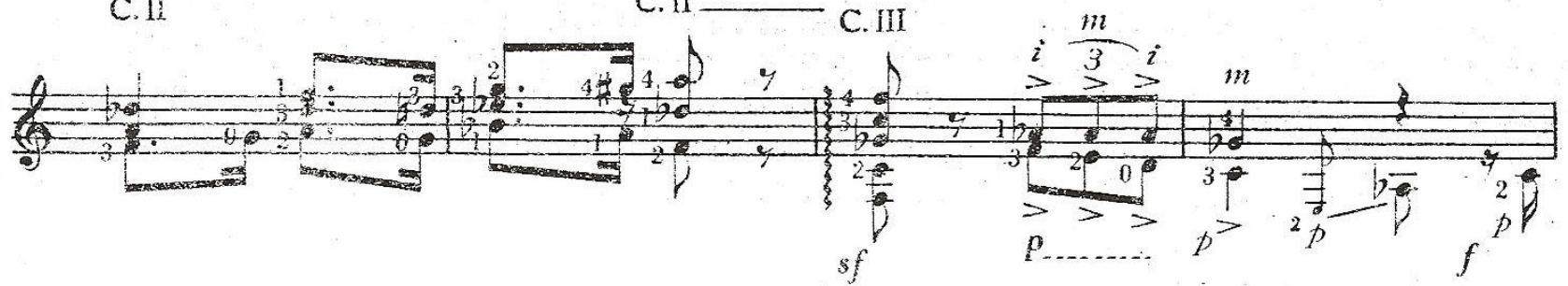


C. II

C. I

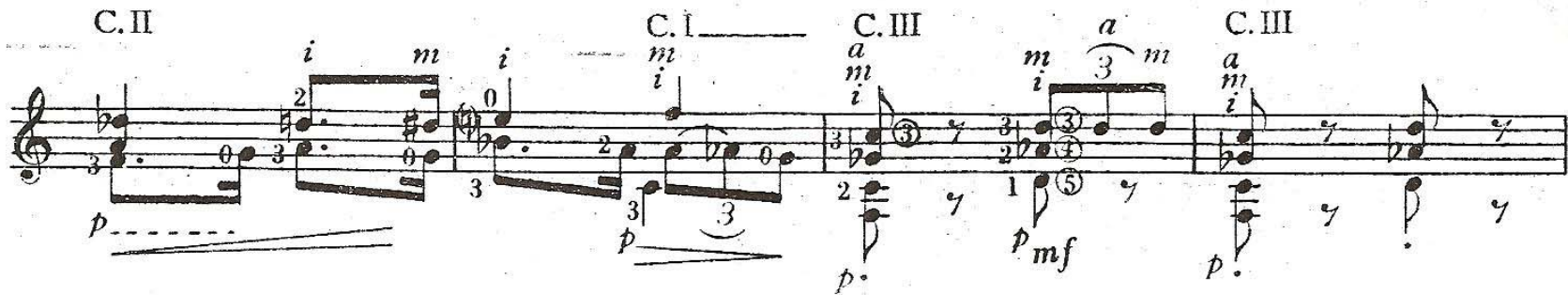

C. III

C. III

C.IX

C.IV

IV

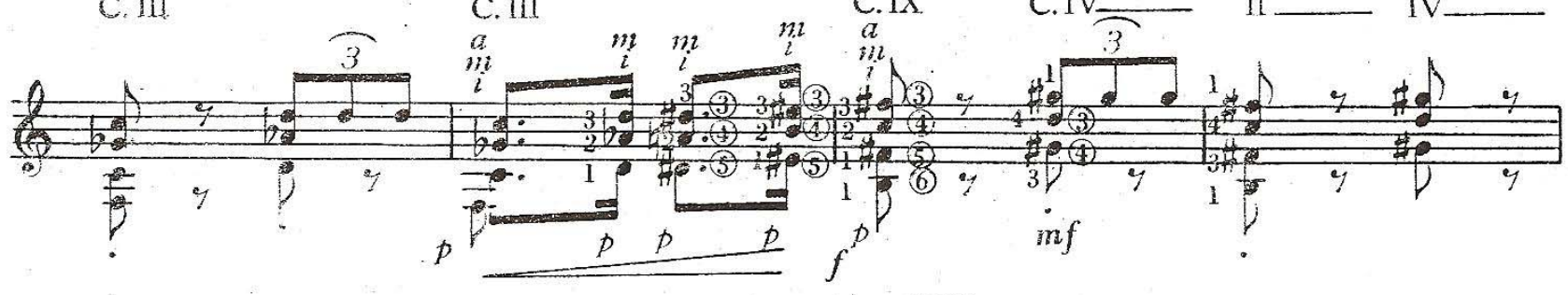

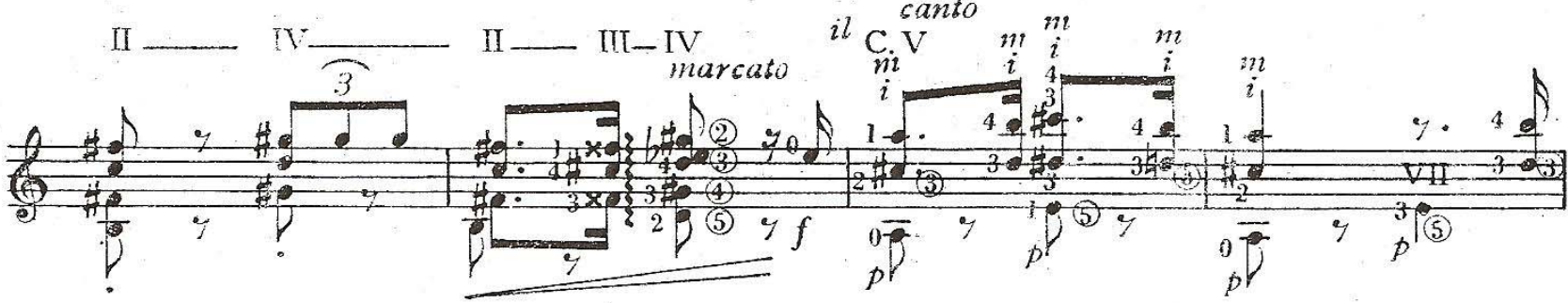

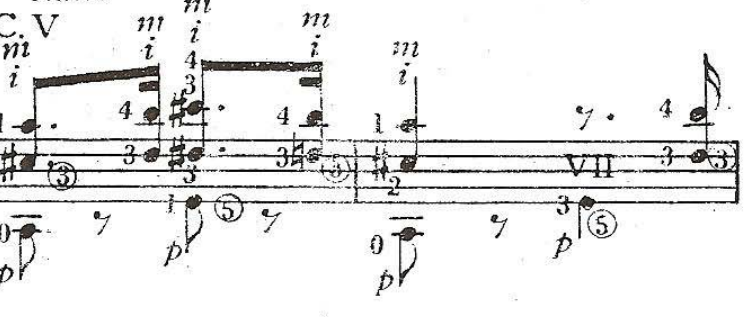

\section{X_- VII}

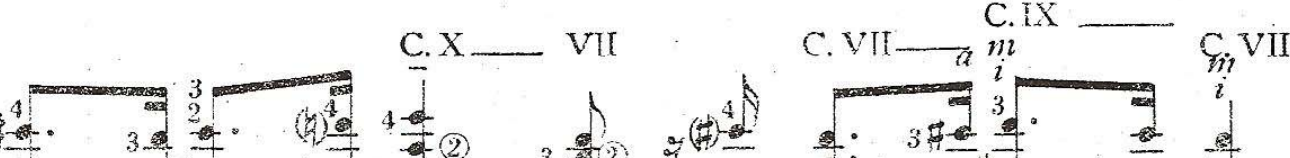

C. IX

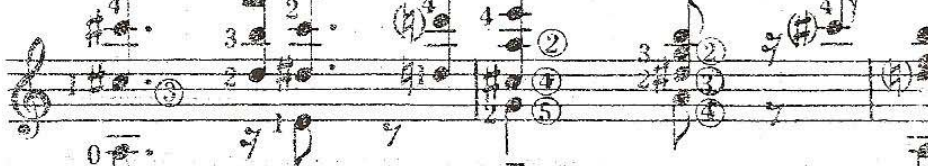

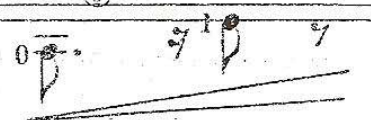

C. VII

C. Vl

in

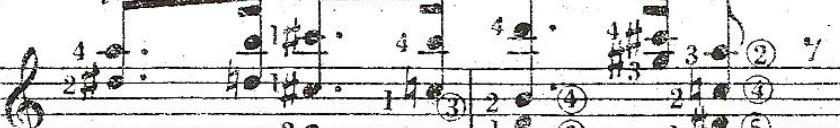

(1)

C. VII
C.IV

3 p)

C. IX

c. VII

i $a$ C. $\mathrm{V}$

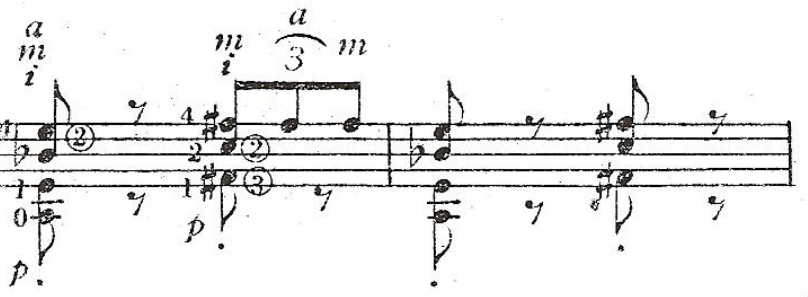



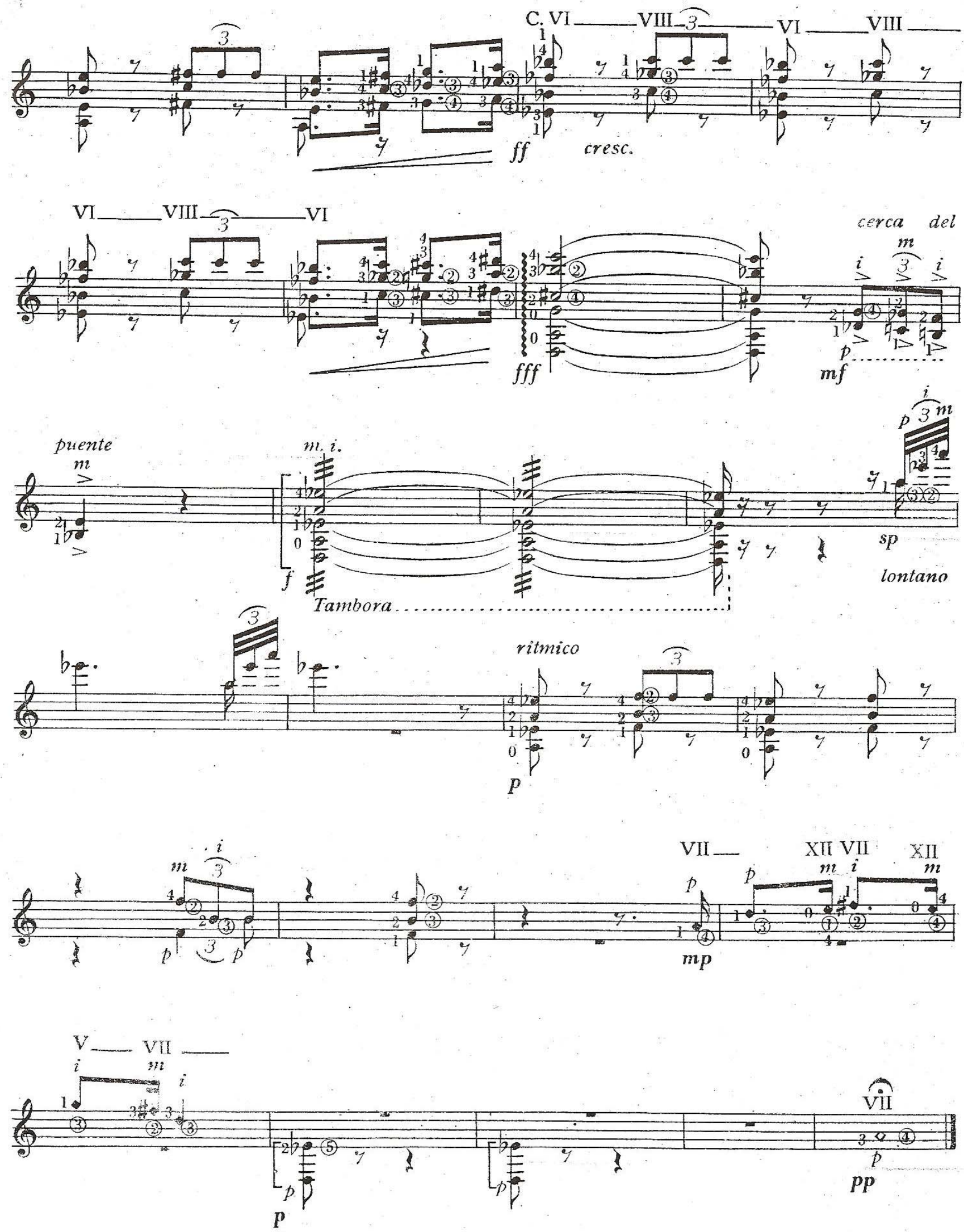


\subsubsection{El Cant dels Ocells}

Esta canção foi usada na obra para violão de Emilio Pujol e possui duas versões $^{132}$.

O pianista Federico Mompou também usou o mesmo tema na Cançó no. 13 para violão solo.

Embora na tradição catalã represente uma canção de ninar, cantada com várias melodias que se adaptam ao ritmo do balançar do berço, tornou-se canção símbolo de patriotismo, a melodia de celebração da Redenção e expressa sentimentos por diversas espécies de pássaros, símbolo de liberdade.

Tal melodia ganhou diversos arranjos através dos anos e simboliza o renascimento do folclore catalão. Alguns afirmam encontrar uma metáfora nos pássaros, cujas vozes se juntaram para ecoar uma mensagem de um passado distante, onde encontramos tais melodias tradicionais, e trazidas ao presente, com a sonoridade dos violões que trouxeram sua voz de volta.

Durante um período de ditadura na Catalunha, El Cant dels ocells se converteu num símbolo nacional, quase um hino patriótico, devido às apresentações do célebre violoncelista Pablo Casals, que costumava encerrar seus concertos com uma adaptação desta canção para piano e violoncelo.

Seu texto raramente oferece variações.

Possui umas modulações curiosas que são surpreendentes numa canção popular, que, de modo geral, não costumam usar elementos de surpresa.

\footnotetext{
${ }^{132}$ As duas versões se encontram no volume 4 da Escuela Razonada de Emilio Pujol (PUJOL, 1954).
} 


\section{El Cant dels Ocells}
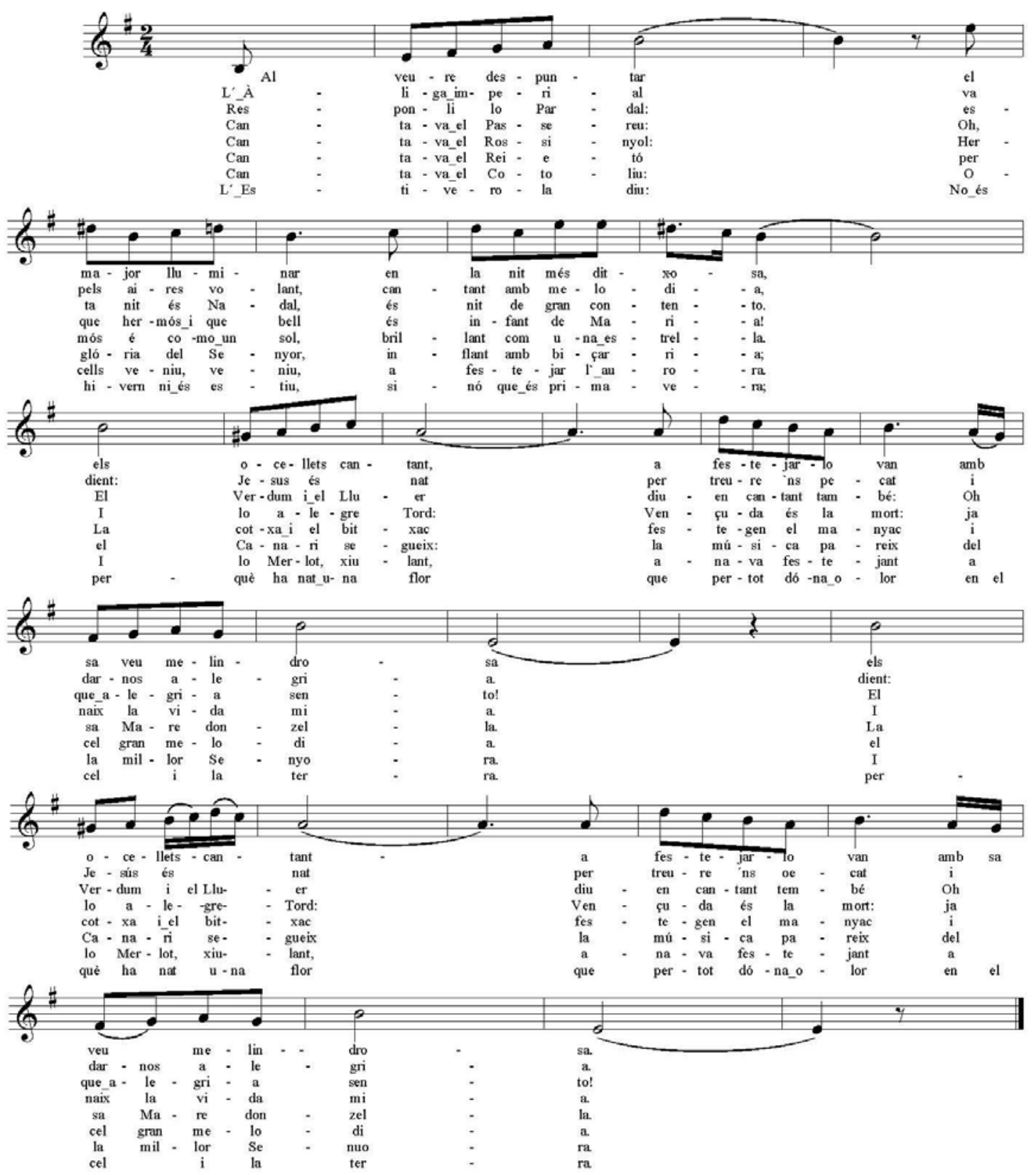

Copyright 1951 by Amades 
Como referência fonográfica, citamos a cantora espanhola Victoria de Los Angeles ${ }^{133}$ e o grupo catalão e o coral Orfeo Catalá ${ }^{134}$, que gravaram esta canção com texto. Outra referência encontrada é o arranjo para piano e voz de Lluís Jordá (19--, p. 18, partitura) e no arranjo para a mesma formação de Joaquin Nin (1924, p. 27) ${ }^{135}$.

A canção segue descrevendo as várias espécies de pássaros que cantam em homenagem ao nascimento de Jesus, que segundo a letra da canção, ocorreu na primavera: “L’Estiverola diu:/ no és hivern ni és estiu/ sinó és primavera”. (AMADES, 1951, p. 13) A tradução livre de El Cant dels Ocells (O Canto dos Pássaros) segue abaixo:

${ }^{133}$ CANÇONS TRADICIONALS CATALANES. Victoria de Los Angeles with Geoffrey Parsons. Collins Classic, 1992 (Cd).

${ }^{134}$ ORFEO CATALÁ. Chansons Traditionnelles de Catalogne. Harmonia Mundi, 1992 (Cd).

${ }^{135}$ Cf. ANEXO A, p. 263 e 264. 
$\mathrm{Al}$ veure despuntar el major lluminar en la nit més ditxosa, els ocellets, cantant, a festejar-lo van amb sa veu melindrosa.

L'Aliga imperial va pels aires volant, cantant amb melodia, dient:_ Jesús és nat per treure 'ns pecat i dar-nos alegria.

Respon-li lo Pardal: - Esta nit és Nadal, és nit de gran contento. el Verdum i el Lluer diuen cantant també:

- Oh, que alegria sento!

Cantava o Passerell:

- Oh, que hermós i que bell

és l'infant de Maria!

I lo alegre Tord:

- Vençuda n'és la mort: ja naix la vida mia.

Cantava el Rossinyol:

- Hermós és com un sol, brillant com uma estrella. la Cotxa i el Bitxac festegen el manyac i sa mare donzella.

\section{Cantava el Reietó} per glória del Senyor, inflant amb biçarria; el Canari segueix: la música pareix del cel gran melodia.

Cantava el Cotoliu:

- Ocells, veniu, veniu, A festejar l'aurora. I lo Merlot, xiulant, anava festejant a la millor Senyora.
Quando vemos despontar a luminária maior (lua) na mais jocosa noite os passarinhos, cantando, vão festejar-lhe com sua vozes angelicais.

A águia imperial vai voando pelos ares cantando com melodia dizendo: - Jesus nasceu para acabar com o pecado e nos dar alegria.

Responde-lhe o Pardal:

- Esta noite é Natal, noite de grande felicidade. o Verdum e o Lluer dizem cantando também:

- Oh, que alegria sinto!

O Passerel cantava:

- Oh, que formoso e belo é o filho de Maria!

E o Tord alegre: - A morte está derrotada! nasceu minha vida.

O Rouxinol cantava:

- É formoso como um sol, brilhante como uma estrela.

a Cotxa e o Bitxac

festejam o doce menino

e sua virgem mãe.

O Reietó cantava pela glória do Senhor, inflando com orgulho

o Canário segue: a música parece uma grande melodia celestial.

O Cotoliu cantava:

- Pássaros venham, venham, festejar a aurora.

E o Merlot, assoviando, seguia festejando à melhor Senhora. 
L'Estiverola diu: no és hivern ni és estiu, sinó que és primavera; perqué há nat uma flor que pertot dóna olor, que el cel i la terra.

Canta el Francollí:

- Ocells: qui vol venir a glossar melodia, a veure el gran Senyor amb son gran resplendor dintre d'uma establia?

Cantava el Puput:

- Esta nit há vingut el Rei de cels i terra. la Tórtora i Colom admirem a tothom, cantant sense tristesa.

Pigots i Borroners se'n pugen pels fruiters, cantant amb alegria; la Guatlla i el Cucut molt de lluny han vingut per contemplar el Messias.

Cantava la Perdiu:

- Me'n vaig a fer lo niu dins d'aquella establia, per a veure l'infant com està tremolant en braços de maria.

La Garsa, Griva i Gaig diuen: - Ja ve-lo Maig. Respon la Cadernera: - Tot arbre reverdeix, tota planta floreix com si fos primavera.

Cantava lo Pinsà:

- Glória avui, festa demà, sento gran alegria de veure el diamant tan hermós i brillant als braços de Maria.
A Estiverola diz:

não é inverno nem verão, ms sim primavera; porque nasceu uma flor que exala seu odor por toda parte, pelo céu e pela terra.

O Francollí canta:

- Pássaros: quem quer vir cantar a melodia, e ver o grande Senhor com seu grande resplendor dentro de um estábulo?

A Puput cantava:

- Nesta noite veio

o Rei dos céus e da terra.

a Tórtora e pomba

admiraram a todos, cantando sem tristeza.

Pigots e Borroners pousam nas árvores frutíferas, e cantam com alegria;

a Guatlla e o Cucut vieram de muito longe para contemplar o Messias.

A Perdiz cantava:

- Vou fazer o ninho dentro daquele estábulo, para ver o menino como está tremendo nos braços de Maria.

A Garsa, Griva e Gaig dizem: - Já está chegando Maio.

Responde a Cadernera:

- Toda árvore brota, toda planta floresce como se fosse primavera.

O Pinsà cantava:

- Glória hoje, festa amanhã, sinto muita alegria de ver o diamante tão formoso e brilhante nos braços de Maria. 
El Xot i lo Mussol, al veure eixir lo sol, confosos se retiren.

El Gamarús i el Duc

diuen: - Mirar no puc:

les resplendors m'admiren.

(AMADES, 1951, p. 13)
O Xot e o Mussol, ao verem o nascer do sol, confusos se retiram.

O Gamarús e o Duc

dizem: - Não posso olhar:

seu resplendor me surpreende. 


\section{ESTUDIO LI}

FTUDE II

(El caxt dels ocells)

Moderato M( $=60$ )

(Le chant des oiseaux)

6 . cuerda en Pe

bème corde en $\operatorname{Re} \stackrel{a}{m}$
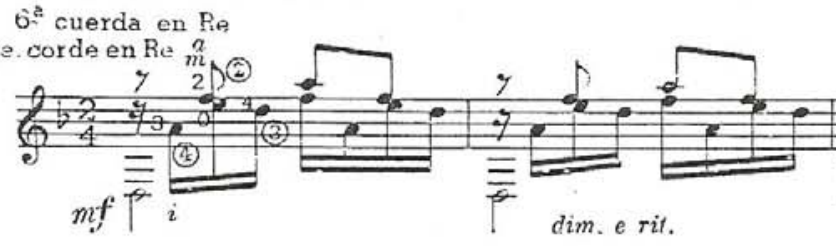

(5)

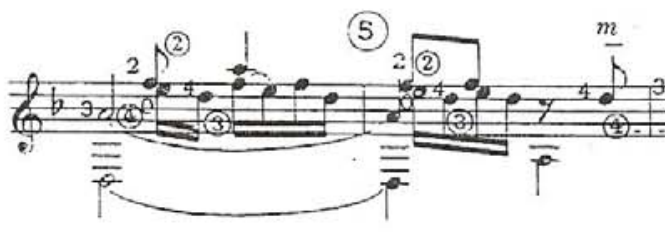

$$
\text { dim. e ril. }
$$
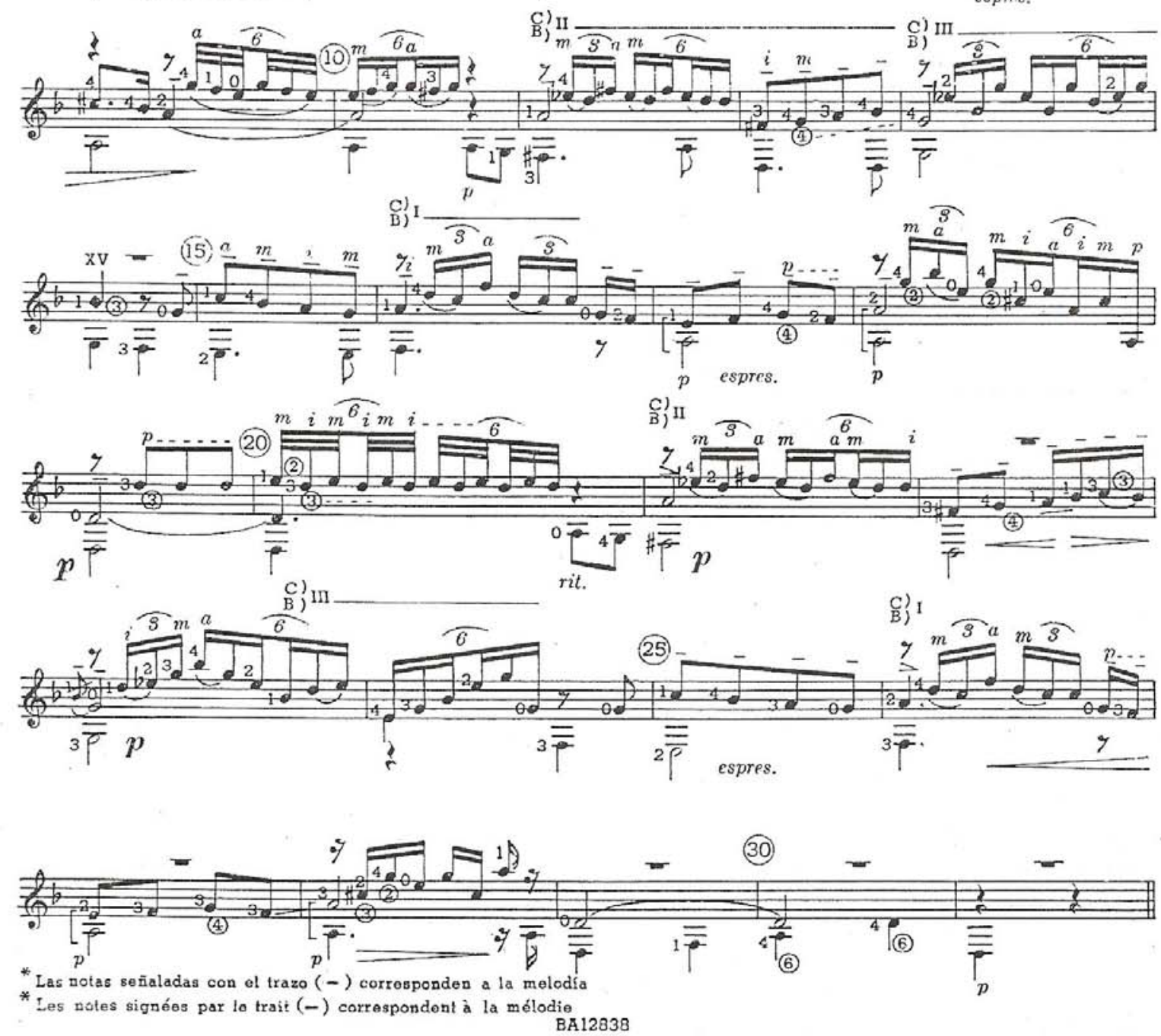

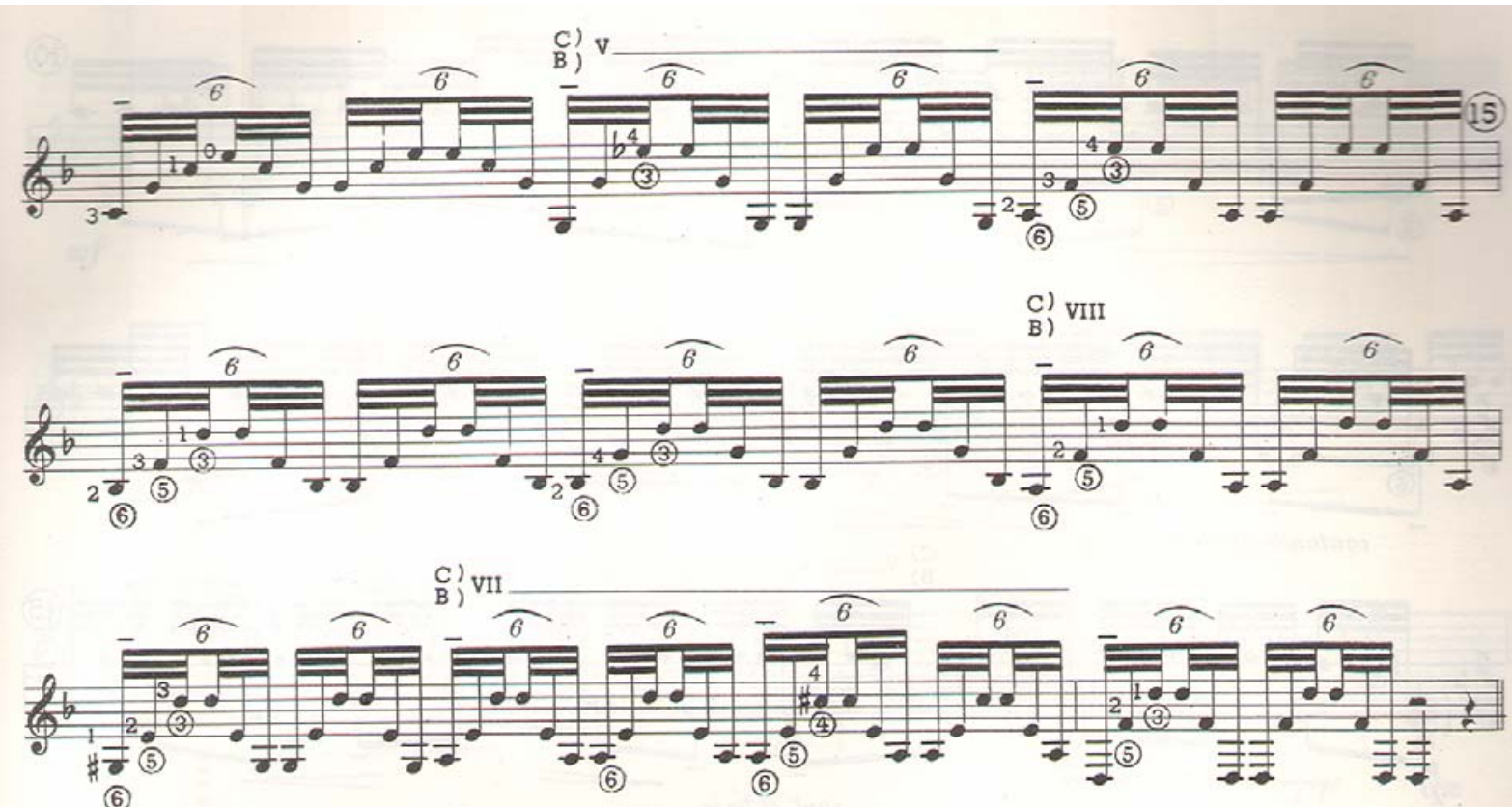

\section{ESTUDIO XLV}

(Trémolo)

$$
\begin{gathered}
M(d=56) \\
6 \text { a cuerda en Re }
\end{gathered}
$$
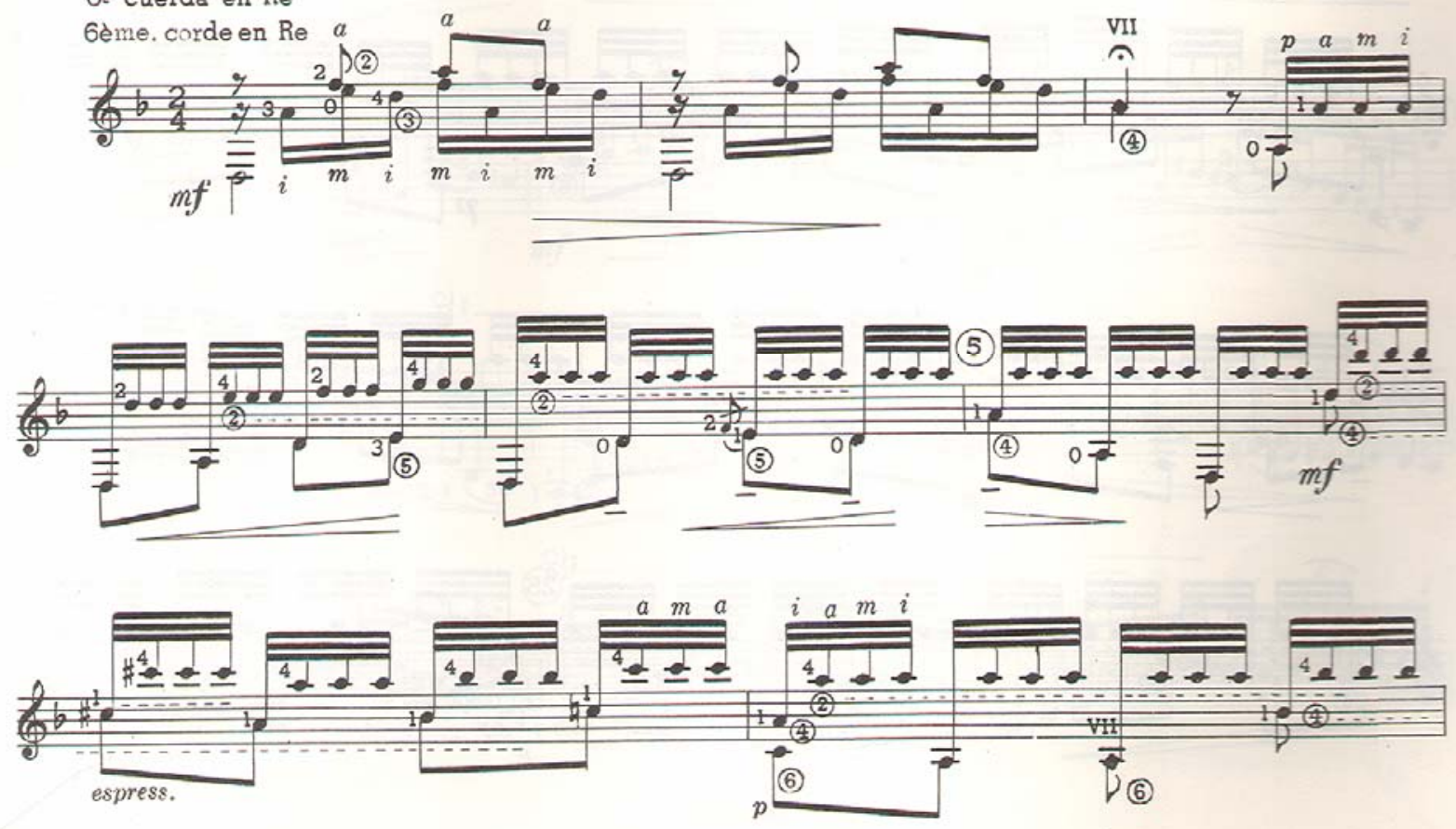


\section{A Narciso Yepes \\ CANÇO Y DANSA N. ${ }^{\circ} 13$}

FEDERICO MOMPOU Revisión y digitación de C A N Ç 0 Jordi Codina

(El cant dels ocells)
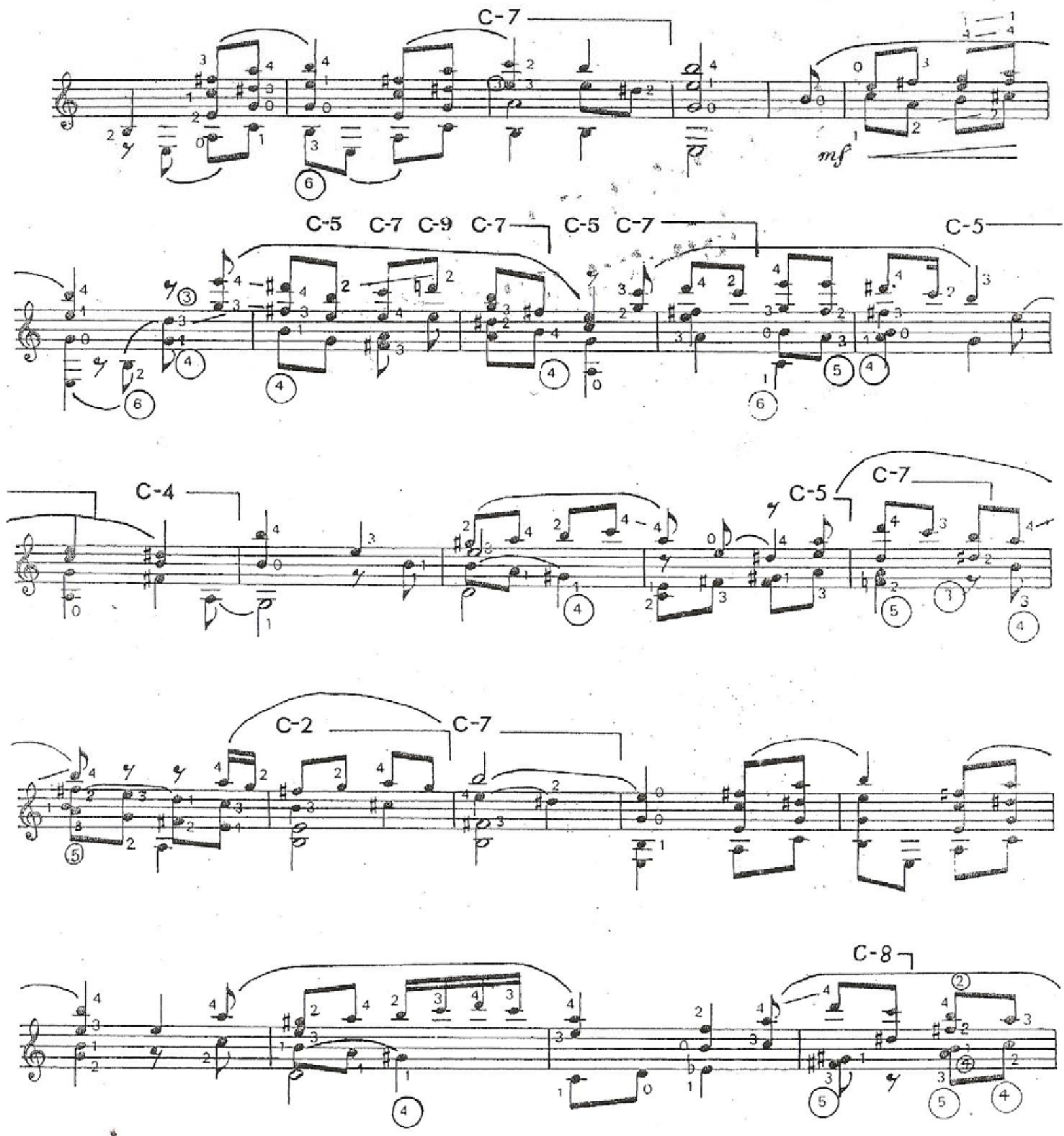

(C) Copyright 1986 by Federico Mompou Dencausse, Barcelona (España).

Edición autorizada en exclusiva para todos los paises a EDITORIAL DE MUSICA ESPAÑOLA CONTEMPORANEA (EMEC). Alcalá. 70. 28009 Madrid (España). 

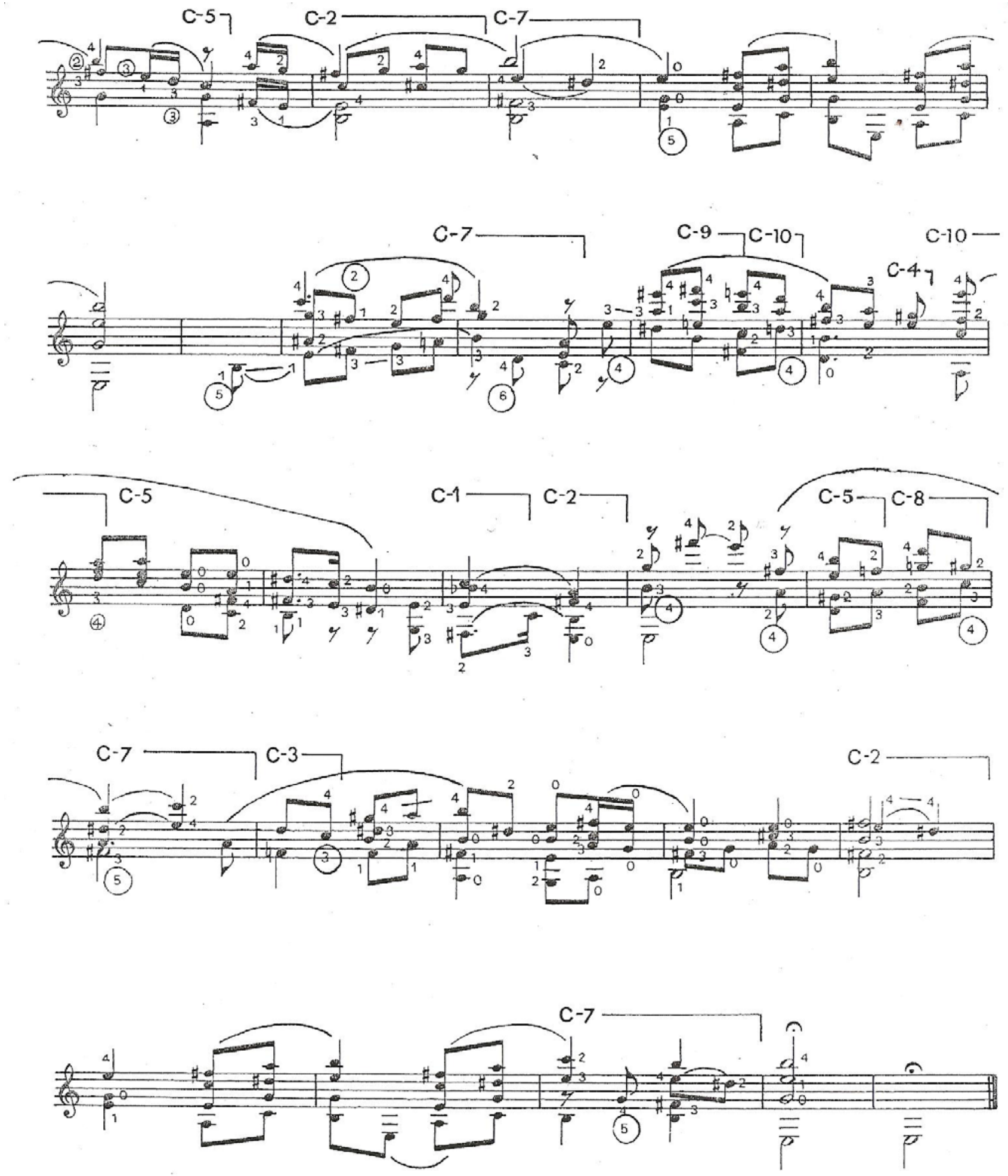


\subsubsection{El Bon Caçador}

Este tema foi utilizado na obra para violão Dança no. 13 da série de Canções e Danças para piano do compositor catalão Federico Mompou.

Ritmicamente, se concentra pelas terminações femininas, característica na obra de Mompou (PAINE, 1989, p. 101) e na poesia na língua catalã (BARGALLÓ, 1983, p. 127).

Na tradição cancionística apresenta uma grande diversidade de variantes literárias e melódicas. Outra referência indicou tais variações - uma descrita em compasso 2/4 e outra em compasso 6/8 (PUJOL, 1926, vol. 2, p. 120)

No final do século passado, se bailava em volta de uma pedra durante uma forada $^{136}$ típica realizada na segunda-feira depois da Páscoa. Colhiam-se flores e ervas aromáticas e medicinais do campo que eram colocadas na pedra e o povo dançava um ball rodó (dança de roda) em volta dela ao som desta canção.

Há uma versão melódica desta canção que se adapta ao ritmo do trabalho dos ferreiros ao cantarolarem a canção enquanto martelavam. O refrão, completamente alienado ao sentido do argumento da letra, faz alusão à ação de usar a bigorna.

Esta canção faz parte do repertório representado no carnaval, especialmente em Alt Berguedá. Os atores dançam o ball rodó ao som da mesma canção.

Como vimos anteriormente, as canções de caça caracterizam-se por frases curtas. Assim, observamos a estrutura melódica de El Bon Caçador, notamos a ocorrência de frases de três compassos:

\footnotetext{
${ }^{136}$ Comida campestre preparada especialmente para diversão do povo.
} 


\section{El Bon Caçador}
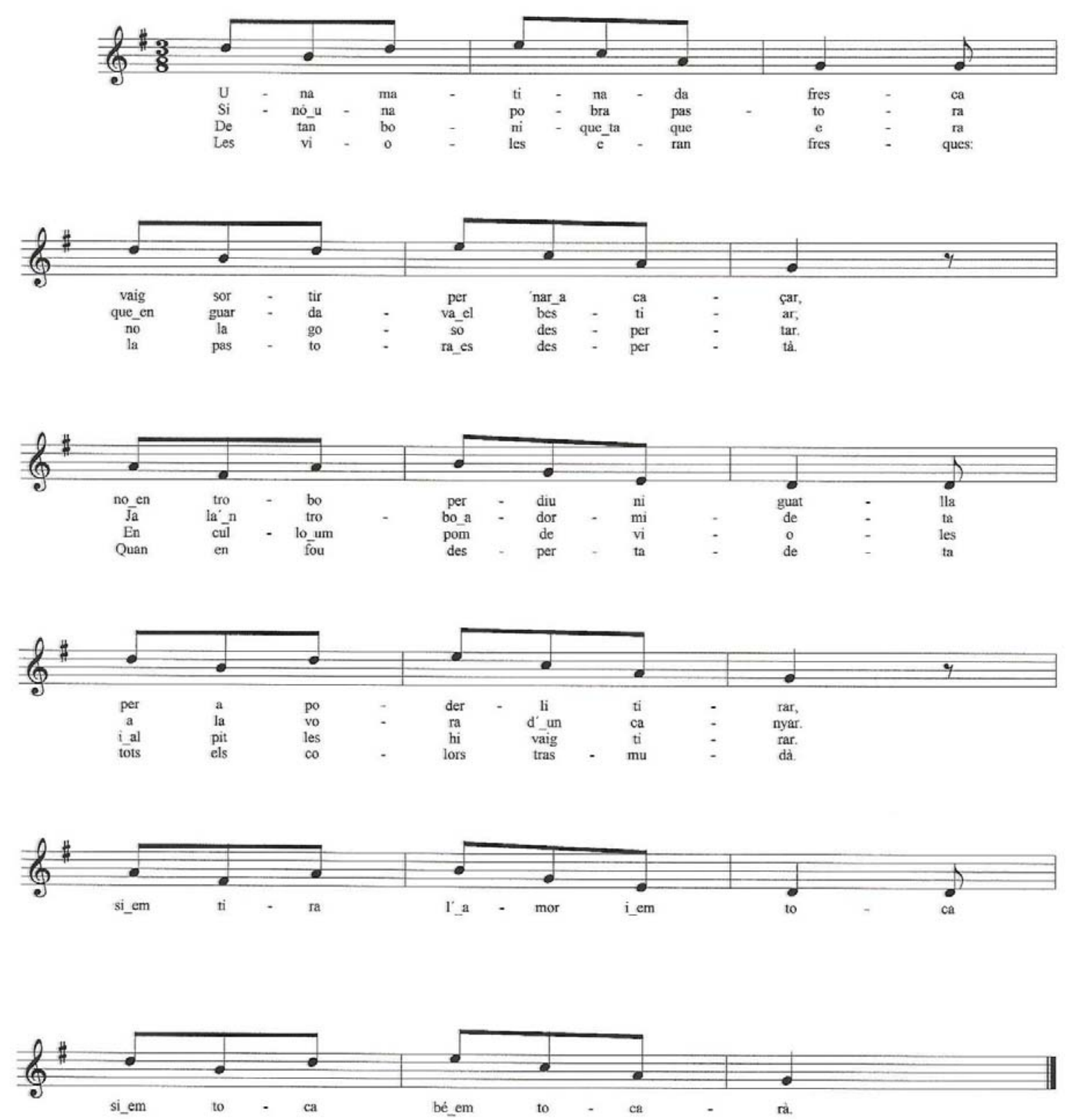

Copyright 1951 by Amades 
Recomendamos a referência fonográfica na obra da soprano Victoria de los Angeles ${ }^{137}$ para uma melhor compreensão do texto.

Segue a tradução livre de El Bom Caçador (O bom caçador):

Una matinada fresca

vaig sortir par 'nar a caçar, no em trobo perdiu ni guatlla

per a poder-li tirar,

Si em tira l'amor i em toca, si em toca bé em tocarà.

Sinó uma pobra pastora que em guardava el bestiar: Já la'n trobo adormideta a la vora d'um canyar.

De tan boniqueta que era no la goso despertar. En cullo un pom de violes $i$ al pit les hi vaig tirar.

Les violes eren fresques: la pastora es despertà. Quyan em fou despertadeta tots els colors trasmudà.

(AMADES, 1951, p.400)
Uma fresca manhã

saí para caçar, não peguei perdiz nem codorniz para poder atirar.

Se atirar no amor e acertar, se atirar bem acertará.

Havia uma pastora que cuidava do gado: Estava adormecida ao lado de um canavial.

De tão bonita que era não quis despertá-la. Colhi um ramo de flores e coloquei em seu peito.

As flores eram frescas: a pastora despertou. Quando acordou ficou com o rosto corado.

${ }^{137}$ CANÇONS TRADICIONALS CATALANES. Victoria de Los Angeles with Geoffrey Parsons. Collins Classic, 1992 (Cd). 


\section{A N S A}
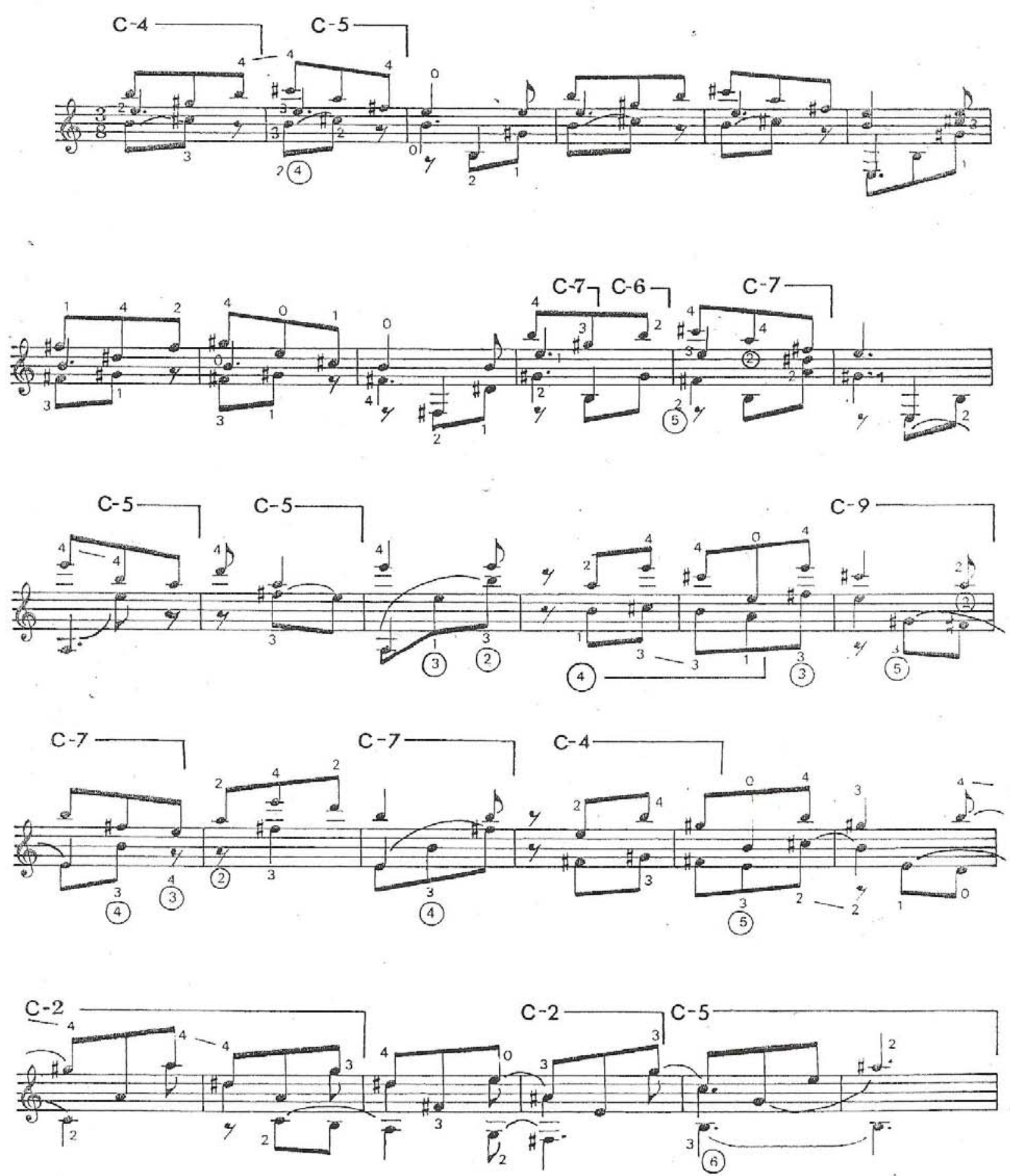

(C) Copyright $1986^{\circ}$ by Federico Mompou Dencausse, Barcelona (España). Edición autorizada, en exclusiva para todos los paises a EDITORIAL DE MUSICA ESPAÑOLA CONTEMPORANEA (EMEC), Alcalá, 70, 28009 Madrid (España). 

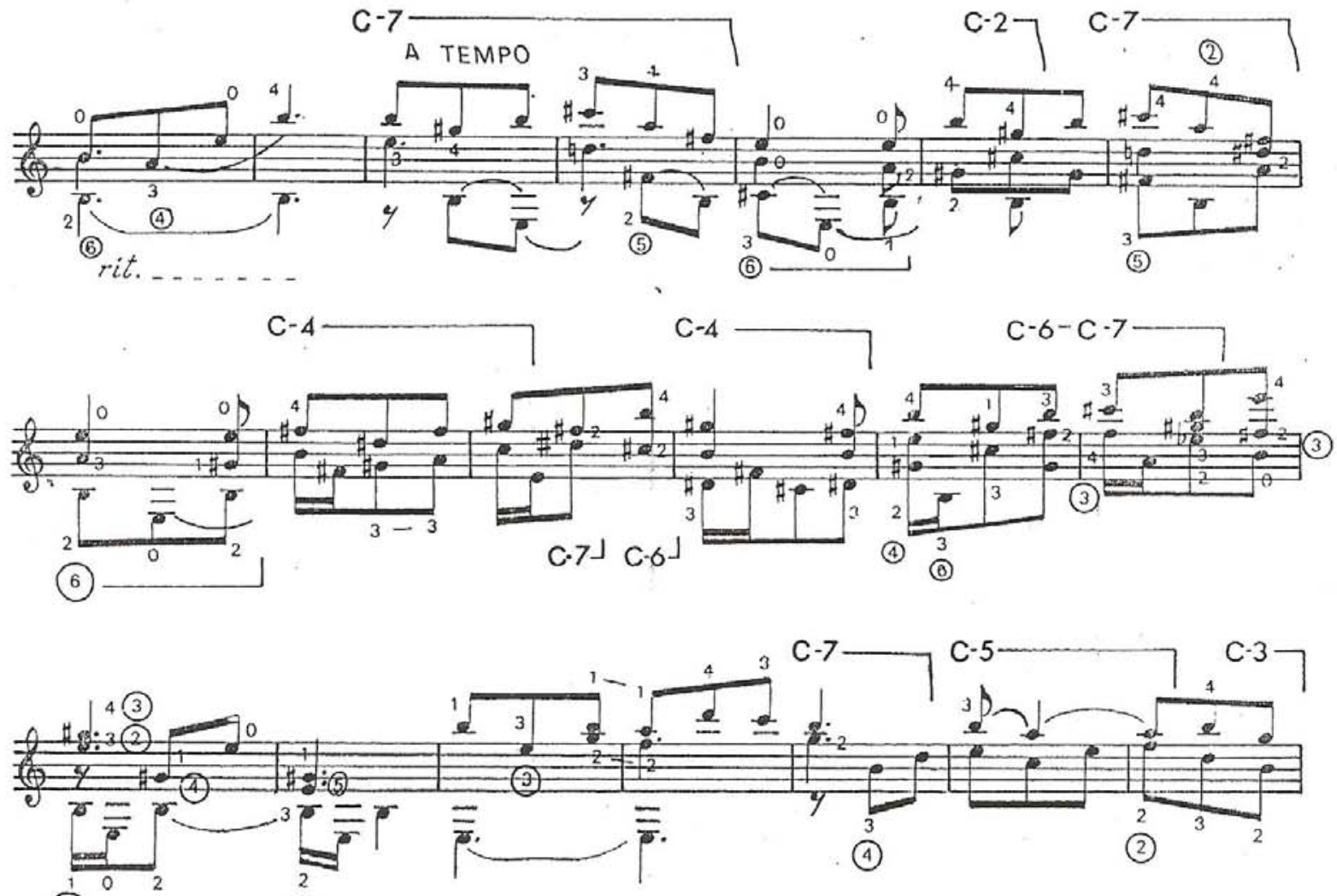

(6)

(6)
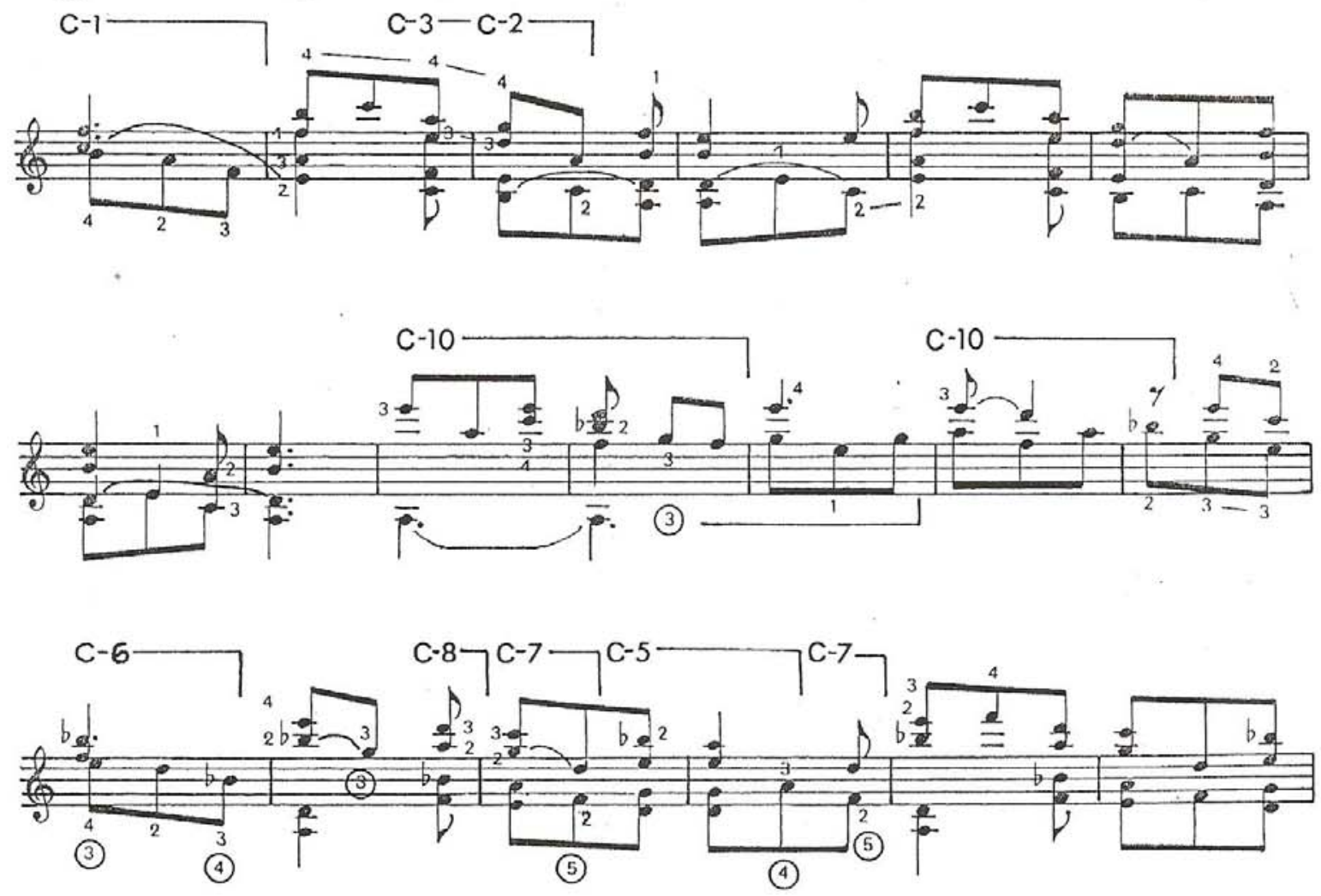

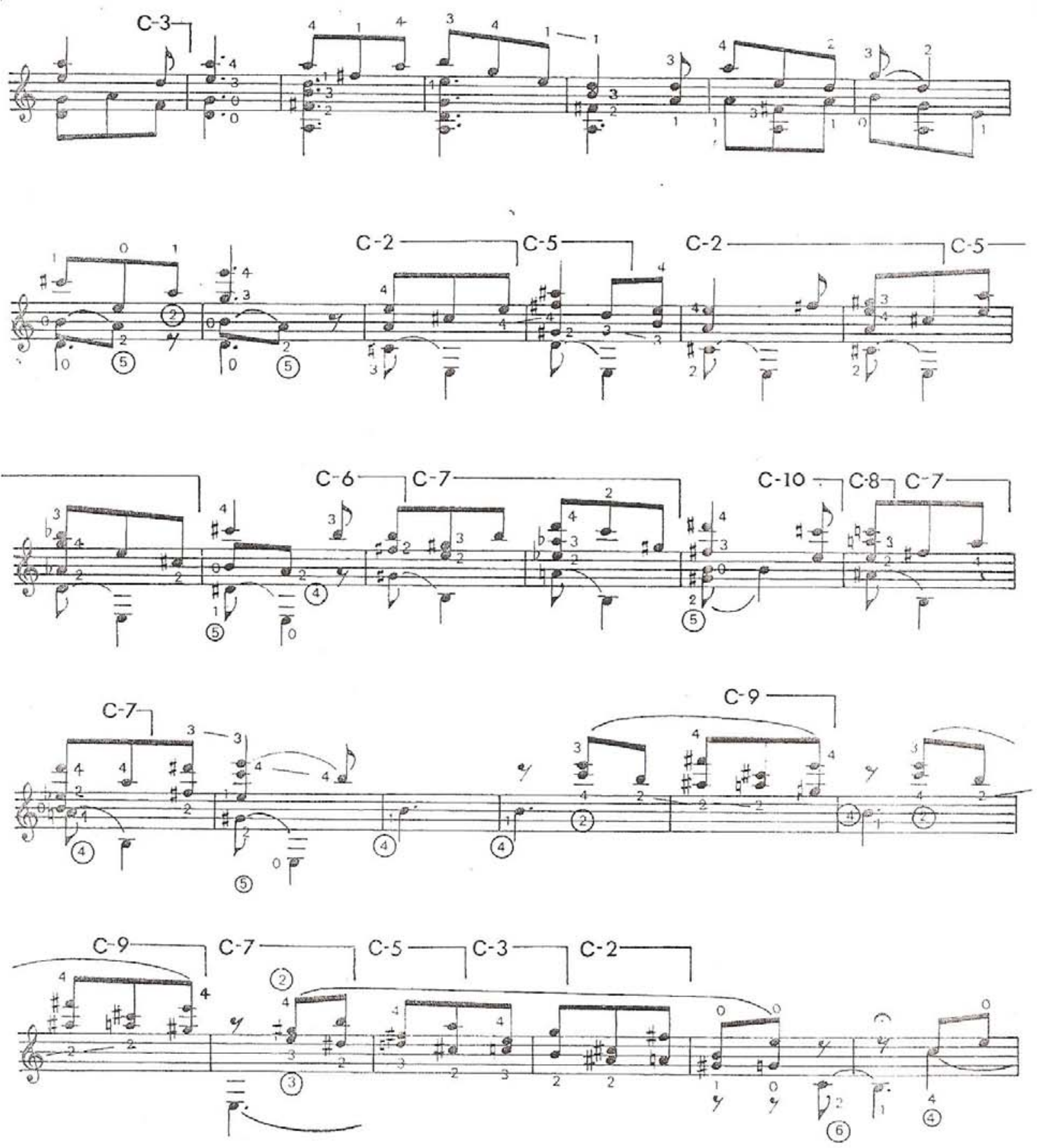

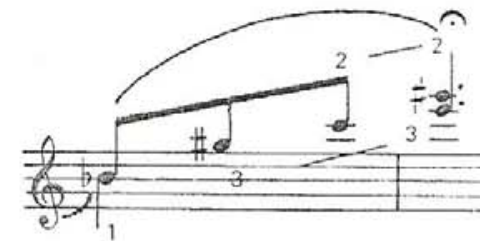

(4)

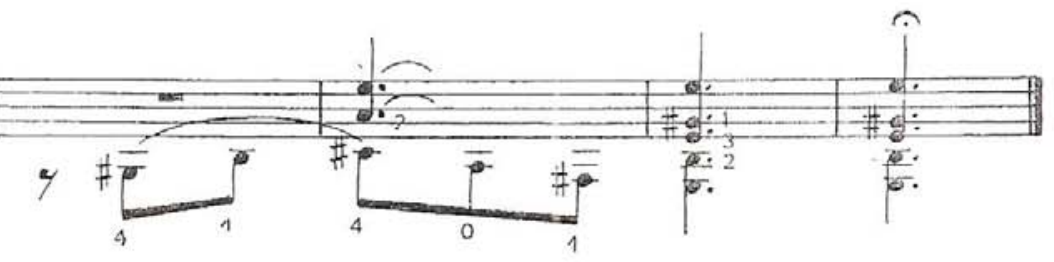




\subsubsection{La Ploma de Perdiu}

Esta canção foi utilizada na obra de Andrés Segovia ${ }^{138}$ e Emilio Pujol ${ }^{139}$ com caráter didático, longe da sofisticação das adaptações de Llobet.

Pujol sugere o andamento Vivace e Segovia Allegretto. Na versão catalã é cantada com ares de dança e faz parte dos encontros sociais ao ar livre - os "aplecs” citados anteriormente - com a finalidade de comer, cantar e dançar a típica sardana.

Classificada como canção de bordar, suas letras fazem referência direta ao trabalho artesanal, junto com temas amorosos e galantes. Também faz parte de cancioneiros de diversas terras francesas ${ }^{140}$, por onde é cantada principalmente por bordadeiras.

Uma outra referência desta canção, além de Amades, encontra-se no Romancerillo (PUJOL, 1926, vol. 1, p. 273).

Encontramos uma referência fonográfica que inclui o texto da soprano Victoria de los Angeles ${ }^{141}$.

O texto de La Ploma de Perdiu (A Pluma de Perdiu) com tradução livre para o português segue abaixo:

\footnotetext{
${ }^{138}$ SEgOVIA, A. 23 Canciones Populares de distintos países. Ancona: Bèrben Edizioni Musicali, s.d. (partitura).

${ }^{139}$ PUJOL, E. Deuxième Triquilandia. Bibliothéque de Musique Ancienne et Moderne pour Guitare. Paris: Editions Max Eschig, 1962 (partitura). Cf. STEFANO GRONDONA. Lo Cant dels Ocells. Stradivarius, 2000 (Cd).

${ }^{140}$ O título usado por Pujol está em francês: La Plume de Perdreau. Segovia chamou simplesmente de Catalana.

${ }^{141}$ CANÇONS TRADICIONALS CATALANES. Victoria de Los Angeles with Geoffrey Parsons. Collins Classic, 1992 (Cd).
} 
La Ploma de Perdiu

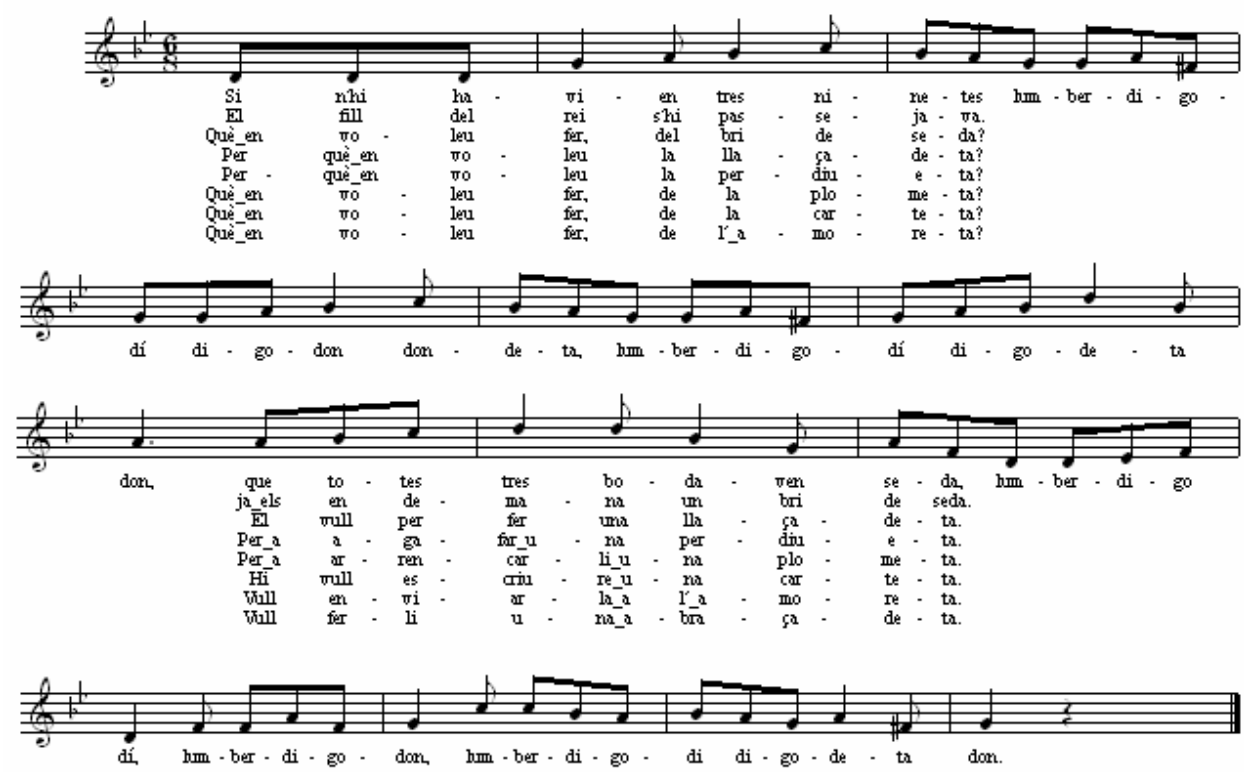

Copyright 1951 by Amades

Seguimos com a tradução livre de La Ploma de Perdiu (A Pena da Perdiz):

Si n'hi havia tres ninetes, lumberdigodí digodon don dondeta, lumberdigodí digodeta don, que totes tres brodaven seda, lumberdigodí lumberdigodon, lumberdigodí digodeta don.

El fill del rei s'hi passejava. Já els demana um bri de seda. - Què em voleu fer, del bri de seda?

- El vull per fer una llaçadeta.

- Per què en voleu la llaçadeta?

- Per a agafar una perdiueta.

- Per què en voleu la perdiueta?

- Per a arrencar-li una plometa.

- Què en voleu fer, de la plometa?

- Hi vull escriure una carteta.

- Què em voleu fer, de l'amoreta?

- Vull em fer-li una abraçadeta.

(AMADES, 1951, p 760)
Haviam três meninas, lumberdigodí digodon don dondeta, lumberdigodí digodeta don, todas três bordavam seda, lumberdigodí lumberdigodon, lumberdigodí digodeta don.

O filho do rei passeava.

Ele encomenda uma peça de seda.

- Que fará com a peça de seda?

- Quero fazer uma laçada.

- Por que quer fazer uma laçada?

- Para capturar uma perdiz.

- Para que quer uma perdiz?

- Para arrancar-lhe uma pena.

- Que fará com a pena?

- Quero escrever uma cartinha.

- Que fará com seu amor?

- Vou dar-lhe um abraço. 


\section{La plume de perdreau}
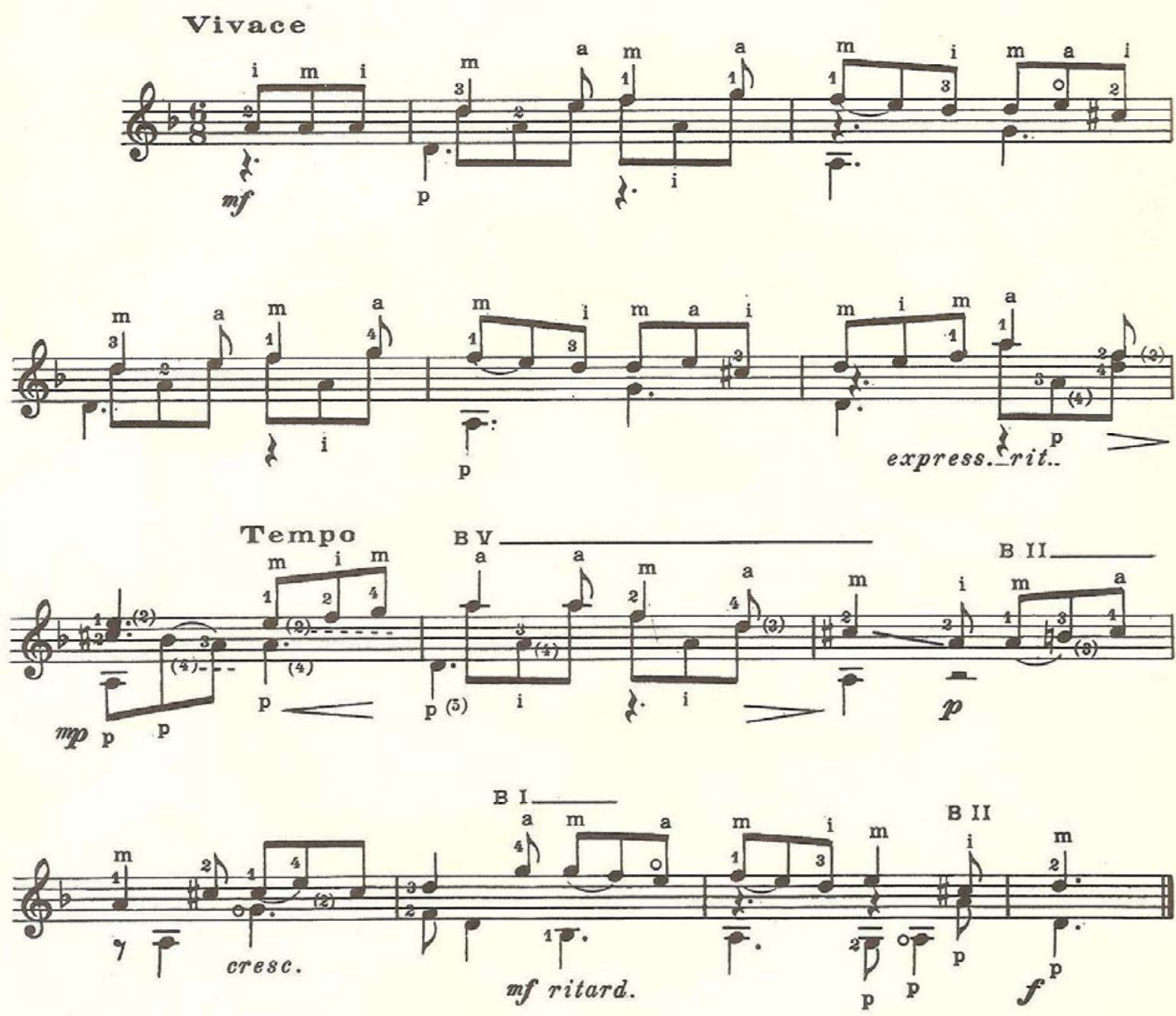


\section{9 - Catalana}

Allegretto
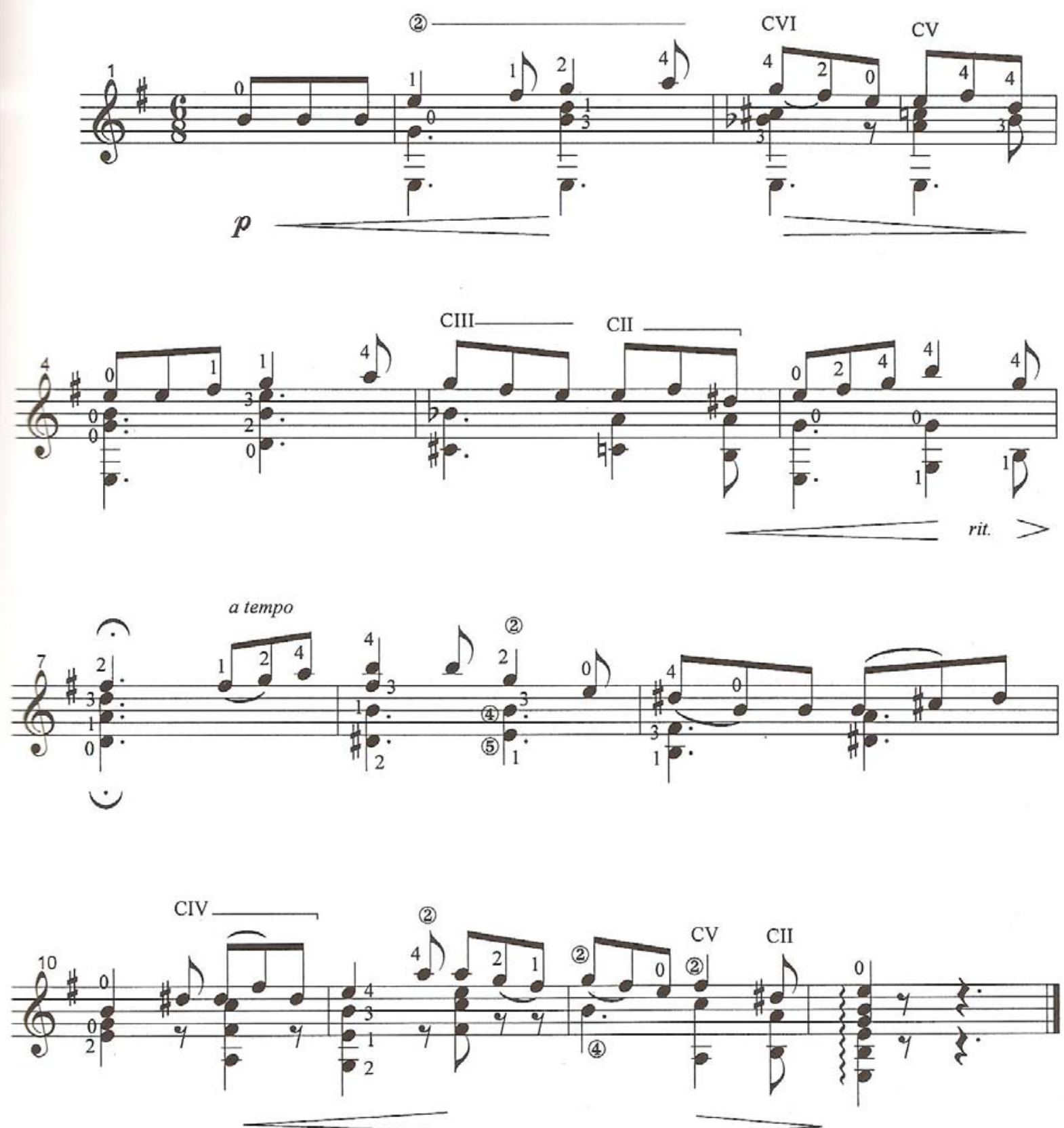


\subsubsection{Els Estudiants de Tolosa}

Segovia usou este tema em caráter didático. Foi gravada pelo violonista Stefano Grondona. ${ }^{142}$

Devido à sua popularidade na França, os eruditos franceses têm feito dela tema de estudo, e acreditam que foi originada num corretivo que alguns estudantes levaram por terem caçado em lugar proibido. Outros opinam que canta um episódio da guerra dos Trinta Anos, ocasionada pelo efeito das lutas religiosas entre os estudantes calvinistas e os estudantes católicos (AMADES, 1951, p. 405).

Era muito cantada em trabalhos monótonos e lentos, a canção preferida dos “espardenyers” (artesãos que faziam as “espardenyas” citadas na Canção do Ladrão). Também era entoada durante trabalhos pesados como, por exemplo, os estivadores da região de Ebre.

Esta canção era apresentada durante o carnaval em algumas regiões da Catalunha (Alt Berguedá) junto com uma espécie de brincadeira teatral: as pessoas formavam uma roda, e quem sabia cantar melhor entoava a melodia que, à medida que ia descrevendo os personagens e cenas, alguns faziam o papel dos atores, dançando e se movendo de acordo com a letra da canção (AMADES, 1951, p. 406).

Amades sugere como andamento para execução desta melodia semínima = 60. Encontramos a referência de uma variação desta melodia que sugere o andamento semínima = 76, descrita em compasso quaternário (PUJOL. 1926, vol. 2, p. 112).

Como referência fonográfica, recomendamos a audição da soprano Victoria de Los Angeles ${ }^{143}$.

\footnotetext{
${ }^{142}$ STEFANO GRONDONA. Lo Cant dels Ocells. Stradivarius, 2000 (Cd).

${ }^{143}$ CANÇONS TRADICIONALS CATALANES. Victoria de Los Angeles with Geoffrey Parsons. Collins Classic, 1992 (Cd).
} 
A tradução livre de Els Estudiantes de Tolosa (Os estudantes de Tolosa) para o português é a seguinte:

\section{Els Estudiants de Tolosa}
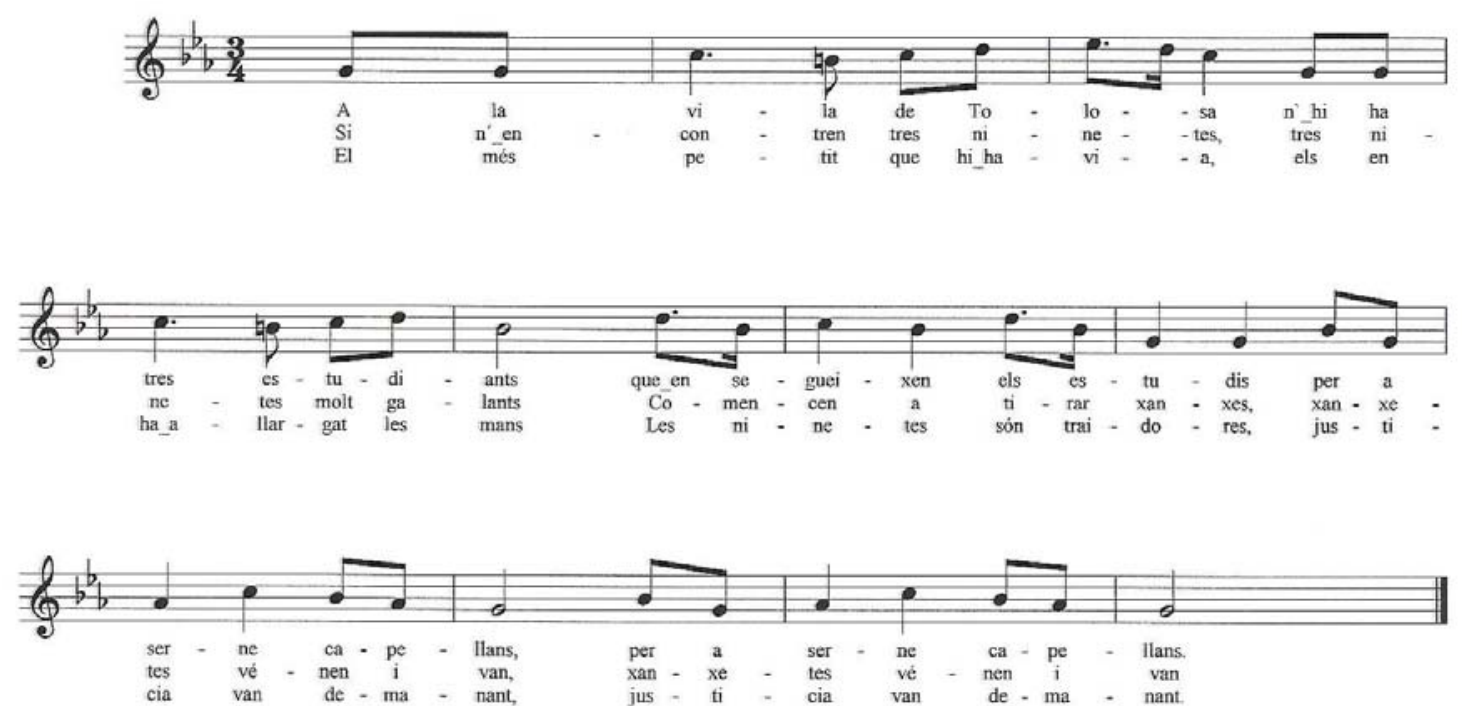

Copyright 1951 by Amades

A la vila de Tolosa

n’hi há tres estudiants

que en segueixen els estudis

per a ser-ne capellans.

Si n'encontren tres ninetes, tres ninetes molt galants, Comencen a tirar xanxes, xanxetes vénen i van.

El mès petit que hi havia, els en há allargat les mans. Les ninetes són traidores, justicia van demanant.

(AMADES, 1951, p. 404)
Na cidade de Tolosa existem três estudantes que estão seguindo seus estudos para se tornarem padres.

Encontraram três mocinhas três mocinhas muito gentis, começaram a fazer gracejos, que vem e vão.

A mais novo dos três extendeu-lhes as mãos As mocinha são traidoras e pediram por justiça. 

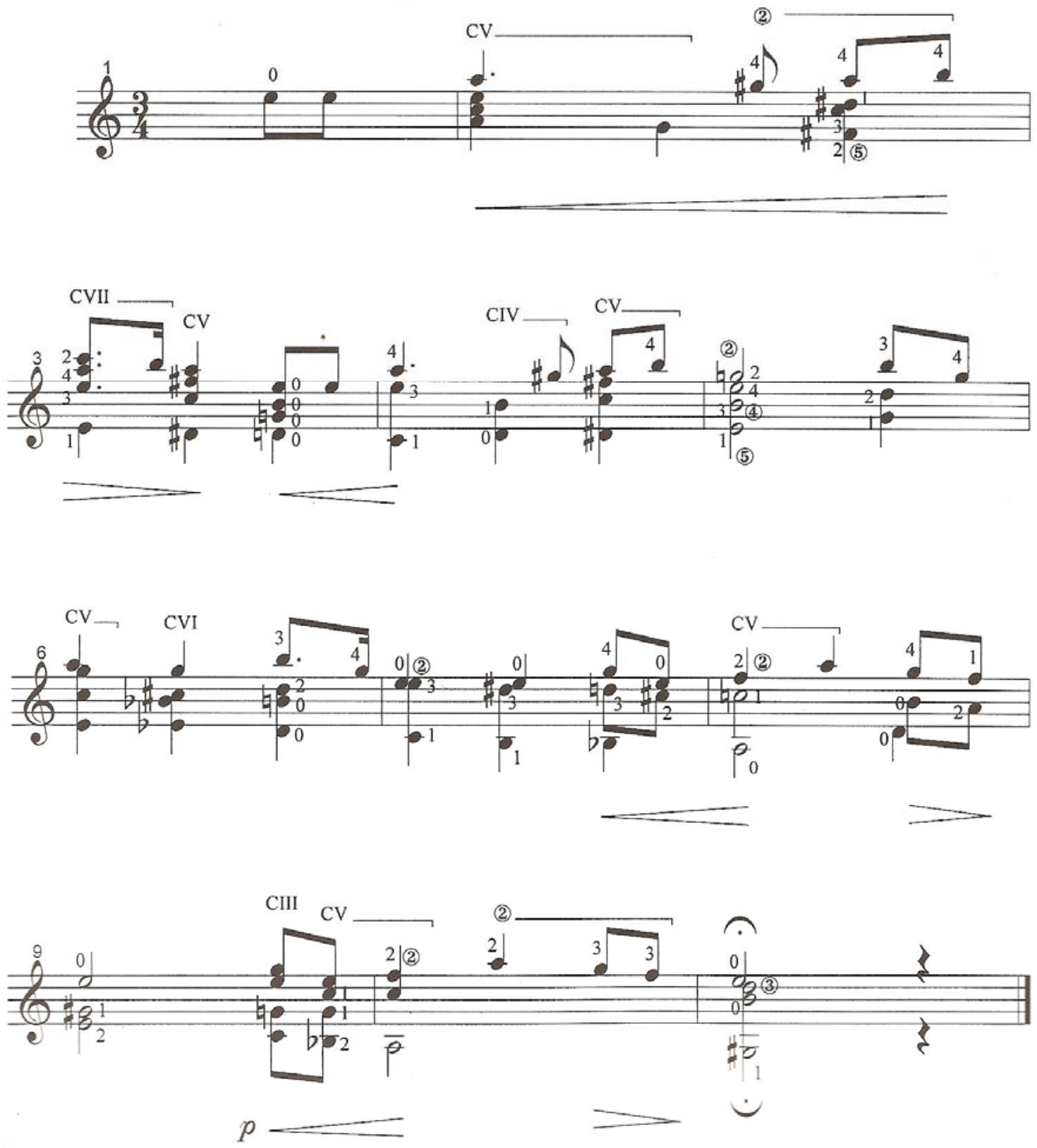


\subsubsection{Muntanyes del Canigó}

Narciso Yepes adaptou esta melodia tradicional para violão ${ }^{144}$.

O fundador do importante coral Orfeo Catalá, Luís Millet citado no capítulo 1, profundamente comprometido com o sentimento popular e influenciado por Pedrell, escreveu a obra $\underline{\operatorname{Los}}$ Pirineos que faz referência a esta melodia popular (LIVERMORE, 1974, p. 335), além de Pahissa (19--, p. 17, partitura) e Jordá (19--, p. 12, partitura) ${ }^{145}$.

A influência do canto litúrgico na canção tradicional catalã, que comentamos anteriormente, é recorrente neste tema, segundo a afirmação de alguns musicólogos (PUJOL, 1926, vol. 2, p. 386).

melodia popular

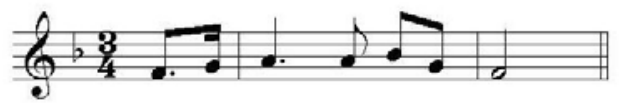

melodia popular
Gradual de la Missa de Virgine non Martyre

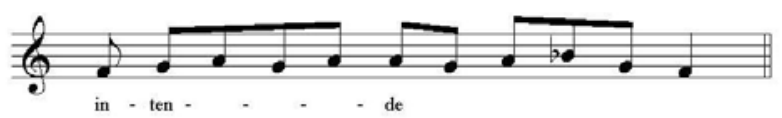

Kyrie de la Missa VIII. Cantus a libitum
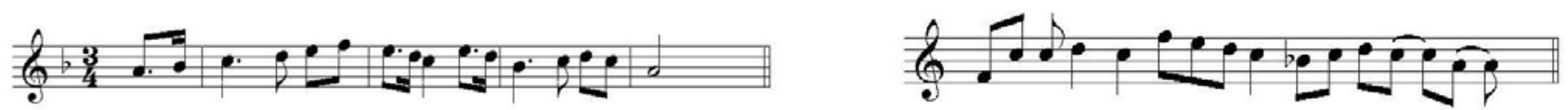

\footnotetext{
${ }^{144}$ Musique Catalane Narcyso Yepes, guitare. Deutsche Gramophon (Lp).

${ }^{145}$ Cf. ANEXO A, p. 265 e 266.
} 
melodia popular

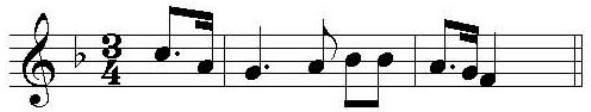

Gradual de la Missa de Virgine et Martyre

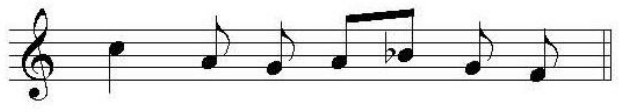

\section{Muntanyes del Canigó}
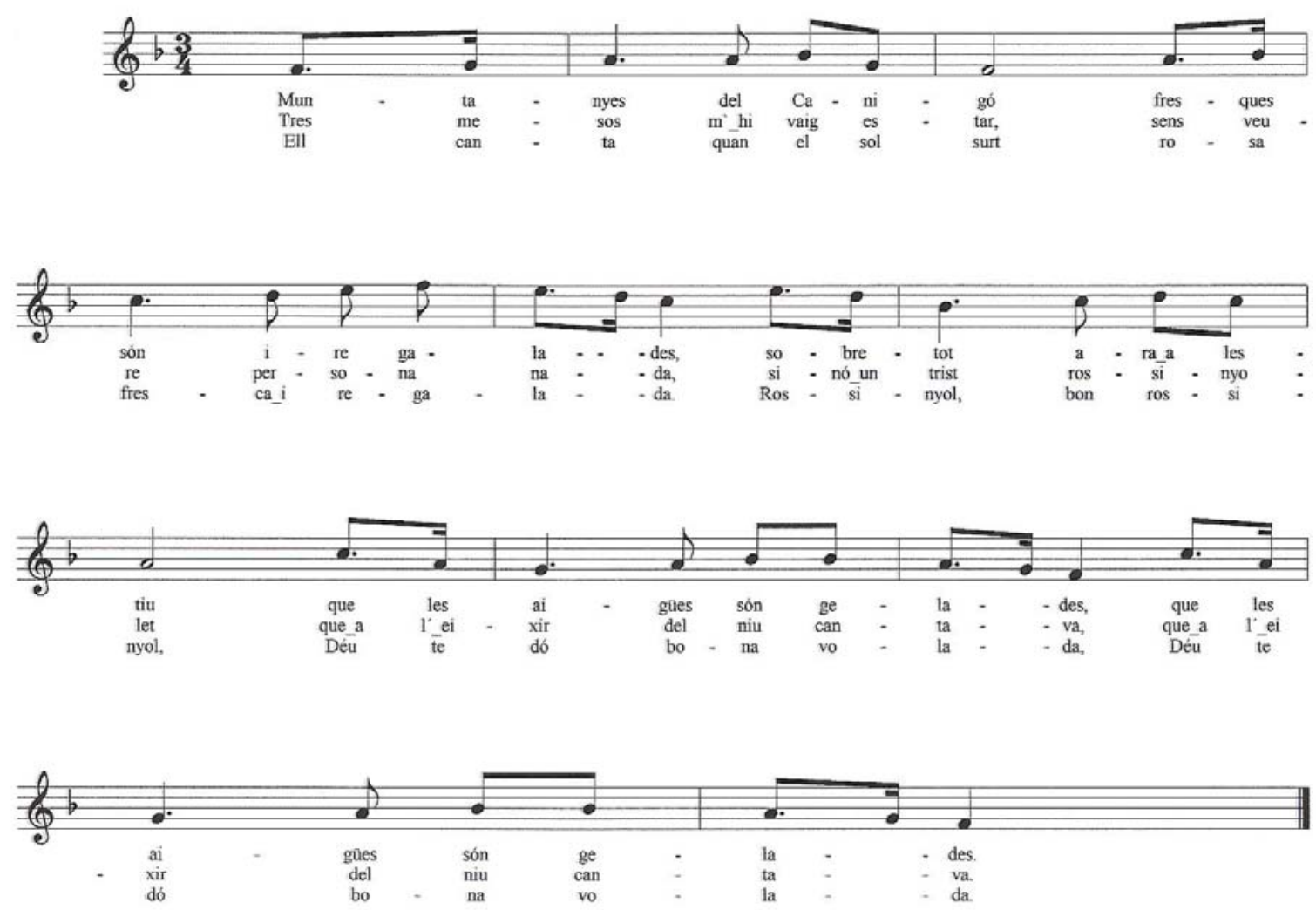

Copyright 1951 by Amades

Segue a tradução livre de Muntanyes del Canigó (Montanhas do Canigó):

Muntanyes del Canigó

Fresques són i regalades,

Sobre tot ara a l'estiu,

Que les aigües són gelades.
Montanhas do Canigó

São frescas e agradáveis,

Especialmente agora no verão

Quando as águas são geladas. 
Tres mesos m'hi vaig estar, Sens veure persona nada, Sinó un trist rossinyolet Que a l'eixir del niu cantava.

Ell canta quan el sol surt Rosa fresca i regalada.

- Rossinyol, bon rossinyol, Deu te dó bona volada.

(AMADES, 1951, p. 422)
Estive lá por três meses

Sem ver ninguém,

Exceto um triste rouxinolzinho

Que cantava ao deixar o ninho.

Ele canta ao nascer do sol Rosa fresca e delicada

- Rouxinol, bom rouxinol, Deus te dê um bom vôo. 
Two Catalan Folk Songs / Zwei Katalanische Volkslieder /

Dos canciones populares catalanas
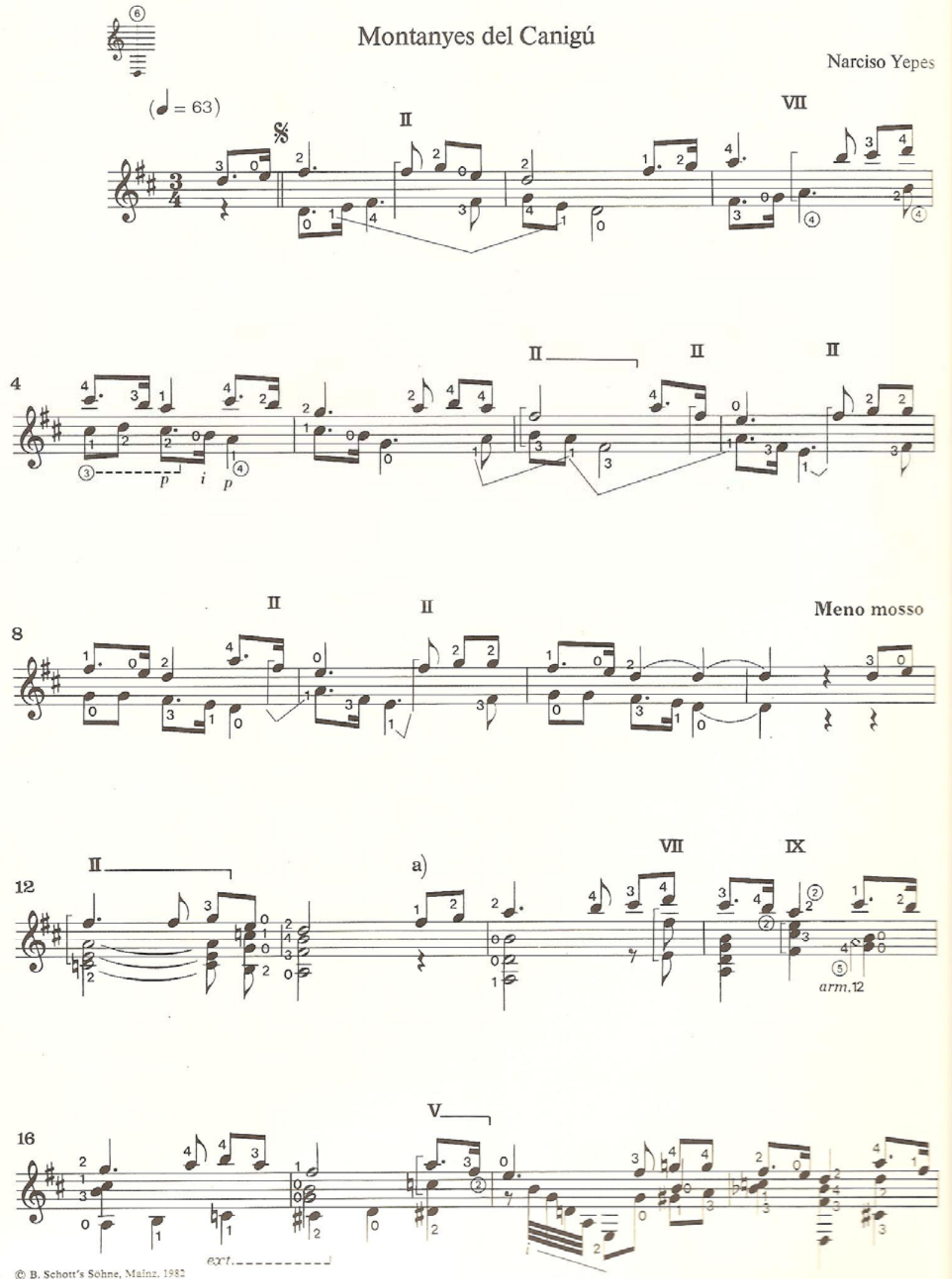

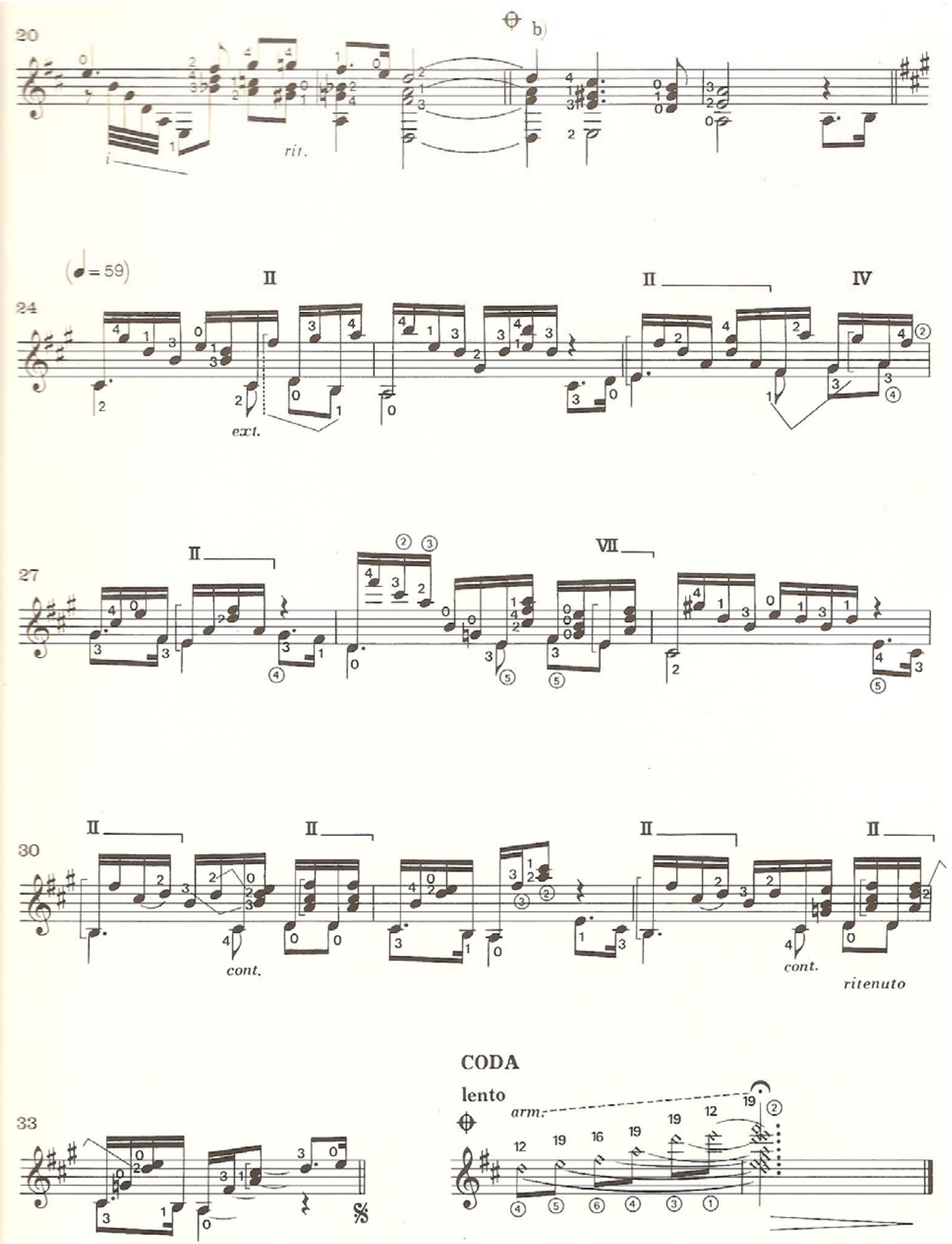

CODA 


\subsubsection{Catarina d'Alió}

Classifica-se como canção de trabalho (cançó de tasca) e descreve a ação de lavar roupas (cançó de rentadora). Em termos gerais, as canções com tema de lavadeiras são cantadas com caráter de dança que se encaixam no ritmo de lavar roupas com os pés. Este costume faz alusão a um tipo de dança muito freqüente entre as lavadeiras. Também é muito difundida na França e típica entre as lavadeiras. (AMADES, 1951, p. 700).

Recomendamos a audição da soprano Victoria de los Angeles ${ }^{146}$, para uma melhor compreensão de seu texto.

\section{Catarina d'Alió}
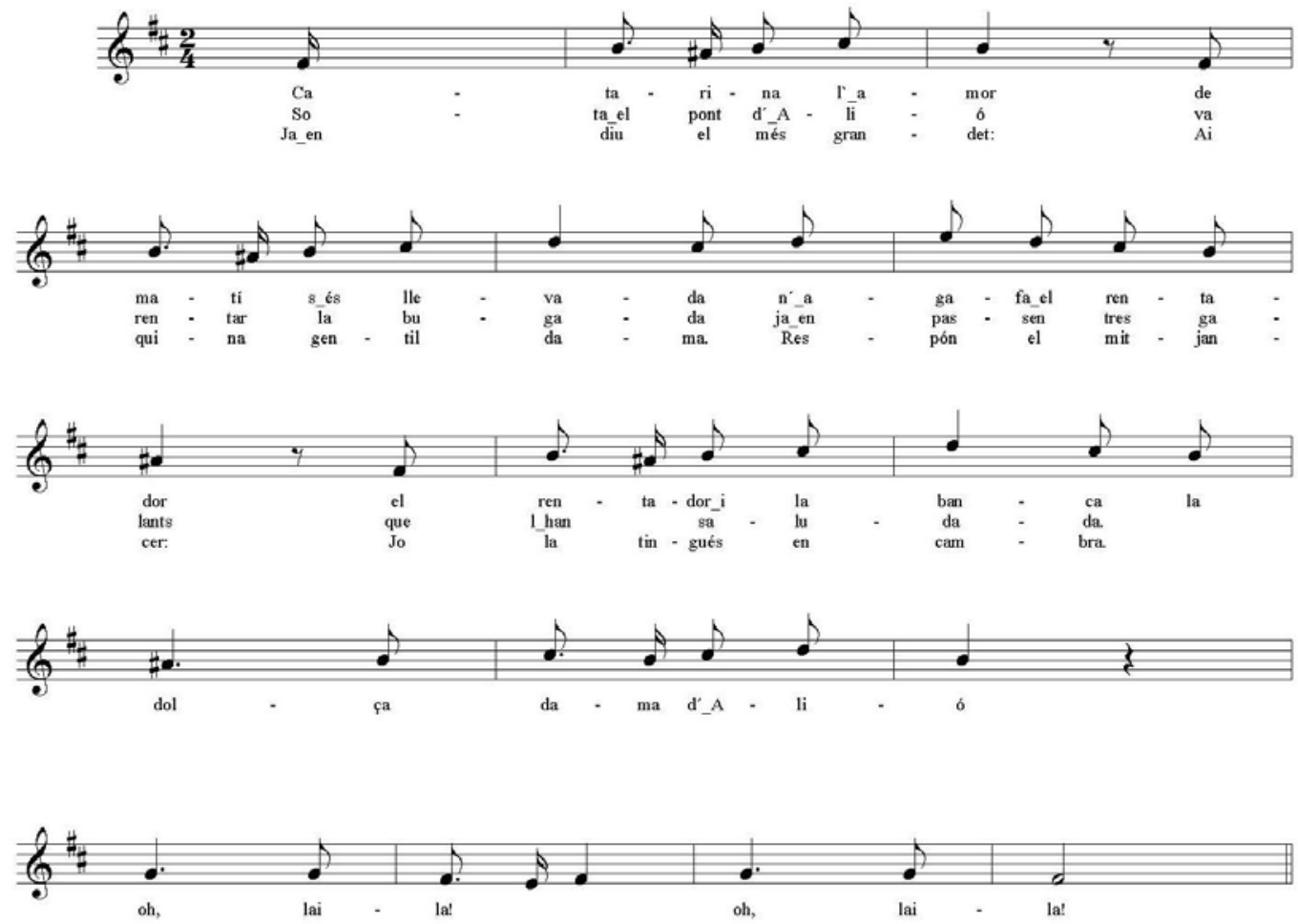

Copyright 1951 by Amades

146 CANÇONS TRADICIONALS CATALANES. Victoria de Los Angeles with Geoffrey Parsons. Collins Classic, 1992 (Cd). 
Segue a tradução livre de Catarina d'Alió (Catarina de Alió):

Catarina, l'amor, de matí s'és llevada, n'agafa el rentador, el rentador i la banca.

La dolça dama d'Alió, Oh, lai lá! Oh, lai lá!

Sota el pont d'Alió va rentar la bugada, ja en passen tres galants que l’han salutada.

La dolça dama d’Alió...

Ja en diu el més grandet:

- Ai quina gentil dama!

Respón el mitjancer:

Jo la tingués en cambra!

La dolça dama d'Alió...

(AMADES, 1951, p. 700)
Catarina, amor,

levanta de manhã cedo, pega o lavador, o lavador e o banquinho.

A doce dama de Alió,

Oh, lai lá!oh, lai lá!

Debaixo da ponte Alió senta para lavar roupas, três rapazes galantes passam e a cumprimentam.

A doce dama d'Alió...

O maior disse:

- Oh que gentil dama!

O do meio responde:

Se eu pudesse tê-la em meu quarto!

A doce dama de Alió... 
6

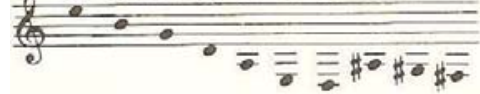

$$
\begin{aligned}
& (d=100-104)
\end{aligned}
$$

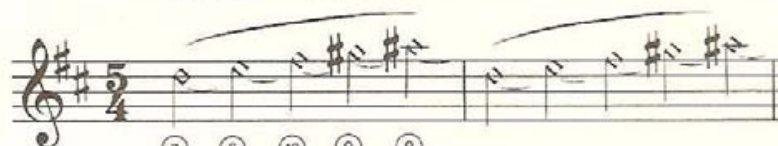$$
\text { (7) (6) (10) (9) (8) }
$$

\section{Catarina d'Alió}

Narciso Yepes

5

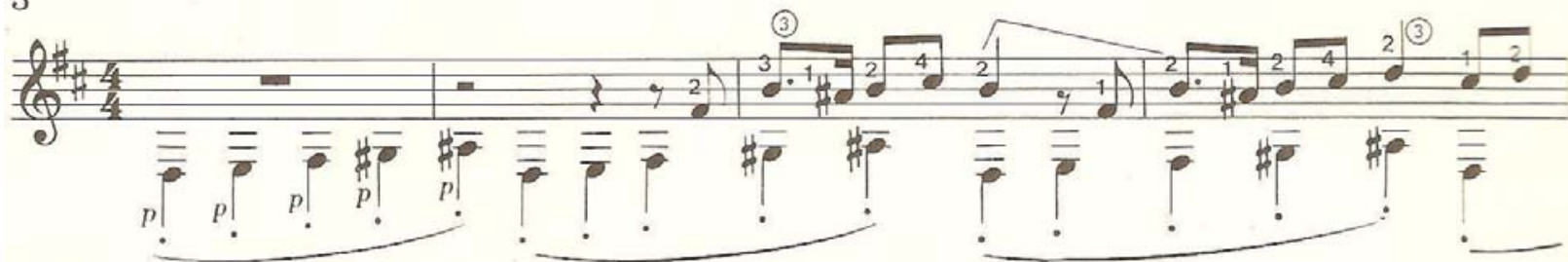

9

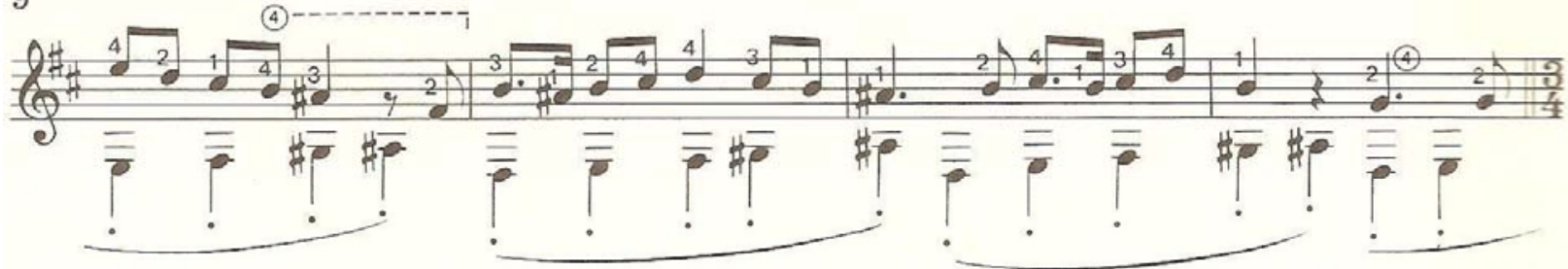

13

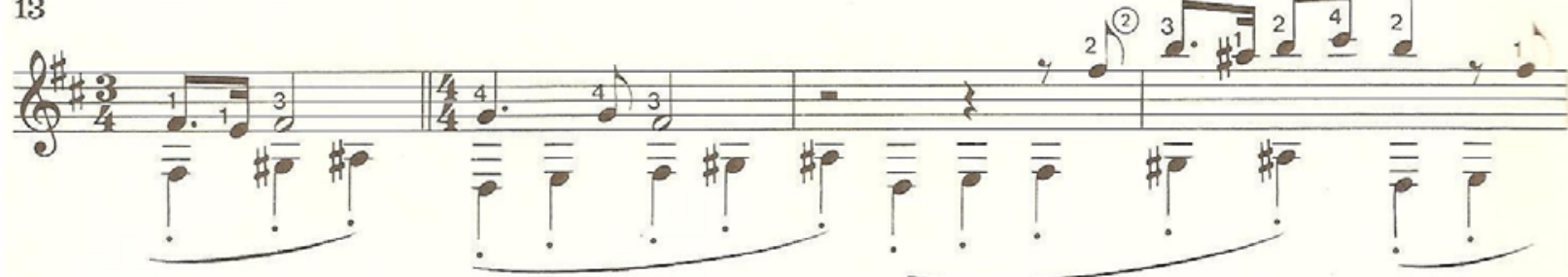

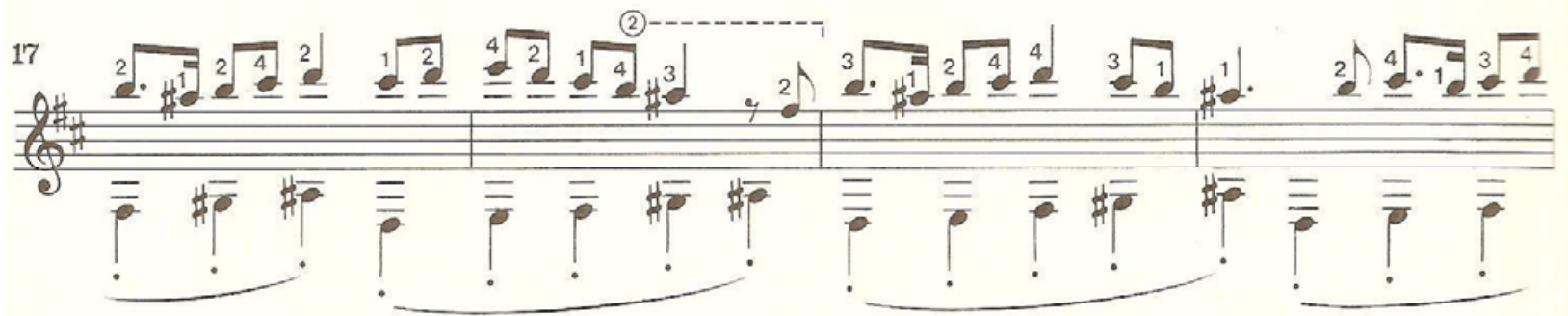

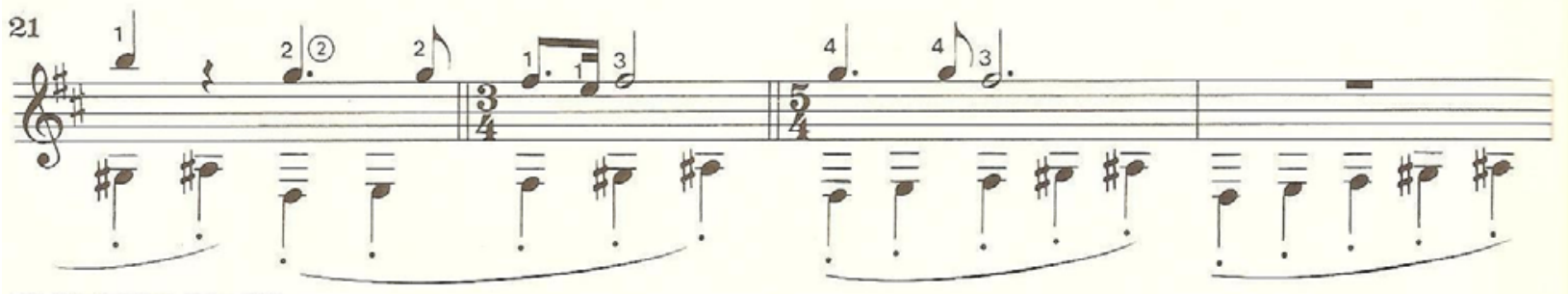


25 arm.24

i $\mathrm{arm} .19$

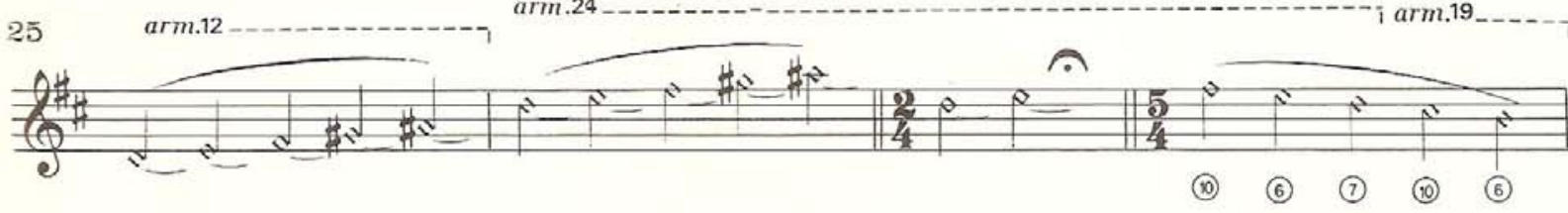

II
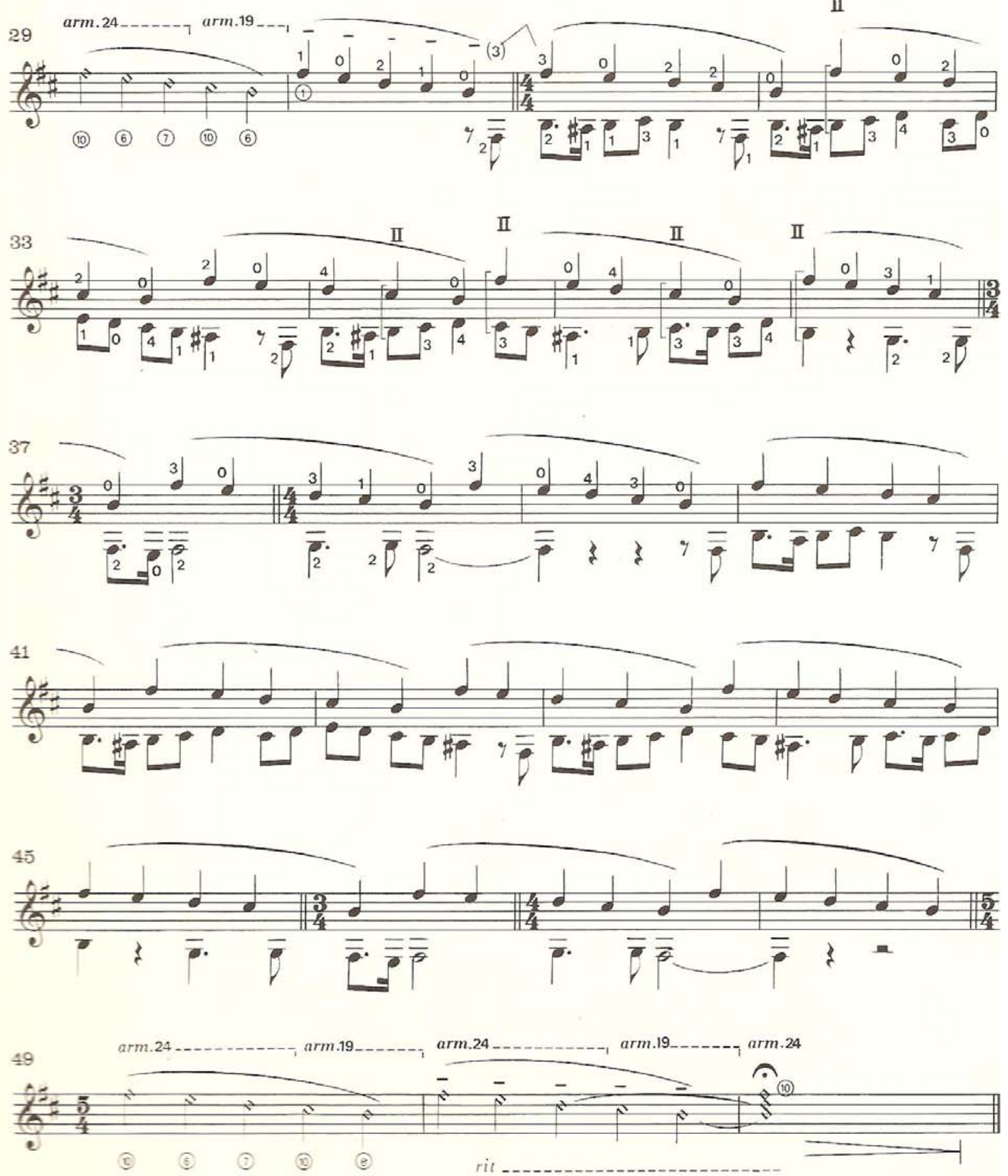


\subsubsection{La Gata i el Belitre}

Esta canção foi adaptada para violão por Francisco Casanovas ${ }^{147}$. O violonista Narciso Yepes, que também realizou adaptações de melodias tradicionais catalãs, gravou esta versão junto com outras adaptações de Llobet, Segovia e Mompou ${ }^{148}$.

Possui melodia igual a uma canção de caçador - La Capta del Llop (AMADES, 1951, p. 399). Traduzimos livemente La Gata i el Belitre (A gata e o Selvagem):

\section{La Gata i el Belitre}

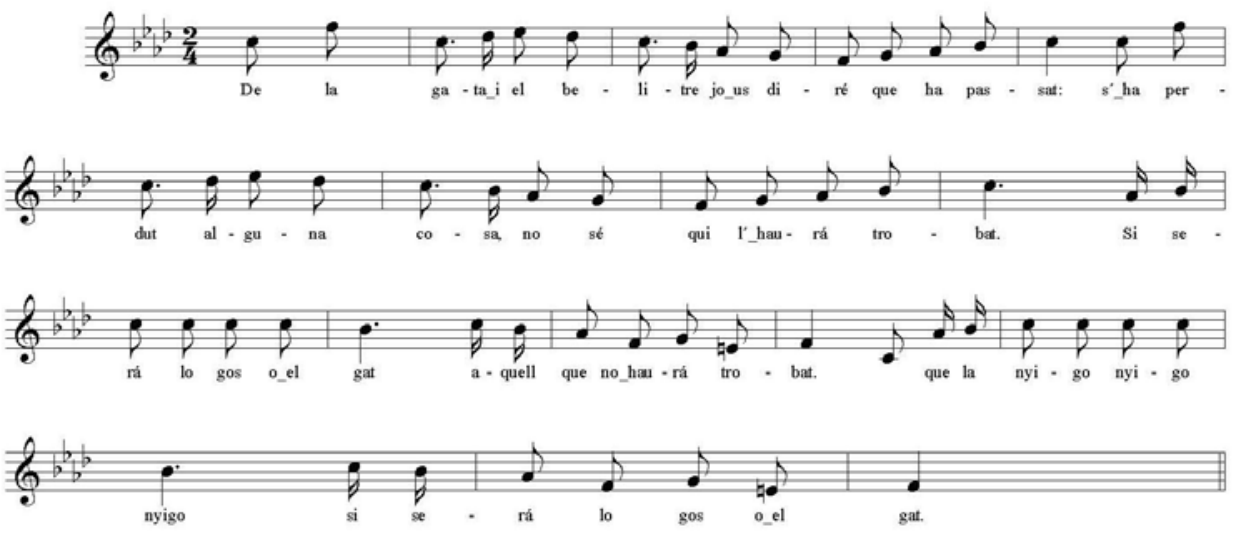

Copyright 1951 by Amades

A tradução livre de La Gata i el Belitre (A gata e o Selvagem):

De la gata i el belitre jo us diré lo que há passat: s’ha perdut alguna cosa, no sé qui l'haurá trobat, Si será lo gos o el gat, que la nyigo, nyigo, nyigo; Si será lo gos o el gat, aquell que no haurá trobat. (AMADES, 1951, p. 741)
Da gata e o selvagem vou dizer a vocês o que passou: alguma coisa tem se perdido, não sei quem a terá achado, Se será o cão ou o gato, que a nhigo, nhigo, nhigo; se será o cão ou o gato, aquele o terá achado.

${ }^{147}$ CASANOVAS, Francisco. La Gata i el Belitre. Disponível em: http://dirk.meineke.free.fr. Acesso em: 23 Novembro 2007.

${ }^{148}$ Musique Catalane Narcyso Yepes, guitare. Deutsche Gramophon. (Lp). 


\section{La Gata I El Belitre}
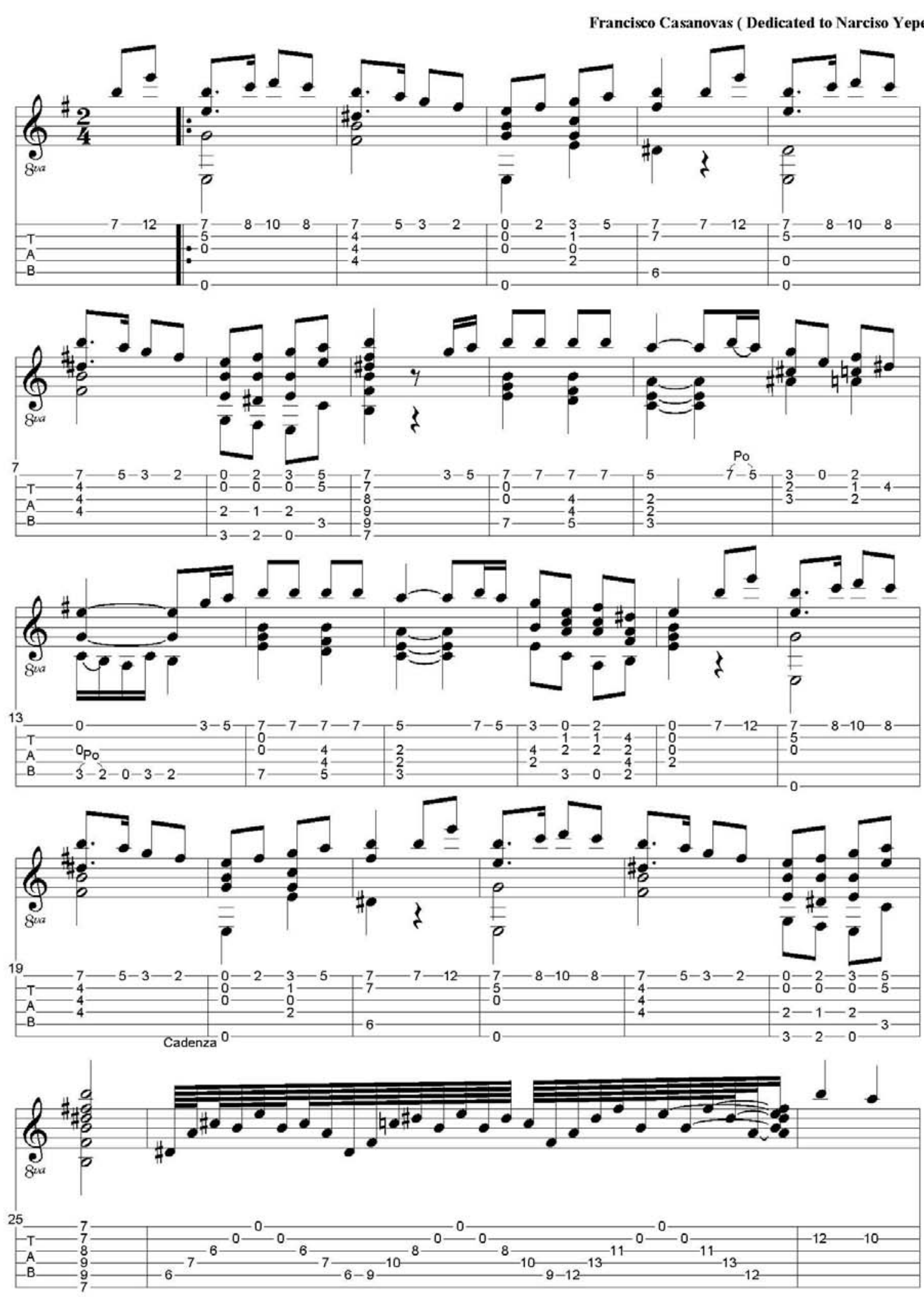
Page Zaf Gata I El Belitre - Francisco Casanovas (Dedicated to Narciso Yepes)

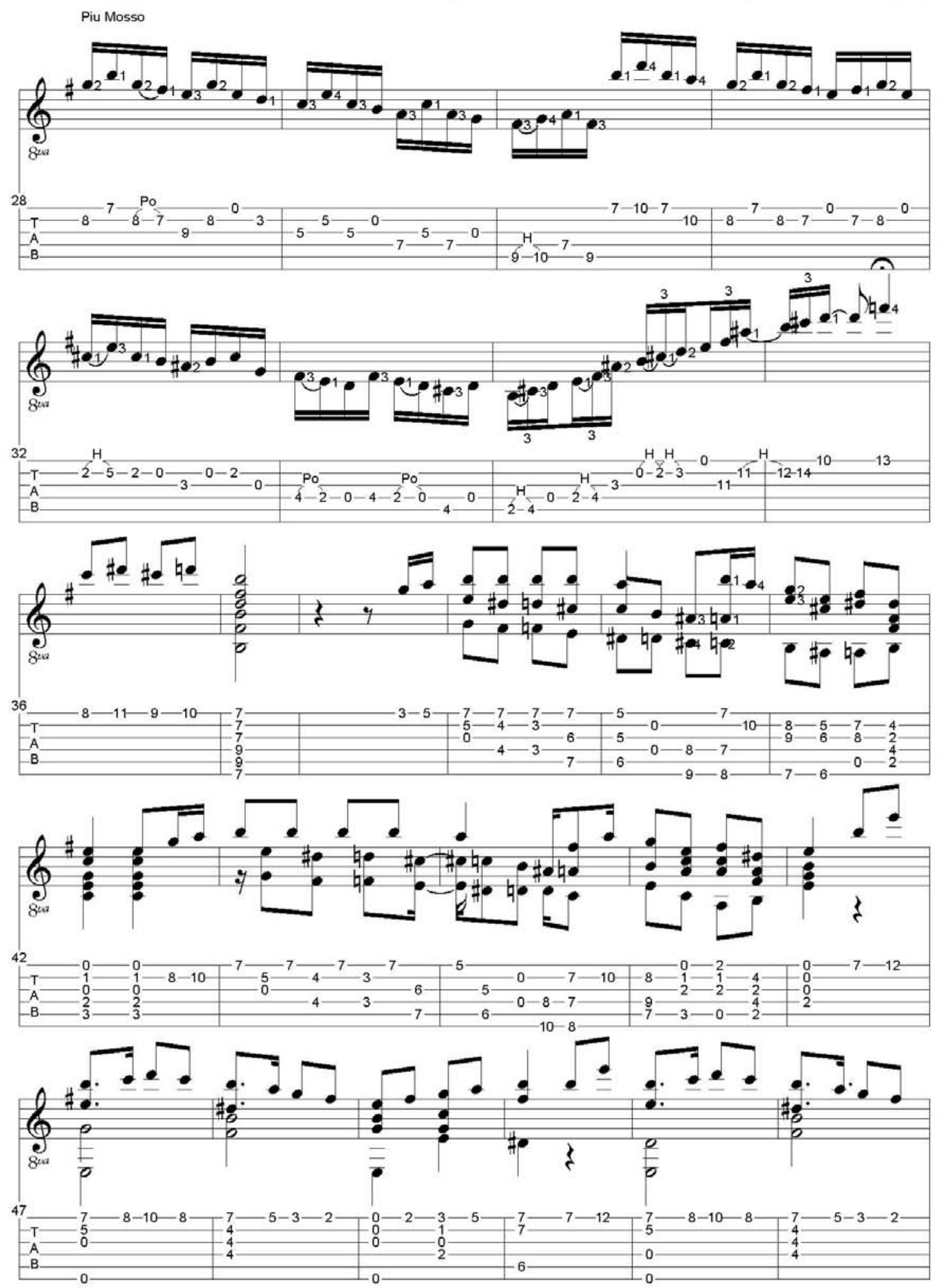


Page 3Laf Gata I El Belitre - Francisco Casanovas (Dedicated to Narciso Yepes )
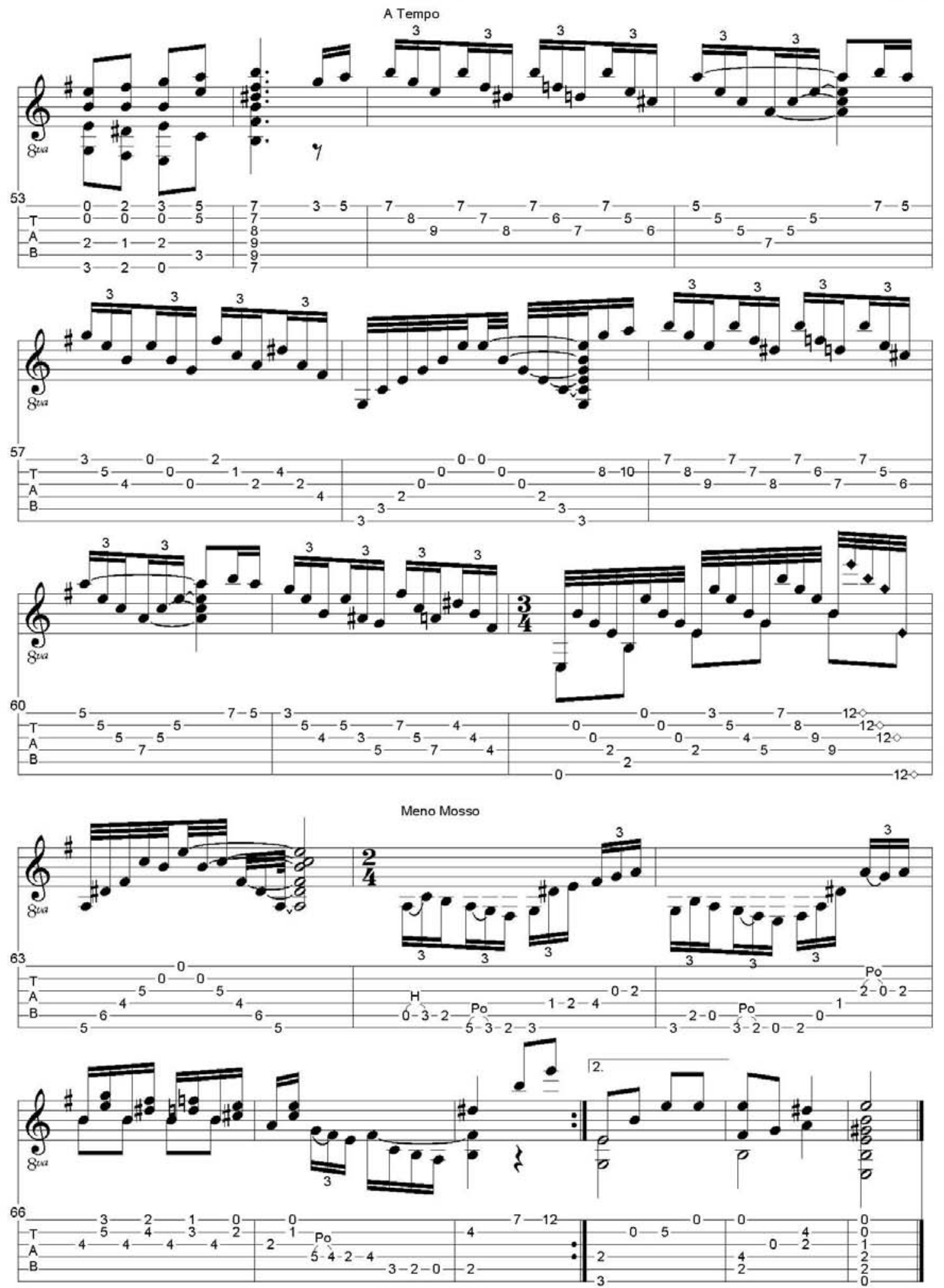


\section{CONCLUSÃO}

Procuramos neste trabalho localizar os elementos da escola nacional catalã, depois os elementos da escola do violão e notamos que os violonistas catalães do século XIX e XX são as principais referências da historia do violão naquele momento.

O período em que as adaptações das Canciones Catalanas de Llobet foram concebidas foi decisivo para a afirmação do violão, desde o início do século XX até hoje, como o conhecemos atualmente, depois de algumas transformações realizadas num período anterior a Miguel Llobet. Neste momento histórico oportuno de processo evolutivo, Llobet teve uma participação importante como compositor, arranjador e concertista. Notamos também em sua personalidade as facetas de intelectual, musicólogo e artista plástico. Esta característica multifacetada de Llobet o fez um artista muito interessante e difícil de classificar, além da falta de uma documentação mais completa a respeito de sua obra e vida artística. Enquanto não se escrever uma biografia documentada sobre Llobet a história do violão nunca estará completa.

Ao levantarmos as informações da origem destas canções tradicionais, percebemos a faceta de musicólogo de Llobet, pois ao utilizar melodias antigas em sua obra, resgatou um passado histórico.

Vimos que alguns temas usados podem datar do século XII, período dos trovadores e do século XIV, quando os monastérios impulsionavam a evolução da música caracterizada por diversos elementos populares. Algumas das canções históricas e lendárias datam do século XVI e durante o século XVII e XVIII foram produzidas um grande número delas. 
A pesquisa da possível origem das canções, junto com a inclusão dos textos e sua tradução para o português oferece novos elementos de interpretação aos violonistas, pois conhecer seu contexto histórico e literário contribui para formar uma concepção mais completa do sentido das melodias.

Vimos também o quanto tais melodias estavam ligadas ao movimento nacionalista que revolucionou a cultura catalã. Llobet pode ter usado as melodias tradicionais para impulsionar o estabelecimento do violão como instrumento de concerto, pois eram extremamente populares e atraíam o público, assim como o movimento coral impulsionado pela cultura musical tradicional, atraía grandes massas para as instituições orfeônicas.

Sua atividade como concertista serviu de modelo para Segovia levar adiante o movimento do violão de concerto. Apesar de toda controvérsia que Segovia criou em torno de si e sua trajetória, acreditamos que o contato de Segovia com Llobet o tenha mostrado as novas possibilidades que o violão oferecia, mudando o perfil de intérprete de Segovia.

Além de algumas melodias estarem ligadas ao movimento social catalão, outras estavam relacionadas com a situação política da Catalunha que no período de Llobet passava por diversas transformações. Não sabemos ainda até que ponto Llobet estava engajado politicamente em tais acontecimentos, pois não temos nenhuma declaração escrita por ele ou outros autores sobre isso. Estamos na expectativa de encontrar nas duas versões citadas Els Segadors e L'Emigrant algumas pistas de seus ideais políticos.

Com as Canciones Catalanas Llobet iniciou uma espécie de tratamento de música folclórica que não existia no repertório violonístico que estava voltado para transcrições de obras clássicas, fantasias e pout-pourris que exploravam temas de óperas famosas. Além disso, podemos afirmar que ele foi o primeiro a mostrar as possibilidades 
expressivas do violão e sua complexidade abrindo o caminho para outros compositores escreverem para o instrumento de forma sofisticada.

O trabalho de Llobet vem sendo reconhecido, o que tem levado muitos a dar o crédito a ele por uma nova linguagem do violão. A música de Tárrega estava posicionada na linguagem do século XIX e a música de Llobet ajudou a posicionar o violão no século XX.

Acerca de sua originalidade, maior sensibilidade para nuances harmônicas e exploração de timbres, acreditamos que a coleção das Canciones Catalanas merece ter seu status de obras originais. Muito além de meros arranjos para violão, foi um marco na literatura para violão do século XX.

O reconhecimento da importância das Canciones Catalanas e do conjunto da obra de Llobet tem motivado alguns pesquisadores a desvendar o universo deste importante violonista catalão. Graças à pesquisa do violonista italiano Stefano Grondona, obras inéditas vêm sendo reveladas através de suas gravações citadas na pesquisa, e mais informações a respeito de traços dos diferentes momentos criativos de Llobet podem ser fornecidas.

Diante da possibilidade do surgimento de mais obras, aguardamos a publicação do patrimônio musical que Llobet deixou para o violão. Este fato abre campo para outras pesquisas a respeito do legado musical de Miguel Llobet. 


\section{REFERÊNCIAS BIBLIOGRÁFICAS}

ANGLÉS, H. Diccionario de la Musica Labor. Barcelona, Madrid, Buenos Aires, Rio de Janeiro, México, Montevidéu, 1954. 2 vol.

AMADES, J. Folk-lore de la Catalunya, cançoner. Barcelona: Editorial Selecta, 1951. Les Cent Millors Cançons Populars. Barcelona: Editorial Selecta, 1948.

AMAT, J. C. Guitarra Española. Complete facsímile edition with an introduction by Monica Hall. [ ]:Editions Chanterelle S.A., 1980.

BARGALLÓ, J. C. El folklore musical. In: OSABA, P. L. de. Historia de la musica española. Madrid: Alianza Editorial, 1983. vol. 7.

BALDELLÓ, F. Elements Gregorians dins la Cançó Popular Catalana. In: Pujol, F. Observaciones, apendix i notes al "romancerillo catalán” de Manuel Mila i Fontanals. Barcelona: Imprenta Elzeviriana, 1926. 3 vol.

BUADES, J. M. Os espanhóis. São Paulo: Editora Contexto, 2006.

CAMARGO, G. de. A Guitarra do século XIX em seus aspectos técnicos e estilísticoshistóricos a partir da tradução comentada e análise do "Método para Guitarra” de Fernando Sor. São Paulo: ECA/USP, 2005. Dissertação de mestrado.

CARVAlhO, H. B. de. O canto do pajé. Villa-Lobos e a Música Popular Brasileira. Rio de Janeiro: Editora Espaço e Tempo, 1988.

DE LA CUESTA, I. M. Desde los orígenes hasta el “ars nova”. In: OSABA, P. L. de. Historia de la musica española. vol. 1. Madrid: Alianza Editorial, 1983.

DEMARQUEZ, S. Manuel de Falla. Barcelona: Nueva Colección Labor, 1968.

DUDEQUE, N. História do Violão. Curitiba: Editora UFPR, 1994.

DUFOURCQ, N. La Música. Los Hombres, Los Instrumentos, Las Obras. Barcelona: Librairie Larousse, 1965. 2 vol.

FERNANDEZ-CID, A. La Musica Española en el Siglo XX. Madrid: Publicaciones de la Fundacion Juan March, Colección Compendios, Rioduero, 1973.

GLOEDEN, E. O Ressurgimento do violão no século XX: Miguel Llobet, Emilio Pujol e Andrés Segovia. São Paulo: ECA/USP, 1996. Dissertação de mestrado. 
GRONDONA, S.; WALDNER, L. La Guitarra di Liuteria. Master Pieces of Guitar Making. L'officina del libro, 2001.

HELGUERA, J. Conversaciones con Guitarristas. México: Escenologia, A. C., 2001.

JEFFERY, B. Fernando Sor. Composer and Guitarrist. Londres: Tecla Editions, 1977.

JONES, A. C. The Judgement of Paris. Part 5: Pujol's article in Lavignac's Encyclopédie. Revista Classical Guitar, 17, no. 4 (December, 1998), p. 24-28.

LIVERMORE, A. Historia de la Musica Española. Barcelona: Barral Editores, S. A., 1974.

MANGADO, J. M. La Guitarra en Cataluña, 1769-1939. Londres: Tecla Editions, 1998.

MASSIN, J. \& B. História da Música Ocidental. Rio de Janeiro: Nova Fronteira, 1997.

MELO, F.M. Historia de los movimientos, separación y guerra de Cataluña en tiempo de Felipe IV. Madrid, 1904.

MITJANA, R. Cancionero de Upsala. México: El Colegio de Mexico, 1944.

NAVARRO, ANTONIO J. J. Rey y. Los Instrumentos de púa en España, Bandurria, cítola y “laúdes españoles”. Madrid: Alianza Música, 1993.

NERY, R. V. Para uma história do fado. Lisboa: Edição Público, 2004.

OTERO, C. Manuel Ponce Y la Guitarra. México: Fondo Nacional para Actividades Sociales, 1981.

PAHISSA, J. Sendas y Cumbres de la Musica Española. Buenos Aires: Librería Hachette S. A., 1955.

. Vida y obra de Manuel de Falla. Buenos Aires: Ricordi Americana, 1947.

1945.

. Espíritu y Cuerpo de la Música. Buenos Aires: Librería Hachette S.A.,

PAINE, R. Hispanic Traditions in Twentieth-Century Catalan Music (with particular reference to Gerhard, Mompou and Montsavage). New York \& London: Garland Publishing. Inc., 1989.

PHILLIPS, R. Barcelona, Cradle of the modern classical guitar: the Llobet archive rediscovered. Revista GFA SOUNDBOARD, volume XXVIII, no. 4, spring 2002a. p. 31-33. 
. The influence of Miguel Llobet on pedagogy, repertoire and stature of the guitar in the twenthieth century. University of Miami/EUA. 2002b. Tese de doutorado.

PRAT, D. Diccionario de Guitarristas. Columbus, Ohio: Editions Orphée, 1986.

PUJOL, E. Tárrega. Ensayo biográfico. Lisboa: Ramos, Afonso \& Moita, LDA, 1960.

Escuela Razonada de la guitarra. Basada en los principios de la técnica de Tarrega. Buenos Aires: Ricordi Americana, 1954. 4 vol.

PUJOL, F. Observaciones, apendix i notes al “romancerillo catalán” de Manuel Mila i Fontanals. Barcelona: Imprenta Elzeviriana, 1926. 3 vol.

RIERA, J. Emilio Pujol. Lérida: Artis Estudios Graficos, 1974.

RUBIO, S. Desde el “ars nova” hasta 1600. In: OSABA, P. L. de. Historia de la musica española. Madrid: Alianza Editorial, 1983. vol. 2.

SEGOVIA, A. An autobiography of the years 1893-1920. Translated by W. F. O’Brien. New York: Macmillan Publishing Co., Inc, 1976.

SOPENA, F. Historia de la Musica Española Contemporanea. Madrid: Ediciones Rialp, S.A., 1958.

SPAIN. Ministerio de Cultura. Manuel de Falla: his life \& works. Ediciones Opponax. Madrid, 1996.

SUBIRÁ, J. Historia de la Musica Española e Hispoamericana. Barcelona: Salvat, 1953.

The New Grove Dictionary of Music and Musicians. [ ] Edited by Stanley Sadie. 20 vol.

TONAZZI, B. Miguel Llobet, Chitarrista dell’Impressionismo. Ancona: Bérben, 1966.

YATES, S. Heitor Villa-Lobos Valsa Concerto no. 2, Op. 8 (1904): Rediscovery and Completion of an Early Solo Guitar Work. Revista GFA Soundboard, volume XXV, no. 04, spring 1999. p. 7 a 10.

\section{REFERÊNCIAS COM MATERIAIS ESPECIAIS}

\section{Cds}


ANDRÉS SEGOVIA 1927-1939 Recordings. Volume 1. EMI Records, 1980. 1 CD (61:04 min.), remasterização digital. CDH-7 610482

ANDRÉS SEGOVIA 1927-1939 Recordings. Volume 2. EMI Records, 1980. 1 CD (58:44 min.), remasterização digital. CDH-7 610492

CANÇONS TRADICIONALS CATALANES. Victoria de Los Angeles with Geoffrey Parsons. Collins Classic, 1992. 1 CD (57:15 min.), digital, estéreo. 13182

EDUARDO FERNÁNDEZ. English Chamber Orchestra. Arnold, Chappell, Brouwer. London, 1990. 1 Cd (60: 22 min.), digital, estéreo. 430 233-2

ELIOT FISK. World Première Recording. Segovia Canciones Populares. Music Masters Classics, 1996. 1 Cd (76:09), digital, estéreo. 01612-67174-2

JOHN W. DUARTE. Variations on a Catalan folk-song, Sonatinette, English Suíte, Musikones. Guitar Music, Antigoni Goni. NAXOS, 2001. 1 Cd (72:26 min.), digital, estéreo. 8. 554554

JORDI MASÓ. Frederic Mompou. Piano Music Volume 1. Cançons i Danses. Charmes Scènes d'enfants. NAXOS, 1997. 1 CD (72:15 min.), digital, estéreo. 8. 554332

LA CAPELLA REIAL DE CATALUNYA. Cançons de la Catalunya mil-lenària. Planys e Llegendes. Astrée, 1977. 1 CD (ca. 70 min.), digital, estéreo. ES 9937

LORENZO MICHELI. Miguel Llobet Guitar Music. NAXOS, 2004. 1 CD (ca. 60:13 min.), digital, estéreo. 8.557351

MIGUEL LLOBET. The Guitar Recordings 1925-1929. Chanterelle Historical Recordings. 1 CD (44:35 min.), remasterização digital. CHR 001

MICHAEL TRÖESTER. Michael Tröster plays Miguel Llobet. Thorofon Classics Digital, 1998. 1 Cd (65:24 min.), digital, estéreo. CTH 2378

ORFEO CATALÁ. Chansons Traditionnelles de Catalogne. Harmonia Mundi, 1992. 1 Cd (48:31 min.), digital, estéreo. HMI 1907006

RAFAËLLA SMITH. Antonio Jimenez Manjón 1866-1919. Accent, 1998. (58:56 min.), digital estéreo. ACC2 98131 D

STEFANO GRONDONA. La Guitarra de Torres. Appassionato, 2000. 1 Cd (60 min.), digital, estéreo. CDX 29701-ES

STEFANO GRONDONA. La Leona. Stefano Grondona plays Julián Arcas (1832-1882). Stradivarius, 2004. 1 Cd (58:28 min), digital, estéreo. STR 33692 
STEFANO GRONDONA. HOMENAJE Manuel de Falla, Miguel Llobet and their world. Stefano Grondona, Maria José Montiel, Laura Mondiello, Nova Lira Orfeo. Stradivarius, 2006a. 1 Cd (1h 10 min.), digital, estéreo. STR 33660

STEFANO GRONDONA. Lo Cant dels Ocells. Stradivarius, 2000. 2 Cds (Cd 1 56:22 min.; Cd 2 60:54 mim.), digital, estéreo. STR 33589

STEFANO GRONDONA. RESPUESTA. Stefano Grondona Plays the Guitar Works of Miguel Llobet. Stradivarius, 2006b. 2 Cds (CD 1 59:40 min. ; CD 2 25:37 min.), digital, estéreo. STR 33770

STEPHEN HOUGH. Piano music by Federico Mompou. Hypérion, 1997. 1 Cd (76:48 min.), digital, estéreo. CDA 66963

TAKEMITSU. To the edge of dream. Takemitsu played by John Willians. Esa-Pekka Salonen London Sinfonieta. Sony Classical, 1989. 1 Cd (60: 26 min.), digital, estéreo. SK 46720

$\mathbf{L p}$

Musique Catalane Narcyso Yepes, guitare. Deutsche Gramophon. Lp, estéreo 2530273.

\section{Partituras}

ALBENIZ, I. Capricho Catalán. Trasncribed by R. Balaguer. Shawnee Press, s.d. 1 partitura. Violão.

ALBENIZ. I. Suíte Española op. 47. Transcribed and Fingered for Guitar by Manuel Barrueco. Bewin- Mills Publisher Corp., 1981. 5 partituras. Violão.

ALBENIZ, I. Suíte Española no. 2, Cataluña für 2 Gitarren bearbeitet von Hans-Gerhard Fey. Berlin: Edition Margaux, 1989. 1 partitura.Violão.

CARCASSI, M. Estudos op. 60. Editorial Lemoine, Paris, s.d. 25 partituras. Violão.

DUARTE, J.W. Variations on a Catalan Folk Song Op. 25. Cançó del Lladre. Novello \& Company Limited, 1968.

FALLA, M. de. Siete Canciones Populares Españolas. Paris: Editions Max Eschig. 7 partituras. Violão e voz.

JORDÁ, L. G. Cançons Populars Catalanes. Barcelona: Casa Editorial de Música Boileau, [19--]. 15 partituras. Piano e voz.

MANJÓN, A. J. Collected Works. Londres: Chanterelle Verlag, 1996. Violão. 
MARRACO, J. S. Cansons Populars Catalanes. Barcelona: Editorial Boileau. [19--]. 10 partituras. Coral.

MOMPOU, F. Cancion y Danza. Madrid: Union Musical Española, 1924, 1926, 1928. Piano.

MOMPOU, F. Cancion y Danza no. 13. Madrid: EMEC, 1986. 1 partitura. Violão.

MORERA, E. Cançons Populars Catalanes. L'hereu Riera. Barcelona: Edició Llobet [190]. 1 partitura. Coral.

. Cançons Catalanes harmonisades per Enric Morera. L’Hostal de la Peira. Barcelona: Fill d’Andreu Vidal y Roger Editors. 1 partitura. Coral.

NIN, J. Vingt Chants Populaires Espagnols. Paris: Editions Max Eschig, 1924. 10 partituras. Piano e voz.

PAHISSA, J. Canciones Populares Catalanas. Buenos Aires: Ricordi Americana. [19--]. 6 partituras. Piano e voz.

Seis Canciones Populares Españolas. Para coro a dos voces blancas. Buenos Aires: Ricordi Americana, [194-]. 6 partituras. Coral.

PONCE, M.M. Twenty-four Preludes for Guitar. Boston: Tecla Editions, 1981. Partitura. Violão.

PUJOL, E. Canción de Cuna. Paris, Max Eschig. 1 Partitura. Violão.

PUJOL, E. Festívola. Paris, Max Eschig. 1 Partitura. Violão.

PUJOL, E. Deuxième Triquilandia. Bibliothéque de Musique Ancienne et Moderne pour Guitare. Paris: Editions Max Eschig, 1962. 4 partituras. Violão.

PURCELL, R. Miguel Llobet Guitar Works. 11 Original Compositions. 2 Etudes, Mazurka, 4 Preludes, Romanza, Respuesta, Scherzo-Vals, Variaciones sobre un Tema de Sor. Chanterelle Verlag, 1989. Nueva Colección Llobet, vol. 1.11 partituras. Violão.

. Miguel Llobet Guitar Works. 16 Folksong Settings. 13 Canciones Catalanas, Leonesa, 2 Estilos Populares Argentinos. Chanterelle Verlag, 1989. Nueva Colección Llobet, vol. 2. 16 partituras. Violão. 
. Miguel Llobet Guitar Works. 10 Famous Transcriptions of works by: Albéniz, Granados \& Valverde. Chanterelle Verlag, 1989. Nueva Colección Llobet, vol. 3. 10 partituras. Violão.

. Miguel Llobet Guitar Works. 12 Famous Guitar Duos of works by: Albéniz, Daquin, Granados, Lopez-Chavarri, Mendelssohn, Mozart \& Tchaikovsky. Chanterelle Verlag, 1989. Nueva Colección Llobet, vol. 4. 12 partituras. Duo de violões.

PURCELL, R. Manuel de Falla. Homenaje pour le Tombeau de Claude Debussy. Londres: Chanterelle Verlag, 1989. Nueva Colección Llobet. 1 partitura. Violão.

PURCELL, R. Miguel Llobet. Preludio \& Estilo. Londres: Chanterelle Verlag, 1992. Nueva Colección Llobet. 2 partituras. Violão.

RIBÓ, J. C. Ars Chorum Publicació d’obres chorals de gèneres diversos. La Filla del Marxant. Barcelona: Casa Editorial de Musica, s.d. 1 partitura.Coral.

Ars Chorum Publicació d'obres chorals de gineres diversos. La Preso de Lleida. Barcelona: Casa Editorial de Musica, s.d. 1 partitura. Coral.

SEGOVIA, A. 23 Canciones Populares de distintos países. Ancona: Bèrben Edizioni Musicali, s.d. 23 partituras. Violão.

SOR, F. Variations sur Malbrough s'en va-t-em-guerre. Paris: Max Eschig. 1 partitura. Violão.

Cf. STOVER, R. (org). The Complete Works of Agustin Marrios Magoré, vol. 1 e 2. Pacific: Mel Bay, 2003. Violão.

TÁRREGA, F. The Collected Guitar Works. Espanha: Chanterelle Verlag, 1992. 48 partituras, vol. 1. Violão.

TÁRREGA, F. The Collected Guitar Works. Espanha: Chanterelle Verlag, 1992. 63 partituras, vol. 2. Violão.

VILLA-LOBOS, H. Álbum das Cirandas. Coleção de 16 peças para piano sobre temas. Rio de Janeiro: Editora Arthur Napoleão Ltda, 1968. 16 partituras. Piano.

\section{Páginas da internet}

RC, Relats em Català . Disponível em:

http://www.relatsencatala.com/rec/Controller?rp_action=view_relat\&rp_relat_id=367934.

Acesso em: 6 Janeiro 2008). 
XTEC, Serveis Educatius. Disponível em:

http://www.xtec.es/serveis/crp/a8903084/docs/himne1.pdf. Acesso em: 18 novembro 2007).

Partituras disponíveis na internet:

CASANOVAS, Francisco. La Gata i el Belitre. 1 partitura. Violão. Disponível em: http://dirk.meineke.free.fr. Acesso em: 23 Novembro 2007. 


\section{ANEXOS}




\section{ANEXO A - Partituras \\ LA HIJA DEL HOSTAL}

LA FILLA DEL MARXANT

Canción popular catalana

Adaptación, letra y música de JAIME PAHISSA
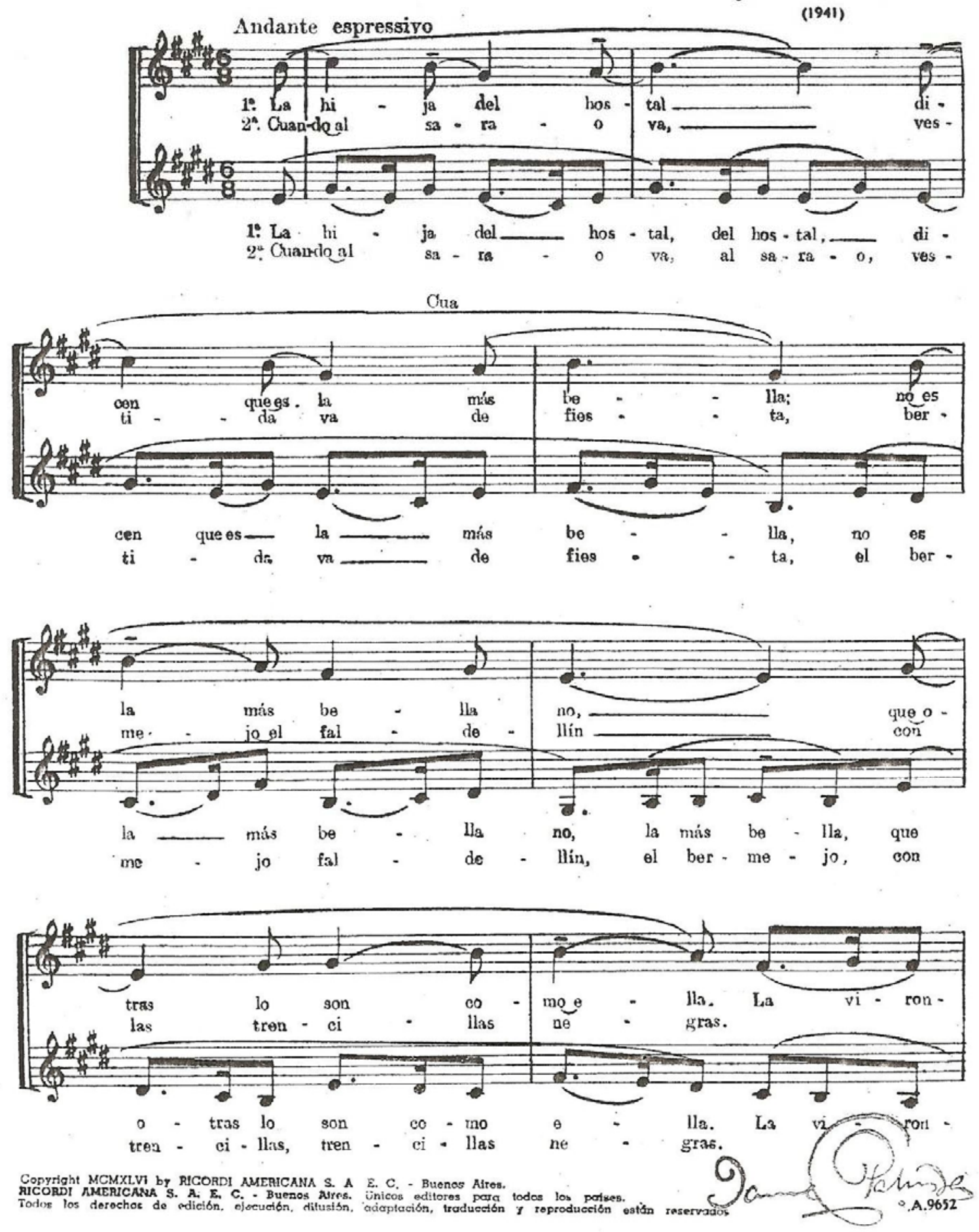
Al Mtre. En'Joan Lamote de Grignon.

\section{LA FILLA DEL MARXANT}

\section{CANÇÓ POPULAR}

harmonitzada per a chor a set veus mixtes

\section{J. Cumellas Ribó}

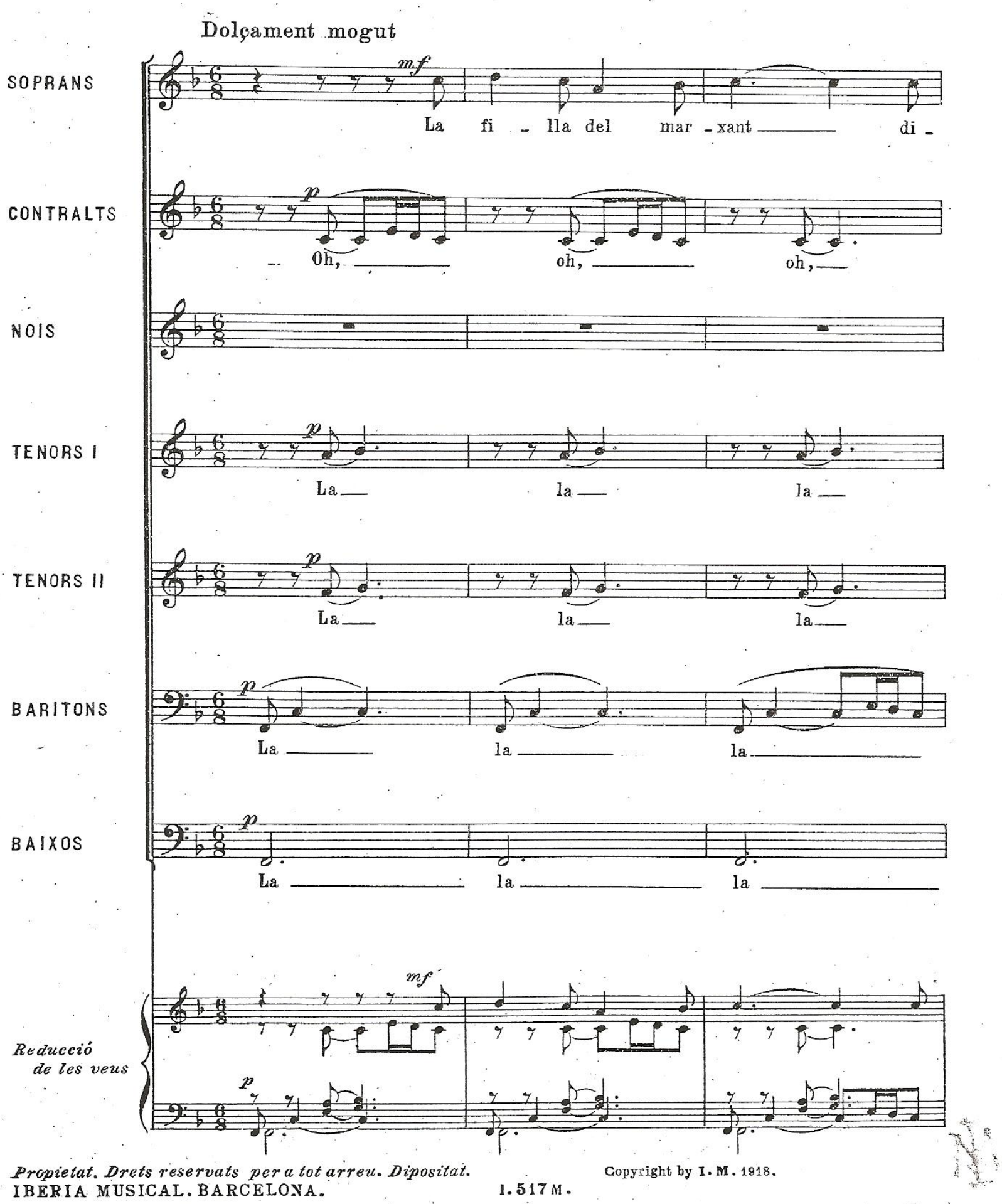




\section{9. - El testament d’'Amelia}

\section{J. SANCHO MARRACO}
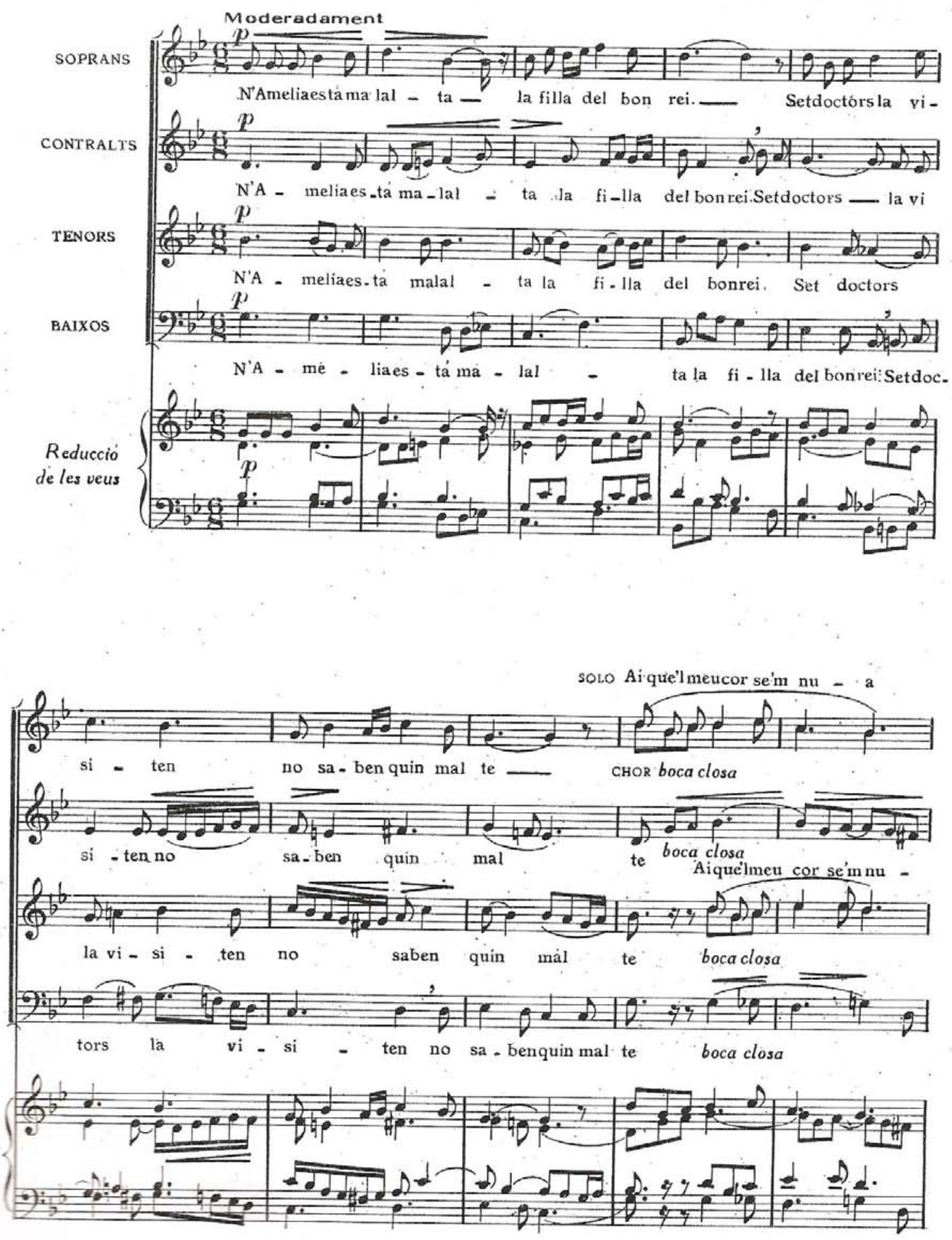


\section{RIERA, EL HEREDERO}

\section{L'HEREU RIERA \\ Canción popular catalana}

JAIME PAHISSA

(1941)
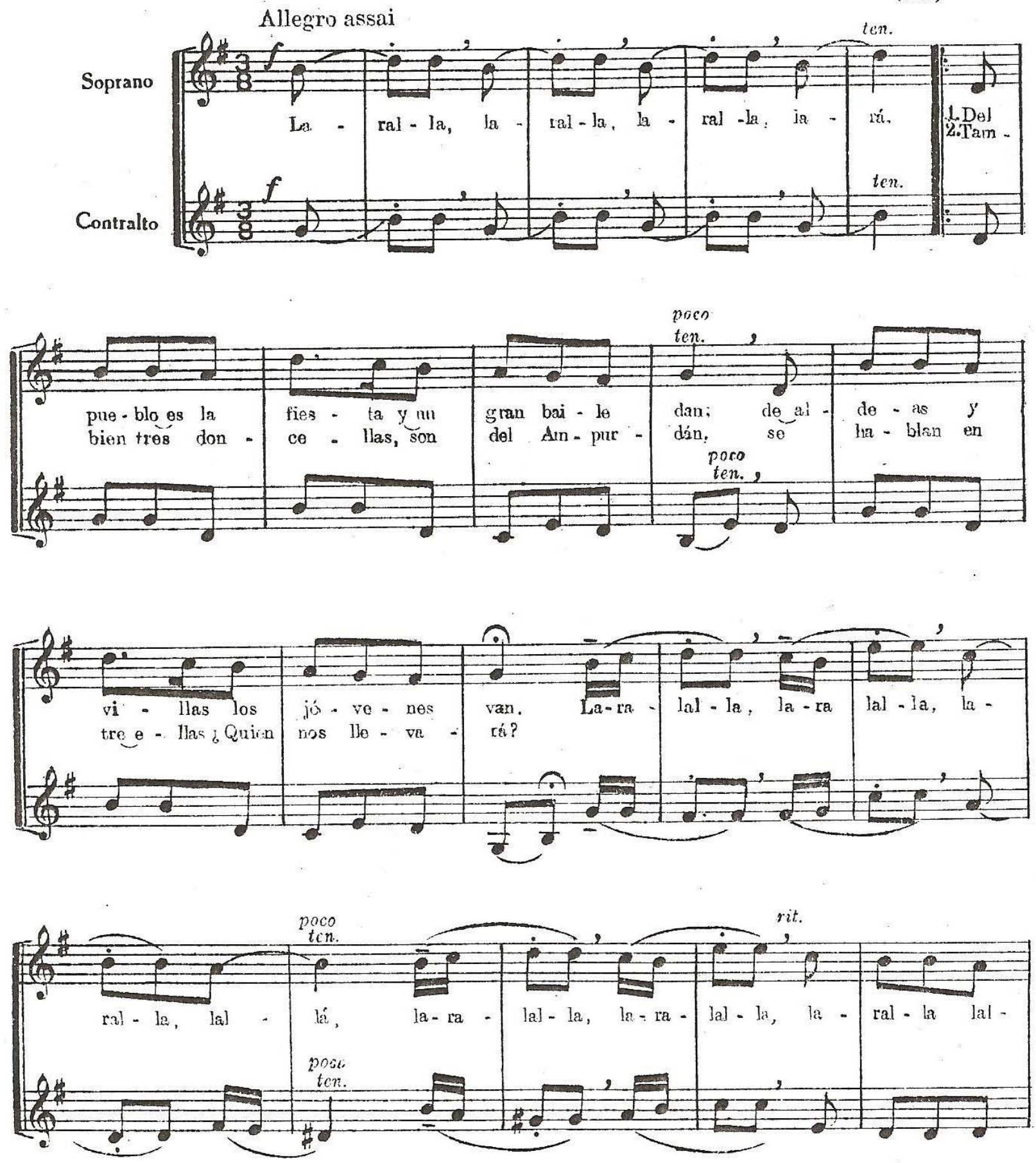


\section{L'herèu Riera}

Tiempo de Minueto

Per a SantAn - to - ni grans ba_llas hi ha; pe - ra Sant Mau
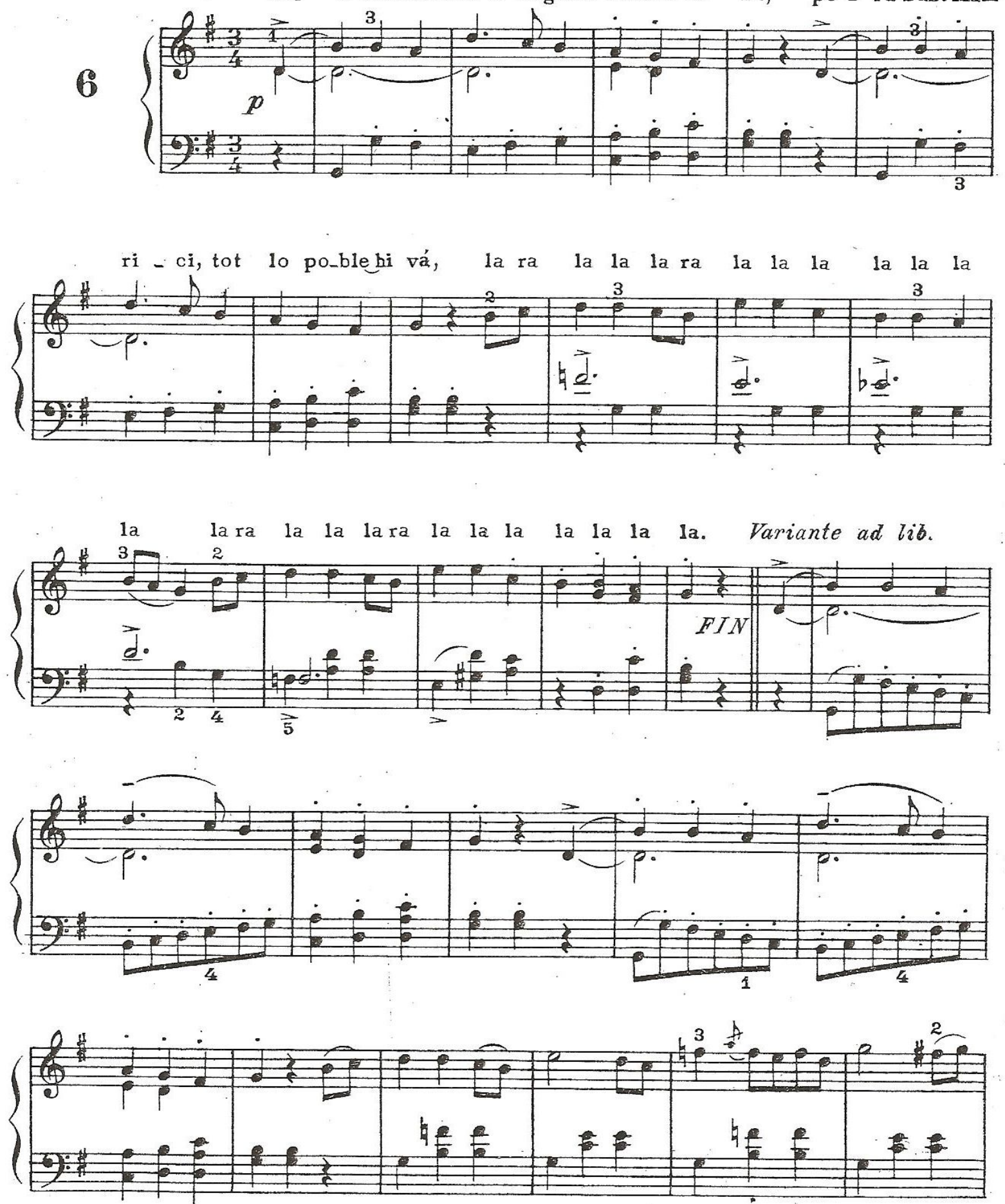


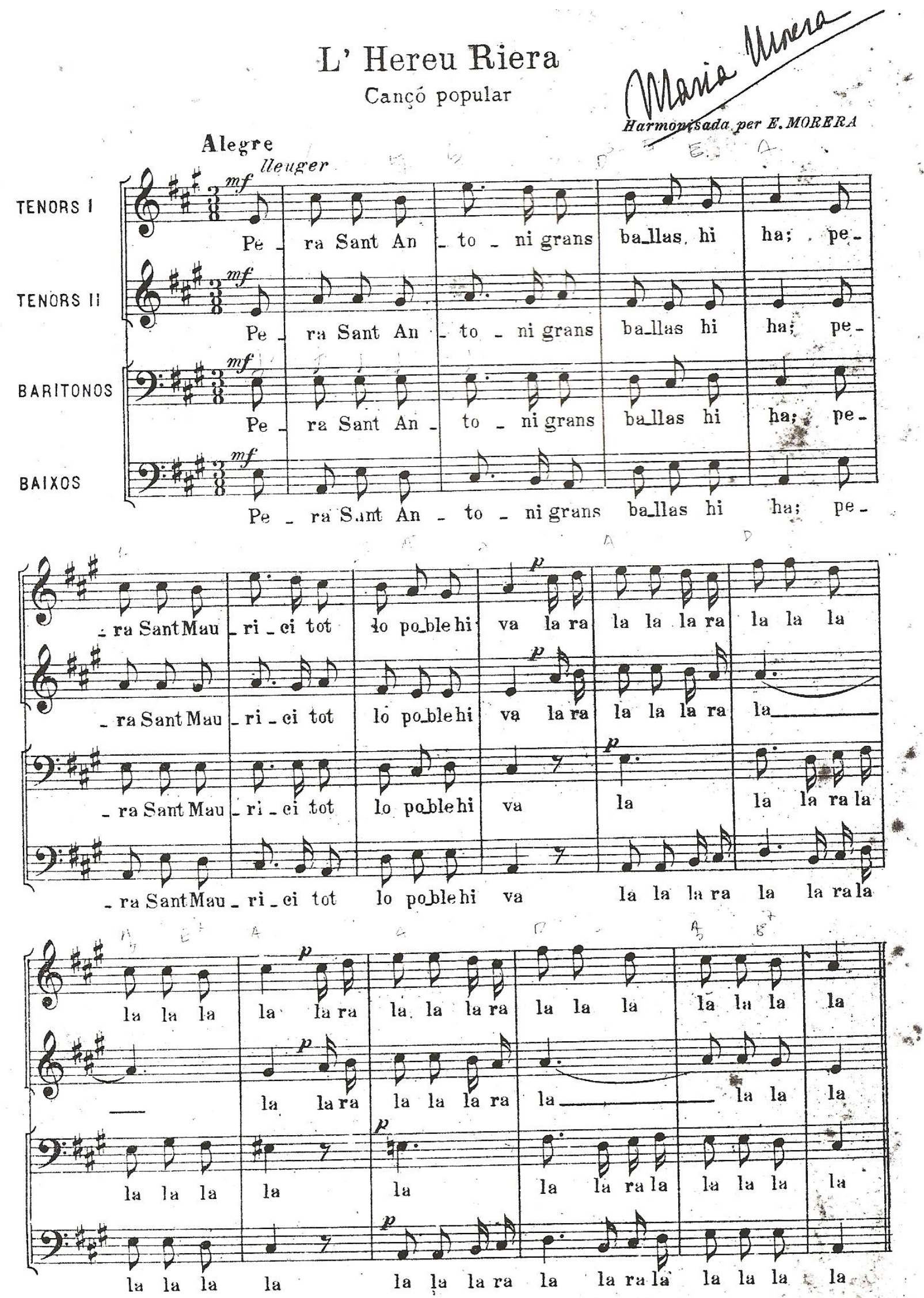

Copyrigtli by 1908 by J.M.Llobet.

Musicaï Emporium-Barcelnsa.

Tous droits d'execution et de reproduction 24.

réservés pour tous pulys. 


\title{
E1 desembre congelat
}

\author{
Canço de Nadal
}
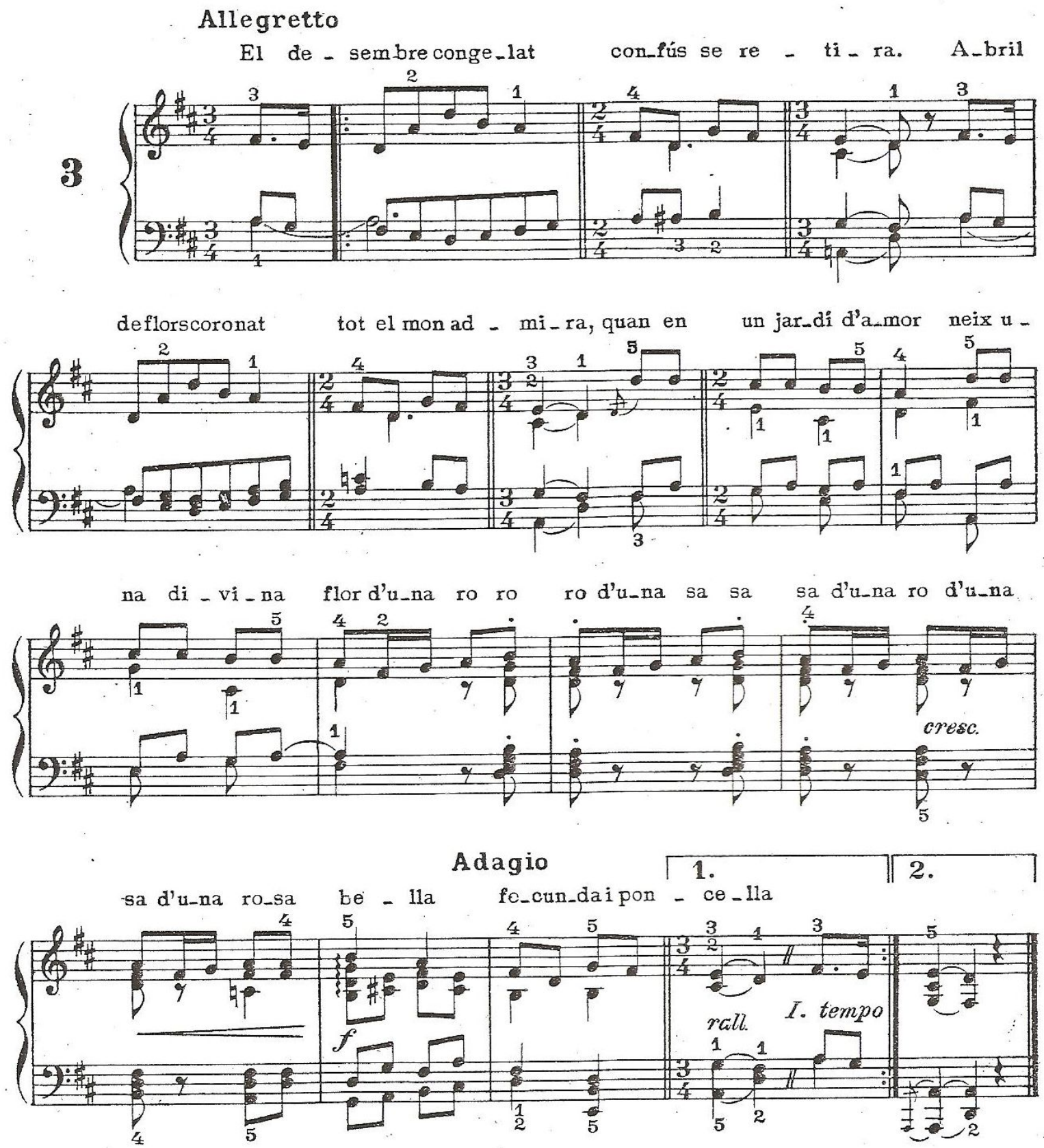


\section{La filadora}
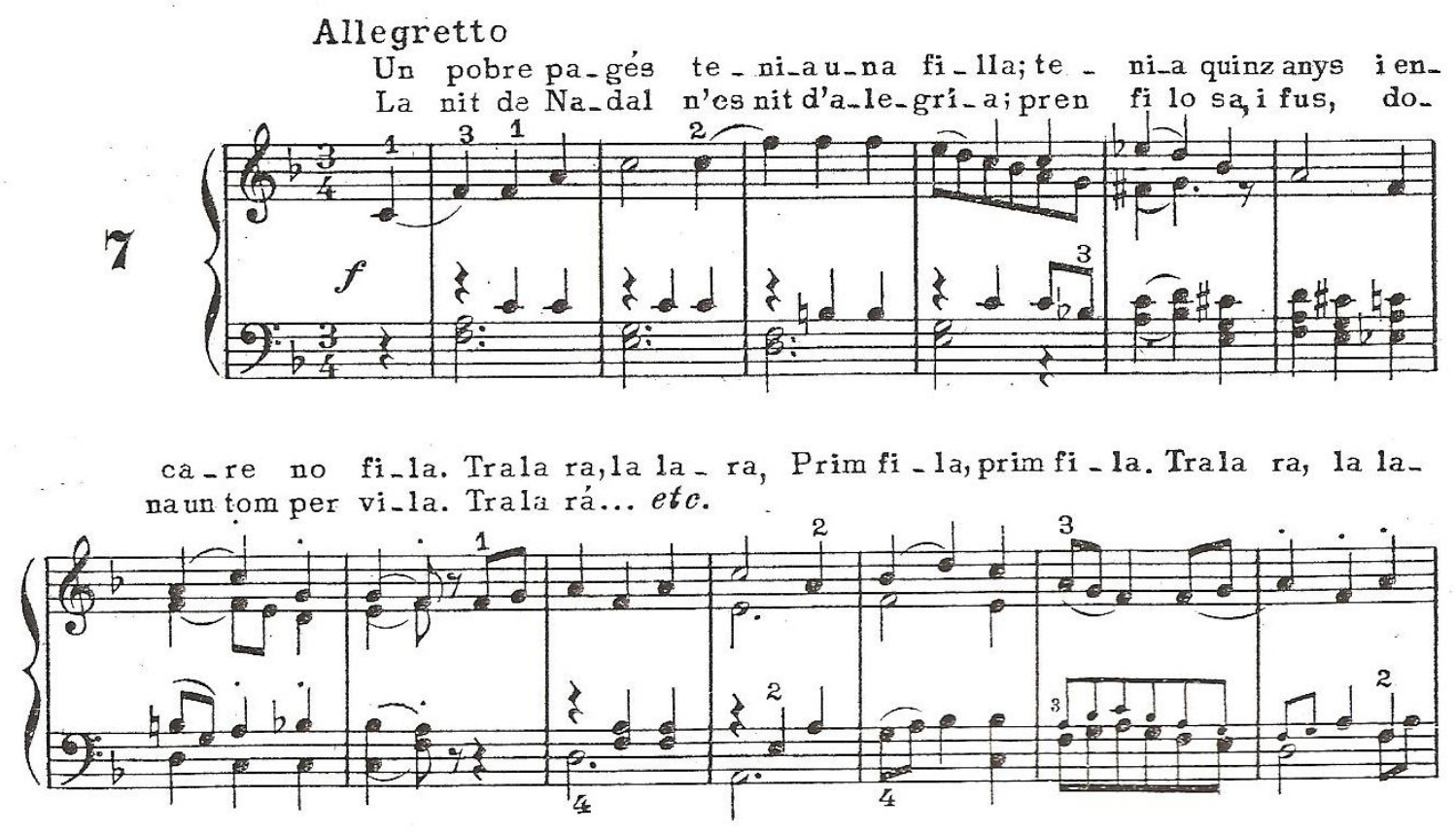

rá. Prim fi-laise'n vá. tariant ad lib.
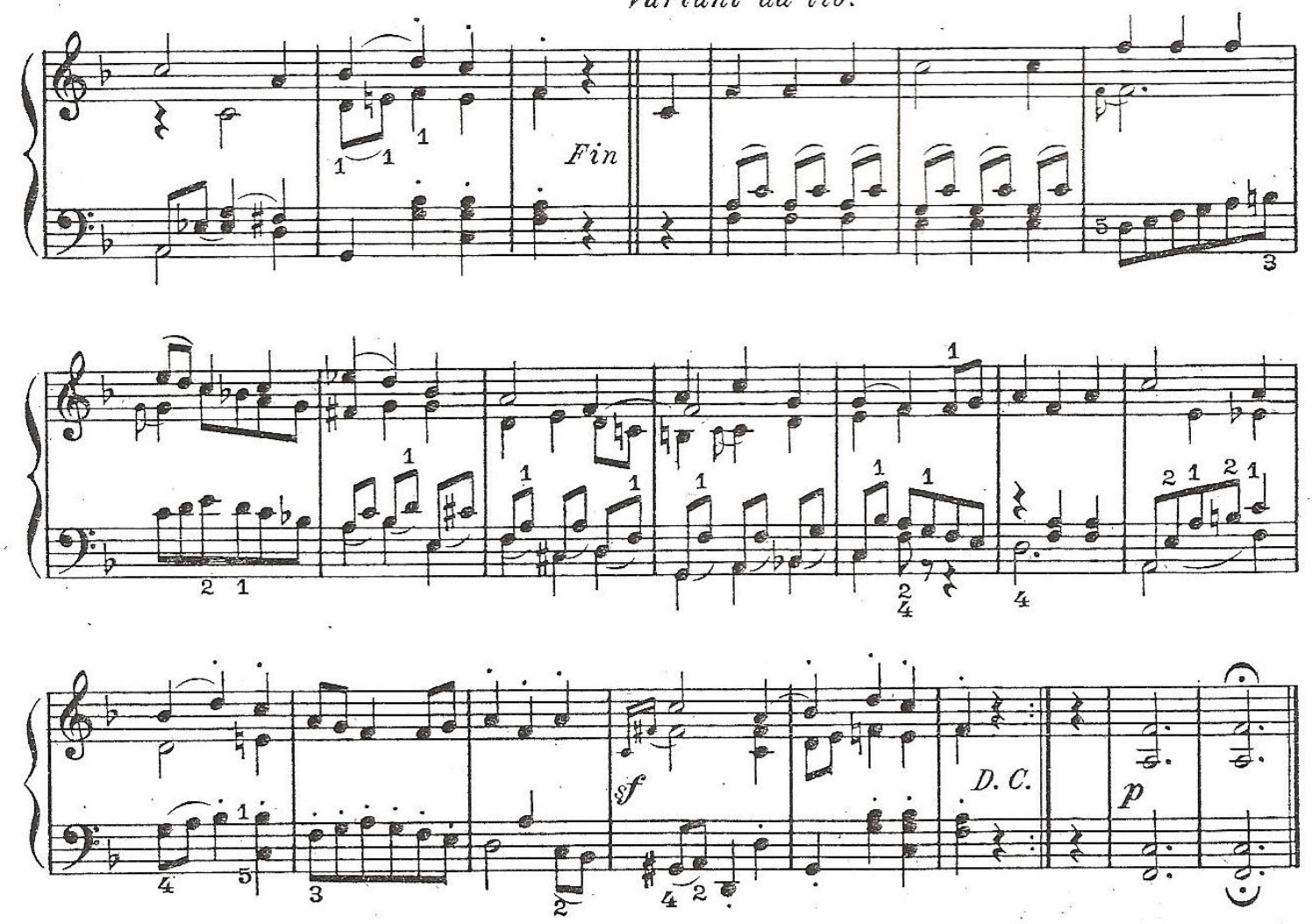


\section{3. - La filadora}
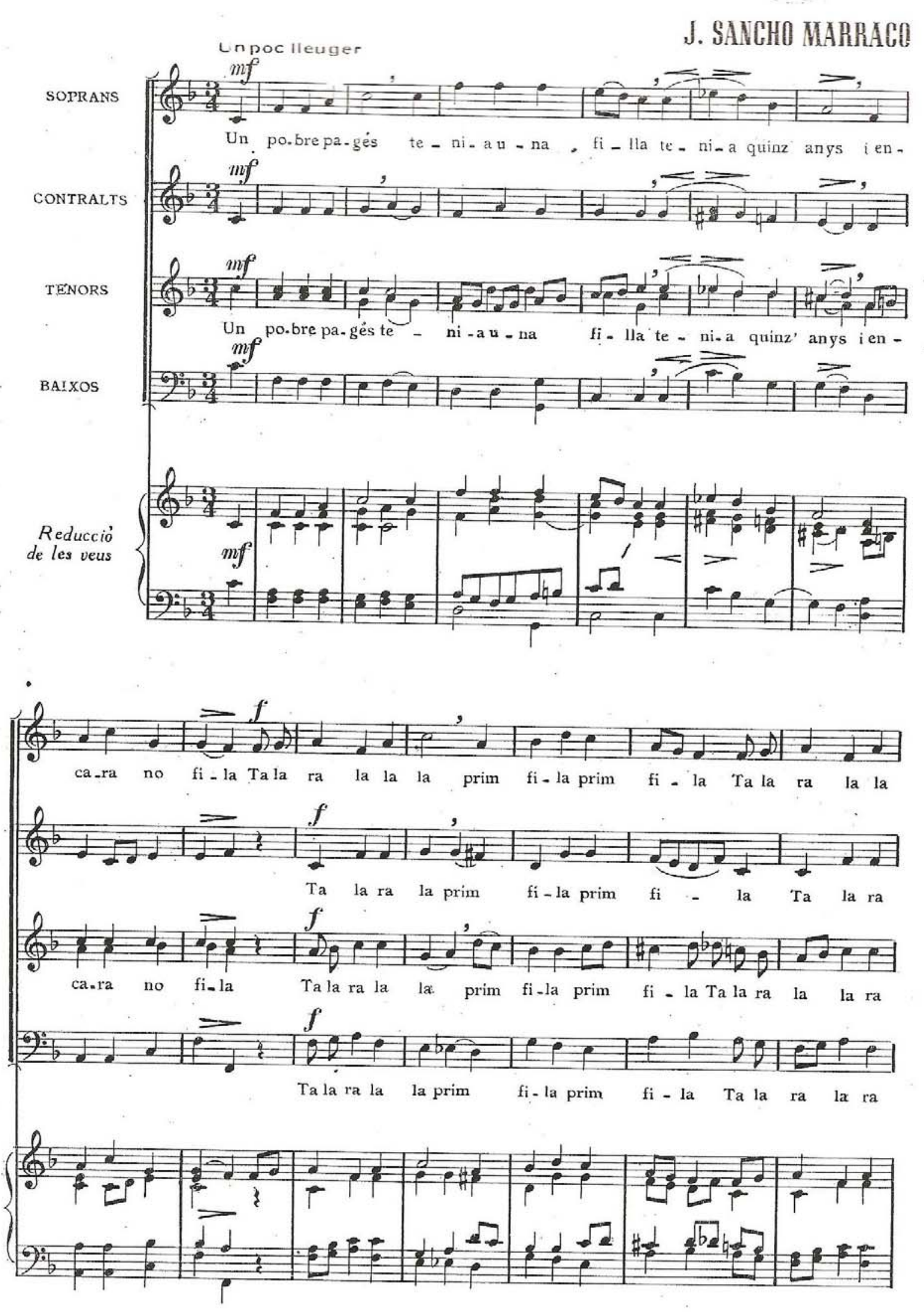


\section{La pastoreta}
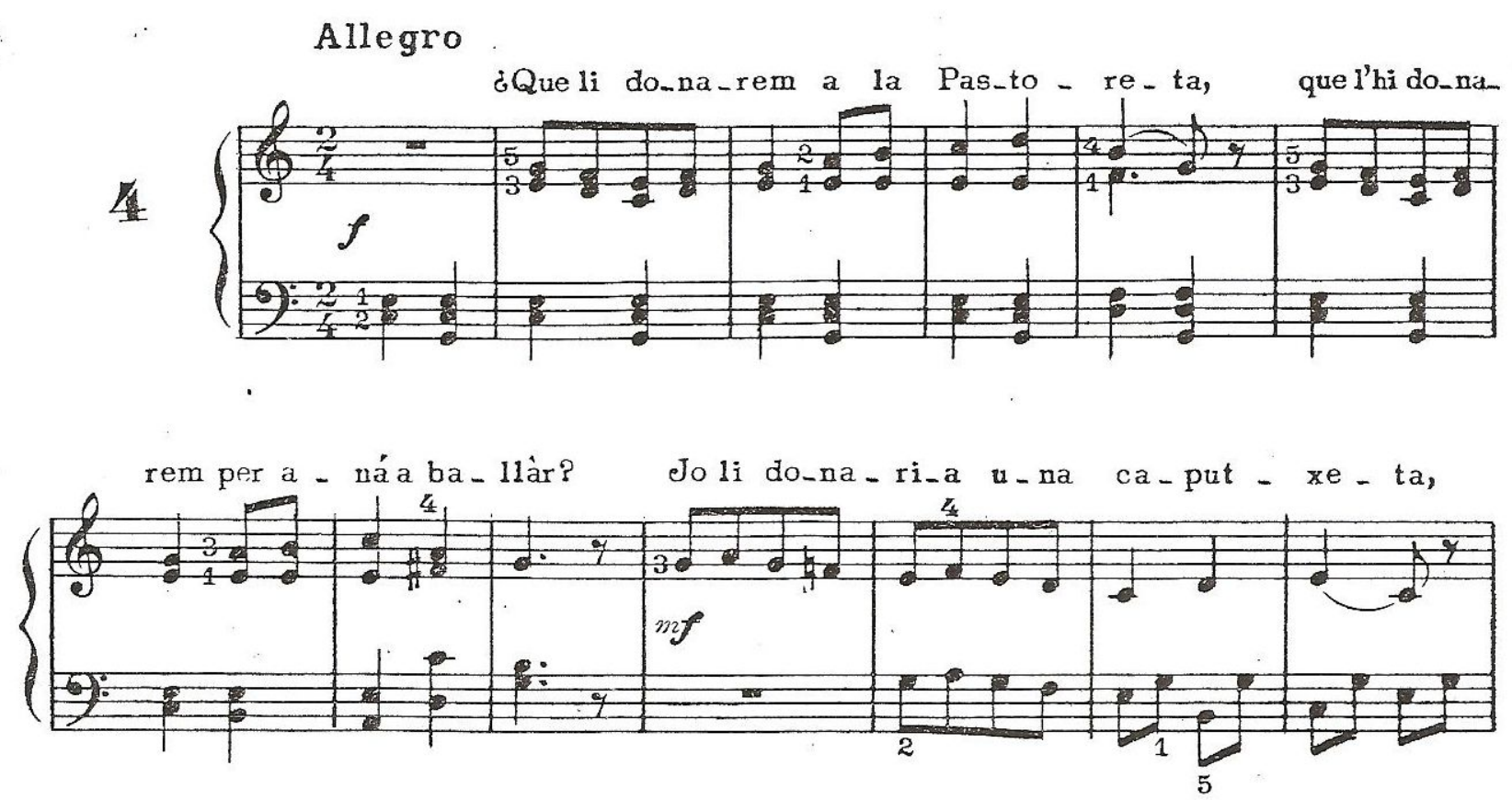

i a la monta - nye-ta la fa - ri - a a - nar. A la monta - nye_tanohine_
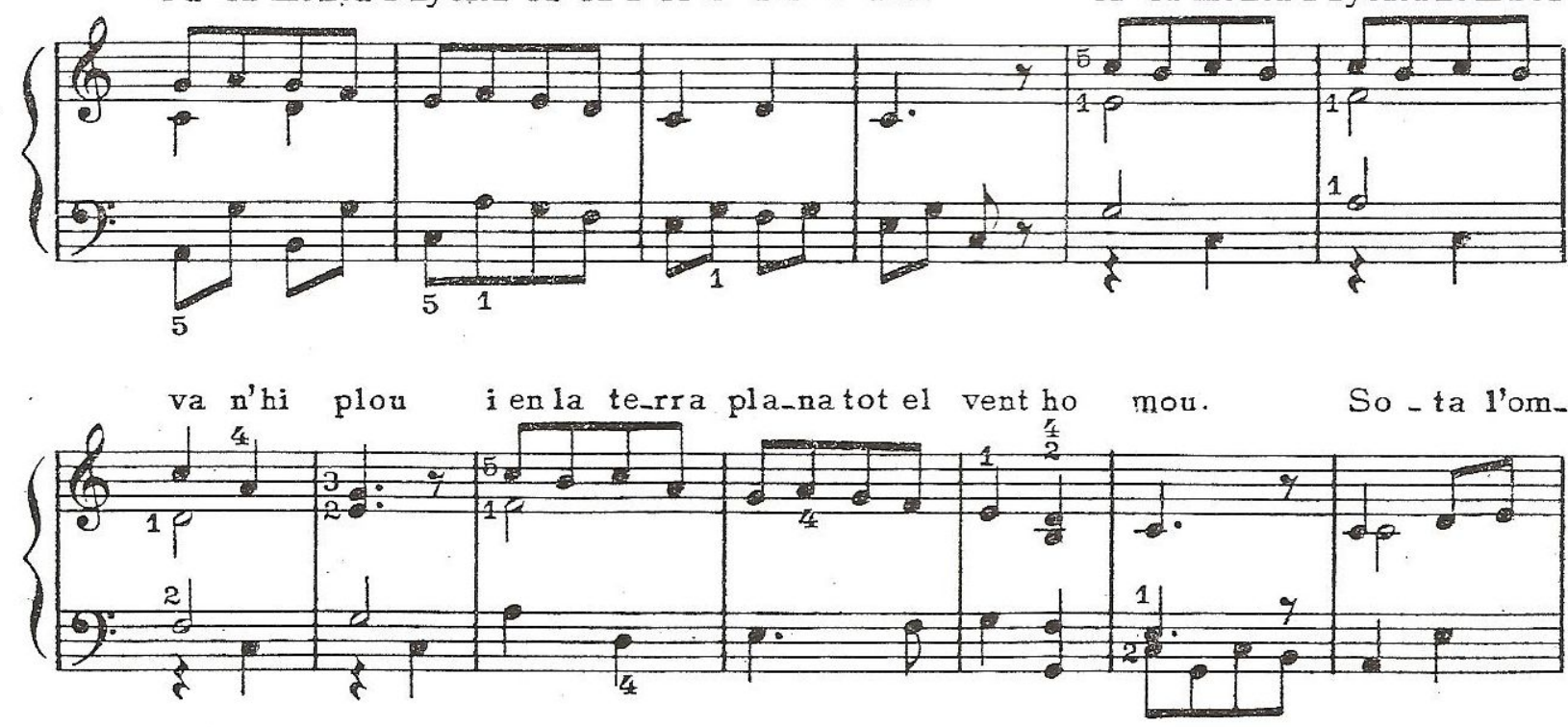

bre-ta, l'om - bre-ta l'om_bri, florsi vi-o-las i ro-ma-mí.

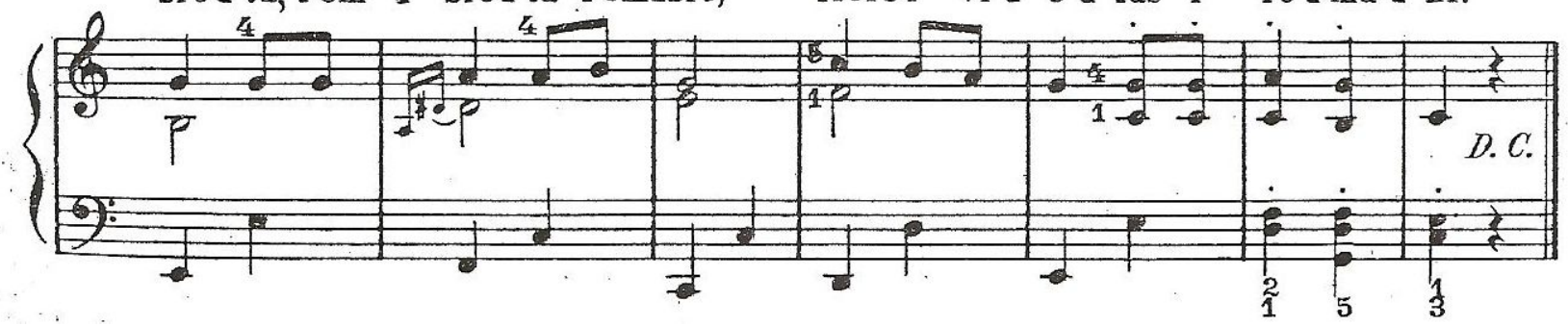




\section{La Presó de Lleida}

\section{„CANÇÓ POPULAR}

harmonitzada a quatre veus mixtes i solo de tiple

J.Cumellas Ribó
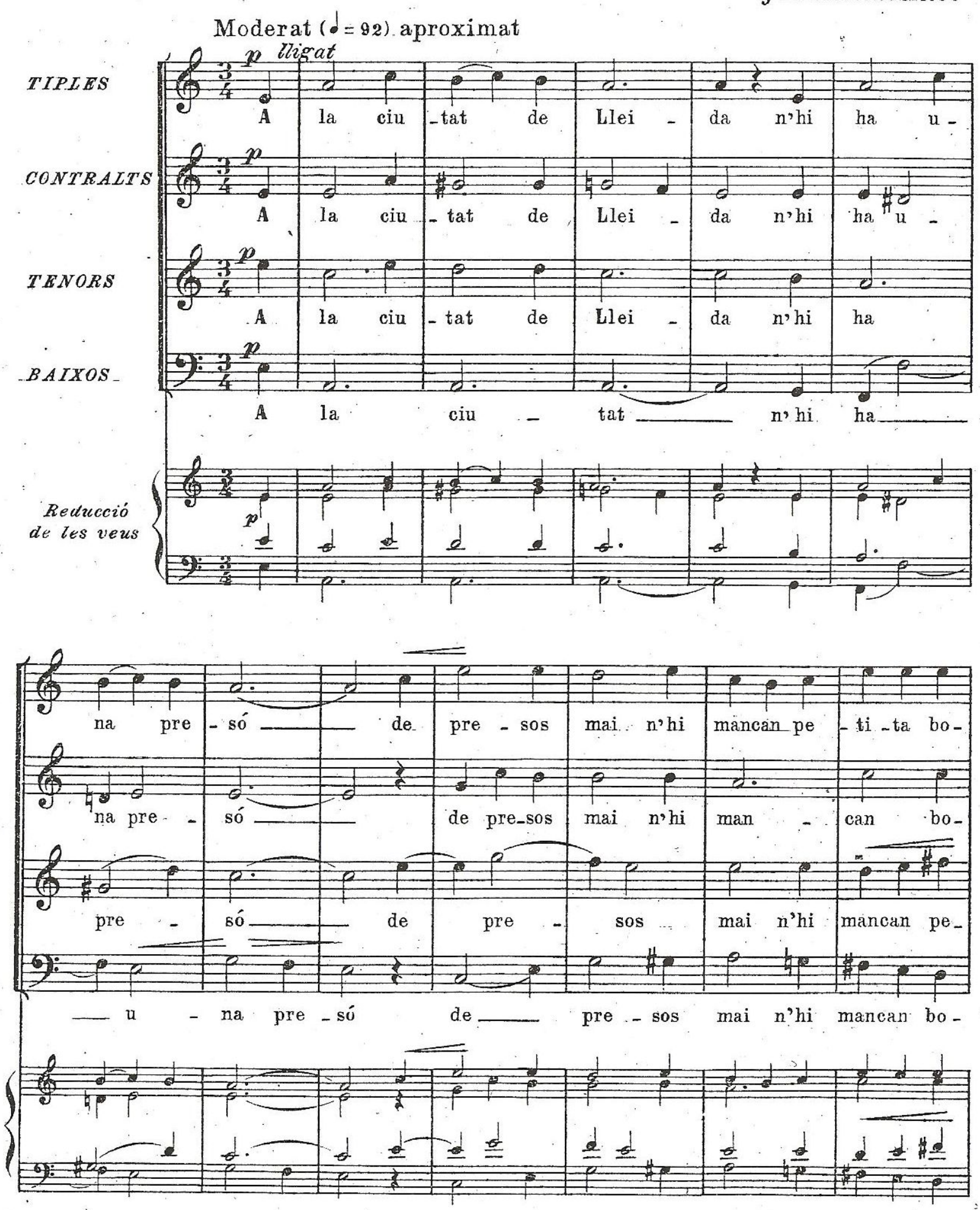


\section{El noi de la mare}
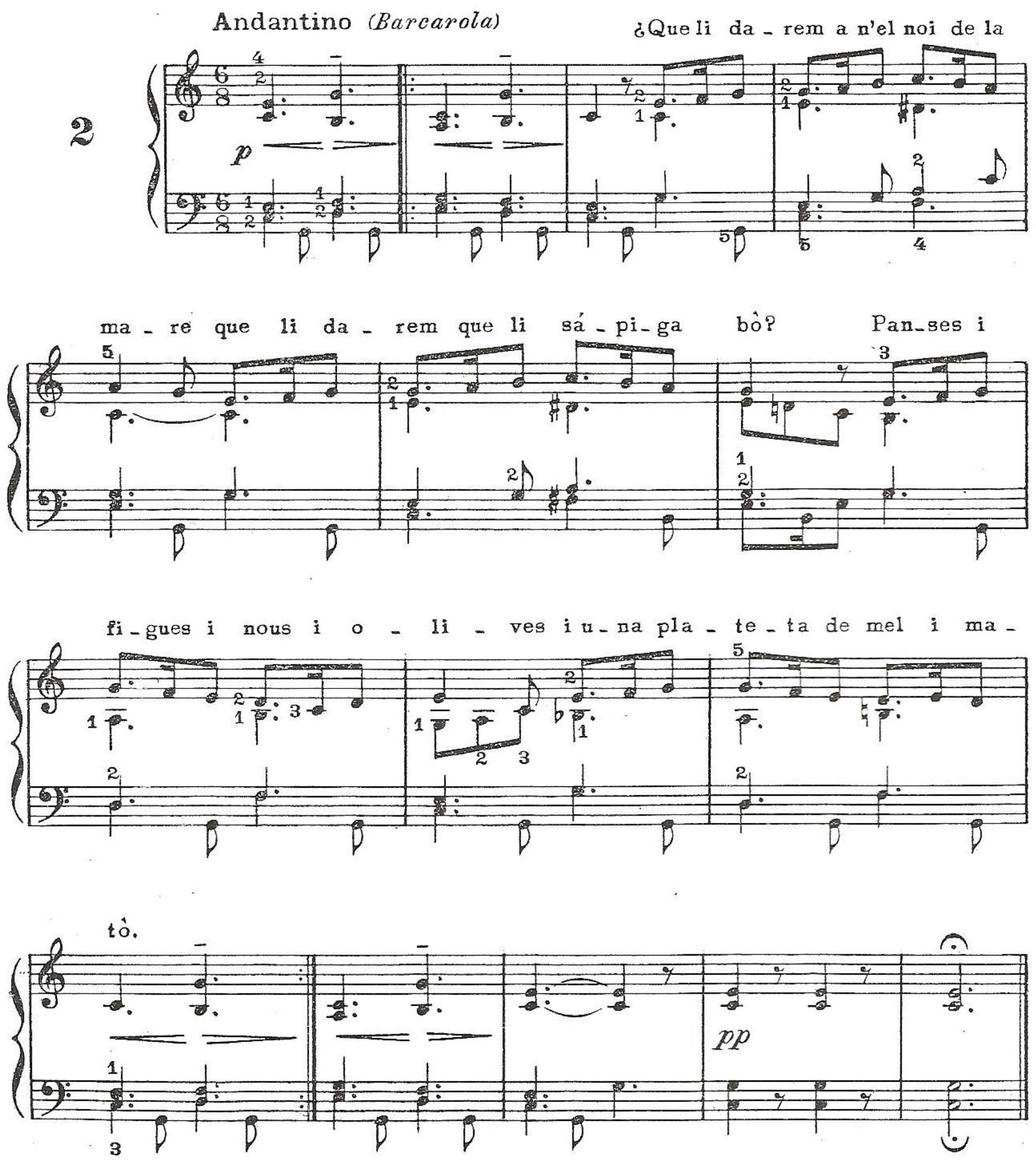
a Marisa Landi

\section{EL NOI DE LA MARE CANCION DE CUNA}

LETRA POPULAR CATALANA

Traducción castellana de

J. PAHISSA

JAIME PAHISSA
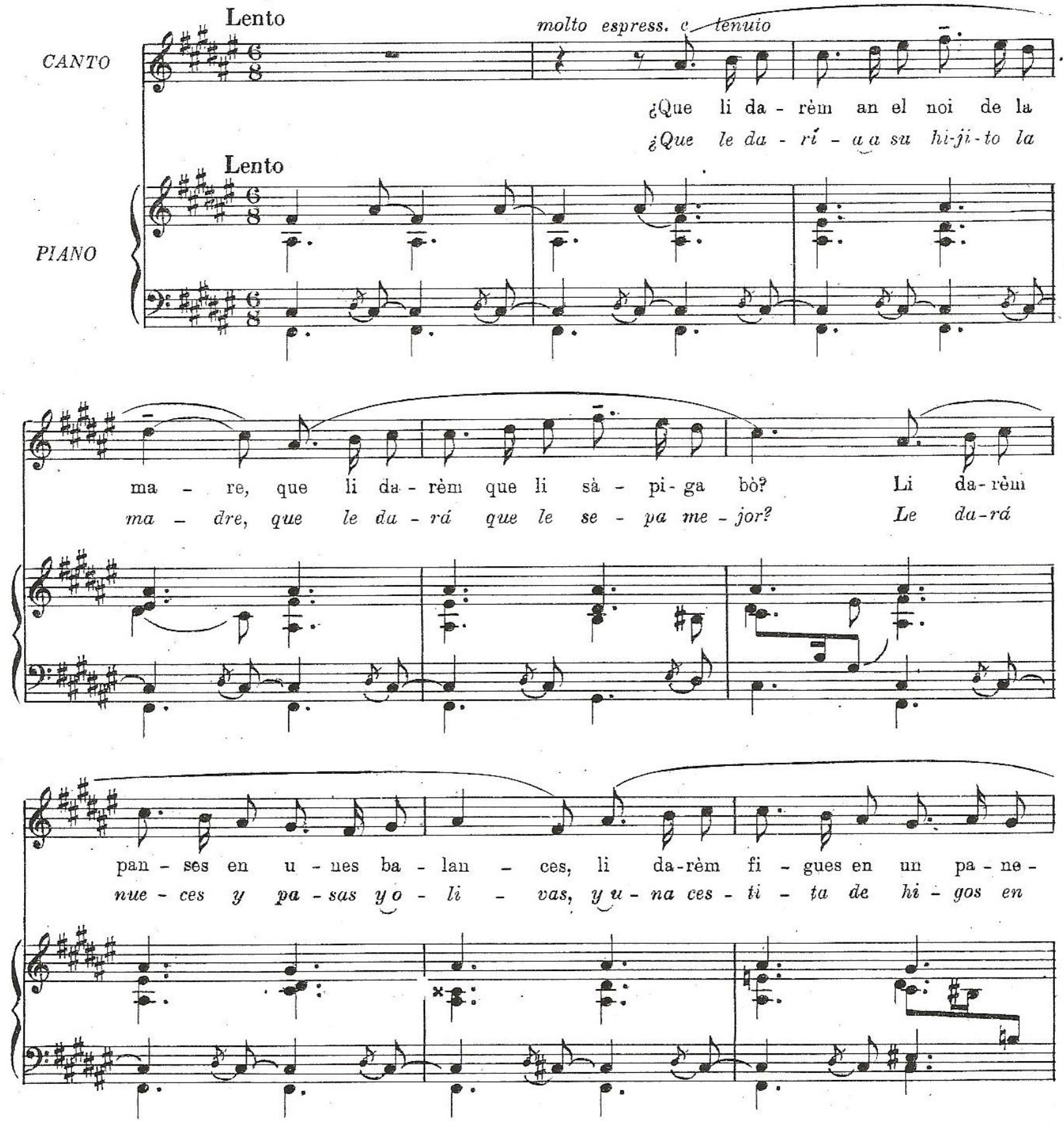


\section{La Mare de Deu}
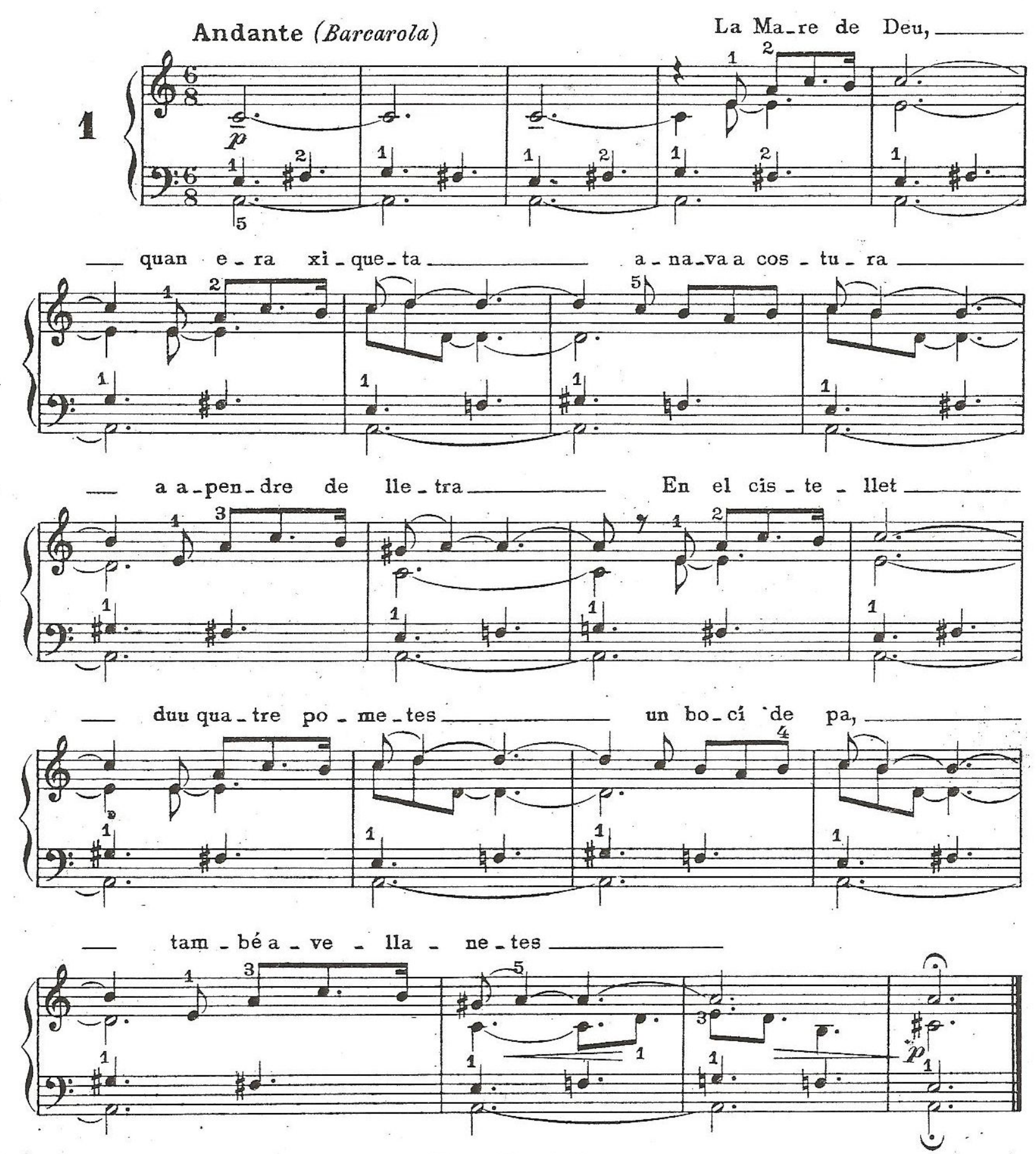


\title{
L'Fostal de la Peira
}

\author{
CANÇÓ POPULAR
}

ARMONISADA PERA GORO D'OMES

- per enRIG MORERA
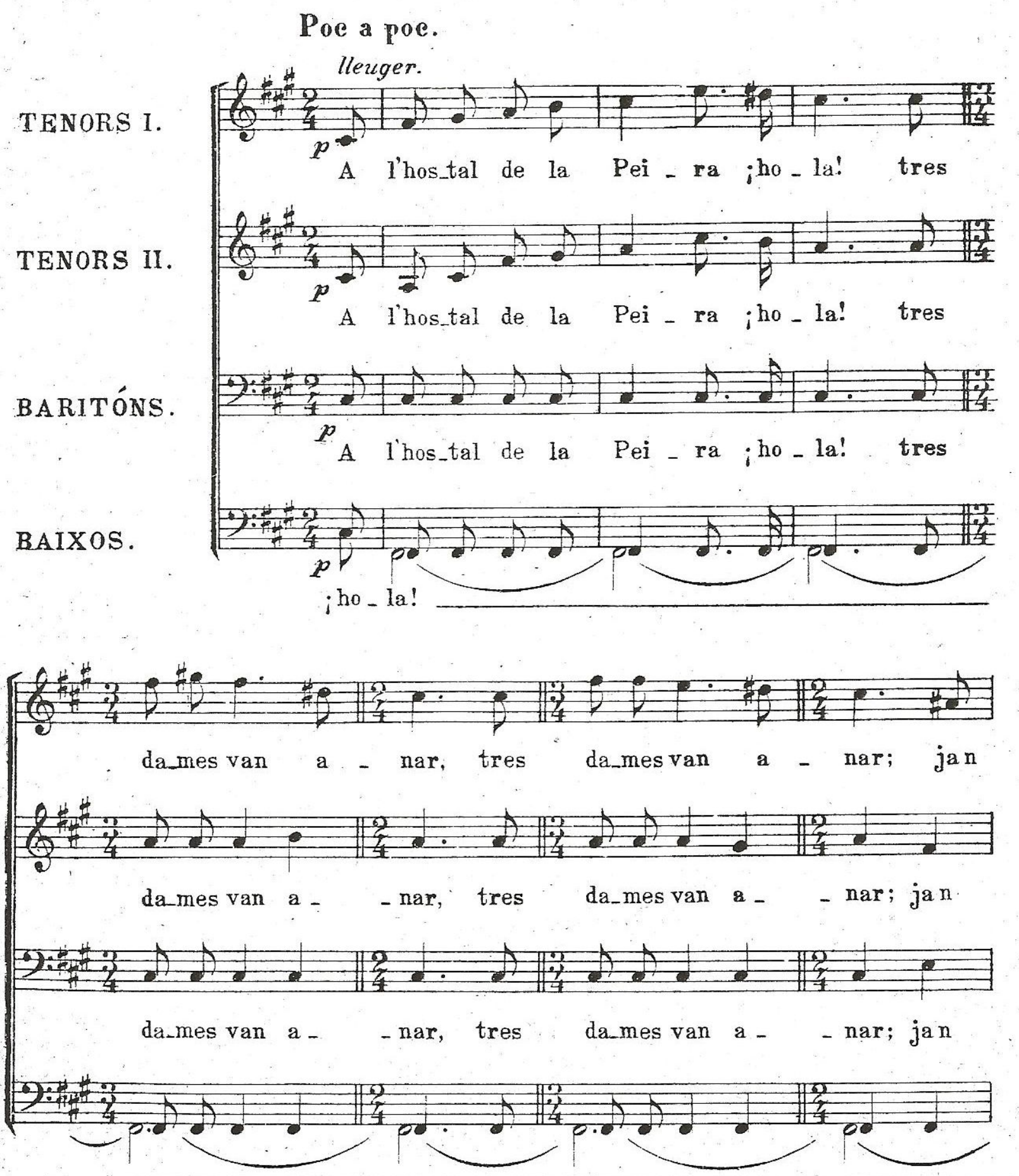


\section{Els tres tambors}
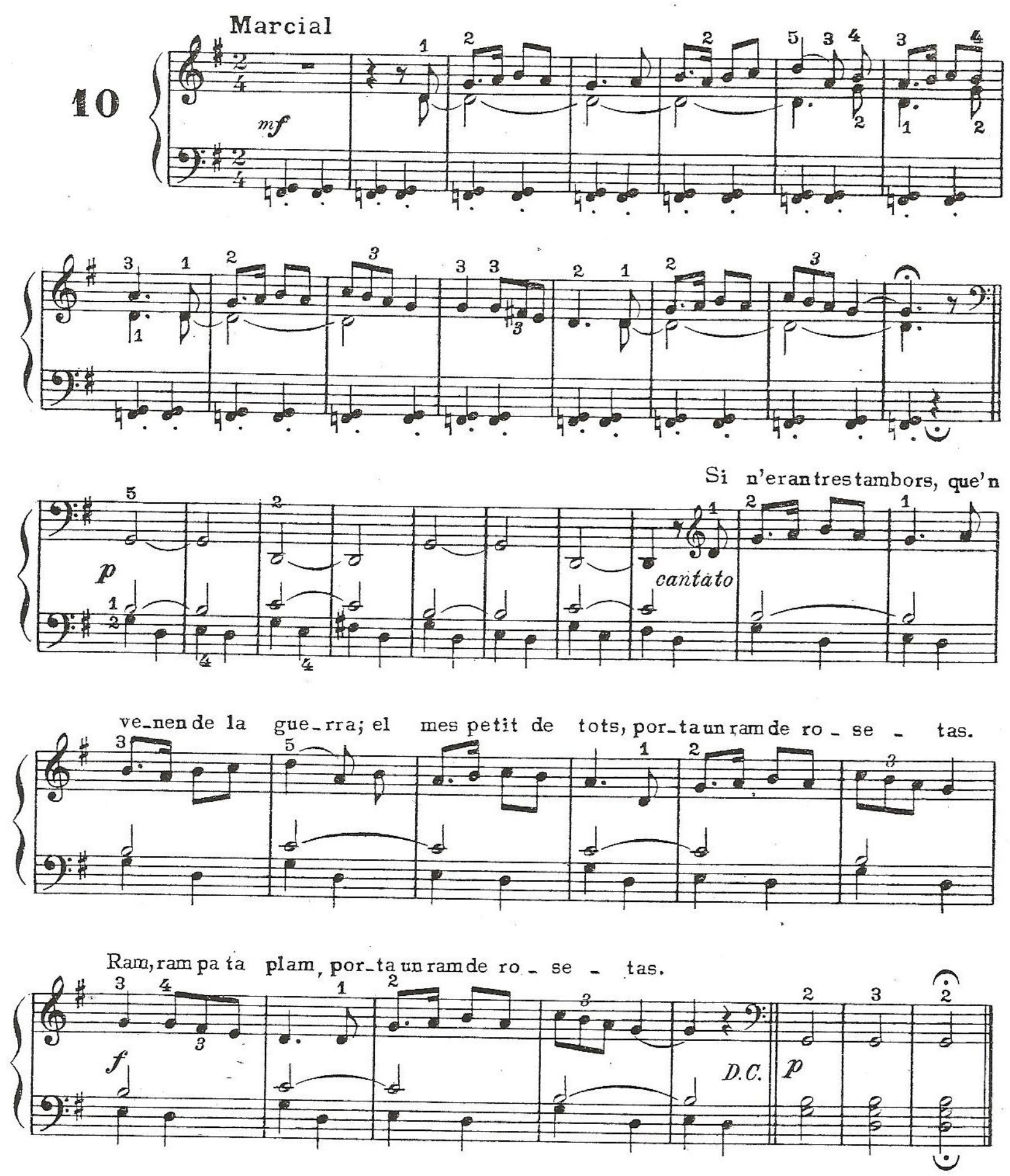


\section{E1 cant dels aucells}

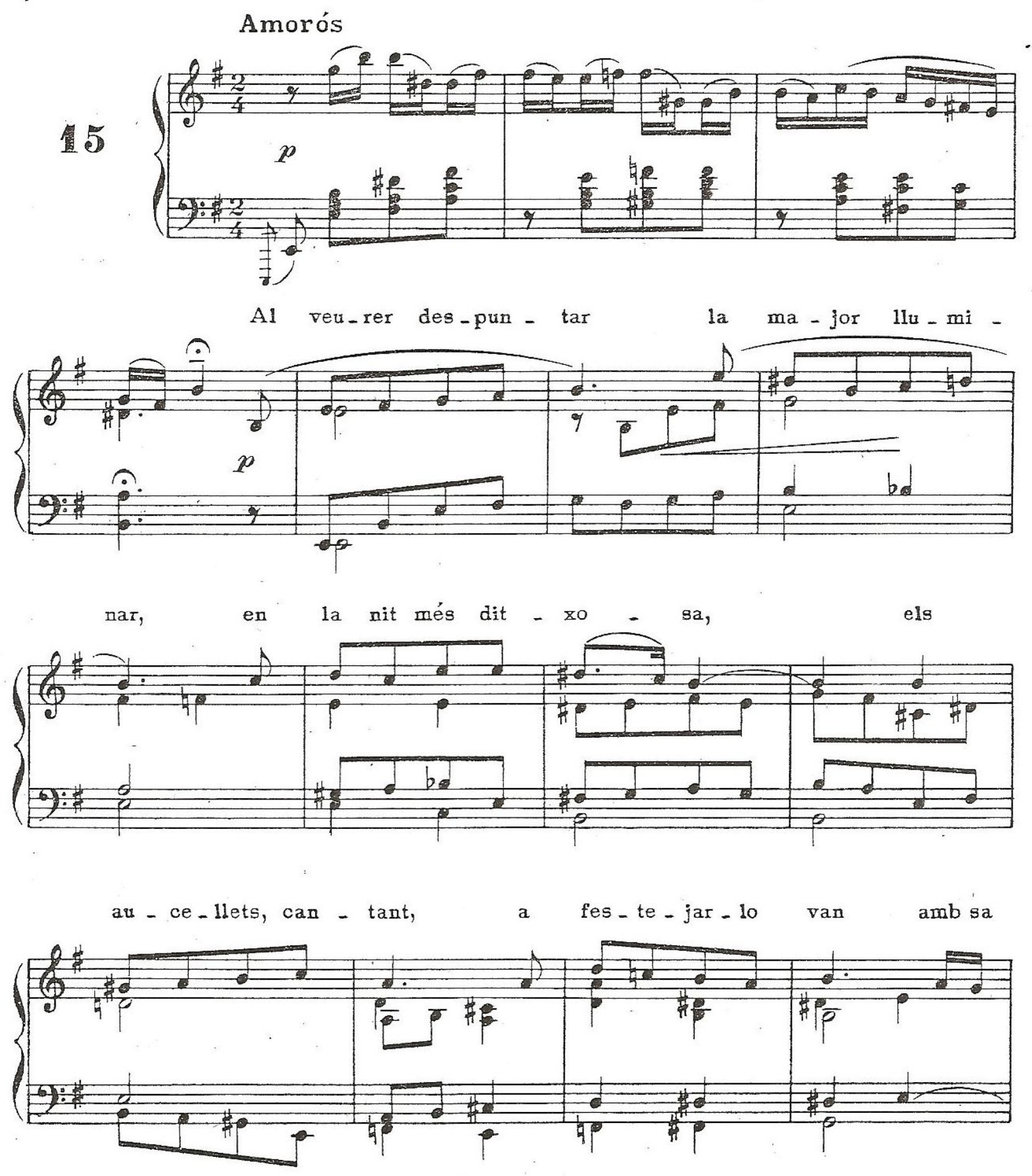




\section{E1 Canto áe los Pájaros \\ E1 Cant dels Auce11s (1) \\ LE CHANT DES OISEAUX ${ }^{(1)}$ \\ (CATALOGNE)}

Texte en langue Catrlane

Version frangaise de

Henri COLLET

Hommage à CLAUDE DEBUSSY (1)

Version simpirfiec

Joaquin $\mathrm{N} I \mathrm{~V}$ MCMXXIX
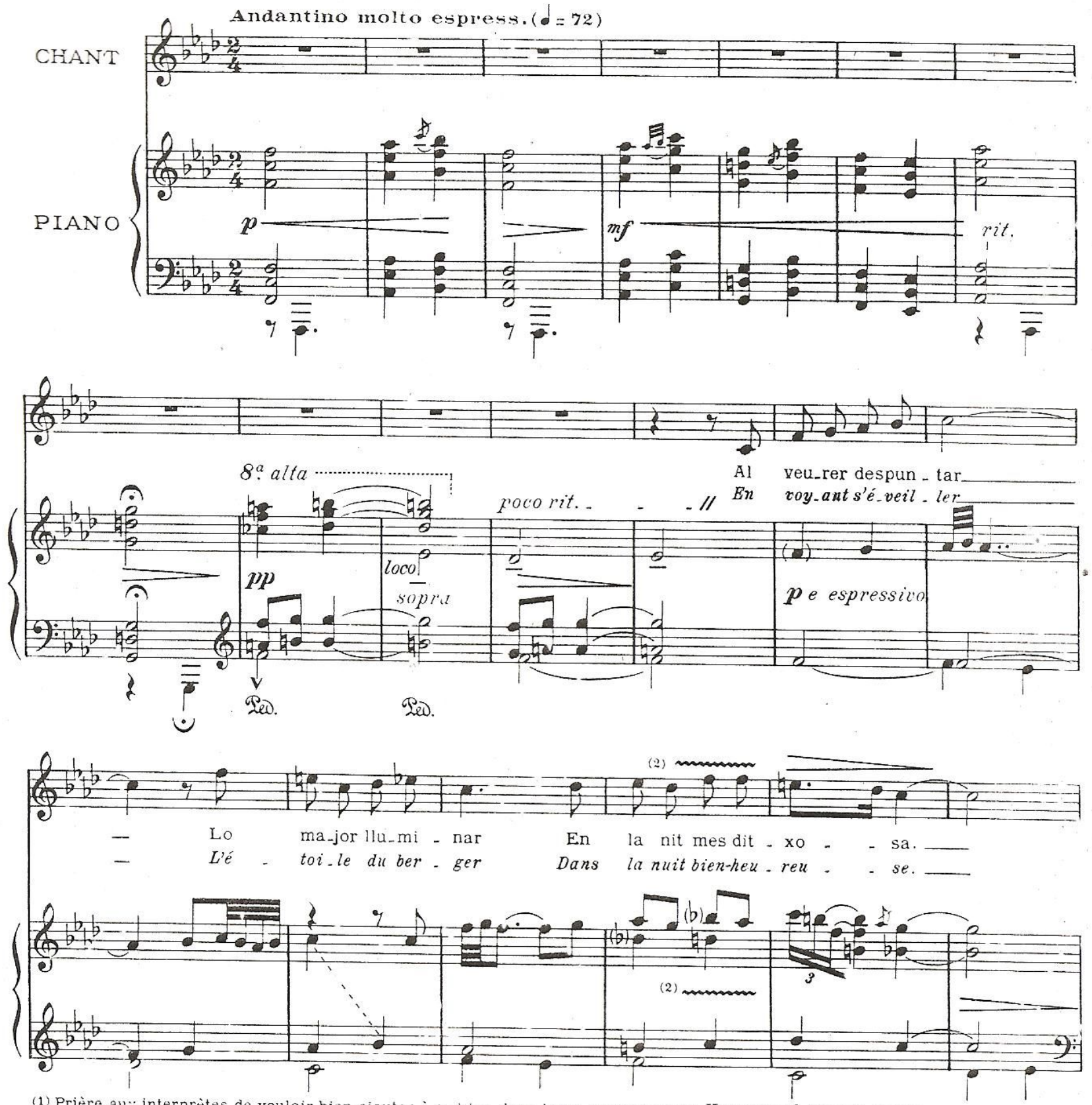

(1) Prière au: interprètes de vouloir bien ajouter à ce titre, dans leurs programmes: Hommage à Claude Debussy.

(2) Le signe asose équivaut à un ritenuto à $n$ sine perceptible. 
a Elisa Ramonedc de Ruliz

\section{MUNTANYES DE CANIGO Montañas de Canigó}

Del poema "Canigó" de J. VERDAGUER

Traducción castellana de J. PAHISSA

JAIME PAHISSA

Lento
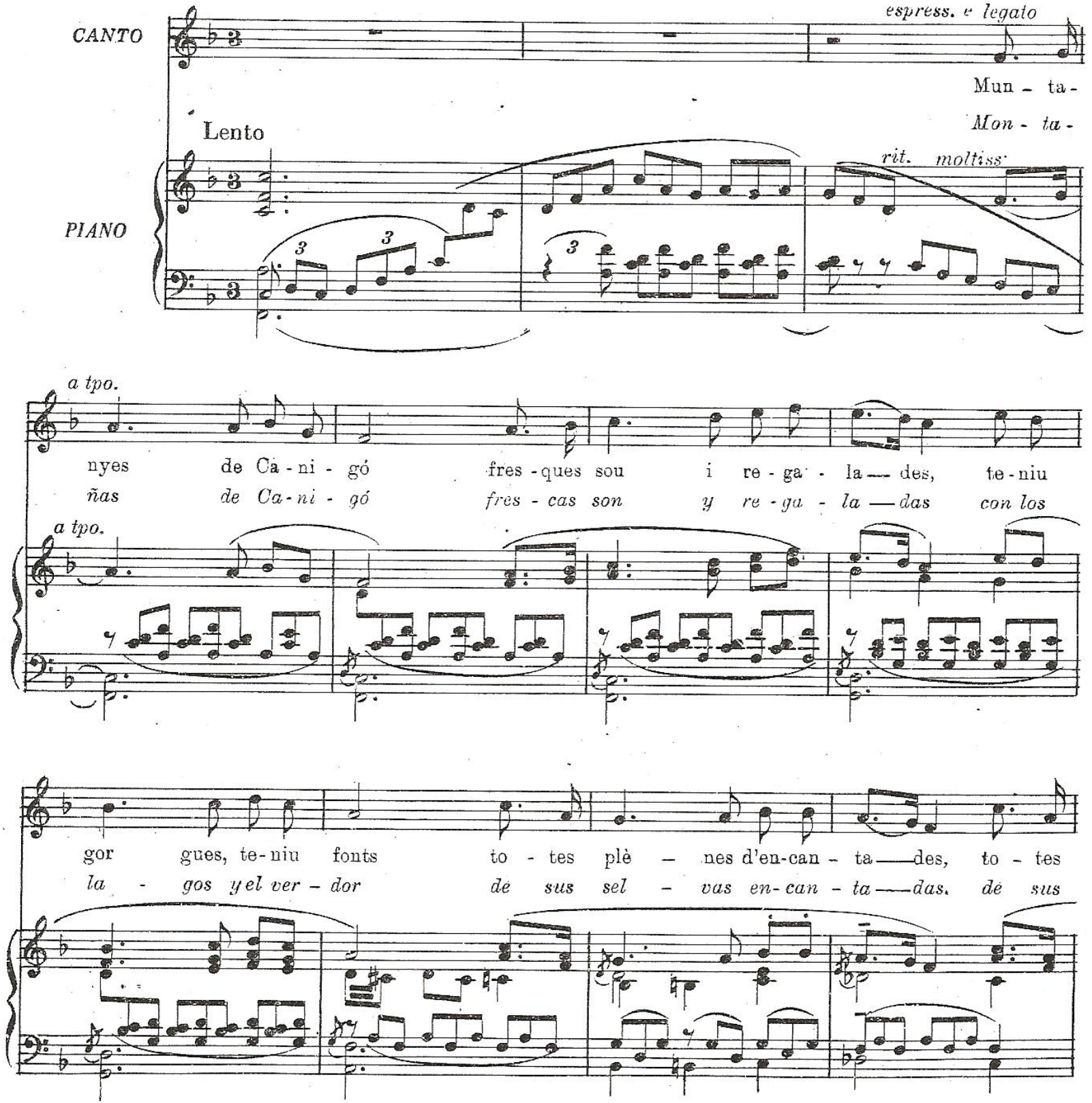

B.A. 10065 


\section{Montanyes del Canigó}

Lento
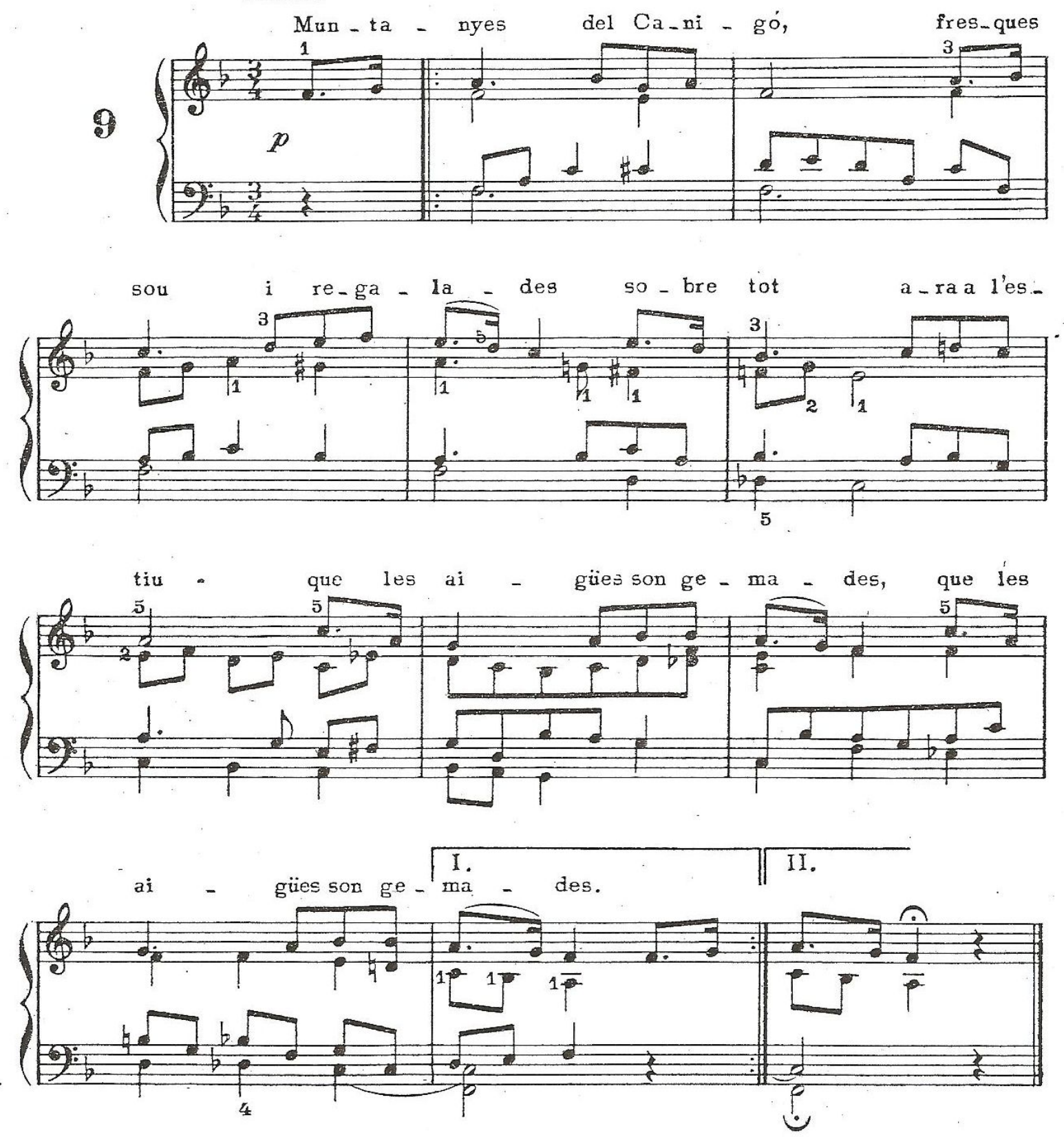


\section{Variations sur Malbrough s'en va-t-en guerre}

Révisé et doigté

par Turibio aANTOE

Enregistri sur disgwe BRATO (70707)

Fernando SOR

INTRODUCTION : Andante

6e Corde en Ré
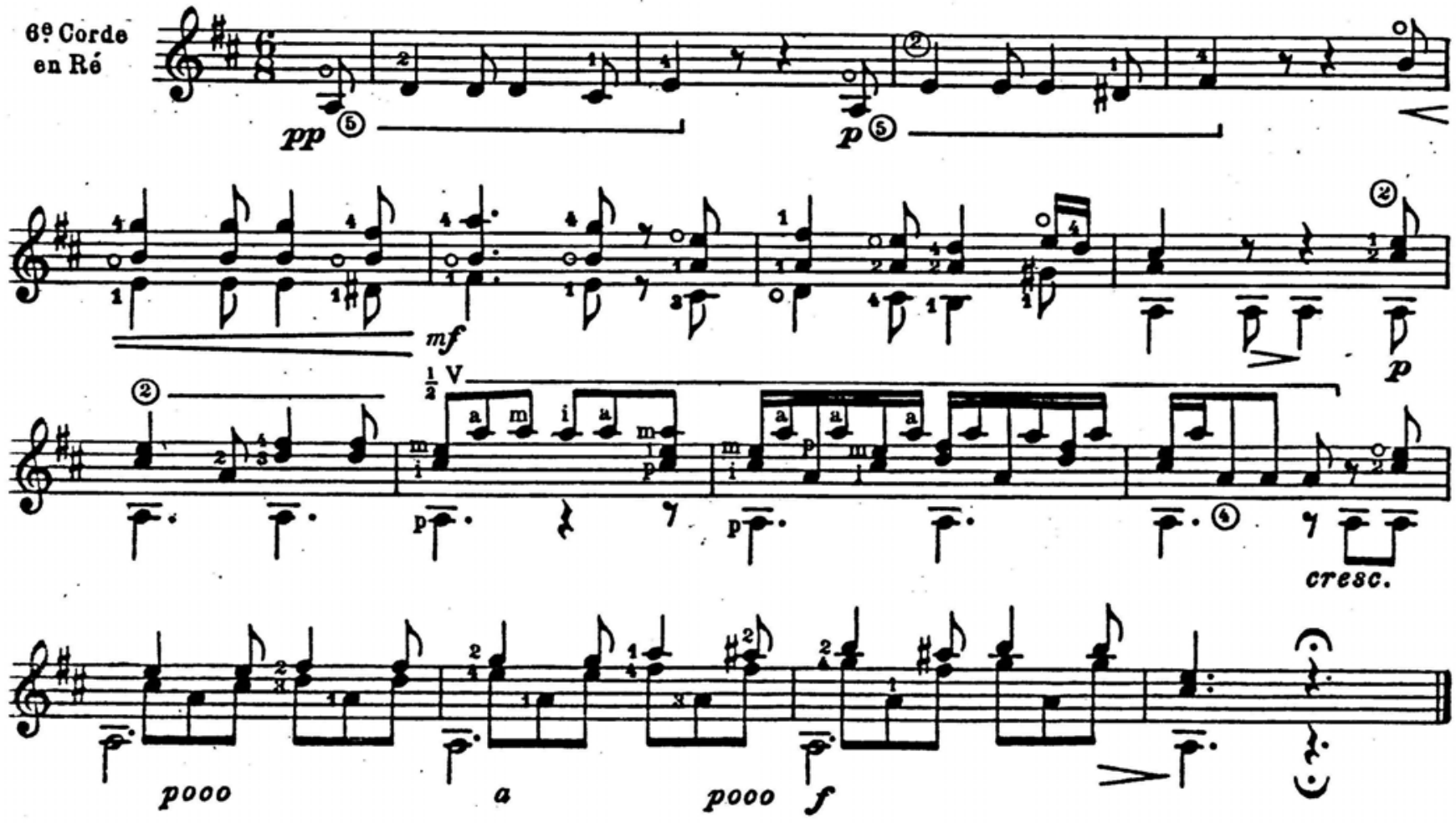

TH'ेME. Allegretto
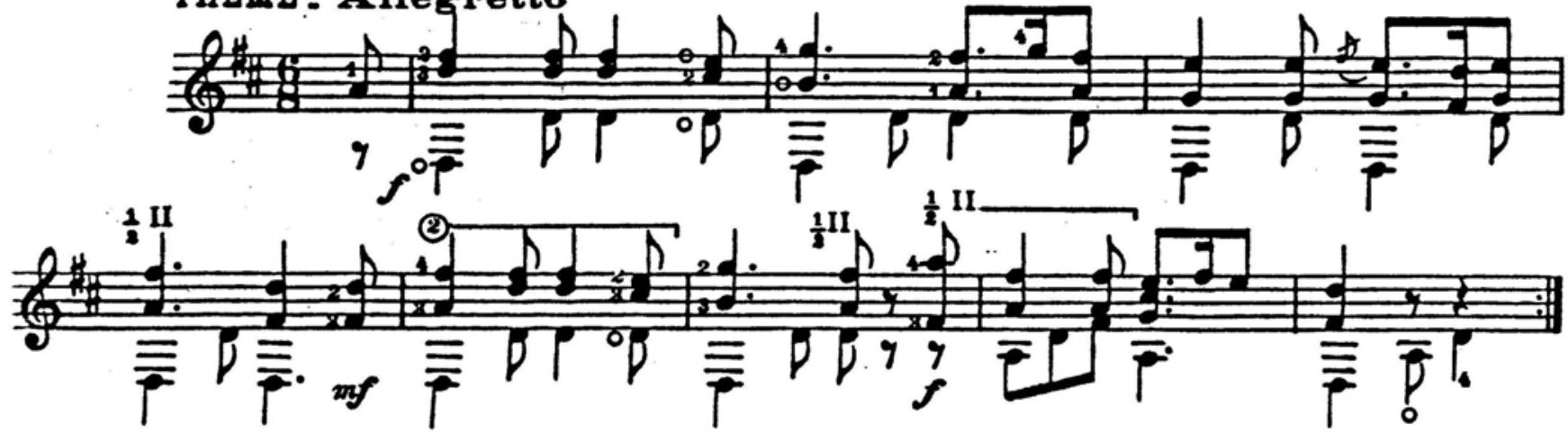
Andante

(6) $\mathrm{re}$
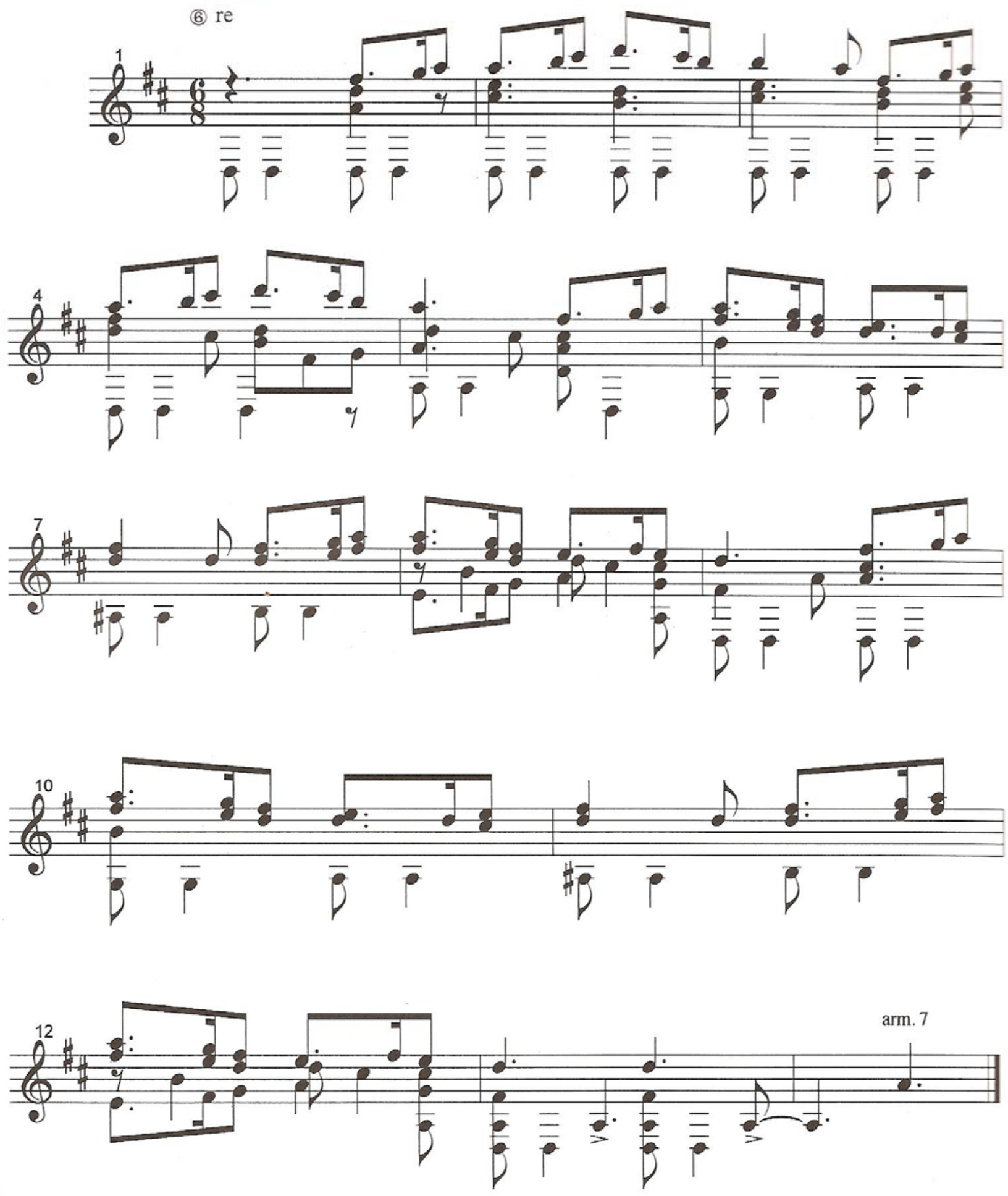
Quasi Allegretto
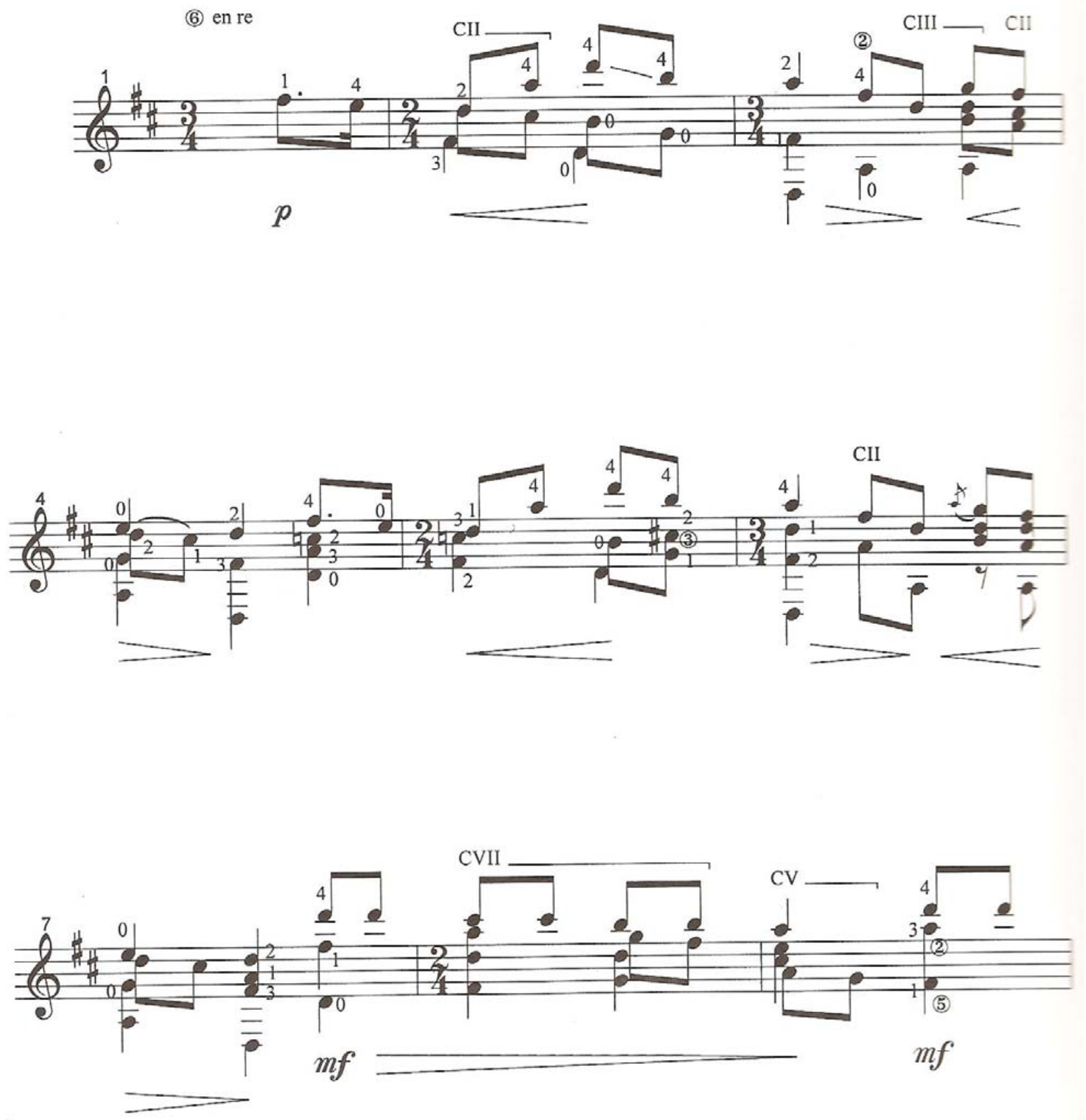


\section{ANEXO B - Entrevista com Stefano Grondona}

\section{Dagma: Muitos violonistas brasileiros, estudantes e profissionais, executam as Canções Catalãs de Miguel Llobet, mas não conhecem sua origem e o texto delas. Como é na Europa?}

Grondona: Os violonistas europeus também não sabem nada a respeito das canções, o que elas dizem e as consideram como simples peças fáceis. Mas não é verdade. Por exemplo, La Pastoreta representa um verdadeiro tratado de como movimentar a mão esquerda! Alguns não valorizam as transcrições, mas o que Llobet tem de especial está nestas canções, ao mesmo temo simples e elaboradas. O que Llobet fez com as canções é maravilhoso!Explorou temas do folclore, adaptando-os para o violão de maneira extremamente expressiva.

La Presó de Lleida, El testamento d'Amelia são melodias muito antigas, de uma longa tradição, mas os violonistas não tem conhecimento disso. Uma fonte de pesquisa importante sobre a tradição destas melodias é o livro de Joan Amades - Folklore de Catalunya. Acho importante que os violonistas saibam mais sobre as Canções Catalãs. Elas não são simples obras, como muitos as consideram.

\section{Dagma: Você tem algum dado sobre a canção Plany?}

Grondona: Não consegui nenhuma informação sobre esta canção.

Dagma: A carreira de Miguel Llobet, bem como sua obra para violão, não tiveram tanto destaque quanto Tárrega e Segovia. A que você atribui este fato?

Grondona: Acredito que isso se deve ao período difícil que a Espanha enfrentava com a Guerra Civil, que colocou uma espécie de cortina sobre tudo o que estava sendo realizado naquele momento, na Catalunha. Llobet não ficou imune aos efeitos sócio-políticos de seu 
tempo e não conseguiu sobressair-se como Tárrega e Segovia. Segovia era um leão, diferente de Llobet. Muito mais decidido e objetivo quanto ao que pretendia em sua carreira. Acredito que tanto Llobet quanto Arcas ficaram sufocados entre a notoriedade de Tárrega e Segovia.

Dagma - Qual a sua opinião sobre a possibilidade de Segovia ter feito aulas com Llobet?

Grondona - Llobet, além de virtuoso, era um intelectual. Realmente uma figura muito importante. Por isso Segovia foi para Barcelona para encontrar Llobet. Segovia é resistente em afirmar isso, mas em sua biografia ele cita que observou Llobet na realização de alguns trechos musicais, algumas soluções técnicas, talvez. Para mim isso é ter aulas.

Dagma - Podemos dizer que a escola moderna de violão que conhecemos iniciou-se na Catalunha?

Grondona - Sim, podemos. Embora os catalães não tenham consciência disso. Não se toca violão diferente lá, do que no resto da Europa. Mas os grandes intelectuais e músicos se encontravam nesta região: Sor, Arcas, Tárrega obviamente, Llobet e Pujol.

Torres era andaluz, mas enviava seus instrumentos para Catalunha. Era lá onde estava o centro de música erudita para violão. Outro luthier importante foi Enrique Garcia.

Dagma - Você gravou uma série de obras inéditas de Llobet. Pode nos contar como foi encontrar este tesouro?

Grondona - Fernando Alonso (violonista e proprietário da Casa Sor, em Barcelona) encontrou este arquivo na casa de uma antiga amiga da família de Llobet, ex-aluna de piano de sua esposa. Graças a um entendimento entre mim e Alonso e uma colaboração ao longo de dez anos, foi possível realizar as gravações deste patrimônio musical. São novas adaptações de canções tradicionais catalãs (L'Anunciació e L'hostal de la Peira, além de 
uma nova adaptação de La Filla del Marxant) para grupo de violões. Llobet era o responsável por um grupo chamado Lira Orfeu. O grupo era formado por violões, mandolinas, alaúdes e um arquialaúde. Tais adaptações foram feitas para este grupo, entre outras (Mozart, Beethoven, Chopin, Mendelssohn, Schumann, de Falla e Albeniz).

Dagma - Uma curiosidade é a suposta relação que Llobet teve com Villa-Lobos e sua, também suposta, Valsa-Concerto, dedicada a Llobet. Tem alguma informação sobre esta obra?

Grondona - Isso é algo não esclarecido. Existem algumas anotações na partitura do próprio Llobet, algumas “correções”, o que coloca em dúvida se realmente ela foi escrita por VillaLobos.

Dagma - Um artigo da revista Soundboard cita Llobet como sendo o “pai do violão moderno”, título dado anteriormente a Tárrega. O que você acha disso?

Grondona - Acredito ser correto. Tárrega foi o responsável pela criação de um novo conceito, mas foi Llobet, que conferiu ao violão um perfil mais modernista, e sua obra transcendeu as possibilidades do violão já exploradas. Estou muito satisfeito por estar ajudando a sensibilizar o público a reconhecer a importância deste artista de tantas facetas, que precisam ser descobertas. 
ANEXO C - Programas de Recital realizados durante o II Encontro Internacional de Violonistas de Tatuí

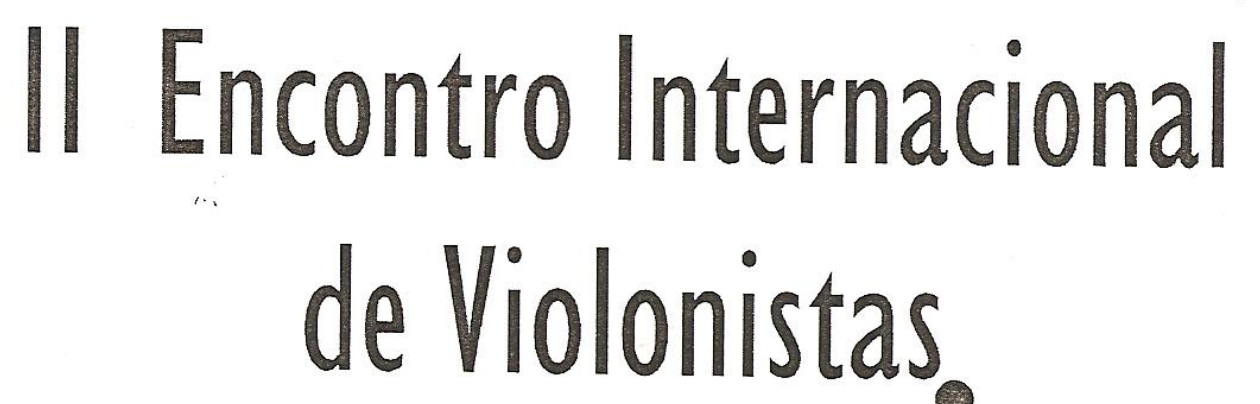

II International Guitar Meeting
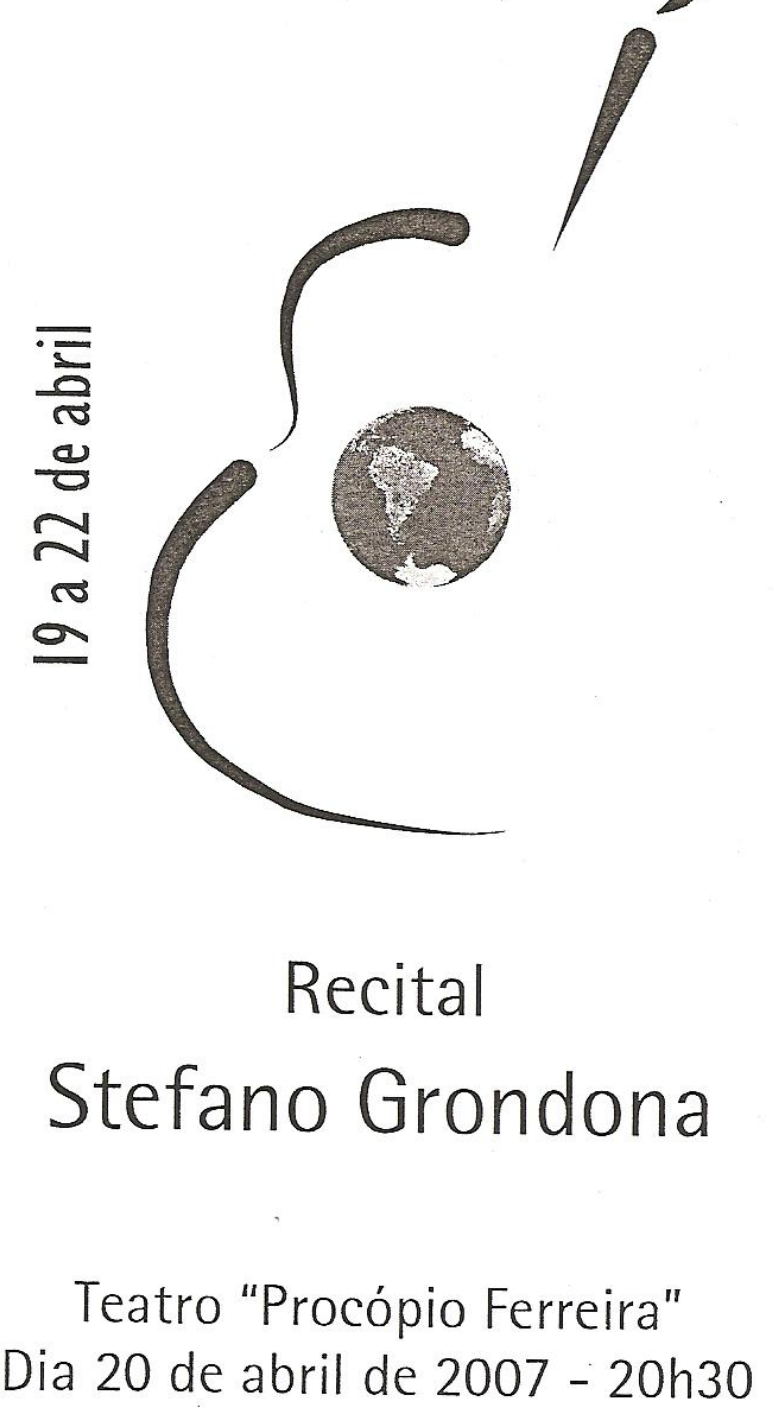


\section{$\begin{array}{llllllll}P & R & O & G & R & A & M & A\end{array}$}

J. J. Froberger

S. Sacarlatti

J. S. Bach

INTERVALO
Suite em ré menor transcrição Stefano Grondona

Allemande - Courante - Sarabande - Gigue

Três Sonatas

transcrição Stefano Grondona

Toccata BWV 914

transcrição Stefano Grondona
J. Arcas

M. Llobet

R. Villar-Llobet

M. Falla

E. Granados-Llobet

I. Albéniz - Llobet
Fantasia sobre "El Paño"

El Mestre

Danza Española

Homenage

Danza Espanõla n 5

Torre Bermeja 
II Encontro Internacional

de Violonistas

II International Guitar Meeting

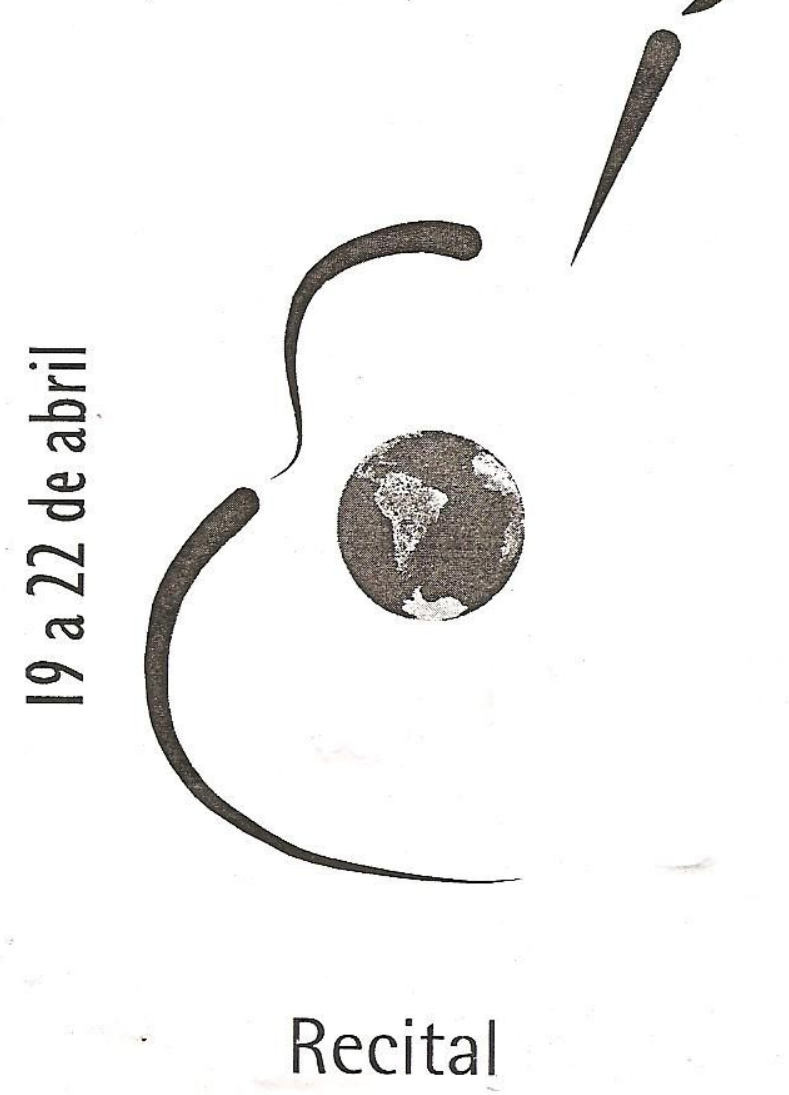

Stefano Grondona e Laura Mondiello

Teatro "Procópio Ferreira"

Dia 22 de abril de 2007 - 20h30 


\section{$\begin{array}{llllllll}P & R & O & G & R & A & M & A\end{array}$ \\ 0 duo Estefano Grondona e Laura Mondiello dedicam o concerto em homenagem ao histórico duo Miguel Llobet e Maria Luisa Anido}

W. A. Mozart

F. Mendelssohn

P. Tchaikovsky

I. Albéniz
Minuetto de la Sinfonia $n^{\circ} 39$

Romanza sin palabras $n^{\circ} 20$

Romanza sin palabras $n^{\circ} 25$

Humoresque op. $10 n^{\circ} 2$

Rumores de la Caleta

Bajo la palmera

Evocación

Castilla

Intervalo

E. Granados

Danza Española n ${ }^{\circ} 11$, Zambra

M. Falla

Cubana

Danza del molinero

Pantomima

Medianoche y Danza Ritual del Fuego

Todas as obras no programa são arranjos históricos do grande violonista catalão Miguel Llobet 